\title{
Branding Books \\ Across the Ages
}

\section{Strategies and Key Concepts in Literary Branding}

Edited by

Helleke van den Braber, Jeroen Dera, Jos Joosten and Maarten Steenmeijer
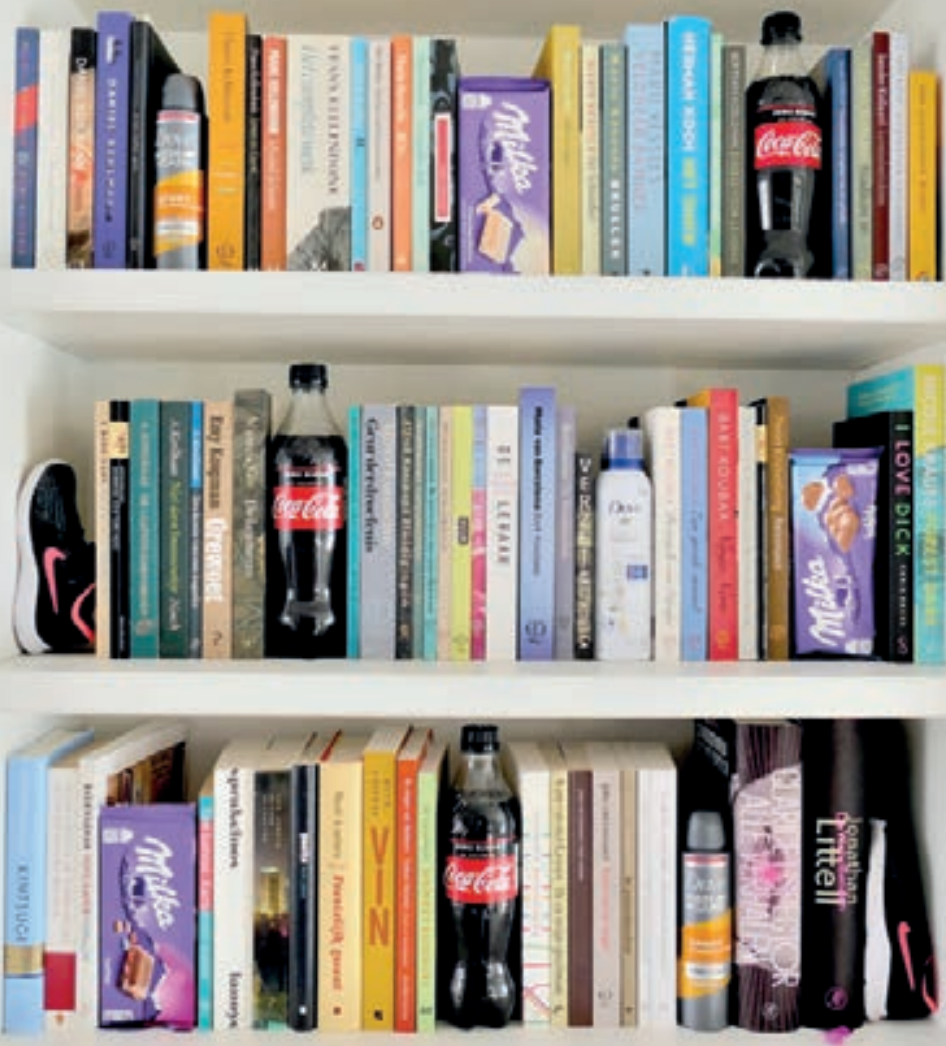
Branding Books Across the Ages 



\title{
Branding Books Across the Ages
}

\author{
Strategies and Key Concepts \\ in Literary Branding
}

\author{
Edited by \\ Helleke van den Braber, \\ Jeroen Dera, \\ Jos Joosten, and \\ Maarten Steenmeijer
}

Amsterdam University Press 
This volume is supported by the Stichting Frederik Muller Fonds, the Paul Hazard Stichting, the Radboud Institute for Culture and History, and the Department of Modern Languages and Cultures at Radboud University.

The authors thank Demi Schoonenberg and Tommie van Wanrooij for their invaluable help during the editorial process of this book.

Cover design: Coördesign, Leiden

Typesetting: Crius Group, Hulshout

$\begin{array}{ll}\text { ISBN } & 9789463723916 \\ \text { e-ISBN } & 978904854440 \text { o (pdf) } \\ \text { DOI } & 10.5117 / 9789463723916 \\ \text { NUR } & 621\end{array}$

\section{(C) $(1) \Theta \Theta$}

Creative Commons License CC BY NC ND (http://creativecommons.org/licenses/by-nc-nd/3.o)

@ The authors / Amsterdam University Press B.V., Amsterdam 2021

Some rights reserved. Without limiting the rights under copyright reserved above, any part of this book may be reproduced, stored in or introduced into a retrieval system, or transmitted, in any form or by any means (electronic, mechanical, photocopying, recording or otherwise). 


\section{Table of Contents}

Introduction

Helleke van den Braber, Jeroen Dera, Jos Joosten, and

Maarten Steenmeijer

Cultural Branding in the Early Modern Period

The Literary Author

Lieke van Deinsen and Nina Geerdink

Telling a Double Story

61

The Branding of a Cultural Magazine, 1904-1919

Helleke van den Braber

A Hero and His History

The Branding of Jan III Sobieski and His Letters in the Northern

Netherlands during the Early Nineteenth Century

Paul Hulsenboom

From Immorality to Immortality

Branding Madame Bovary in the Netherlands Maaike Koffeman

Allegories of Branding

How to Successfully Fail Charles Bukowski

Gaston Franssen

Branding or Excluding?

The Tenability of the 'Branding' Concept in the History of

Nineteenth-Century Dutch Book Publishing, Book Printing, and

Bookselling

Robvan de Schoor

Hugo Claus

'I'm Not Searching for Myself, but for the Media. I Don't Know Who I Am, I'm Not Interested.'

Gwennie Debergh 
One Book's Brand is Another Book's Frame

Covering the Dutch Cover of Carlos Ruiz Zafón's La sombra del viento Maarten Steenmeijer

'The Most Successful Writer of the Netherlands'

On the Success Myth of Dutch Bestselling Author Herman Koch Sander Bax

Young Adults as Branded Readers 239 Linda Ackermans

Of Dust and Dollars

Branding Poetry in the Twenty-first Century -The Case of Ellen

Deckwitz Jeroen Dera

'This Is What We Share'

Co-branding Dutch Literature at the 2016 Frankfurt Book Fair Jack McMartin

The One Unforgivable Transgression?

Branding 'Kluun' as a Literary Strategy Jos Joosten

Branding the Open-minded Nation

Dutch Authors at the 2011 Beijing Book Fair Laurens Ham

Against the Grain

The Das Mag brand and Lize Spit's The Melting (2016)

Roel Smeets

In Search of the Most Effective Way of Branding

The Label 'Literature' as a Means to an End

Bertram Mourits

Index of Names 


\section{List of Figures}

Figure i.1

Figure 1.1 Steven van Lamsweerde, Sight on the Dom in Utrecht anno 1660

Rijksmuseum Amsterdam: RP-P-AO-5-23

Figure 1.2 Portrait ofJan Jansz. Starter. in: Starter, Jan Jansz. Friesche lust-hof, beplant met verscheyde stichtelijcke minne-liedekens, gedichten, ende boertige kluchten Amsterdam: weduwe Dirck Pietersz Voscuyl, 1621. UBU

Figure 1.3 Jan van de Velde (II), Portrait ofJan Jansz Starter. in: Starter, Jan Jansz. Friesche lust-hof, beplant met verscheyde stichtelijcke minne-liedekens, gedichten, ende boertige kluchten, 2nd edition

Amsterdam: weduwe Dirck Pietersz Voscuyl, 1623.

Rijksmuseum Amsterdam: RP-P-OB-15.270

Figure 1.4 Arnoud van Halen, Portrait Jan Jansz Starter, 1700-1732

Rijksmuseum Amsterdam: SK-A-4567

Figure 1.5 Jacob Houbraken, after Joseph Marinkelle, Portrait of Sara Maria van der Wilp, 1771

Rijksmuseum Amsterdam: RP-P-OB-48.395

Figure 1.6 Reinier Vinkeles, after Daniël Bruyninx, Portrait of Sara Maria van der Wilp, 1772

Rijksmuseum Amsterdam, RP-P-OB-62.953

Figure 2.1

Figure 3.1 Title page of Brieven van den Koning van Polen Jan

Sobieski [...]

's Gravenhage: A. Kloots, 1831. KB | Nationale bibliotheek: 3107 B 9

Figure 3.2 Title page of Brieven van den Koning van Polen Jan

Sobieski $[. .$.

's Gravenhage: A. Kloots, 1835. Bijzondere Collecties, Universiteit van Amsterdam, UBM: 230 B 17

Figure 3.3 Pieter Schenk (I) and Jan Norel, Portrait of Jan III

Sobieski, king of Poland, ca. 1670-1713

Rijksmuseum Amsterdam: RP-P-OB-9243

Figure 3.4 Portrait of Jan III Sobieski, from Brieven van den

Koning van Polen Jan Sobieski [...]

's Gravenhage: A. Kloots, 1831. KB | Nationale bibliotheek: 3107 B 9 
Figure 4.1 Second edition of G.H. Priem's Madame Bovary translation in the series Meesterwerken der buitenlandsche romanlitteratuur

Amsterdam: Van Holkema \& Warendorf, 1910

Figure 4.2 Advertisement in De Amsterdammer, 10 August 1913

Figure 4.3 Advertisement in Algemeen Handelsblad, 28 February 1941

Figure 4.4 Dust jacket of the illustrated edition of C.J. Kelk's translation

Amsterdam: Contact, De Onsterfelijken, 1941

Figure 4.5 The first Dutch paperback edition of Madame Bovary, translation by Margot Bakker

Amsterdam: L.J. Veen, Amstelboeken, 1960

Figure 4.6 The first of many editions of the translation by Hans van Pinxteren

Utrecht/Antwerpen: L.J. Veen, 1987

Figure 4.7 Luxury edition of the revised translation by Hans van Pinxteren

Amsterdam: Athenaeum - Polak \& Van Gennep,

Perpetua Reeks, 2009

Figure 6.1 Picture: Antiquariaat Fokas Holthuis, The Hague

Figure 12.2 @ Stefan Vanfleteren 


\title{
Introduction
}

\author{
Helleke van den Braber, Jeroen Dera, Jos Joosten, and \\ Maarten Steenmeijer
}

'Brands prefigure our experiences of products.' - Michael Bhaskar

Branding Books Across the Ages researches the process of branding writers, literary works, oeuvres, genres, publishers, and literary journals through the centuries. We take as our starting point the idea that, both in a contemporary context and historically, literature has been subject to branding. Moreover, it is assumed that this complex cultural process is determined by time-related factors in which a diverse range of actors (writers, agents, publishers, book traders, critics, readers) play a role. We ask under which conditions such literary branding takes place, whose interests are being served, and what the impact of this process - of 'turning something into a brand' - has on the creation and dissemination of literature. Via the sixteen case studies discussed in the chapters of this book, we examine the branding of Dutch literature in the Netherlands, the branding of Dutch literature abroad, and the branding of foreign literature in the Netherlands, from early modernity up to and including the present day. Whilst we demonstrate how writers themselves have consistently played a leading role in this process, the guiding role of publishers, book traders, critics, and the organizers of book fairs also becomes apparent. Throughout the centuries, the brands they have created (for themselves, their products, or literature as a whole) have been aimed towards their readers. Inevitably, our exploration of such processes also leads us towards an examination of the historical and the contemporary reader.

Below, we first explore the term and the concept of branding in the broadest sense, and subsequently define what we understand as branding within the literary domain in the context of this book. Proceeding, we

Helleke van den Braber, Jeroen Dera, Jos Joosten, and Maarten Steenmeijer (eds), Branding Books Across the Ages: Strategies and Key Concepts in Literary Branding. Amsterdam, Amsterdam University Press 2021 DOI: 10.5117/9789463723916_INTRO 
present a theoretical framework based on the following three pairs of central concepts:

1 the balance between economic and symbolic interests, which is crucial to branding;

2 the equally crucial choice of either auto-image or hetero-image;

3 the complex negotiation between resistance to or acceptance of branding.

These three pairs of concepts, which will be discussed in greater detail shortly, structure all sixteen contributions.

\section{The Concept of Branding}

It was only in the seventeenth century that the term brand (originally meaning a piece of burning wood) came to refer to a practice that dates back millenia: marking or identifying goods. Thus, in the first instance, a brand was a means of registration, an identity mark. During the industrial revolution, the possibilities for (re)production and distribution increased as never before and, as a consequence, so did competition between producers. In a market that would become increasingly globalized and competitive, a growing need arose for companies to distinguish themselves from their competitors - especially those producing and marketing similar products. At the end of the nineteenth century and the beginning of the twentieth century, companies such as Kellogg's and Coca-Cola developed branded products: products with recognizable symbols that clearly distinguished them from unbranded commodities. In this way, brands changed from simple identity marks into trademarks. In its most specific meaning, when understood as a trademark, a brand is a

unique design, sign, symbol, words, or a combination of these, employed in creating an image that identifies a product and differentiates it from its competitors. Over time, this image becomes associated with a level of credibility, quality, and satisfaction in the consumer's mind [...]. Thus brands help harried consumers in [an otherwise] crowded and complex marketplace, by standing for certain benefits and value. ${ }^{1}$

Brands can be created for various reasons (e.g. Mihailovich 2006). First of all, of course, commercial motives play a role: maximizing the sale of a product, 
or the trading value of a company. However, brands can also serve 'altruistic goals', such as (environmental) sustainability and humanitarian aid. In such cases, gaining economic capital is not the goal, but the means to an end. Yet, in both cases - and thus, this is also the case when gaining economic capital is the ultimate aim - gaining symbolic capital is crucial in order to realize the intended goals. After all, a brand is not a product in its own right, but rather is a sign or, even more concretely, an icon that embodies an identity myth. For example, the Apple brand stands for modernity, imagination, freedom, and individuality: someone who wears Nike shoes conquers their inner slacker; and drinking Coca-Cola with others creates happiness. According to Jennifer L. Aaker (1997), analogous with the Big Five from psychology, the characteristics of a brand's personality ('the set of human characteristics associated with a brand' (Aaker 1997:347)) can be condensed into the following five core dimensions: sincerity, excitement, competence, sophistication, and ruggedness. However, Aaker also notes that, whilst 'the human personality dimensions remain robust across cultures [...], the same may not be so for brand personality', and hence the 'brand personality scale' she proposes 'might not be appropriate for measuring brand personality in a different cultural context' (Aaker 1997: 355).

Initially, we might only associate brands with large companies such as Apple, Nike, and Coca-Cola. The brands of such companies and their products are especially makeable, whereas their products are essentially endlessly reproducible, and as products (based on the 'product-related attributes' that relate to their 'pure' usage functions) they do not necessarily have to differ from similar products by a different brand. However, within the domains to which the phenomenon of branding has been extended during recent decades - for example, cities, regions, and even entire countries - this is more complicated. Today, much time, effort, and money is invested in nation and city branding with an eye on specific commercial and symbolic functions, interests, and goals (e.g. the substantial increase of certain economic activities, such as tourism; attracting (mega-)events such as the Olympic Games; large-scale architectural projects). As a result of these differences, the process of place branding differs from those related to companies and their products:

Rather than a top-down authoritarian structure, the best model for implementing a nation brand is probably something closer to Al Qaeda than Josef Stalin: a loose network of semi-independent groups, each planning and carrying out its own activities and communications which are inspired by a commonly held belief in some simple, powerful mission. (Anholt 2005: 226) 
Finally, personal branding must also be mentioned here. We live in a world in which it is increasingly important to brand oneself correctly if one is to gain employment, gain funding, or secure a project.

\section{Branding in/and Literature}

Writers, literary works, oeuvres, genres, publishers, movements, and trends can also be conceived of as products that function in a certain way and gain meaning within the literary field via 'identity myths', which are (at least initially) intentionally constructed for this purpose. In a broader context, this may be compared to the idea of national literature as the brand of the nation state. As brands, writers, literary works, and so on could thus be considered signs with 'a set of regimented associations' (Moore 2003: 339) that together constitute a story or, even better, a collection of stories. After all, brands are always subject to transformation: 'For identity brands, success depends on how well the brand's myth adjusts to historical exigencies' (Holt 2004:38). 'All brands need to keep moving, keep building their stories' (Mihailovich 2006: 232). This is why Schroeder (2009:123) emphasises the importance of 'a focus on cultural processes that affect contemporary brands, including historical context, ethical concerns, and representational conventions'. Additionally, the dynamic of the complex interplay between different actors (writers, literary agents, publishers, book traders, critics, and readers) is specific to the literary field, each capable of directing and diversifying the process of branding.

In his interesting study Under the Cover: The Creation, Production, and Reception of a Novel, the cultural economist Clayton Childress (2017) discusses the structure of the process of branding within literature. For him, branding is one of the most important driving forces behind the movement of texts across fields. For him, branding comes down to the 'telling of a story' about a particular text. Both the content and the tone of that story depend on the interests and goals of the writers, agents, editors, book traders, reviewers, and readers who tell it. In every field (creation, production, reception), a different story is told about the text, and it is the development and transformation of this narrative that pushes the text from field to field. For Childress, branding thus not only occurs during the final stage of the route, when a text enters the market and has to reach a readership: rather, he emphasises the idea that processes of branding play a crucial role at every stage of the route. On the way, he argues, many conflicts occur between what one actor has to say about a particular text (how he or she wants to brand the text), and the visions of other stakeholders (Childress 2017). 
In each of the three fields - creation, production, and reception - a story is told about what makes a text interesting or important in the eyes of the actors who are working on it during that particular stage. They have an interest in 'branding', 'pitching', or recommending the text, both for themselves and for each other, in the hope that this improves the text's chances along its long route from field to field. In the chapter by Helleke van den Braber, we see how this process of 'telling stories' played a role in the branding of the early-twentieth-century Dutch journal De Beweging (The Movement). She demonstrates how the stories that editor Albert Verwey told his readers and publishers about the importance of the journal collided - with various degrees of productivity - with the stories that those readers and publishers wanted to hear, or wanted to tell themselves. In this respect, the case study of De Beweging dovetails neatly with Childress' argument that within every field a different story is told about the text.

Childress (2017) primarily points towards the breaking points that emerge at the boundaries between fields. Every field has its own (professional) language, he argues, and the 'translation process' can lead to myriad conflicts and miscommunications. Not all actors are prepared or able to speak each other's language, and the story that is told about the text or oeuvre in question over time often bears these marks. In his chapter, Gaston Franssen demonstrates how this works by researching how a miscommunication between (the persona of) the writer and the reader can be a driving force behind successful branding in relation to the authorship of Charles Bukowski. Bukowski's success as a writer primarily depended upon his image as an antisocial outlaw - a persona that increasingly came under pressure as his work became more visible. This has led to an interesting paradox in which the success of Bukowski's branding, as Franssen argues, 'belies the values that readers have come to associate with the author'.

Childress (2017) points out that, within the field of production, it is primarily the authors themselves who brand their stories, their primary aim being to bring their work, their oeuvre, or their writer's persona to the attention of agents and other intermediaries. For example, they can point towards the autobiographical background of their story, or towards a special creation narrative. When the text subsequently moves towards the next field (production), this story, which has been embraced in the initial phase, often takes on a different hue. Publishers and marketing departments each have their own ideas about what makes a text interesting or 'marketable'. This often leads them to abandon the author's or the agent's story, replacing it with a new one - often the story publishers may want to tell about the plot, 
characters, and the extent to which this text can be compared to texts by other (usually more renowned) authors.

For the authors, it is sometimes hard to accept this transformation. They have to allow their book, their oeuvre, or their writer's persona to be marketed based on arguments that differ from those they had originally envisioned. For their part, publishers sometimes have difficulty dealing with the fact that the language marketing departments (in the third and final field) use to pitch the book to reviewers can differ significantly from the arguments the publishers used - both internally and externally - to justify their publishing decisions. Reviewers have different expectations and employ different selection criteria from the general readership, and hence marketers offer them a different (branding) story about the novel to the one the in-house editors themselves might employ. For example, the branding story that is aimed at reviewers often highlights the reception of earlier texts by the same author, rather than aspects related to the plot or the characters.

Thus, with every transition from one field to another, there is a necessary and intentional 'making and remaking' of the branding of a given text. Those who 'throw' a story in one field just have to wait and see what those who 'catch' it in another field will do with the story they have created. However, at the same time, a continuous interaction between actors and fields does take place. In the best-case scenario, a 'shared language' emerges from this interaction in which all stakeholders can recognise themselves. However, following Childress (as well as Van den Braber and Franssen in the context of this volume), this is not always successful, and often disagreements between authors, publishers, and readers or reviewers about what a given text, oeuvre, or author 'is' or 'means', or what makes it saleable or interesting, originate within these branding transitions. Notwithstanding these conflicts, such disagreements and transitions constitute wonderful research material (either in their own right or for historical comparison) for scholars of literature who are interested in the 'how' and the 'why' of literary branding.

In Marketing Literature: The Making of Contemporary Writing in Britain (2007), professor of publishing studies Claire Squires points out the unstable, uncertain moments when a text travels from agent to publisher, and from publisher to the marketing department. She considers the moment at which a cover is designed, a genre category is determined, and the 'blurb' on the back face is written, to be the moment of 'authorial anxiety' - the moment when authors lose control of the publishing and branding process. The text is reinterpreted in a way they had not necessarily intended. From that moment onwards, their own vision of the genre, meaning, and importance 
of the text is subordinated to the opinion of those marketing the work. The chapter written by Lieke van Deinsen and Nina Geerdink demonstrates the long history of this anxiety through examples of early modern authors who lost control over their own brands. They demonstrate that already at that time, conflicts between the various parties involved in the branding of authorship occurred, offering striking examples of authors who did not accept the decisions that were taken for them. The authors' resistance is understandable: even then, the audience was not always sympathetic to such disconnects between the ways in which an author branded him- or herself and the ways in which they were branded by publishers.

In Branding Books Across the Ages, we assume that, in the words of Tom Peters (1997), 'a brand is a promise on the value you'll receive'. All parties involved contribute to the accumulation of expectations regarding that promise and its possible fulfilment in various (and historically variable) ways. We thus consider branding in the literary field as a process, not only in a diachronic but also in a synchronic sense. In Branding Books Across the Ages, we describe the interactive process in which authors, publishers, and readerships over time 'make a brand' of an author, a work, or a genre. How this happens, via which means and interventions, according to which processes, with which intensions, and with which results, differs for each case study.

We aim to research all stages in this process, both in the present and in the past, paying special attention to the dynamic between the three most important participants: author, publisher, and readership. We ask to what extent this entire process is intentional. Often, the publisher is the initiator of the branding process, whereas the author is the one who is being made into a brand, and the readership is the target group considered to be sensitive towards that branding, yet these roles are unstable. In the course of the process, they can be turned around and shifted in various ways and for various reasons. These transformations too, in the form of agency within the process of branding, deserve our attention.

Despite the diachronic approach of Branding Books Across the Ages, an emphasis is placed on case studies from the twenty-first century. However, this is not merely coincidental. During recent decades, the literary world has become increasingly commercial and international (Sapiro 2018). Additionally, the growth of digital technology has fundamentally changed the possibilities of connecting with (and branding for) a particular readership. At the same time, the expectations and needs of the readership are fully in transition. Today, buyers of books seem just as interested in (actively) experiencing literature as they are in (passively) reading it, and this places new 
demands upon branding strategies. Whilst this is true for both emerging and established authors, it also applies to publishers, retailers, and marketeers. Therefore, the branding of writers and texts seems more intensive than ever. One of the questions posed in this book is the extent to which this impression is indeed correct, and in which ways and to what extent previous models and strategies of branding have precipitated and heralded those we see today. Whilst Branding Books Across the Ages arguably does not contain enough historical case studies to reach any definitive statements as to the continuities and discontinuities in the history of literary branding, they are numerous enough to indeed suggest such a hypothesis. In what follows, we will first discuss the aforementioned three pairs of concepts, which are woven through, and guide, subsequent chapters.

\section{Economic versus Symbolic Interests}

When approached from the perspective of institutional sociology - or, more concretely, from Pierre Bourdieu's (1993a) theory of reversed economy - it becomes clear that branding is a complicated process. First of all, Bourdieu assumes that economic capital and symbolic capital are diametrically opposed. In short, the first (which can be expressed in money) exists in an oppositional and unilateral relation to the second (prestige, literary renown). In his classic article 'The Production of Belief', originally published in 1983 (and later adapted for, and included in, his magnum opus Les règles de l'art from 1992), Bourdieu thematizes this conflict between economic and symbolic capital, arguing that within the field of literature, economic principles are disavowed:

The challenge which economies based on the disavowal of the 'economic' present to all forms of economism lies precisely in the fact that they function, and can function, in practice - and not merely in the agents' representations - only by virtue of a constant, collective repression of narrowly 'economic' interest and of the real nature of the practices revealed by 'economic' analysis. (Bourdieu 1993b: 74)

Clearly, this poses an inevitable problem to literary publishers who, on the one hand, derive their status and raison d'être from their symbolic capital, yet on the other hand, from a business perspective, cannot escape basic economic demands (such as paying the printer, designer, or their sales department), and are thus always forced to take economic concerns 
into account. More concretely: they have to make sure their books are being sold. With regard to this problem, Bourdieu makes a clear division, in the first instance, between two types of publishing. Economic gain and (artistic) prestige seem mutually exclusive, and manifest themselves in two different cycles:

on the one hand, [there is] a short production cycle, based on the concern to minimize risks by adjusting in advance to the identifiable demand and provided with marketing circuits and presentational devices (eyecatching dustjackets, advertising, public relations, etc.) intended to ensure a rapid return of profits through rapid circulation of products with built-in obsolescence. On the other hand, there is a long production cycle, based on acceptance of the risk inherent in cultural investments and above all on submission to the specific laws of the art trade. Having no market in the present, this entirely future-oriented production presupposes high-risk investments tending to build up stocks of products which may either relapse into the status of material objects (valued as such, by the weight of paper) or rise to the status of cultural objects endowed with an economic value incommensurate with the value of the material components which go into producing them. (Bourdieu 1993b: 79)

It seems evident that the short production cycle, with its commercial logic, is intrinsic to branding as the 'putting on the market' of a writer as a product, via the related marketing strategies. However, in reality, this is more nuanced. Similarly, branding in Bourdieu initially seems irreconcilable with the practice of the publisher who strives towards optimal literary prestige and in any case, publicity strategies cannot be made too explicit: 'the law of this universe whereby the less visible the investment, the more productive it is symbolically, means that promotion exercises, which in the business world take the overt form of publicity, must here be euphemized.' (Bourdieu 1993b: 77)

Yet the disavowal of 'economy' does not lead to a complete division between both forms of capital. Bourdieu acknowledges the fact that publishers who primarily aim to gain symbolic capital do (and indeed must) also gain economic capital. He notes this almost casually when he speaks of those publishers who 'derive a sometimes very substantial economic profit from the cultural capital which they originally accumulated through strategies based on denial of the "economy"' (Bourdieu 1993b: 102). In addition, whilst the short production cycle makes use of 'advertising' and 'public relations', so, too, does the publisher with prestige who assumes a long production 
cycle. The only difference is that (what one could call) the 'branding' of the latter publisher takes place in a different way, 'deriving a strategic advantage from its refusal to use the lower forms of public relations' (Bourdieu 1993b: 99). The disavowal of economic logic and the accompanying commercial mechanisms become its brand; its adjusted mechanisms to assure itself of a position within the field.

The strategies which he [the publisher] applies in his relations with the press are perfectly adapted (without necessarily having been so conceived) to the objective demands of the most advanced fraction of the field, i.e. to the 'intellectual' ideal of negation, which demands refusal of temporal compromises and tends to establish a negative correlation between success and true artistic value. (Bourdieu 1993b: 100)

At the time Bourdieu wrote this text, he still made a rather stark division between the two systems. Fifteen years later, he published an article with the telling title 'A conservative revolution in publishing', in which he described how a new generation of publishers unproblematically and openly deployed both the short and the long production cycles:

Certain publishers new to the game may try to reconcile strategies that would be irreconcilable if the literary field were more autonomous: those geared toward a long-term investment in writers promising long and productive careers, and those geared toward more immediately profitable literary production over the short term. They are supported in this ambition by a type of modernized marketing based on the methodical use of the allodoxia. (Bourdieu 2008:142)

In the final years of his life, Bourdieu increasingly forwent his stance of analytical distance, more openly positioning himself in favour of the autonomy of the writer/artist. In his eyes, the development described in the quote above (which also made use of 'modernized marketing') was most questionable. Jos Joosten's chapter on the development of the work of the bestselling Dutch author Kluun demonstrates that this relation is still highly relevant. With Kluun, we see how the process of creating the brand 'Kluun' in the course of his first novel became the theme of his latest novel, $D J$.

Nevertheless, we cannot help but note that, even in Bourdieu's earlier work, the workings of marketing mechanisms were already evident. After all, the explicit, public disavowal of the importance of economic capital 
contributes to the gaining of symbolic capital - and thus ultimately, in the long term, to economic efficiency. Consequently, perhaps it is useful - at an institutional level and in parallel with Bourdieu's original division - to differentiate between 'economic branding' and 'symbolic branding', the first being an instrument of economic efficiency in the short term, and the second geared towards gaining symbolic capital.

Linda Ackermans' case study concerning Young Adult Literature also demonstrates the complexity of the relation between symbolic and economic capital. On the one hand, questions of symbolic prestige (e.g. encouraging the young to read and cultivating a rudimentary literary awareness) obviously play a role in the discourse surrounding this new genre. On the other hand, this is clearly also a market of great economic interest. Maaike Koffeman's chapter shows a different side of the relation between the symbolic and the economic, demonstrating that, in the Dutch marketplace at least, Gustave Flaubert's Madame Bovary emerged simultaneously as a commercially interesting mass product and a high-cultural classic with symbolic prestige.

\section{Persona versus Self-Image}

As mentioned previously, a brand is always an interplay between producers, distributers, and consumers within a specific context - in this case, the literary market. Yet it is precisely this interplay that makes it especially difficult to analytically define the concept of branding. If understood primarily as a process in which products, distributers, and consumers constitute a chain in which a story is formed about a product (i.e. a book or an author), the story in question comes to be perceived as a tangle that necessarily needs to be untangled in order to determine which actors contributed to the story at which point in time, and based on which ideas and/or with which motives.

A crucial question in this context is with which goal the story of a given brand is being told. As Laurens Ham demonstrates in his chapter on the branding of Dutch literature at the Beijing Book Fair in 2011, this question can be approached from a political perspective. Ham shows how the story of Dutch literature is permeated with national stereotypes concerning tolerance and the 'open mind' of the Dutch citizen. Conversely, branding scholar Philippe Mihailovich (2006: 229) thinks from the perspective of a market with its own related economic terminology: brands can be created for commercial reasons ('to be sold', 'to increase in value on the stock market') or can serve 'altruistic goals' - albeit ones that cannot be considered outside 
of the market context ('sustainable, long-term employment and prosperity'). Yet, as mentioned previously, within the literary field, in addition to economic capital (money), symbolic capital also plays a constitutive role. Thus, the intentional branding of books and especially authors is not always self-evident. Therefore, there are many writers (as will be explored in more detail in the subsection discussing the dual concepts of 'resistance' and 'acceptance') who disagree with the story that marketing departments tell about them, and who aim to maintain control over their own persona as authors.

Even for marketing scientists like Mihailovich, unravelling a brand's complexity is a difficult task. Whatever is being branded, there is always an interaction with the public, which plays a constitutive role in the formation of any given brand. For example, the chocolate brand Milka and their purple fields only reach their goal when the public makes the connection between Milka and 'purple', and in their turn start telling the story. In the same way, Michel Houellebecq is only an enfant terrible if not only his publisher, but also his critics and readers associate him with this archetype.

Yet there are some pronounced differences between brands such as Milka or Coca-Cola and literary brands. As mentioned previously, Milka's basic story, for example, is the same for every chocolate bar, and its branding is aimed towards making consumers buy as many of those bars as possible. Conversely, the buyers of Particules élémentaires will generally only buy a single copy of the novel. More complicated still is the influence of the object of literary branding itself, especially from an analytical perspective. Whilst a Coca-Cola advertisement tells a story about Coca-Cola as a brand, the branded bottle itself does not make its own contribution to that story. However, where the branding of authors is concerned, clearly this is a different story altogether. Whereas a brand such as Coca Cola can be considered as a research object that is being branded, as a research object, a literary author is both branded by other actors within the literary field (publisher, critique, book shop, education, societies, etc.), and also makes his or her own active contribution to that branding - unless, of course, it concerns posthumous branding, a complex process that is explored in Gwennie Debergh's chapter on Hugo Claus.

Because the process of branding is characterized by this tension between passivity and activity, research into literary branding introduces the analytical dual concepts of 'self-image' and 'persona'. The work of the Swiss literary sociologist Jérôme Meizoz offers a theoretical tool to further explore this pair of concepts. The central concept in Meizoz' thinking is 'posture'; 
a concept that he at closer inspection utilises inconsequently. In his book Postures littéraires, he defines the concept as follows:

La 'posture' est la manière singulière d'occuper une 'position' dans le champ littéraire. Connaissant celle-ci, on peut décrire comment une 'posture' la rejoue ou la déjoue. Qui fait imprimer un ouvrage (un disque, une gravure, etc.) impose une image de soi qui dépasse les coordonnées d'identité du citoyen. (Meizoz 2007: 18)

The concept of 'posture' points towards the unique way in which actors within the literary field consolidate their position (in which occuper can mean both 'occupying' and 'conquering'). In this way they not only mark their own unique position, but also differentiate themselves as 'authors', as opposed to citizens who do not play a role in the literary field. Crucial to this definition is the idea that the authors create an 'image de soi'. This explicitly concerns a self-image, to which other actors within the field do not make any defining contributions.

In his later work, Meizoz seems to add more precise nuance to this idea. For example, in 2010, he writes the following about posture in his first analysis written in English: 'Posture is not uniquely an author's own construction, but an interactive process: the image is co-constructed by the author and various mediators (journalists, criticism, biographies) serving the reading public' (Meizoz 2010: 84). Thus, it is no longer about a singular image that the author creates on his or her own account, but about a co-construction to which other institutions within the field also contribute. With this 'overarching' definition of the concept of posture, Meizoz also touches upon the question of branding. Like a brand can be considered a sign with a 'set of regimented associations' - as Moore (2003: 339) called it - posture can also leave a strong mark on the way in which a given readership perceives an author.

Meizoz' theory on posture is clearly a work in progress, and this is partly why he gives different definitions of his own concept in different contexts. This forces researchers to operationalize very narrowly what they understand as 'posture'. On a methodological level, it is highly questionable whether posture concerns purely a construction by the author, or if it concerns a co-construction between the author and others. In the first case, posture can be seen as a form of auto-presentation, whilst in the second, both auto- and hetero-presentation are part of an author's posture. In order to avoid this vagueness of terminology, and because authors can react to their hetero-presentation through auto-presentation, we propose to conceptually 
differentiate between these two terms. Therefore, we understand 'posture' as referring to self-representations by the author, whilst we refer to representations by others (critics, teachers, publishers, marketers, other authors, journalists, radio and television commentators) with the term 'persona' (cf. the work of Ruth Amossy). In practice, the concepts of posture and imago exist in a mutual interaction, because authors can react (with varying degrees of success) to their persona via their posture. This is especially true for 'domestic authors', as opposed to 'foreign authors', as Maarten Steenmeijer argues in his chapter on the Dutch cover of Carlos Ruiz Zafón's bestseller The Shadow of the Wind, which he analyses as a brand for the covers of the Dutch translations of novels by other Spanish authors.

The difference between posture (one's self-image) and persona (one's image in the eyes of others) is especially helpful in research into literary branding because it allows us to analyse the specific contribution of a branded author to the story that is being told. The case studies in this book demonstrate the following three scenarios when this form of agency is concerned. First of all, it is possible that an author is merely the object of branding, in which case the author's image thus consists of a persona only. This is revealed in the chapter by Paul Hulsenboom, in which he demonstrates how a specific persona of the Polish king and letter writer Jan III Sobieski was created as a direct result of the prevailing Dutch translation style of the early nineteenth century. In the second scenario, the publisher takes the initiative in creating a brand, whilst the author plays a facilitating role. For example, Roel Smeets' chapter on the publisher Das Mag and its author Lize Spit illustrates how Spit primarily supports the story that the publisher wants to tell about itself, thus grafting her own posture on that of her publisher. Last, the initiative for an author's brand can also explicitly lie with the author - the third scenario, in which the author explicitly turns him- or herself into a brand, carefully monitoring his or her own public persona. This becomes evident, for example, in Jeroen Dera's chapter on Ellen Deckwitz, who presents a consistent story about her role as an ambassador of poetry via her self-presentation.

Meanwhile, Meizoz's thinking about 'posture' offers another productive framework with which to approach branding. Meizoz considers literary authors in terms of their uniqueness. Within the boundaries of the literary field, authors aim to establish an image of themselves that is as unique as possible - a trademark. The process of branding can confirm the author's singular self-image (which leads to an effective 'posture', according to Meizoz), but it is equally possible that the author's persona (as branded by other actors) conflicts with this singular self-image. The link with the dual concepts 'resistance' and 'acceptance' is thus easily made. 


\section{Resistance versus Acceptance}

The third pair of concepts we utilise in this book foregrounds forms of contested branding, based on the assumption that authors can accept, embrace, or strengthen the brand their work is being made into, but can also express resistance towards it. They can collaborate with others in the process of branding (publisher and readership), but they can also oppose and resist them. In that case, they will try to undermine, adjust, or overthrow their brand in every possible way. Such resistance can be either implicit or explicit, stay behind closed doors, or be played out in the media. In this instance, the readership also has agency, either finding a brand believable and taking it seriously, or considering it unbelievable or 'farfetched'.

Concerning the relationship between the brand and the public, Linda Ackermans's chapter demonstrates just how precarious the connection between the two can be. She researches the strategies with which publishers of Young Adult literature try to convince a young readership of the credibility and attractiveness of the genre. Finding a convincing way to connect with their life worlds turns out to be a challenging task. In his chapter, Roel Smeets points out that the publisher Das Mag seeks precisely this sort of controversy by opposing competing publishers. This young publisher energises the Das Mag brand via the provocative (because not necessarily realistic) claim that it does business in a completely different way to more established companies. The fact that this message (and hence the brand) was immediately contested, put the publisher on the map. The Dutch writer Kluun also saw the potential in controversy and thus, in his chapter, Jos Joosten argues that writers such as Kluun navigate between complicity on the one hand, and distinction within the field on the other. As Joosten shows, Kluun established his brand by operating predictably and in accordance with the rules of the field on the one hand, whilst provocatively opposing them on the other. The fact that this double strategy led to a widespread rejection of his brand (and the kind of authorship he tried to project) was all simply part of the strategy.

These are examples of processes of resistance and acceptance that have until now hardly been mapped, and theorization in this field remains largely absent. Contested branding can perhaps best be researched by studying the tensions in the relationships between makers and other participants in cultural life. The art world perspective of Howard Becker (1982) offers several interesting insights not only into the modern period, but also in a historical context. Clayton Childress (2017) and Claire Squires (2007) researched modern forms of marketing in the publishing business. Whilst 


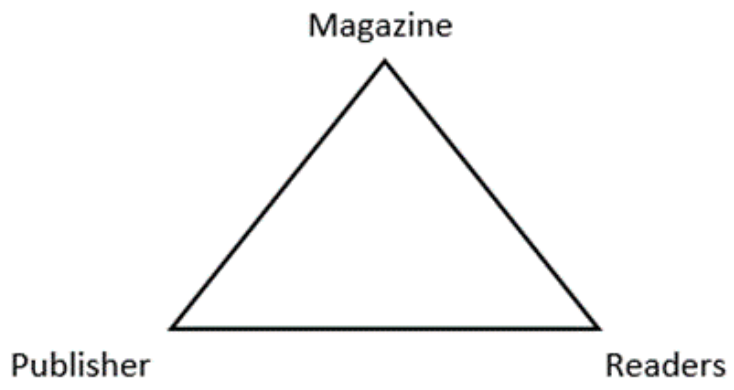

their institutional analyses are directed towards contemporary process of branding, they can also help to understand the more historical disagreements (whether deliberate or not) between the three stakeholders in the branding process.

These are the three basic participants found in every form of literary branding - both historical and contemporary. Publisher, author, and readership each play a role, either as initiator, object, or recipient of the branding process. Because branding is an interactive process, these roles are inherently unstable, and the relations between the different actors in this process are in a state of constant transformation. The exchange between writer, publisher, and readership differs, not only for each (historical) period, but also for each (national) field, and for each case study. Finally, on the level of individual case studies, the nature of their interaction differs for each stage in the writing, publishing, and reception process. The extent to which the branding visions and intentions of these three stakeholders converge, is equally changeable and unstable.

Those who want to research the how and why of this instability may look towards the aforementioned work of Clayton Childress. In his Under the Cover: The Creation, Production, and Reception of a Novel (2017), Childress envisions a perspective other than the triangle presented above. Rather, he describes it as part of a long, linear route, arguing that each literary text that travels this route, visits three fields. He discerns the following steps: first, the text travels from author to agent (both actors operate in what Childress calls the 'the field of creation'), and subsequently moves to the publicity department via the publisher (who both operate within 'the field of production'). The text then travels to the reader or to the reviewer via the book seller (active within 'the field of reception'). It is not difficult to make Childress's perspective on 'branding as a route' productive for earlier historical periods, in which journals and newspapers, for example, inspired authors in 'the field of creation' to produce feuilletons, and printers 
(rather than publishers) took care of the dissemination of texts within the field of production. The basic idea of a linear route still holds true in these contexts. However, Childress's use of the term 'field' can also be confusing, as in his work the term seems to refer to the simple domains of production, distribution, and reception, rather than to the more complex idea of a field as a 'space of positions and position-takings', as espoused by Pierre Bourdieu (1993a: 30).

Like Squires and Childress, the sociologist Howard Becker (1982) studies the structure of the cultural field in his work Art Worlds, although providing a more systematic and a-historical perspective than the aforementioned authors. He also pays detailed attention to the processes of collaboration within the art worlds he describes. According to Becker, makers, disseminators, and recipients of art contribute to smoothly functioning art worlds, combining their efforts to "[produce] the kind of art works that art world is noted for' (Becker 1982: $\mathrm{x}$ ). This collaboration is partly organized via a system of (unspoken) guiding conventions. Becker refers to those actors who are familiarized, and operate in accordance, with such conventions as 'integrated professionals' - people who know what kind of work will most easily find an audience amongst those interested in that type of art, and which approach can cause that specific art world to function most efficiently. A shared tradition of problems and solutions makes it easier to establish workable conventions and habits, as well as to cope with tensions and change. Integrated professionals (which, in the literary world, can be the authors themselves, but also publishers, marketers, reviewers, or intermediaries) will not consciously choose a course of action that will endanger the status quo of that particular world, or oppose accepted ways of working. Whilst the art they promote does not have to be safe or predictable, their ways of making, disseminating, and receiving definitely are. Integrated professionals, Becker argues, are not easily tempted to consciously oppose conventions or conceptions, or force a break with the ways in which a readership perceives a text, an author, or an oeuvre. They have an interest in (re)presenting the activities within their particular arts world as the result of a well-oiled machine. In other words, we cannot expect any forms of contested branding to result from their actions.

This is different for those actors who Becker (1982) refers to as 'mavericks' (an interesting detail here being that, as a figure of speech, 'maverick' is derived from the name of a quirky nineteenth-century American livestock farmer who refused to brand his cattle). Every field of art has its mavericks. Often, mavericks start out as integrated professionals, after which they distance themselves from the usual or accepted course of action having grown 
discontented with established practice, their own role in it, or the position of their work. Precisely because they are well aware of the rules of the game, these dissidents also know how to oppose them. Often, they consciously push boundaries to strengthen or emphasise their position through their resistance. In this way, they claim attention and recognition they would otherwise not receive. Mavericks enjoy creating tension and do not hesitate to make or exhibit this friction publicly. Sometimes their resistance is subtle, and sometimes it is radical in nature. They willingly oppose implicit artistic and organizational conventions, for example by making them explicit, questioning them, rejecting them, or ignoring them. When mavericks enjoy a strong position or a prominent reputation, such acts of resistance forces art worlds to somehow justify their established choices and defend 'how things are done'. The chapter by Roel Smeets demonstrates how Das Mag consciously assumed the maverick position and indeed managed to raise these kinds of questions within the field. As we will see in Gaston Franssen's chapter, the writer Charles Bukowski both benefited and suffered from his branding as a maverick. It seems logical to link the idea of contested branding to the role of mavericks in the art world. Yet whether writers who resist their brand are also recalcitrant in different domains is an interesting question. In addition, it remains questionable whether such displays of public resistance are always authentic, or whether they can also be (at least partly) seen as stunts. Furthermore, it is also open to question under which conditions internal unrest (directed towards the publisher or editor) remains behind closed doors or, conversely, finds its way into the outside world.

Writers are not the only ones who sometimes resist brands; readers can also resist new or existing stories about who or what a given writer, text, or oeuvre 'is', or should 'mean'. In marketing science, much has been written about consumers who turn against brands. Following Childress's argument that the branding of literature is a process in which actors tell and re-tell stories about texts, it is interesting to look at existing research into the (lack of) success of brands that practice so-called 'emotional branding'.

Craig J. Thompson, Aric Rindfleisch and Zeynep Arsel (2006) argue that emotional branding is a way to involve consumers in a brand by telling stories 'that demonstrate a genuine understanding of consumers' lifestyles, dreams, and goals' (50). Such 'story-driven' emotional branding is directed towards optimal resonance, and is more successful than other forms of marketing in engaging and affecting consumers. The author Ellen Deckwitz is an example of a writer who utilises this form of emotional branding by emphasizing her generosity and 'relatability' towards both her readership, and her fellow writers. Jeroen Dera demonstrates how Deckwitz manages 
to highlight this story with credibility. However, following Thompson, by employing such an approach Deckwitz also risks that her readers may not perceive these stories as authentic and fitting, and might actively resist them.

Story-driven strategies of emotional branding sometimes cause a 'cultural backlash' amongst consumers. Sometimes this leads to public resistance, led by a loosely organized network of consumers, antibrand activists, bloggers, and opinion leaders in news and entertainment media' (Thompson et al. 2006: 50). Together, they ensure that the stories told by a given company are made into a parody, contested, undermined, and ridiculed. If such resistance persists, this can lead to what Thompson et al. call a 'full-blown brand image crisis' (2006: 62). This divide between a brand and its public is always driven by a loss of trust in the authenticity of the story or the 'aura' of that brand. The 'meaning' of the brand as perceived by the audience no longer matches the meaning of the branding story projected by the company. In yet another interesting crossover to the dual concepts 'economic' and 'symbolic', Thompson et al. conclude that 'the cultural tension between the ideal of authenticity and popular conceptions of commercialism' (2006: 53) often lies at the base of the mismatch between the story that is being told, and the story that the public wants to hear.

Although emotional branding is not applied within the literary segment of the publishing industry on a large scale, the telling of stories is indeed an important way to brand authors, texts, and oeuvres. According to Thompson et al. (2006), this means that the sector is relatively vulnerable to 'cultural backlash', which may occur when consumers are not able or willing to believe such stories. This vulnerability is possibly increased by the internal tensions of the publisher between (the creation and projection of) economic and symbolic value. The friction between authenticity and commerce is omnipresent in this sector and, according to Thomson et al., this can complicate the communication between literary brands and consumers in a myriad ways, as for example becomes evident in the chapter by Sander Bax about the bestselling author Herman Koch.

Branding Books Across the Ages closes with a chapter by Bertram Mourits. With a $\mathrm{PhD}$ in Dutch, Mourits has been a publishing editor at the renowned publishing house Atlas Contact in Amsterdam for over ten years. The composers of this volume are very pleased he accepted their invitation to draw some critical conclusions between the various contributions to this book from his specific, manifold (practical) expertise. It is evident that research into branding throughout the centuries sometimes reveals uncomfortable mechanisms that undermine the idea (or the cliché) of literature as a timeless phenomenon, the worth of which will sooner or later become apparent. However, the extent to which processes of branding manifest themselves differently, or even seem 
largely absent, during particular periods, is for example evidenced by Rob van de Schoor's chapter on Dutch publishing practices in the nineteenth century.

Finally, we must consider the fact that the studies presented in Branding Books Across the Ages are primarily focused on the literary field. It thus concerns a domain that, economically speaking, forms a relatively small proportion of the total books on offer, which currently in the Netherlands comprises around 40 million books per year (Anonymous 2019). To give a small, estimated indication of the relation of this literary segment compared to the total production of books, the 'CPNB Top 1002018 ', listing the 100 best-selling novels of 2018, comprised a total of seven Dutch 'literary' titles (taking a title's inclusion on the shortlist for the Libris Literature Award as the criterion for what counts as 'literature'), together accountable for an estimated total of 400,000 sold copies - that is, 1 per cent of the total book sales in the Netherlands. ${ }^{2}$ This is only a fraction of the total production of literary titles: the shortlist of the Libris Literature Award 2018 contains 227 titles. ${ }^{3}$ Even when doubled or multiplied by a factor of three or four of the total of sold copies in the Top 100, the contribution of the literary sector when compared to total book sales remains modest. Other sectors of the publishing industry (e.g. school and study books, informative books) function in ways that differ greatly from those in the literary sector, and thus, their branding plays a very different - and generally speaking less contested - role. Therefore, paradoxically, Branding Books Across the Ages confirms the unique character of the literary field by analysing a phenomenon - branding - which is seemingly alien to the field, even if this exceptional status is becoming increasingly contested in the twenty-first century.

\section{References}

Jennifer L. Aaker. 1997. 'Dimensions of Brand Personality'. Journal of Marketing Research 34: 347-356.

Simon Anholt. 2005. 'Editorial: Nation Brand as Context and Reputation'. Place Branding 1.3: 224-228.

[Anon] 2009. 'Boekenverkoop stabiliseert'. Available at: Leesmonitor Sticht-

ing Lezen. Onderzoek naar lezen, leesbevordering en literatuureducatie.

2 The seven authors who are both shortlisted for the Libris Literature Award and occur in the Top 100 are: Murat Isik, Hendrik Groen (with three titles), Tommy Wieringa, Lévi Weemoedt, Marieke Lucas Rijneveld, Pieter Waterdrinker, and Jan van Aken. Compare https://www.cpnb.nl/ sites/default/files/cpnb_files/EMBARGO\%2oCPNB\%2oTop\%20100\%2obest\%2overkochte\%2o boeken\%202018\%2odef.pdf [accessed 13 October 2019].

3 https://www.librisprijs.nl/groslijst-2018 [last accessed 13 October 2019]. 
https://www.leesmonitor.nu/nl/boekenvak\#boekverkoop-stabiliseert [accessed 10 December 2020]

Howard Becker. 1982. Art Worlds. Berkeley: University of California Press.

Michael Bhaskar. 2013. The Content Machine: Towards a Theory of Publishing from the Printing Press to the Digital Network. London: Anthem Press.

Pierre Bourdieu. 1993a. 'The Field of Cultural Production, or: The Economic World Reversed'. In Pierre Bourdieu, The Field of Cultural Production: Essays on Art and Literature, pp. 29-73. Cambridge: Polity Press.

Pierre Bourdieu. 1993b. 'The Production of Belief: Contribution to an Economy of Symbolic Goods'. In Pierre Bourdieu, The Field of Cultural Production: Essays on Art and Literature, pp. 74-111. Cambridge: Polity Press.

Pierre Bourdieu. 2008. 'A Conservative Revolution in Publishing'. Translation Studies 1.2: 123-153.

Clayton Childress. 2017. Under the Cover: The Creation, Production, and Reception of a Novel. Princeton, NJ: Princeton University Press.

Douglas B. Holt. 2004. How Brands Become Icons: The Principles ofCultural Branding. Boston: Harvard Business School Press.

Jérôme Meizoz. 2007. Postures littéraires: Mises en scène modernes de l'auteur. Essai. Geneva: Slatkine.

Jérôme Meizoz. 2010. 'Modern Posterities of Posture: Jean-Jacques Rousseau'. In G.J. Dorleijn, R. Grüttemeier and L. Korthals Altes (eds.), Authorship Revisited: Conceptions of Authorship around 19oo and 200o, pp. 81-93. Leuven: Peeters.

Philippe Mihailovich. 2006. 'Kinship Branding: A Concept of Holism and Evolution for the Nation Brand'. Place Branding 2.3: 229-247.

Robert E. Moore. 2003. 'From Genericide to Viral Marketing: On “Brand”'. Language and Communication 23: 331-357.

Tom Peters. 1997. 'The Brand Called You'. Fast Company Magazine, August/September. https://www.fastcompany.com/28905/brand-called-you [accessed 10 December 2020]

Gisèle Sapiro. 2018. 'Publishing Poetry in Translation: An Inquiry into the Margins of the World Book Market'. In J. Blakesley (ed.), Sociologies of Poetry Translation: Emerging Perspectives, pp. 23-42. London: Bloomsbury.

Jonathan E. Schroeder. 2009. 'The Cultural Codes of Branding'. Marketing Theory 9: $123-126$.

Claire Squires. 2007. Marketing Literature: The Making of Contemporary Writing in Britain. London: Palgrave Macmillan.

Craig J. Thompson, Aric Rindfleisch, and Zeynep Arsel. 2006. 'Emotional Branding and the Strategic Value of the Doppelgänger Brand Image'. Journal of Marketing 70.1: 50-64. 



\title{
Cultural Branding in the Early Modern Period
}

\author{
The Literary Author ${ }^{1}$ \\ Lieke van Deinsen and Nina Geerdink
}

\begin{abstract}
The early modern commercial book market was the cradle of authorial branding. Authors and publishers increasingly explored the construction of authorial brands: a set of recurring and recognizable characteristics associated with authorial images. This chapter looks at branding in the context of the media landscape of the early modern Dutch Republic. Authorial branding developed over time in conjunction with new conceptions of the individual, technological innovations, and the changing role of - amongst others - patrons and publishers. Analyses of the branding of Jan Jansz. Starter (1593-1626) and Sara Maria van der Wilp (1716-1803) illustrate how the non-formalized, dynamic constellation of the literary field inspired various agents to create a range of (multifaceted) author brands on the spectrum 'economic-symbolic'.
\end{abstract}

Keywords: early modern period, Dutch literature, authorship constructions, Jan Jansz. Starter, Sara Maria van der Wilp

\section{Introduction: Branding as a Useful Concept in the Early Modern Period}

Shortly after the renowned philosopher Erasmus (1466-1536) died, his Rotterdam house became a place of pilgrimage and, as one of the first

1 The authors would like to thank Arnoud Visser for his constructive comments and recommendations on an earlier version of this chapter.

Helleke van den Braber, Jeroen Dera, Jos Joosten, and Maarten Steenmeijer (eds), Branding Books Across the Ages: Strategies and Key Concepts in Literary Branding. Amsterdam, Amsterdam University Press 2021 DOI: 10.5117/9789463723916_CHO1 
Figure 1.1 Steven van Lamsweerde, Sight on the Dom in Utrecht anno 1660. Rijksmuseum Amsterdam: RP-P-AO-5-23

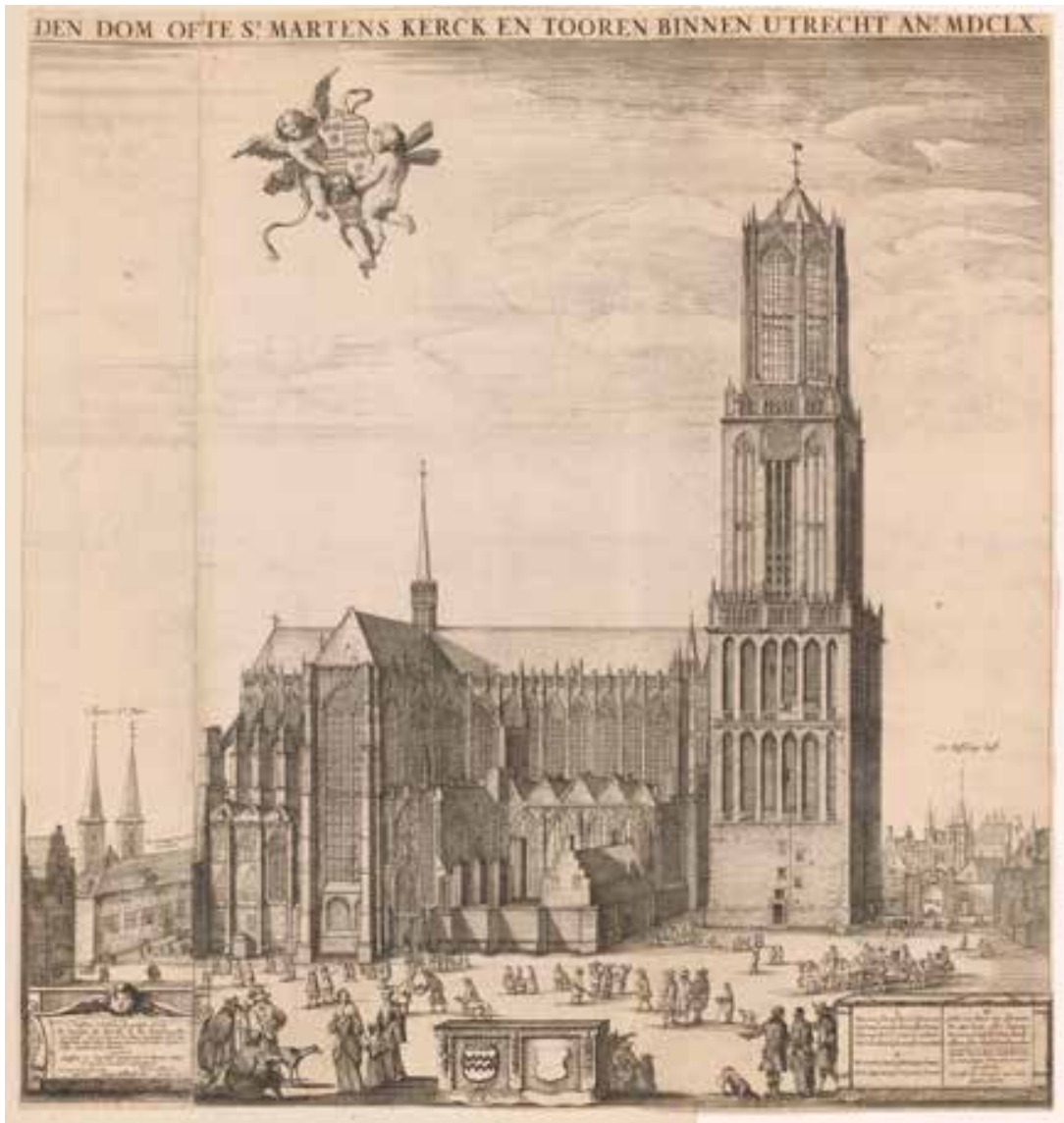

non-royal figures, he was honoured with a statue as early as 1557 (Visser 2013: 21-23; Becker 1979:11-62). This form of (cultural) hero-worship can be regarded as a characteristic of the early modern period that in many cases can be related to branding. Brands, not only as identity marks but also as trademarks, already existed prior to the industrial revolution - and the global trade and competition it brought - within the cultural world in any case. One such example can be seen in the way an author's reputation could become incorporated into the branding of a city. The house of Anna Maria van Schurman (1607-1687) was marked on several prints of the city centre of Utrecht (see Fig. 1.1). The phenomenon of branding cultural products and especially its creators expanded enormously within the early modern period. 
This chapter focuses on authorial brands, which we define as a set of recurring and (even on an associative level) recognizable characteristics connected to authorial images, both discursive and non-discursive. Early modern authorial brands were, as we will argue, a construct of the (sometimes unintended) interaction between multiple agents involved in the processes of production, distribution, and reception of (printed) literary works. In particular, publishers and booksellers proved eager to explore opportunities to profit financially from the branding of authors in their funds. Supported by the lack of clear copyright regulations for authors, some profit-driven publishers even went so far as to cleverly hijack successful authors from their colleagues in the printing business. An early example of the (legitimate) branding of a literary author by a publisher is the way the Amsterdam publisher and bookseller Cornelis van der Plasse (1585-1641) handled the legacy of Gerbrand Adriaensz. Bredero (1585-1618). He made Bredero posthumously into his 'star author' by publishing his collected works with biographical notes, personal documents such as letters, and portraits in its preliminaries (Jansen 2019). Furthermore, early modern authors themselves - both male and female - were often actively involved in the branding of their authorship and public image, as will become clear from the two cases central to this chapter, Jan Jansz. Starter (1593-1626) and Sara Maria van der Wilp (1716-1803).

The usefulness of the concept of branding for the early modern period was recently convincingly argued by book historian Andrew Pettegree. In his tellingly titled Brand Luther, Pettegree traces the origins of the large-scale success of the Reformation to the fact that its religious leader, Luther, was presented as a Europe-wide recognized brand (Pettegree 2015). To achieve this, Pettegree (11) describes how 'Luther and his friends used every instrument of communication known to medieval and Renaissance Europe: correspondence, song, word of mouth, painted and printed images.' Supported by his network of (among others) publishers, painters, theologians, and intellectuals, Luther not only succeeded in establishing a unique public image for himself but also for his printed publications. Both Luther himself and his works shared a distinctive new 'look' which made them immediately recognizable as part of what Pettegree labels as the 'brand Luther'.

Pettegree's book-historical analysis not only proves the usability of the concept of branding for the early modern period but stresses also its fundamental historicity. He shows how Luther's branding was at the same time a cause and consequence of both the development of the printing press into an effective medium and the development of the Reformation into an effective European-wide movement. Indeed, as has been argued in the 
general introduction to this book, brands are dynamic phenomena that take shape and function in a specific historical context. In our case, focusing on literary authors, this is the context of early modern literary culture, which was integrated strongly in society as a whole. Literary authorship in the period was, in the words of Berensmeyer, Buelens, and De Moor (2012: 8), a heteronomous 'product of cultural networks and their acts of authorization'. Therefore, before we further explore manifestations and specificities of the branding of (literary) authorship in the early modern Dutch Republic, we will focus on two important developments that had a major impact on the position of the author and the dynamics of the cultural field in this period: the rise of the individual and the increasingly public character of literary culture as a consequence of, among other things, technological and commercial innovation of the printing presses.

\section{Individualization and Print as Motors of Early Modern Branding}

The early modern period has often been described as the age in which the self became a matter of international debate, and scientific and societal changes reshaped its concept. The rising prominence of the individual was also reflected in the growing interest in the author's persona. ${ }^{2}$ In his influential Renaissance Self-fashioning: From More to Shakespeare (1980), Stephen Greenblatt (2005: 1) famously contended that in the sixteenth century 'there were both selves and a sense that they could be fashioned'. Greenblatt studied the processes of this self-fashioning for a specific group of persons: literary authors. It is important to note here that the early modern concept of literature differs greatly from present-day conceptions of it, and self-fashioning was a process of negotiation that went beyond the demarcated literary field as presented by Bourdieu. Early modern literature was emphatically part of society as a whole and self-fashioning depended on much more than literary values alone. ${ }^{3}$ Literature was, for example, constantly negotiating with all kinds of political and religious powers. However that may be: Greenblatt leaves us with the pertinent conclusion that the early modern period was not only marked by a growing self-consciousness of the individual but also by an increased interest in actively modelling it,

2 See, for example, Taylor 1989.

3 For an introduction on literature's role in the early modern world see for example Geerdink and Montoya 2018, about the concept of literature, especially 159-161. See also: Leemans and Johannes 2013 . 
especially by literary authors. Indeed, scholars of the early modern period agree that, gradually, a process of individualization took place that provided literary authors with a new kind of authority which went hand in hand with the increasing importance of their distinctive names and personalities. Building on these insights, many of their studies have situated the 'birth' of the modern author in this period. ${ }^{4}$ Then again, it should be noted medievalist and Renaissance scholars have made equally convincing cases to pinpoint the origins of the autonomous author in earlier periods. ${ }^{5}$ With regard to the early manifestations of cultural branding, the cases of Dante (1265-1321), Petrarca (1304-1374), and Chaucer (c. 1343-1400) - and their claims to literary fame - are especially interesting, yet exceptional for their times (Cooper 2010; Braudy 1997: 228-229).

The reason this chapter primarily focuses on the early modern period has to do with a second development which had a major impact on both the function and form of cultural branding: literary culture gained an increasingly public character. There was, for example, an increasing number of public spaces and platforms to perform, including the chambers of rhetoric, the theatre, festive events, public buildings, and - in the eighteenth century - literary societies. It was, however, predominantly due to print culture that the reputation of authors definitively transcended its initially local character (Pettegree 2015: 11). Technological innovation of the printing presses in the second half of the sixteenth century provided publishers with - amongst other things - the opportunity of higher print runs of both texts and images, which radically changed the commercial potential of the book market. ${ }^{6}$ Due to this upscaling, the early modern book industry became increasingly oriented towards an anonymous readership. Many authors no longer primarily wrote their works for a small and often well-known public. This need to appeal to a larger audience of potential buyers proved highly stimulating, as we will illustrate, to the development and uses of branding strategies (Berensmeyer, Buelens, and Demoor 2012: 16).7

As in modern times, the branding of early modern literary authors was not limited to authorial agency only. On the contrary, sometimes the author

4 See, for example, Viala 1985; Couturier 1995; Ingressia 2015.

5 See, amongst others, Cooper 2010: 361-378; Ascoli 2008; Braudy 1997.

6 Cf. Rasterhoff 2017; Van Netten 2014.

7 It is important to emphasize, though, that literary authors from the early modern period did not write solely for the book market. Many print-publications were intended for a specific audience of, for example, patrons, and moreover, manuscript culture flourished in the period, too. For reasons of coherence, we focus on the area in which authorial branding most evidently plays a pivotal role: commercial print culture. 
him- or herself was not even involved in the construction and distribution of their own brand, especially since the early modern literary field did not know any copyright legislation to protect authors as the owners of their works. In the Netherlands, author's copyright was only formally recognized in 1812 (Van Vliet 2007: 253-255). Networks were crucial in early modern literary reputation management - whether directed by the author him- or herself or by any other agents. ${ }^{8}$ Branding was built on a potentially unlimited number of agents, including not only the profit-seeking publisher-booksellers, who often carried the financial risk of a publication, but also, for example, editors, translators, (possible) patrons, other writers, literary critics or journalists, and even readers. ${ }^{9}$ Sometimes these different agents had contradictory interests. For literary authors, print culture and its power to quickly and widely disseminate brands, therefore, not only brought chances but also contained risks ${ }^{10}$ - as our discussion of the image of Sara Maria van der Wilp will vividly illustrate.

Both the growing importance and individualization of the author's persona and the commercialization of the book market proved to be, as Andrew Pettegree has illustrated in his survey The Book in the Renaissance, dynamic developments which spread with different speed and intensity through early modern Europe (Pettegree 2010). The early modern Dutch Republic provides a particularly interesting focus area. Its status as one of the most important centres of Europe's transnational intellectual community, the Republic of Letters, went hand in hand with both the vivid circulation of new enlightened ideas on, amongst others, the growing importance of the individual, and the early rise of a highly developed market for printed materials which made the Dutch presses international leaders in the dissemination of books. ${ }^{11}$

Against this background, the remainder of this chapter will argue how authorial brands in the early modern Dutch Republic were hardly ever unambiguous. Since processes of branding were not formalized, the specific role of the agents, including the audiences, varied. As such, a very diverse range of brands was possible. In the next section, we will elaborate on this thesis

8 As in other periods, you could argue on the basis of Craik 2009.

9 Cf. MacLean 2012, with a telling enumeration of agents (53); and also, for example, Visser 2011: 8; Visser 2013: 19; Berensmeyer, Buelens, and Demoor 2012: 10.

10 See also Sebastiani 2014: 107-124, especially 115 .

11 On the Dutch book market, see for example Van Vliet 2007: 253-255; Dijstelberge and Verkruijsse 2010, and, most recently, Pettegree and Der Weduwen 2019; on individualization (and authorship) in the Dutch Republic Porteman and Smits-Veldt 2008, especially 17, 21, 28, 160, 171, 189; Jensen Adams 2009, especially 22. 
and then illustrate it with the case of the multifaceted branding of the early seventeenth-century Dutch author Jan Jansz. Starter, who, as a hack writer, turned out to be able to orchestrate his own branding to a large extent. Such author-driven branding appears to become impossible later in the early modern period as a consequence of an increase in the diversity of media. In the last two sections of this chapter, we will focus on this development and show how the late eighteenth-century poet Sara Maria van der Wilp operated within a field of conflicting interests between agents, in which she proved - despite considerable efforts - unable to orchestrate her own brand to her liking.

\section{Early Modern Diversity of Brands}

The dynamics of the early modern publication context, leading to a diverse range of brands, are related to the early modern literary field being tied up with society at large, as elaborated above. At the end of the sixteenth century, literature first and foremost had a social and intellectual function. This function could not easily be reconciled with a commercial interest. The literary elite was initially not eager to be printed and traded as a brand. P.C. Hooft, for example, even published his first poetic publications without his name on it - although his authorship must have been clear to his inner circle, for example from the first emblem in his Emblemata Amatoria (1611), with the motto 'Zij steeckt om hoogh het hooft' (She raises the head [hoofd]) (Hooft 1611: 78-79). The initial reluctance of Dutch authors to be part of the world of print could probably also be related to its commerciality and the reputations of the profit-oriented publishers, who were, especially in the Dutch Republic, infamously seen as 'moneygrubbers' (geldwolven). ${ }^{12}$ In due course (or very quickly, as the example of Starter below will show) many authors overcame the aversion to print and, stimulated by ongoing processes of individualization, the number of authors who print-published their literary works openly was on the rise throughout the whole of the seventeenth century. Publishers would turn out to be of major importance for the branding of literary authors (Rasterhoff 2017: 82), while authors themselves increasingly came to recognize the possibilities of print and learned to profit from it.

12 See Van Vliet 2007. Some critical contemporaries, especially in England, even characterized the business of book publication in terms of 'paper-prostitution', which became an increasingly urgent matter in relation to the growing presence of the individual author in the course of the seventeenth century. McCarthy 2020: chapter 5 . 
Due to the rising number of authors from the second half of the seventeenth century onwards, it became increasingly important for them to distinguish themselves from others (Geerdink 2012: 13-15, 19; Johannes 2001-2002: 351-354). Notably, the growing focus on publishing in the vernacular, due to the decline of Latin as the lingua franca of the learned world and the (assumed) dominance of French translations, particularly in the Dutch theatres, stressed the limits of the Republic's book market and forced Dutch authors into competition. ${ }^{13}$ Berensmeyer, Buelens, and Demoor (2012: 18) even argue that authorial branding, led by actors from the book market, intensified because of the decrease of the prestige of literary authors: 'What is needed then is a surplus of energy invested in the staging and presentation of authors in the media, in the marketing of faces and signatures - some authors have to be made more special, more valuable than others'. Consequently, authors' brands could vary greatly and should be related to their - and their publishers - intended audiences.

Authors who did not write solely as amateurs for their own social network - an authorial form that remained important during the whole of the seventeenth and eighteenth centuries - could have had various and not always distinct reasons for distributing their works, related to, for example, ideology, moneymaking, or reputation management. In distributing their works, they could focus on at least two kinds of audiences: a wider and anonymous audience, or a more specific audience of one or more (possible) patrons. Writing primarily for the book market, an author needed a brand that attracted an audience as large as possible, whereas when writing for patrons, without necessarily meaning the opposite, an author's brand should (also) be very specifically related to the interests of the patron(s). Patronage is a fundamental and, in comparison with modern times, distinguishable characteristic of the early modern literary field and thus of the branding of literary authors.

Just like branding, patronage in the early modern period was scarcely formalized. It could be defined as any relationship between an author and someone of a higher class or socioeconomic standing in which services were exchanged. This exchange was reciprocal and literary products were part of the reciprocity. This social practice was important in a country such as the Dutch Republic, where court culture was less rich

13 This was, for example, one of the points of debate in the so-called 'Poëtenstryt' (War of the Poets). See Van Deinsen 2017, especially 41-46. For an international perspective on the matter, see Turnovsky 2010. 
and dominant than in other European countries (Geerdink 2012: 13-15). ${ }^{14}$ Patronage could lead to personal relationships of longer duration, ${ }^{15}$ but it could also easily be characterized as commercial professionalism as it consisted of, in the words of Helen Smith (2012: 30), 'a series of separable and isolated transactions in which cultural goods are traded for money or favour'. Authors tried their best to win patron's favours, for example by writing occasional poems and dedicating books (Smith 2012: 30). In return, they received gifts or payments, but more often, they profited in an indirect manner: their patrons, for example, arranged jobs for them, or introduced them to networks that could be relevant for their jobs by inviting them to dinners and parties. Authors wrote poems in praise of their patrons and their political, commercial, and cultural deeds and importance. In many cases, a patron would like to have distributed this praise as widely as possible. An author's brand was therefore instrumental for the interests of patrons as well. They were publicly associated with an author, and thus wanted to be associated with characteristics of this author which advanced their own symbolic capital. Authors, on the other hand, could brand themselves in relation to their patrons by making their relationship public and thus emphasizing how they were appreciated by a specific person or a specific group of persons who possessed, for example, high standing in cultural circles, political influence, or great wealth. A patron could also actively participate in the process of authorial branding by publicly advertising the relationship or specific characteristics of the author. A case in point is an author like Jan Vos (1610-1667), who wrote occasional poetry and plays and maintained relationships of patronage with many among the political elite of Amsterdam around the middle of the seventeenth century. His brand consisted of the conventional characteristics of a lofty poet, but some specific associations were added that related directly to either his relationship with his patrons or with the larger audience. Vos's visual style was, for example, part of his brand, and indeed a characteristic that made him popular with the public at large. He needed a large audience of readers in order to manage both his own reputation and the reputations of his patrons. It was precisely the

14 Throughout Europe, informal patronage began to play an increasingly important role during the seventeenth and eighteenth centuries. Brewer (1997:162-163) shows how in England informal patronage evolved as a consequence of the marginalization of court patronage during the eighteenth century. See also Prescott 2003: 112-115; Smith (2012) argues convincingly it evolved even earlier, from the sixteenth century onwards, and existed next to court patronage.

15 This is a crucial part of the definition of patronage that De Beer 2013 uses in line with Griffin 1996. 
success of Vos's printed publications that made him into a useful client for his patrons (Geerdink 2012).

Writing for the larger public, writing for specific patrons, or (as happened most often) a combination of these, could all lead to both economic and symbolic capital, which were dynamically interrelated. Branding, as the Introduction to this book describes in more detail, falls roughly into two forms, which often interact: economic and symbolic capital. This distinction proves fruitful when looking at the early modern period, too, but it is impossible to separate the two completely, and we might even want to add a third manifestation as part of symbolic capital: social capital. Whereas Bourdieu's symbolic capital refers first and foremost to an author's position within the demarcated literary field, an early modern author's production and branding was also, as we described above, strongly related to his or her position in society at large. ${ }^{16}$

An early modern author's brand could be profitable on either side of the symbolic-economic spectrum: there was the brand 'Vondel' on the one side (the lofty author without economic imperatives) and the brand 'Campo Weyerman' on the other (the non-imposing professional author writing for money, or hack writer). Most early modern authorial brands were located somewhere between these two poles. There was thus no such thing as one successful brand for early modern literary authors, nor was unambiguity a precondition for successful branding.

Moreover, the example of Katharina Lescailje (1649-1711) ${ }^{17}$ shows that for certain authors it could be profitable not only to refrain from choosing between the two ends of the spectrum but to stay out of sight altogether, to be 'non-branded'. Lescailje was both a poet and a publisher and in this dual capacity was able to brand herself in a profitable way, for example by publishing her collected works or by including textual and visual elements in the front matter of publications of her own poetry - but she did not. On the contrary, although she published some of her own works under her own name, her self-representation in these works and its front matter is neutral at least (Geerdink 2020). She did not put herself in the spotlight and, contrary to the emerging convention, she declined to have her portrait made or distributed. As a woman, and being unmarried, it would have been

16 This works both ways: an author's social position was part of his literary reputation, whereas literary reputation could lead to social mobility. We are here elaborating on ideas presented by Ingo Berensmeyer during the KNAW-colloquium Reputation Cultures in Early Modern Europe, 27-28 August 2018, Amsterdam.

17 Biographical information in Van Gemert 2010: 308-315. 
harmful to her reputation should she eulogize herself, and as a publisher, Lescailje's income depended on her reputation within literary and political elite circles. As we have argued before, authors could not, in the end, completely control their own branding, and Lescailje's collected works were published twenty years after she had died. The front matter of this monumentally designed publication in three volumes is branding at work: the publisher - tellingly, Lescailje's nephew - included many poems full of praise of the author, a portrait of Lescailje, and a short introduction to her life and works (Lescailje 1731).

\section{The Branding of Jan Jansz. Starter (1593-1626)}

The fact that early modern branding was seldom unambiguous, and should be interpreted in terms of the constant dynamics between the strife for symbolic and economic capital, becomes strikingly clear if we look at the branding strategies of Jan Jansz. Starter and his publishers. Starter, born to English parents, lived and worked alternately in Amsterdam, Leeuwarden, and Franeker as a poet and publisher before he participated in the Thirty Years War (1618-1648) as a chronicler in the service of a German count. In this capacity, he would eventually meet his end in Hungary. ${ }^{18}$ Although little more is known about his life, relatively many sources survived about the ways Starter tried to make money with his literary works. ${ }^{19}$ It turns out he did not exclude any possible way to do this. This meant his publications functioned in the contexts of both patronage and the commercial book market. Starter was actively engaged in the printing of all of his publications and tried to brand himself as suitable for his specific public of patrons and the public at large at the same time. These audiences asked for partly overlapping but also partly conflicting manifestations of authorship, which led to ambiguities in Starter's brand.

That Starter operated in between patronage and book market is apparent from his publication strategies. Obviously aiming for patronage, he dedicated works to several authorities and wrote occasional poetry within elite circles in both Amsterdam and Friesland. Starter received small rewards for these

18 There are many publications about Starter's works and lives, but especially the older ones suffer under romanticized images of Starter that hide the facts or even disclose untruths. More reliable is the most recent publication about Starter, Breuker 2016: 83-110. Older but more detailed and likewise reliable is Brouwer 1940.

19 Mentioned (and in many cases reprinted) in Brouwer 1940. 
dedications, for example from the States-General or the city of Groningen, and he agreed to write poetry for a group of wealthy Amsterdam merchants in exchange for a weekly pension of twelve guilders. At the same time, Starter turned to the market by acting as his own publisher when republishing a collection of poetry with the addition of some of his own poems in 1617 , evidently hoping to profit from its sales. He also worked on commission for the Amsterdam publisher Van der Plasse, who paid in 1623 'a fair amount of money' (groote kosten) to let Starter finish a play by the popular and admired poet Bredero. ${ }^{20}$ Both contexts - patronage and the book market - could also interact within one and the same publication: whereas Starter published his songbook the Friesche Lusthof (1621) to sell on the market for his own profit, he included in it many poems that had originated in a context of patronage, especially nuptial poetry. ${ }^{21}$ Moreover, he dedicated the book to a group of rich Frisian individuals who supported him in making the publication happen: crowdfunding avant la lettre. ${ }^{22}$

The brand Starter, as created by himself and other agents (such as his publishers and patrons in both Amsterdam and Friesland, but also other contemporary authors), served Starter's position and income in the contexts of both patronage and the book market at large. For his patrons, it was important that the brand portrayed Starter as a lofty poet, someone they wanted to be associated with. Indeed, his brand is, on the one hand, modelled on the accepted, classically inspired image of a lofty poet. On the other hand, Starter's brand shows a joyful author who wrote in the first place to please the larger public - and thus did not avoid vulgar humour, eroticism, and references to everyday life among the middle and lower classes. The two sides of Starter's brand conflicted, since elite patrons wanted to support foremost authors who were highly esteemed within the cultural elite, whereas the public of buying readers could be put off by too much loftiness and classical references. There was one characteristic though that could potentially please members of both audiences - his patrons from the

20 In Angeniet, Amsterdam: C. van der Plasse / Paulus Aertsz van Ravesteyn, 1623, 'Aen den leser'. T'Vermaeck der Ieught was originally published by Abraham van den Rade, Leeuwarden 1616 and reprinted (illegally?) by Starter himself in 1617 .

21 That he aimed to profit from the publication himself appears most clearly from the privilege Starter requested for the Friesche Lusthof. In the Dutch Republic, it was not common for authors to request a privilege, nor to be included as one of the persons that had to be paid a fine when the privilege was violated.

22 There is one copy of the Friesche Lusthof with a list of subscribers (in the Groningen University Library). In the accompanying poem, P. Knijff thanks the 'liefhebbers' on the list for their support of Starter's enterprise. 
Frisian elite and the public at large within this province - and this indeed was played as a trump card: Starter's Frisian background and connections (Breuker 2016; Brouwer 1940: 211-218).

These parts of Starter's branding may appear to be mutually exclusive, but in practice they could also operate side by side. Very tellingly, the three aspects of Starter's brand appear altogether in the front matter of the play Timbre de Cardone (1618), in which Starter emphasizes, while addressing the reader, how he cannot reach the level of Heinsius, Hooft, or Bredero - of whom especially the two first-mentioned authors were famous examples of the classically inspired lofty poet - and how his only aim is to entertain his readers. In the laudatory poem immediately following his own address, however, his Frisian colleague Boudewyn Jansen Wellens presents Starter emphatically as the Frisian Hooft or Bredero. Since Starter print-published the play himself, he was self-consciously emphasizing his 'Frisianness' while consolidating the discrepancy between the lofty author and the crowd-puller.

Starter's ambitious songbook the Friesche Lusthof, which already plays the 'Frisian' card in its title, again plays with the seeming discrepancy of Starter's brand. The volume opens with Starter's portrait, illustrating its strong classical component. The frontispiece (Fig. 1.2) presents the portrait of the author with a laurel wreath, the classical symbol of poetic honour. The upper side of the cartouche contains his coat of arms. The author portrait and a copy of the book are placed on a shell flanked by two swans floating on the water, gaining speed thanks to the wind-catching putti on top of it. Significantly, the classical image of Starter is recreated in a slightly different manner on the comparable frontispiece of the enlarged second edition of the Friesche Lusthof (1623) (Fig. 1.3). The two swans now are carrying Jocus, the personified classical god of jests, and his counterpart Cupid, the god of love. These additions characterize the contents of the songbook emphatically as joyful and related to love. Since these are exactly the elements that must have appealed to the larger public, the change in Starter's visual representation can be related to the other side of his brand, which is that of the crowd-puller.

Indeed, in the address to the readers, Starter demonstrates himself unhappy with the fact that his songs and poems have been published before, without his consent. This is harmful to himself as much as his publisher, he emphasizes, but not for the same reasons: 'he took away my honour, but my publisher's pay'. ${ }^{23}$ For himself, he states, it is only a matter of honour, whereas his publisher is hurt financially by the pirate edition. He thus places himself in the classical tradition, refraining from any economic imperatives 
Figure 1.2 Portrait of Jan Jansz. Starter. In: Starter, Jan Jansz. Friesche lust-hof, beplant met verscheyde stichtelijcke minne-liedekens, gedichten, ende boertige kluchten. Amsterdam: weduwe Dirck Pietersz Voscuyl, 1621. KB Nationale bibliotheek, sign, KW 5 B 1

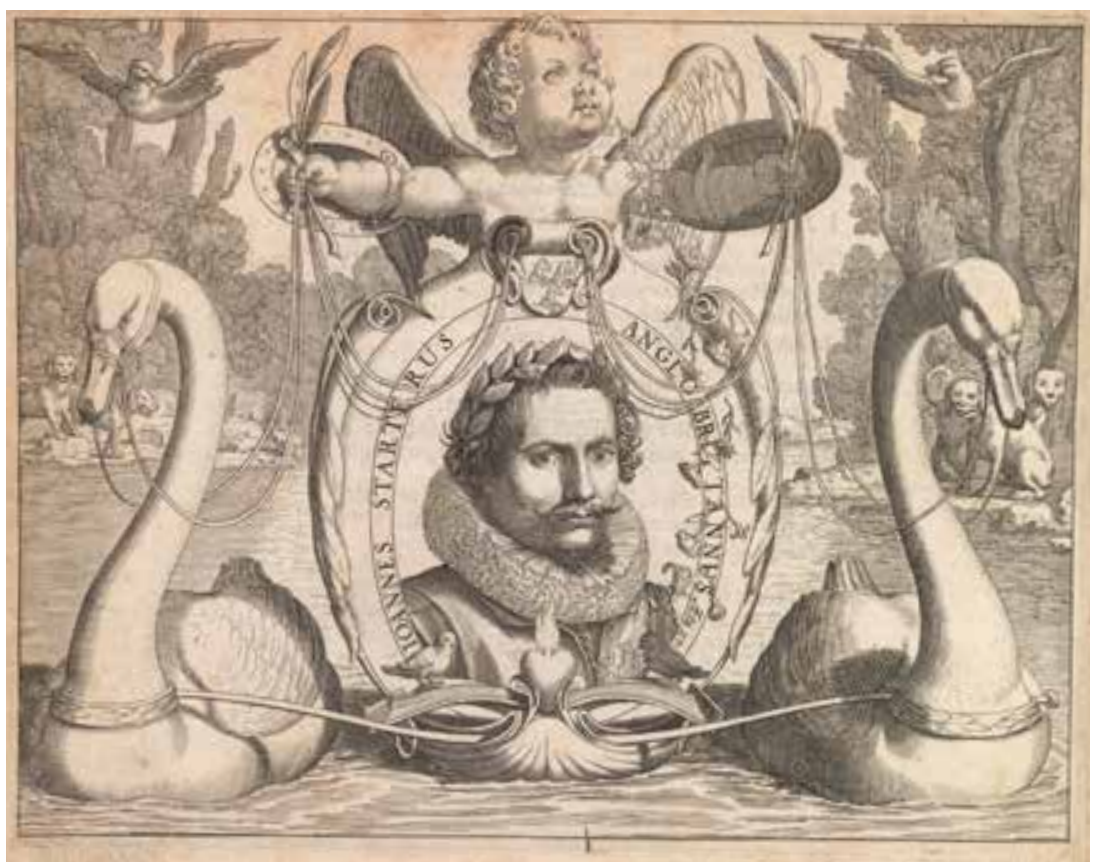

for writing, although we do know these imperatives were of importance for him. In the same address, Starter emphasizes the importance of the reading public. He states that the satisfaction of the public is his pay, and that he will publish a sequel to the Friesche Lusthof as soon as he notices his readers like it. A sequel

will follow immediately, as I will notice,

That you like my works, if only a little bit

Because honest pay sweetens labour's burden. ${ }^{24}$

The Friesche Lusthof thus not only shows Starter as a lofty poet, but also as a poet who writes for a larger audience, that should buy his books if they want to read more of it. This image of the crowd-puller is further emphasized by

24 'Daedlijck volgen sal, soo veer ick kan bemercken / Dat ghy in 't minste schept behagen in mijn wercken / Want eerelijcke loon des arbeyds last versoet' (vs. 47-49). 
Figure 1.3 Jan van de Velde (II), Portrait of Jan Jansz Starter. in: Starter, Jan Jansz. Friesche lust-hof, beplant met verscheyde stichtelijcke minne-liedekens, gedichten, ende boertige kluchten, 2nd edition. Amsterdam: weduwe Dirck Pietersz Voscuyl, 1623. Rijksmuseum Amsterdam: RP-P-OB-15.270

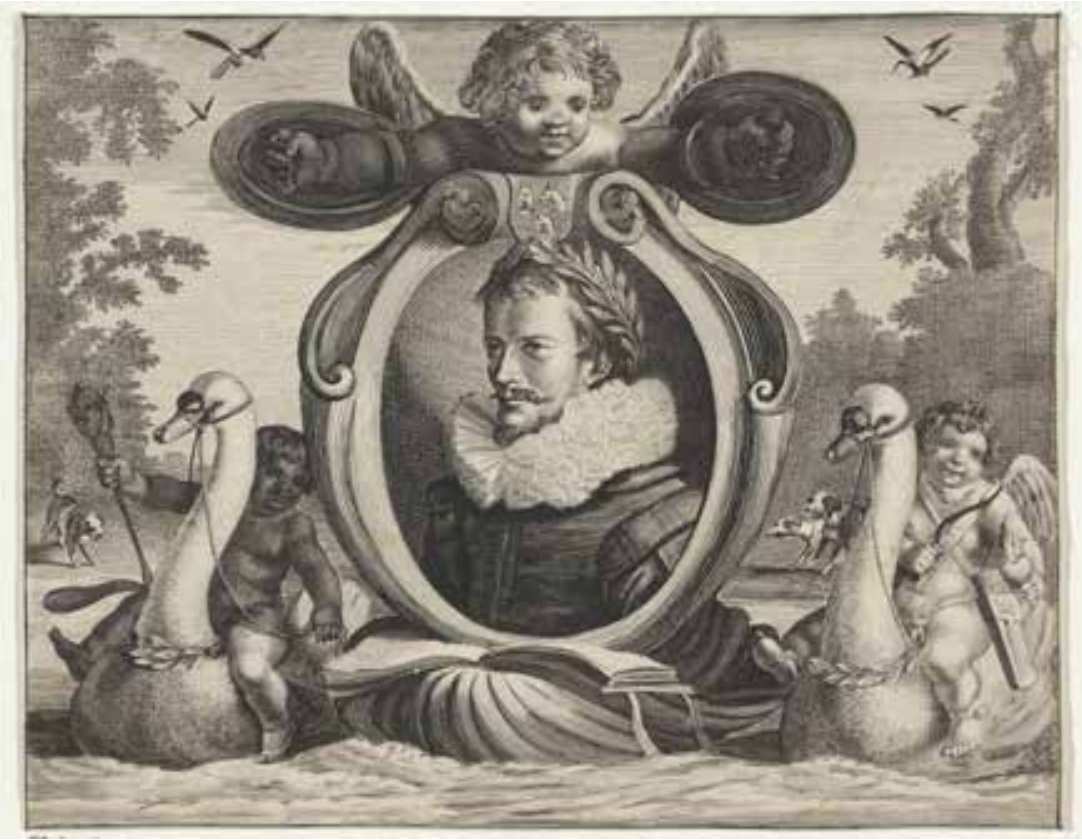

the fact he 'crowdfunded' his Friesche Lusthof and advertises this within the publication.

Starter's multifaceted brand was adopted and used strategically by all the agents involved. Starter's orientation towards a popular readership was not only veiled by the dominance of the classical representation of his authorial image but also by the way he carefully orchestrated his publications in relation to several specific publics. One surviving copy of the Friesche Lusthof has additional front matter that should be connected to the subscribers that financially supported Starter to make the publication happen. ${ }^{25}$ Poems by several of Starter's colleagues were added. One of these is a poem praising the subscribers, who are listed within the poem. The other poems praise Starter emphatically as a poet of great importance for Friesland. It cannot be a coincidence that all his subscribers are from the Frisian elite. In other 
cases, Starter published works with differing front matter that was adapted to his patrons for that specific publication. ${ }^{26}$

In the end, Starter's multifaceted branding was, both economically and symbolically, rather successful. Most tellingly, publisher Van der Plasse presents him as the author who finished Bredero's play Angeniet in 1619, attributing to him great renown and qualities comparable to Bredero's, while mentioning the high price he had to pay Starter for this job. Moreover, Starter's Friesche Lusthof was reprinted time and again. ${ }^{27}$ And although he was far from rich and legal sources referring to his debts even suggest he encountered recurring financial troubles, Starter did succeed in making a living as a literary author, which was far from common in the early seventeenth-century Dutch Republic. ${ }^{28}$ Contemporary sources give the impression that he was generally regarded as the lofty author of his portrait, although there are some references to critical voices, among them the barking dogs on that same portrait. ${ }^{29}$ Of these critical voices, only few examples survived, most famously a poem in which he is criticized for writing erotic songs only to please the larger public. It was published only after his death..$^{30}$ At the same time, his representation as a lofty author also continued after his death. Somewhere around 1720, for example, his likeness - including the significant laurel wreath as symbol of poetic honour - was painted for the Panpoëticon Batavûm, an eighteenth-century collector's cabinet containing the portraits of the foremost literary and intellectual figures in the Dutch Republic (Fig. 1.4) $\cdot^{31}$

26 See, for another example, Breuker 2016: 103 note 86.

27 STCN: six reprints between 1621 and 1634 .

28 This appears in general literary histories of the period, for example Porteman and SmitsVeldt 2008; Leemans and Johannes 2013. There is a lack of studies focused on literary authors and their profits in the Dutch Republic. Nina Geerdink's ongoing NWO-Veni project Poets and Profits: A New History of Literary Authorship in the Dutch Republic, 1550-1750 aims to provide the first systematic inquiry into the matter. Some of the results are presented in a theme issue of Nederlandse letterkunde, edited by Van den Braber et al. (2020).

29 Starter mentions the criticism himself in a poem addressed to his friend the poet Dirck Graswinckel, published in the front matter of Starter's play Daraïde (1621). The dogs in the frontispiece portrait are on the background, looking at the floating book and Starter's head. It seems as if their pose was more aggressive in the frontispiece of the second edition, which suggests that Starter received (more) criticism as a consequence of the publication of the Friesche Lusthof. 30 The poem, 'Klagte van Jan Jansz Starter', was probably written by Christoffel van Langerack and published for the first time in Camphuysens Stichtelyke Rymen (1647). See Porteman and Smits-Veldt 2008: 469. Within the poem, the popularity of the Friesche Lustfhof is mentioned as a reason for its critical position: Starter's vulgarity was the more blameworthy since it reached so many people.

31 For the history of the Panpoëticon Batavûm, see Van Deinsen 2016; Van Deinsen 2017:149-248. 
Figure 1.4 Arnoud van Halen, Portrait Jan Jansz Starter, 1700-1732. Rijksmuseum Amsterdam: SK-A-4567

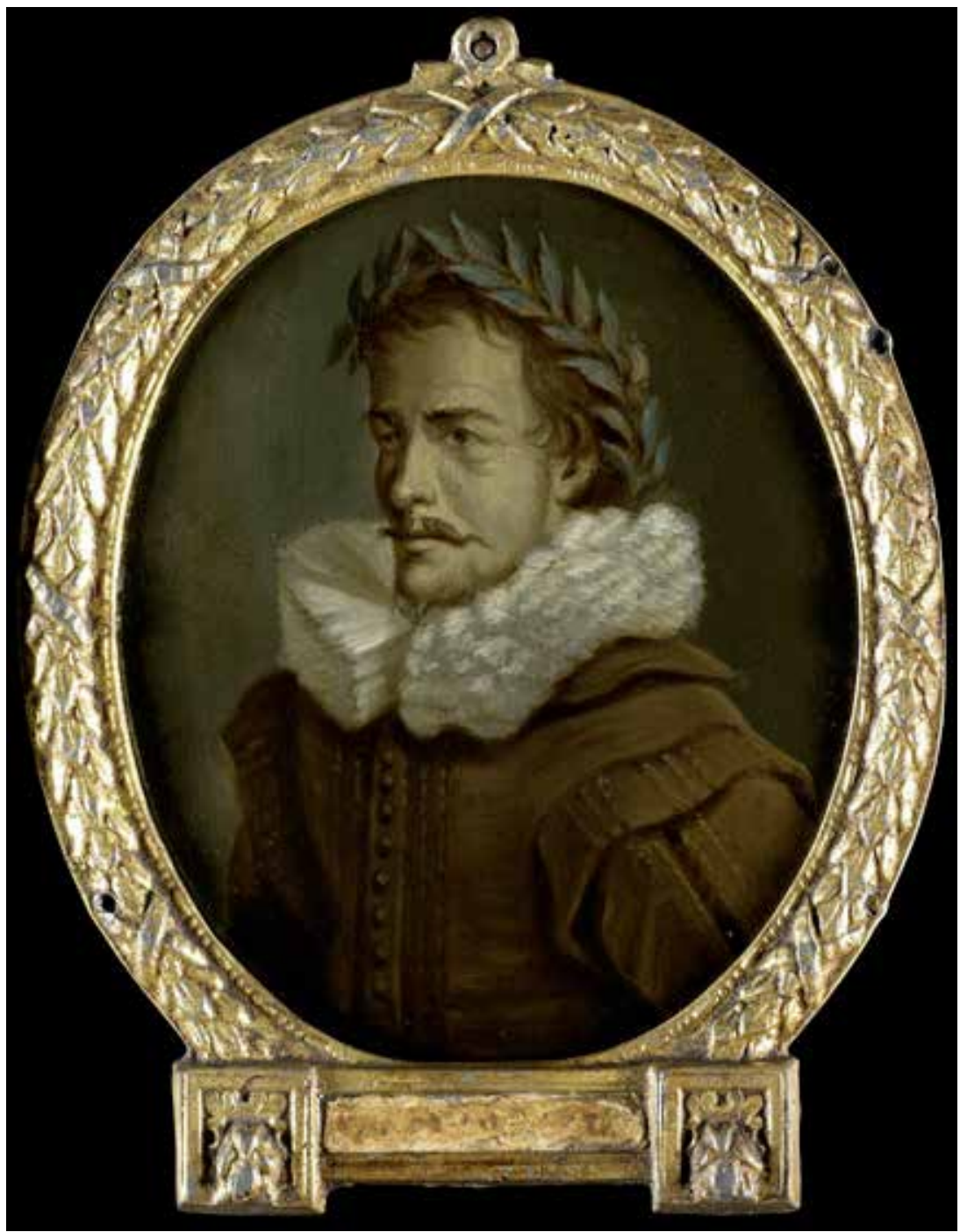

The success of Starter's branding should be related to the fact he orchestrated his brand carefully. Other agents, such as publishers and patrons, were involved, but as far as we can reconstruct the process on the basis of the available sources, it seems Starter himself took the lead in the printing of every single publication. This allowed him to create a brand with balanced ambiguity, profitable in both contexts of patronage and the book market at 
large. The specific contexts of Starter's authorship (including his geographical whereabouts and his economic motives) are in itself not representative for early modern authorship, but we contend that his multifaceted branding was. The same accounts for the diversity of media used in Starter's branding, which should certainly also be related to its success. In the next section, we elaborate on the use of media in branding processes, and specifically on the increase of visual components during the early modern period. This early in the seventeenth century, it was far from common that almost all of an author's publications should be accompanied by (different) author portraits, as Starter's were.

\section{Developments in Early Modern Media of Branding}

The media used in early modern branding were as varied as the brands themselves and became even more varied over time as a consequence of the innovative printing presses. These not only provided authors and other agents with the opportunity to make a broad audience familiar with textually constructed brands but also disseminated visual images that helped to shape the image of the author. In particular, the author portrait would become an important aspect of authorial branding. Although we should not forget the importance of oral and manuscript culture, print was thus the most significant medium for early modern branding.

The influential role of print in constructing and disseminating the reputation of authors becomes especially clear - as the case of Starter has already illustrated - in the growing prominence of front matter in early modern books. In the course of the seventeenth century, a book's front matter, which consisted of both textual elements (such as prefaces, dedications, and privileges) and visual elements (such as frontispieces and author portraits), became more and more extensive and started to serve an increasingly commercial purpose (Saenger 2016). These texts and images should be read as transactional and have a preparatory function to the perception of the reader. Agents in the process of branding actively used front matter to present authors and their brand to their public. By, for example, explicitly dedicating the publication to a prominent patron or including lauds by renowned poets, the reputation of both the work itself and its author was stressed to the reading public.

Over the course of the early modern period, a writer's face became a progressively more important feature of his or her authorship that could also function independently of the context of book publications. 
Sixteenth-century humanists, for example, started including portraits of themselves in their letters. These portraits functioned, as Anthony Griffiths (2016: 399) has argued, as 'the face-to-face introduction to a distant colleague whom they were unlikely ever to meet in person'. From the seventeenth century onwards, stimulated by the growing individualization of the self, the demand for printed author portraits, both to be included in publications or sold separately, significantly increased and the business of printed author portraits became booming (Griffiths 1998: 193; Burke 1998: 151-154). ${ }^{32}$ As such, a relatively wide public could become familiar with the faces of their admired writers, even if they could not read. This provided both the publisher and the writer with yet another opportunity to brand the author's public image. Prominently placed in the front matter of early modern books, these portraits credentialled the text and forced the reader to recognize the authority conveyed by the gaze of the author (Ezell 2012: 31-45; Enenkel 2011: 149-180). Often, these portraits were carefully modelled and loaded with iconographical elements to stress the specific reputation of the author. Author portraits frequently contained elements visualizing the symbolic status (i.e. literary or intellectual authority) of the depicted, for example by incorporating associations to the ideal of the classical author, as was the case with Starter.

The branding of authors was, however, not only limited to books written by these authors. Another important development in the expanding media landscape of the early modern period was the coming into being of the periodical press, which started to play a fundamental role in the dissemination and evaluation of an author's reputation and brand. This complicated the branding process by bringing in a new set of agents. As a result, it could prove difficult to control a brand and some authors were confronted with the undesirable effects of their public image, as was the case with Sara Maria van der Wilp.

\section{The Branding of Sara Maria van der Wilp (1716-1803)}

The growing importance and risks of different media, both textual and visual, in the branding of early modern authorship is illustrated in a particular

32 With regard to the Dutch Republic systematic data on the subject is lacking. Lieke van Deinsen's ongoing research on the portraits of women writers and the depiction of intellectual and literary authority aims to provide the first systematic inquiry into the matter. 
way in the case of the Amsterdam poet Sara Maria van der Wilp. ${ }^{33}$ In 1772, having written primarily occasional poetry - often included in the works of others - and an incidental translation, Van der Wilp decided it was about time for the publication of a first ambitious volume of her individual poetry. The renowned literary bookseller Pieter Meijer (1718-1781) proved willing to provide her with the opportunity to showcase her authorship to the broader public. ${ }^{34}$ She dedicated the luxuriously designed volume to poet and art patron Bernardus de Bosch (1709-1786). For the forthcoming publication of Gedichten, Van der Wilp also decided to keep up with the literary fashion in wanting her readers welcomed by her engraved portrait. In doing so, she became part of the increasing number of early modern women writers who started to use their author portrait to stress their reputation as a writer (Van Deinsen 2019). They often portrayed themselves in the act of writing, in their study, surrounded by books. As such these portraits undeniably combined their inevitable femininity and authorial authority into one image. ${ }^{35}$

Her eye fell on miniaturist Joseph Marinkelle $\left(173^{2-1782}\right)^{36}$ to draw her portrait and the established engraver Jacobus Houbraken was appointed to translate the portrait into print. The final result (Fig. 1.5), however, did not please her audience, nor, eventually, the poet herself. After its publication, the portrait provoked a torrent of criticism that would result in a fierce argument between the painter and the poet who had tried so carefully to construct her visual image. The genesis of the portrait and the juicy details of the dispute that followed its publication were memorialized by Marinkelle (1772) in Oprecht verhaal, wegens het portraitteeren van mejuffrouw Sara Maria van der Wilp. This pamphlet reveals not only the growing importance of the visual image in the branding of early modern authorship but also makes clear that it could sometimes end up being counterproductive, and as such illustrates that the branding of an author could result in active and open resistance.

In Oprecht verhaal, Marinkelle recounted how a tenacious Van der Wilp had forced him to portray her exactly to her liking. She had persuaded him to depict her dressed with 'antique taste': 'bareheaded, with an unsecured

For a biographical sketch of Van der Wilp, see Van Strien 1997: 561-564.

34 Pieter Meijer's intended public transcended the Amsterdam market. New publications in his fund were announced in several national newspapers. See, for example, Leydse Courant 25 May 1772.

35 For an exposition of the problematic nature of the author portrait of female authors, see also Simonin 2002: 35-57.

36 On Joseph Marinkelle, see Staring 1948: 132-146; Schaffers-Bodenhausen 2012: 509-510, 512. 
Figure 1.5 Jacob Houbraken, after Joseph Marinkelle, Portrait of Sara Maria van der Wilp, 1771. Rijksmuseum Amsterdam: RP-P-OB-48.395

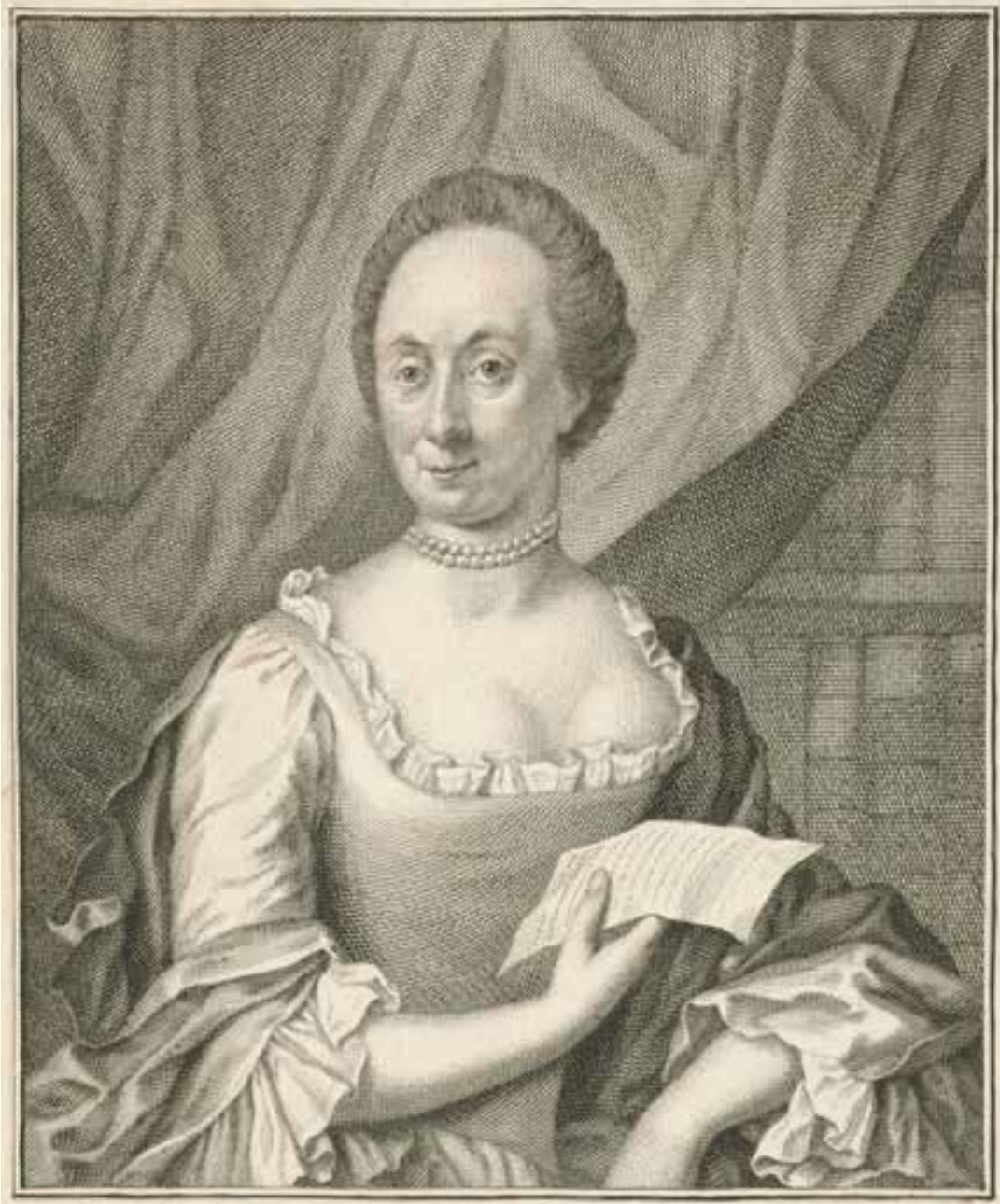

bosom and a Paper in the hand' (Marinkelle 1772: 1-2). ${ }^{37}$ Every suggestion the artist came up with for a more 'usual, modern', and fashionable gown was brushed aside by the stubborn poet out of fear of being 'dated' too quickly. Eventually, the artist gave in. He drew the portrait as his client wished, so it could be engraved and prepared for publication. In the end, and

37 '[... blootshoofds, met een ongedekte boezem en een Papier in de hand, verbeeld te worden; en dit een antique smaak te noemen.' 
Figure 1.6 Reinier Vinkeles, after Daniël Bruyninx, Portrait of Sara Maria van der Wilp, 1772. Rijksmuseum Amsterdam, RP-P-OB-62.953

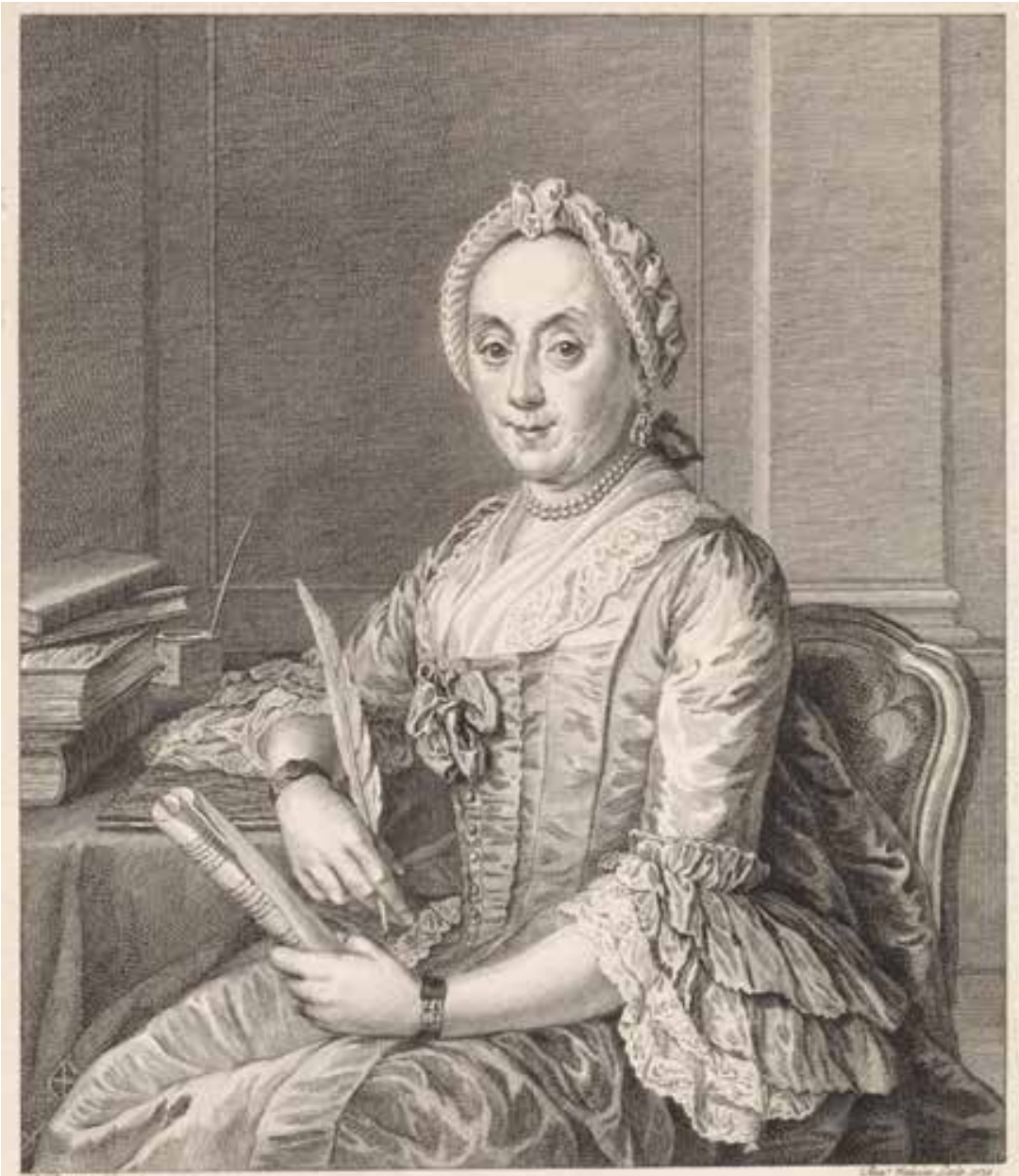

pushed by the firm deadline of bookseller Meijer, Van der Wilp's collection of poems - including the portrait - appeared as planned before the turn of the year (Van der Wilp 1772).

Not long after the publication of the collection, Marinkelle was summoned to Van der Wilp's home. The unsuspecting painter had barely entered the house when he was met by a tirade. In uncovered terms, the furious Van der Wilp told him that several contemporaries had reached out to her to proclaim their aversion to the portrait and its negative effect on her public image: 'they said that I looked like a shrew; a dragon of a wife, [...] an impertinent 
Whore, with Breasts like the udders of a cow' (Marinkelle 1772: 7), she told him. ${ }^{38}$ She had even received a letter urging her to 'destroy' all the circulating portraits and advising her to demand the portrait's maker openly apologize for the damage he had done to her immaculate reputation. Following this suggestion, she urged him to publish a pre-digested rectification in the local newspapers that absolved both herself and Marinkelle of all responsibility and blamed the final result on the respected yet elderly engraver Houbraken.

Initially, Marinkelle respectfully declined, but he reconsidered after the message reached him that Houbraken had proclaimed he was no longer inclined to engrave after his drawings. In the meantime, to make matters worse, Van der Wilp had commissioned a second author portrait by Marinkelle's foremost competitors, miniaturist Daniël Bruyninx (1724-1787) and upcoming engraver Reinier Vinkeles (1741-1816). His surprise was all the greater when it turned out that this time, without hesitation or arguing, the poet had exchanged the hated classical costume for a modern and fashionable look from her own closet. As such, the new portrait (Fig 1.6) took the form Marinkelle had argued for in the first place: 'a modest figure, with a cap and a covered bosom'. In the poem Van der Wilp wrote to accompany the new portrait, she openly distanced herself from the former portrait, urging her readers to: 'reject the first print, which displeases me and everyone / Although it carries my name, it does not carry my likeness'. ${ }^{39}$

The situation left Marinkelle little other option than to follow suit and publicly defend himself. It would, however, not be the advert Van der Wilp had in mind. On 19 May 1772 the Amsterdamsche Courant posted the following lines:

MARINKELLE, who values his reputation and does so not without reason, cannot but make known to everyone that he does not acknowledge the Resemblance between the Print placed before Ms. VAN DER WILP's Poetry and the Drawing by his Hand. He leaves to the judgement of others, who have seen his drawing alongside it, to see how it is copied..$^{4}$

38 '[...] een ieder als uitschreeuwde de leelykheid van de uitgegeven Plaat; dat men zeide, dat zy wel een Viswyf geleek, een dragonder van een Wyf, daar men eerder mede zoude verkiezen te eeten, dan te vegten; en daarenboven nog, een onbeschaamde Hoer, met Borsten als Koe-uiëren, enz.'

39 'Verwerp dan de eerste print, die mij en elk mishaagt, / Mijn' naam wel, maar geen' zweem van mijn gelijknis draagt'. Poem included in the engraving.

40 'MARINKELLE, op zyne Reputaasie niet zonder reden gesteld zynde, kan niet wel naar laten, een ieder bekend te maken, dat by die Gelykenis in de Plaat, voor het Dichtwerk van Mejuff. VAN 
The unfortunate artist, however, did not achieve his goal, for his colleagues - Vinkeles ahead - interpreted his words as an attempt to 'smear the established fame' of the old Houbraken; Marinkelle feared for his earnings. At stake was his honour: 'not the honour of a poet, who in her livelihood did not depend on her reputation, but the honour of an artist, who's incomings are directly related to his reputation'. In a final attempt to save his damaged reputation, he published his lengthy pamphlet.

The purpose of the pamphlet, however, most likely went further than just saving Marinkelle's damaged reputation. Although not explicitly mentioned on the title page, it is likely that Van der Wilp's own bookseller, Pieter Meijer, had a hand in its production and distribution. The choice to use a rather peculiar format (in quarto) and the corresponding watermark between Van der Wilp's Poems and the Pamphlet at least suggests the use of the same presses, and provided buyers with the evident option to bind the two together. In addition, based on the fact that practically every existing copy of Van der Wilp's Poems not only contains the two portraits but also the critical pamphlet, it is highly likely they were all sold in the same bookshop. Did Meijer - whose commercial instincts notoriously outweighed the interests of his authors, sometimes - perhaps add fuel to the fire to promote sales (De Vries 2005: 81-89; De Vries 2005: 36-52)? Although conclusive evidence of Meijer's involvement is lacking, the pamphlet did indeed boost Van der Wilp's public attention. This shows how a scandal could also become part of the process of branding. The leading literary journal Vaderlandsche Letteroefeningen published a critical discussion of the controversy and several readers added handwritten notes to the portraits included in their copies, taking position in the controversy. ${ }^{41}$ One might even conclude that, for a substantial part of the reading public, the dispute about the portraits became the foremost element of the Van der Wilp brand.

The case of Sara Maria van der Wilp illustrates not only the impact of visual branding but also places emphasis on the growing influence of media outside the book on the reputation of an author. The controversy also highlights the different (sometimes conflicting) interests of parties involved in the branding of early modern authorship. Whereas Van der Wilp pursued poetic honour (symbolic capital), both Marinkelle and Pieter Meijer were most likely primarily driven by commercial motives (economic capital).

DER WILP, geplaatst, niet voor de Zynen, in de Tekening gebragt, erkent; en aan het Oordeel van een ieder, die 'er de Tekening by zie, overlaat, hoe dezelve gevolgd is.'

41 See, for example, the handwritten notes added by B.S. in the UBN edition of Van der Wilp's Gedichten [OD 456 c 229]. 
All the same, eventually her branding had not the effect Van der Wilp intended. The publication of Gedichten (1772) would prove to be her first and last individual book and Van der Wilp silently disappeared into oblivion.

\section{Concluding Remarks}

The increasingly commercialized early modern Dutch book market proved a breeding ground for the literary branding of authorship. Early modern branding was part of a dynamic historical context and developed over time, interacting with new conceptions of the individual, technological innovations of the media landscape, and the changing role of - among other actors - patrons and publishers. The non-formalized yet extremely dynamic constellation of the early modern literary field invited agents to explore new possibilities to market authors to the fullest and brought about the creation of a wide range of (often multifaceted) author brands on a spectrum running from 'economic' to 'symbolic', which was created by various agents, varying from case to case. In direct relation to the rapidly changing and expanding media landscape, branding strategies quickly intensified over the course of the early modern period.

In some cases, authors proved adept at managing their own brand, as Starter did. In other situations, they ended up caught between the interests of other agents, as happened with Van der Wilp. Both an author's interest on the spectrum of symbolic-economic advancement and the availability of specific media of branding were directly connected to the possibility of (successfully) engaging in one's own branding. Whereas Starter modelled himself after Vondel to emphasize the symbolic side of his authorial representation, his imperatives proved emphatically to be (also) social and financial, which resulted in a multidimensional brand, distributed by the common media of his time, and used in innovative ways. Van der Wilp's modelling and imperatives were both on the symbolical side and made her brand, at first glance, less ambiguous. In the way it was created, however, ambiguity originated from the question of how an author should be depicted if branded to appeal to this end of the spectrum. The media element of branding increased and diversified during the period, which increased the possibilities but, at the same time, also increased the risks. This was probably the reason for the relative success of Starter's branding as opposed to Van der Wilp's failure.

The brands of both Starter and Van der Wilp, and those of other early modern authors, were created within a literary culture that in comparison 
to the present-day publishing industry was very dynamic and hardly formalized. The lack of copyright agreements for authors made the 'market for branding' full of possibilities on the one side, and full of agents with specific and often contradictory interests on the other. Even though success is never guaranteed when branding literary authorship, this surely was the case in the early modern Dutch Republic.

\section{References}

Albert Russell Ascoli. 2008. Dante and the Making of a Modern Author. Cambridge: Cambridge University Press.

Amsterdamsche Courant. 19 May 1772. Amsterdam: Otto Barentsz Smient.

Jochen Becker 1979. “De Rotterdamsche heylich”: zeventiende-eeuwse echo's op het standbeeld van Erasmus'. In Lode Roose and Karel Porteman (eds.), Vondel bij gelegenheid 1679-1979, pp. 11-62. Middelburg: Merlijn.

Susanna de Beer. 2013. The Poetics of Patronage. Poetry as Self-Advancement in Giannantonio Campano. Turnhout: Brepols.

Ingo Berensmeyer, Geert Buelens, and Marysa Demoor. 2012. 'Authorship as Cultural Performance: New Perspectives in Authorship Studies'. ZAA: Zeitschrift für Anglistik und Amerikanistik 6o.1: 5-29.

Helleke van den Braber, Nina Geerdink, Laurens Ham, and Johan Oosterman (eds.). 2020. Literaire auteurs en hun verdiensten. Een diachrone blik, theme issue Nederlandse letterkunde 1.

Leo Braudy. 1997. The Frenzy of Renown: Fame and Its History. New York: Vintage Books.

Philippus Breuker. 2016. 'Virtuoos Starter in het internationale Leeuwarden (16141620)'. In Henk Oly and Gaert de Vries, Leeuwarden in de Gouden Eeuw, pp. 83-110. Hilversum: Verloren.

John Brewer. 1997. The Pleasures of the Imagination: English Culture in the Eighteenth Century. New York: Routledge.

J.H. Brouwer. 1940.Jan Jansz. Starter. Assen: Van Gorcum.

Helen Cooper. 2010. 'Poetic Fame'. In Brian Cummings and James Simpson (eds.), Cultural Reformations: Medieval and Renaissance in Literary History, pp. 361-378. Oxford: Oxford University Press.

Maurice Couturier. 1995. La Figure de l'auteur. Paris: Seuil.

Kenneth H. Craik. 2009. Reputation. A Network Interpretation. Oxford: Oxford University Press.

Lieke van Deinsen. 2016. The Panpoëticon Batavûm. The Portrait of the Author as a Celebrity. Amsterdam: Rijksmuseum. 
Lieke van Deinsen. 2017. Literaire erflaters. Canonvorming in tijden van culturele crisis. Hilversum: Verloren.

Lieke van Deinsen. 2019. 'Visualising Female Authorship. Author Portraits and the Representation of Female Literary Authority in the Eighteenth-century Dutch Republic'. Qucerendo 49.4: 283-314.

Paul Dijstelberge and Piet Verkruijsse. 2010. 'Een schitterend moeras. Boek en wereld in de zeventiende eeuw'. Jaarboek voor Nederlandse Boekgeschiedenis 17:141-170.

Karl A.E. Enenkel. 2011. 'The Author's Portrait as Reader's Guidance: The Case of Francis Petrarch'. In C. Brusati, K.A.E. Enenkel, and W. Melion (eds.), The Authority of the Word:Reflecting on Image and Text in Northern Europe, 1400-1700, pp. 149-18o. Leiden/Boston: Brill.

Margaret J.M. Ezell. 2012. 'Seventeenth-Century Female Author Portraits, Or, The Company She Keeps'. Zeitschrift für Anglistik und Amerikanistik 6o.2: 31-45.

Lia van Gemert. 2010. 'A Life of Books: Katharina Lescailje'. In Lia van Gemert, Hermina Joldersma, Olga van Marion, Dieuwke van der Poel, and Riet Schenkeveld-van der Dussen (eds.), Women's Writing from the Low Countries 1200-1875: A Bilingual Anthology, pp. 308-315. Amsterdam: Amsterdam University Press.

Nina Geerdink. 2012. Dichters en Verdiensten. De Sociale Verankering van het Dichterschap van Jan Vos (1610-1667). Hilversum: Verloren.

Nina Geerdink. 2020. 'Economic Advancement and Reputation Strategies: Seventeenth-century Dutch Women Writing for Profit'. Renaissance Studies 34.2: 350-374.

Nina Geerdink and Alicia C. Montoya. 2018. 'Introduction'. In Maarten De Pourcq and Sophie Levie European Literary History, an Introduction, pp. 153-162. London: Routledge.

Stephen Greenblatt. 2005. Renaissance Self-fashioning. From More to Shakespeare. Chicago: Chicago University Press.

Dustin H. Griffin. 1996. Literary Patronage in England 1650-180o. Cambridge/New York: Cambridge University Press.

Anthony Griffiths. 1998. The Print in Stuart Britain, 1603-1689. London: British Museum Press.

Anthony Griffiths. 2016. The Print Before Photography: An Introduction to European Printmaking 1550-1820. London: British Museum Press.

Pieter Cornelisz. Hooft. 1611. Emblemata Amatoria. Afbeeldinghen van minne. Emblèmes d'amour. Amsterdam.

Catherine Ingressia. 2015. Authorship, Commerce and Gender in Early EighteenthCentury England. A Culture of Paper Credit. Cambridge: Cambridge University Press.

Jeroen Jansen. 2019. 'Drie decennia boekenzorg. Cornelis vander Plasse en Gerbrand Bredero'. Jaarboek voor Nederlandse Boekgeschiedenis 26: 53-78. 
Ann Jensen Adams. 2009. Public Faces and Private Identities in Seventeenth-Century Holland. Portraiture and the Production of Community. Cambridge: Cambridge University Press.

Gert-Jan Johannes. 2000-2001. 'The Development of the Literary Field and the Limitations of 'Minor' Languages: The Case of the Northern Netherlands, $175^{0}$ 1850'. Poetics 28.5-6: 349-376.

Inger Leemans and Gert-Jan Johannes. 2013. Worm en donder. Geschiedenis van de Nederlandse literatuur 1700-180o: De Republiek. Amsterdam: Bert Bakker.

Katharina Lescailje. 1731. Tooneel-en Mengelpoëzy. 3 vols. Amsterdam: Erfgen. Van J. Lescailje \& Dirk Rank.

Ian Maclean. 2012. Scholarship, Commerce, Religion. The Learned Book in the Age of Confessions, 1650-1630. Cambridge, Massachusetts/London, England:Harvard University Press.

Joseph Marinkelle. [1772]. Oprecht verhaal, wegens het portraitteeren van mejuffrouw Sara Maria van der Wilp. Haarlem.

Erin McCarthy. 2020. Doubtful Readers: Print, Poetry, and the Reading Public in Early Modern England. Oxford: Oxford University Press.

Djoeke van Netten. 2014. Koopman in kennis. De uitgever Willem Jansz Blaeu in de geleerde wereld (1571-1638). Zutphen: Walburg Pers.

Andrew Pettegree. 2010. The Book in the Renaissance. New Haven: Yale University Press.

Andrew Pettegree. 2016. Brand Luther. How an Unheralded Monk Turned His Small Town into a Center of Publishing, Made Himself the Most Famous Man in Europe - and Started the Protestant Reformation. London: Penguin.

Andrew Pettegree and Arthur der Weduwen. 2019. The Bookshop of the World. Making and Trading Books in the Dutch Golden Age. New Haven: Yale University Press.

Karel Porteman and Mieke B. Smits-Veldt. 2008. Een nieuwvaderland voor de muzen. Geschiedenis van de Nederlandse literatuur 1560-170o. Amsterdam: Bert Bakker.

Sarah Prescott. 2003. Women, Authorship and Literary Culture, 1690-1740. Basingstoke: Palgrave.

Clara Rasterhoff. 2017. Painting and Publishing as Cultural Industries: The Fabric of Creativity in the Dutch Republic, 1580-1800. Amsterdam: Amsterdam University Press.

Michael Saenger. 2016. The Commodification of Textual Engagements in the English Renaissance. Burlington: Ashgate.

Karen E. Schaffers-Bodenhausen. 2012. 'Joseph Marinkelle (1732-1782). Een aantal miniaturen uit zijn nalatenschap'. In E. Buijsen, Ch. Dumas, and V. Manuth (eds.), Face Book. Studies on Dutch and Flemish Portraiture in the 16th-18th Centuries. Liber Amicorum Presented to Rudolf E.O. Ekkart on the Occasion of His 65th Birthday, pp. 509-516. Leiden: Primavera Pers. 
Valentina Sebastiani. 2014. 'Erasmus of Rotterdam in Print: A Question of Reputation (1514-1521)'. In Konrad Eisenbichler (ed.), Collaboration, Conflict, and Continuity in the Reformation. Essays in Honour ofJames M. Estes on his Eightieth Birthday, pp. 107-124. Toronto: Centre for Reformation and Renaissance Studies.

Charlotte Simonin. 2002. 'Les portraits de femmes auteurs ou l'impossible representation'. In R. Crescenzo (ed.), Espaces de l'image, Europe XVI-XVIIe siècles, pp. 35-57. Nancy: PU de Nancy.

Helen Smith. 2012. Grossly Material Things. Women and Book Production in Early Modern England. Oxford: Oxford University Press.

A. Staring. 1948. Kunsthistorische verkenningen. Een bundel kunsthistorische opstellen. The Hague: A.A.M. Stols.

Charles Taylor. 1989. Sources of the Self. The Making of the Modern Identity. Cambridge, Massachusetts: Harvard University Press.

Geoffrey Turnovsky. 2010. The Literary Market. Authorship and Modernity in the Old Regime. Pennsylvania: Pennsylvania University Press.

Marleen de Vries. 2005. 'Pieter Meijer (1718-1781), een uitgever als instituut'. Mededelingen van de Stichting Jacob Campo Weyerman 28: 81-98.

Marleen de Vries. 2005. 'Uitgegeven... en uitgebuit. Over achttiende-eeuwse bestsellerauteurs, liegende uitgevers, stiekeme privileges en het gedeeld auteurschap'. De Achttiende Eeuw 37: 36-52.

Sara Maria van der Wilp. 1772. Gedichten. Amsterdam: Pieter Meijer.

Ton van Strien. 1997. 'Sara Maria van der Wilp: een gevarieerd oeuvre: (Amsterdam, gedoopt 19 november 1716 - Amsterdam, 3 april 1803)'. In M.A. Schenkeveld-van der Dussen, Karel Porteman, Piet Couttenier, and Lia van Gemert (eds.), Met en zonder lauwerkrans: schrijvende vrouwen uit de vroegmoderne tijd 1550-1850, pp. 561-564. Amsterdam: Amsterdam University Press.

Alain Viala. 1985. Naissance de l'écrivain. Sociologie de la littérature à l'âge classique. Paris, Éditions de Minuit.

Arnoud Visser. 2011. Reading Augustine in the Reformation: The Flexibility of Intellectual Authority in Europe, 1500-1620. Oxford: Oxford University Press.

Arnoud Visser. 2013. In de gloria: Literaire roem in de Renaissance. The Hague: Algemeen-Nederlands Verbond.

Rietje van Vliet. 2007. 'Print and Public in Europe 1600-1800'. In Jonathan Rose and Simon Elliot (eds.), A Companion to the History of the Book, pp. 253-255. Chichester: Wiley-Blackwell. 


\section{About the Authors}

LIEKE VAN DEINSEN (KU Leuven) is a postdoctoral researcher and conducts research on the visual and textual representations of female authorship and authority in early modern Europe. In 2017 she completed her PhD on processes of literary canon formation (Literaire erflaters. Canonvorming in tijden van culturele crisis, Verloren 2017). In the capacity of the Rijksmuseum's Johan Huizinga Fellow, she published The Panpoëticon Batavûm. The Portrait of the Author as a Celebrity (Rijksmuseum 2016).

NiNA GEERDINK (Utrecht University) is an assistant professor in early modern Dutch literature and is currently working on a project about early modern Dutch literary authors' financial advancement and its representations. She has published on authorship, patronage, women's writing, and social poetry. Among her publications is the co-edited volume Economic Imperatives for Women's Writing in Early Modern Europe (Brill 2018). 


\title{
Telling a Double Story
}

\author{
The Branding of a Cultural Magazine, 1904-1919
}

Helleke van den Braber

\begin{abstract}
Between 1904 and 1919, Dutch author and critic Albert Verwey spearheaded the prominent magazine De beweging. Though it was a cultural commodity that needed to be sold, the autonomy of De beweging had to be defended and negotiated as well, sometimes at a significant cost. This chapter explores this paradox, focusing on the ways Verwey 'sold the unsaleable' and used the stories he told about his journal to market De beweging. Branding cultural objects comes down to not only telling a story about them, but also pitching that story against the stories others may create. I argue that Verwey's ambition was to persuade other stakeholders to engage with his story by investing materially or symbolically in De beweging.
\end{abstract}

Keywords: cultural branding, autonomy, market, storytelling, cultural magazine.

Instead of reflecting on the branding of a writer, an authorship, a literary text, an oeuvre, or a genre, this chapter will examine the branding of a cultural magazine. Between 1905 and 1919, Dutch author and critic Albert Verwey spearheaded the prominent magazine De beweging (The Movement). As editor and owner of the magazine, he was faced with the challenge of 'selling' $D e$ beweging - first of all to his publishers, and then to as many subscribers as was necessary to keep the magazine symbolically relevant and financially afloat. This task was not an easy one, as having to sell the magazine was

1 Significant parts of this article were published earlier in Van den Braber 2014 and in Van den Braber 2019. Translation of all quotes is by Jeske van der Velden.

Helleke van den Braber, Jeroen Dera, Jos Joosten, and Maarten Steenmeijer (eds), Branding Books Across the Ages: Strategies and Key Concepts in Literary Branding. Amsterdam, Amsterdam University Press 2021 DOI: 10.5117/9789463723916_CHO2 
Figure 2.1

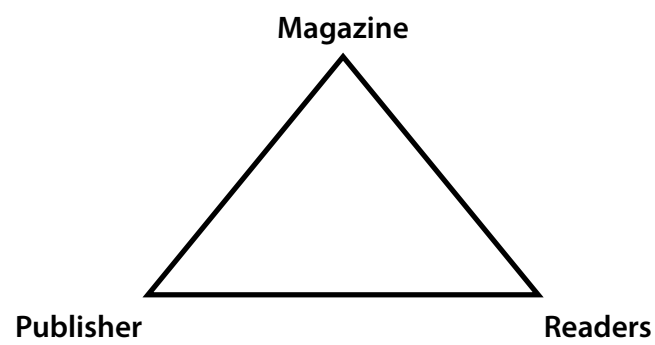

strikingly at odds with the store Verwey set by the notion of independence: he strongly valued maximal artistic, economic, and ideological freedom and took pride in 'the complete independence from profitability etcetera in which he "aimed to maintain the journal"' (quoted in Van Faassen 1997: 37). For him, independence meant autonomy - from readers' expectations, the wishes of fellow authors, the whims of publishers, and the demands of the market. Still, over the years it became clear that this autonomous stance posed some serious challenges. On the one hand, De beweging was a cultural commodity that needed to be sold (even if only on the market of symbolic goods), but on the other, the autonomy of the journal had to be defended and negotiated, sometimes at a significant cost. In this chapter I will explore this paradox, focusing on the ways Verwey 'sold the unsaleable' and used the stories he told about his journal to face the very real necessity of marketing De beweging.

In the preface to this edition, a simple triangular model was introduced to visualize the structure of the process of literary branding (see Fig. 2.1).

In this model, three stakeholders are connected in a three-way interactive relationship, leading to the collective creation and construction of a brand - a brand all three can subsequently either accept and embrace or reject and adapt. Clayton Childress, who has examined a similar process in detail in his seminal Under the Cover: The Creation, Production, and Reception of a Novel (2017), suggests that a literary brand develops and functions by virtue of the stories about the brand the stakeholders tell themselves and each other. In this case, this would mean that as an editor, Verwey is in the business of constructing stories about the identity, value, and meaning of his magazine. He would then face the task of pitching these narratives against any stories about De beweging his publishers and his readers might construct, either in reaction to Verwey's stories or on their own account. The editor's goal would then be to deliver a credible 'brand promise', and to persuade the other stakeholders to engage with that promise by investing materially or symbolically in his magazine - by taking out a subscription 
in the case of the readers, and by agreeing to publish De beweging in the case of the publisher.

Childress points out that for researchers, getting to grips with this process is complicated by the fact that a brand is constructed collectively and in constant interaction. This means that the actors' roles are not stable, nor are their interrelationships, and nor are the stories they may tell about the brand. Their (often inconsistent) intentions and visions can frequently be at odds. In this case, this means that the tone, content, and substance of the narratives about De beweging can vary with the transient interests and targets of the three stakeholders.

In this chapter, the case of Albert Verwey's De beweging will serve to explore different dimensions of Childress' take on literary branding. Three premises underlie my exploration. Firstly, it is assumed that in this period (as in any other), magazines, their publishers, and their readers all have an interest in collectively creating a certain brand. Secondly, that there is a certain tension between the story told by the editors of the journal, and the story the publisher and readers might like to hear or might want to tell. And thirdly, that the interaction between the stakeholders, however fuzzy or fraught, leads to a productive 'making and remaking' of the journal's brand.

De beweging is a particularly interesting test case, because the interaction between the journal, its publishers, and its readers was put under severe pressure by Verwey's insistence on autonomy and independence. His attitude was by no means unique; in the early years of the twentieth century, like elsewhere in Europe, the concept of autonomy was a hot topic in Dutch literary circles (Ruiter and Smulders 1996:133). Dutch authors and magazines found themselves at the centre of a diverse and often contradictory play of forces. Operating in an expanding field that was becoming ever more commercial, they struggled to redefine their role and position, economically, socially, and artistically. Should they resist or embrace the commodification of their work? Should they choose an isolated but independent position at the fringes of society, or seek bourgeois approval and legitimacy? These choices were all intricately connected to questions of autonomy and (in) dependence, and they all impacted the definition of authorship that Dutch authors projected. Their views on collaboration with their publishers and on reaching their readers played a major part in this positioning. Exchanges with actors in a position to confer value on their work were pivotal in creating a brand and in the (subsequent) recognition of their value and position, especially in the case of less commercially interesting authors and magazines (Bourdieu 1985: 21). Amidst the upheaval of the literary field at 
the time - which, like elsewhere in Europe, was scaling up in terms of scope and commercialism - this type of interaction proved crucial.

Albert Verwey's definition of autonomy as a form of artistic and economic independence is consistent with that of sociologist Pierre Bourdieu, who stated that in 188 os Europe, autonomy meant 'the right of artists to legislate within their own sphere - free from subordination to religious or political interests' (Bourdieu 1985: 15). Cultural sociologist Gisèle Sapiro (2005: 42) points out that around 1900, less commercially oriented authors like Verwey gained independence both through their writings and through the 'personalized relationships' (33) they maintained with other stakeholders. Social anthropologist Aafke Komter (2005) maintains that these exchanges can be both seemingly disinterested ('autonomous') and more commercially interested at the same time. What distinguishes her model from Pierre Bourdieu's $(1983 ; 1985)$ is that for her, economic and anti-economic or 'reversed economic' behaviour are less strictly separated. Disinterested and interested behaviour can go together; one may obscure the other or pose as the other - a relevant observation when it comes to the negotiations surrounding a journal like De beweging, which aimed to be successful both in economic terms and in terms of cultural prestige, moving both in the commercial and symbolic marketplace (Van den Braber 2017). Following Komter, the process of branding may in fact be seen as a strategy to credibly bridge the gap between both types of marketplace. Also relevant to a study of the branding interaction surrounding De beweging is Komter's claim that every exchange between stakeholders relies on (an implicit) reciprocity. ${ }^{2}$ Within the branding triangle, each of the three players is indebted to the other, creating a state of necessary and productive imbalance which may shift every time a step in the exchange process takes place. In this light, the power imbalance (between the stakeholder who initiates branding and the stakeholder who has to legitimize the branding attempt in order to make it work) is in fact conducive to the relationship.

I will use the triangle model presented above to examine the play of forces around the branding of De beweging, and to take stock of the ways Verwey tried to keep the struggling magazine financially afloat. To map the interaction between Verwey and his branding associates, I have studied about 500 unpublished letters, including correspondence between Verwey and his publishers. It is interesting how methodically complicated it is to do justice to the perspective of the third corner of the branding triangle (the readers) on the basis of this material. This complexity is partly due to 
the historical nature of the case study: it is hard to reconstruct in 2019 how the subscribers of the magazine reacted to the magazine in 1904, and what they may have thought about the brand narratives of Albert Verwey. Still, their contribution to the process is covered to some extent by the frequent reflections on the part of the other two actors (editor and publisher) on their actions and reactions. The Verwey archive is relatively complete (although inevitably some letters have been lost) and offers an excellent insight into the day-to-day operations of the journal and into Verwey's careful negotiations. I will refer to this material throughout this chapter and quote abundantly to show how Verwey struggled to find a balance between his own narratives and the stories of others, and how carefully he had to tread to keep his independence. ${ }^{3}$ It is important to note that I have used the material presented in this chapter before (in Van den Braber 2014 and Van den Braber 2019). In those two earlier incarnations of this chapter, I approached the interactions between Verwey and both other actors from a different angle (working from gift theory and theories of authorship, respectively). Here, I will deploy the Verwey archive to explore the relevance and potency of Childress' views on branding as a form of interactive storytelling.

\section{'The Finest Possible Gift to One's Fatherland'}

By 1905, Albert Verwey was an established author, highly respected as both a poet and journal editor. Starting in 1886 , he had successively managed the iconic and prestigious literary journals De nieuwe gids, Tweemaandelijksch tijdschrift and DeXXe Eeuw - journals with a position and poetics comparable to La Jeune France, The Yellow Book, or Blatter für die Kunst in neighbouring countries (Van den Braber 2016: 54; Van den Braber 2014: 302). Between 1905 and 1919, he would use De beweging to publish the idealistic essays and cerebral poetry in which he believed and to further position himself as an author, an editor, and a mentor to young disciples, many of whom made their debut in the magazine. He had strong views on the subjects of authorship, power, autonomy, and aesthetic and social leadership, and he regarded the editorship of his journal as a means of putting these opinions in practice. Inevitably, these views also informed the branding stories he constructed around De beweging. Interestingly, he always maintained that De beweging was not an effort at self-promotion. Instead, he viewed his

3 I also examined promotional materials, prospectuses and financial accounts of the journal (Verwey collection, University of Amsterdam [henceforward: UVA]). 
editorship as a disinterested gift to Dutch literature. He was careful not to give the impression that putting the magazine on the map was a means for personal gain or profit. In an early letter, written in 1903, a few months before De beweging was launched, he chose to tell an entirely different story instead:

The Journal is not to me what it might be to other editors: a benefit to ourselves, a means to other than Spiritual influence. I have carried the lifelong conviction that a beautiful literature is the finest possible gift to one's Fatherland, and I have over the years devoted all my energies to keeping this Idea alive as an inspiration to our contemporaries. ${ }^{4}$

Here, we see Verwey loading the brand of his new project with the concepts of spirituality, beauty, of devotion and conviction, and of (national and public) influence. The quote makes very clear that Verwey intended the magazine to take a leading and prominent position straight off. It also demonstrates that Verwey is aware of the (symbolic) benefits of casting himself in a central role ('I have carried [...] a conviction [...] I have devoted $[. .$.$] all my energies'). Verwey was both the sole owner and sole editor of D e$ beweging. With absolute control comes absolute power, but such a lonely position also entails a constant dependence on outside help. For the journal to stand a chance, Verwey had to find a way to inspire loyalty in contributors, publishers, and readers. His position was complicated by the journal's limited readership and repeated financial losses. Putting the magazine first and constantly referring to its narrative was, he felt, a necessity. 'None of us,' he wrote to his contributors in 1906, 'may go about our lives without reference to De beweging'5 - adding, in this quote, the concepts of 'loyalty' and 'community' to the magazine's brand.

Despite De beweging's continually precarious financial situation, Verwey's attempts to develop a brand fitting to (his idea of) the journal were not primarily aimed at procuring money. From the start, the atmosphere surrounding the journal was one Bourdieu (1983) would call 'reversed economic':

4 Letter from Verwey to August Vermeylen, 4 December 1903 (UVA XLI B 1223 ); 'Het [geplande] Tijdschrift is voor mij niet wat het voor andere redacteuren zijn mag: een voordeel voor onszelf, een middel tot anderen dan geestelijken invloed. Ik [ben] levenslang overtuigd geweest dat een schoone literatuur het fraaiste geschenk is dat men zijn Vaderland maken kan, en om dit Denkbeeld levend te houden en van invloed te doen blijven op onze tijdgenooten, heb ik jaren aaneen alles gegeven wat ik te geven had'.

5 Letter from Verwey to Is.P. de Vooys, 6 December 1906 (UVA XLI B 16620): 'Niemand van ons mag zijn leven inrichten zonder rekening te houden met De Beweging'. 
Verwey preferred investing his publication with symbolic rather than economic value. His approach, although professional, was never commercial. Despite being aware that the viability of his project depended on money, the story he constructed about the 'spiritual' dignity of the journal still meant more to him than any potential profit. Perhaps because of this, the archival material makes clear that the personal relationships he engaged in with other stakeholders were distinctly hybrid in nature: never merely business, nor purely artistic, but many things at once: part professional, part personal, part strategic, part grounded in a shared vision on literature. This hybrid nature makes Verwey's position as editor - and as actor in the branding process - particularly interesting.

Albert Verwey was highly conscious of both the value and the vulnerability of the position of De beweging vis-à-vis other stakeholders. He viewed himself as the autonomous connecting link, the spider at the centre of its web, whose job it was 'to keep abreast of notable events, always selecting that which in the long run seemed most significant to me. ${ }^{6}$ As we will see below, only those publishers, and contributors who respected the autonomy of Verwey's editorship without question were tolerated. He had no time for 'half-hearted elements': admittance to the inner circle was limited to those who shared De beweging's ideals. ${ }^{7}$ This meant that any investment in the journal constituted an investment in Verwey and in the brand narrative he constructed around De beweging.

Still, Verwey's need for autonomy was always complemented by a need for affinity and exchange. His goal was to make De beweging productive not just for himself but for a community of kindred spirits, and he was keen to view (and brand) the journal as a meeting ground for the like-minded. He promised his contributors that together, and with their readers, they were to shape the 'spiritual movement' of their day:

[I] cannot shake off the thought that De beweging is more than the platform of a single person, supported by some who are his friends and take an interest in his work. [...] At this time, I cannot cease to believe that there is something else which binds the writers of De beweging. There exists between them, I imagine, a community of taste and ideas; and this

6 Letter from Verwey to Scheltema \& Holkema's Boekhandel, 25 January 1904 (UVA XLI B 12212; copybook 4 261-265): 'het oog te houden op alle verschijnselen van betekenis, daaruit telkens dat te kiezen wat me op den duur het belangrijkst leek.'

7 Letter from Verwey to Alex Gutteling, 17 September 1904 (UVA XLI B 5124): 'halfslachtige elementen'. 
taste and those ideas find their expression in De beweging [.] (Quoted in Uyldert 1955: 231 $)^{8}$

Verwey attached great importance to this brand promise of a 'shared experience'. His journal was to command the respect of readers and peers alike by the implicit but no less evident correlation existing between its contributions. ${ }^{9}$ Here, Verwey explicitly tries to sell the idea of constructing a community as a means of building and defending a central, shared idea of authorship - an idea that encompassed autonomy as well as artistic like-mindedness and networked cooperation. He expected that after integrating fellow authors into the community surrounding De beweging, his interests and theirs would somehow align. ${ }^{10}$ The resulting 'community of taste and ideas' was not intended to remain small and exclusive, but to grow in size and influence: 'to the public, the plot of ground on which we make our stand may seem small, but the influence will be all the greater, when its impact becomes apparent'. ${ }^{11}$ In this quote, we again see Verwey construct a brand identity around terms like 'influence' and 'impact'. He also liked to use military terms in his narrative about De beweging: he intended to 'follow the battle between other parties without being aggressive, but stay at the forefront by means of our output and professional criticism. ${ }^{12}$ Here, Verwey ties in with his earlier assertion, in 1903, that he intended De beweging to have a leading position. Interestingly, shaping the magazine's brand this way did have the intended effect on his contributors. J.C. Bloem (1995: 243), who frequently published in De Beweging, emphasizes that thanks to Verwey, the writers had found their rallying point in the journal'. The contributors to the magazine could identify with the narrative of a 'community of taste and ideas' that Verwey was spreading - but it is an interesting question whether the readers of De beweging felt the same way.

8 '[Ik] kan de gedachte niet van me afzetten dat De Beweging meer is dan het orgaan van één persoon gesteund door sommigen die met hem bevriend zijn en in zijn werk belangstellen. [...] Op dit ogenblik kan ik niet ophouden te geloven dat wat de schrijvers van De Beweging verenigt nog iets anders is. Er is tusschen hen, verbeeld ik me, een gemeenschap van smaak en denkbeelden; en die smaak en die denkbeelden hebben in De Beweging hun orgaan'.

9 Letter from Verwey to Scheltema \& Holkema's Boekhandel, 25 January 1904 (UVA XLI B 12212; copybook 4 261-265).

10 Letter from Maas \& Van Suchtelen to Verwey, 29 May 1908 (UVA XLI B 8692).

11 Letter from Is.P. de Vooys to Verwey, 23 November 1904 (UVA XLI B 16501).

12 Letter from Verwey to Alex Gutteling, 4 February 1909 (UVA XLI B 5401). Verwey wanted 'den strijd tusschen de andere groepen volgen zonder zelf agressief te zijn, de leiding houden alleen door onze produktie en zakelijke kritiek'. 


\section{Readers}

In 1904, Albert Verwey was optimistic about the number of readers that would subscribe to De beweging. He revelled in playing the part of the underdog against the competing journal DeXXe eeuw ('I will attempt to seem worth less than I am for as long as possible') and expected De beweging's brand to quickly become established. ${ }^{13}$ He was disappointed. By the end of the first year he reported to his readers:

The Editor was met by more than ample cooperation, and future assurances of such, and received evidence of appreciation from countless circles [...]. However, in the publisher's opinion, this interest is not supported by a corresponding number of subscribers. ${ }^{14}$

Verwey's use, here, of terms like 'cooperation' and 'appreciation' aligns perfectly with his earlier attempts to load his magazine's brand with notions of loyalty and community. In a bid to widen the journal's readership he followed this up by urging his contributors in 1907 to rally round $D e$ beweging and 'stand together as a significant group of writers, each doing their utmost to promote the journal in his own circle.. ${ }^{15}$ Verwey had expected his narrative about the magazine to have immediate resonance, and was genuinely surprised at the low number of subscribers. He felt he had made every effort on behalf of the journal and given it all he had. Why, then, were the readers not prepared to do their bit?

So far, many of those who are known to sympathize with the inventions or ideas in De beweging, have, nevertheless, either failed to subscribe themselves, or failed to rouse others to do so. Too much of the labour and sacrifice was consigned to others, and the journal was thoughtlessly left to fend for itself by those on whose aid it depends for its existence. ${ }^{16}$

13 Letter from Verwey to Alex Gutteling, 9 December 1904 (UVA XLI B 5136): 'Ik zal zoo lang mogelijk probeeren minder te lijken dan ik waard ben'.

14 Draft of prospectus aimed at 'Subscribers of De beweging and other interested parties', 1 December 1905 (UVA, XLI A 15:36,18.11): 'De Redacteur vond meer dan genoegzame medewerking, die hem ook in de toekomst verzekerd blijft, en ontving uit tal van kringen blijken van instemming [...]. De uitgever is van meening dat met die belangstelling het aantal inteekenaren niet in overeenstemming is.'

15 Letter from Verwey to M. Uyldert, 6 February 1907 (UVA XLIV I: II): 'Vormen wij een flinke groep van schrijvers, waarvan ieder in zijn kring zijn uiterste best voor het tijdschrift doet'.

16 Draft of prospectus aimed at 'Subscribers of De beweging and other interested parties', 1 December 1905 (UVA, XLI A 15:36, 18.11): 'Tot nu toe evenwel hebben velen van wie het toch 
It is interesting that, in this quote, Verwey chooses to contrast the 'failure' of his readers to engage with and invest in his own lonely 'labour and sacrifice'. He adds the concepts of 'value' and 'worthiness [of investment]' to the story he constructed around De beweging in an attempt to involve his readers in his positioning of the magazine. To him, his subscribers did not represent an anonymous body but a group of kindred spirits, who, on the basis of that connection, even had a moral obligation to support the journal. What is interesting is how Verwey legitimized his request for support: 'when a journal represents the platform of a party, the members of that party consider themselves honour-bound to maintain it', he argued (adding the concept of 'honour' to the brand story). ${ }^{17}$ In his eyes, De beweging to some extent represented such a party. Together, producers and readers would ideally form an independent community, working on representing the magazine's brand to the rest of the (potentially hostile) world:

Even more divided are the readers, and as long as the journal continues to exist, none deem it necessary to labour themselves, or incite others to labour. This must end: those who truly feel sympathy for the independent development of a spiritual life by means of its own organ, must consider the interests of that organ their own, and stand up for it, each in his own circle. $^{18}$

For Verwey, constructing and maintaining a brand narrative was intricately connected to sustaining and upholding the magazine itself. He called on 'the many who feel sympathy for the journal' to 'do their part NOW, to help it over the final hurdles', ${ }^{19}$ because 'only through cooperation with others

bekend is dat zij in de voortbrengselen of denkbeelden van De Beweging zijn ingenomen, óf zelf niet ingetekend óf anderen niet tot inteekening opgewekt. Tezeer lieten zij den arbeid en de opoffering over aan anderen, zonder te bedenken dat ook van hun hulp het voortbestaan van het tijdschrift kan afhangen'.

17 Draft of prospectus aimed at subscribers [not dated] (UVA, XLI A 13:1 and XXXII.135): 'Indien een tijdschrift het orgaan van een partij is, dan achten de leden van die partij zich verplicht het in stand te houden'.

18 Draft of prospectus aimed at subscribers [not dated] (UVA, XLI A 13:1 and XXXII.135): 'Meer nog verspreid zijn de lezers, en zoolang het tijdschrift bestaat, acht niemand het van belang zelf ervoor te ijveren, of de ijver van anderen aan te zetten. Dit nu moet ophouden: wie werkelijk ervoor voelen dat het geestelijk leven zich in een eigen orgaan onafhankelijk zal kunnen bewegen, moeten het belang van dat orgaan als het hunne aanzien en er elk in zijn kring voor opkomen'. 19 Prospectus, 1 February 1907 (UVA, folder Maas \& Van Suchtelen): 'de velen die sympathie voelen voor het tijdschrift'; 'THANS het hunne [te] doen, om het over de laatste belemmeringen heen te helpen'. 
can the highest be achieved,. ${ }^{20}$ In this narrative he emphasized that fostering community spirit was needed to uphold De beweging:

Several persons, including the composers of this epistle, would consider the demise of 'De Beweging' an irreparable blow to the spiritual and especially the poetical development of this nation [...]. We hope, dear reader, to count you among us, and to rely, should this indeed be so, on your aid to prevent the temporary or permanent discontinuance of this publication. (Bloem 1997: 69) ${ }^{21}$

Readers could help the journal by subscribing, or convincing others to do so. Sixty new subscriptions proved enough to save De beweging. But there is a paradoxical ring to this rallying cry: can a community still be one if it is open to all? And: can branding still be effective if the people for whom the story is told recognize the story for what it is (an appeal to invest and a plea for legitimacy)? Verwey was perfectly aware of these complexities. He worked hard to keep the journal's financial troubles out of the public eye, for fear that 'for all the [journal's] proud attitude, its distress should show'. ${ }^{22}$ Those who want to operate autonomously do well to hide or at least not to emphasize their dependence on the willingness of others to believe in their brand promises:

It did not appear desirable to us to present this request openly before a general public, the majority of whom most likely do not place much importance on 'De Beweging', and to whom to address a request such as ours would constitute an immodesty. We ask only those, who appreciate the journal, to seize this opportunity to prove their affection. ${ }^{23}$

20 Verwey 1914: 175. '[Omdat] alleen door saamwerking met anderen het grootste kan worden tot stand gebracht'.

21 'Verscheidenen, waaronder de stellers van dezen rondzendbrief, zouden het verdwijnen van 'De Beweging' een niet te vergoeden gemis achten voor de geestelijke en inzonderheid de poëtische ontwikkeling van ons land. Zij weten, dat een zij het niet zeer grote, dan toch zeer getrouwe kring van lezers iedere maand met belangstelling naar het verschijnen van de nieuwe aflevering uitziet. Wij hopen, dat ook gij daartoe behoort, en dat, als dit zoo is, gij er toe zult willen medewerken, dat deze uitgave tijdelijk noch voorgoed behoeft te worden gestaakt'.

22 Letter from Verwey to Is.P. de Vooys, 17 May 1909 (UVA XLI B 16795): 'dat ondanks de hooghartige houding [van het tijdschrift] de noodlijdendheid toch blijken zou'.

23 Prospectus [undated] (UVA, folder Maas \& Van Suchtelen): 'Het kwam ons niet gewenscht voor, openlijk dit verzoek te doen aan een publiek, waarvan het meerendeel de belangrijkheid van 'De Beweging' waarschijnlijk toch niet volledig inziet, en tot hetwelk een oproep als de onze te richten dus een onbescheidenheid zou zijn. Wij vragen alleen hun, die het tijdschrift op prijs stellen, nu die genegenheid ook daadwerkelijk te toonen'. 
This plea proved mostly unsuccessful. In reality, most new subscribers were introduced through contributors. ${ }^{24}$ Apparently, readers did not recognize themselves in these statements and failed to be convinced ('resisting' the brand, as referred to in the Introduction to this volume), or else they formed a less closely knit community than Verwey hoped. Between 1905 and 1919, the number of subscribers would remain consistently low.

It is interesting that this small readership, disappointing in itself, only served to reinforce the stories of exalted independence and solidarity Verwey and his contributors disseminated. De Vooys informed the editor:

I finally rejoice in the fact that we will now be at the truest terms. Even if it concerns a small group only, even if we are embarrassed and scorned by an indifferent public who praise only appearances and conventions, we can now proceed without all of those former considerations [...]. Still, with the limited support it enjoys, we will maintain De beweging in the manner our circle, small in number, small in influence, but most decided in its views and convictions, deems necessary. We could ask for no greater support. ${ }^{25}$

Projecting a brand image of De beweging centring on the ideas of participation on an autonomous basis, upheld by loyalty and community spirit and autonomously united against a hostile public, was Verwey's way of selling his magazine. To this he added stories of sacrifice and redemption. Readers as well as contributors should be prepared to make any effort on behalf of De beweging, like he was. Or, as Verwey posited:

One cannot benefit both De beweging and himself. Those not prepared to do the former [...] are right to ask money for themselves. Those who are, merely forgo an early reward. This does not mean an earthly reward is not forthcoming. ${ }^{26}$

24 For instance letter from J.I. de Haan to Verwey, 21 March 1915 (UVA XLI B 5835) and of F.C. Gerretson to Verwey, 16 March 1915 (UVA XLI B 4429).

25 Letter from Is.P. de Vooys to Verwey, 17 September 1909 (UVA XLI B 16819): 'dat ik me tenslotte verheug, dat we op zuiveren grond zullen komen te staan. Al is 't maar met een klein clubje, al is het genegeerd en gehoond door een onverschillige, den schijn en de conventie huldigende massa, we kunnen toch nu voortgaan zonder al die vroegere consideraties [...]. Toch met de geringe steun zullen we de Beweging blijven voeren zooals ons kringetje, klein van aantal, klein van invloed, maar zeer beslist in opvatting en overtuiging dat noodig te vindt. We vragen niet om meer steun'.

26 Letter from Verwey to M. Uyldert, 4 April 1910 (UVA XLIV I: II): 'Men kan niet én de Beweging én zichzelf bevoordelen. Wie het eerste niet wil doen [...] heeft gelijk als hij geld voor zich vraagt. 


\section{Publishers}

Out of all the relationships Verwey maintained around De beweging, those with his publishers were arguably the most important. The publisher was responsible for the distribution, subscriber administration, relations with printer and binder, and (crucially) also financial backing and marketing. Despite his narrative about community and group loyalty, Verwey hated to feel dependent on his subscribers and was very reluctant to give the impression of being in any way dependent on the revenues they brought in. To maintain this autonomous stance, it was essential to find a publisher who was willing to invest in the magazine - preferably without having to relinquish too much control. Verwey only agreed to contracts for $D e$ beweging on a commission basis, with the publisher receiving a fixed annual percentage of the subscription income, without sharing in profit or loss. This guaranteed a certain autonomy but also made the journal vulnerable, because this type of contract entailed fewer financial obligations than those implied by shared ownership. Little wonder then that Verwey relentlessly searched for a publisher who was 'serious' and 'rich in capital' - but also, importantly, 'committed to the journal's ideal'. ${ }^{27}$ Verwey's main worry was that the journal's brand would be 'unable to develop fully for lack of means'. His concern proved justified: De beweging never had above 250 subscribers, and rarely made it out of the red figures. ${ }^{28}$ This means that publishers who ventured to have dealings with Verwey certainly cannot have been motivated by commercial motives alone. For example, Versluys, his first publisher, realized that exploiting the journal boiled down to 'work [...] from which we make no profit'. ${ }^{29}$ Investments by publishers were therefore of a more or less hybrid character - they were in reality as much gifts or investments as business transactions.

Verwey's search for a generous investor/publisher/branding partner was not an easy one. Between 1905 and 1919, he pitched the journal to at least

Wie het wél wil staat een onmiddellijk voordeel af. Het is daarom niet gezegd dat zijn middellijk voordeel zal uitblijven'.

27 Memo [by Verwey], titled 'Overwegingen voor Nijhoff ['Considerations concerning Nijhoff'] (UVA XLI A 26:14). He was looking for a publisher who was 'ernstig', but also 'kapitaalkrachtig', 'met hart voor wat het tijdschrift bedoelt'.

28 A small profit was made between 1915 and 1917 (letters of W. Versluys to Verwey, 9 March 1912, 12 January 1916 and 15 February 1917 (UVA XLI B 14966; XLI B 14988; XLI B 15011).

29 Letter from W. Versluys to Verwey, 10 September 1909 (UVA XLI B 1489o): 'Werk [...] waaraan we niets verdienen'. 
nine different publishers and made agreements with five of them. ${ }^{30}$ As far as can be gleaned from available sources, he appears to have approached them with a view to persuade them to invest in the narrative about the magazine he had constructed. This tactic worked reasonably well in his relationship with the first two publishers (Versluys and Maas \& Van Suchtelen): with them, all interactions were based on reciprocity and shared values. With every publisher that followed, he would try to build relationships based on arguments circling around the concepts of community and loyalty (this applies to his ties with G. Schreuders and again Maas \& Van Suchtelen). He also tried to persuade all of his publishers (except Versluys) to invest by referring to the symbolic profits awaiting them in later years (tying in with Verwey's narrative of 'sacrifice and redemption').

'The present is comfortable, and I have high hopes for the future,' Verwey reported in November $1904 \cdot{ }^{31} \mathrm{He}$ had every reason to feel confident, financially and otherwise. The $f 1900$ he had made from the sale of his share in De XXe eeuw provided him with the starting capital for his new journal. ${ }^{2}$ This was backed up by a further $f 9000$ from an inheritance (Uyldert 1955: 210). These were not paltry sums: in 1905, 1900 Dutch guilders bought the equivalent of $€_{23}, 000$ in today's market, $f$ gooo being roughly equivalent to $€ 111,000 .{ }^{33}$ The money provided freedom: it made him 'independent from those with an interest in holding him back' and made sure he could 'cover the risk of the first year' ${ }^{34} \mathrm{His}$ small fortune also made it easier to ask for a matching investment from a publisher. He succeeded with the publisher Versluys, who, halfway through 1904, paid him an advance of $f 4000\left(€_{49,500}\right)$. Although not a gift (Verwey was expected to repay the money), Verwey still took this financial gesture as a vote of confidence in his enterprise. ${ }^{35}$ Their

30 Versluys published the journal from January 1905 until July 1906, G. Schreuders from July 1906 until January 1907, Maas \& Van Suchtelen from January 1907 until January 1909, the Amsterdamsche Boekhandel from January 1909 until March 1913; W. Versluys again from March 1913 until January 1919, and Nifterik (a printer) for the rest of 1919. Verwey also approached Tjeenk Willink (1907), Veen \& Wolters (1908), Brusse (1909) and Nijhoff (1912) (Kwant 2000, Van Faassen 1997).

31 Letter from Verwey to Is.P. de Vooys, 17 November 1904 (UVA XLI B 16498): 'Het heden is ruim en voor de toekomst heb ik de beste verwachtingen'.

32 Letter from Verwey to Scheltema \& Holkema's Boekhandel, 22 December 1904 (UVA copybook XLI B 4).

33 http://www.iisg.nl/hpw/calculate2-nl.php offers a historically accurate calculating tool for converting guilders to euros.

34 Letters from Verwey to J.P. Veth, 22 October 1904 and Is.P. de Vooys, 23 November 1904 (UVA XLI C 347; XLI B 16501). It made Verwey 'onafhankelijk van partijen in wier belang het was me te belemmeren' and made sure that the 'risico van het eerste jaar' was 'door de tegenpartij gedekt'. 35 Verwey repaid the money in 1905 and 1906 (UVA copybook XLI B 1; Van Faassen 1997, 38). 
correspondence shows him negotiating with the publisher on equal terms and in a friendly, informal manner, even when the advance ran out halfway through 1906 and Versluys showed himself less than inclined to cough up more money. Versluys admitted:

I am truly sorry for the way things have turned out, I regard the journal most highly, but we have always said from the beginning that we cannot bear any risk [...]. We had two reasons for this: first, that we were unprepared and therefore had no funds available; second, that we are of the opinion that a journal like De beweging stands or falls with its editor and therefore cannot represent a secure investment to us. This was your feeling too [...], it was your express desire to retain sole ownership of the journal. ${ }^{36}$

The atmosphere of equal exchange between both parties was sustained by the lack of commercial pressure on the relationship. Both parties agreed in writing that Versluys bound himself to 'have the journal printed, to administrate it, and exploit it without retaining any profit for himself'37 which, again, neatly ties in with the brand's narrative strand of 'sacrifice'.

Exploitation, in this case, meant that Versluys collected the subscription fees and used them to pay for the printing and distribution of the journal. Should the journal make more than it cost (which it never did), both parties would share the profit. It seems that in Versluys's case, Verwey managed to achieve what he called 'the true attitude', that is, 'the attitude wherein you neither expect too much, nor promise too much'. ${ }^{38}$ Their shared disregard for profit (and regard for 'sacrifice') created a bond and gave stability to their relationship. In retrospect, Verwey concludes:

The complete independence from profitability etcetera, in which I aim to maintain the journal, was only in agreement with Versluys when he was

36 Letters from W. Versluys to Verwey, 23 and 26 May 1906 (UVA XLI B 14875; XLI B 14876): 't Spijt mij werkelijk zeer, dat 't zoo loopen moest, ik hecht werkelijk zeer aan het tijdschrift, maar we hebben $U$ van 't begin af gezegd, dat wij geen risico konden dragen [...]. We hadden daarvoor twee redenen: 1e dat we er niet op gerekend en er dus geen geld voor beschikbaar hadden; ze dat we van mening zijn, dat een tijdschrift als de beweging staat en valt met de redacteur en dus voor ons geen goede geldbelegging kan zijn. Dit was ook uw gevoelen [...], het was uw uitgesproken wil alleen eigenaar van het tijdschrift te zijn'.

37 Letter from W. Versluys to Verwey, 1 August 1904 (UVA XLI B 14822): 'Het tijdschrift te laten drukken, te administreeren, en te exploiteren zonder hierop winst voor zichzelf te berekenen'. $3^{8}$ Letter from Verwey to M. Uyldert, 9 March 1910 (UVA XLIV I: II): 'de ware houding [...], de houding waarin je niet teveel verlangt, maar ook niet teveel belooft'. 
amicable and not businesslike. Now that [in 1918] he is proving to become the latter in the worst possible way, I must admit that the right kind of businesslike approach would be preferable; but even the best does not agree with De beweging's independence. (Quoted in Van Faassen 1997: 37$)^{39}$

After leaving Versluys, and after a short episode with G. Schreuders, Verwey finally entered into an agreement with Maas \& Van Suchtelen. The publishing house proved itself ambitious from the start, immediately agreeing to invest $f 4000$ (nearly $€ 45,000$ ) over the course of three years. ${ }^{40}$ Verwey himself at this point had about $f 6500$ to spare, enough for both parties to be financially balanced. But despite their financial equality, this publisher's approach differed radically from that of Versluys, starting with the tone in which they made their position clear. Gone is the atmosphere of gentle acceptance and shared sacrifice - now it is all about hard work in the business of promoting and selling the magazine. The publishers:

In our view, our task as publisher is not limited to the distribution of new issues and financial funds. Please understand our aim is not to put pressure on your editing but to provide friendly support, and even if editors and publishers work together to bind contributors - both great in number and ability - to De beweging, they will assuredly still find their work cut out for them. You should not forget that we are more closely involved in this periodical than Mr. Versluys was at the time. If this should be apparent from our keener interest, please do not ascribe it to meddlesomeness or presumption, but merely to the wish to contribute to the journal's becoming all it can and should be. ${ }^{41}$

39 'De volslagen onafhankelijkheid ten opzichte van rentabiliteit etc, waarin ik het tijdschrift wensch te houden, was met Versluys alleen vereenigbaar zoolang hij gemoedelijk was en niet zakelijk. Nu hij het laatste op een slechte manier wordt, moet ik erkennen dat goede zakelijkheid te verkiezen zou zijn; maar ook de beste komt niet overeen met de bewegings-vrijheid van De Beweging'.

40 Letter from Verwey to Is.P. de Vooys, 6 February 1907 and publishing contract between Maas \& Van Suchtelen and Verwey (16 January 1908; UVA XLI B 16635; XLI B 8673).

41 Letter from Maas \& Van Suchtelen to Verwey, 20 March 19o6 (UVA XLI B 8648): 'Onze taak als uitgever bepaalt zich o.i. niet uitsluitend tot het expedieeren der afleveringen en 't financieren der gelden. Wij bedoelen allerminst pressie op Uw redactie, maar vriendschappelijke steun, en als redactie en uitgevers samenwerken om zooveel en zoo goed mogelijke medewerkers aan 'De Beweging' te verbinden is toch stellig ook op dat gebied nog veel te doen. U moet niet vergeten dat wij tot het maandschrift in veel nauwer relatie staan dan de Heer Versluys destijds. Als dat blijkt in onze grootere belangstelling moet $U$ dat vooral niet aan bemoeizucht of aanmatiging toeschrijven maar uitsluitend aan drang om ook er toe bij te dragen dat van het tijdschrift 
Verwey could do little else than resign himself to this vigour. Without the support of these publishers, De beweging would have ceased to exist; thanks to them, he felt he had 'for the first time room to breathe, [...] truly the courage to take the matter in hand'. ${ }^{42}$ Through them, he hoped to gain the autonomous freedom he needed to manage the journal.

Neutralizing the dominance of the publishers, and keeping them from assuming too much control on the basis of their investments, was therefore of paramount importance. Interestingly, in this case Verwey chose the strategy of 'if you can't beat them, join them', and proceeded to offer his publisher not only a business alliance but also an entrance into the magazine's circle. The idea appeared to be that should he succeed in integrating them into the community surrounding De beweging, his interests (and brand stories) and theirs would align. He had a clear interest in presenting his dealings with Maas \& Van Suchtelen in light of the friendly community spirit he wanted others to associate with De beweging. This is why, despite the obvious threat they represented, Verwey insistently spoke of his publishers in emotional terms: 'These publishers [feel] more for De Bew. than any other,' he claimed, and 'they work, not only with greater acumen, but indeed with more heart for the journal's vision'. ${ }^{43}$ He ratified the exchange by letting them know that with their involvement 'the publishing of 'De Beweging' [...] was in the hands of kindred spirits'. ${ }^{44} \mathrm{He}$ framed (or branded) their support of the journal as an expression of shared ideals - with the purpose of eliciting further investments and adherence to its brand. ${ }^{45}$ Verwey was aware that these publishers, too, would not see any return on their money. From them, too, he expected a similar blind eye to the market and a repetition of the 'un-businesslike' attitude he had admired in Versluys. But (despite their willingness to offer 'friendly support') Maas \& Van Suchtelen were not impressed with Verwey's emotional appeal and kept a tight hand on the purse strings. Halfway through 1908, Verwey's personal funds ran out, after which they forced him to seek external financing and eventually presented

gemaakt wordt wat het kan en moet zijn. Wij zullen echter niet uit 't oog verliezen dat wij in redactioneele zaken hoogstens adviseur kunnen zijn'.

42 Letter from Verwey to Is.P. de Vooys, 6 February 1907 (UVA copybook XLI B 4): 'voor 't eerst een ruimte, [...] een werkelijke moed om de zaak aan te pakken'.

43 Letters from Verwey to M. Uyldert, 6 February 1907 and 1 March 1907 (UVA; both XLIV I: II): 'deze uitgevers [voelen] meer voor De Bew. dan eenige andere' [...] 'ze werken, niet alleen met meer inzicht, maar ook met meer hart voor wat het tijdschrift bedoelt'.

44 Letter from Maas \& Van Suchtelen to Verwey, 20 March 1907 (UVA XLI B 8648): 'de uitgaaf van 'De Beweging' [...] in handen [was] van geestverwanten'.

45 Letter from Maas \& Van Suchtelen to Verwey, 29 May 1908, UVA XLI B 8692). 
him with an ultimatum: face discontinuation or come up with another $f 500$ per year. ${ }^{46}$ On that basis both parties managed to drag out their partnership until 1 January 1909 - after which the publisher immediately applied for suspension of payment.

It is interesting that Verwey did not stop at projecting a narrative of 'community' and 'solidarity' to Maas \& Van Suchtelen. Verwey used another framing strategy to coax his publishers into recognizing both his autonomy and the magazine's brand, by (again) referring to the concepts of 'honour', 'sacrifice', and 'redemption'. When asking for material investments, he did not fail to self-consciously stress the immaterial profit De beweging in turn represented. This immaterial compensation, Verwey implied, was invaluable, far exceeding the material value of the investment he sought. For example, he told the publisher Nijhoff that 'De beweging is poetically, economically and artistically authoritative' and therefore 'possesses those qualities which a serious publisher seeks in a journal'. Indeed, he argued, 'De beweging [...] is a distinguished journal, and enjoys such high esteem [...] the opportunity to take it on is, to an open-minded publisher looking to publish a journal of general interest, a golden one. ${ }^{47}$ According to Verwey, publishers who took on De beweging were without exception the better and 'more prestigious' for it, which was why the proposed deal was not in fact to his own advantage, but to theirs.

The trade-off proposed by Verwey might at first seem like an equitable exchange of economic for cultural capital. But because Verwey considered the autonomous prestige he offered infinitely more valuable than the publisher's 'greasy till', he still operated from a position of relative dominance and conscious asymmetry. A journal like De beweging would always be misunderstood by contemporaries, Verwey lamented:

[S]ustaining a general journal called De beweging is no mean feat. Recognition can only be expected at a future date. Should this cold-blooded assessment be acceptable to you, then we can depend on one another. If trust is lacking, however, this will be impossible. ${ }^{48}$

46 Letter from Verwey to Maas \& Van Suchtelen, 21 March 1908 (UVA XLI B 8686).

47 Memo written by Verwey, undated (UVA XLI A 26:14); '[dat] De Beweging een voornaam tijdschrift [is, en] zoo in aanzien staat [...] is voor een uitgever die een eenigszins breeden blik heeft en wanneer hij de uitgaaf van een algemeen tijdschrift op prijs stelt, de gelegenheid een tijdschrift als De Beweging te kunnen overnemen een buitenkans'.

48 Letter from Verwey to Maas \& Van Suchtelen, 1 January 1908 (UVA copybook XLI B 5): 'een algemeen tijdschrift handhaven dat De Beweging heet zal een knap stuk zijn. Gewaardeerd 
Through De beweging, Verwey asserted, publishers were really investing in their own immortality. They were supplying on credit. He looked down on publishers whose motives were simply mercantile and who preferred short-term profits to loftier future rewards. ${ }^{49}$ As far as he was concerned, investing in De beweging was losing a fly to catch a trout.

\section{Concluding Remarks}

In this chapter, I have followed Clayton Childress's (2017) assertion that branding a text (or any cultural object) comes down to telling a story about $i t$, and then pitching that story against the stories other stakeholders in the branding process may create. The point of departure of my exploration of the branding of De beweging was, then, that Verwey's ambition was to construct such a story to use it to deliver a credible 'brand promise', and to persuade the other stakeholders to engage with his story by investing materially or symbolically in the magazine.

My research of the Verwey archive has made clear that the branding of De beweging took shape through a 'branding triangle' in which Verwey, his publishers, and his readers participated. The interactions in this triangle were invariably initiated by Verwey. In letters, prospectuses, and memos, but also in essays published in the magazine itself, he constructed stories about (the meaning and significance of) De beweging. These bids to load the magazine's brand triggered various reactions on the part of Verwey's branding partners. Sometimes his stories were (explicitly) accepted (for instance by his publisher Versluys and by his contributor J.C. Bloem), sometimes (implicitly) rejected (by the readers who did not respond to Verwey's call to action), and sometimes (implicitly) rejected and then (explicitly) reframed (by his publisher Maas \& Van Suchtelen). It is clear that not all attempts at branding were immediately successful: Verwey's readers proved unprepared to make the sacrifices he asked of them, and his publishers tried to seize control despite his efforts to check their influence. These dynamics of acceptance and rejection offer us an intriguing insight in the (interactive) workings of the literary field in this period.

If we look more closely at Verwey's branding narratives, some interesting patterns emerge (see Fig. 2.2 below). Verwey seems to have constructed four

worden zal het eerst later. Is u met deze koelbloedige beschouwing tevreden dan kunnen we op elkaar rekenen. Zonder vertrouwen zal het in dit geval niet gaan'.

49 Letter from Verwey to Is.P. de Vooys, 11 June 1909 (UVA XLI B 16798). 
Figure $\mathbf{2 . 2}$

\begin{tabular}{llll}
\multicolumn{2}{c}{ Storyline } & Brand promise & Targeted branding partner \\
1 & Esoteric & Spirituality, beauty, value & Readers \\
2 & Collective & $\begin{array}{l}\text { Solidarity and community (based on a sense of } \\
\text { like-mindedness and mutual appreciation) }\end{array}$ & Publishers, readers \\
& Personal & $\begin{array}{l}\text { Devotion (to literature and authorship), } \\
\text { conviction, sacrifice and redemption }\end{array}$ & Publishers \\
& & Instrumental & Influence, dominance
\end{tabular}

types of storyline, each covering two to four different brand promises. Not all storylines were targeted to all branding partners: one (the storyline I have labelled 'esoteric') was directed exclusively at readers, two (the storylines I have labelled 'personal' and 'instrumental') exclusively to publishers, and one (the 'collective' storyline) at both readers and publishers.

It is worth noting that even within the same partner category, Verwey appears to have chosen to differentiate the targeting of his storylines. He directed his instrumental storyline, for instance, to his publisher Versluys, but not to his publisher Maas \& Van Suchtelen. To them, he consistently targeted his collective storyline - in a bid, perhaps, to counter the aggressively instrumental storyline Maas \& Van Suchtelen chose to direct back at him. It is also interesting that his contributors (operating, of course, in Verwey's own corner of the branding triangle) proved very susceptible to Verwey's stories of solidarity and community, not only accepting but positively embracing his narrative of kinship and affinity. De beweging seems to have provided them with a rallying point that was hard to find elsewhere.

The final point I would like to make concerns the connection between the four storylines I have presented above, and the importance Verwey attached to the concepts of autonomy and independence. Paradoxically, the only storyline directed at both branding partners is the storyline that least emphasizes the idea of autonomy. The collective storyline deals, after all, with participation and teamwork, and has overtones of dependence instead of independence, and of reliance on others instead of self-reliance. In an earlier analysis (Van den Braber 2019, 407), I have claimed that 'autonomy was the bargaining chip in the exchanges and negotiations between all parties, and the effort to protect it was the driving force behind many of the interactions between Verwey and others'. Now, looking at the case from the perspective of branding theory, I believe a more nuanced conclusion is in order. Verwey told a double story, in which the image of De beweging seems to have curiously amalgamated both poles of the autonomy spectrum. 
The brand image he projected centres on the idea of participation, but on a defiantly autonomous basis, both upheld by loyalty and community spirit, and by the wish to be independent of (and united against) an indifferent and ignorant (larger) public.

From a historical perspective this Dutch case study reveals a number of aspects regarding the way in which literary journals were managed and branded at the turn of the twentieth century. During this period both culture and society were in a state of rapid transition, and the value of literature was heavily debated. Interestingly, Verwey continued to regard literature as sacrosanct and his journal worthy of every sacrifice. This belief in and selling of the irrefutable value of literature were closely tied to the value attached to autonomous authorship. Verwey felt that writers and readers should defend literature at all cost - irrespective of their personal situation, of financial or ideological considerations, and of the value attached or denied to literature by society at large. This underlying ideal of unconditional commitment makes the branding game around De beweging all the more meaningful.

\section{References}

J.C. Bloem. 1997. De brieven aan Albert Verwey. Maarssen: Umbra.

Pierre Bourdieu. 1983. 'The Field of Cultural Production, or: The Economic World Reversed'. Poetics 12.3-4: 311-356.

Pierre Bourdieu. 1985. 'The Market of Symbolic Goods'. Poetics 14.1-2: 13-44.

H.M. van den Braber. 2014. 'Geven en krijgen rond het tijdschrift De Beweging (1905-1919)'. Nederlandse Letterkunde 19.3: 301-325.

H.M. van den Braber. 2016. 'De Nieuwe Gids and its informal patronage system'. Journal of European Periodical Studies 1.1: 53-69.

H.M. van den Braber. 2017. 'Reciprocal Interactions and Complex Negotiations: Three Nineteenth-century Models of Patronage'. European Journal of English Studies 21: 43-6o.

H.M. van den Braber. 2019. 'Negotiating Authorship and (In)dependence Around 1900: The Case of Dutch Literary Magazine De beweging'. Nineteenth-Century Contexts. An Interdisciplinary Journal 41.4: 393-407.

Clayton Childress. 2017. Under the Cover. The Creation, Production, and Reception of a Novel. Princeton: Princeton University Press.

Sjoerd van Faassen. 1997. 'Een uitgeverij voor de groep rond het tijdschrift De Beweging'.Jaarboek Letterkundig Museum 6. The Hague: Letterkundig Museum. Frank van der Goes. 1986. 'Welke beweging?'. In Harry G.M. Prick (ed.), De briefwisseling tussen Lodewijk van Deyssel en Albert Verwey. Deel III: april 1898 
- januari 1905 pp. 292-307. The Hague: Nederlands Letterkundig Museum en Documentatiecentrum.

Alvin Gouldner. 1960. 'The Norm of Reciprocity: A Preliminary Statement'. American Sociological Review 25.2: 161-178.

Aafke Komter. 2005. Social Solidarity and the Gift. Cambridge: Cambridge University Press.

Elsbeth Kwant. 2000. De Noodzakelijkste, de Waardigste en de Wenschelijkste van alle uitgaven. De Beweging 1905-1919. Master's thesis, University of Leiden.

Elsbeth Kwant. 2009. 'Het laatste tijdschrift der dromers: de uitgave van "De Beweging” 1905-1919'. De boekenwereld 26.2: 77-86.

Marcel Mauss. 2002. The Gift: The Form and Reason for Exchange in Archaic Societies. London: Routledge.

Frans Ruiter and Wilbert Smulders. 1996. Literatuur en moderniteit in Nederland, 1840-199o. Amsterdam/Antwerp: De Arbeiderspers.

Gisèle Sapiro. 2005. 'Elemente einer Geschichte der Autonomisierung. Das Beispiel des französischen literarischen Feldes'. In Markus Joch and Markus Wolf(eds.), Text und Feld. Bourdieu in der literaturwissenschaftlichen Praxis, pp. 25-44. Tübingen: De Gruyter.

Maurits Uyldert. 1955. Dichterlijke Strijdbaarheid. Uit het leven van Albert Verwey (Deel II). Amsterdam: Allert de Lange.

Albert Verwey. 1914. 'Bij een eindpunt', De beweging 10: 173-177.

\section{About the Author}

Helleke van den Braber holds an endowed chair in Patronage Studies at Utrecht University (The Netherlands), and is director of studies of the Department of Literary and Cultural Studies at Radboud University Nijmegen, where she coordinates MA programmes in 'Cultural Policy and Patronage' and 'Creative Industries'. From 2015-2020, Helleke was leader of the Radboud research group SCARAB, which examines cultural infrastructure and criticism studies. Her research interests include the history and theory of patronage, and historical and modern practices of strategic giving. 


\title{
A Hero and His History
}

The Branding of Jan III Sobieski and His Letters in the Northern Netherlands during the Early Nineteenth Century

\author{
Paul Hulsenboom
}

\begin{abstract}
In the late 1820 s and early 1830 s, Europe saw the appearance of several editions of the correspondence of Jan III Sobieski, former king of Poland and liberator of Vienna in 1683 . Three Dutch editions were published in The Hague. This chapter analyses the ways in which Sobieski and his letters were branded in these Dutch editions, particularly in the books' extensive front matter. It argues that, while the Dutch branding was directly inspired by the French and Polish versions, the motives behind these different editions varied greatly, depending on their contexts. Of key importance were events related to Polish patriotism, such as the November Uprising. A number of reviews furthermore make clear how the brands in the Dutch editions were received.

Keywords: Jan III Sobieski, king of Poland, personal correspondence, posthumous branding, Dutch and French translations, nineteenth-century reviews, Polish patriotism
\end{abstract}

\section{Introduction $^{1}$}

'My soul's and heart's one and only comfort, prettiest and dearest Molly! God our Lord, who is blessed for all eternity, has given our nation a victory and glory the like of which the past ages have never seen' (Sobieski 1970:

1 I would like to thank Prof. dr. Kris Van Heuckelom and Alan Moss MA for proofreading a previous version of this text and sending me their valuable comments.

Helleke van den Braber, Jeroen Dera, Jos Joosten, and Maarten Steenmeijer (eds), Branding Books Across the Ages: Strategies and Key Concepts in Literary Branding. Amsterdam, Amsterdam University Press 2021 DOI: 10.5117/9789463723916_CHO3 
522). ${ }^{2}$ These are the opening lines of the letter the Polish king Jan III Sobieski (1629-1696) wrote to his wife in the night of 13 September 1683 while sitting in the tents formerly belonging to Grand Vizier Kara Mustafa Pasha. The day before, he had won the Battle of Vienna.

That battle is often seen as one of the defining moments in European history. Sobieski, personally leading a coalition of troops from PolandLithuania and the Holy Roman Empire, achieved a decisive victory over the Ottomans, who had laid siege to the imperial city in July that year. The siege had been the result of a campaign designed to strengthen the Ottoman Empire's influence in Europe. Providing military support to the Hungarians under Habsburg rule, the Ottomans had proclaimed their vassal Imre Thököly king of Upper Hungary and declared war on the Habsburg Empire in 1682. Emperor Leopold I subsequently allied himself with Sobieski, who rode to Vienna's aid and took command over the city's relief. The charge of the Polish heavy cavalry, the famous Winged Hussars, played a particularly vital part in the battle. In the end, the Ottomans were routed and forced to retreat, eventually losing their foothold in Hungary and Transylvania. Sobieski's triumph thus marked the end of the Ottoman expansion into Europe. ${ }^{3}$

Some 140 years later, around 1820, the Polish count Edward Raczyński (1786-1845) was rummaging through his family archive. As he did so, he uncovered an intriguing set of documents, entitled Korrespondencya nieboszczyka Króla z Królowa w czasie wyprawy Wiedeńskiey (The Correspondence of the Late King to the Queen at the Time of the Vienna Expedition). The documents appeared to be copies of the Polish letters by Jan III Sobieski, written around the time of the king's celebrated expedition, and addressed to his wife, Marie Casimire Louise de La Grange d'Arquien (1641-1716). ${ }^{4}$ In 1823, a few years after Raczyński's fortunate discovery, a collection of thirty letters was published by the Glücksberg press in Warsaw, including an introduction and notes by Raczyński himself. Although some of these letters were already known to exist, this was the first time a larger collection of Sobieski's correspondence to his queen consort was found and published. It was, as Raczyński put it, 'an important monument to

2 'Jedyna duszy i serca pociecho, najśliczniejsza i najukochańsza Marysieńku! Bóg i Pan nasz na wieki błogosławiony dał zwycięstwo i sławę narodowi naszemu, o jakiej wieki przeszłe nigdy nie słyszały'.

3 Cf. Stoye 2008 and Wheatcroft 2008 for more information on the battle, its prelude and aftermath.

4 As Raczyński himself explains, his forefather Michał Raczyński worked as a diplomat for the Polish king and may have had access to the royal family's archive. See Sobieski 1823: ii. 
the fame of our [Poland's] nation' (Sobieski 1823: i) , $^{5}$ and a second edition was printed in 1824 .

It would not be long before this 'monument' would receive recognition elsewhere. In 1826, a French translation of Sobieski's letters was issued in Paris. This in turn prompted three more editions, published the following year: a French version from Louvain, an almost identical edition from Tournai, and a Dutch translation of five letters based on the Paris edition and printed in The Hague by A. Kloots. In 1831, Kloots furthermore produced a complete Dutch translation of the letters, which met with favourable reviews. Such was the demand, moreover, that a second edition was put on the market in 1835 .

The popularity Sobieski's correspondence enjoyed in the Northern Netherlands was no doubt partly caused by the branding of the letters and their author. The ways in which the Dutch editions were advertised and presented by the publisher and translator - who cleverly made use of the historical context, recycled the previous editions, and combined old stereotypes with new information - were key factors. This chapter discusses how Sobieski and his letters were branded in the Northern Netherlands during the early nineteenth century and explores the reactions to the brands by the book's reviewers. Part of the topic's interest lies in the fact that Sobieski had no say in this branding process: by the 1800 s, he was long dead, and there are no indications that he ever intended his correspondence to be so widely disseminated. ${ }^{6}$ It is thus an example of posthumous branding in its purest form. The subject is all the more interesting as it concerns the branding of a Catholic author in a predominantly Protestant country.

The chapter begins with an analysis of the brands present in the Dutch editions. I use the plural 'brands', because a distinction can be made between a brand formed around the author, Jan Sobieski, and a brand surrounding the letters themselves. The following section moves back in time to trace the origins of these brands by looking at the Paris and Warsaw printings. The final section discloses several reviews of the book, and thus reveals which elements of the Dutch branding of both Sobieski and his correspondence were successful and why. In the conclusion, the findings of this case study are used to discuss more general aspects of literary branding.

5 'Ważny ten pomnik sławy narodu naszego'.

6 Sobieski was actively involved in the shaping of his own image. Several of his letters to his wife, for example, make clear that he used them to transmit information about his achievements to foreign courts and media. There is no proof, however, that he meant for his correspondence to be published. See on Sobieski's propaganda in text and image for example: Czarniecka 20og, Gutowska-Dudek 2013, and Fijałkowski 2014. 
Figure 3.1 Title page of Brieven van den Koning van Polen Jan Sobieski [.... .'s Gravenhage: A. Kloots, 1831. KB | Nationale bibliotheek: 3107 B 9

\section{$276 \times 28$}

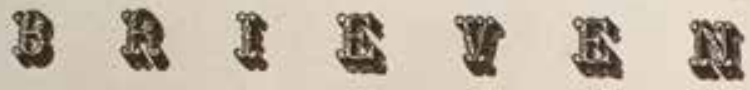

VA $\mathbf{N}$ D $\mathbf{B} \mathbf{N}$

KONING VAN POLEN

J A N S S O B I E S K I I, A A N D E

K O N I N G I N

\section{MARIA CASIMIRA,}

GEDURENDE DEN VELDTOGT, TOT ONTZET

VAT WEENEN EN DE BEVRTJING

DER CHRISTENHEID, IN 1683.

Naar het Fransch van den Graaf PLATER.

TE 'S GRAVENHAGE,

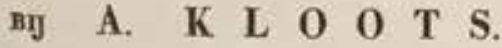

1831. 


\section{The Dutch Translations: A Sign of the Times}

As has already been stated by Van Deinsen and Geerdink in the present volume, both a book's textual and visual front matter has long since played a significant role in the literary branding process. This is particularly evident in the case of Sobieski's letters. In every new edition, moreover, the front matter was expanded.

The most extensive version of the book's front matter was added to the Dutch translation published in 1831 by A. Kloots from The Hague (Fig. 3.1). The brands employed by both Kloots and the translator form an intricate patchwork of images. Preceding the title page is an engraved portrait of Sobieski. As argued by Van Deinsen and Geerdink, portraits such as this one often had a prominent place in early modern books and conveyed specific information about the author. Furthermore, the book consists of a 35-page introduction. The edition opens with a 'Foreword by the Dutch translator', followed by three other introductory texts: 'Message from the French editor', 'Foreword by the French translator', and 'Historical overview of the events which preceded the moment upon which the King of Poland wrote his letters. By Count Plater'.

The front matter thus leaves no question as to the book's French provenance. Who this Count Plater was, and which French edition had been used, will be discussed later on, but for now it is interesting to point out that Kloots apparently found these things important. Indeed, whereas the French editor and translator are named and exalted (Sobieski 1831: xv), the Dutch translator himself remains anonymous. It is only through a novel entitled De wederwaardigheden des levens, of de gevolgen van onwettige verbindtenissen (The Experiences of Life, or the Consequences of Unlawful Unions), published by Kloots in 1833 , that the identity of the translator is revealed: the royalist poet Quirijn de Flines (1771-1847). ${ }^{7}$ It would appear, then, that De Flines was also responsible for the 'Foreword by the Dutch translator', as well as the translation of the other three introductory texts. As will be explained below, however, this was only partly the case.

Now for the brands the edition associates with Sobieski and his letters. The engraved portrait of Sobieski, which shows him wearing a suit of armour and a furred cloak, conjures up the image of a warrior-king. In the second edition, printed in 1835 , the portrait was incorporated into the title page (Fig. 3.2). The image of Sobieski as a warrior-king is echoed in two

7 The title-page advertised the book as a translation from the English, made by 'the translator of the letters of the king of Poland Jan Sobieski'. He is introduced as 'Q. de F.....' in the introduction. 
Figure 3.2 Title page of Brieven van den Koning van Polen Jan Sobieski [...]. 's Gravenhage: A. Kloots, 1835. Bijzondere Collecties, Universiteit van Amsterdam, UBM: 230 B 17

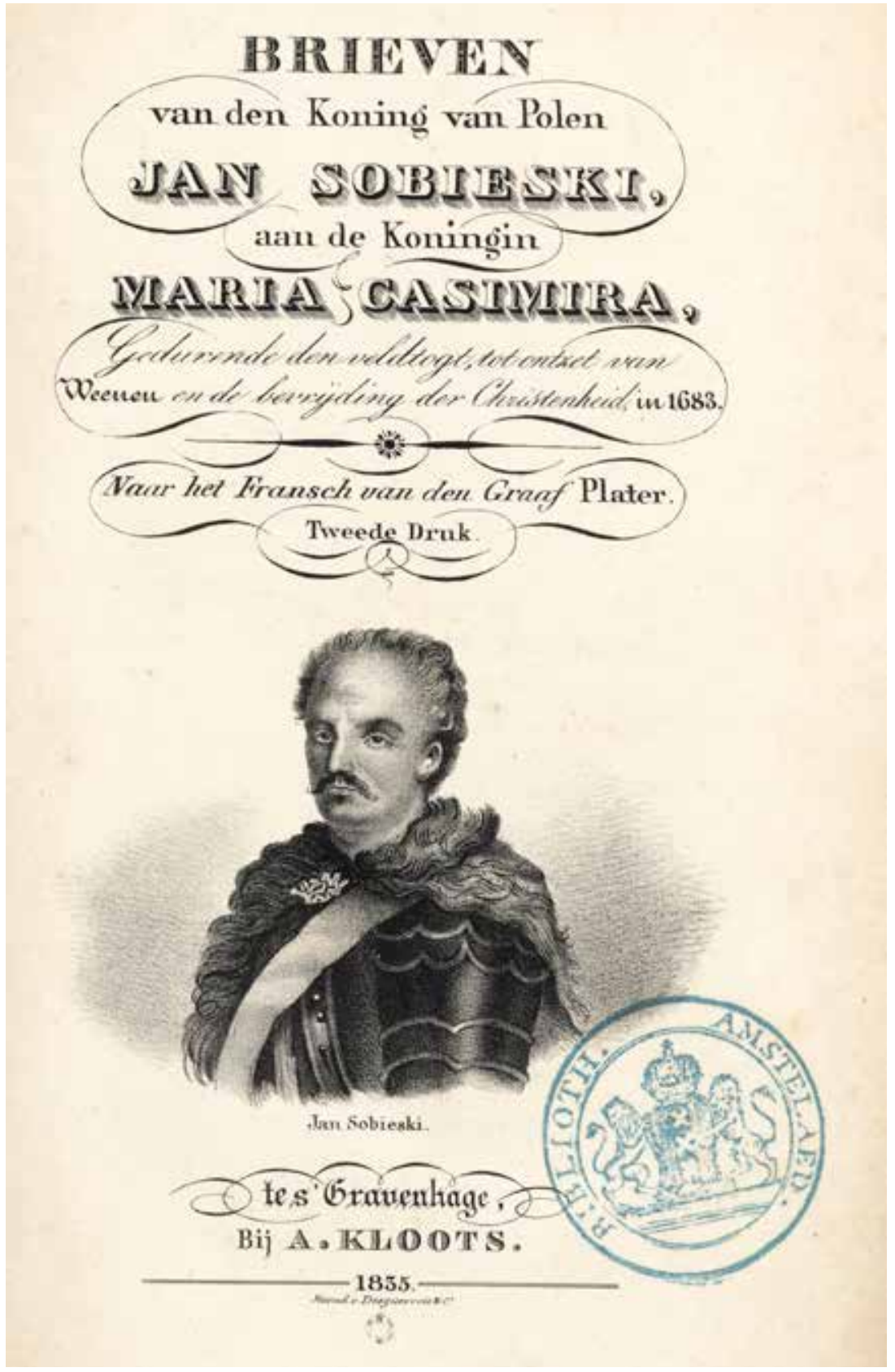


introductory texts in particular. The 'Foreword by the Dutch translator' opens with a lengthy discussion of the two moments when the followers 'of the prophet Mahometh' threatened 'Christian Europe' the most (Sobieski 1831: vii): ${ }^{8}$ in the eighth century, when they were beaten by the French hero Charles Martel, and in 1683, at the Battle of Vienna. The text concludes that Sobieski's victory was even more significant than Martel's, as 'Christendom was saved from its downfall' (xi). ${ }^{9}$ Later on, mention is made of 'the fame and spirit of the Polish hero', who with God's help had 'saved the oppressed Christendom' (xiv). ${ }^{10}$ The monarch is thus branded as a supreme defender of the entire continent, united by the Christian faith. This image recurs once more in the 'Foreword by the French translator', which again briefly mentions Charles Martel, and calls Sobieski 'a hero from the ages of the crusades, $[. .$.$] who knows no equal in the history of the past centuries, and$ whose glory is immortal' (xxvii). ${ }^{11}$

The correspondence itself is merited for having several qualities. Firstly, the 'Foreword by the Dutch translator' says that 'these kinds of events namely the redemption from great and urgent dangers - cannot, in our opinion, be called to mind often enough' (Sobieski 1831: xii). ${ }^{12}$ This historical consciousness can be tied to several remarks in the other introductory texts, which stress the letters' importance. The 'Foreword by the French translator', for example, points to other editions of letters by historical heads of state and argues that the correspondence will '[provide] the historian of that age with valuable material' (xxiii). ${ }^{13}$ After all, the 'crisis' it concerns was 'one of the most significant in modern history' (xxiii-xxiv). ${ }^{14}$ But while the letters are said to be of particular importance to the Poles and Germans, the French editor and translator also did their best to underscore the texts' 'French connection': the letters were known at the court of Louis XIV, so the editor writes, and parts of them were already cited by Madame de Sévigné and Voltaire (xviii-xx). The French translator furthermore states that the events of 1683 were intertwined with the politics of Louis XIV (who had

8 'Van den [...] profeet Muhammed [...]', , [...] christelijk Europa'.

9 'De [...] christenheid werd voor den ondergang behoed'.

10 'De roem en de geest van den Poolschen held', and p. xv: 'redde de bedrukte christenheid'.

11 'Eenen held uit de tijden der kruistogten, [...] die zijns gelijken niet heeft in de geschiedenis der laatst verloopene eeuwen, en wiens roem onsterfelijk is'.

12 'Soortgelijke gebeurtenissen - namelijk de verlossing uit groote en nijpende gevaren - kunnen ondertusschen, naar onze gedachten, niet te dikwerf in het geheugen terug geroepen worden'.

13 'Den geschiedschrijver van dat tijdvak kostbare bouwstoffen opleveren'.

14 'De staatkundige beslissende uitkomst (crisis) [...] is een der gewigtigste uit de hedendaagsche geschiedenis'. 
been trying to weaken Habsburg Austria) (xxiv). Lastly, of course, Sobieski's wife herself was French.

Expanding this historical significance with the correspondence's value on another level, the 'Message from the French editor' remarks that the texts are charming due to their 'constant contrast between the simplest preoccupations of normal life and the greatest changes of fortune and the most terrible resolutions in the political world' (Sobieski 1831: xx). ${ }^{15}$ The letters are advertised as opening a window into the person of Sobieski himself, a point which is also made in the 'Foreword by the Dutch translator': 'in order to get to know the people who have come into the possession of history, nothing better suits that purpose than examining their personal letters' (xii). ${ }^{16}$ This aspect also adds to the image of Sobieski, as it gives the reader an insight into his personality, and he is praised for combining his role as a military commander with that of a loving husband. Indeed, the correspondence is even said to reveal how he trembled 'before his domineering wife, who kept him under control' (xx-xxi). ${ }^{17}$

The literary qualities of the letters, meanwhile, are only briefly touched upon. This is done by the French translator, who states that 'the style [of the letters] is tedious and incoherent, jumping from one subject to the next'. However, he manages to interpret this favourably by saying that the style is 'such, to conclude, as one often finds in intimate contacts' (Sobieski 1831: $\mathrm{xxxi})$, thereby relating it to the correspondence's personal nature. ${ }^{18}$

Finally, the French translator's foreword also argues that Sobieski's person offers the reader 'the perfect traits of the ancient Polish character' (Sobieski 1831: xxvii), ${ }^{19}$ consisting of such elements as a warlike and chivalrous spirit, sincere piety, subservience to women, a taste for luxury and elegance, kindness, and a tendency towards honest and liberal politics. And yet, the letters also show Poland's so-called anarchic system of government, revealing the events which led up to the country's dissolution in the late

15 'Gedurige tegenstelling der eenvoudigste vooringenomenheden van het gemeene leven, tegen de grootste lotverwisselingen en de verschrikkelijkste ontknoopingen in de staatkundige wereld'.

16 'Immers is toch niets geschikter, om de personen, welke de eigendom der geschiedenis zijn geworden, beter te leeren kennen, dan uit hunnen vertrouwelijke brieven'. This statement is an almost exact copy, furthermore, of a sentence featuring in the 'Foreword by the French translator' (xxv).

17 'Dáár ziet men den grooten man beven voor de, hem onder bedwang houdende, heerschzuchtige vrouw'.

18 'De stijl derzelve is langwijlig en onzamenhangend, van het eene onderwerp tot het andere overgaande, zoodanig, eindelijk, als men zulks in het vertrouwelijk verkeer dikwerf aantreft'.

19 '[...] de volmaakte trekken van het oud Poolsche karakter'. 
eighteenth century. ${ }^{20}$ As such, the correspondence is once again presented as an important historical source.

This, then, is how the Dutch editor and translator branded both Sobieski himself and his correspondence. But what prompted Kloots to publish the letters in the first place? Was it his firm belief in their importance, for example, and thus an ideologically motivated decision? The answer is probably quite different. August 1830 saw the beginning of the Belgian Revolution. A few months later, the Polish November Uprising against the Russians began in Warsaw. The concurrence of the two events naturally provoked a large number of Dutch reactions to the Polish rebellion. ${ }^{21}$ Some supported the Poles' fight for freedom and independence, but many condemned the insurgents' so-called insubordination and ingratitude to the Russian tsar, frequently comparing the Poles to the Belgians. One such text, seemingly written by a Pole, yet evidently propagating pro-Russian views, was in 1831 published by Kloots himself. ${ }^{22}$ The simultaneous edition of Sobieski's letters thus tied in perfectly with the time's interest in Polish affairs.

This is also visible in some of Kloots's newspaper advertisements, in which he announced Sobieski's letters together with another work, ${ }^{23}$ tellingly entitled Clausse, of Hollandsche trouw, een geschiedkundig tafereel uit den strijd met de Belgen (Clausse, or Dutch Loyalty, a Historical Scene From the Struggle Against the Belgians), a play which patriotically recounts a Dutch soldier's heroism during a battle against the Belgian foe. It goes to show Kloots's engagement with the time's politics, as well as the indirect link between the Poles and Belgians.

That link is not made explicit, however, neither in the advertisements nor in the book itself. Perhaps the most plausible explanation for this has to do with the unwillingness to pick sides: any reference to the uprising could very easily label the book as an expression of support to the Polish cause, something which may not have been in the publisher's interest. For even though the introduction mentions Sobieski's weakness for women and Polish anarchy, the overall image of Sobieski, his countrymen, and the letters themselves is clearly and decidedly positive. Considering Kloots's other publications, notably the already mentioned pro-Russian piece of

20 Sobieski 1831: xxvii-xxviii. Polish so-called anarchy had become almost proverbial during the eighteenth century.

21 Cf. Goddeeris 2011.

22 Bedenkingen 1831.

23 See, for example, advertisements in the Algemeen Handelsblad 11 October 1831, Bredasche courant 8 October 1831 and 14 October 1831, Middelburgsche courant 15 October 831, and Rotterdamsche courant 8 October 1831. 
propaganda and the patriotic play, appearing to support the Polish insurgents was probably not his intent. As it is, the book does not purport to be anything but an important and intriguing collection of letters, written by a king who is presented first and foremost as a supranational Christian hero who just happened to be Polish. Anyone with sympathy for the Poles could read the book as a reminder of Poland's former greatness; anyone without it did not have to. Whatever the personal opinions of Kloots and De Flines, they cleverly responded to what was making news at the time, turning the letters into an economically attractive opportunity. ${ }^{24}$

Interestingly, however, this was not the first time Kloots had shown an interest in Sobieski's correspondence. Four years earlier, in 1827, he had already published several letters as part of another work, which was the first in a series entitled Tafereelen uit het rijk der geschiedenis (Scenes From the World of History). The collection consists of the first five letters, which are preceded by a foreword similar to the 1831 version. It is evident that the other letters were meant to be included in the rest of the series, but this never came to pass, as the series would not be continued. Indeed, a footnote in the 1831 edition explains that this was due to someone's (probably the unnamed translator's/editor's) death (Sobieski 1831: xviii). This could mean that Quirijn de Flines did not have a hand in the 1827 volume, particularly as there are differences between the two translations. The letters are part two in a set of six different texts, which apart from Sobieski's correspondence relate to the history of the Americas (in general), Greece, Egypt, Sweden, Paraguay, Chile, and Peru. This alone provides the letters with an aura of international importance and even exoticism. In addition, the book's general introduction informs the reader that the anonymous editor wished to collect 'important events from the history of the world and mankind' (Sobieski $1827 \mathrm{c:v}$ ), ${ }^{25}$ and in doing so had a higher educational, moralizing, and even political goal. For example, he wished to inspire the Dutch hunger for knowledge, virtue, duty, philanthropy, and patriotism, and to support those who strived to expand both religious and civilian freedom (v-vi). Apparently, then, the editor believed that Sobieski's letters were suited to these endeavours, and the correspondence was intended first and foremost as a historical example, meant to instruct the Dutch readership.

24 There is one interesting omission: in one of the letters, Sobieski mentions Maurice of Orange, saying he means to follow his example in the battle against the Ottomans. It is an obvious link between Sobieski and Dutch history, which De Flines could easily have exploited in order to spark the readers' interest. He did not do so, however.

25 'Belangwekkende voorvallen, in de geschiedenis der wereld en der menschheid opgeteekend'. 
Looking at the correspondence's front matter specifically, it is clear that it provided the basis for the 1831 introductions, with several paragraphs being literally the same. This is why it is uncertain that Quirijn de Flines was the author and translator of the entire 1831 front matter, even though he did offer a new translation of the letters themselves. In the 1827 version, however, there are only two introductory texts: a general introduction, which comes down to a concise version of the first three forewords from 1831, and a historical overview, which four years later would be reprinted, with slight differences. The brands featured are, however, virtually the same. For example, the foreword opens with the passage about Charles Martel, the letters are compared to those of other heads of state and advertised as a means of getting to know a historical figure, and Sobieski himself is once again presented as a hero from the age of the crusades, whose correspondence furthermore offers an insight into the old Polish character and the nation's 'discord and anarchy' (Sobieski 1827c: 61). ${ }^{26}$

One passage, which is absent from the $183^{1}$ edition, reveals the motives behind the editor's interest in Sobieski's correspondence. He argues that the Muslims are once again at the gates of Europe, threatening 'a Christian people' (Sobieski 1827c: 56 ). ${ }^{27}$ This is without doubt a reference to the Greek War of Independence, fought between the Ottomans and Greek freedom fighters since $1821 .{ }^{28}$ Only in 1827 did a combined Russian-French-British fleet intervene and crush the Ottoman-Egyptian fleet at the Battle at Navarino, thereby changing the course of the war. The editor comments that the letters are of particular importance 'in these times', branding them as a lesson and inspiration for Dutch Christians during Europe's struggle against the Ottomans. By 1831, the Greeks had won their independence, and so the passage was removed from the introduction. Once again, then, political circumstances played a crucial part in the publication of Sobieski's correspondence. In 1827 , however, the editor's clearly formulated ideological goals were there for all to see.

Before moving on to the Paris and Warsaw editions, it is important to briefly discuss the manner in which the letters were translated in both the 1827 and the 1831 versions. The translations are fairly literal, or at least contain no significant (ideologically motivated) alterations to the main text. The only notable additions are a couple of footnotes in which the

26 'Verdeeldheid en regeringloosheid'.

27 'Een christenvolk'.

28 Indeed, the fate of the Greeks is lamented and discussed immediately following Sobieski's letters (111-152). 
translator criticizes France (first in the form of Francis I, then Louis XIV) for being on too friendly terms with the Ottomans (Sobieski 1827c: 50, 52-53; Sobieski 1831: vii-x).

\section{The Correspondence's History: Sobieski's Letters in Paris and Warsaw}

During the nineteenth century, it was common practice for Dutch translators to work on the basis of French (or occasionally other) translations, instead of the originals (Ingelbien 2016: 64). This was also the case with Kloots's editions of Sobieski's letters. Indeed, the title of the 1827 version even indicated which edition had been used specifically, saying that the letters were 'translated from the original into the French language by Count Stanislas Plater and (in 1826) published by Mr N.A. de Salvandy' (Sobieski 1827c: 49). ${ }^{29}$ This was a reference to a French version issued in Paris by the printer L.G. Michaud. Kloots thus did not base his editions on the Louvain or Tournai printings, which were published in 1827 , and which did not mention De Salvandy on their title page. This is why the Louvain and (nearly identical) Tournai versions will not be discussed, as they probably had little or no influence on the editions from The Hague..$^{30}$ It should be noted, however, that by the $1830 \mathrm{~s}$ multiple editions of Sobieski's letters were available in the Low Countries, both in French and Dutch translations.

29 'Uit het oorspronkelijke in de fransche taal overgebragt, door den graaf Stanislaus Plater, en (1826) uitgegeven, door den heer N.A. de Salvandy.'

30 Suffice to say that the Louvain printing, by Vanlinthout et Vandenzande, was published as part of the Bibliothèque Catholique de la Belgique, a series of works of a religious nature, to which readers from both the Southern and Northern Netherlands could subscribe. The translations are the same as in the Parisian version, but the introductions are somewhat different: the translator's 'Préface du traducteur' and 'Aperçu historique' have been copied almost literally (with the addition of a few footnotes), yet instead of the editor's 'Avertissement de l'éditeur', there is now a 'Notice sur Jean Sobieski, roi de Pologne, ajoutée a la présente édition', which is an elaborated version of the biographical information on Sobieski found in part forty-two of the Biographie universelle, issued in Paris in 1825, again by L.G. Michaud. In line with the series' religious identity, the editors elaborated on Sobieski's Christian piety, which they found lacking in the Biographie universelle. This aspect of the Polish king's image or brand is thereby enforced even further. The Tournai edition, published by J. Casterman, is an almost exact copy of the Louvain version, but with a slightly different title (and title page) and without the information on the Bibliothèque Catholique. As Casterman is mentioned in the Louvain printing as one of the booksellers with whom one could subscribe to the series, this is likely how he got to publish the letters under his own name. Neither edition has the portrait of Sobieski. 
The Parisian printing was mainly the work of two men: the translator, the Polish-Lithuanian count and historian Stanisław Plater (1784-1851), who among other things wrote the Atlas historique de la Pologne, published in Posen (Poznań) in 1827; and the editor, the French politician Narcisse-Achille de Salvandy (1795-1856), who in 1829 would publish his own Histoire de Pologne in Paris. They were responsible for the book's front matter, made up of the three previously discussed texts from Kloots's 1831 translation: the 'Avertissement de l'éditeur', written by De Salvandy, and two texts by Plater, entitled 'Préface du traducteur' and 'Aperçu historique des événements qui ont immédiatement précédé l'époque de ces lettres'. Similarly to Kloots's 1831 edition, moreover, the front page is preceded by a portrait of Sobieski wearing armour and a furred cloak. This time, though, the portrait is signed and mirrored, and the engraving is of a distinctly better quality. ${ }^{31}$

It is clear that Kloots and the Dutch translators made extensive use of the Paris edition, particularly in the 1831 volume. In 1827 , the introductory texts by Plater and De Salvandy were used more freely, with numerous paragraphs and sentences being relocated, removed, or replaced. The most important additions concerned the extensive comparison between Sobieski and Charles Martel, as well as the current threat posed by the Ottomans. Only the 'Aperçu historique' was copied and translated almost literally, but this too was elaborated. In 1831, of course, things looked quite differently. Quirijn de Flines was given his own foreword, which was for the most part a combination of the text concerning Charles Martel and several pages previously added to the 'Aperçu historique', with some slight alterations. Next came the three texts by De Salvandy and Plater, all of them translated quite literally.

This means that the Dutch editions echo the brands of Sobieski and his letters found in the Parisian printing. To begin with, much of the abundant praise Sobieski received in the Dutch editions comes from the French introductions, with Plater for example likening the monarch to a hero from the age of the crusades (Sobieski 1826: xiii). ${ }^{32}$ Similarly, the comparison between Sobieski and Charles Martel was first made by Plater, who thereby probably expected to spark the French public's attention (Sobieski 1826: x). Importantly, however, the comparison was substantially elaborated in the Dutch editions, where Sobieski no longer merely equalled his predecessor, but even surpassed him, something which to a French audience may have been less acceptable.

32 The comparison with the crusades was also made in English seventeenth-century texts. See Mirecka 2014: 216, 218. 
Moving on, Kloots had Paris to thank for the branding of the correspondence as being of international, and even specifically French, importance. It was De Salvandy, namely, who first mentioned how several letters were already known in France (quoting Madame de Sévigné and Voltaire) (Sobieski 1826: xix-xx), and Plater remembered that collections of letters by other important heads of state had been popular in the past (Sobieski 1826: ix). While this statement would later be copied in the Dutch editions, it made more sense in the case of the Parisian volume, as the second half of the eighteenth century had seen various French printings of the correspondences of Louis XIV of France (in 1755), Gustavus II Adolphus of Sweden (in 1790), and Frederic the Great of Prussia (for example in 1787 and 1790).

Similarly, the arguments pertaining to the person of Sobieski and the old Polish character had already made their entrance in the Parisian volume. One of the reasons for this again had to do with the time's political context and with Polish patriotism in particular. At the time of the book's printing, namely, Poland no longer featured on the map of Europe. The once vast and powerful Polish-Lithuanian Commonwealth had been partitioned out of existence by its neighbours: Habsburg Austria, the Kingdom of Prussia, and the Russian Empire, in the years 1772, 1793, and 1795. Following these partitions, many members of the Polish-Lithuanian intelligentsia emigrated to France (and Belgium), particularly after the failure of the 1830 Uprising. ${ }^{33}$ Indeed, Count Stanisław Plater, the translator of the letters, also lived in Paris for some time. As stated by De Salvandy, Plater translated the letters for 'the glory of his country', and at least part of the expected readership, though living in France, was likely to be of Polish origin. In addition, De Salvandy himself had a keen interest in Polish matters, as he was working on his own history of Poland. ${ }^{34}$ Whereas Plater (and, to a lesser extent, De Salvandy) no doubt had a symbolic interest in the publication of his translation, the printer L.G. Michaud would furthermore have been well aware of its possible profitability.

While most of the brands employed by Kloots and the Dutch translators stemmed directly from the Parisian volume, their origins can be traced back even further to the 1823 Polish edition. As was already mentioned, the original Polish version was published by the Glücksberg press in Warsaw and included an introduction and notes by Count Edward Raczyński, the man who had uncovered the letters in the first place. A comparison between

33 See, on the nineteenth-century Polish migration to France and Belgium, Scher-Zembitska 2009 and Goddeeris 2013 respectively.

34 De Salvandy 1829. 
the Paris and Warsaw editions not only reveals that Plater had based his French translation on the Polish originals, but also shows how Raczyński's foreword, even though markedly shorter, provided Plater and De Salvandy with the foundation and inspiration for their own introductions, thereby also laying the basis for the majority of brands that have hitherto been discussed.

In a fashion similar to the Parisian volume, Polish patriotism permeates the Warsaw edition. The letters bore testament to a time when PolandLithuania was still strong and independent and even deemed responsible for the salvation of Christianity. Moreover, they formed the personal correspondence of one of Poland's greatest heroes, written during his finest hour. No doubt Raczyński wished for his edition to heighten his countrymen's spirits, and the Glücksberg press expected the book to perform well on the Polish-reading market. ${ }^{35}$ This combination of symbolic and economic interests helped shape the brands that Raczyński in his foreword associates with both Sobieski and his letters. Firstly, the Polish king is presented as a great national hero and outstanding Christian. In addition, he is said to be both a military genius and a family man, and his only weakness seems to be a disproportionately large soft spot for his wife: the letters show his 'indomitable valour, passion for the nation's glory, trust in the Almighty's assistance, attachment to his children, and fond affection for his wife' (Sobieski 1823: ii). ${ }^{6}$ Sobieski's 'exaggerated compliancy' with the queen, Raczyński admits, would surely be 'justly' criticized by others, but the count nonetheless gives the trait a positive spin, saying that he was glad to see that the 'bloody and long wars' Sobieski fought had not corrupted his tenderness of heart (ii-iii). ${ }^{37}$ All this would later be recycled, adjusted, and expanded in the French and Dutch editions. Whereas Raczyński primarily portrays Sobieski as a national Polish hero, however, this aspect was downplayed in the French and Dutch versions, or in any case it had to compete with a brand of a more supranational character.

Something similar is at work regarding the brand of the correspondence itself. The letters are merited for being of paramount importance for Polish history and for opening a window into the true nature of the great Sobieski. As was already mentioned, Raczyński in his foreword refers to the papers he unearthed as an 'important monument to the fame of our [Poland's]

35 Considering the fact that the book's second edition appeared in 1824 , this expectation was justified.

36 'Nieustraszone męstwo, gorliwość o sławę narodu, zaufanie w pomocy Naywyższego, przywiązanie do dzieci i czuła do żony przychylność'.

37 'Zbytnie uleganie', 'słusznie', 'krwawe i długie boie’. 
nation'. This notion, although still present in the translations, would later be expanded with a European and specifically French layer, although it should be noted that the statements concerning the ancient Polish character were added by Plater. In order to convince his readers of the authenticity of the letters, furthermore, Raczyński explains where he found them and how they had come to be in his possession, and also spends quite some time discussing other documents, so as to prove that his versions were truthful copies..$^{8}$ This 'authenticity argument' was almost completely left out of the translations, possibly because the French and Dutch had no way of checking Raczyński's assertions and preferred not to arouse their readers' suspicions, or because they simply thought it less interesting. Lastly, the foreword explains the run-up to the Battle of Vienna, thereby (re)acquainting the reader with the correspondence's historical context. This part of Raczyński's foreword was used and elaborated by Plater in his 'Aperçu historique'. Instead of a portrait, the letters are furthermore preceded by a large folding map, showing the movements of the Polish army during the Vienna campaign and thereby adding to the book's value as a historical source.

\section{Reviewing the King's Letters}

In order to gain a better understanding of the specific ways in which the predominantly Protestant Dutch public responded to the brands shaped around Sobieski and his letters, this section studies four different reviews of the 1831 edition, published when Dutch literary criticism was still in its infancy (Korevaart 2001: 45-54). What do they reveal about the success of the brands? What conditioned their acceptance or rejection?

The four reviews found were published in various Dutch magazines or newspapers from 1832. Two of them were subsequently reprinted in other publications by Kloots himself, who thus got to blow his own trumpet. 39

38 One such set of other documents, including the letters' originals, which were found nearly simultaneously and which Raczyński sought to consult while preparing his edition, he described as 'for the History of Poland in the seventeenth century such important papers' (iii: 'do Historyi Polskiéy siedmnastego wieku, tak ważne papiery').

39 Three reviews I found outside of Kloots's books: one in a magazine called Vriend des vaderlands, one in the Vaderlandsche letteroefeningen, and one in the Letterkundig magazijn van wetenschap, kunst en smaak. This last review was also (partly) printed in a book entitled Eer en trouw, published by Kloots in 1833 . One review, originally published in 1832 in the Utrechtsche courant, was that same year reprinted in another of Kloots's publications, entitled Morgenwandelingen. I was unable to compare it with the original. 
Three of the reviews are outspokenly positive about the letters, while the fourth criticizes the book, albeit solely on the basis of its many typographical and translational errors. Still, it is evident that the brands employed by Kloots were effective: each of the reviews discusses one or more of the brands' elements in a positive way, sometimes almost literally copying formulas from the book's front matter. That front matter itself is also mentioned several times, indicating its significance. The various introductory texts are said to 'deserve careful reading by all, as they [...] shed a great deal of light on the contents [of the letters]' (Letterkundig magazijn 1832: 158). ${ }^{40}$ It goes to show the impact of the introductions and thereby of the brands they conveyed.

It is interesting to see that some of the brands' elements were picked up more frequently, while others apparently made less of an impression. The one thing mentioned in all four reviews is the historical importance of the correspondence, an aspect which was already put forward by Raczyński and was later recycled in the Paris and The Hague editions. One review states that the letters are of particular significance to Poles, Germans, and Hungarians, or to Dutchmen who study these peoples' histories, but also asserts that even 'those who are no strangers to general history will gladly spend several hours reading these letters' (Vaderlandsche letteroefeningen 1832: 383$) \cdot{ }^{41}$ This idea of the correspondence as an important historical source clearly stuck, since even the negative review goes so far as to say that 'if this work, which is significant to history, were translated and printed more correctly, we would dare to recommend it to our countrymen more readily than we do now' (Vriend des vaderlands 1832: 573 ). ${ }^{42}$ Three reviews furthermore appeal to the reader's historical knowledge, thereby also calling to mind a far older Sobieski image. The one negative review, for example, begins by arguing that 'every civilized Dutchman who has studied modern history, even if only in general terms, knows the brave Jan Sobieski' (570). ${ }^{43}$ In three other cases, Sobieski is associated with the saving of Christendom (and sometimes Europe) specifically, a branding element used in all editions, especially in the ones issued by Kloots. One reviewer goes out of his way to

40 'Verdienen aller aandachtige lezing, omdat zij [...] zeer veel licht over den inhoud derzelve verspreiden'.

$41 \mathrm{Zij}$, die slechts in de algemeene geschiedenis geene vreemdelingen zijn, zullen met genoegen eenige uuren besteden aan de lezing dezer brieven'.

42 'Wanneer dit, voor de geschiedenis belangrijke, werk zuiverder vertaald en gedrukt ware, zouden wij hetzelve met meer ruimte aan onze landgenooten durven aanbevelen, dan wij thans doen'. The letters' importance is also briefly mentioned in Boekzaal 1832: 509 .

43 'Ieder beschaafd Nederlander, die de nieuwere geschiedenis, al is het dan slechts alleen in groote of ruwe, omtrekken, beoefend heeft, kent den dapperen Jan Sobieski'. 
praise Sobieski, even harking back to Julius Caesar: 'the hero came, he saw, he conquered' (Utrechtsche courant 1832). ${ }^{44}$

I believe that a key reason why this notion of the Catholic Polish king as a great Christian and European hero was so readily accepted in the predominantly Protestant Northern Netherlands was because it corresponded perfectly with the already existing Dutch image of Sobieski. Following the Battle of Vienna, news of the heroic Christian victory soon spread, and writers and artists all over Europe began honoring the man who had made it all possible. In the Dutch Republic, too, eulogies and other glorifying texts were written, and celebratory engravings were made, leading to the formation of a Sobieski image which was to live on into the nineteenth century. Without going into too much detail, ${ }^{45}$ it is clear that several texts helped shape Sobieski's reputation in the Northern Netherlands as a 'god of war', a formidable and universally acclaimed hero, comparable to both Classical heroes like Hercules and to historical rulers such as Charlemagne. In addition, the monarch was praised for his Christian piety and selfless character, and heralded as the 'restorer of the faith. ${ }^{46}$ From the 1670 s onwards, moreover, numerous engraved portraits of Sobieski were produced, which often portrayed the king as a so-called rex armatus, embodying both ancient virtus and Christian piety (Fig. $3 \cdot 3) \cdot{ }^{47}$ Texts

44 Reprinted in Morgenwandelingen 1832: no page number: 'de held kwam, zag en overwon'. This is probably also a reference to something which Sobieski supposedly said after his victory: 'I came, I saw, God conquered.' The reviewer in question paid close attention to the book's contents, as he loosely repeats the claims about the letters of 'great men', almost literally copies a sentence from Plater's historical overview, and ends by underlining the correspondence's one Dutch connection, namely a passage where Sobieski praises the military skills of Maurice of Orange. Not even the translation itself had mentioned that.

45 The international reception of Sobieski has been the subject of various, mostly Polish studies. A good starting point is the catalogue of a 1983 exhibition in Warsaw, edited by Fijałkowski and Mieleszko, which discusses Sobieski's reception in both art and literature. Fijałkowski 2014 offers a similar overview. Śliziński 1979 and Klimaszewski 1983 focus on Sobieski in international literature, while Treiderowa 1960, Gawlikowska 1983, Widacka 1987 and 2010, Jagodzinski 2012, and Górska 2017 analyse the king's graphical representations. Kalinowska and Mirecka 2014, and Mirecka 2014: 213-226 deal with aspects of Sobieski's English reception, while Hulsenboom 2019 examines Dutch reactions to Sobieski prior to 1683 . Czarniecka 2009 provides a thorough analysis of Sobieski's own propaganda. The topic of Sobieski's reception in the Dutch Republic will also feature prominently in the author's PhD thesis.

46 Examples are Bake 1683, Van den Broek 1684, Van der Linde 1685, and Francius 1687. The phrases 'god of war' ('Oorlogs-God') and 'restorer of the faith' ('herstelder van 't Geloof') come from Van den Broek 1684: 49 and 53 respectively.

47 The best-known portrait was designed by the famed Romeyn de Hooghe (1645-1708), the other was printed in the workshop of one Peeter Smith (dates unknown). Both engravings would in later years be widely copied by other printers, particularly after 1683. See Widacka 2010: 19-24; and Hulsenboom 2019. 
Figure 3.3 Pieter Schenk (I) and Jan Norel, Portrait of Jan III Sobieski, king of Poland, ca. 1670-1713. Rijksmuseum Amsterdam: RP-P-OB-9243

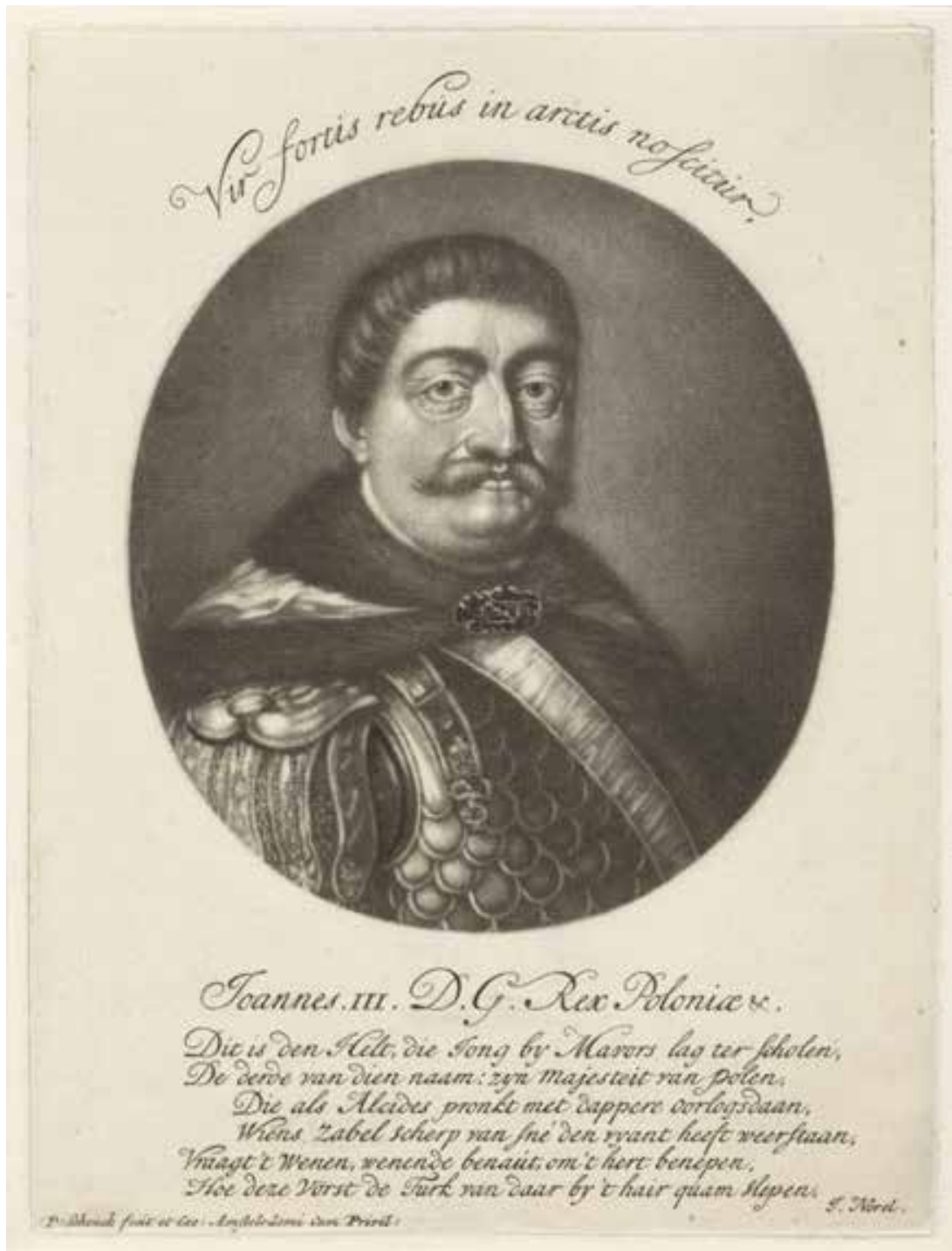

and engravings thus worked together to forge an enduring Dutch Sobieski image, which was recycled and reaffirmed in Kloots's editions. Even the portrait of Sobieski preceding the letters was clearly inspired by seventeenth-century engravings, which more often than not pictured the king wearing armor and 
Figure 3.4 Portrait of Jan III Sobieski, from Brieven van den Koning van Polen Jan Sobieski [...]. 's Gravenhage: A. Kloots, 1831. KB | Nationale bibliotheek: 3107 B 9

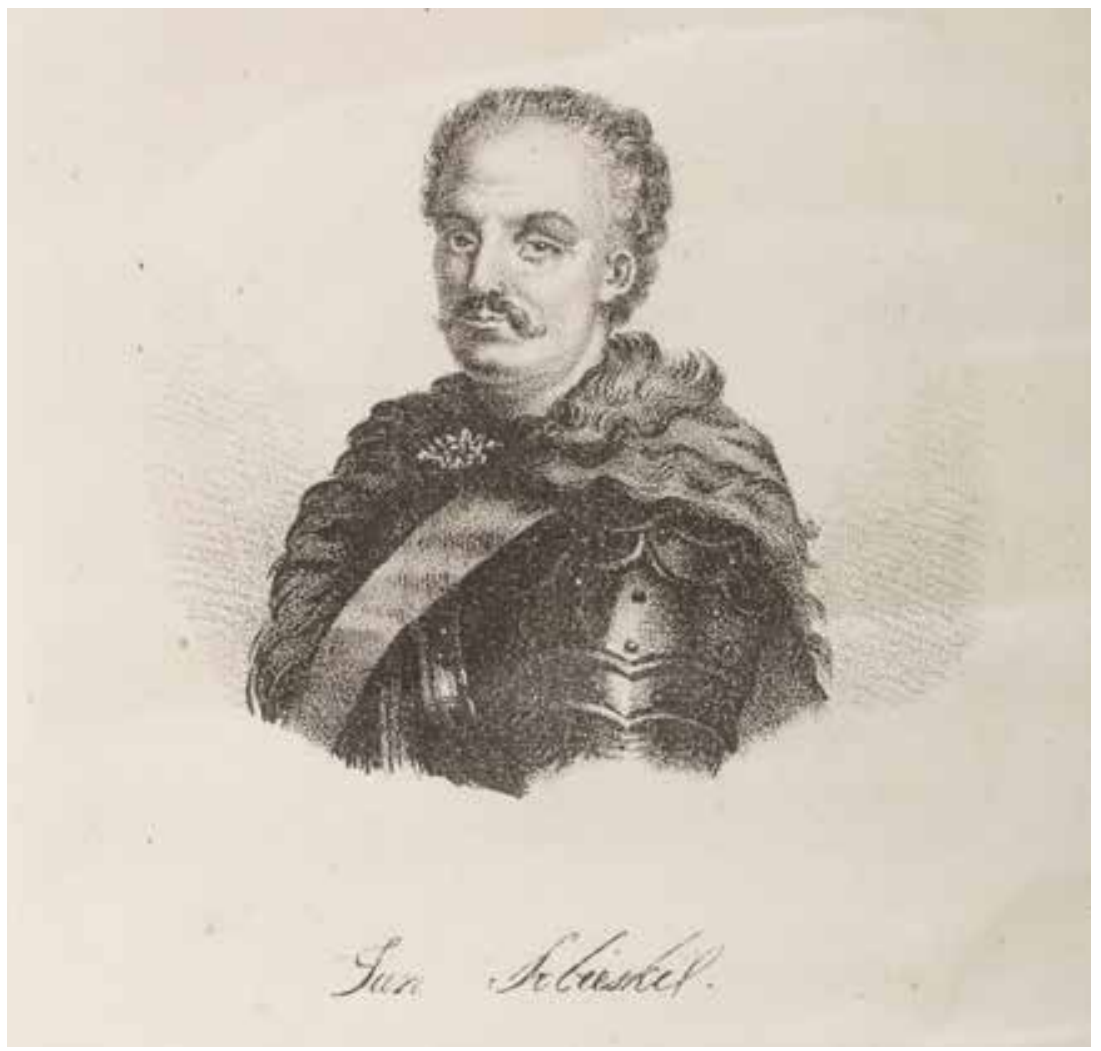

a furred cloak (Fig. 3.4). Small wonder, then, that the book's reviewers easily accepted this brand: it tapped into Dutch collective memory.

In addition, three reviews briefly mention yet another element of the letters' branding, which was introduced by Raczyński and later became enhanced in the translations: the fact that 'one can, from these letters, make out his [Sobieski's] entire character, in both its good and its bad aspects'. According to this reviewer, 'they are therefore very much worth the read' (Letterkundig magazijn 1832: 158). ${ }^{48}$ Nothing is said, however, about the ancient Polish character which the letters could supposedly reveal, or about the correspondence's value for understanding Polish history specifically.

48 'Men kan uit deze brieven zijn geheel karakter, zoo wel aan zijne goede als zwakke zijde, opmaken. Zij zijn dus zeer lezenswaardig'. 
Evidently, these were aspects which meant little to the Dutch public. The same can be said of the fact that Sobieski was Polish: even though this is mentioned several times, it always appears to be more of a sideways remark than anything else.

Only one review expressly ties the book to the Polish revolution, something which the work itself had refused to do. The review opens by stating that 'Poland has ever attracted the attention of Europe' (Utrechtsche courant 1832), ${ }^{49}$ and that much has already been said and written about the current uprising, which some find lawful and others find unlawful. Next, mention is made of the pro-Russian book also published by Kloots ('may the reader convince himself of the ingratitude of the Poles') and the reviewer argues that the correspondence 'is not inappropriate in our time' (ibidem)..$^{50}$ In this case, then, the reviewer has added a layer to the letters' branding, by making explicit what the book itself had left implicit. As Kloots reprinted this review in one of his other publications in 1833 , this may have been exactly what he was hoping for. A book's topicality to a high degree decided whether it would be reviewed, and how it would be received. Works regarding the Belgian Uprising were particularly popular (Korevaart 2001: 104, 137-143). The concurrence of the Belgian and Polish Uprisings thus no doubt enhanced the demand for Sobieski's letters.

Finally, it is interesting to note that none of the reviews discusses the literary (i.e. aesthetic/artistic) qualities of Sobieski's letters. The focus lies on their historical, imagological or biographical importance. In this instance, therefore, 'literary branding' is still a far broader concept than it would later become.

\section{Conclusion}

What overall lessons can be learnt from this case study? Firstly, the significance of paratexts for the shaping and study of literary branding, in this instance both a book's visual and textual front matter on the one hand and the reviews on the other, has been clearly confirmed.

Secondly, in the case of a translation, it is essential to study the branding of the book in its previous versions, as the brands these versions carry can have a significant impact on later editions. By keeping an eye on the book's

49 Reprinted in Morgenwandelingen 1832: no page number: 'Polen heeft te allen tijde de aandacht van Europa tot zich getrokken'.

$5^{0}$ 'Men overtuige zich van de ondankbaarheid der Polen. [...] in onzen tijd niet te onpas'. 
previous branding, even in other languages, it is possible to see which branding elements were copied and which are original to the translation. In this instance, the images first produced by Raczyński, for example of the letters as important historical documents, made their way to both the French and Dutch translations and were eventually appreciated in the reviews of the 1831 Dutch edition.

Furthermore, it is likely that the success or failure of posthumous branding at least in part depends on its ability to tie in with the already existing historical reception of the author, even if (or perhaps especially when) that person was not known (primarily) as an author before..$^{11}$ The brands created by the publisher, editor, and/or translator stand a better chance of being accepted by the public if they are anchored in the author's pre-existing image. Consequently, new layers can be built on top of the brand's historical foundation. In this case, one of the brands most prominently present in the Dutch translations harked back to the Dutch Sobieski reception from the late seventeenth century, when he was presented as a 'god of war' and 'restorer of the faith', essentially the saviour of Christian Europe. The reviews of the $183^{1}$ edition showed that this brand of Sobieski as the defender of Christendom was readily accepted. Indeed, three reviews even reminded the readers of their historical knowledge concerning the Polish king, thereby confirming that the brand employed in Kloots's edition aligned with the already existing Dutch Sobieski images.

Lastly, it is vital to study a book's historical context when trying to uncover the motives behind its publication and the literary brands it employs. While it can be difficult to distinguish between a publisher's or editor's symbolic and economic interests, knowledge of the book's historical context has proven to be a valuable asset. In the case of the original Polish edition, it is safe to say that patriotism was the publication's main incentive. As regards the French translation, Polish patriotism was still in play, but the addition of French and European layers to Sobieski's image also points to a more economically inspired publication. Finally, the Dutch translations had differing motivations, even though they both responded to what was making news at the time: the Greek War of Independence and the Polish November Uprising, respectively. Whereas the 1827 version primarily appears to have had a moralizing objective, the 1831 edition probably had little to do with symbolic interests.

$5^{1}$ The same may apply in the case of the branding of authors who are not deceased, but have been around long enough to build up a public identity. 


\section{References}

[Anon.] 11 October 1831. 'Bij den boekhandelaar A. Kloots [...]'. Algemeen Handelsblad, no page numbers.

[Anon.] 8 October 1831; 14 October 1831. 'Bij den boekhandelaar A. Kloots [...]'. Bredasche courant, no page numbers.

[Anon.] 15 October 1831. 'Bij den boekhandelaar A. Kloots [...]'. Middelburgsche courant, no page numbers.

[Anon.] 8 October 1831. 'Bij den boekhandelaar A. Kloots [...]', Rotterdamsche courant, no page numbers.

[Anon.] 1831. Bedenkingen over de jongste Poolsche omwenteling; door eenen Pool. 's Gravenhage: A. Kloots.

[Anon.] 1832. 'Brieven van den Koning van Polen [...]', Letterkundig magazijn van wetenschap, kunst en smaak I, pp. 157-159.

[Anon.] 1832. 'Brieven van den Koning van Polen [...]', Vaderlandsche letteroefeningen [...] I, pp. 382-384.

[Anon.] 1832. 'Brieven van den Koning van Polen [...]', Vriend des vaderlands 6, pp. 570-573.

[Anon.] 1832. 'Brieven van den Koning van Polen [...]'. In [Jacob Andriessen], Morgenwandelingen door en in den omtrekvan's Gravenhage [...], no page numbers. The Hague: A. Kloots.

[Anon.] 1832. Boekzaal der geleerde wereld [...]. Amsterdam: Erven D. onder de Linden en Zoon.

[Anon.] 1833. 'Brieven van den Koning van Polen [...]'. In [Anon.], Eer en trouw [...]. Trans. by Jacob Andriessen, no page numbers. The Hague: A. Kloots.

[Anon.] 1833. De wederwaardigheden des levens; of de gevolgen van onwettige verbindtenissen. Trans. by Q de Flines. 's Gravenhage: A. Kloots.

Laurens Bake. 1683. Op het Ontzet der Stad Weenen [...]. Amsterdam: David Ruarus. Lambertus van den Broek. 1684. Beleg, en ontzet van Weenen [...]. Amsterdam: Albert Magnus/Antwerp: Hendrick van Dunwalt.

Anna Czarniecka. 2009. Nikt nie stucha mnie za życia... Jan III Sobieski w walce z opozycyjna propaganda (1684-1696). Warszawa: Wydawnictwo Neriton.

Wojciech Fijałkowski and Jadwiga Mieleszko (eds.). 1983. Chwata i stawa Jana III w sztuce i literaturze XVII-XX w. Katalog wystawy jubileuszowej z okazji trzechsetlecia odsieczy wiedeńskiej wrzesień - grudzień 1983. Trans. by Tadeusz Dorzeniecki and others. Warszawa: Muzeum Pałac w Wilanowie.

Wojciech Fijałkowski. 2014. 'Gloryfikacja Jana III w sztuce i literaturze jego czasów'. Studia Wilanowskie 21: 11-33.

Petrus Francius. 1687. Laurus Europaea, seu celebres Christianorum de Turcis victoriae. Amstelodami: [n. pub.]. 
Krystyna Gawlikowska. 1983. 'Wjazd Sobieskiego na koronację do Krakowa. Alegoria programu politycznego na sztychu Romeyna de Hooghe'. Studia Wilanowskie 9:5-20. Idesbald Goddeeris. 2011. 'Poland and the Netherlands in the 19th century'. In Duco Hellema, Ryszard Żelichowski and Bert van der Zwan (eds.), Poland and the Netherlands. A Case Study of European Relations, pp. 41-54. Dordrecht: Republic of Letters.

Idesbald Goddeeris. 2013. La Grande Emigration polonaise en Belgique (1831-1870). Elites en masses en exil à l'époque romantique. Frankfurt am Main: Peter Lang. Magdalena Górska. 2017. The Protector of Europe. On Graphical Theses GlorifyingJan III Sobieski. Trans. by Antoni Górny. Warszawa: Muzeum Pałac w Wilanowie. Krystyna Gutowska-Dudek. 2013. 'Portraits of the Great and Invincible King Jan III Sobieski and Their Role in Shaping His Military Triumph, Politics and Dynastyoriented Plans'. In Dominika Walawender-Musz (ed.), Primus inter pares. The First among Equals - The Story of King Jan III, pp. 92-99. Warszawa: Wilanów Palace Museum.

Paul Hulsenboom. 2019. 'De Poolse Hercules. Romeyn de Hooghe en de Nederlandse receptie van Jan III Sobieski voorafgaand aan het Ontzet van Wenen'. Neerlandica Wratislaviensia 29: 87-109.

Raphaël Ingelbien. 2016. 'National Images in Transit. Historical Fiction and Its Translation in an Age of Competing Nationalisms'. In Luc van Doorslaer, Peter Flynn, and Joep Leerssen (eds.), Interconnecting Translation Studies and Imagology, pp. 53-67. Amsterdam/Philadelphia: John Benjamins.

Sabine Jagodzinski. 2012. 'The Portrait of the King - Imagining and Representing Jan III Sobieski as Ruler of Poland and Lithuania'. Acta Academiae Artium Vilnensis 65-66: 283-312.

Anna Kalinowska and Martyna Mirecka. 2014. 'Bohater czy malcontent? Odbiór Jana Sobieskiego w Wielkiej Brytanii w świetle “London Gazette”, 1665-1674'. In Dariusz Milewski (ed.), Marszatek i Hetman Kornonny Jan Sobieski, pp. 295-316. Warszawa: Muzeum Pałac w Wilanowie.

Bolesław Klimaszewski. 1983.Jan III Sobieski w literaturze polskiej i zachodnioeuropejskiej XVII i XVIII wieku. Kraków: Uniwersytet Jagielloński.

Korrie Korevaart. 2001. Ziften en zemelknoopen. Literaire kritiek in de Nederlandse dag-, nieuws- en weekbladen 1814-1848. Hilversum: Verloren.

Cornelis van der Linde. 1685. Leven en Daaden van Johannes Sobietzki de III, Tegenwoordig-Regeerende Koning van Polen [...]. Amsterdam:Jan, en Timotheus ten Hoorn, Jan Bouman en Aart Dirkse Oossaan.

Martyna Mirecka. 2014. 'Monarchy As It Should Be?'. British Perceptions of PolandLithuania in the Long Seventeenth Century. Unpublished PhD thesis, University of St Andrews. 
Stanisław Plater. 1827. Atlas historique de la Pologne [...]. Posen: G. Decker.

Narcisse-Achille de Salvandy. 1829 Histoire de Pologne avant et sous le roi Jean Sobieski. Paris: A. Sautelet.

Lydia Scher-Zembitska. 2009. Les Polonais en France au XIXe siècle. Paris: la documentation Française.

Jan Sobieski. 1823. Listy Jana III krola polskiego, pisane do krolowy Maryi Kazimiry w ciagu wyprawy pod Wieden w roku 1683. Ed. by Edward Raczyński. Warszawa: Glücksberg.

Jan Sobieski. 1826. Lettres du roi de Pologne Jean Sobieski, a la reine Marie Casimire, pendant la campagne de Vienne. Ed. by Narcisse-Achille de Salvandy, trans. by Stanisław Plater. Paris: L.G. Michaud.

Jan Sobieski. 1827a. Lettres du roi de Pologne Jean Sobieski, a la reine Marie Casimire, pendant la campagne de Vienne. Trans. by Stanisław Plater. Louvain: Vanlinthout et Vandenzande.

Jan Sobieski. 1827b. Lettres du roi de Pologne Jean Sobieski, pendant la campagne de Vienne. Trans. by Stanisław Plater. Tournai: J. Casterman.

Jan Sobieski. 1827c. Brieven van den koning van Polen, Jan Sobieski, aan de koningin, Maria Casimira, gedurende den veldtogt, tot ontzet van Weenen en de bevrijding der Christenheid, in 1683 [...]. In [Anon.] (trans.), Tafereelen uit het rijk der geschiedenis; tot op den tegenwoordigen tijd [...], pp. 49-110. 's Gravenhage: A. Kloots en Comp.

Jan Sobieski. 1831. Brieven van den koning van Polen Jan Sobieski, aan de koningin Maria Casimira, gedurende den veldtogt, tot ontzet van Weenen en de bevrijding der Christenheid, in 1683. Trans. by Quirijn de Flines. 2nd ed. 's Gravenhage: A. Kloots.

Jan Sobieski. 1970. Listy do Marysieński. Ed. by Leszek Kukulski. Warszawa: Czytelnik.

John Stoye. 2008. The Siege of Vienna. The Last Great Trial Between Cross \& Crescent. New York: Pegasus Books.

Jerzy Śliziński. 1979. Jan III Sobieski w literaturze narodów Europy. Warszawa: Ministerstwo Obrony Narodowej.

Anna Treiderowa. 1960. 'Tematyka polska w twórczości Romeyna de Hooghe'a'. Rocznik biblioteki Polskiej Akademii Naukw Krakowie 6: 5-47.

Andrew Wheatcroft. 2008. The Enemy at the Gate: Habsburgs, Ottomans and the Battle for Europe. New York: Basic Books.

Hanna Widacka. 1987. Jan III Sobieski w grafice XVII i XVIII wieku. Warszawa: Państwowe Wydawnictwo Naukowe.

Hanna Widacka. 2010. Lew Lechistanu. Warszawa: Muzeum Pałac w Wilanowie. 


\section{About the Author}

Paul Hulsenboom (1990) is a PhD candidate at Radboud University Nijmegen. He specializes in early modern relations between the Low Countries and Poland-Lithuania, particularly in the fields of cultural exchange and diplomacy. His $\mathrm{PhD}$ project concerns the development of Dutch perceptions of the Polish-Lithuanian Commonwealth and Polish-Lithuanian perceptions of the Dutch Republic during the long seventeenth century. 


\title{
From Immorality to Immortality
}

\author{
Branding Madame Bovary in the Netherlands
}

\author{
Maaike Koffeman
}

\begin{abstract}
This article analyses the publication history of Dutch translations of Madame Bovary within the wider context of Flaubert's reception more generally. In the decades following its publication, Madame Bovary was widely criticized due to its 'scandalous' subject matter. Gradually, these moralistic views gave way to a growing recognition of the novel as a modern classic. However, the immorality scandal continued to resonate with readers. We investigate how these diverging views on the novel informed the branding strategies employed by the publishers of its Dutch translations. Combining reception history, translation studies, paratextual analysis, and cultural sociology, we demonstrate how each publisher established a branding narrative that was informed by the status of the translator in question and that targeted a specific readership.
\end{abstract}

Keywords: French literature, Gustave Flaubert, translation, reception, paratext, cultural sociology

\section{Introduction: The Early Reception of Flaubert in the Netherlands}

One of the first items that pops up in a library catalogue search on the Dutch reception of Gustave Flaubert is a publication entitled Madame Bovary in Holland, by Taco de Beer. Based on the title, one would expect it to be an account on the reception or the influence of Flaubert's epoch-making debut novel within the Dutch literary field. However, the pamphlet in question makes only a few passing references to Flaubert. It is in fact an attack against

Helleke van den Braber, Jeroen Dera, Jos Joosten, and Maarten Steenmeijer (eds), Branding Books Across the Ages: Strategies and Key Concepts in Literary Branding. Amsterdam, Amsterdam University Press 2021 DOI: 10.5117/9789463723916_CHO4 
Lidewyde (1868), a novel of adultery written by the influential critic Conrad Busken Huet. By framing this book as the Dutch equivalent of Madame Bovary, De Beer intends to dismiss it as scandalous. The self-evident presentation of Flaubert's novel as the epitome of French immorality indicates that, within a decade of its publication, Madame Bovary had become a household name in the Netherlands. The 1857 trial against Flaubert had been widely reported in the Dutch press and established his reputation as a controversial author. ${ }^{1}$

As a consequence, readers would have to wait until 1904 before the first Dutch translation of this notorious book came out. Compared to other countries, this is exceptionally late; Russian and German translations of Madame Bovary appeared as early as 1858 and most other countries followed in the years 1860-189o. ${ }^{2}$ Toos Streng (2020: 78-105) has argued that this is a symptom of a larger cultural pattern: between 1830 and 1875 , relatively few French novels were translated into Dutch due to their perceived immorality. Her research shows that, within the Dutch critical discourse, the 'French novel' functioned as a distinctive brand, combining a reputation of aesthetic appeal with a sense of moral danger. Within this controversial genre, Madame Bovary was one of the most frequently mentioned examples. However, the reception of Flaubert gradually changed with the breakthrough of Dutch naturalism and the so-called Tachtigers ('Movement of the 1880s') whose proponents saw him as a model of artistic dedication and a champion of literary autonomy. By the end of the nineteenth century, the public opinion on the author of Madame Bovary had evolved from a widely shared moral reprobation to a general admiration of his literary craftsmanship. This of course made his work a more legitimate and potentially profitable investment for publishers.

This mind shift became particularly evident in 1896 , when the famous novelist Louis Couperus published the first ever Dutch translation of a work by Flaubert (an adaptation of La Tentation de Saint Antoine). A regional newspaper described Couperus as being besieged by publishers offering big sums of money for more Flaubert translations (Provinciale Overijsselsche en Zwolsche courant 1896). ${ }^{3}$ Apparently, there was a great

1 For a more in-depth discussion of the Lidewyde affair in the context of early Flaubert reception in the Netherlands, see Koffeman 2012.

2 On Flaubert's international translation history, see the Flaubert sans Frontières database hosted by the CÉRÉdI research Center at Rouen University: flaubert.univ-rouen.fr/jet/public/ fsf/recherche.php.

3 'De werken van Couperus volgen elkander met groote snelheid op. Het laatst is door hem een vertaling gegeven van Flaubert's verzoeking aan den Heiligen Antonius. In de Kroniek 
demand for such publications. Since then, virtually all of Flaubert's works have been translated into Dutch, and several of them more than once. ${ }^{4}$ Madame Bovary tops the list with four different translations totalling 64 different editions up to the present day. Within contemporary Dutch literature and criticism, references to this novel are numerous, showing that it is part of the common cultural repertoire and a major source of inspiration for aspiring writers. Therefore, one could say that Madame Bovary has acquired a strong brand equity within the Dutch literary field, a reputation of quality based on its innovative narrative technique rather than the controversial subject matter.

\section{Translation History and Paratextual Analysis}

Research into the critical reception of Madame Bovary in other countries, as well as the book covers and illustrations of its translations, has shown that the representations of the novel tended to become less moralistic representations over time; however, the association with the 1857 immorality trial never completely disappeared from the discourse surrounding Madame Bovary. ${ }^{5}$ In what follows, we will investigate how these diverging visions of the novel informed the way it was presented to the Dutch reading public. Obviously, the earlier critical reception of the novel was a factor to be reckoned with; each publisher who brought out a translation had to decide whether, and how, they would include the notorious literary scandal surrounding the novel in their branding narrative. In order to find out how they dealt with this issue, the paratexts surrounding a number of Dutch editions of Madame Bovary will be analysed. Following the definitions coined by Gérard Genette (1987:11), we will study two types of paratexts, namely the peritexts (cover design, forewords, blurb texts, etc.) and a certain number of epitexts (newspaper advertisements and other promotional materials).

As shown by Sharon Deane-Cox (2012), the phenomenon of retranslating literary classics is particularly interesting in this regard. Analysing the way each new English translation of Madame Bovary uses paratexts in order

geeft Bauer ons den auteur zelf te aanschouwen als de Heilige Antonius. Van alle kanten dagen uitgevers op met groote geldbuidels. "Vertaal ons Salammbô, vertaal ons St. Julien, Bovary..." is de algemeene kreet'.

4 For an overview of all Dutch Flaubert translations, see Koffeman 2018 and www.flaubert. $\mathrm{nl} /$ vertalingen.htm.

5 See Lacoste 2008; Jackson 1966; Rouxeville 1977; Remak 1954; Gallice 2014; Donatelli 2014. 
to position itself with regard to its predecessors and to the source text, Deane-Cox reveals the power struggles which are at play in the literary field. Her approach can be qualified as a fruitful combination between reception history, translation studies and cultural sociology. For the sake of our research, we propose to add to this theoretical framework the concept of cultural branding as a means of drawing attention to publishers' efforts to establish a consistent narrative around a title in order to target a particular readership. According to the field theory of Pierre Bourdieu, publishers' strategies are likely to be aimed at either gaining symbolic capital in the 'sub-field of restricted production' or the accumulation of economic capital within the 'sub-field of large-scale production' (1993: 53-54). In what follows, we will investigate how the branding of Madame Bovary within the Dutch literary field relates to these two theoretically opposed prises de position.

\section{Branding Bovary in the Dutch Literary Field}

The first Dutch translation of Madame Bovary was published in 1904 by C.L.G. Veldt. Unfortunately, we have not found any background information on how this publication came about. We do know that Veldt was a small Amsterdam-based publisher who brought out translations of contemporary European literature but also original Dutch novels and non-fiction books on subjects such as sexuality and socialism. Considering the previous reception history of Madame Bovary, it is not surprising that it needed a rather progressive publishing house to take up the challenge of publishing the first translation. Since we have not been able to get hold of a copy of this particular edition, information on the Veldt's branding strategy must be deduced from the epitexts.

The first advertisements for this first translation, entitled Mevrouw Bovary, are rather curious. Instead of presenting a proper branding narrative centred on the novel itself, they defend the quality of the translation. In November 1904, Veldt advertised in the newspaper Algemeen Handelsblad, stating that 'it is forgivable, in these days of book avalanches, to pass a hasty judgment on a translation without even opening the book, but wise people judge by themselves'. ${ }^{6}$ This defensive statement was a reaction to an

6 'Een vluchtig oordeel te vellen over een vertaling, het boek daarbij niet eens open te snijden, is in deze dagen van boeken-lawine vergeefelijk, echter verstandige menschen oordeelen zelf'. 
article published three days earlier in the same newspaper. The anonymous reviewer criticized the translation, stating that it did not come close to rendering the stylistic quality of the original. ${ }^{7}$ The translator in question was Gerrit Hendrik Priem (1865-1933), a regular contributor to Veldt's publication catalogue. He was the author of several novels and poetry collections and had translated or adapted works by Dostoevsky, Maeterlinck, and Nietzsche. Therefore, we can assume that Priem had accumulated a sufficient amount of symbolic capital to qualify as a competent Flaubert translator. However, the epitexts reveal that his work was met with rather mixed reviews. Despite this initial controversy, an advertisement published in Algemeen Handelsblad on 18 March 1905, presented Veldt's editions of Mevrouw Bovary and Dostoevsky's Schuld en Boete (Crime and Punishment) as 'books of reputation' that 'had been recommended by the major newspapers and periodicals'. ${ }^{8}$ In November and December 1906, Het nieuws van den dag placed advertisements presenting Mevrouw Bovary as a 'masterpiece of French literature' and a 'respectable St Nicolas present'. Veldt obviously tried to position the book as a modern classic of untainted reputation, but their branding strategies were not very coherent or sophisticated compared to later ones.

Priem's translation clearly responded to a public demand: it was reissued twice and continued to circulate for several years. The second edition deserves a closer inspection (see Fig. 4.1). It appeared in 1910 with the publishing house Van Holkema \& Warendorf as part of the book series Meesterwerken der buitenlandsche romanlitteratuur (Masterpieces of Foreign Novel Literature). The book has an elegant hard cover in the art nouveau style and contains a number of interesting paratexts, such as advertisements for other books from the same series and for Priem's own literary works. The translator is thus framed as a man of letters, probably implying that only a real writer can do justice to Flaubert's text. On the title page, a quote by Emile Zola states that 'Flaubert restera toujours la [sic] culte même de la littérature'. Since Zola was one of the best known and most translated French realists within the Dutch literary field, ${ }^{9}$ it was a clever move to exploit his symbolic capital in order to claim a reputation

$7 \quad$ 'Wie "Madame Bovary" waardeeren kan, verstaat in ons land Fransch genoeg om het in het oorspronkelijk te lezen. Wie dat kan, leze het niet in de vertaling van den heer Priem. Want al staat de heer Priem zeker niet gelijk met de hoopen vertalende juffers a F 2 het vel, toch is ook zijn Hollandsch lang Flaubert in het Fransch niet'.

8 'Boeken van reputatie'; 'Aanbevelingen van deze werken gaven de voornaamste dagbladen en periodieken'.

9 See Streng 2020 (especially 92). 
Figure 4.1 Second edition of G.H. Priem's Madame Bovary translation in the series Meesterwerken der buitenlandsche romanlitteratuur. Amsterdam: Van Holkema \& Warendorf, 1910

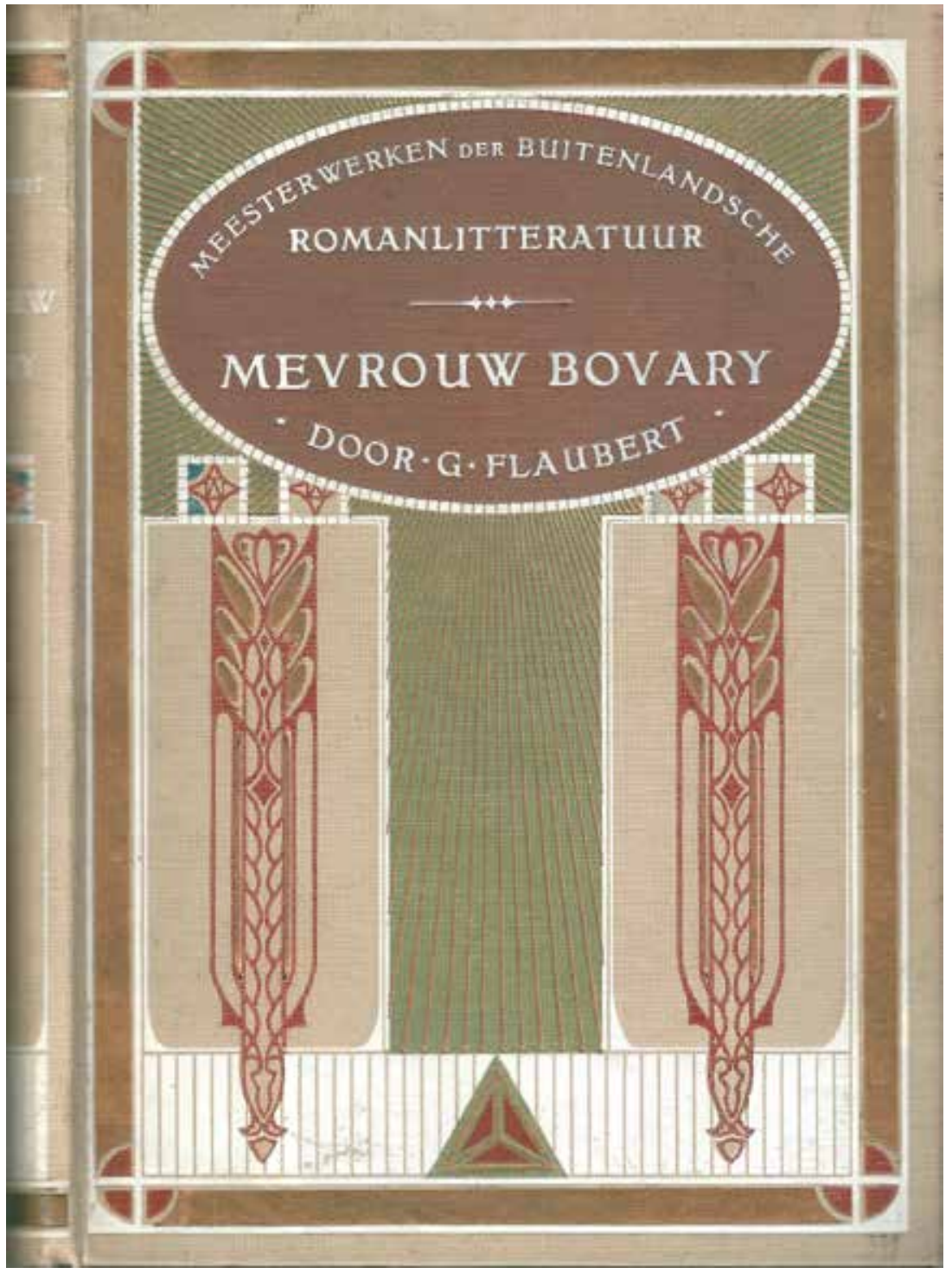

for Flaubert. Priem also wrote a short foreword to his translation, stressing the classic status of the novel and presenting Flaubert as one of the best realist authors. Priem praises Flaubert's superior sense of style, only to conclude that making a perfect translation of this masterpiece is an 
impossibility. ${ }^{10}$ Interestingly, he also comments on the lack of earlier translations:

Among the things that have always surprised me a lot is the fact that a superior work that has become a classic, like Flaubert's 'Madame Bovary', has not yet appeared in translation. Was it the national prudishness, which refused to take interest in a book which, according to the French public prosecutor, 'outraged public morality and religion'? I believe that, at the beginning of the twentieth century, public morality and religion are self-confident enough not to oppose the Dutch translation of the book that once established Flaubert's fame once and for all. (Flaubert 1910:1) ${ }^{11}$

The history of moral controversy around the novel explains why both the publisher and the translator actively contest the reputation of the novel as a succès de scandale and try to replace it with a brand narrative revolving around notions of canonicity and literary quality. Rather than targeting a mass audience that could potentially be seduced by the dramatic and 'immoral' subject matter, they choose to claim symbolic capital and thus position it in a more elitist section of the literary field.

This branding strategy can be deduced from a 1913 newspaper advertisement (see Fig. 4.2). Flaubert's novel is presented in the context of a book series, thus suggesting that it qualifies as a 'masterpiece'. The header reads 'gripping novels' and the text goes on to explain that the Meesterwerken series contains the best foreign novels, always in excellent 'adaptations'. Despite the beautiful binding, these books are quite affordable, which suggests that they are aimed at a middlebrow audience with cultural aspirations.

In 1917, J.M. Meulenhoff brought out the third and last edition of Priem's translation. This time, Mevrouw Bovary is included in a book series (Meulenhoff-Editie) which presents itself as 'a general library' composed of

10 There is a fascinating parallel between Priem's self-effacing posture and the words of the first English translator, Eleanor Marx-Aveling: 'no critic can be more painfully aware than I am of the weaknesses, the shortcomings, the failures of my work; but at least the translation is faithful. [...] It is pale and feeble by the side of its original' (quoted in Deane-Cox 2011: 4.)

11 'Tot de dingen, die mij altijd grootelijks verwonderd hebben, behoort het feit dat tot nog toe van een klassiek geworden superieur werk als "Madame Bovary" van Flaubert geen Hollandsche vertaling was verschenen. Was het de bekende vaderlandsche pudibonderie, die weigerde de oogen op te slaan naar een boek, waarin volgens het Fransche Openbare Ministerie "de publieke zedelijkheid en de godsdienst werden beleedigd?" Ik meen dat, in het begin der twintigste eeuw, de publieke zedelijkheid en de godsdienst voldoende weten wat zij van zichzelf te denken hebben, om niet langer tot sta-in-de-weg te dienen voor de Nederlandsche vertaling van het boek, dat Flauberts roem grondvestte op-eens en voor altijd'. 


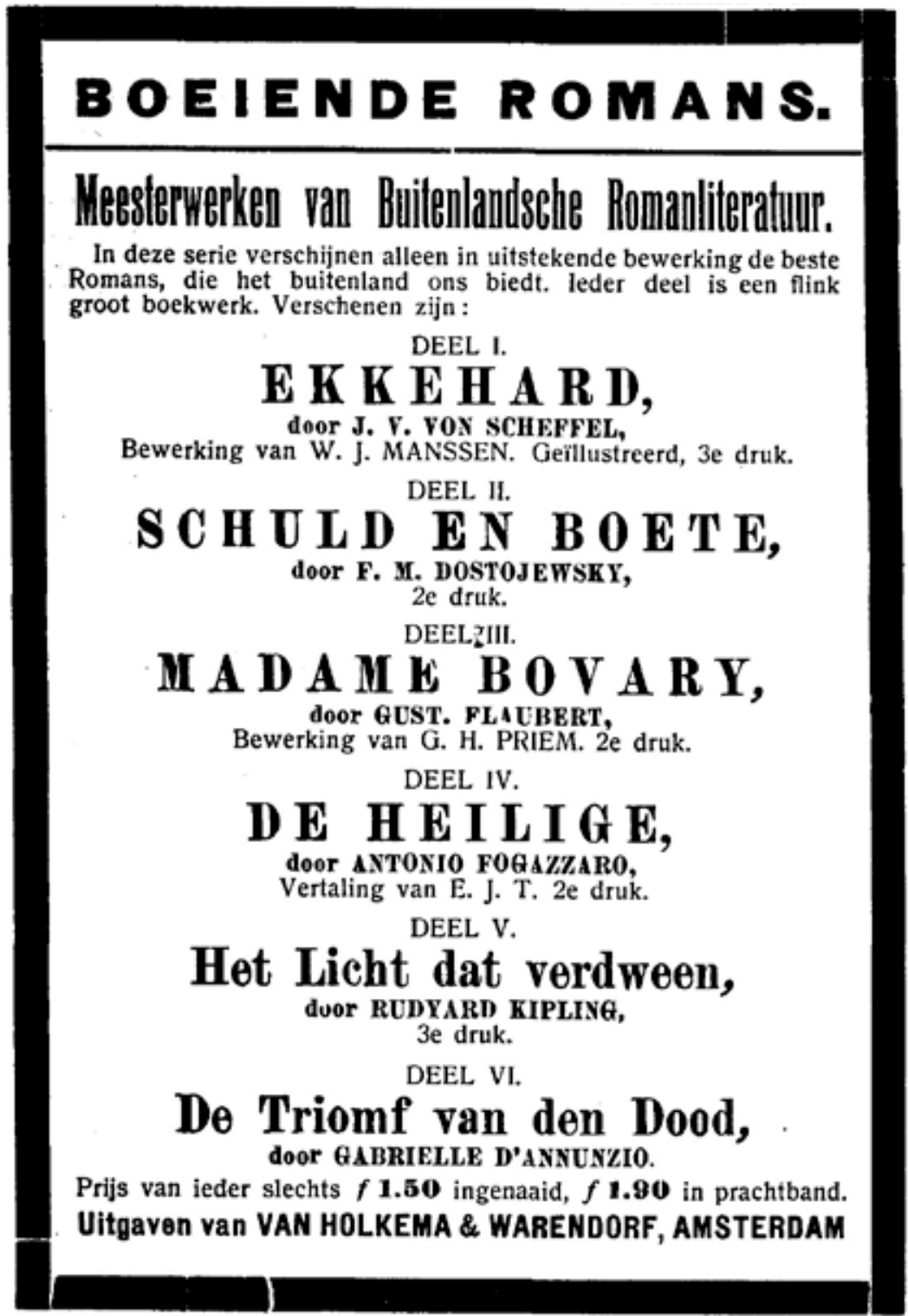

'good books in good dress for little money' (Van Voorst 1997:50). Compared to the previous edition, it has a less luxurious look and feel and it comes at a lower price. Moreover, the translator's foreword and the references to his own literary oeuvre have disappeared. These paratextual indications suggest that Meulenhoff targeted a more popular audience. It seems, however, that 
this strategy was not very successful, since a 1929 advertisement in Het volk offered the remaining copies at a reduced price.

We can conclude from this first case study that, by the early twentieth century, there was an obvious market potential for a Dutch translation of Madame Bovary and the earlier resistance against French realism had mostly subsided. Flaubert had evolved from the controversial avant-garde of literature to the realm of consecrated classics, thus becoming a safe investment for publishers. As Bourdieu (1980: 283) points out, classics are 'best-sellers over the long run, which owe their consecration, and therefore widespread durable market, to the educational system'. They benefit from a great mindshare, since their titles are widely known by the general public. Thus, from the outset, Dutch publishers try to sell Madame Bovary to a culturally ambitious audience by branding it as an undisputable masterpiece. However, our analysis shows that the use of paratextual branding strategies is still in a rudimentary state at this point. Blurb texts, for instance, are completely absent. Whereas the 1910 edition contains a few paratexts that stress the literary status of the novel and its translator, most of them are not continued into the 1917 edition. However, one important aspect unites those editions: both are part of a book series that presents itself as a selection of literary masterpieces. As we will see, this will be the dominant strategy in the branding of Madame Bovary within the Dutch literary field.

The second Dutch translation appeared in 1941 and was made by Cornelis Kelk (1901-1981), a generalist man of letters who combined the writing of novels, poems, and plays with translating and literary journalism. Kelk had lived in France until the war broke out. Refusing to join the Nederlandsche Kultuurkamer founded by the Nazis, he was not allowed to publish and survived on translation jobs and the composition of literary anthologies. His Madame Bovary translation was published by Contact, an antifascist publishing house that had been founded in 1933 and did relatively well during the Second World War, thanks to the creation of a successful book series called De Onsterfelijken (The Immortals).

As Lisa Kuitert (1997) has shown, the marketing of books via series became very common in the second half of the twentieth century. Publishers courted a rapidly growing reading public, hoping they would be enticed to collect multiple volumes of the same series. Cover design, emblems, and other paratexts played a crucial role in the establishment of book series as identifiable brands. In the case of De Onsterfelijken, we can gain a lot of information from a 1941 prospectus in which Contact presents its publication programme, conceived as 'a series of masterpieces from world literature, interesting and 
Figure 4.3 Advertisement in Algemeen Handelsblad, 28 February 1941

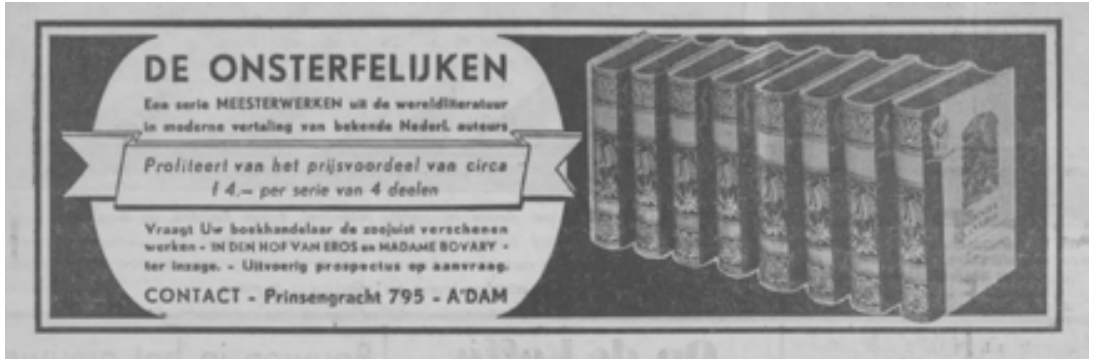

accessible to the modern man' (Uitgeverij Contact 1941). ${ }^{12}$ The best Dutch translators, illustrators, and essayists are said to contribute to the series. With regard to the material quality of the books, the publisher is no less ambitious: they are to be illustrated with wood cuts, set in a distinguished font, and printed on laid paper. Advertisements suggest that, placed together, they will look great in a modern living room thanks to their elegant design (see Fig. 4.3). ${ }^{13}$ Brand loyalty is further promoted by offering reductions to customers who buy a set of four books at once. Within this new book series, Madame Bovary played a prominent role, since it was among the very first volumes to come out and one of its illustrations is reproduced in the brochure.

If we take a closer look at this first Contact edition of Madame Bovary, we find that the publisher has translated the concept of immortality into the material design of the book, which comes in a beautifully designed leather hardcover and dust jacket. The luxurious paper quality and elegant layout provide it with a timeless appeal. The numerous illustrations in the form of wood cuts made by Désiré Acket refer to the nineteenth century, both in the scenes portrayed and in the printing technique. ${ }^{14}$ The name of the translator is mentioned on the cover, which indicates that he brings along a literary reputation of his own. The text is further surrounded by a wealth of paratexts stressing the symbolic capital attached to Flaubert's novel, most notably a seventeen-page long introduction by Kelk himself. Quite remarkably, he makes no reference to Priem's translation, a move that may be interpreted as condescending. His introduction is much longer

12 'Een reeks meesterwerken uit den Wereldliteratuur, interessant en toegankelijk voor den modernen mensch'.

13 See Kuitert 1997: 78-79.

14 This book stands in the tradition of illustrated editions of Madame Bovary that were in vogue in France in the first half of the twentieth century. See Gallice 2014. 
than his predecessor's; Kelk demonstrates his extensive literary-historical knowledge by situating the novel in its context. While suggesting that there is a connection between the author's temperament and Emma Bovary's psychological issues, but Kelk also stresses the ironic distance between the narrator and his protagonist. He then goes on to describe Flaubert's writing method and search for the perfect style and composition. Near the end of his introduction, Kelk comes to speak of the immorality trial, stating that 'the prosecutor was of course, from our point of view as modern men, very wrong' (Flaubert 1941: XIV). ${ }^{15}$ Kelk thus takes on the posture of a well-informed literary historian and a defender of the once so contentious novel whose reputation has now evolved into that of an undisputed modern classic. The same opinion had been voiced by Priem, but Kelk substantiates his claims much more extensively.

Between 1941 and 1975, Contact issued eleven different editions of Kelk's translation, mostly hardcover volumes in the series De Onsterfelijken but also in a book club edition entitled De Boekenschat (The Book Treasure) and, from 1968 onwards, also in paperback. Throughout the different editions, Madame Bovary is consistently branded as belonging to the realm of high literature. The Contact publishing house, targeting a sophisticated and well-to-do readership, clearly aimed at acquiring symbolic capital by stressing the timeless quality and universal appeal of the text. The original controversy surrounding the novel is only rarely hinted at and dismissed as being obsolete. In this case, the translator plays a quite prominent role in the branding of the novel. He appears in the paratexts as a cultivated man of letters, well aware of the critical tradition surrounding the novel and of the stylistic challenges posed to him.

In the 196os, the literary paperback started to conquer the Dutch book market, thanks to the coming of age of the baby boomers, who combined a keen interest in reading with a preference for cheap editions. L.J. Veen, a publishing house dating from the late nineteenth century with a strong focus on foreign literatures, launched a series of cheap pocketbooks (Amstelboeken, later renamed Amstelpaperbacks). In order to compete with Contact, they chose to target a different audience by means of affordable editions that did not overly stress the canonical status of the books (Van Voorst 1997: 172). It is in this context that the third Dutch translation of Madame Bovary saw the light of day. One might ask why L.J. Veen issued a new version of the novel when a respectable one was readily available on the

15 'De aanklager had hierin, naar de zienswijze van ons moderne menschen, natuurlijk grondig ongelijk'. 
Figure 4.4 Dust jacket of the illustrated edition of C.J. Kelk's translation. Amsterdam: Contact, De Onsterfelijken, 1941

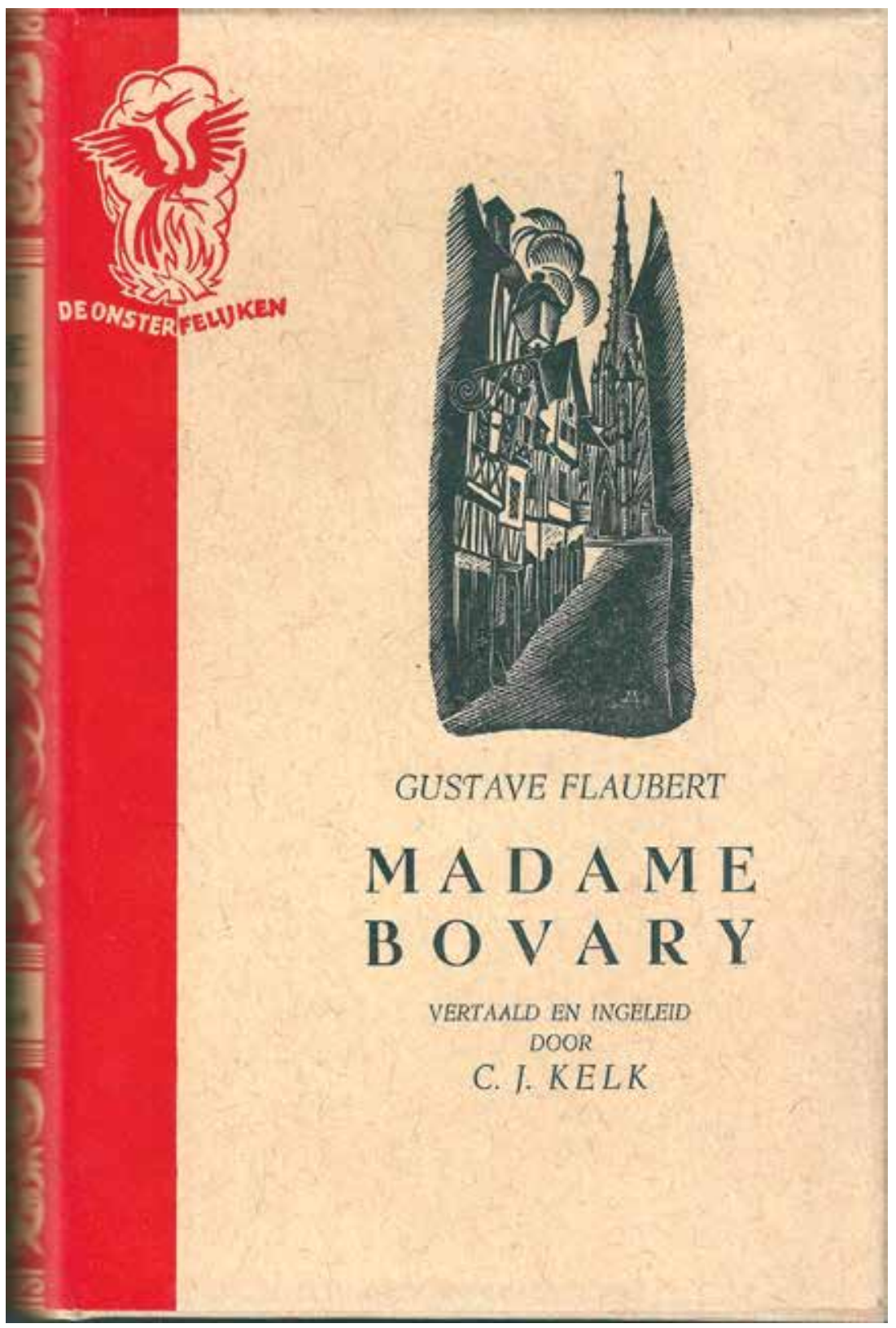


market. Perhaps they considered that a classics series would be incomplete without Flaubert's famous novel. Since it was out of copyright, there were no legal impediments to bringing out a competing translation of the same title.

For reasons unknown to us, the challenging task of retranslating the novel had been entrusted to Margot Bakker (a pseudonym of Geerdina Aaltje Kuiper, 1917-1992), a rather obscure translator of popular fiction. The quality of her translation is generally considered mediocre, with certain errors revealing a poor understanding of the text and a general lack of rhythmic and stylistic sophistication. ${ }^{16}$ Whereas Kelk's literary status is consistently being foregrounded by the publisher of his translation, this is never the case with Bakker. Nor did she write a foreword or any other text reflecting on Flaubert's novel and her work as a translator.

When examining the - not very numerous - paratexts surrounding Bakker's translation, we find that they take a much less intellectual approach to the novel. The first edition comes in a small, cheap-looking paperback (see Fig. 4.5), with a blurb text presenting the book as 'one of the masterpieces of the nineteenth-century novel', before going on to highlight the dramatic aspects of the story: 'Flaubert depicts the moral downfall of a hysterically predisposed girl who, alienated from her own peasant class, marries an insignificant country doctor. In her attempt to escape the banality of her environment, she commits one misstep after another'. ${ }^{17}$ Thus, L.J. Veen presents us with a different brand narrative, one which foregrounds the sensational aspects of the story rather than Flaubert's innovative writing technique. The plot summary is presented in a moralistic tone of voice that reminds us of nineteenth-century representations of Emma Bovary as a hysterical seductress. The cover image similarly foregrounds the adulterous plot matter, thus making it look like a lowbrow romance novel. The differences with the branding strategies employed by Contact are striking, which indicate that L.J. Veen tried to conquer a markedly different segment of the potential market for translated novels, one that was much more oriented towards the subfield of large-scale production.

The branding of Madame Bovary as a succès de scandale is a constant factor in the paratexts accompanying the nine editions of Bakker's translation published by L.J. Veen until 1980. Subsequently, the translation was

16 See Koffeman 2018; Van Pinxteren 2011; Coumans 2010.

17 'Flaubert schildert de zedelijke ondergang van een hysterisch aangelegd meisje, dat, vervreemd als zij is van haar eigen boerenmilieu met een onbeduidende boerendokter trouwt. In haar poging om de banale omgeving te ontvluchten, vervalt zij van de ene misstap in de andere'. Blurb text, Flaubert 1960. 
Figure 4.5 The first Dutch paperback edition of Madame Bovary, translation by Margot Bakker. Amsterdam: L.J. Veen, Amstelboeken, 1960

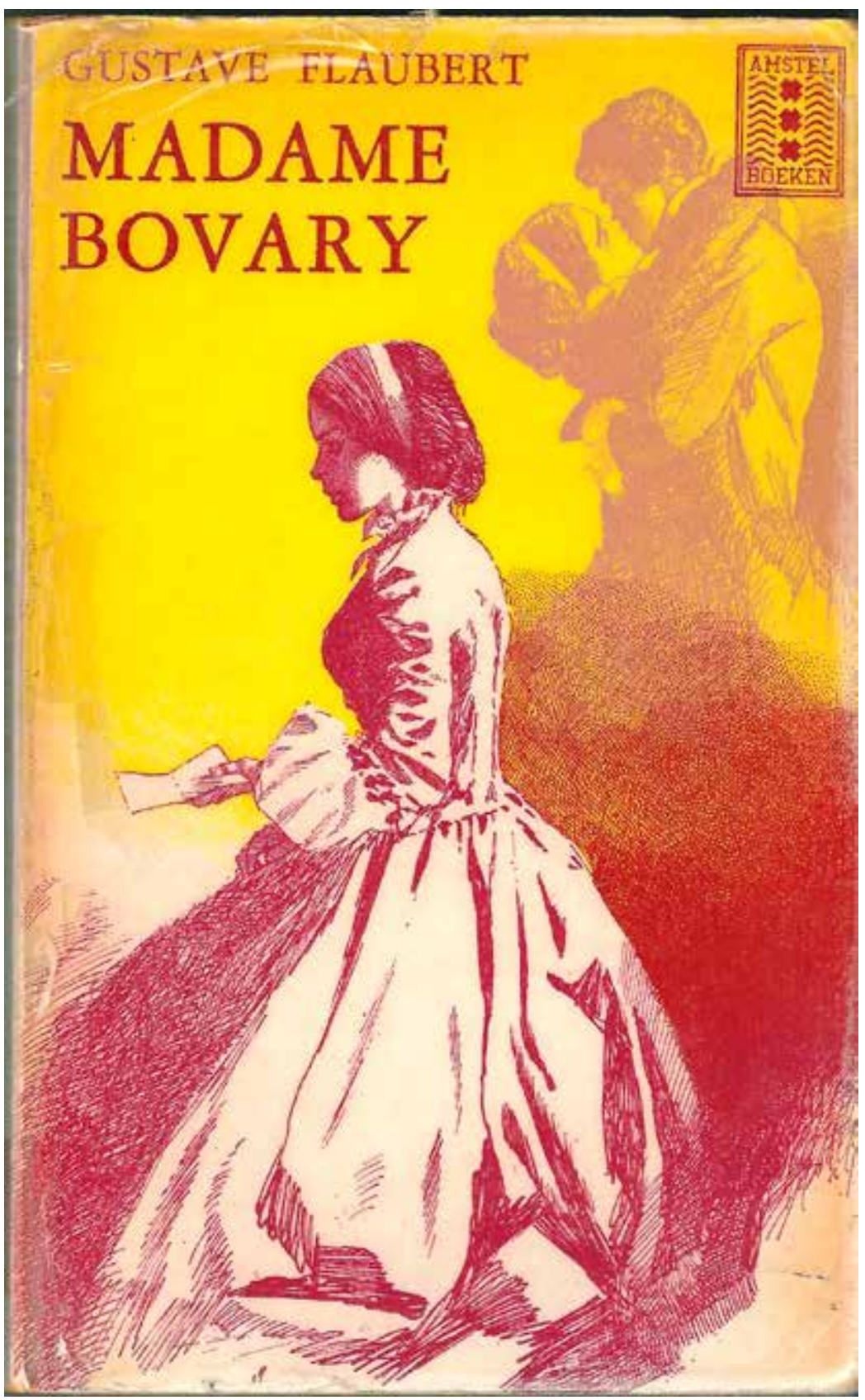


licensed to different publishers where it appeared in very low-profile series such as Skarabee Pockets (a miscellany of controversial literary novels, crime fiction, erotica, and popular non-fiction) and Reader's Digest. In these editorial contexts, not much is left of the author's symbolic capital, whose name is even misspelled ('Gustav Flaubert') on the cover of the 1982 Skarabee edition.

In the meantime, L.J. Veen had approached the renowned translator Hans van Pinxteren (b. 1943) to make yet another version of Madame Bovary in Dutch. In 1974, Van Pinxteren had been awarded the Martinus Nijhoff Award for his translation of Salammbô. He had gone on to translate several works by Flaubert, in the process becoming a fine connoisseur of his work. Therefore, he must have seemed the ideal candidate for making a new and more prestigious translation of Madame Bovary. His version first appeared in 1987 in an expensive and soberly designed hardbound edition (see Fig. 4.6). On the inside flaps, we find a short summary stressing Flaubert's psychological insight and the topicality of his subject matter, followed by a reference to the writing process and the publication scandal. The back flap praises the author as one of the most admired stylists of the nineteenth century and mentions a few canonical twentieth-century authors who considered him their predecessor. It ends by drawing attention to the fact that the translator is a Martinus Nijhoff laureate, which is yet another way of claiming symbolic capital for this edition.

The book itself contains several new elements compared to earlier translations. Firstly, the title page includes the original subtitle (Provinciaalse zeden en gewoonten; a literal translation of Moeurs de province). On the next page, we find Flaubert's dedications to his lawyer Sénard and his friend Louis Bouilhet. In order to clarify the historical backgrounds of the novel, Van Pinxteren also includes an afterword and a series of explanatory notes. The intention of the afterword is to provide insight into both the writing and the translating process. His training as a literary scholar is evident from his reflections on stylistic issues such as the style indirect libre and the way he places Madame Bovary in its literary context. The 1857 trial is mentioned in passing, with the emphasis being placed on Flaubert's acquittal and subsequent consecration.

Although Van Pinxteren's translation was published by the same company as Bakker's, the differences in paratextual framing are striking. The publisher replaced its populistic branding strategy by one that was primarily directed towards the accumulation of symbolic capital. It thus started to target the audience that had previously been served by Contact. The fact that the respected Kelk translation was no longer on the market may very well have 
Figure 4.6 The first of many editions of the translation by Hans van Pinxteren. Utrecht/Antwerpen: L.J. Veen, 1987

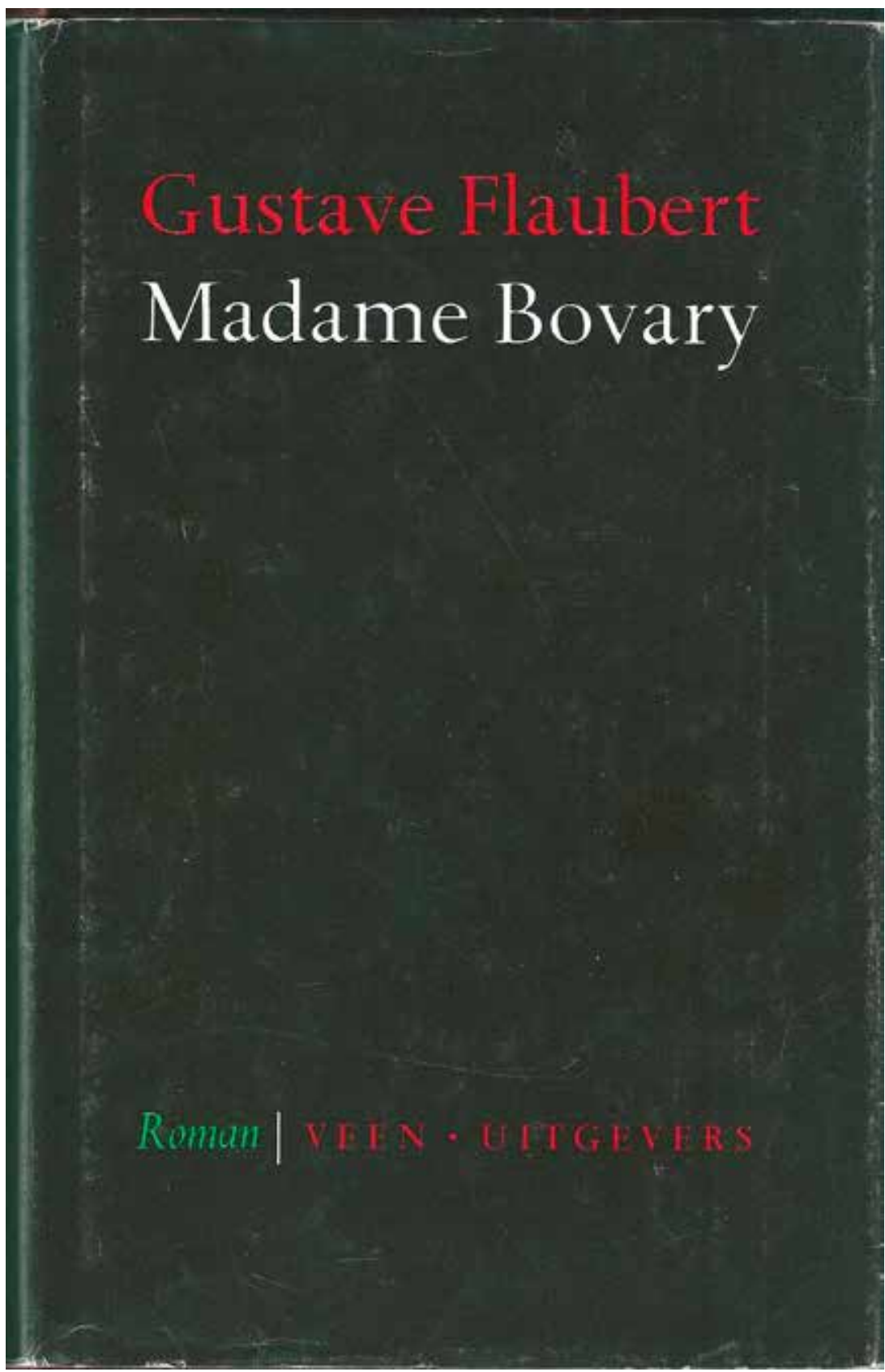


motivated this decision. This more highbrow approach did not prevent the translation from also being a great commercial success. Since 1987 , it has been reissued approximately once a year and licensed to third parties for school editions (Gouden Lijsters, 2001) and a series of 'Forbidden Books' issued by the national newspaper de Volkskrant (Verboden boeken, 2012). Van Pinxteren's translation has been made available in a wide variety of formats, from affordable movie editions in paperback to luxurious hardcovers. Whichever type of readership they target, however, these editions always take a rather intellectual approach to the novel, never failing to reproduce Van Pinxteren's afterword and notes.

By far the most prestigious edition of Van Pinxteren's translation came out in 2009, as part of the Perpetua project. This book series, launched in 2007 by Athenaeum - Polak \& Van Gennep, intends to 'bring out the 100 best books from world literature in the most beautiful design of the Low Countries' (Singel Uitgeverijen 2018). ${ }^{18}$ The books have a classic design with a high-quality linen binding and integrated bookmark, beautiful eco-friendly paper, and tasteful typography (see Fig. 4.7). The visual coherence of the dust covers, featuring only the author's name, title, publisher's emblem, and translator's name, incites customers at the high end of the cultural spectrum to collect a personal library of undisputed classics. In order to present these editions as superior to all previous ones, particular attention is being paid to the quality of the text. Often, new translations are made and prominent contemporary authors or literary scholars are invited to write an afterword. In the case of Madame Bovary, Hans van Pinxteren was invited to revise and improve his text. His afterword and notes remained unchanged; a second afterword, by the prominent novelist Thomas Rosenboom, was added. ${ }^{19}$ Thus, through a sophisticated amalgam of branding strategies, this edition claims a huge amount of symbolic capital for all parties involved (author, translator, book series, and publisher).

Besides being a respected translator, Van Pinxteren has also made a name for himself as a poet and critic. Not only do his essays on French literature contribute to the intellectual prestige of his translations, they also represent strategic position-takings in the literary field. In an article on the ageing of translations, he compares his version of Madame Bovary with those of his predecessors, critiquing their translational choices with both 
Figure 4.7 Luxury edition of the revised translation by Hans van Pinxteren.

Amsterdam: Athenaeum - Polak \& Van Gennep, Perpetua Reeks, 2009

\section{Gustave Flaubert}


rigour and respect (Van Pinxteren 2011). By demonstrating his meticulous approach and fine understanding of the inner workings of Flaubert's prose, Van Pinxteren comes across as a highly competent translator who is entitled to almost the same literary status as the author. It is fair to say that Van Pinxteren's translation has eclipsed all previous ones and solidly established the reputation of the novel as a timeless masterpiece that inspires some of the most ambitious writers within the Dutch literary field.

\section{Conclusion: Between Controversy and Canonization}

Looking back on the history of Madame Bovary in the Netherlands, we can conclude that the branding of the once so controversial novel as a timeless literary masterpiece has prevailed ever since the first translation came out in 1904. However, a conflicting representation of the book as a roman à scandale, rooted in the first reception of Flaubert, has resurfaced every now and then. Our research has shown that the nature of the branding narratives presented by the paratexts is closely related to the status of the translator and the intellectual profile of the target audience. Branding Madame Bovary as a sensational novel of forbidden passion occurs most conspicuously around Margot Bakker's translation, whereas the ones by Kelk and Van Pinxteren are embedded in a discourse that values style over storyline. The material quality of these publications tends to be of an equally high standard. The 1910 and 1941 editions of the translations by Priem and Kelk are both elegantly designed hardcover books, presenting themselves as timeless and culturally enhancing objects, whereas Bakker's 1960 translation comes out as a cheap pocket edition, thus being a much more ephemeral and less prestigious commodity. The first editions of the original and the revised Van Pinxteren translation are published as soberly designed and quite expensive hardcover volumes and, subsequently, marketed as more affordable paperbacks. Its publisher targets different types of book buyers, ranging from middlebrow to highbrow, whilst consistently telling a branding narrative that revolves around the timeless appeal of the plot, the psychological depth of the characters, and the author's widely recognized stylistic mastery.

An interesting aspect of the publication history of Madame Bovary in the Netherlands is the frequent inclusion of the novel in a book series dedicated to the classics. This is a form of consecration that contributes a great deal to the reputation of the novel as a timeless masterpiece that every culturally aspiring person should read, or at least proudly showcase 
in their personal library. In the book business, branding is thus a dynamic and multifaceted phenomenon where brand identities can function on the level of the individual title, author, translator, series, imprint, and publishing house. In the most successful cases, these levels are interconnected and mutually reinforcing. As we have seen, the publisher of the Van Pinxteren translation is able to maximize its symbolic capital by stressing not only the canonical status of the book and the artistic prowess of the author but also the reputation of the translator as a Flaubert specialist and a literary master in his own right. This strategy culminates in the Perpetua edition, which positions the novel in the most prestigious national and international literary context by means of the Rosenboom afterword and the association with the very highest echelons of the Western literary canon. It goes without saying that this transfer of symbolic capital works in both directions.

Finally, the way the different Madame Bovary translations were presented to the reading public also provides some insight into the evolution of the book business throughout the twentieth century. The general impression is that of an advancing professionalization and diversification of branding strategies. The numerous editions of Van Pinxteren's translation, varying in design and price so as to cater to different audiences, are a case in point. They also show that Madame Bovary, after having been denied access to the Dutch literary field for almost half a century, has since then conquered an unassailable position within that same field, both in terms of economic capital and of literary prestige.

\section{References}

[Anon.] 22 November 1904. 'Nieuwe uitgaven', Algemeen Handelsblad.

[Anon.] 25 November 1904. [advertisement], Algemeen Handelsblad.

[Anon.] 18 March 1905. [advertisement], Algemeen Handelsblad

[Anon.] 19 November and 3 December 1906. [advertisement], Het nieuws van den dag.

[Anon.] 10 August 1913. [advertisement], De Amsterdammer.

[Anon.] 6 October 1896 [no title]. Provinciale Overijsselsche en Zwolsche courant.

[Anon.] 22 May 1929. [advertisement]. Het volk.

T.H. de Beer. 1868. Madame Bovary in Holland. Kunstmiskenning! À propos van

Huët's roman, ook met het oog op Van der Meulen's recensie. Zaandijk: Heijnis.

Pierre Bourdieu. 1980. 'The Production of Belief: Contribution to an Economy of

Symbolic Goods'. Media Culture Society 2: 261-293.

Pierre Bourdieu. 1993. The Field of Cultural Production. Cambridge: Polity Press.

Conrad Busken Huet. 1981. Lidewyde. Ed. M. Schenkeveld. The Hague: Nijhoff. 
Kiki Coumans. 2010. 'Het laarsje van Emma Bovary. Stijl in de Nederlandse Madame Bovary-vertalingen'. Filter 17.4: 43-52.

Sharon Deane-Cox. 2012. 'The Framing of a Belle Infidèle: Paratexts, Retranslations and Madame Bovary'. Essays in French Literature 49: 79-96.

Bruna Donatelli. 2014. 'Des vitrines sur le roman: les couvertures de Madame Bovary et Salammbô'. Flaubert. Revue critique et génétique 11. [Via: journals. openedition.org/flaubert/2307]

Piet Driest. 'Nederlandse vertalingen van Madame Bovary'. www.flaubert.nl/ vertalingen.htm. [accessed 21 December 2020]

Gustave Flaubert. 1896. Deverzoeking van den H. Antonius. Trans. by Louis Couperus. Amsterdam, L.J. Veen.

Gustave Flaubert. 1910. Mevrouw Bovary. Trans. by G.H. Priem. Amsterdam: Van Holkema \& Warendorf, Meesterwerken der Buitenlandsche Romanlitteratuur. Gustave Flaubert. 1917. Mevrouw Bovary. Trans. by G.H. Priem. Amsterdam: Meulenhoff, De Meulenhoff Editie, Een algemeene bibliotheek.

Gustave Flaubert. 1941. Madame Bovary. Trans. and intr. by C.J. Kelk. Amsterdam: Contact, De Onsterfelijken.

Gustave Flaubert. 196o. Madame Bovary. Trans. by Margot Bakker. Amsterdam: L.J. Veen, Amstelboeken.

Gustave Flaubert. 1982. Madame Bovary. Trans. by Margot Bakker. Utrecht: Skarabee.

Gustave Flaubert. 1987. Madame Bovary. Provinciaalse zeden en gewoonten. Trans. and intr. by Hans van Pinxteren. Utrecht/Antwerp: L.J. Veen.

Gustave Flaubert. 1995. Madame Bovary. Trans. by Margot Bakker. Amsterdam: Reader's Digest, 's Werelds Meest Geliefde Boeken.

Gustave Flaubert. 2001. Madame Bovary. Provinciaalse zeden en gewoonten. Trans. and intr. by Hans van Pinxteren. Groningen: Wolters Noordhoff, Gouden Lijsters.

Gustave Flaubert. 2009. Madame Bovary. Provinciaalse zeden en gewoonten. Trans. and intr. by Hans van Pinxteren. Afterword by Thomas Rosenboom. Amsterdam: Athenaeum - Polak \& Van Gennep, Perpetua Reeks.

Gustave Flaubert. 2012. Madame Bovary. Provinciaalse zeden en gewoonten. Trans. and intr. by Hans van Pinxteren. Amsterdam: de Volkskrant / Atlas Contact, Verboden Boeken.

Bruno Gallice. 2014. 'Rémanence de Madame Bovary dans l'édition illustrée'. Flaubert. Revue critique et génétique 12. [Via: journals.openedition.org/flaubert/2356]

Gérard Genette. 1987. Seuils. Paris: Éditions du Seuil.

Ernest Jackson. 1966. The Critical Reception of Gustave Flaubert in the United States, 1860-196o. The Hague: Mouton and Co.

Maaike Koffeman. 2012. 'Images de la culture française dans la presse périodique néerlandaise du XIXe siècle: Madame Bovary en Hollande'. Documents pour l'Histoire du Français Langue Étrangère ou Seconde 49: 201-218. 
Maaike Koffeman. 2018. “Une rencontre presque physique.” Traduire Flaubert en néerlandais'. Revue Flaubert 17. [Via: flaubert.univ-rouen.fr/revue/article. php?id=256]

Lisa Kuitert. 1997. Het uiterlijk behang. Reeksen in de Nederlandse literatuur 1945-1996. Amsterdam: De Bezige Bij.

Francis Lacoste. 2008. 'La réception de Madame Bovary (1858-1882)'. Revue Flaubert 8. [Via: flaubert.univ-rouen.fr/revue/article.php?id=74]

Hans van Pinxteren. 2011. 'Madame Bovary of het perspectief van de verteller'. In idem, De Hond van Rabelais, pp. 32-52. Amsterdam: Voetnoot.

Henry H. Remak. 1954. 'The German Reception of French Realism'. PMLA 69.3: 410-431.

Annie Rouxeville. 1977. 'The Reception of Flaubert in Victorian England'. Comparative Literature Studies 14.3: 274-284.

Singel uitgeverijen. 2018. Prospectus uitgeverij Athenaeum najaar 2018. [Via: issuu. com/singeluitgeverijen/docs/athenaeum_najaar_2018_lr]

Toos Streng. 2020. De roman in de negentiende eeuw. Geschiedenis van een nieuwkomer. Hilversum: Verloren, 2020.

Sandra van Voorst. 1997. Weten wat er in de wereld te koop is. Vier Nederlandse uitgeverijen en hun vertaalde fondsen 1945-1970. The Hague: SDU.

Uitgeverij Contact. 1941. Prospectus for De Onsterfelijken.

\section{About the Author}

MaAike Koffeman is Assistant Professor of Cultural Studies and French Literature at Radboud University Nijmegen. She wrote her dissertation on the French literary magazine La Nouvelle Revue française (Rodopi, 2003) and has been active in the field of periodical studies ever since. Her current research focuses on cultural exchange between France and the Netherlands, and more specifically on the Dutch reception of Gustave Flaubert, within the context of the international project 'Flaubert sans frontières' (laboratoire CÉRÉdI / Université de Rouen). 


\title{
Allegories of Branding
}

\author{
How to Successfully Fail Charles Bukowski
}

Gaston Franssen

\begin{abstract}
The American author Charles Bukowski (1904-1984) has become an authorial brand - that is, a complex symbol that projects a set of associations onto commercial products. This brand emerges from interactions between the fields of creation, production, and reception. Bukowski himself fuelled this interaction by constructing a recognizable, albeit contradictory public figure: that of the successful loser. Focusing on the Dutch reception of Bukowski as a case study, I demonstrate how cultural producers and suppliers capitalize on this figure, invoking it to suggest that their products allow consumers to partake in the Bukowskian lifestyle. However, the contradictions inherent in the persona of the successful loser subvert this process. As a consequence, instances of Bukowskian branding appear as normative failures, as their very success belies the values associated with the author.
\end{abstract}

Keywords: Bukowski, authorship, branding, cross-field interaction, the Netherlands, deconstruction

\section{Introduction: The Brandability of the Beastbuk}

The phrase 'What would Bukowski do?' is a life mantra for many fans of Charles Bukowski (1904-1984). Admirers of 'Buk' or the 'Beastbuk', as the author would refer to himself at times, can even wear their hearts, in a very literal sense, on their sleeves, for there is an impressive supply of Bukowski merchandise (Churkovski 1991: 41). Numerous pin badges and T-shirts feature the question, portrayed as if an aphorism on how to navigate through life.

Helleke van den Braber, Jeroen Dera, Jos Joosten, and Maarten Steenmeijer (eds), Branding Books Across the Ages: Strategies and Key Concepts in Literary Branding. Amsterdam, Amsterdam University Press 2021 DOI: 10.5117/9789463723916_CHO5 
Curiously, it seems to be the question itself, rather than its possible answers, that holds the key to understanding the Bukowskian way of life. Even if the question goes unanswered, the phrase functions as an indicator of a specific attitude, or mode of being - in other words, of a lifestyle. 'Bukowski' has become a successful brand, a specific set of connotations attached to books, films, clothing, beverages, home accessories, and even restaurants and bars, all allowing individuals to partake in the Bukowskian lifestyle.

However, this branding of Bukowski - by which I refer to the process of the author becoming a brand as well as the use of the author as a brand to market products and services - has something profoundly self-subversive to it. Here, too, the aphoristic phrase 'What would Bukowski do?' provides an insightful starting point for further reflection, as semantic fault lines quickly appear when one attempts to actually answer this question - indeed, what would the Beastbuk do? As will become clear, potential answers that would concur with what has become the author's trademark persona include: Bukowski would never conform to the existing order or dominant aesthetic conventions; he would refuse all opportunities to success, social mobility, or increase of status; he would embrace his position as an outsider and self-determined loser. ${ }^{1}$ Taken together, such answers point to an implied cluster of choices and preferences that make up the quintessential Bukowskian lifestyle. Yet paradoxically, these answers also indicate that there are certain practices that the intractable author would certainly not engage in. For example, Bukowski would refrain from engaging in commercial endeavours such as advertising or merchandise production; he would never bother with fashionable clothing or home accessories, let alone buy or wear badges featuring authors' quotes; and he would certainly not allow either himself, or his work, to be transformed into a commodity tailored to audiences' expectations. On closer inspection, the quintessential Bukowskian lifestyle appears to be deeply at odds with the process of branding.

These reflections on the afterlife of Bukowski already reveal that the author's branding is driven by a negative moment or, in the terms of literary theory, by a deconstructive impulse. Reflecting on the process of literary reading, the post-structuralist critic Paul de Man argues that this impulse manifests itself when it is revealed that readers' most profound insights are often the result of a 'peculiar blindness' - of a 'negative moment that animates the critic's thought' and simultaneously leads his language away

1 Tellingly, Bukowski figures prominently in the opening pages of Mark Manson's popular self-help book The Subtle Art of Not Giving a Fuck: A Counterintuitive Approach to Living the Good Life. Manson (2016). 
from its asserted stand' (De Man 1971: 103, 106). I propose that this 'blinded vision' (De Man 1971: 106) can be clearly seen to be at work in the branding of Bukowski. The appeal of the Bukowski brand is dependent on the author's characteristic refusal of all forms of success, be it in terms of sales figures, social elevation, or cultural prestige. However, at the precise moment that the author is successfully branded - which seemingly bolsters his market visibility and cultural presence - important elements of the Bukowskian lifestyle appear to be downplayed or even negated. As a result, commercially appealing or socially accepted instances of Bukowski branding turn out to be normative failures, since their very success belies the values that readers have come to associate with the author. In this contribution, I want to explore this deconstructive dynamic. Thus, I will argue that the branding of Bukowski can be read in terms of what De Man would call an allegory of unreadability - or, in this case, a narrative about the author's unbrandability.

My analysis is driven by two fundamental questions: Firstly, what are the elements and operations that constitute the Bukowski brand? Secondly, how does the negative moment at work in the author's branding affect the use of the author as a brand by others? In seeking answers to these questions, and for two interrelated reasons, I will focus on Bukowski's reception in the Netherlands. Bukowski's early acceptance and ongoing popularity in the Netherlands constitute my first reason. All of his novels and most of his poetry collections have been translated into Dutch. Well-known Dutch authors have praised him and even attempted to emulate him, and his work has generated Dutch film, dance, and theatre adaptations, Bukowski reading tours, and Bukowski festivals. Perhaps Bukowski has appealed to Dutch markets because his work and lifestyle harmonized with the tolerant, anti-authoritarian, and culturally alternativist self-image of the Dutch, given that critics were quick to welcome the author as an 'anarchistic figure' and a 'leading representative of underground poetry' (Anon. 1970; Anon. 1980). Whatever the cultural explanation for his appeal may be, it is undeniable that the Netherlands comprises an extensive and profitable market for the branding of Bukowski. A second reason to focus on the author's impact in the Netherlands is that the transposition of the author's work to a non-American context, in which it must be tailored to audiences with different tastes, initiates a selective foregrounding and exploitation of those elements of the Bukowskian universe that are considered to be compatible with the Dutch market. Bukowski's extensive Dutch success, in other words, holds out the promise of providing ample insights in the transformative and expansive work of the branding process. 
Before I turn to the 'Dutch' Bukowski, in the following section I first develop a theoretical framework that conceptualizes branding as a dialectical process. As I will demonstrate, a brand is not merely a marketing tool employed by a particular company, but a dynamic, collaborative construct constituted through cross-field reactivity - that is, through an ongoing interaction between the cultural fields of creation, production, and reception. This conceptualization implies that branding is to be understood as a process of emergence that lies significantly beyond the control of individual actors. In the third section, I turn to the Bukowski brand itself and trace its origins in the author's work and biography, paying special attention to the role of success and failure in his self-presentation. Whilst it appears that the author was unable to control his public image, his self-presentation did introduce key elements to what would become the Bukowski brand. The fourth section focuses on the reception of Bukowski's work in the Netherlands, exploring how the success of his Dutch translations and adaptations relates to the connotations and values associated with the Bukowski brand. First, however, a more conceptual issue needs to be addressed: How might we understand literary authorship in terms of branding?

\section{Conceptualizing Authorial Branding}

Modern, (post)romantic discourses of authorship often presuppose the finiteness of, and indissoluble tie between, an author and his or her oeuvre (Bennett 2005: 55). As Roland Barthes (1977:147) famously observed in his essay The Death of the Author, '[t]o give a text an author is to impose a limit on that text, to furnish it with a final signified, to close the writing'. Yet the process of authorial branding is characterized precisely by a proliferation of meaning (which can, but does not necessarily have to be controlled by a managerial strategy, as the next section will show) and a disconnection of author and text. After all, Bukowski did not author the phrase 'What would Bukowski do?', but it is nonetheless an undeniable product of the signifying potential of his oeuvre. Likewise, his work does not contain references to, for instance, the 'Bukowski Tavern', but his name has been effectively affixed to the restaurants bearing that name in Boston and Cambridge, Massachusetts, as a mark of quality. It is this productive, expansive dimension of branded authorship that I aim to conceptualize in this section.

Jeroen Dera et al. (2021: this volume) define a cultural brand as a set of regimented associations, resulting from an interactive process in which cultural producers, intermediaries, and consumers are involved. Given this 
definition, authorial branding implies that an author has been transformed into a complex, collectively construed symbol that bundles specific values associated with commercial products. The idea that artists, too, can be thought of as brands has already been pursued by several marketing scholars. For example, in his article, 'The Artist and the Brand', Jonathan E. Schroeder (2005: 1292) argues that artists are 'exemplary instances of image creation in the service of building a recognizable look, name, and style', and as such, they 'can be thought of as brand managers, actively engaged in developing, nurturing, and promoting themselves as recognizable "products"'. However, as others in the field point out, an analysis such as Schroeder's, which emphasizes the role of artists as brand 'managers', runs the risk of underplaying the influence that audiences have in the creation of their public image. In order to resist such a 'managerialist blinding', Daragh O'Reilly (2005:582) claims that 'it is important always to keep in mind the dialogic character of branded communications' and to assert that all 'brand identities', including those of artists, are 'to be constructed and negotiated in the context of social interaction'.

Within a literary context, this means that the branding of an author should not be understood merely as a form of consolidation or reproduction of existing texts and images by the author. Rather, it has to be valued as an emergent process, entailing authorial control and continuity as well as spontaneous change and the addition of new texts and images by others. In Under the Cover: The Creation, Production and Reception of a Novel, Clayton Childress (2017: 8-11) introduces a terminology for the analysis of the literary industry that can help to clarify this. Building on Pierre Bourdieu's field theory, Childress distinguishes between three fields within the publishing world: the field of creation, that of production, and that of reception. These fields are interdependent - novels, authors, and reputations can travel between fields. For example, literary agents pitch authors to publishers; marketing agencies introduce novels to audiences; publishers then adapt backlists depending upon their audiences' responses; thereby affecting authors, and so on. Although these fields are generally oriented towards the maintenance of the market's status quo, Childress (2017:241) points out that their interdependence can result in what he describes as 'loops' of 'exogenous forces of change'. By this, he refers to reiterative shifts in one field in response to changing conditions in another. This 'cross-field reactivity' provides continuity within fields as well as accounting for the proliferation and differentiation of what the different fields produce.

Although Childress (2017: 241) does not write on the process of branding per se, his terminology helps to conceptualize branding as a product of cross-field interaction. The authorial brand, too, emerges out of this 
inter-field reactivity. First, the author's success in a field of reception - be it with literary critics, the general audience, or a particular subculture results in the production of new meanings: audiences construct images of authors and associate them with values they find appealing. The author's impact sends ripples throughout the other fields, stimulating other actors to play into the success. On the one hand, this capitalization depends on continuity and repetition: in order to catch the attention of its target audiences, well-known images or texts of the author have to be reproduced, underlining the attributes appreciated by the audiences. This produces the authorial brand as a set of associations, built up and reaffirmed over a period of time. On the other hand, the use of the brand as a tool to target new audiences - to generate innovative meanings, in line with the required market differentiation - requires adjustments and extensions of the author as a brand: the associated set of attributes has to be tailored to a new field of reception. Such transformations in one field, responding to changing conditions of supply and demand in other fields, are examples of Childress's loops of exogenous forces of change. Over time, the changes in the brand narrative can even eclipse its origins in the field of creation, invoking values with only very indirect relations to the author.

Here, one can think of examples such as the 'aesthetic' qualities of the persona of Oscar Wilde invoked to sell cigars, or a photograph of Ernest Hemingway's penny loafers to market a shoe shining product, or a line from Bukowski - 'food is good for the nerves and the spirit' - quoted in a menu to suggest the countercultural, underground appeal of a restaurant. ${ }^{2}$ In all of these cases, the author does not function as an ultimate signified that closes the writing of the text (as Barthes would say), but as an emerging and proliferating brand - as a complex symbolic structure, invoking the author's semiotic potential and redirecting it in order to introduce a commercial product in selected fields of reception. In Bukowski's case, this symbol is easily recognizable but comes with certain contradictions, as illustrated in the next section.

\section{Locked in the Arms of a Crazy Life: The Origins of the Bukowski Brand}

The main elements that constitute the Bukowski brand can be traced back to his personal life story. All of his biographers paint a picture of a rough-hewn

2 See Mayer (2016: 114) on Wilde; Ogilvy (2018) for Hemingway; and Bukowski Tavern (2018) for the Bukowski quote (taken from his 1971 novel Post Office). 
loner, who wastes his days in the 'seedier' parts of Los Angeles, rubbing shoulders with barflies, prostitutes, and dropouts, whilst spending his money on alcohol, women, and gambling. Neeli Cherkovksi, his first biographer, describes him as a 'lone figure', growing up 'in cheap dives and dead-end jobs' to become a 'rough-edged libertine' and a 'boozing, sex-crazed character' (Cherkovski 1991: 57, 264, 207, 231). In his book, Charles Bukowski (2005), Barry Miles (2005: 12, 203) also characterizes the author as an 'outsider, loner', a 'hard-drinking, belligerent wild-man'. Howard Sounes (2007: 6-8) chimes in with his portrait of a 'bawdy writer' who is a 'a roaring drunk for much of his life', and whose life philosophy revolves around a stubborn 'refusal to try and "get on" in life'. This, indeed, was the preferred self-image of the author: the 'Dirty Old Man' - from the title of his underground press column series, Notes From a Dirty Old Man - who feels at home at the bottom of American society (Miles 2005: 159).

The first-person narrator of Bukowski's poetry and his novelistic alter ego Henry (Hank) Chinaski answer to the same description. The life stories they tell are similar: a difficult childhood, an abusive father, a life spent drinking and fighting - with practically everyone, from alcoholic men, loose women, pestering bosses, to pretentious authors - whilst writing a good story or poem every once in a while. The world they inhabit is roughly the same: one of 'sleazy bars, littered alleyways, [and] dark furnished rooms', where they mingle with 'the disenfranchised, the marginalized, the mad and [the] dysfunctional' (Cherovski 1991: 97; Miles 2005: 10). Michael Hemmingson (2008: 45-46) effectively sums up the literary universe of Bukowski/Chinaski with a list of core ingredients: first, 'alcohol', as both narrator and characters spend their time drinking beer and cheap wine; second, 'work', understood as something that is necessary but 'either loathed or not there'; third, 'women', mainly in the figure of 'barflies, prostitutes, nymphomaniacs'; and finally, 'the ugly' - that is, the ugliness of the life of the modern urban underclass, which the author transforms into 'the beauty of the human grotesque'. Of course, from a biographer's point of view it is important to keep in mind that the author was prone to self-mythologizing. Most biographers are quick to point out that Bukowski created an exaggerated 'persona' that cannot be taken at face value; Miles even claims that the author reinvented 'the Bukowski myth' so often 'that it is now impossible to sort out the truth from fantasy' (Cherkovski 1991: 114; Miles 2005: 83, 60).

Be that as it may, it is precisely this almost caricatural self-stylization as a boozing tough guy from the urban underclass that became his defining trademark. Both Abel Debritto and David Charlson have charted how Bukowski developed into an iconic figure, with Charlson (2005: 42) helpfully 
outlining three stages: first, the real author builds a 'personal myth' from real experiences; then, 'the author and the man [...] use the personal myth' to 'further define themselves'; finally, the myth is fleshed out in the Chinaski novels. The resulting persona, suggests Andrew J. Madigan (1996: 456), 'was increasingly becoming an entity in its own right'. Already at the beginning of his fame, the real Henry Bukowski Jr. struggled with his popular doppelgänger - a creation that was increasingly out of his control. He complained about 'this shitty image, this Humphrey Bogart image of me', and about 'those who worship me as some totally wild Hemingway, or some slum-god from the sewers of L.A.' (Cherkovski 1991: 178). However, once the public image of Bukowski was set, there was no escape: all of the author's biographers note that he felt compelled to live up to the audience's expectations. In this sense, the author was (referring to the subtitle of Sounes' biography) 'locked in the arms of a crazy life'.

Although the components that constitute the Bukowski brand vary over time, as the next section will illustrate, one persistent dimension of the author's public image needs to be addressed separately here, as it introduces the negative moment that complicates the use of the author as a brand. This dimension pertains to the role of success. Both in the form of bestseller print runs and literary fame, success came relatively late for Bukowski: despite his mid-1940s debut in Story magazine and his cult status in the little magazines, it was only in the late 1960 s and early 1970 s that he was to finally reach a wider audience. ${ }^{3}$ As a result of his growing popularity, Bukowski was not only able to support himself as a full-time writer, he even became a literary celebrity: his readings were crowd pullers, his work was adapted to the big screen (with Hollywood actor Mickey Rourke starring as Chinaski), and the author found himself in the company of famous authors and stars, such as Alan Ginsberg, Norman Mailer, Sean Penn, and Madonna (Miles 2005: 198, 254, 260, 275).

Yet in spite of this popularity, the Bukowski persona and the lifestyle it represented continued to be predicated on a stubborn disavowal of all forms of success. ${ }^{4}$ The self-image projected by Bukowski is, in fact, that of the ultimate loser. In a letter from 1965 , for instance, the author distances himself from fans who take him to be a role model: 'I am a fucking oracle

3 Bukowski's slow rise to success, from the little magazines and zines to mainstream culture, is documented by Debritto (2013) and Madigan (1996).

4 See also Charlson's (2005: 92) analysis of Bukowski's position in the field of tension between high culture and popular culture; and Madigan's (1996:451-461) reading of Bukowski's Hollywood (1989) as a fictionalized expression of his unease with regard to his Hollywood success. 
[...] for the lost or something, is what they tell me. that's nice. but I am the lost.' Indeed, the author prefers 'losers' to 'winners', as in his opinion the latter's success can only be the result of giving in to social expectations or aesthetic conventions. 'You say you never care much for losers, but it's all I've known', Bukowski (1995a: 22) confesses to John William Corrington in 1962: 'I don't like winners. Winners get fat and careless and write things like The Old Man and the Sea which is printed in Life magazine for a public which was long ago gaffed by the formula.' Not much later, again in personal correspondence, he even characterizes himself as 'the Image of the Loser, the Man who doesn't care, the Man who didn't quite make it' (Bukowski 1995a: 87). It is a pattern of self-fashioning that returns in Bukowski's literary work, which embodies, according to Russell Harrison (1994: 14), a wholesale 'rejection of the ideology of success and power'. In the following section I take a closer look at two examples in order to illustrate this rejection more clearly.

In one of his Notes of a Dirty Old Man columns, Bukowski (2011: 163-165) puts forward a distinction between two forms of fame, although turning away from both. Some writers, he proposes, 'are famous not because their work is excellent and original but because the masses identify with the output' (163). The books of the authors are highly popular and thus, as a consequence, they line the stands of the bookstores in the shopping malls. The Heartbeat's Wail. Thunderblossom'. These writers are 'more rich than famous', he maintains, but they are not 'real': they are 'false in their ideals, their actions, their lives' (163). At the other end of the spectrum of success, according to Bukowski, are 'the literary writers': 'Their idea is that if something is written tediously enough, if it is involuted enough, if it is hardly understood, then, that's art.' (164) The success of these authors is not based on mass appeal, obviously, but on favouritism, as 'they promote, publish and teach each other'. Hence, 'these writers are more famous than rich', according to Bukowski, since 'they are the only ones who buy each other's books' whilst constantly complaining 'of the success of such writers as those who put out books entitled The Heartbeat's Wail; Thunderblossom and so forth' (165). Bukowski concludes that an author, when confronted with these two models of success, can never be sure if it is truly deserved, 'so there's only one thing to do: go on typing, as I have been doing here' (165). With his column, Bukowski explicitly refutes success in the form of what sociologists would label 'economic capital' - short-term, mass-market success that will quickly fade away - as well as success in the form of 'symbolic capital' - that 
is, acknowledgment by other authors or critics, leading to limited but longterm prestige, albeit only within a small circle of connoisseurs (Thompson 2012: 21-31). Bukowski presents himself as completely opting out of the economic dynamics of the literary field: he is not in it for profit, status, or power. In reality, of course, columns like this one did have a profound field effect, turning Bukowski into a 'Los Angeles celebrity' (Miles 2005: 159). However, notwithstanding his celebrity status, it seems safe to conclude that the author preferred not to be seen as a 'winner'.

The aptly titled poem 'The Loser', first published in 1960, confirms Bukowski's unease with winning (Bukowski Net 2018). Evoking the aftermath of a bar fight in fragmentary images, it is an exemplary Bukowski poem, with an intriguing programmatic twist at the end. It starts mid-sentence with the first-person narrator recalling how he once found himself lying 'on a table' - presumably after being struck down. He remembers 'some toad', 'smoking a cigar', looking down on him and saying: '“Kid, you're no fighter." The narrator goes on to describe how he 'got up' nonetheless and 'knocked him over a chair'. Dumbfounded, his opponent repeats 'over and over: “Jesus, Jesus, Whatsmatta wit / you?"'. The poem ends with the lines 'I got up and dressed, / (believe it or not) / the tape still on my hands and / wrote my first poem, / and I've been fighting / ever since' (Bukowski 1973: 45). The scene invokes the classic Bukowski persona: a washed-up tough guy, picking fights in smoke-stained bars. Interestingly, the experience of taking a beating coincides with the birth of the poet, as the act of fighting is aligned with the writing of poetry. This closing twist, together with the title, invite the reader to interpret the invoked persona as a trope: the first-person narrator is not a literal loser, but the allegorical Loser - the personification of the Bukowskian lifestyle.

The final lines introduce an important ambiguity to this portrayal. On the one hand, they suggest that the poet cannot be anything but a 'loser', as the barroom trashing that kick-starts his poetic production marks him from the outset, quite literally as a 'beaten-down' figure. On the other hand, the closing lines raise doubt about whether or not the first-person narrator really is to be identified with the allegorical figure of 'the Loser'. After all, the narrator does not fail: as a fighter, he succeeds in flooring the 'toad'. As if to confirm this, his opponent's “you're no fighter"' is countered with the claim that he has been 'fighting / ever since'. Similarly, despite being a beaten-down poet, he successfully turns his fighting spirit into a source of creative energy - with a first poem as result. Moreover, the structural parallel between fighting and writing suggests an alternative phrasing of the poem's last line, with the undefeated poet 'writing / ever since'. Thus, 
in the end, the allegorical setup of the poem subverts itself, producing a highly contradictory persona: a successful loser.

\section{Brands and Bars: Cross-Field Interaction in the Netherlands}

Once Bukowski started to enjoy popularity, audiences wanted to see and read more of the same. From within the field of creation and production, this demand was happily met by publishers, magazine editors, and cultural journalists as well as by Bukowski himself, all supplying the audience with new images and texts confirming the qualities that readers had come to associate with Bukowski and his work. Out of this cycle of production and reception arose the complex symbol of 'Bukowski' - an authorial brand. However, as this section will demonstrate, this brand is susceptible to change, as the different loops of inter-field reactivity foreground some aspects of the set of associations whilst downplaying others. At the same time, the contradictions inherent to the Bukowskian figure of the successful loser will prove to have profound consequences for the use of this author as a brand.

In order to explore this dynamic, I now turn to the Dutch fields of production and reception. As stated in the introduction to this chapter, Bukowski's success in the Netherlands offers ample insights into the expansive and transformative work of cultural branding. A first important observation is how, with the publication of a volume of Dutch translations of his poems in 1970, Bukowski was characteristically introduced to the Dutch market as the author of poetry about failure and defeat. ${ }^{6}$ A review in the Dutch newspaper Trouw praises the author for the 'relentless honesty' with which he analyses 'his own spinelessness, his non-conformity, and his self-pity'. This 'spinelessness', the reviewer contends, marks the poet's 'mode of being in a world where all the good things and all the beautiful women are for the others'. Clearly, Bukowski's work is presented as a literature of losers - as a 'poetry of the failure of the adjusted and the defeat of the maladjusted' (RK 1970). ${ }^{7}$ This trend continues with the reception of Postkantoor (1977), the Dutch translation of Post Office. An initial reviewer applauds the author for

6 The translation, Dronken Mirakels \& Andere Offers (Bukowski 1970), was produced by the Cold Turkey Press, an underground publisher from Rotterdam; see Brus (2012).

7 RK (1970): 'Met een niets ontziende eerlijkheid ontleedt de dichter zijn eigen zakkigheid, zijn onaangepastheid, en zijn zelf-medelijden'; 'het is zijn wijze van bestaan in een wereld waar al de goede dingen en alle mooie vrouwen naar anderen gaan'; 'Poëzie derhalve van het echec der maatschappelijken en ook van de nederlaag die de onmaatschappelijken van vandaag voortdurend te lijden hebben'. All translations from Dutch are my own. 
his hilarious portrait of an 'alcoholic troublemaker' (Luijters 1977), ${ }^{8}$ whilst a second confirms the beaten-down tough guy persona, touching upon all the core elements of the Bukowski myth as inventoried by Hemmingson (2008): 'a decade of continuous inebriation' (alcohol), 'dozens of trades and countless accidents' (work), 'a great amount of trouble with the ladies' (women), 'broke and down' (the ugly) (Lieshout 1977). ${ }^{9}$ Finally, a third reviewer evokes the image of Bukowski/Chinaski as failure personified: 'Chinaski, whose experiences are without a doubt based on Bukowski's own, is prototypical of the guy who is "had" by this society time and again' (Maandag 1977)..$^{10}$ This characterization would prove to be a constant theme in the Dutch reception of Bukowski: he was praised again and again for being a successful loser. The publisher De Bezige Bij, who translated and marketed most of Bukowski's prose works during the 1980 s and 1990s, began to play into this image: the jacket notes of the 1980 translation of Erections, Ejaculations, Exhibitions and General Tales of Ordinary Madness (1972) presents the author to the Dutch audience as 'the born loser turned into a winner' (Bukowski 1980). ${ }^{11}$ Following Bukowski's death in 1994, the author Martin Bril (1994) summarized Bukowski's oeuvre as follows: 'His work is the triumph of one single theme: losing. Missing the boat. Coming off worst. Getting the short end of the stick. ${ }^{12}$ Clearly, an ongoing interaction between the field of production and that of reception was taking shape.

However, it was only when others began to use the image of Bukowski to launch their own products that a brand - as conceptualized in the second section of this chapter - really began to emerge. 'Bukowski' became a form of shorthand used to refer to the specific interests of potential consumers. In the 1980 s, for instance, the music magazine Vinyl - a Dutch version of The Face - advertised one of its issues with the slogan: 'Also in this issue: Charles Bukowski [...], pop videos and clothing' (Anon. 1983). A further example can be found in the marketing of the cult film Crazy Love (1987), directed by the Belgian filmmaker Dominique Deruddere and based on

8 'alcoholische dwarsligger'.

9 'een tiental jaren onafgebroken dronken'; 'dozijnen ambachten en talloze ongelukken'; 'uitermate veel gelazer met dames'; 'blut in de put'.

10 'Chinaski, in wie Bukowski zonder enige twijfel een aantal persoonlijke ervaringen heeft gestopt, is het prototype van de vent, die in deze maatschappij steeds weer "gepakt" wordt, maar die er met een borrel en een vrouwtje [...] tracht boven uit te komen'.

11 'De geboren verliezer is een winnaar geworden'. The De Bezige Bij translations are collected in Bukowski (1995b).

12 'Zijn werk is dan ook de triomf van één thema: verliezen. De boot missen. Het onderspit delven. Het loodje leggen.' 
Bukowski's stories. Newspaper advertisements for the film prominently featured the lines 'based on stories by Charles Bukowski' (Anon. 1987), with the author's name in capital letters and in a distinctly larger font than the names of either the director or the actors. ${ }^{13}$ Bukowski was obviously no longer in need of any introduction; rather, the author's name itself had come to stand for an implied set of connotations, introducing products of a certain type and quality to the audience.

As the branding process intensified, 'Bukowski' increasingly became a cluster of suggested qualities of commercial products instead of an authorial identity - with the result that contradictions began to manifest themselves. The production and reception of Pussy Album (2016), a novel by Stella Bergsma - a Dutch poet, author, and singer of the band Einstein Barbie - illustrates this perfectly. Bergsma has repeatedly expressed her admiration for Bukowski. In one interview, she praises him as 'one of my heroes because he wrote in a "stripped-down" style about sex, drugs, and rock and roll' (Steenberghe 2017). ${ }^{14}$ More importantly, with Pussy Album she attempts to follow in the footsteps of the author. Upon its publication, the novel, narrated by a self-destructive teacher who embarks on an affair with a pupil and gets caught in a downward spiral, was presented as a 'literary experiment'. Bergsma 'wanted to write a Charles Bukowski novel from the perspective of a woman, with all the related depressing sex, hectolitres of booze, self-destruction, craziness, and total degradation' (Vullings 2016). ${ }^{15}$ Bergsma's critics followed up on the suggested comparison, comparing her to her literary hero, whilst praising her stylistic fireworks and her gripping description of the main character's downfall (Breukers 2016; Vullings 2016; Witteman 2016).

However, successful as the attempt to brand Pussy Album as novel $\grave{a}$ la Bukowski may have been, the book goes against the grain of the Bukowskian lifestyle. Although alcohol abuse and sexual encounters play an important role, the novel's style and themes differ distinctly from Bukowski's work. Stylistically, Pussy Album, by employing the stream of consciousness approach to its prose - which is rich with intertextual references and language experiments - ends up being a far cry from the American author's strippeddown realism, which Bergsma praised. Additionally, the novel's heroine

13 'gebaseerd op verhalen van Charles Bukowski'.

14 'een van mijn helden omdat hij in een "uitgeklede” stijl over seks, drugs en rock-'n-roll schreef'.

15 'een literair experiment: ze wilde een Charles Bukowski-roman schrijven vanuit het perspectief van een vrouw, met alle deprimerende seks, hectoliters drank, zelf-vernietiging, gekte en totale verloedering van dien'. 
has little of the principled 'refusal to work ethic' embodied in Bukowski's underclass characters (Harrison 1994:140). In Bergsma's novel, the monotonous despair of lower-class life described by Bukowski is substituted for the eventful melodrama of a middle-class tragedy. Rephrasing Bukowski's words on the success of Hemingway, one could argue that, on the one hand, Bergsma is one of those literary 'winners', producing a branded bestseller work aimed specifically at 'a public which was long ago gaffed by the formula' (Bukowski 1995a: 22). On the other hand, Bergsma can be said to have failed her American idol, as her success and the qualities for which her work is praised are markedly un-Bukowskian. Pussy Album thus illustrates how the components that make up the brand's set of attributes can change over time and might even become incompatible with some of the values associated with the brand at an earlier stage of its history. This negative movement manifests itself even more profoundly in non-literary uses of the author as a brand. To illustrate this point, I conclude my discussion of the Dutch reception of Bukowski with another example - 'Bar Bukowski' in Amsterdam.

Situated in a trendy city neighbourhood, Bar Bukowski presents itself as 'the hottest place in the eastern part of Amsterdam' (Bar Bukowski 2018). Its name is far from coincidental; indeed, the bar's website claims:

Named after the writer Charles Bukowski, this bar is breathing his love for alcohol, women and literature. From a type-machine light fixture above the bar to his quotes on the menu; as Bukowski said, 'there is always a reason to drink!16 (Bar Bukowski 2018)

The menu includes a citation from Post Office next to the bar's logo, which is based on the famous 1981 portrait of a teeth-baring Bukowski by photographer Mark Hanauer. ${ }^{17}$ A mural in the style of Bukowski's cartoonish self-portraits adorns the walls, next to another quote: 'Life's as kind / as you let it be.' (Bukowski 2002: 193) Furthermore, customers can order a (blonde) beer named after the author, its logo promising 'a wild ride with an outspoken blonde'. ${ }^{18}$ The author's love for literature' is evoked in the bar's event programme, entitled 'Notes of a Dirty Old Man' - a monthly evening of public readings by young authors. Finally, the bar's website includes a

16 In 1989, another Dutch bar, this time in the city of Haarlem, was named after Bukowski, and subsequently sued by the author for copyright infringement (Anon. 1989).

17 The Hanauer portrait of Bukowski is reprinted in Debritto (2013:171).

18 The beer is only marketed as 'Bukowski' by the bar itself; for the general market, it is labelled as 'Flink'; see RateBeer (2018). 
restaurant review from a local newspaper that concludes: 'Bukowski would have smiled approvingly if he would have entered this place thirstily and positioned himself at the bar' (Bar Bukowski 2018). ${ }^{19}$ In short, Bar Bukowski presents itself as an establishment that offers customers a chance to truly partake in the world of Bukowski.

It is not difficult, however, to point out a series of incongruities in this particular example of authorial branding. To begin with, the set of associations built up around the author is evoked only selectively at Bar Bukowski, to the exclusion of important elements, such as the ugliness of urban underclass life or the refusal to work ethic. Admittedly, the bar's branding process does reproduce key elements of the Bukowskian universe, such as alcohol, sex, and literature, but in a sanitized manner: the menu offers a customized list of local craft beers and popular cocktails; the Bukowski beer is euphemistically presented as a 'wild blonde'; and the literary evenings are organized in collaboration with respected Dutch literary institutions such as Das Mag magazine and Lebowski publishers. Significantly, the author's statement that 'there is always a reason to drink!', cited in order to set the desired Bukowskian atmosphere, cannot be traced back to his letters, poems, or novels. It appears to be a paraphrase of what the bar owners believe to be the essence of the Bukowskian lifestyle. ${ }^{20}$ It is a crucial paraphrase, however, as it rewrites the defeatist alcoholism of Bukowski's hard-nosed losers into the more acceptable conspicuous consumption of middle-class, well-to-do bons vivants. In other words, Bar Bukowski presents its customers with a gentrified Bukowski - a branded author that has been adapted to meet the demands of the creative urban middle class. By doing so, it cannot help but fail the author: popular as the bar may be, it is unlikely that Bukowski, upon entering the establishment, would have smiled approvingly. Paradoxically, it is much more likely that he would have not felt at home in such a place.

\section{Failing Bukowski: By Way of Conclusion}

Tracing the interaction between the Dutch fields of production and reception, I have illustrated how the branding of Bukowski can be understood as

19 'Bukowski zou goedkeurend hebben geglimlacht als hij hier dorstig was binnengestapt en had plaatsgenomen aan de bar'.

20 The quote appears to be a paraphrase of a paragraph taken from Bukowski's Women: 'That's the problem with drinking, I thought, as I poured myself a drink. If something bad happens you drink in an attempt to forget; if something good happens you drink in order to celebrate; and if nothing happens you drink to make something happen.' (Bukowski 2007: 77). 
a collective and expansive process: loops between the fields construct the author as an emergent brand, which is subsequently projected onto a range of commodities in order to suggest that these have been produced 'under the sign' of Bukowski. However, the author's public image as a hard-nosed dropout who rejects all forms of success as false, turns out to complicate and subvert this process. Consequently, those who successfully evoke the author as a brand end up failing the Bukowskian lifestyle.

As has become clear, Bukowski's figure of the successful loser is the crux of the matter: he is an indeterminable personification that cannot be identified as a trope of either success or failure. In a literary context, De Man (1979: 204) has shown how such unstable tropes put into question the 'readability' of the text, as they demonstrate that the text in which they appear 'cannot be closed off by a final reading'. De Man goes on to distinguish between two types of 'unreadable' texts: first-degree, 'tropological' narratives, which 'tell the story of the failure to denominate' (that is, tropes that demonstrate their undecidability); meanwhile, second-degree, 'allegorical narratives' tell 'the story of the failure to read' (that is, tropes that self-reflexively narrate their own unreadability) (205). Thus, in the context of Bukowskian branding, it can be concluded that the contradictory figure of the successful loser questions the brandability of the author's work. Indeed, as I hope to have shown, branding attempts that evoke this persona, such as Bergsma's Pussy Album, or Amsterdam's Bar Bukowski, reveal themselves to be tropological narratives, demonstrating the indeterminacy of this figure and telling the story of their failure to brand.

The Bukowskian figure has also been shown to engender allegorical narratives. Returning to the poem 'The Loser', one might argue that the 'toad's' repetitive expression of bewilderment at the loser's winning punch - 'Jesus, Jesus, Whatsmatta wit / you?' - mirrors the reader's profound incomprehension of the figure of Bukowski, which refuses to be identified as a trope of either success or failure. Thus, the branding of the author turns out to be a process that generates allegories of unbrandability - narratives about the failure of branding. After all, in becoming a brand, the Bukowskian figure has been transformed into a trademark or logo, and by the same token, it has been misidentified and disfigured. In that sense, invoking the etymological history of the word 'brand' in its meaning of 'burning as a mark of identification' (Stern 2006: 219), Bukowski can be said to have been doubly branded. 


\section{References}

[Anon.] 1970. 'Dubbel echec in unground-poëzie'. In Trouw, 28 October.

[Anon.] 1980. 'Anarchist Bukowski'. In de Volkskrant, 22 October.

[Anon.] 1983. [Advertisement for Vinyl]. In de Volkskrant, 23 December.

[Anon.] 1987. [Advertisement for Crazy Love]. In Het vrije volk, 11 November.

[Anon.] 1989. 'Schrijver Bukowski wil niet als cafélogo dienen'. In Het Parool, 25 July.

Bar Bukowski. https://barbukowski.nl/index.html [accessed 1 November 2018].

Roland Barthes. 1977. 'The Death of the Author'. In Stephan Heath (ed.), Image,

Music, Text, pp. 142-148. London: Fontana Press.

Andrew Bennett. 2005. The Author. London: Routledge.

Stella Bergsma. 2016. Pussy Album. Amsterdam: Nijgh \& Van Ditmar.

Martin Bril. 1994. 'Hoe diep kan een man zinken'. In Het Parool, 27 August.

Chretien Breukers. 2016. 'Schrijven en liefde en niets anders'. Staalkaart, http:// www.staalkaart.be/?q=artikel/schrijven-en-liefde-en-niets-anders [accessed 1 November 2018].

Erik Brus. 2012. Gehavende stad: muziek en literatuur in Rotterdam van 1960 tot nu. Amsterdam: Lebowski.

Charles Bukowski. 1970. Dronken mirakels \& andere offers. Trans. by G. Belart. Rotterdam: Cold Turkey Press.

Charles Bukowski. 1973. 'The Loser'. In Douglas Blazek (ed.), A Bukowski Sampler, p. 45. Madison, WI: Druid Books.

Charles Bukowski. 1977. Postkantoor. Trans. by Susan Janssen. Amsterdam: De Bezige Bij.

Charles Bukowski. 1980. Verhalen van alledaagse waanzin. Trans. by Susan Janssen (Amsterdam: De Bezige Bij.

Charles Bukowski. 1989. Hollywood. Santa Rosa: Black Sparrow Press.

Charles Bukowski. 1995a. Living on Luck: Selected Letters 196os-197os. vol. 2, ed. by Seamus Cooney. New York: HarperCollins ebook.

Charles Bukowski. 1995b. Postkantoor; Vrouwen; Kind onder kannibalen; Hollywood.

Trans. by Susan Janssen et al. Amsterdam: De Bezige Bij.

Charles Bukowski. 2002. Hot Water Music. New York: Ecco.

Charles Bukowski. 2007. Women. New York: Ecco Books.

Charles Bukowski. 2011. More Notes from a Dirty Old Man. ed. by David Stephen Calonne. San Francisco: City Lights Books.

Bukowski Net. https://bukowski.net/database/detail.php? WorkNumber $=3280$ [accessed 1 November 2018].

Bukowski Tavern. https://bukowskitavern.net/ [accessed 1 November 2018].

David Charlson. 2005. Charles Bukowski:Autobiographer, Gender Critic, Iconoclast.

Victoria: Trafford Publishing. 
Neeli Cherkovski. 1991. Hank: The Life of Charles Bukowski. New York: Random House. Clayton Childress. 2017. Under the Cover: The Creation, Production and Reception of a Novel. Princeton: Princeton University Press.

Abel Debritto. 2013. Charles Bukowski, King of the Underground:From Obscurity to Literary Icon. New York: Palgrave Macmillan.

Etsy. https://www.etsy.com/nl/search?q=bukowski [accessed 1 November 2018].

Russell Harrison. 1994. Against the American Dream: Essays on Charles Bukowski. Santa Rosa: Black Sparrow Press.

Michael A. Hemmingson. 2008. The Dirty Realism Duo: Charles Bukowski and Raymond Carver on the Aesthetics of the Ugly. San Bernardino: Borgo Press.

Peter H. van Lieshout. 1977. 'Vertraagd succes, ongewone romans'. In de Volkskrant, 18 June.

Guus Luijters. 1977. 'Boek vol lachbuien'. In Het Parool, 11 June.

Ben Maandag. 1977. 'Bukowski en Kotzwinkle'. In Het vrije volk, 18 June.

Andrew J. Madigan. 1996. 'What Fame Is: Bukowski's Exploration of Self', Journal of American Studies 30.3: 447-461.

Paul de Man. 1971. Blindness and Insight: Essays in the Rhetoric of Contemporary Criticism. New York: Oxford University Press.

Paul de Man. 1979. Allegories of Reading: Figural Language in Rousseau, Nietzsche, Rilke and Proust. New Haven: Yale University Press.

Mark Manson. 2016. The Subtle Art of Not Giving a Fuck: A Counterintuitive Approach to Living the Good Life. New York: Harper One.

Sandra Mayer. 2016. 'The Art of Creating a Great Sensation: Oscar Wilde (18541900)'. In Gaston Franssen and Rick Honings (eds.), Celebrity Authorship and Afterlives in English and American Literature, pp. 111-132. London: Palgrave Macmillan.

Barry Miles. 2005. Charles Bukowski. London: Random House.

Ogilvy. 2018. 'Every Story He Wrote Started with a Man Standing at a Typewriter, Wearing Loafers' [Advertisement for Kiwi Quality Shoe Care]. https://www. adsoftheworld.com/media/print/kiwi_hemingway [accessed 1 November 2018).

RateBeer. https://www.ratebeer.com/beer/39t-ij-bukowski/254271/ [accessed 1 November 2018].

RK. 1970. 'Double Failure in Underground Poetry'. In Trouw, 28 October.

Daragh O’Reilly. 2005. 'Cultural Brands/Branding Cultures', Journal of Marketing Management 21.5-6: 573-588.

Jonathan E. Schroeder. 2005. 'The Artist and the Brand', European Journal of Marketing 39.11-12: 1291-1305.

Howard Sounes. 2007. Charles Bukowski: Locked in the Arms of a Crazy Life. Edinburgh: Canongate.

Els van Steenberghe. 2017. 'We zijn zo tuttig geworden'. In Knack, 3 May. 
Barbara B. Stern. 2016. 'What Does Brand Mean? Historical-Analysis Method and

Construct Definition', Journal of the Academy of Marketing Science 34.2: 216-223. John B. Thompson. 2012. Merchants of Culture: The Publishing Business in the Twenty-First Century. Cambridge: Polity.

Jeroen Vullings. 2016. 'De letteren'. In Vrij Nederland, 9 April.

Sylvia Witteman. 2016. 'Zelfdestructie in Pussy Album'. In de Volkskant, 25 March.

\section{About the Author}

Gaston Franssen is Assistant Professor of Literary Culture at the University of Amsterdam. He has published on literary celebrity in the Journal of Dutch Studies, Celebrity Studies, and the European Journal of Cultural Studies. In 2016, he co-edited Celebrity Authorship and Afterlives in English and American Literature, and in 2017, Idolizing Authorship: Literary Celebrity and the Construction of Identity, 1800 to the Present. 



\title{
Branding or Excluding?
}

\author{
The Tenability of the 'Branding' Concept in the History of \\ Nineteenth-Century Dutch Book Publishing, Book Printing, \\ and Bookselling
}

Robvan de Schoor

\begin{abstract}
Various aspects of branding can be recognized in the Dutch nineteenthcentury literary book trade, even though for a long time publishers and booksellers shied away from the explicit commercialization of what was considered to be merchandize of superior cultural value. A search for examples of branding reveals that branding studies seem to lack their own heuristic methodology: what can be described as branding is often a relabelling of the findings of 'old school' literary studies. Moreover, the history of important nineteenth-century printing houses has yet to be written. Research into branding strategies therefore might be somewhat premature, although the branding concept might be useful for book historians in describing the relations between publisher (printer), author, and reader.
\end{abstract}

Keywords: book publishing, book printing, Louis Couperus, W.J. van Zeggelen, J.A. Alberdingk Thijm

In one of his reviews, Dutch critic Conrad Busken Huet advised writers how to become famous in the afterlife. Celebrity cannot be achieved through excellent literary qualities, but only by branding yourself as the author of just one book: 'Be as witty as hundreds of your peers, be as skilful as the best and an accomplished stylist: as long as you can't present yourself to your descendants as "the writer of - ", their unawareness of your existence and your literary merits won't ever be a cause for self-reproach to them,

Helleke van den Braber, Jeroen Dera, Jos Joosten, and Maarten Steenmeijer (eds), Branding Books Across the Ages: Strategies and Key Concepts in Literary Branding. Amsterdam, Amsterdam University Press 2021 DOI: 10.5117/9789463723916_CHo6 
other than by fits and starts'1 (Busken Huet $1884^{6}:$ I, 112). This recipe for canonization entails specialization, the reduction of one's literary scope to just one 'masterpiece'. Huet found evidence for his somewhat cynical view on canonization in literary history; moreover, his practice as a literary critic had taught him that his contemporaries were too shallow or narrowminded to grasp the full extent of a writer's literary accomplishments. His advice on how to become famous is essentially advice to give in to branding: to brand yourself and allow your readers to do so as well, to suit their own whims.

If we were to try to rephrase Huet's statement, using the vocabulary of present-day literary studies, the appeal to present yourself as the author of just one book and to identify yourself with it should be read as an admonition to adopt an appropriate habitus (Bourdieu) or posture (Meizoz). Branding, canonization, literary fame, habitus, posture, or self-fashioning: these are all concepts that should enable us to grasp the economic and social laws that govern the Republic of Letters. They all claim to be relevant to both contemporary and historical book production and book trade. However, as branding is foremost associated with advertising and sales strategies, this concept might be less usable for describing nineteenth-century literary commerce, when books were looked upon as instruments to promote civilization and social, scientific, and political progress. Of course, branding is more than merely advertising, but whoever brands and whatever is branded (intentionally or unintentionally), it should not be forgotten that high-brow literature, at least - on which I focus here - was considered to have an inherent value and was therefore less likely to be promoted as a product throughout the nineteenth century. Mass-produced literature for the middle and lower classes, such as popular genres on the one hand or literary series (such as Warendorf's Novellen-Bibliotheek) on the other, were already subjected at an earlier stage to modern advertisement and branding strategies (Kuitert 1993).

Accepting the definitions of various aspects of literary branding that were highlighted in this volume's Introduction, I will concentrate here on identity myths and regimented associations, both of which come into being in the interaction between publisher/printer, bookseller, author, and reader/critic. This interaction is at the heart of the definition of branding in

1 'Heb geest voor honderd van uw gelijken, wees de kunde in persoon en daarbij een volleerd stilist: zoolang gij het regt niet hebt $\mathrm{u}$ bij den nakomeling aan te melden als den schrijver van - zoolang zal zijne onbekendheid met uw bestaan en uwe letterdaden hem nooit anders dan bij tusschenpoozen eene bron van zelfverwijt worden.' 
the Introduction, where it is presented as - if I may rephrase it for a better understanding - 'a process during which authors, publishers, printers, book designers, booksellers and readers/critics, in connection with each other, tell stories about a book and about each other'. Myths and associations arise where stories have been told: stories about a publisher's or an author's identity, and stories about the way a book should be perceived and read.

My aim is to investigate the history of publishing, printing, and bookselling in the Netherlands during the nineteenth century, looking for opportunities to use the various meanings of branding, being fully aware that aspects of branding as they are understood today only came into being in the first half of the twentieth century. If certain branding strategies might be detected, it is obvious that they will be of a relatively primitive nature. My survey will be mainly anecdotic, as the history of Dutch nineteenth-century book publishing, book printing, and bookselling has yet to be written. Therefore, I will present scraps from the history of nineteenth-century book trade as recorded by the Haarlem publisher A.C. Kruseman in his two-volume Bouwstoffen voor een geschiedenis van den Nederlandschen boekhandel, gedurende de halve eeuw 1830-1880 (Amsterdam 1886-1887), together with some observations of my own, especially concerning the last two decades of the nineteenth century. Recent research into nineteenth-century Dutch literature and the conditions under which it flourished will also be part of my investigation. I wonder whether these studies could simply be relabelled as 'branding research' - which would mean we are celebrating old ideas presented as new ones. Or will recent investigations into the nature of different aspects of branding, as pointed out in the Introduction to this volume, reveal new research perspectives that were overlooked in the past?

I will adopt the three points of view that are mentioned in the volume's Introduction: the publisher (1), with his economical and symbolical (ideological) interests, whose reputation is defined by regimented - i.e. ideological - associations; the author's brand (2), constructed on identity myths; and authorial anxiety (3), where the author's self-image conflicts with the images the publisher wants him to have and the reader/critic attributes to him. The section on the publisher's brand is subdivided in three parts. I will discuss a letter from a poet to a friend who is looking for a publisher (Advising a Friend), take a closer look at The Publisher's Showcase, which might reveal the importance of titles and bindings, and by the examination of some Uncommercial Travellers in the Republic of Letters we will become acquainted with writers who tried to avoid the buzz of literary commerce. 


\section{The Publisher's Brand}

As the nineteenth century progressed, publishing, printing, distributing, and selling - activities that had always been executed by one, maybe two actors - gradually became separate trades, although printers and even booksellers sometimes acted as publishers. A remarkable change in the book trade came about when 'second-hand' bookselling was introduced (Kuitert 1991). At first, it was heavily disputed because it would have devastating effects on the publication of books of high quality and the profits of booksellers (Lisa Kuitert (1991: 199) writes: 'It seems as if to some cheap literature was a contradictio in terminis'). The introduction of this new way of selling books opened up opportunities for modern, somewhat cheeky marketing strategies, that until then had been barred from the civilized society of learning, printing, and reading.

One of the first of these shameless literary entrepreneurs was J.L. van der Vliet (1814-1851), also known as Boudewijn (Kruseman 1866-1867: I, 370-382). Van der Vliet set up a magazine, De Tijd. Merkwaardigheden der letterkunde en geschiedenis van den dag voor de beschaafde wereld, which he edited and published. Subscribers participated in a lottery that knew no losers. Everyone could win a prize, varying from 'a work of art' to a set of novels that were picked from booksellers' fixtures - worthless, unsaleable books (Van de Schoor 2007; Lion 1849). Boudewijn boasted no less than 50,000 subscriptions to his periodical, which focused on sensational nonsense. His enterprise was generally disapproved of. Even Kruseman, who wrote about him a few decades later, qualified his talents as being partly humbug, deceit 'that to my relief in the long run doesn't take root in our country' (1866-1867: I, 370-371). ${ }^{2}$

A publisher who operated in a more civilized way but caused even more complaints about the decline of Dutch book trade was K. Fuhri (1814-1858; Kruseman 1866-1867: I, 783-803). He modernized Dutch book trade by publishing books and magazines that took advantage of what was new and caused a sensation. According to Kruseman, Fuhri's enviable publishing strategy was to take snatches from the events and needs of his time. By taking over the 'houtgraveerschool' (school for wood engraving) at The Hague, he did not only stimulate this craft, he also ensured himself of illustrations for the magazines he published, like the Kunstkronijk and Geilllustreerde Courant. He was the first Dutch publisher who acknowledged the importance

2 'onder al zijn talenten was ook dat van wat met het woord humbug betiteld wordt en dat hier te lande op den duur gelukkig niet veel opgeld doet.' 
of international exhibitions, like that in London in 1851. One could say that Fuhri's versatility and wish for modernization 'branded' his publications.

Other publishers were less innovative, but certainly created their own brand by adhering to an outspoken religion or world view. Roman Catholic authors like J.A. Alberdingk Thijm preferred their books to be published by Roman Catholic publishers. Since he had become director and owner of the Amsterdam publishing house of C.L. van Langenhuysen in 1863 (established in 1826), Thijm published his writings with Van Langenhuysen. Before that date, he had been looking for a decent Roman Catholic publisher and had tried several others, like Kemink \& Zoon (Utrecht). ${ }^{3}$ D'Ablaing van Giessenburg sympathized with Enlightenment writers and modern freethinkers: it is no wonder that Multatuli found his way to his publishing house. Others were orthodox Calvinists and preferably published religious literature. The history of Dutch nineteenth-century publishing resembles the reverse side of the embroidery that represents literary history as we know it: it shows all the choices that have been made by writers, publishers, printers, book cover designers, bookbinders, and printers. All these choices have yet to be systematically examined. It seems a trifle premature, therefore, to go looking for branding strategies in the largely unwritten history of nineteenth-century printing.

\section{Advising a Friend}

Jozef Alberdingk Thijm (1820-1889) was the foremost promotor of Roman Catholic cultural emancipation in the nineteenth century (Van der Plas 1995; Geurts 1992; Alberdingk Thijm 1972). Before he had taken over the printing house of C.L. van Langenhuysen, Thijm had been drifting from one publisher to another. In a letter to the Hague poet W.J. van Zeggelen, written in the summer of 1843 , Thijm asked his friend if he knew a (Roman Catholic) publisher in The Hague that would be willing to print a volume of his poems. Van Zeggelen's answer, an unpublished letter that will be partly reproduced here, is especially noteworthy because Van Zeggelen worked in the printing shop of Giunta d'Albani in The Hague. As a printer and as a poet, he knew his way around booksellers, printers, and publishers in The Hague and elsewhere.

This letter is presented here, together with some annotations, to show how publishers' reputations were established. Archives, like that of the

3 De Nederduitsche spelling, in haar beginsel, haar wezen, en eischen beschouwd. Kemink \& Zoon published Algemeen Letterlievend Maandschrift, in which a prior version of his treatise had appeared. 
Vereeniging ter Bevordering der Belangen des Boekhandels, as well as (unpublished) correspondence between authors and publishers, are still to be explored in the quest to gain a proper understanding of the many ways branding operated. Van Zeggelen's letter provides us with a fair impression of how publishers' reputations were perceived by authors and how these reputations were passed on. One might consider these transactions to be branding strategies.

W.J. van Zeggelen to J.A. Alberdingk Thijm, 15 July $1843:^{4}$

You ask my advice on a publisher at The Hague? My dear friend, I don't know what to answer, because I really can't name one who unites in himself the qualities that you would like to find in him. Roman Catholic booksellers! Well, that is the problem. In our city we have three of those, but if only one of them was useful to distribute works of taste, belief me, our friend Leesberg wouldn't have fled to Fuhri with his volume of pastoral poetry. ${ }^{5}$ These three are de Groot, Langenhuizen and Ten Hagen. The first one never publishes anything but comedies that he prints in his own printing shop. This man is a cashier at the theatre, hence his love for comedies. ${ }^{6}$ With him you will not agree, as you will not with Langenhuizen, who as a printer takes more commissions from others than he will work for himself. Occasionally, he publishes books, but never a volume of poetry and he doesn't have connections with our booksellers in general. ${ }^{7}$ Ten Hagen confines himself to religious books; moreover, he publishes very little, especially since the unfortunate end of the Maatschappij van schoone kunsten. ${ }^{8}$ That affair seems to have done him considerable harm.

4 KDC, Archief Thijm, nr. 1214, letter 3.

5 Leesberg 1843. A new (enlarged, improved) edition of these poems was published in 1867 with (Roman Catholic) Henri Bogaerts in 's-Hertogenbosch. Bogaerts was 'printer and bookseller of Pope Pius IX', a title which he had taken over from his predecessor, P.N. Verhoeven. He published the periodicals De Katholiek (since 1866), Het Dompertje van den Ouden Valentijn (together with H.A. Banning) and Katholieke Illustratie.

6 H.S.J. de Groot (1783-186o), bookseller and printer at the Groenmarkt; cf. Nieuwsblad voor den Boekhandel, 20 September 1860.

7 A.P. van Langenhuysen, publisher and lithographer.

8 J.W. ten Hagen (1804-1867), bookseller, printer, and publisher at The Hague; he was director of the Maatschappij van schoone kunsten. His son Th.C.B. ten Hagen took over the bookshop in 1852. The troubles that caused this Maatschappij are discussed in Kruseman (1886-1887: I, 229-241). A violent attack on the Maatschappij (before Ten Hage took over the function of director) was made by Eenige woorden in 1840. The most important grievance of booksellers and publishers was that the Maatschappij hurt their privileges: they were called interlopers. See Van Giersbergen (1999). 
Amongst the protestant booksellers, I could only name a few that publish works of taste, viz. Fuhri and Van Stockum. ${ }^{9}$ Nevertheless I know that these gentlemen can't be moved to publish poetry. They have tried to do so several times, by publishing poems by Calisch, Ten Kate, Greb, and others, ${ }^{10}$ but they are fed up with poetry, as they say. So, they're not fit to feed the vanity of poets - unless they want to pay for it.

Van Zeggelen proceeds to discuss other Hague publishers who prove to be even less fit for the job than the Roman Catholic ones. He presents a random variety of printers and booksellers: Van 't Haaft, ${ }^{11}$ Van Cleef, ${ }^{12}$ Thierry and Mensing, ${ }_{13}^{13}$ Belinfante (a Jewish publisher!), ${ }^{14}$ and Schinkel. ${ }^{15}$ Other booksellers do not publish themselves and live entirely by commission business. ${ }^{16}$

Once he has completed his survey of Hague printers, publishers, and booksellers, he turns to other cities and provinces:

But, my friend, why overlook Amsterdam, the city where the best and finest publishers reside? Have you thought about Laarman and Schoonekat? ${ }^{17}$ Both Roman Catholic, both, to my knowledge, respectable men? Although Catholic, they will not confine themselves to ecclesiastical stuff, and that is, I think, what you are looking for. Wherever you live, I would recommend

9 K. Fuhri has already been introduced; W.P. van Stockum (1810-1898) owned a bookstore at the Buitenhof. He actively took part in The Hague's literary life: together with S.J. van den Bergh, W.J. van Zeggelen, A. van Heel, and N. Bosboom he founded the literary society Oefening Kweekt Kennis in 1834, whose works he published in 24 volumes.

10 Calisch 1839; Ten Kate 1838; Ten Kate 1839a; Ten Kate 1839b; Greb 1838.

11 J.M. van 't Haaff's main literary achievement was the publication of Een achttiende hoofdstuk voor de 'Physiologie van Den Haag'. Door een' Hagenaar, 1843. Physiologie van den Haag, door een' Hagenaar was published by Fuhri in the same year. Fuhri's publication was a huge commercial success; a sequel to this booklet (Physiologie van den Haag contained seventeen chapters) was no hazardous enterprise.

12 Pieter van Cleef (1781-1851), in Bijdragen tot de geschiedenis van den Nederlandschen boekhandel 1884: 51-54.

$13 \mathrm{~J}$. Thierry \& C. Mensing (heirs) published mainly theological treatises but also B. ter Haar (1844-1845).

14 Jacob Belinfante; see Kruseman 1886-1887: II, 616-619.

15 A.D. Schinkel (1784-1864), printer, antiquarian and collector of historical items. See Noordziek 1865 .

16 A bookseller who lived by commission business (commissiehandel) only sold books that were sent to him by a publisher and did not print or publish himself. He could return unsold copies to the publisher.

17 J.H. Laarman published Nederlanders door Nederlanders geschetst, 1842; M.H. Schonekat, publisher in Amsterdam, contributed to the debate on the decline of Dutch book trade (Nieuwsblad voor den boekhandel, 19 October 1843, bijlage). 
first for all Laarman. Besides him, there is Romond in Utrecht, who has published Moore's Songs, translated by Ten Kate and v.d. Bergh, who hid behind the initials 'A. en Z. ${ }^{18}$ From what I have heard, he is an intelligent young man, not void of ambition, who may be willing to accept some of your writings by an appropriate preference for his co-religionists. [...] He is said to be friends with a liberal Roman Catholic priest to whom he submits the manuscripts he has received; surely you wouldn't object to this procedure, would you? I can't recommend Palier in Den Bosch or another Brabant bookseller; ${ }^{19}$ I could if you had written a religious work, but I suppose your poems deal with more worldly subjects, with a thin layer of Roman Catholic veneer, am I not right?

This last remark was definitely not very sensitive and must surely have irritated Thijm. Evidently, from a Protestant point of view, there were easy-going, liberal Roman Catholics (publishers included) with a rather superficial adherence to their faith, amongst whom he counted Thijm - he was very wrong to do so, as the continuation of their correspondence was to show - and strict, orthodox ones, who were better avoided.

After he has evaluated Roman Catholic publishers outside of The Hague, he turns to Protestant ones. It turns out that an orthodox Protestant for Van Zeggelen is less of a problem than a strict Roman Catholic - once again a (implicit) statement that must have embarrassed Thijm:

The publisher of my poems (Lagerwey in Dordrecht) certainly won't be the man you are looking for: he is a straightforward orthodox Calvinist. ${ }^{20}$ In our business we have few or no intimate relations with booksellers. For the most part, we print administrative, military, municipal, and governmental papers, and although we work for some booksellers, it is not our core business. I am a close friend of Van Stockum's, but that is why I am familiar with his way of thinking and his dislike of poems. Should

18 H.H. van Romondt (1809-1881) had a bookstore in Utrecht, at first in the Choorstraat, and after 1838 at the Drift. Thomas Moore 1841 . The translators' introduction is signed 'A. en Z.' Thijm would publish Drie gedichten (1844) and De klokvan Delft. Een romantiesch verhaal (1846) with H.H. van Romondt.

19 Hendrik Palier (1785-1853); printer, publisher, and bookseller. Collector of books printed in Brabant, numismatic and antiquarian. The Paliers were protestants. Bijdragen tot de geschiedenis van den Nederlandschen boekhandel 1884: 44-48.

20 Hendrik Lagerwey (1808-1859); Dordrecht publisher and bookseller. He published schoolbooks and literary and scientific works. He founded the literary periodical Europa in 1838 . 


\section{I be a publisher, my friend, and the head of our printing shop, I wouldn't hesitate to ask you for your manuscript. ${ }^{21}$}

21 'Ge vraagt mijn advies omtrent een Haagschen Uitgever? Beste vriend! ik sta verlegen wat U te antwoorden; want ik weet er waarlijk niet één te noemen, die de hoedanigheden en eigenschappen in zich vereenigt, welke ge gaarne in hem zien zoudt. - Roomsche boekhandelaars! ja, daar zit de knoop. We hebben daarvan in onze stad drie exemplaren; doch wanneer er een van te gebruiken was om werken van smaak te verspreiden, geloof mij, dan had onze vriend Leesberg met zijn bundel herderszangen niet naar Fuhri gegaan. Die drie zijn de Braat, Langenhuizen en Ten Hagen. De eerste geeft nooit iets anders uit dan commedies, die hij zelf op zijn drukkerijtje bewerkt. Deze man staat als kassier in betrekking tot den Schouwburg, vandaar zijne commedie-liefde. Bij hem zijt ge dus niet t'huis, evenmin bij Langenhuizen, die als drukker meer voor anderen dan voor zich zelven werkt. Hij geeft wel eens wat uit, doch nimmer verzen en hij staat ook niet in betrekking tot onzen boekhandel in het algemeen. Ten Hage bepaalt zich uitsluitend tot godsdienstige boeken, bovendien doet hij zeer weinig, vooral in den laatsten tijd sedert den ongelukkigen afloop der Maatschappij van schoone kunsten. Die zaak schijnt hem een geduchte knaauw te hebben gegeven.

Onder de protestantsche Boekverkoopers zou ik U slechts een paar kunnen opnoemen, die werken van smaak uitgeven, namelijk Fuhri en van Stockum; en toch, weet ik, dat deze beide Heeren er niet toe te bewegen zijn om verzen uittegeven. Ze hebben het beide herhaaldelijk beproefd met verzen van Calisch, ten Kate, Greb en anderen; doch hebben van de poezij hun buik vol, zoo als ze zeggen. Zij zijn dus de mannen niet om de ijdelheid der dichters in de hand te werken, ten zij voor hunne rekening.

Bij de overige uitgevers moet men nog veel minder wezen: van 't Haaft geeft zeer weinig uit, soms een enkele roman, of iets anders, maar deze zorgt altoos eerst, het zij door den schrijver of door voorafgaande bestelling gedekt te zijn; Van Cleeff bepaalt zich uitsluitend tot wetenschappelijk en militair werk; Thierrij en Mensing tot schoolgoed en gereformeerde leerboeken; Belinfante (een jood) tot regtszaken. Et voilà tout. Al de overige boekverkoopers leven slechts van commissie handel. Neen, in den Haag moet men niet wezen om een uitgever te zoeken, die voor de kunst iets wil wagen. Schinkel zoudt ge misschien zeggen; ja, maar deze moet het weêr door anderen doen distribueren, en dit weet ge wel, hoe het gaat. S. heeft meer dan eens iets belangloos en louter uit ambitie uitgegeven doch dit zijn meerendeels stukken die tot de wetenschap en onze oude schrijvers en dichters betrekking hebben; nimmer zoo ver ik weet, een dichtstuk uit onzen tijd; en dan geschiedde dit ook veelal uit vriendschapsbetrekking tot den schrijver of compilateur. - Maar vriend, waarom Amsterdam, de plaats waar de eerste en knapste uitgevers wonen, voorbijgezien? Denkt ge wel aan Laarman en Schoonekat? Beide roomsche Boekverkoopers, beide, zoo ver ik weet, solide menschen? en die, ofschoon katholijk, zich niet bij het roomsche kerkgoed bepalen; en zulk een, moet ge, mijns inziens juist hebben. - Waar gij ook woondet, ik zou U Laarmans altoos het eerste aanbevelen. Behalve deze hebt ge nog van Romond te Utrecht, degeen, welke de Zangen van Moore door ten Kate en v.d. Bergh, onder de initialen A. en Z. vertaald, heeft uitgegeven. Dit is, zoo als ik hoor een knap jong mensch, die nog al ambitie heeft, en welligt uit een gepaste voorliefde voor zijn geloofsgenooten, te gereeder iets van UEd. zou willen hebben. [...] Zoo als ik hoor, heeft hij een verlicht Roomsch geestelijke tot vriend, die hij eerst de handschriften ter lezing geeft; nu hieraan zoudt ge u zeker wel willen onderwerpen, niet waar? [...] Palier uit den Bosch of een ander Noordbrabantsch Boekh ${ }^{\mathrm{r}}$. kan ik U niet aanraden; wél indien ge een religieus werkje geschreven hebt; doch ik veronderstel dat Uwe verzen iets wereldsch ten onderwerp hebben, met een katholijk vernis er over; is 't zoo niet? 
Van Zeggelen's letter is teeming with regimented associations, reducing publishers to adherents of a particular confession. It makes quite clear that the confessional brand of a publisher was expected to be transferred to his books. Thijm's concerns were to find a publisher whose confessional profile did not conflict with the religious drift of his poems. These concerns were not restricted to the willingness of the publisher to take care of Thijm's poems, but they may also have had to do with the expectation that his book could be contaminated by the publisher's confessional profile. If his volume of poetry had borne the name of a protestant publisher on its title page, it would have been noticed foremost by protestant critics in protestant (or liberal) magazines and newspapers. The intended Roman Catholic readership would remain unaware of the existence of Thijm's new poetry.

This letter demonstrates that the analysis of literary networks by studying the digitized edition of literary correspondences may bring to light interactions that can be qualified as branding strategies. However, this case also draws our attention to a fundamental problem: does a sociological approach to literature that entails the study of branding have its own heuristic methods? Instead of cherry picking, there is a lot of factual research to be done to fully understand these letters, as the annotations show.

\section{The Publisher's Showcase: Titles and Bindings}

It is remarkable that most Dutch poetry before 1885 was published with very unpretentious titles: there were Versjes en rijmpjes, poems were written in Snipperuren ('Idle hours') as a result of Mijne uitspanning in ledige uren ('My relaxation during spare hours'), or qualified as Beuzelarijen ('Twaddles'), Praatjes ('Small talk'), or Schetsjes ('Tiny sketches'). The collector of nineteenth-century Dutch poetry establishes a library where the scents of

De uitgever van mijne stukjes (Lagerweij uit Dordt) zou zeker Uw man niet zijn; 't is een echte Dortenaar (alias orthodox gereformeerd). Intieme connecties hebben wij in onze zaak met de HH Boekhandelaars weinig of niet. Ons werk is voor't grootste gedeelte, administratief, militair gemeentelijk en Gouvernementaal, en, hoewel wij voor eenige boekhandelaars drukken, is dit toch ons fort niet. Met van Stockum ben ik eigenlijk het meest bevriend; doch ik ben daardoor juist zoo goed met zijne denkwijze en zijn uitgeversafkeer van verzen bekend. Was ik uitgever, vriend! en te gelijk meester van onze zaak, ik bedacht mij geen oogenblik om U te verzoeken mij de kopij aftestaan.

Wat ik U aanraad, begin den boekverkooper niet zoo dadelijk van een plaat of vignet te spreken; dit weten zij, is nog al kostbaar, en kon dus wel aanleiding geven, dat men het uit vrees voor de kosten weigerde. Zijt ge zoo eenmaal het met elkaâr eens, dan kan dit een punt van nadere overweging worden; ten zij ge het volstrekt niet anders, dan met een plaat wildet uitgegeven hebben.' 
hundreds of flowers intermingle: flowers of every season (Lente-, Zomer-, Herfst-, even Winterbloemen, such as Sneeuwklokjes), flowers that grow in the dunes (Duinbloemen), in the woods (Bosch-viooltjes), on the heath (Heide-bloemen), on the field (Bloemen in 't koren), or all by themselves (Eenzame bloemen). All these flowers, with their promise to wither soon, are wonderful metaphors for the wilted beauty of nineteenth-century poetry.

These flowery titles branded the reading of poetry as an almost exclusively female occupation. Evidently, publishers aimed at a female readership, to whose taste volumes of poetry were shaped: the booklets were gilt-edged and had wonderful decorative bindings and illustrations. Even the format was adapted to women's needs: they should fit in a lady's purse or in the pocket of a dress. Research into handwritten dedications or signatures of book owners in nineteenth-century volumes of poems might reveal the success of this gender-based branding of poetry. The Tachtigers tried hard to free poetry from its female outlook, redefining it as the result of a huge, masculine effort (Kloos 1882: 59). ${ }^{22}$

Sometimes the titles of new publications referred to older books. This may indicate some kind of intertextual relation, if the newer book wishes to enter into a discussion with the earlier one, but a wish to participate in the success of the predecessor is another explanation for similar titles. C.E. van Koetsveld's Schetsen uit de pastorij te Mastland. Ernst en luim uit het leven van den Nederlandschen dorpsleeraar (Schoonhoven: Van Nooten, 1843) provoked a novel entitled Schetsen uit de kosterie te Kleihuizen. Ernst en luim uit het leven van den Nederlandschen Dorpsonderwijzer (Amersfoort: W.J. van Bommel van Vloten, 1846); Cosinus' Kippeveer, of het geschaakte meisje (Amsterdam: Elsevier, 1888) inspired an author calling himself Sinus to publish Hanepen (Amsterdam: E.L.E. van Dantzig, [1897]). The partners in both duets have nothing in common except their titles. Books that want to comment on preceding novels are Chonia's Wat ervan Diepenbeek werd (Utrecht/Meppel: Van Heijningen, 1849) and Veritas's De Waarheidsvrienden te Hoogenbeek (Utrecht: J.H. Siddré, 1851), both answers to P. van Limburg Brouwer's Het leesgezelschap van Diepenbeek (Groningen: Van Boekeren, 1847); and a multitude of books and pamphlets that tried to complete or alter the (evidently disappointing) end of Jacob van Lennep's famous novel

22 Kloos 1882: 59: 'De poëzie is geen zachtoogige maagd, die, ons de hand reikend op de levensbaan, met een glimlach leert bloemen tot een tuiltje te binden, [...] doch eene vrouw, fier en geweldig, wier zengende adem niet van ons laat'. Translation: 'Poetry is no soft-eyed damsel who holds our hand on life's journey and who with a smile teaches us how to arrange flowers into a bouquet [...], but a woman, fierce and proud, whose scorching breath holds us captive'. 
De lotgevallen van Klaasje Zevenster, such as Klaasje Zevenster is dood and Klaasje Zevenster is niet dood! Lastly, Egberta van der Mandele's Zusterzielen (Utrecht: Becht, 1895) is a wonderful comment - a moral rejection - on Louis Couperus's Extaze (Amsterdam: Veen, 1892). All these novels profit from regimented associations with successful predecessors and engage in the ongoing debate about the books their titles (often, not always) refer to.

Publishers' bindings, some of which were produced in various editions of the same book or almanac, were a fine expression of the way the publication was branded. During the first decades of the nineteenth century, publishers gradually replaced paper and cardboard bindings, which only served as provisory covers for books to be replaced by private bindings, by covers that were to last longer (Van der Linden and Struik 1989). Cloth (or leather) bindings could be coloured and decorated by blind or gold stampings and ornaments. Books were to reflect the good life, the sublime, and exalted (that literature reached for) one could taste in spare time. Nowadays these bindings are condescendingly characterized as middle-class exuberance: 'the taste of the rich, the means of the poor' (Van der Linden and Struik 1989: 8). The literary almanac Aurora (1840-1878), published by K. Fuhri, appeared in a new (leather) luxury binding and was illustrated with steel engravings every year (Eijssens 2017:204-205). Almanacs pretended to present the finest poetry of the best poets and prose writers; their appearance emphasized this pretension.

Later on, uniform bindings enabled publishers to present series of books, like Warendorf's Novellen-Bibliotheek, that served as an identifying mark for their trade (Kuitert 1993; Dijkhuis 2018: 54-59), much like the small, red-clothed travel guides that were recognized throughout the world as Baedekers. Bindings served branding, either by being exceptional or, on the opposite, by being recognizable. The name Baedeker had become a brand and the various novel series tried to become one: the uniform bindings served a signal of the brand.

\section{Uncommercial Travellers in the Commonwealth of Letters}

Sometimes writers of literary prose and poetry preferred to keep the wonders they had wrought in solitary hours out of the vile hands of mean critics. They chose to keep their books and booklets 'buiten den handel'; their publications were branded for private use by title page notices like 'Niet in den handel', or 'Voor rekening van den schrijver'. ${ }^{23}$ They were often destined for the family

23 A wonderful description of a collection of these publications in England can be found in: Catalogue of books printed for private circulation 1906. 'A small list of books privately printed 
circle or a select company, written for a special occasion. Other books that were not for sale in a regular bookstore are of a private, intimate nature. In Museum Catsianum (1870), Jhr. mr. W.C.M. de Jonge van Ellemeet provided a bibliography of all Cats imprints he had collected (he was to bestow his collection to the Maatschappij der Nederlandsche Letterkunde in 1887). J.P. Heije published delicate, intimate poems in two wonderfully bound volumes entitled Innigst levens eens dichters (Amsterdam 1873-1875), of which only 50 copies were printed. The poems were so dear to him that he forbade the reproduction of any of them before the date of 1 March 1909 (Van de Schoor 1992-1993). These publications kept away from book trade were nevertheless noticed by literary journals; there were even readers interested in purchasing the forbidden goods. In Nieuwsblad voor den Boekhandel of 27 January 1880, bookseller W.P. van Stockum (in The Hague) published a request for a copy of J.C. Hacke van Mijnden's Dante translation. Hacke had distributed a good many copies of his three volume De Komedie van Dante Alighieri. In dichtmaat overgebracht (Haarlem 1867-1873, 'niet in den handel') amongst his friends but had definitely shunned the bookstore.

It is as if the writers of these publications were afraid to step into the harsh light of day and preferred a shadowy existence for their literary achievements. This remarkable phenomenon can hardly be adequately described by some kind of branding. One can only say that these writers did not want to be branded at all - and by avoiding a public brand, they branded themselves as outsiders, or 'mavericks'. The adage that you cannot choose not to act, which might be quoted to justify this reasoning, is nevertheless somewhat unsatisfying: thus, there can be no escape from being labelled.

\section{The Author's Brand}

Nowadays, as in the past, authors are branded by media (in the nineteenth century that was done by magazines, newspapers, and their critics), by readers, and by fellow authors (for this period the obituaries (levensberichten) written for the Maatschappij der Nederlandsche Letterkunde are noteworthy). The way a writer was perceived by contemporaries and later generations

in France, compiled by the eminent bibliographer Pierre-Gustave Brunet (1807-1896)' - this description is taken from Catalogue 184. From Trithemius to Proctor. Bibliography and Reference Books Before 19oo. Part I of the Private Library of Hans P. Kraus (New York 1991) - can be found in the Bulletin du Bibliophile Belge, Vol. 8 (1853): Gustave Brunet, 'Livres imprimés à petit nombre et non destinés au commerce'. 
becomes interesting as it differs from his self-image. I will illustrate a few of such mishaps in what follows.

An awkward incident at a literary event in Voorburg is reported in the annals of Oefening Kweekt Kennis, a literary society that gathered in The Hague. A recital by humourist poet W.J. van Zeggelen of his poem 'Hansje van Keulen' was received by his cheerful audience with laughter and merriment - no one noticed the serious, dramatic content of the poem. As the hero died and was laid to rest alongside his dearest Hansje, Van Zeggelen's audience shed tears of laughter. ${ }^{24}$ The poet shook his head, stepped down from the pulpit and decided never again to write a single line that failed to match the expectations of his readers. ${ }^{25}$ Busken Huet blamed the poet for this concession to the mediocre taste of a backward audience and ridiculed Van Zeggelen's 'fatal talent for whistling popular tunes' ('noodlottig vedelaarstalent'; Busken Huet 1884': VII, 59). He neglected the practice of more serious poetical genres to please his audience.

Marcellus Emants was branded throughout his life as a pessimist. He accepted this qualification ('You call me a pessimist and I accept that name'), ${ }^{26}$ but only if understood as the outcome of a process of rational consideration, not as a lingering nasty sentiment (like suffering from cold feet). In his review of Emants' novel Op zee (1899), critic J. van den Oude (Carel van Nievelt) refused to acknowledge a serious, philosophical meaning of pessimism. For him, pessimism was produced by either a sentiment, or a biased and therefore inadequate observation of reality. Perhaps, he considered, optimism could just as well be described in this way, but its advantage over pessimism is obvious: it provokes energy and happiness, perhaps even the belief in a benevolent Supreme Being (Van den Oude 1901: II, 79). ${ }^{27}$

This trivial interpretation of pessimism bothered Emants throughout his life, especially since he thought pessimism did not cover the deepest meaning of his novels and poems, that was to be found in the conviction that everyone

24 'En vraagt ge, wat lot aan den lijder verbleef?... / Dra vond hij een graf bij zijn Hansje van Kleef.'

25 Smit Kleine 1877: 156-158; Margadant 1934: 12, n. 1; Conviva 1878: 3-4.

26 'U noemt mij pessimist en ik aanvaard die naam.' Marcellus Emants in a letter to Carel Scharten, 4 June 1917, in Emants 1995: 184.

27 'Pessimisme is een product, ò van eene stemming, een temperament, òf van eene eenzijdige en dus gebrekkige waarneming der verschijnselen en der feiten. Het optimisme is misschien niets anders; maar het heeft tenminste dit vóór, dat het de levens-energie opwekt, het levensbehagen aanmoedigt, de waarschijnlijkheid van eene redelijke Oppermacht laat gelden'. This review had previously been published in Nieuws van den Dag, 11 November 1899. See Dubois 1980: 225. 
constantly misled himself and was forced to do so. ${ }^{28}$ The characters in his books that were appointed to prove this thesis had been denounced by critics as unrealistic, as pathologies. Once again, Emants protested against this interpretation in an essay entitled 'Pathologie in de litteratuur' in De Gids (1916). Surely, he would not have agreed either with the opinion of Willem van den Berg in Alles is taal geworden, who explained the renewed interest in Emants's novels, especially Een nagelaten bekentenis (with Willem Termeer as a protagonist), after World War II as a result of post-war deception in human nature. According to Van den Berg (2009: 568), modern readers might have recognized the dark sides of their own personalities, knowing that the boundaries between normal and abnormal were fluid. By thus actualizing the meaning of the novel, Emants becomes a writer far ahead of his time: probably the most depressing of posthumous brandings an author can get.

Caricatures provide us with wonderful information about the gap between an author's self-image and his perception by readers. Frederik van Eeden, who thought of himself as a guide to the moral improvement of humanity, is depicted as a naïve farmer on wooden shoes, whose agricultural experiment Walden is ridiculed, or a 'Dutch Tolstoi' (Maas 1991). A well-known photograph of gloomy poet Willem Kloos, taken by Willem Witsen, was developed into further stages of future decay - a prophecy inspired by the poet's alcoholism and growing misanthropy (Maas 2003) ${ }^{29}$ Couperus was portrayed as an elegant woman (Maas 1990, Van Vliet 2019), notwithstanding his self-ridicule and gender-crossing playfulness that denied any possibility of discovering the author's true face behind the mask (although playing with masks may be considered a genuine homosexual theme)..$^{30}$

Couperus's brand as a homosexual writer is debated by some even today. In his article 'Diversités du passé', Nop Maas (1990:1) states: 'Nowadays, to almost everybody it is obvious that Louis Couperus was a homosexual. Disagreement may only exist about the question whether he practiced his sexual inclination. ${ }^{31}$ There was (is) however more disagreement about

28 'Inderdaad is 't mijn overtuiging dat van elk leven de rekening koerant - mits eerlik en met kennis van zaken opgemaakt - een nadelig saldo oplevert aan geluk. Toch meen ik, dat niet dit de hoofd-idee van mijn werk is. Die zoek ik veeleer in mijn andere overtuiging, dat ieder mens zich zelf misleidt en misleiden moet.' Emants in a letter to Carel Scharten, 4 June 1917, in Emants 1995: 184-185.

29 Drawing (by Ton van Tast) in De Ware Jacob (1907-1908), 384.

30 De Roskam, 12 November 1915. See Maas 1990.

31 'Dat Louis Couperus homoseksueel was, staat tegenwoordig voor bijna iedereen vast. Eventuele onenigheid heerst er slechts over de vraag of hij ook praktische consequenties aan deze geaardheid verbond.' 
Couperus's inclination (and hence about the interpretation of his novels and poems) than Maas suggests: he takes his opponents for granted by using the phrase 'to almost everbody'. In 2000, Maarten Klein published Noodlot en wederkeer. De betekenis van de filosofie in het werk van Louis Couperus, in which he writes that the author's favourite theme of androgyny was often autobiographically misinterpreted and understood as an indication of Couperus's homosexuality. Klein (2000: 9) vehemently disagrees: 'Of course, this possibility can't be precluded, but it can't be proved either, for the sole reason that there is no convincing evidence for Couperus's putative homosexuality. ${ }^{32}$

In his recent biography of Couperus, Rémon van Gemeren (2016) had to deal with this sensitive problem. Though Van Gemeren (2016: 20) initially avoids choosing sides in this debate and even appears reluctant to admit that homosexuality was an issue in Couperus's life ${ }^{33}$; he eventually, in his account on Couperus's friendship with lieutenant Jhr. Johan Ram, reaches a somewhat unsatisfying compromise (after a blurry and lengthy exposé on the history of homosexuality within its social and cultural conditions) as he wonders if Couperus's impotence (for which a former biographer, F.L. Bastet, had chosen) was a cruel fate for a homosexual, or rather a blessing in disguise? ${ }^{34}$ (Van Gemeren 2016: 170-183)

Van Zeggelen branded as a humourist poet, Emants as a pessimist, and Couperus as a (crypto)homosexual - or absolutely not a homosexual at all: the stories that were told about them, as well as the caricatures of other writers, contributed to identity myths - most of them conflicting with the posture of the authors. The branding of Couperus offers a unique connection between a sociological approach of literature and text interpretation. Novels like Noodlot (Footsteps of Fate) or De Berg van Licht (The Mountain of Light)

32 'Uit te sluiten is dat natuurlijk niet, maar te bewijzen is het ook niet, en wel om de eenvoudige reden dat er voor Couperus' vermeende homoseksualiteit geen enkele doorslaggevende evidentie is.'

33 'De biograaf moet de ontstane [biografische] portretten bestuderen en tevens een nieuw portret schilderen van Couperus, gedetailleerd en genuanceerd, en immuun voor het aantal clichés dat de pan uit rijst en hem even overvloedig tekortdoet. De Tachtiger, de naturalist, de fatalist, de narcist, de dandy, de seksueel gefrustreerde dégénéré, de actieve homoseksueel, de onvermurwbare pessimist, de onveranderlijke optimist, de zorgeloze levensgenieter, de sociale lastige - zo niet antisociale - einzelgänger, de nichterige homoseksueel, de aanstellerige aristocraat, de nukkige zakenman, de miskende schrijver, de geëxalteerde schrijver, de geïsoleerde schrijver, de op geld beluste schrijver - het is allemaal, meer dan eens, over hem gezegd, en het meeste ervan doet hem geen recht, sterker, het meeste is niet eens waar.'

34 'Zal, indien Couperus impotent was, de combinatie met zijn seksuele geaardheid hem als een wreed lot zijn voorgekomen of eerder als een zegen?' 
are open for different interpretations, including queer reading, depending on assumptions about the author's sexual preferences.

All these examples are wonderful demonstrations of the branding of an author, but the problem is that they were all taken from 'old school' literary studies: biographical research, analysis of reviews, or hermeneutical textual interpretation. There are plenty of anecdotes that fit into the concept of branding, but it remains unclear how to search for branding strategies without pillaging the stores of conventional literary research. So far, it looks as if branding research boils down to relabelling well-known findings.

By once more presenting the poet Van Zeggelen in this section, I have tried to make clear that the use of the branding concept neglects an obvious problem concerning the reputation of this poet: how did a humorous poet like him fit in with the publisher's list of an orthodox Calvinist publisher like Lagerwey?

\section{Authorial Anxiety}

'Authorial anxiety' would have been an appropriate title for the edition of the correspondence between Louis Couperus and his publisher, L.J. Veen (Couperus 2013; Couperus and Veen 1987). Time and again, Couperus anxiously awaits Veen's decisions concerning drafts for bindings and his choice for a particular typeface - decisions that the author often disagrees with. Uncalled-for corrections made him furious, such as an editor who had changed 'het salon' into 'de salon'. An author who, less than half ironically, claimed that the beauty of a text consists of the commas that are dispersed in it, is evidently not apt to tolerate others' interventions in what he has written.

'The taste of the audience remains an amiable secret to me', Couperus wrote to his publisher, shortly after he had decided to stop writing in Dutch, since - according to Veen - his books were hard to sell..$^{35} \mathrm{~A}$ few years before, Veen had encouraged Couperus to come up with another title for Sproken van Leven en Dood (Tales of Life and Death), because that would be a commercial fault. Couperus's reaction illustrates his desperation to find out how to entice buyers: 'I rack my brains over a title! Why won't Sproken van Leven en Dood do? What about: Over Lichtende Drempels? ${ }^{\prime 36}$ Wonderful book titles were Couperus's carefully constructed trademark. In 1911, he published a 
serial in Het Vaderland ${ }^{37}$ in which he pondered about the beauty of the title Midzomerloomtes (Midsummer Languidnesses):

Midsummer Languidnesses... If you read that, you see your author before you, don't you... Then you'll say: that is Louis Couperus... Look, his vanity is not greater than it is, that author of yours, but still, I am convinced that, when you read Midsummer Languidnesses... then you'll see him and no other, then his melodious, affected title conjures up images of him, especially that plural does, and you'll say to yourself: no other would have chosen exactly that title, no one but he, whom we now see before us... ${ }^{8}$

Considerations like these draw our attention to two issues concerning branding. First of all, it becomes apparent that Couperus was constantly searching for a way to approach the 'amiable mystery' he wrote about. Secondly, the letters writer and publisher exchanged make us realize that the brand we have in mind for Couperus nowadays is not the same as the contemporary reader's. Evidently, around 1902 a book title with medieval connotations such as Sproken was rejected, while for us it fits in with the variety of Couperus's literary achievements.

Couperus's preference for cover designs was not intended to entice buyers but was solely the result of strong feelings on how the book he had written had to be understood. In a letter to J. Toorop, he praised the binding the artist had designed for Metamorfoze (1897) because of its symbolic representation of the novel's content: 'I am very pleased with your interpretation: the figure that unwraps itself from her bandages represents for me in a very delicate way the idea of metamorphosis and development, while the harmonically winding lines that stretch wider are a poem of harmony' (Braches 2003: $178-179))^{39}$

Despite all deliberations with his publisher, it happened that Couperus was taken aback by the receipt (by post) of a copy of his latest novel, 'his umpteenth'. In a serial he published in the newspaper Het Vaderland of

37 Het Vaderland, 26 August 1911; republished in Couperus 1990: 233-238.

38 Couperus 1990: 233-234: 'Midzomerloomtes... Als ge dat leest, dan ziet ge uw auteur voor u, niet waar... Dan zegt ge: dat is Louis Couperus... Kijk, hij is niet ijdeler dan hij is, uw auteur, maar toch, ik ben overtuigd, dat, als ge leest: Midzomerloomtes... dan zièt ge hèm en geen ander, dan roept zijn muzikale, precieuze titel, en vooral dat meervoud, u hèm voor den geest, dan zegt ge tot uzelve: geen ander zoû juist dièn titel hebben gekozen, dan hij, die wij nu voor ons zien...'

39 'Ik ben bizonder ingenomen met Uwe opvatting; de uit haar windselen zich los wikkelende figuur geeft mij zeer fijn gevoeld de idee van metamorfoze en wording weêr, terwijl de zich verder zoo harmonisch kronkelende lijnen een poëem van harmonie zijn' (19 November 1897). 
4 October 1913 (entitled 'Mijn zooveelste', 'My umpteenth'), ${ }^{40}$ he complained about the binding and subtitle of his recently published novel Herakles (Couperus 1996: 146-152). His indignation with Veen was reshaped as a fictional conversation with the book he had just unwrapped. Couperus was shocked when he noticed that the binding of an older novel, Majesteit (1893), designed by R.N. Roland Holst (Van Vliet 2000: 143, 281-284), was reused for Herakles, an antique, mythological novel. The medieval symbols on the cover of Majesteit (crown, sceptre, sword, and orb) now served as ornaments for a Greek demigod. In utter despair Couperus cries to his book: 'Why do you look so silly?', whereupon the novel answers:

It's your fault! [...] Can I help it if Uncle Veen didn't find another costume for me than the uniform coat of Majesteit? You really don't care about your youngest book children and what they look like! Now you can see how Uncle Veen rigs us out, when you don't instruct him beforehand how to clothe us! (Couperus 1996: 147)

But that is not the only scar the book has to live with: it draws Couperus's attention to its subtitle 'Roman in Twee Deelen' (novel in two volumes). 'That is not how I subtitled you', Couperus angrily exclaims. 'But Uncle Veen did', the novel responds. Couperus then feels obliged to defend his publisher, against his better judgement: '[...] Uncle Veen is a publisher and he thinks you will be very well sold as a "Roman in Twee Deelen", and that no one will buy you as a thick, single volume that is called Herakles and tells the story of gods and demigods' (Couperus 1996: 147-148). Indignant as he was, Couperus even forgot to mention that the title of his novel was horribly misspelt as Herackles.

By publishing this serial, Couperus emphasized the great importance he attached to the exterior and presentation of his books. A book itself should be a work of art, a promise of its literary content. As mentioned earlier, Couperus' preference for bindings and typeface was not intended to entice buyers. Nevertheless, since then Couperus's imprints have become enviable collector's items. Veen was rather reluctant to spend money on bindings.

All of these findings were provided by book historians and the editors of Couperus's correspondence; once more, the branding concept profits from their research, adding little - if anything - to it.

40 Couperus wanted to republish 'Mijn zooveelste' in the second volume of Van en over mijzelf en anderen, but Veen prevented him from doing so. After Couperus' death, his widow included the serial in the third volume of Proza. 


\section{Conclusion}

It is doubtful whether the various, partly yet to be described mechanisms of nineteenth-century book trade can be elucidated by present-day sociological concepts such as branding. The fact that it can be applied to all kinds of transactions between the participants in literary commerce rather seems to blur our understanding of what was actually going on between publishers, booksellers, and readers (including critics) between 1800 and 1900. The scope of branding, as defined at the beginning, is simply too wide, the interactions between all participants too complex - and often of an implicit nature. Using concepts like branding might invite researchers to jump to conclusions.

During a considerable period of time, nineteenth-century Dutch publishers were reluctant to embrace marketing strategies for books that were intended to civilize society. Gradually however, economy took over when publishers decided to sell books at a reduced price and to advertise. Of course, branding is not always an intentional part of a marketing strategy, but one can expect to notice more examples of it as book industry adapted to the laws of modern trade. The problem is, as the annotations that accompany Van Zeggelen's letter demonstrate, that the history of book publishing, book printing, and bookselling - more specifically that of the literary book - still has to be written. The letter can hardly be understood without additional documentary information about publishers and their fund. Exhaustive studies of particular publishers do exist, but there are still many gaps to be filled.

The expertise of the researchers involved in writing the history of nineteenth-century publishing and bookselling is another concern: literary historians, book historians (who will play a major role), and those who study literature from a sociological point of view evidently will not always agree on what is to be understood as branding and on the value of such an interpretation. Some might argue that in branding studies there is no need for a focus on literature. What are the differences, if any, between research on branding of literature and any other commodity? Perhaps literary studies' interest in sociological aspects of the production of literature is due to a certain embarrassment about studying literature for inherent aesthetic and ethical values by textual analysis. One might suggest that textual analysis could profit from the study of branding strategies. As to this, I absolutely do not want to extend the discussion about whether textual analysis and a sociological approach of literature can coexist. Gillis Dorleijn (2009) closed it by formulating the following statement as the first conclusion to his article on this issue: 'A textual-analytical approach and an institutional 
Figure 6.1 Picture: Antiquariaat Fokas Holthuis, The Hague

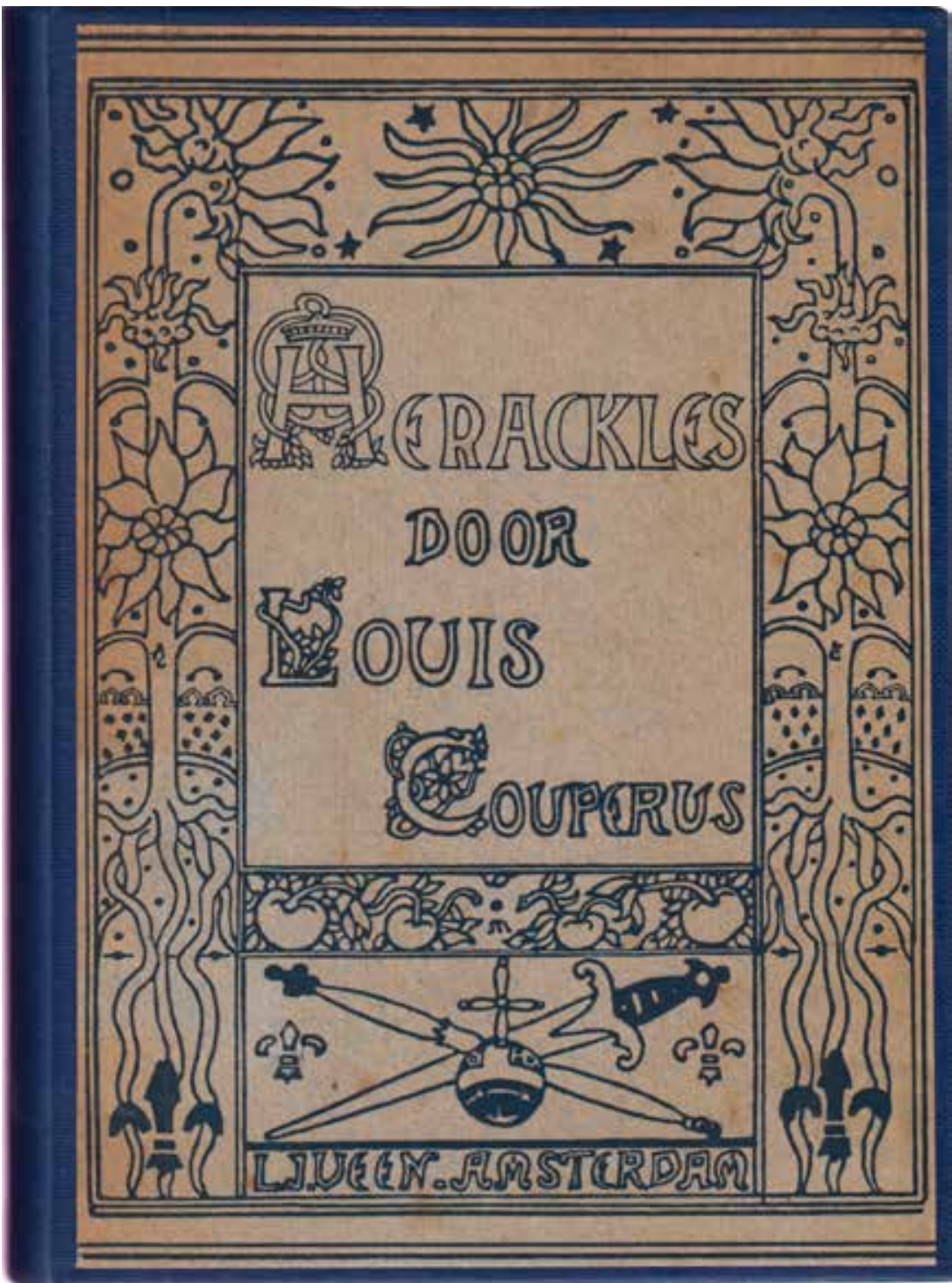

approach are incompatible. End of discussion. Tennis is not football. ${ }^{41}$ The reader was prepared for this conclusion after he had read verdicts like this: 'Within this theoretical framework we are not interested in the meaning

41 'Een tekstinterpretatief en een institutioneel-poëticaal of institutioneel-literair-historisch kader zijn onverenigbaar. Laten we de discussie daarover sluiten. Tennis is geen voetbal.' 
of a poem or a novel. At best, we are interested in the way actors within collective institutional boundaries provide texts with meaning, because this is a kind of behaviour that can be studied within the context of material and symbolic production. ${ }^{42}$ I wonder if every literary scholar will agree with such a radical, exclusive opinion.

The concept of branding as it has been developed so far is not only too wide, but it also suffers from its vagueness. In fact, every perception, every story told can be understood as a way of branding. It is exactly this problem that relates branding to similar concepts as fame or celebrity. They are all about appearances and they reveal nothing but reflections, the various, ever-changing ways the participants in the field of book production and consumption look at each other. This train of thought opens up a perspective on what I think is a far greater problem: branding reduces literature to merchandize and its perception. As others try very hard to ridicule the importance of humanities, there is no need for us to supply them with further ammunition. Books are merchandise, sure, but novels and poems also help us to reflect on how we think and live.

\section{References}

J.A. Alberdingk Thijm, een keuze uit zijn werk. Ingeleid en toegelicht door de projektgroep 'Alberdingk Thijm'. 1972. Zutphen: W.J. Thieme \& Cie.

Willem van den Berg and Piet Couttenier. 2009. Alles is taal geworden. Geschiedenis van de Nederlandse literatuur 1800-1900. Amsterdam: Bert Bakker.

Bijdragen tot de geschiedenis van den Nederlandschen boekhandel. Uitgegeven door de Vereeniging ter Bevordering van de Belangen des Boekhandels. 1884. Deel 1. Levensschetsen en verspreide stukken. Amsterdam.

Ernst Braches. 2003. Nieuwe Kunst en het boek. Een studie in Art Nouveau. Amsterdam: De Buitenkant.

Cd. Busken Huet. $1884^{6}$. Litterarische Fantasien en Kritieken. I-XXV. Haarlem: H.D. Tjeenk Willink.

E.M. Calisch. 1839. Gedichten. 's-Gravenhage: Fuhri.

Catalogue of books printed for private circulation. Collected by Bertram Dobell, and now described and annotated by him. 1906. London: Published by the author.

42 'Wij zijn binnen dit onderzoekskader niet geïnteresseerd in de betekenis van een gedicht of een roman. Wij zijn hoogstens geïnteresseerd hoe actoren binnen collectieve institutionele kaders betekenis geven aan teksten, omdat dit een vorm van gedrag is dat binnen de context van materiële en symbolische productie onderzocht kan worden.' 
Conviva [Gerard Keller]. 1878. Het Servetje. Herinnering aan 'Oefening Kweekt Kennis'. Leiden.

Louis Couperus and L.J. Veen. [1987]. Bloemlezing uit hun correspondentie. Bezorgd, ingeleid en van aantekeningen voorzien door H.T.M. van Vliet. Utrecht/ Antwerpen: L.J. Veen.

Louis Couperus. 1990. Van en over alles en iedereen (Volledige werken Louis Couperus, 35.) Utrecht/Antwerp: L.J. Veen.

Louis Couperus. 1996. Ongebundeld werk. (Volledige werken Louis Couperus, 49.) Amsterdam/Antwerp: L.J. Veen.

Louis Couperus. 2013. De correspondentie. Bezorgd door H.T.M. van Vliet. 2 vols. Amsterdam: Polak \& Van Gennep.

J.L. Dijkhuis. 2018. 'Opkomst en ondergang van de novellenbibliotheek'. De Boekenwereld 34. 4: 54-59.

Gillis Dorleijn. 2009. 'De plaats van tekstanalyse in een institutioneel-poëticale benadering'. Nederlandse Letterkunde 14.1: 1-17.

Pierre H. Dubois. 1980. Marcellus Emants, een schrijversleven. 's-Gravenhage: Nijgh \& Van Ditmar.

Eenige woorden over eene de nationaliteit kwetsende, de kunsten hoonende en den handel verdrukkende Maatschappij, zich noemende 'voor schoone kunsten in Nederland'! 1840. 's Gravenhage: A.J. van Tetroode.

H.J. Eijssens. 2017. De literaire almanak als standmetervan de Nederlandse poëzie. Gedemonstreerd aan de Nederlandsche Muzen-Almanak (1819-1840). Arnhem: Eijssens.

Marcellus Emants. 1995. Voor mij blijft het leven een krankzinnigheid. Een portret in brieven. Amsterdam: Atlas Contact.

Rémon van Gemeren. 2016. Couperus. Een leven. Amsterdam: Prometheus.

P.A.M. Geurts, A.E.M. Janssen, C.J.A.C. Peeters, and Jan Roes (eds.). 1992.J.A. Alberdingk Thijm 1820-1889. Erflatervan de negentiende eeuw. Baarn: Arbor.

Wilma van Giersbergen. 1999. 'De Nederlandse Maatschappij van Schoone Kunsten in Den Haag, 1840-1843. Oprichting en ontbinding van de Maatschappij en het voortbestaan van de houtgraveerschool en Kunstkronijk (1843-1855)'.Jaarboek Die Haghe: 12-37.

F.H. Greb. 1838. November 1813 herdacht. Dichtregelen.'s-Gravenhage: Van Stockum.

B. ter Haar. 1844-1845. De geschiedenis der Kerkhervorming, in tafereelen. 2 vols., 's-Gravenhage: Thierry \& Mensing.

J.J.L. ten Kate. 1838. Parisina, een verhaal. Vrij naar Lord Byron gevolgd. 's-Gravenhage: Van Stockum.

J.J.L. ten Kate. 1839a. Vertaalde poëzy. 's-Gravenhage: Fuhri.

J.J.L. ten Kate. 1839b. Welkomstzang aan hare koninklijke hoogheid de Erfprincesse van Oranje. 's-Gravenhage: Fuhri. 
Maarten Klein. 2000. Noodlot en wederkeer. De betekenis van de filosofie in het werk van Louis Couperus. Maastricht: Shaker.

Willem Kloos. 1882. 'Inleiding', in: Jacques Perk, Gedichten, p. 42-58. Sneek: H. Pijttersen Tz.

A.C. Kruseman. 1886-1887. Bouwstoffen voor een geschiedenis van den Nederlandschen boekhandel, gedurende de halve eeuw 1830-1880. 2 vols. Amsterdam: P.N. van Kampen \& Zoon.

Lisa Kuitert. 1991. 'De second-hand handel. Een doorbraak op het gebied van goedkope literatuur' De negentiende eeuw 15·4: 185-202.

Lisa Kuitert. 1993. Het ene boek in vele delen. De uitgave van literaire series in Nederland 1850-19oo. Amsterdam: De Buitenkant.

J.F.A. Leesberg. [1843]. Herdersdichten. 's-Gravenhage: Fuhri.

F. van der Linden and A.S.A. Struik. 1989. Dejas van het woord. De boekband en de uitgever 1800-1950. Alphen aan den Rijn: Samsom.

I.J. Lion. 1849. Boudewijn en De Tijd: nieten ook zonder loterij. Amsterdam: Meijer.

Nop Maas. 1990. 'Diversités du passé'. Maatstaf 38.11: 1-15.

Nop Maas. 1991. Een duivelsvent. Frederik van Eeden in caricatuur. Verzameld en toegelicht door Nop Maas. Amsterdam: De Beuk.

Nop Maas. 2003. 'Ouwe Willem poetst zijn knopen. Kloos in karikatuur en parodie', De Parelduiker 8.2-3: 105-119.

S.W.F. Margadant. 1934. Geschiedenis van het letterkundig genootschap Oefening Kweekt Kennis 1834-1934. The Hague.

Thomas Moore. 1841. Godgewijde zangen. Naar het Engelsch van Thomas Moore. Utrecht: H.H. van Romondt.

J.J.F. Noordziek. 1865. 'Levensschets van Adrianus David Schinkel'. In Jaarboek van de Maatschappij der Nederlandse Letterkunde, pp. 24-56. Leiden: E.J. Brill.

J. van den Oude, 1899, 1901. Litterarische interludiën, I-II. Leiden: S.C. van Doesburg.

Michel van der Plas. 1995. Vader Thijm. Biografie van een koopman-schrijver. Amsterdam: Ambo/Anthos.

Rob van de Schoor. 1992-1993. "Niet in den handel". Voorbehouden negentiendeeeuwse letterkunde'. De Boekenwereld 9.5: 243-256.

Rob van de Schoor. 2007. 'Periodieke oefeningen van oude kennissen. De Tijd, Geïllustreerde Courant en Polichinel en andere tijdschriften rond De Spektator (1843-1850) op zoek naar een geslaagde marketingstrategie'. Ts: Tijdschrift voor tijdschriftstudies 22: 4-33.

Frits Smit Kleine. 1877. 'Van Zeggelen'. De Banier 3, II: 140-170.

H.T.M. van Vliet. 2000. Versierde verhalen. De oorspronkelijke boekbanden van Louis Couperus'werk (1884-1925). Amsterdam/Antwerp: L.J. Veen.

H.T.M. van Vliet. 2019. Een orchidee tussen de aardappels. Louis Couperus bespot in woord en beeld. Kalmthout: De Carbolineum Pers. 


\section{About the Author}

RoB VAN DE SCHOOR (1959) is assistant professor of nineteenth-century Dutch literature at the department of Modern Languages and Cultures at Radboud University Nijmegen. 



\title{
Hugo Claus
}

'I'm Not Searching for Myself, but for the Media. I Don't

Know Who I Am, I'm Not Interested.'

Gwennie Debergh

\begin{abstract}
This contribution examines how the Flemish author Hugo Claus forged his media image, from his early literary breakthrough in 1948 until right before his death in 2008. Claus's relationship with the press was twofold. On the one hand, he did not believe in a 'clear-cut identity', which in interviews led him to hide behind a game of masquerades. On the other, he gladly and unequivocally communicated his progressive political and social ideas. This chapter pays ample attention to the early years of Claus's career, including - amongst other episodes - his membership of COBRA and his sojourns in Paris and Rome. It also discusses his complex relationship with the Catholic Church and with confessional newspapers. Finally, it examines the impact of Claus's public persona on post-war Flanders.
\end{abstract}

Keywords: literary masquerade, biographical metamorphoses, De eendenjacht (The Duck Hunt), COBRA, Het verdriet van België (The Sorrow of Belgium), author as moral beacon

The literary branding of Hugo Claus (1929-2008) rests on a paradox: he built his image on his refusal to let himself be branded. While most of his fellow writers presented a relatively distinct and clear-cut self-image, Flanders' most mediatized writer of the twentieth century seemed to constantly strive for the opposite. Claus resisted being typecast and cultivated an image of elusiveness. He presented himself as a chameleon on a lyrical, biographical, and sartorial level, and opted in interviews for the tactics of the masquerade and the lie.

Helleke van den Braber, Jeroen Dera, Jos Joosten, and Maarten Steenmeijer (eds), Branding Books Across the Ages: Strategies and Key Concepts in Literary Branding. Amsterdam, Amsterdam University Press 2021 DOI: 10.5117/9789463723916_CHO7 
What holds true for his hybrid identity holds even more so for his oeuvre. Claus was productive in a range of genres: he wrote prose, poetry, and plays, he painted, made films, and collaborated on the libretto of an opera. Within each discipline, he always tried to renew himself. A pulp novel followed a hermetic, well-wrought poetry collection; a provocative pamphlet followed a universally acclaimed play.

As a result, an essay on 'the' branding of Hugo Claus appears to be doomed to get bogged down in a never-ending description of metamorphoses. And yet it is not so difficult to distinguish a certain unity behind the variety of poses. 'All brands need to keep moving and to keep building their stories.' (Michailovich 2009) All brands change, indeed, but in the case of the Hugo Claus 'brand', it is the speed at which the stories succeed one another that is quite dizzying. Perhaps this is an advantage. Claus's versatility is that of a multicoloured gobstopper. If you look at a gobstopper slowly and carefully, you will each time discover new facets in an apparently unending kaleidoscope. But if you spin the gobstopper very fast on its own axis, you will see the heterogeneous colours blend into a homogeneous whole. This contribution seeks to outline briefly both the versatility and the unity in the way in which Claus presented himself as an artist.

The central axis on which this particular gobstopper spins is play. Claus made a distinction in his poetics between two types of authors: diggers and players. Diggers, he believed, searched in every (autobiographical) book for the essence of their own self, which they tried to define as precisely as possible. Players, by contrast, saw each new work as an opportunity to reinvent themselves. According to Claus, diggers tried to strip reality of its ambiguity, while players added extra layers to it precisely by inventing endlessly. Claus saw the lying' writer like a child at play, absorbed in a world of its own where it withdraws from the laws of reality which it trades briefly for other rules. It is clear what category he saw himself in: 'I like including a number of ambiguities, telling the truth through lies, at least surrendering something. Play. Not lying for the sake of lying' (Bibeb 1978). ${ }^{1}$ That game of lying constitutes the essence of his image. From the start, it determined his position in the literary field.

\section{'A Youngster of Considerable Stature'}

November 1948. A review appears in the Ghent student magazine Ons Verbond about De eendenjacht (The Duck Hunt, also translated as Sister of

1 'Ik houd van een aantal dubbele bodems, liegend de waarheid zeggen, althans toch iets prijsgeven. Het spel. Niet liegen om te liegen.' 
Earth), the debut novel of nineteen-year-old Hugo Claus. Reviewer Anatole Ghekiere praises the book as 'one of the most powerful works in recent years' ${ }^{2}$ and calls the debutant 'a youngster of considerable stature'. ${ }^{3}$ The novel's tragic aspects and scope remind the reviewer of famous Flemish novels such as Het recht van de sterkste (1893) by Cyriel Buysse and Abel Gholaerts (1944) by Louis Paul Boon. And yet, in The Duck Hunt, according to Ghekiere, the young Claus dares to go further than these two established authors, among others by opting for the theme of incest - 'that had not yet been dealt with in Flanders ${ }^{4}$ - and by taking a fragmentary and oblique approach in order to shed light on the events in a breathtaking, beautifully unrigged, faltering style. ${ }^{5}$ In combination with the stream of consciousness technique, that approach reveals, according to Ghekiere, a clear affinity with international modernist greats such as Céline, Joyce, and Faulkner. 'The novel The Duck Hunt is one of the most powerful works of recent years', he concludes, 'and, I can say unhesitatingly, of a tonality the likes of which we have not yet encountered around here' (Ghekiere 1948). ${ }^{6}$

It took several decades to discover that the author of this review was not Anatole Ghekiere, but Claus himself, who had concealed himself behind his childhood friend's name. The fraudulent construction at once explains why the review appeared while the novel had not yet even been printed. It appears from the correspondence between Claus and Ghekiere that the review seemed to be part of a genuine media strategy through which the author wanted to conquer his place in the literary field. As the editor-in-chief of Ons Verbond, Ghekiere not only could publish the review effortlessly, but also had the necessary contacts through which he could get Claus an interview in a prominent daily or weekly such as De Standaard or De Vlaamse Linie. In addition, he promised to cause the necessary hoo-ha by releasing a negative review in another publication that would reject The Duck Hunt 'on moral grounds'. 'I'll write it under a pen name. It'll work out.'7

\footnotetext{
2 'een der sterkste werken van de laatste jaren'.

3 'een jongere van groot formaat'.

4 'dat nog niet in Vlaanderen werd behandeld'. Absillis 2008 (96): “"Ghekiere” here sells Flemish literature short: Lode Zielens had dealt with the theme of incest in Het duistere bloed (1930), Boon in his 'utopian' novel Vergeten straat (1946).'

5 'adembenemende, prachtig onttakelde, hortende stijl'.

6 'De roman De eendenjacht is een der sterkste werken uit de laatste jaren en ik aarzel niet te noemen: van een tonaliteit, die wij bij ons nog niet hebben vernomen.'

7 'Dit doe ik dan onder schuilnaam. Dit wordt OK.' Source: Undated letter from from Anatole Ghekiere to Hugo Claus, probably written in October 1948. A copy of the letter is to be found in the archive of the Hugo Claus Centre, University of Antwerp.
} 
In the end, neither of these plans materialized. Owing to various financial and other issues, publisher Dries Masure kept postponing the release of The Duck Hunt until Claus ultimately withdrew the manuscript. ${ }^{8}$ And yet the correspondence between Claus and Ghekiere remains interesting because it sheds light on the principles underlying Claus's branding strategy. He wanted to retain strict control and did not shrink from manipulating the book's reception. What is more, he not only made clever use of his friends, but was also provocative enough to antagonize the right opponents. He would continue to use this strategy later in his career.

\section{From Bohémien to Gigolo}

For the publicity of The Duck Hunt, Claus had to rely on an adolescent double act with his childhood friend Ghekiere, but in the course of his career as a writer, he built up an impressive international network of useful contacts. The start of his career shows how quickly his talent was noticed by the key figures of the post-war literary field.

In the late 1940s, the young and ambitious Claus was not intent on passively waiting for the reception of his texts. Among other things, he sent his manuscripts to two prominent literary critics. One of them was Raymond Herreman, an influential reviewer for the socialist newspaper Vooruit, to whom Claus had already been sending work since 1945 and who, from 1949 onwards, mentioned him regularly as a promising talent in his influential literary column Boekuil.

The other was the liberal writer and journalist Jan Walravens. Claus had sent him his poetry debut Kleine reeks in late 1947 already, and although Walravens was not immediately won over by the collection, they began to correspond. Walravens was interested in Claus for two reasons. He wanted to launch a new literary and cultural review, and initially saw in Claus, the son of a printer, someone who could be of use to him logistically. But he soon realized that the well-read and talented young writer could also assist him in terms of content. As a result, he increasingly took on the role of Claus's coach and mentor. ' 'Really, Hugo, you are going to be somebody. Each of your writings says so to me. I am waiting for an opportunity to write that in public. ${ }^{10}$ For Claus, the contact with Walravens offered the ideal opportunity

8 See Absillis 2008: 105-107 for more details.

9 For more details, see Joosten 1996: 165-175 and Joosten 2018: 142-150.

10 'Heus Hugo, gij wordt iemand. Elk uwer geschriften bevestigt mij dat. Ik wacht op een gelegenheid om het in het openbaar te schrijven.' Letter from Jan Walravens to Hugo Claus, 
to turn the spotlight on his work. They corresponded for several months about both the editorial and business aspects of the planned magazine, Janus, but realized in the autumn of 1948 that the ongoing obstruction of Claus's father Jozef would be fatal to the project. 'I hope you will continue to write', Walravens wrote to Claus when the plans for Janus were definitively shelved. 'That alone is what it comes down to with your talent. I already swear by your talent to all my friends."11

Walravens grew even more convinced of Claus's talent when he read the manuscript of The Duck Hunt a month later. 'I found it masterful. [...] Just as you were the first to express a modern sound in our poetry, so too you are the first to write a modern book. [...] You have written an impressive book that MUST be published. ${ }^{12}$

Following the advice of Walravens, Claus worked on a second novel that he wanted to submit for the prestigious Leo J. Kryn Prize, but progress was laborious and the young author was in a rush: in April 1949 he was called up to do his military service. The new manuscript ultimately hit a dead end and Claus decided to try his luck once more with The Duck Hunt, albeit under a different title (De Metsiers instead of De eendenjacht). ${ }^{13}$ During his military service, he worked for the newspaper Soldatenpost. During his free time, Claus the conscript wrote, among other things, poems for his beloved Elly Overzier that would be included in the first issue of Tijd en Mens, the new review launched by Jan Walravens, and in the fourth issue of the Nieuw Vlaams Tijdschrift, whose editorial board included virtually all the Flemish literary lions.

Claus also painted. His visual work was exhibited in the Ostend bookshop of his friend Henri Vandeputte, where it caught the attention of Cobra founder Christian Dotremont. Claus joined the artists' collective and in April $195^{\circ}$ the newly discharged conscript took part in a Cobra exhibition

30 September 1948. A copy of the letter is to be found in the archive of the Hugo Claus Centre, University of Antwerp.

11 'Ik hoop dat gij zult verder schrijven. Daar alleen komt het met uw talent op aan. Bij al mijn vrienden zweer ik al op uw talent.' Letter from Jan Walravens to Hugo Claus, 29 October 1948. A copy of the letter is to be found in the archive of the Hugo Claus Centre, University of Antwerp. 12 'Ik heb het meesterlijk gevonden. [...] Zoals gij de eerste waart die een moderne klank in onze poëzie liet horen, zo zijt gij de eerste om een modern boek te schrijven. [...] Gij hebt een indrukwekkend boek geschreven, dat MOET verschijnen.' Letter from Jan Walravens to Hugo Claus, 29 November 1948. A copy of the letter is to be found in the archive of the Hugo Claus Centre, University of Antwerp.

13 The title of this novel changed in Dutch, but the title of the English translation (The Duck Hunt) refers to the original title De eendenjacht. 
in Brussels, together with Asger Jorn and Corneille (Wildemeersch 1994: 67). This gave his career a first cosmopolitan injection.

In January 1950, two months before he was allowed to leave the army, Claus won the Kryn Prize for the manuscript of The Duck Hunt. His literary breakthrough was now definitive. The jury's decision was made public in late January in all the leading newspapers, with Walravens acting as the key cheerleader (Absillis 2008: 301). The publication of his novel in the Nieuw Vlaams Tijdschrift (part 1 in June 1950, part 2 in September) heightened Claus's prestige even more. In September 1950, Walravens wrote to him: 'Your fame has, I believe, been established permanently.'14

One month later, Claus moved to Paris, where he once more met promising contemporaries such as Lucebert, Hans Andreus, Remco Campert, and especially Simon Vinkenoog, to whom he was introduced by Cobra artist Corneille. Vinkenoog was enthusiastic about his meeting with Claus, with whom he could discuss French literature and share his admiration for the surrealist Antonin Artaud. Vinkenoog found Claus's erudition and personality 'such a respite and for my part such a discovery that I feel happy, as it were' (Fokkema 1979:142). ${ }^{15}$ He accepted pieces by Claus for publication in his one-man magazine Blurb, which sold well in Amsterdam, where it stimulated interest in the young artists who had traded the bourgeois north for the City of Light, home to surrealism, jazz, and experimentation. Working from Paris, they injected Dutch literature and painting with the ideas of the latest international movements.

In the space of two years, Hugo Claus transformed from unknown poet to prizewinning novelist, Cobra artist and trend-setting experimenter who, moreover, moved effortlessly in Parisian artistic circles. His network was not limited to the Dutch scene of the City of Light. He immersed himself in the intellectual life of the Left Bank, frequented the same bar as Raymond Queneau, attended the vernissages of Salvador Dalí. And yet life in Paris was not all roses. Beneath the gold leaf of the French capital, Dutch artists lived in bitter poverty and the glamorous couple Hugo Claus and Elly Overzier were constantly fighting (Wildemeersch 2018: 217). But in the spotlights, Claus's literary status was rising visibly, leading him to contrast his cosmopolitanism with the Flanders he came from. He dressed as a bohémien and swapped his West-Flemish dialect for Standard Dutch. ${ }^{16}$ He used the media to provoke

14 'Je faam is, geloof ik, definitief gevestigd .' Quoted in Absillis 2008: 301.

15 'zulk een verademing en mijnerzijds zo'n ontdekking dat ik me a.h.w. gelukkig voel.'

16 Rudy Kousbroek in Calis 2001 (87): 'Simon [Vinkenoog] still spoke the dialect of Amsterdam at the time, but he soon lost it. With Hugo Claus too, whose Flemish I could initially understand with difficulty, it also soon disappeared.' 
the home front enough to cultivate his rebel image, but at the same time he maintained useful contacts with the éminences grises of the Nieuw Vlaams Tijdschrift, for whom he was highly interesting in terms of publicity. As such, he combined the best of both worlds: world citizen and Fleming, a metropolitan with his feet in the countryside. He was the enfant terrible who was embraced as a wunderkind by his established colleagues.

After Paris came Rome in early 1953, where his girlfriend Elly Overzier was trying to build up her acting career. In the media of the Low Countries, the Parisian bohémien transformed into an Italian gigolo: 'I grew a moustache and wore those showy Italian jackets' (Gomperts 1963, quoted in Schaevers 2004). ${ }^{17}$ But in the City on the Tiber, too, two souls wrestled with each other in his chest: by 1955, the struggle between the European cosmopolitan and the home-loving West Fleming ended in the latter's favour. Claus returned to Flanders, settling in Ghent and taking the opportunity to create yet another identity in the media: 'In fact I'm quite old-fashioned. Bound by blood and soil. I like Rome a lot. And Italians. All that is enjoyable for a while. But the chatter I heard around me was not mine. I wanted to hear the dialects of Ghent, Ostend, Kortrijk' (De Bruyn 1962). ${ }^{18}$

The pattern would repeat itself over the next decades, during which Claus systematically redefined his fragmentary identity in interviews on the basis of the place where he was living: first the countryside of Nukerke ('I am not blood and soil-minded, I did not withdraw to the countryside as an incarnation of Streuvels in order to experience my Flemishness'), ${ }^{19}$ later the Amsterdam of the 196os ('Of all the cities that I know, Amsterdam is the one I love most. [...] It is a city that exhales freedom') ${ }^{20}$ and lastly the years as a homeowner in the French Provence ('For years I was a proletarian, now I am a nouveau riche ${ }^{21}$ (Bouchez 1994, quoted in Schaevers 2004)) and his experience as an 'immigrant' in Antwerp (the city's residents 'possess a grotesque pompousness that suits me. I feel myself slowly becoming an Antwerpenaar $^{\prime 22}$ (Antoine 1995, quoted in Schaevers 2004)).

17 'Ik liet een snor groeien en droeg van die opzichtige, Italiaanse jasjes.'

18 'Eigenlijk ben ik erg ouderwets. Bloed- en bodemverbonden. Ik hou veel van Rome. Van de Italianen. Zo iets is gunstig voor een tijdje. Maar ik hoorde een weerklank rondom mij die niet van mij was. Ik wou Gents, Oostends, Kortrijks horen.'

19 'Ik ben niet bloed-en-bodemachtig aangelegd, ik heb me niet als een incarnatie van Streuvels op het land teruggetrokken om mijn Vlaamsheid te beleven.'

20 'Onder al de steden die ik ken, is Amsterdam de stad waarvan ik het meeste houd. [...] Het is een stad die vrijheid uitademt.'

21 'Jarenlang ben ik een proletariër geweest, nu ben ik een nouveau riche.'

22 '[De Antwerpenaar] heeft een groteske hoogdravendheid die me ligt. Langzaam aan voel ik me een Antwerpenaar worden.' 


\section{Larvatus Prodeo}

By the time of his return from Rome, Claus was a media figure. The number of interview requests increased rapidly and would not diminish for the rest of his career. Journalists always describe his appearance as a mix of nobility ('the amiable Flemish writer with the head of a Roman senator"23 (Anon. 1962)) and nonchalant coolness ('dark sweater and blue jeans with rolled-up trousers $^{24}$ (Gielens 1966), wearing 'an open shirt under a leather jacket' ${ }^{\prime 25}$ (Huysman 1972)). They never fail to mention the presence of charming wives ('inexorable beauty, whom we naturally immediately recognized from the glamour pictures' ${ }^{26}$ (De Lussanet 1980)).

But whoever goes looking in the interviews for the person behind the writer will be disappointed. 'I don't see the need to shed light on my entire life for someone who, it so happens, wants to publish a piece in a newspaper, ${ }^{27}$ according to the writer (Heyting 1982). "The only thing that interests me are questions of a technical nature. For instance: "Why did you use this adjective here, on this line?" Where I come from, what my psychology is, what I like to read, etc. are questions I find unimportant. They concern my self, which does not differ in essence from that of other people. The only thing that distinguishes me from others is that I sometimes try to record my illusions and fantasies' (De Moor 1979). ${ }^{28}$

Claus often professed his hatred of interviews, claiming he only tolerated them for commercial purposes. He took pleasure in leading journalists up the garden path and admitted so openly: 'Ask away. All I can do is to embroider further some of the misconceptions that have taken root in you' (Vandenbroucke 1996). ${ }^{29}$ There are many interviews where his biographic details contain more Dichtung than Wahrheit, where his past suddenly seems

23 'de vriendelijke Vlaamse schrijver met de kop van een Romeinse senator.'

24 'donkere pull en blauwe blue-jean's met omgeslagen pijpen.'

25 'in open overhemd met leren jack'.

26 'onverbiddelijke schoonheid, die we natuurlijk onmiddellijk herkenden van de glamourfoto's.'

27 'Ik zie niet de noodzaak om mijn hele leven te belichten voor iemand die toevallig een stukje in de krant wil hebben.'

28 'Het enige wat mij interesseert, zijn vragen van technische aard. Bijvoorbeeld: "Waarom hebt u dit adjectief daar gebruikt, in deze regel?" Waar ik vandaan kom, mijn psychologie, wat ik het liefste lees en dergelijke zaken, dat zijn vragen die ik onbelangrijk vind. Dat zijn immers vragen naar mijn ego, dat zich niet wezenlijk onderscheidt van het ego van andere mensen. Het enige wat mij van anderen onderscheidt is dat ik soms probeer mijn waanbeelden en wensdromen te fixeren.'

29 'U vraagt maar. Het enige dat ik kan doen is bepaalde misverstanden die bij u gerezen zijn nog aandikken.' 
to include stints as a night watchman in London or as a fashion designer in Amsterdam. Ten years after his death, actress Hilde Van Mieghem, who knew Claus well for many decades, related how the writer, at the start of her career, tried to show her the ropes as to how to deal with the media. "What you have to do", Claus said, "is to say on day one that you have a lover, on the next that you are in fact a lesbian, on top of that you say that in fact you are in a three-cornered relationship with that lover and that lesbian, and then again that you're single and you're sticking to two cats and a dog. That way you'll drive everyone crazy and they won't have a clue about you. Then you'll be safe. Learn how to lie!"' (Peters 2018). ${ }^{30}$

Only once was Claus in league with a journalist. On 1 April 1951, an interview was published in De Periscoop in which he gave Flemish literature a proper dressing down from Paris and reproached it for its literary short-sightedness: his fellow writers were 'blind' to modern masterpieces by Louis Paul Boon and Albert Bontridder and took the public for a ride with botch-jobs and make-believe (Dijkvogel 1951). These claims caused an outcry on the home front, but it later became apparent that the words were not Claus's at all: it was a fictive interview that Jan Walravens, with the knowledge of the author, had made up and published.

Larvatus prodeo is the motto that Claus borrowed from Descartes: 'I go forward masked' (Vanegeren 1996, quoted in Schaevers 2004). Like his books, his interviews were not meant to be repositories of the 'real' Hugo Claus, if such a person existed at all. 'I'm not searching for myself, but for the media', he told journalist Ischa Meijer in an interview. 'I don't know who I am, I'm not interested, I don't even want to know who I actually am. Because I already know that it's not interesting. My self is only interesting in relation to others. I certainly don't lead an isolated life, I have a protective suit of armour around me in the form of my close friends whom I trust completely. Most of the relations that I have outside that are based on suspicion, on feeling out, in short, that very secret radar with which you are equipped when you meet the other' (Meijer 1970). $\cdot^{11}$

$3^{0}$ "'Wat je moet doen", zei Claus, "is de ene dag zeggen dat je een minnaar hebt, de volgende dat je eigenlijk lesbisch bent, daarop zeg je dat je een driehoeksverhouding hebt met die minnaar én die lesbienne, en dan weer dat je celibatair bent en het houdt bij twee poezen en een hond. Zo maak je iedereen gek, en weten ze niets meer van je. Dan ben je veilig. Leer liegen!"'

31 'Ik ben niet op zoek naar mezelf, maar naar de media. Ik weet niet wie ik ben, het interesseert me niet, ik wil niet eens weten wie ik nou eigenlijk ben. Omdat ik van tevoren weet dat dat niet interessant is. Mezelf is alleen interessant in relaties tot anderen. Ik leef beslist niet geïsoleerd, ik heb wel een harnas van beveiliging om me heen in de vorm van m'n naaste omgeving die 
The mask as armour is a recurrent image in Claus's pose and shows that there is a clear distinction between his public image and his selfimage behind the scenes. 'I live beneath many masks. Beneath them lurks everything that you can possibly fill out in terms of shame, vulnerability, and sadness, but those masks stay on as my way of defending myself' (Camps 1986). ${ }^{32}$ Certainly in the early phase of his oeuvre, the defence mechanism came in handy to hide any doubts about the quality of his work. Behind the boyish swagger with which Claus tried to manipulate the reception of The Duck Hunt in 1948 lurked a very insecure writer, or so it appears from the correspondence with his friend Roger Raveel. In it he repeatedly asked the painter to give him his opinion about the manuscript by return of post. When Raveel initially reacted with a couple of bland sentences, Claus insisted more vehemently: 'You should also write something to me about my novel, because I am beginning to doubt that I should publish it. I know that if you say that it is good, then it is indeed so, but I was expecting some comments, what you think ought to be changed, what struck you as particularly good. It's ridiculous, I can't wrap my head around it, so write something to me about it at least' (Jacobs 2007: 85-86). ${ }^{33}$ The same insecurity resonates in the early correspondence with Raymond Herreman, ${ }^{34}$ and in a letter to Simon Vinkenoog Claus talks about his 'concrete self-assurance for appearances' sake and for myself.'35 A pose, in other words.

ik volledig vertrouw. De meeste relaties die ik daarbuiten heb, zijn gebaseerd op wantrouwen, op aftasten, enfin, die hele heimelijke radar waarmee je uitgerust bent, wanneer je die ander ontmoet.'

32 'Ik leef achter vele maskers. Daarachter schuilt alles wat je maar kunt invullen aan schaamte, kwetsbaarheid en verdriet, maar die maskers blijven overeind als mijn manier om me te verdedigen.'

33 'Je zou mij ook iets of wat over mijn roman moeten schrijven, want ik begin te aarzelen hem uit te geven. Ik weet dat, als je zegt dat het goed is, dat het zó is, maar ik verwachtte wat opmerkingen, wat je zou willen veranderd zien, wat je opgevallen is, bizonder goed te zijn. Het is idioot, ik kan er geen idee van krijgen, dus schrijf mij er tóch iets over.'

34 Absillis 2008 (97): 'From his letters to Raymond Herreman, Claus emerges as a shy and uncertain young man in search of confirmation. When Herreman did not appear to react immediately to his novel, he wrote a concerned letter: "Put this letter down to the well-known overconfidence of youth because I am now worried that you may have not received my manuscript of The Duck Hunt. Then I imagine that you did receive it but did not like it, so that you hesitated to write back. After that I asked myself whether I could ask of you to read my book on that very evening. And so forth, and so forth. When you have a moment, will you answer me in this regard - and forgive me my impatience."'

35 'Een betonnen zelfzekerheid pour la galerie et pour moi-même.' Claus to Vinkenoog, early April 1953, cited in Claus and Vinkenoog 2008: 129. 


\section{'I Am Honoured when a Catholic Feels Shocked when Reading My Books'}

Those who were not allowed to pick up that insecurity in any case were Hugo Claus's opponents, and they were there from the start. When The Duck Hunt was at last published in March 1951 by Manteau, Claus was marketed as a literary wunderkind. His debut novel caught the attention of established fellow authors such as Maurice Roelants (1951) ('a 19-year-old master'), Simon Vestdijk (1951) ('proof of undeniable mastery' and 'the best novel of the last six or seven months at least'), Ferdinand Bordewijk (1951) ('Claus needs to mature, but he has the talent'), and Paul Rodenko (1951) ('despite the shortcomings [...] nevertheless a good and even fascinating novel'). ${ }^{36}$

Amidst the praise, dissenting voices could also be heard. Jan Walravens even evoked 'two camps' opposing one another: 'Some felt the greatest awe for his talent. They believed they could perceive a voice whose originality and eloquence were such that it had to resonate far beyond our borders. Others saw in Claus merely an imitator of American and existentialist tricks and did not spare him the most severe criticism' (Walravens 1955). ${ }^{37}$

In particular, conservative-minded critics of a confessional persuasion were angered by the story about a marginal family in which brother and sister maintained an incestuous relationship. In Boekengids, The Duck Hunt was given a 'code I', which meant that Catholics were banned from reading it. Critic André Demedts, who sat on the jury of the Kryn Prize and was not blind to Claus's talent, nevertheless found the story 'deplorable as a result of its one-sided excess' and hoped that Claus's next novel would be 'morally healthier'. 'Seen from a moral viewpoint, The Duck Hunt is a repulsive book' (Demedts 1951: 239, 240). ${ }^{38}$ The Dutch Catholic professor Anton van Duinkerken agreed: "The boldness of the subject and the unvarnished nature of the execution prompt serious reservations' (Van Duinkerken 1951). ${ }^{39}$

$3^{6}$ 'een meester van negentien jaar' (Maurice Roelants); 'een proeve van onbetwijfelbare meesterschap', 'de beste roman, op zijn minst van de laatste zes of zeven maanden' (Simon Vestdijk); 'Claus moet rijpen, maar hij kan het' (Ferdinand Bordewijk); 'òndanks de tekortkomingen [...] niettemin een goede en zelfs fascinerende roman' (Paul Rodenko).

37 'De enen voelden het grootste ontzag voor zijn talent. Zij meenden een stem te vernemen waarvan de oorspronkelijkheid en de zeggingskracht zo groot was, dat zij wel ver over de grenzen moest weerklinken. Anderen wilden in Claus slechts een nabootser van Amerikaanse en existentialistische knepen zien en spaarden hem de heftigste critiek niet.'

38 'bedroevend door zijn eenzijdige overdrijving', 'Onder zedelijk oogpunt beschouwd is $D e$ Metsiers een afstotend boek.'

39 'De gedurfdheid van het onderwerp en de onverbloemdheid van de uitwerking nopen tot ernstig voorbehoud.' 
The criticism was not entirely unexpected, and neither was it entirely inopportune. In the review that Claus himself published under the pseudonym of his childhood friend Anatole Ghekiere, he had already anticipated the moral outcry that his debut novel would cause. More so still: from the correspondence with Ghekiere, it appears that both friends hoped for this sort of controversy as a source of extra publicity. In his self-composed review, Claus predicted that a number of 'salacious situations' would be labelled 'sacrilegious': 'A little army of insipid, withered souls, parched of spirit and blood, will see in this novel a provocation, will feel shocked and unsettled because of some strong language and here and there a detail they find objectionable. But I repeat: the withered and the insipid' (Ghekiere 1948). ${ }^{40}$

The moral reservations that critics such as André Demedts and Anton van Duinkerken aired upon the publication of The Duck Hunt thus suited the young author quite well. It gave him the necessary street credibility, as it were, that he was looking for as a maverick of the new generation. And yet his provocation of the Catholic critics was more than some superficial image-building. Claus attended a strict Catholic boarding school as a youth and for the rest of his life would keep opposing the Church's influence on all aspects of society, not least on literature. For the rest of his writing career, he would thus continue to be at loggerheads with the clergy and its literary critics, who experienced his world as shocking and morally objectionable. Both parties benefited from the struggle. Claus could present himself as a moral freedom fighter and intellectual leader of progressive Flanders, while the conservative-minded reviewers could appoint themselves as the necessary keepers of bourgeois decency: 'We admire the great talent of Hugo Claus very much. We regret all the more having to reject this book entirely owing to the sickly and trivial erotica. What shamelessness and lack of good taste have to do with art remains obscure to us. ${ }^{41}$

That Claus's image inflamed not only literary feelings became clear in Ghent in 1957, when his work was at the centre of a political conflict. For the touristy summer season, the city authorities were planning a sound and light show for the famous Abbey of St. Bavo and for that purpose had called on Hugo Claus, a resident of the city, who titled his work Van de Vikings tot

40 'Een legertje tammen en verdorden naar geest en bloed, zullen in deze roman een provocatie zien, zich geschokt en uit hun rust verstoord gevoelen om wat krasse taal en hier of daar een voor hen hinderlijk detail. Maar ik zei: de verdorden en de tammen.'

41 'Wij bewonderen het grote talent van Hugo Claus zeer. Des te meer spijt het ons dit boek volkomen te moeten afwijzen om de ziekelijke en triviale erotiek. Wat schaamteloosheid en gebrek aan goede smaak toch te maken hebben met kunst, wil ons niet duidelijk worden.' In: I.D.I.L. (Information office on literature), 31 December $195^{2}$. 
Keizer Karel. When Claus's text was presented to the Ghent authorities for the sound and light show, the Catholic opposition found that 'the script does not meet the epic and moral mission of St. Bavo's Abbey' and that 'the writer of the script is not the desired person' (Anon. 1957). ${ }^{42}$ Claus was called a 'bestialized and debauched person ${ }^{43}$ and the posters for Van de Vikings tot Keizer Karel were plastered over (Vinkenoog 1960: 34). Even before the first letter of the sound and light show was officially published, the Catholic newspapers Het Volk, De Standaard, and De Linie denounced the contents of Claus's play, which in their view zoomed in all too eagerly on the negative aspects of the abbey's past. For weeks on end, supporters and opponents dug in their heels and harassed one another with reproaches via the right dailies and weeklies. In the leftist Vooruit, Louis Paul Boon reached the conclusion: 'No matter how Claus would have developed this sound and light show, it would never have gone down well with Het Volk, De Standaard, and De Linie' (Boon 1957). ${ }^{44}$

Boon's remark hit the nail on the head. The content of Claus's play was in essence nothing more than a catalyst for the entire discussion in the press and in politics, and as such perfectly interchangeable with other pieces of his - witness later, similar conflicts around, among others, Omtrent Deedee (1963) and Masscheroen (1968). The rub was Claus's licentious, provocative, anti-Catholic image, which formed the real stake of an ever-recurrent battle between the progressive and the conservative camps, between leftist supporters and rightist opponents, between free-thinkers and believers. And to the horror of his opponents, this aspect of Claus's pose would never change. Contrary to the endless roguishness with which the writer tried to avoid biographic questions in interviews, or always changed his appearance, he remained steadfast on issues such as these. Without a hint of irony, he kept hammering away at the issue of the ubiquitous power that the Catholic Church had in Flanders and at the short-sightedness it had led to: 'I am honoured when a Catholic feels shocked when reading my books. That means that he reads with prejudices and wears blinkers. And those are precisely the readers I don't want' (Cl. R. 1966). ${ }^{45}$

42 'dat het spel niet beantwoordt aan de epische en morele gedachte van de St.-Baafsabdij'; 'dat de schrijver van het scenario niet de gewenste persoon is'.

43 'een verdierlijkt en verliederlijkt mens'.

44 'Om het even hoe Claus dit licht- en klankspel zou hebben uitgewerkt, het ging toch nooit in de smaak van Het Volk, De Standaard en De Linie vallen.'

45 'Ik vind het een eer als een katoliek zich geschokt voelt bij het lezen van mijn boeken. Dat betekent dat hij leest met vooroordelen, met oogkleppen aan. En zulke lezers wil ik juist niet.' 
Conflicts like that in Ghent can give the impression that Claus took aim exclusively at the conservatism of the Catholic Church. That image is incorrect. Although that battle remained a constant in his work, from the start he expressed himself on many controversial social themes such as the Algerian War of Independence, the atrocities committed by Belgium and the Belgian monarchy in the Congo, the war in the former Yugoslavia, the fatwa against Salman Rushdie, or the attacks of 11 September 2001. On all these social issues, he articulated his opinions unambiguously. In the late 1980s, he lambasted Islamic fundamentalism in the same sharp terms with which he had attacked the Roman Catholic authorities for decades. 'The call to kill [Salman Rushdie] arouses my most aggressive feelings. Rushdie has attacked Islam, the Prophet was insulted, and in a certain sense it is therefore logical and justified that Muslims are outraged. But then let all those god-lickers, those filthy god-worshippers, both Catholics and Muslims, shut their mouths. Let them sing a song in the corner of the room, but above all, don't let them take up arms' (Schreuder 1989). ${ }^{46}$

In the last years of Claus's life, a certain mildness seemed to seep into his interviews, even with regard to the age-old adversary. 'I have known fury that was focused firmly on the Church and the Vatican. In prose and poems and in my life outside all that. In that, too, I have become more resigned. Today I can even be moved by an artistic treasure like the Cathedral of Reims. But religion remains remote from me. The Church corrects the wrong things', ${ }^{47}$ he said four years before his death (Camps 2004). Ironically enough, Claus's death made painfully clear that that mellowing was not mutual and that his decades-long criticism of the Catholic Church had been anything but forgotten and forgiven. Three days after his death - suffering from Alzheimer's, the writer had opted for euthanasia on 19 March 2008 - the Belgian Cardinal Godfried Danneels hit out viciously at Claus's decision to terminate his life in his Easter vigil. 'By departing this life just like that, one does not answer the problem of life and death. One gives it a wide berth and one circumvents it. Circumventing is

46 'De oproep [om Salman Rushdie] te vermoorden roept mijn meest agressieve sentimenten op. Rushdie heeft een aanval op de islam gedaan, de profeet is beledigd en in zekere zin is het dus logisch en terecht dat de islamieten verontwaardigd zijn. Maar laat al die godlikkers, die schunnige godvereerders, zowel katholieken als islamieten, vervolgens hun bek houden. Laat ze in de hoek van de kamer een liedje zingen, maar laat ze vooral geen wapens in de hand nemen.' 47 'Ik heb woede gekend die sterk gericht was op de kerk en op het Vaticaan. In proza en gedichten en in mijn leven daarnaast. Ook daarin ben ik gelatener geworden. Ik kan nu zelfs ontroerd zijn door een kunstschat als de kathedraal van Reims. Maar religie blijft ver van mij staan. De kerk corrigeert de verkeerde dingen.' 
not a heroic act, is not fodder for front-page news' ${ }^{48}$ the cardinal claimed (Delepeleire 2008). In the ensuing days, the age-old battle between believers and non-believers came once more prominently to the fore. During the farewell ceremony in the Antwerp Bourla Theatre, where the entire cultural world from the Netherlands and Flanders had gathered, writer Erwin Mortier expressed in sharp terms the feeling of indignation that permeated progressive circles:

We are living in the twenty-first century, it's true, and although things have changed, at bottom everything always remains the same. It is a bitter irony that the man who declared us beings who could never civilize themselves entirely is still being lectured posthumously by people for whom he always showed a salutary lack of respect: princes of all sorts, dignitaries of the Church, prelates, and other bearers of shameless pretension - the strange people who wanted to belittle him from the youngest age. Purely and only because it so happens that his choice of death is not theirs, there they come again, creeping out from under the cobbles, spewing their cowardly bile. Celebrating their own moral superiority above the body of a late loved one is not a heroic act. Your Eminence: shame on you. (Mortier 2008) ${ }^{49}$

\section{Ni Dieu, ni Maître}

The shock wave caused by Hugo Claus's death in Flanders shows the extent to which he was a beacon for many people for decades. He led the fight for freedom and self-determination, and in the struggle acted as a moral compass that did not point automatically in the direction of Rome. Not for nothing was his life's motto Ni dieu, ni maître.

48 'Door zomaar uit het leven te stappen, antwoordt men niet op het probleem van lijden en dood. Men loopt er in een boog om heen en omzeilt het. Omzeilen is geen heldendaad, geen voer voor frontpaginanieuws.'

49 'We leven dan wel in de eenentwintigste eeuw, hoeveel er ook veranderd moge zijn, ten gronde blijft alles altijd hetzelfde. Het is een bittere ironie dat de man die ons uitsprak als wezens die zich nimmer volkomen kunnen beschaven, postuum nog de les wordt gespeld door lieden waarvoor hij steeds een heilzaam gebrek aan ontzag heeft vertoond: prinsen van allerlei slag, kerkvorsten, prelaten en andere dragers van schaamteloze pretentie - het slag volk dat hem al van in zijn prilste jaren heeft willen kleineren. Louter en alleen omdat de keuze van zijn levenseinde toevallig niet de hunne is, komen ze weer van onder de plaveien gekropen en spuien hun laffe gal. De eigen morele superioriteit celebreren boven het lichaam van een geliefde dode is geen heldendaad. Meneer de kardinaal: schaam je.' 
As a media figure, Claus's influence reached much further than the circle of his many readers. This is perhaps best illustrated by The Sorrow of Belgium, his magnum opus from 1983. The novel was a critical and commercial hit. The publication was accompanied by the first media hype in Dutch-language literature and dominated the cultural news for weeks. Demand was through the roof, Claus appeared on scores of TV shows, was idolized, and the literary wunderkind of yesteryear achieved the status of a mythical hero. He was frequently tipped for the Nobel Prize in Literature, but in the end, he never won it.

But who has ever really read the novel? On the occasion of the Boekenbeurs book fair in November 2005, the Flemish newspaper De Standaard and the national radio broadcaster Radio 1 invited their readers and listeners to tell them which books they had put back on the shelf unread. The Sorrow of Belgium was at the top of the list. Other titles on the list were the Bible (4), Ulysses (5), and The Name of the Rose (7). Many reasons can be put forward to explain why this was the case - The Sorrow of Belgium unjustly lugs the reputation of being a hermetic cryptogram - but in any case, the result of the survey proves that there is a gap between the media impact of Claus the public figure and familiarity with his work.

A decade after his death, that gap is only getting bigger. The Claus 'brand name' is still essential, even though it is unclear how many people still have an idea of the 'product' behind the logo. Among the current generation of students of Dutch language and literature - children at the time of Claus's death - that knowledge is ebbing away fast, a situation similar to that of Claus's contemporaries Willem Frederik Hermans, Harry Mulisch, and Gerard Reve, some of the other literary lions of the twentieth century. It is therefore a good thing that the year 2018, the tenth anniversary of Hugo Claus's death, was the occasion for a reflection on the writer, with exhibitions in Brussels, Antwerp, and Rotterdam, commemorative evenings in sold-out theatres, and many shows on the radio and television. But what was striking in all this was that once again, much of that attention went to Hugo Claus the phenomenon. On radio and television shows, Flemish celebrities were given plenty of time to relate how they had known Claus in private, as they dished up anecdotes of greater or lesser relevance ('I once peed next to him in a public toilet', 'He once kissed me on the mouth in a lift'). A lot less attention was paid to Claus's literary legacy and to the meaning of his work in the twenty-first century. Young authors who were asked about the oeuvre of their illustrious predecessor often did not manage more than a vague stammer. 
Did the excessive attention for Claus the person(a) stand in the way of a critical analysis of his work? Is the branding gradually having a counterproductive effect? Journalist and literary theorist Frank Albers believed so in any case, as he raised a dissenting voice in the flood of hagiographies:

I saw and heard and read again a lot about the complex, amiable, unfathomable, charming, versatile, etc. man, but in fact I was looking for literary-historical arguments and considerations about the meaning, the value of this oeuvre which, as everyone knows, is particularly multifaceted and of unequal quality. Granted: for a long time, that public image cast a spell on me too. Claus the sardonic dandy, the playful-arrogant coiner of superior one-liners, the master provocateur, etc. I idolized it. But that was 30, 40 years ago. When I now watch archival footage on YouTube of Claus's media appearances in those years, I mostly feel embarrassed. The requisite cigarette, the constant mocking grin, the pseudo-profound insipidities about lying ... - by now I've had it with Claus the coquettish poseur. That says something about how society has changed over the past 30 years. Flanders was another country at the time. I know of no writer of significance in this language area who could act like that in the media today and get away with it. (Albers 2018) $)^{50}$

Albers's criticism is not unjustified, but in my opinion, it shows that the writer risks becoming a victim of his own success. That Flanders has now become another country is in part thanks to Hugo Claus. To his work, but also, and to no lesser extent, to the liberated way in which he appeared in the media. The author who refused to let himself be branded has left a clear impression on the society in which he lived.

50 'Ik zag en hoorde en las weer veel over de complexe, aimabele, onpeilbare, charmante, veelzijdige enzoverder man, maar eigenlijk zocht ik literair-historische argumenten en beschouwingen over de betekenis, de waarde van dit oeuvre dat, zoals iedereen weet, bijzonder veelkantig en ongelijk van kwaliteit is. Toegegeven: dat publieke imago heeft ook mij lang betoverd. Claus de sardonische dandy, de speels-arrogante bedenker van superieure one-liners, de meester-provocateur,... gedwéépt heb ik ermee. Maar dat was dertig, veertig jaar geleden. Als ik nu op YouTube naar archiefbeelden kijk van Claus' media-verschijningen in die jaren, voel ik vooral gêne. De obligate sigaret, het eeuwige monkellachje, de pseudo-diepzinnige flauwigheden over de leugen,...- met Claus de kokette poseur heb ik het ondertussen wel gehad. Dat zegt iets over hoe veranderd deze samenleving wel niet is, de afgelopen dertig jaar. Vlaanderen was een ander land, toen. Ik ken geen enkele schrijver van betekenis in dit taalgebied die zich vandaag zo aanstelt in de media en er nog mee wegkomt ook.' 


\section{References}

[Anon.] 1957. 'Gemeenteraadzitting te Gent. Kritiek op het Klank- en Lichtspel in de St.-Baafsabdij'. Het Laatste Nieuws, 14 May.

[Anon.] 1962. 'Hugo Claus: nieuwe roman en nieuw toneelstuk'. De Telegraaf, 23 February.

Kevin Absillis. 2008. Literaire kwaliteit uit arm Vlaanderen. Uitgeverij A. Manteau en de verzelfstandiging van het literaire veld 1932-1971. PhD thesis, Antwerp University. Published as: Kevin Absillis. 20og. Vechten tegen de bierkaai. Over het uitgevershuis van Angèle Manteau (1932-1970). Antwerp: Meulenhoff/Manteau.

Frank Albers. 2018. 'Wat als Hugo Claus niet had bestaan?'. In www.dereactor.be, 19 March.

Jean Antoine. 1995. 'Hugo Claus au fil du temps', ARTE Television, 21 December.

Bibeb. 1978. "Ik zal nooit echt afvallen iemand die ik bemind heb of die ik bemin." Hugo Claus over het gevaar van de domheid en over de oorsprong van zijn woede'. In Vrij Nederland, 14 January.

Louis Paul Boon. 1957. 'Hugo Claus en de Sint-Baafsabdij'. Vooruit, 18 May.

Ferdinand Bordewijk. 1951. 'Een magnifiek dierenepos. Ernest Claes op grote schrijvershoogte in zijn "Floere, het fluwijn" - Een wordend talent: Hugo Claus'. Utrechts Nieuwsblad, 13 September.

Emmanuelle Bouchez. 1994. 'Hugo Claus, un Belge dans le Vaucluse'. Télérama, 10 August.

Frans de Bruyn. 1962. 'Hugo Claus kan Vlaanderen niet missen'. Vrij Nederland, 31 March.

Piet Calis. 2001. Het elektrisch bestaan. Schrijvers en tijdschriften tussen 1941 en 1951. Amsterdam, Meulenhoff.

Hugo Camps. 1986. 'Ik ben een perfecte lafaard. Het verdriet van Hugo Claus dat elk schrijven zinloos maakt'. Elseviers Magazine, 10 May.

Hugo Camps. 2004. 'Ik ben naakter en kwetsbaarder geworden'. Elsevier, 3 April. Hugo Claus and Simon Vinkenoog. 2008. Laat nooit deze brief aan iemand lezen. De briefwisseling tussen Hugo Claus en Simon Vinkenoog 1951-1956. Amsterdam: De Bezige Bij.

Yves Delepeleire. 2008. 'Kardinaal Danneels: "De dood omzeilen is geen heldendaad.”. De Standaard, 25 March.

André Demedts. 1951. 'Kroniek van het Vlaamse Proza'. Dietsche Warande en Belfort 96.4: 237-240.

Frans Dijkvogel [Jan Walravens]. 1951. 'Ze klagen en zeuren in Vlaanderen'. De Periscoop, 1 April.

Tonko Dop. 2009. De veelvraat Hugo Claus. Documentary by the NPS (Nederlandse Programma Stichting, Dutch Broadcasting Company), in collaboration with Canvas. 
Anton van Duinkerken. 1951. 'Geest en Leven'. De Tijd, 31 March.

Willem Elsschot. 1993. Brieven. Verzameld en ingeleid door Vic van de Reijt met medewerking van Lidewijde Paris. Amsterdam: Querido.

R.L.K. Fokkema. 1979. Het komplot der Vijftigers. Amsterdam: De Bezige Bij.

Anatole Ghekiere [Hugo Claus]. 1948. 'Een jongere van groot formaat: Hugo Claus: De Eendenjacht'. Ons Verbond, November.

T. Gielens. 1966. 'Het huis waarin ze wonen'. Kijk, 1 January.

Henri Albert Gomperts. 1963. 'Literaire ontmoetingen'. AVRO-television, 29 May. Lien Heyting. 1982. 'Eerlijkheid à tout prix vind ik een ramp'. NRC Handelsblad, 12 February.

Peter Huysman. 1972. "De echte Kitty is mooier en intelligenter dan mijn vriendin". Hugo Claus over Het jaar van de kreeft'. Utrechts Nieuwsblad, 14 November.

Katrien Jacobs (ed.). 2007. Hugo Claus. Roger Raveel. Brieven 1947-1962. Ghent: Ludion. Jos Joosten. 1996. Feit en tussenkomst. Geschiedenis en opvattingen van Tijd en Mens (1949-1955). Nijmegen: Vantilt.

Jos Joosten. 2018. De verdeelde mens. Jan Walravens [1920-1965]. Schrijver, ijkpunt, avant-gardist. Nijmegen: Vantilt.

Paul de Lussanet. 1980. 'Bonjour maître'. NRC Handelsblad, 12 December.

Ischa Meijer. 1970. 'De banaliteit van Hugo Claus'. Haagse Post, 25 February.

Philippe Michailovich. 2009. 'Mind the Gap! Branding Bridges in the Brain'. The Journal of the Medinge Group 3.1: https://sharaine.com/mind-the-gap-bridgesin-the-brain/. [accessed 22 december 2020]

Piet de Moor. 1979. 'Praten met Hugo Claus'. De Nieuwe, 27 April.

Erwin Mortier. 2008. 'Meneer de kardinaal: schaam je'. De Standaard, 30 March.

Arjan Peters. 2018. 'Hilde Van Mieghem maakte tentoonstelling over Hugo Claus - "Na 30 jaar heeft hij me voor het eerst gekust"'. de Volkskrant, 16 March.

Cl. R. 1966. 'Hugo Claus: Beatles beter voorbeeld dan Leopold I'. Vooruit, 14 January. Paul Rodenko. 1951. 'Een Amerikaanse injectie'. Critisch Bulletin, XVIII, August.

Maurice Roelants. 1951. 'Een meester van negentien jaar. De Metsiers van Hugo Claus'. Elseviers Weekblad, 21 April.

Mark Schaevers. 2004. Groepsportret.Een leven in citaten. Amsterdam: De Bezige Bij.

Arjen Schreuder. 1989. 'Vrees de domheid. Hugo Claus: "Grote literatuur is niet sober"'. NRC Handelsblad, 10 March.

Diederik Stevens. 2012. Hoogtij langs de Seine. Nederlandse schrijvers en kunstenaars in Parijs. Amsterdam: Atlas.

Johan Vandenbroucke. 1996. 'Hugo Claus: "Je moet chance hebben, dat scheelt"'. Poëziekrant, January-February, 4-11.

Bart Vanegeren. 1996. 'Minstens de helft van de mensen is crapuul'. Humo, 22 October. 
Simon Vestdijk. 1951. 'Een top in de Vlaamse romankunst. Uitgestotenen en hun eenzelvigheid: De Metsiers, debuut van negentienjarige Hugo Claus.' Algemeen Handelsblad, 21 July.

Simon Vinkenoog. 1960. Uit de doeken (signalementen) 1957-1960. Baarn: Boekerij, 1960.

Jan Walravens. 1955. 'Hugo Claus, de gevoelige'. Het Laatste Nieuws, 23 February. Georges Wildemeersch (ed.). 1994. Het teken van de ram. Jaarboek voor de Clausstudie 1. Amsterdam/Leuven: De Bezige Bij/Kritak.

Georges Wildemeersch. 2018. Familiealbum, Antwerp: Polis.

\section{About the Author}

Gwennie Debergh (1975) is affiliated with the Hugo Clauscentrum at the University of Antwerp. In 2006, she obtained her doctoral degree at the Vrije Universiteit Brussel, with a dissertation on Hugo Claus's magnum opus Het verdriet van België (The Sorrow of Belgium). She regularly publishes on Dutch-language prose published after World War II. 


\title{
One Book's Brand is Another Book's Frame
}

\author{
Covering the Dutch Cover of Carlos Ruiz Zafón's La sombra \\ del viento
}

Maarten Steenmeijer

\begin{abstract}
Book covers can be an important part of the branding process in the case of authors from abroad. The branding of Carlos Ruiz Zafón's novels in the Netherlands is a paradigmatic case in point. The front cover of his Dutch debut De schaduw van de wind became a classic: it is a crucial element of the Dutch Zafón brand, while essential features from it have been used to frame a considerable number of other Spanish authors' novels that have since been launched onto the Dutch market. We examine three cases: Arturo Pérez-Reverte, Elia Barceló, and María Dueñas. Emulating successful cover branding seems to have the best chance of succeeding in the case of 'new' authors and appears to be most effective in the short term.
\end{abstract}

Keywords: branding, translations, covers, hetero-representation

Carlos Ruiz Zafón's novel La sombra del viento is every publisher's dream. Worldwide, it has sold more copies than any other Spanish novel, the only exception being, of course, Cervantes' Don Quixote. Germany was the first foreign country where Ruiz Zafón's novel was published (in the summer of 2003). Other countries soon followed and zafonmanía became a global phenomenon. To provide an idea of zafonmanía's key features, it is relevant to cite the blurb from the US cover: 'The number one bestseller.' This is, evidently,

Helleke van den Braber, Jeroen Dera, Jos Joosten, and Maarten Steenmeijer (eds), Branding Books Across the Ages: Strategies and Key Concepts in Literary Branding. Amsterdam, Amsterdam University Press 2021

DOI: 10.5117/9789463723916_CHo8 
a cliché frame ${ }^{1}$ that does not disclose anything of the book's content. But the considerable economic capital attributed to Ruiz Zafón's novel does, in fact, distinguish it from many others and could be an incentive for readers to get interested: success breeds success. It is also interesting to consider the book's content, which is, significantly, not easy to nail down. First, we have its uncertain literary status. On the one hand, we have highbrow intertextual references to modern classics like Gabriel García Márquez's novel One Hundred Years of Solitude and Jorge Luis Borges's short story 'The Library of Babel'. On the other hand, the author lavishly uses lowbrow and middlebrow techniques and stylistic devices (cliffhangers, stereotypes, clichés). Furthermore, the novel is an amalgam of literary and subliterary genres (gothic novel, Bildungsroman, adventure novel, thriller, historical novel, romantic novel, mystery novel, picaresque novel). Even the novel's setting is open to various interpretations. Is Ruiz Zafón's Barcelona 'real'? Is it a literary creation? Or is it both? And what about the references to the Spanish Civil War and to the post-war repression of the Franco regime? Are they true to history or true to the conventions of certain literary (sub) genres? Or are they both? (Steenmeijer 2017).

This openness is matched by the novel's title and front cover illustration, the two paratexts that, as we will argue below, are fundamental for the Zafón brand. ${ }^{2}$ What, to begin with, are the distinctive features of the title and the cover illustration of Ruiz Zafón's novel? There is no doubt that 'la sombra del viento' sounds good: it has rhythm and it pairs two suggestive (or, if you like, 'poetic') nouns. But what does this combination mean? What is, in fact, 'the shadow of the wind'? How can one possibly imagine a wind with a shadow, be it literally or metaphorically? And what is the relation between the novel's title and its story?

The cover illustration also raises interpretative questions. What to make of the photo that dominates the Spanish front cover of La sombra del viento, taken by Francesc Català-Roca (1922-1998)? The overall image is that of a

1 In this chapter, the terms 'frame' and 'framing' refer to 'ideas, conditions, or assumptions' that have a specific goal: creating or maintaining a brand identity. https:/www.merriam-webster. com/dictionary/frame\%2oof\%2oreference [accessed 23 January 2019].

2 Brand is a concept that can be defined from two perspectives: the producer's ('a name, term, sign, symbol, or design, or a combination of them which is intended to identify the goods and services of one seller or group of sellers and to differentiate them from those of competitors' (Kotler 1997: 442)) and the consumer's ('a customer experience represented by a collection of images and ideas; often, it refers to a symbol such as a name, logo, slogan, and design scheme' (American Marketing Association Dictionary)). Both definitions underline the essentiality of a sign or a combination of signs that, at least in the consumer's view, is different from other signs or combinations of signs. 
hazy, almost deserted street. On one side, in the front, we see a street lamp and more to the back there are a man and a little boy (father and son, we may presume) who are walking alongside a row of trees that, strikingly, lack branches and leaves. On the left side there is a wall with tree branches above it, suggesting that there is a park behind the wall. On the other side of the street (or avenue), we see a big building and, vaguely, a few cars that can be associated with the post-war period. The picture has an aura of times past and - perhaps most importantly - mystery, due to the 'effects of perspective' highlighted by Ruiz Zafón himself (2008: 23) that reinforce the haziness and sensation of emptiness or loneliness of the street (or avenue) as well as the diffuseness of the father and son figures, whose facial features can hardly be distinguished.

In the light of these observations, it is coherent to assert that the title and the cover illustration of La sombra del viento are polysemic and, concomitantly, suggestive and attractive. So much so that they became a transnational phenomenon: the novel's editions in others languages used a literal translation of the original title (The Shadow of the Wind; L'Ombre du vent; L'ombra del vento; Der Schatten des Windes; De schaduw van de wind; Vindens skugga, etc.) while the cover illustration (or variations) of the Spanish original were used by 'publishers on the five continents' (Ruiz Zafón 2008: 25), which is quite remarkable if we take into account the fact that novels are routinely given different covers in different countries.

To get an idea of the appeal of these two elements of the Zafón brand, it is important to add that the titles and cover illustrations of Ruiz Zafón's next three novels - together, the four novels form the tetralogy El Cementerio de los Libros Olvidados (The Cemetery of Forgotten Books) - are echoes (or variations) of those of La sombra delviento; the titles have the same grammatical structure and similar polysemic, 'poetic' meanings (El juego del ángel/The Angel's Game, El prisionero del cielo/The Prisoner of Heaven, El laberinto de los espiritus/The Labyrinth of Spirits) while three of the four cover illustrations are based on pictures of Català-Roca, the only exception being El laberinto de los espiritus. ${ }^{3}$ Considering the fact that ' $[\mathrm{b}] \mathrm{rands}$ are inherently visual' (Schroeder 2005: 1292), there can be no doubt, then, that La sombra del viento's archetypical title and, most importantly, its archetypical front cover illustration are essential elements of Ruiz Zafón's brand.

As we will show in more detail below, the impact of La sombra del viento's title and cover illustration reaches much farther: they have been emulated many times and in many ways to frame novels written by other (Spanish) 
authors. We are dealing with a common strategy in the book publishing world: 'for lesser-known authors we often make an association with wellknown authors when marketing them. For example, we use front cover reviews by brand name authors, or give them similar recognizable jacket designs' (Royle, Cooper, and Stockdale 1999: 11). The reason is obvious: 'it is possible that familiarity with that design will lead the browser's eye to particular books on the shelves' (Royle et al. 1999: 9).

\section{The Cover is the Key}

At this point, it is vital to look more closely at the role and functions of book covers. To begin with, we should keep in mind the enormous competitiveness in the book market and the concomitant urgency of effective marketing:

publishers [...] have to compete for the time, attention and money of retailers and customers once a book has been produced. The marketplace of books is enormously crowded [...]. Marketing and sales staff devote a great deal of time and effort trying to ensure that their titles stand out from others and are not simply lost in the flood of new books appearing every season. (Thompson 2010: 11)

In this context, brand-name authors 'are extremely important for trade publishers because they provide the counterweight [...] to offset the inherent riskiness of frontlist publishing. [...] [T] heir sales are predictable because they have readerships that are loyal to them.' (Thompson 2010: 212) Book covers are particularly relevant:

A cover often determines whether the book will be purchased. [...] As publishers concentrate on book packaging perhaps even more than the text itself, covers have become more graphically innovative. Covers may not keep a book in print nor in readers' hands, but in the current market, book industry people agree: The cover is the key - the cover sells the book. (Yampbell 2005: 369)

Without denying or neglecting the other functions of book covers (to inform, to familiarize, to direct), it would be correct to say that, primarily, they are designed to attract the attention and to gain and maintain the interest of the consumer (and of other actors involved in the distribution and reception chain, such as book retailers, newspaper editors, literary critics, librarians). 
As Wil Immink, the designer of the De schaduw van de wind cover, asserts: 'Especially the books of lesser known authors need to be recommended. There are, of course, various factors that make a book a bestseller, but the cover plays a very important role' (Lambriks 2009). ${ }^{4}$ This is a role that has become much more important in a market that has become extremely competitive. As Phillips (2007:19) duly affirms, "[t]he importance of the cover to a book's sales is reflected in the growth of the approval process for new designs'. In Clayton Childress's view, 'the "packaging” of books - from their formats to their covers, back-cover synopses, blurbs, and author-photos - is all advertising' (Childress 2017: 132). Branding plays a major role in the process: " $\mathrm{t}$ ] hrough utilizing design, the author is able to be marketed as any other branded product and by using an established and reliable image the author becomes synonymous with a particular design' (Royle et al. 1999: 11).

For various reasons, though, it is debatable that authors can be 'marketed as any other branded product'. First, the nature of books as a product is different from that of products like soft drinks, perfumes, or clothes. Usually, the content of a book is not created by the company (that is, the publishing house) but by a (self-employed) writer. The essential decisions about the product's content - theme, plot, characters, style - are therefore not made by the company. Thus, the author can only temporarily be identified with the company that (re)produces and distributes his text. Second, the relationship between demand and supply is very different. In contrast with soft drinks, perfumes, or clothes, a book is usually consumed only once. But as Thompson rightly remarks, " $r$ ] eaders become "fans" of a particular writer, or of a series of books by a particular writer, and they want to read more' (Thompson 2010: 212). Consequently, if there is an urgent demand for more (of the same), it is not evident that it can be fulfilled.

'They want to read more', but the purchase of the same product can't be repeated. The author is not a factory that can (re)produce his or her product according to customer demand. This explains the Janus-faced politics in the publishing industry:

The staff of every publishing house are constantly looking over their shoulders to see what their competitors are doing. They constantly scrutinize the bestseller lists and study their competitors' more successful books to see whether they can pick up clues about how they might develop their

4 'Het zijn vooral de minder beroemde schrijvers waarbij je een boek echt moet aanprijzen. Natuurlijk zijn er meerdere factoren die bepalen of een boek ook echt verkoopt, maar de omslag speelt een heel belangrijke rol.' 
own publishing programmes. This kind of inter-organizational rivalry tends to produce a degree of homogeneity or 'me-too' publishing among the firms who publish in the same areas - one successful chick-lit book will spawn a dozen look-alikes. But it also produces an intense desire to find the next big thing, as firms are constantly seeking to prevail over their competitors by being the first to spot a new trend. (Thompson 2010: 10)

Two archetypes of books can be distinguished here. On the one hand we have original, trendsetting books with economic and symbolic capital, on the other hand we have derivative, trend-following books with hardly any symbolic capital, published dominantly for commercial reasons. The first category of books can be considered brands, the second category - books framed on the basis of (strong) brands - could be labelled as bandwagon books (Michael Legat, apud Squires 2007: 74) that can develop into a spin-off brand identity. A core element in this process is the front cover: "The reader has read a fine book, when he sees another cover like that he thinks: yes! [...] That cover can give the good feeling' (Witman 2010). ${ }^{5}$ As far as authors from abroad are concerned, book covers can be an even more important, if not decisive, factor in the branding process than in the case of domestic authors, who are much more available for media appearances, who are more acquainted with the specific codes of the national literary field, and who are, therefore, capable of directing or adapting their self-representation or posture. For all these reasons, it is safe to say that the positioning of authors from abroad is predominantly a question of image or hetero-representation.

\section{De schaduw van de wind}

The Dutch translation of Ruiz Zafón's novel was published in the fall of 2004 and became one of the biggest bestsellers of the new millennium in the Netherlands, selling more than 750,00o copies (Witman 2010). It remained in the Dutch Bestseller 60 for 210 weeks, a feat topped only by Kluun's Komt een vrouw bij de dokter (216 weeks) (Chin-A-Fo and Jaeger 2017). Zafonmanía not only established the author and his work in the Dutch literary field but also created a publishing trend: the Zafón lookalike covers. Before going into detail about these covers, a brief comment on the Dutch cover illustration of Carlos Ruiz Zafón's novel is necessary. Like the Spanish edition, it shows

5 'De lezer heeft een fijn boek gelezen, als hij weer zo'n cover ziet, denkt hij ha! [...] Die cover kan het goede gevoel geven.' 
the Català-Roca picture described above, but unlike that edition - which shows the black and white version of the original - the Dutch edition is in a sepia tone, a change that publishing house Signature made to enhance the picture's nostalgic atmosphere, ${ }^{6}$ as Nelleke Geel remembers it. This decision had considerable repercussions, as we will show below: the sepia tone is one of the major features of many look-alike covers generated by the De schaduw van de wind cover, some of which will be scrutinized below. For practical reasons, we will restrict our analysis to the covers of three Spanish authors. The first one, Arturo Pérez-Reverte, was relaunched with De schaduw van de wind lookalike covers after various attempts to find a substantial public for his novels had failed. The second one, Elia Barceló, had published one novel in the Netherlands before the De schaduw van de wind make-over. The third one, María Dueñas, made her debut in the Dutch literary field with a novel that has a cover similar to De schaduw van de wind's. It is my intention to explore these three cases on the basis of the following questions: what was the position of these three authors in the Dutch literary field before their books were framed on the basis of the De schaduw van de wind cover? How exactly were these books framed? What elements of the De schaduw van de wind cover were emulated and how? What elements were left out, added, or changed? And, most importantly, did the position of these authors in the Dutch literary field change after the De schaduw van de wind makeover? If so, in what way?

\section{Arturo Pérez-Reverte}

The publishing history of Arturo Pérez-Reverte's oeuvre in the Netherlands could be summarized in three words: a Sisyphean task. He is, undoubtedly, one of Spain's most translated authors in the Dutch literary system. To date, twelve of his novels and one non-fiction title have been published by a succession of no less than six publishing houses: de Prom, Anthos, De Fontein, Meulenhoff, Karakter, and Wereldbibliotheek. None of them, however, succeeded in finding a substantial public for Pérez-Reverte. It speaks volumes that only two of his novels were reprinted (and, for that matter, only once). This state of affairs raises the following question: how can we explain this remarkably high number of transfers? What were the motives to continue the efforts to establish Pérez-Reverte in the Dutch

6 Telephone conversation with Nelleke Geel, publisher and translator of De schaduw van de wind. 
literary system? The answer is not evident if we consider that not only were sales poor, but this Spanish author had hardly gained any literary capital over the years, either. From the start, the reception of his work in the Dutch media was more benevolent than enthused, both in terms of quantity (the number and volume of the articles were relatively small) and quality (generally, his novels were labelled as middlebrow literature with literary pretensions). In other countries, however, Pérez-Reverte had built a strong reputation. In Spain he is a highly respected literary writer who had made a name for himself as war reporter before becoming one of Spain's bestselling writers and a well-known (and polemic) public figure. More importantly, in other foreign countries (Italy, France, Germany, Great Britain, the US) he has done (and does) well or even very well (Steenmeijer and Grohmann 2006). This strong international reputation must have been the incentive for various Dutch publishing houses to give Pérez-Reverte's work one chance after another, in spite of the accumulation of failed attempts.

De Prom, part of the publishing company Bosch \& Keuning, was the first Dutch publishing house to jump on the bandwagon of Pérez-Reverte's international successes. In 1993, they published Het paneel van Vlaanderen (original title: La tabla de Flandes), followed by two other highbrow thrillers - De club Dumas (1995; El club Dumas) and Het trommelvel (1997; La piel del tambor) - as well as the non-fiction title Comancheland (1997; Territorio comanche) and the historical novel De zon van Breda (2000; El sol de Breda). Then Anthos, also part of Bosch \& Keuning, gave it another shot, republishing De club Dumas (1999), Het trommelvel (2000) and Het paneelvan Vlaanderen (2001). Next, De Fontein, another publishing house of Bosch \& Keuning, published two new titles, De oude zeekaart (2002; La carta esférica) and De koningin van het zuiden (2003; La Reina del Sur). In 2007 Meulenhoff, an Amsterdam publishing house with a solid catalogue of contemporary Spanish American and Spanish literature, published Pérez-Reverte's most 'literary' novel, De schilder van het kwaad (El pintor de batallas). Then, in 2008, Karakter, an independent publishing house of commercial fiction, relaunched Arturo Pérez-Reverte with, on the one hand, new editions of De zon van Breda (2008), De club Dumas (2009), Het paneel van Vlaanderen (2010), and Het trommelvel (2010), and on the other hand five new titles. ${ }^{7}$

7 One of them is the historical novel De geseling van Cádiz (2011; El asedio), the other four are, similar to De zon van Breda, part of the Capitán Alatriste cycle, a series of adventure novels set in Spain in the first decades of the seventeenth century: Kapitein Alatriste (2009; El capitán Alatriste), Zuiver bloed (2009; Limpieza de sangre); Het goud van de koning (2009; El oro del rey); Het gele wambuis (2009; El caballero del jubón amarillo). 
As it is not feasible to analyse all of them in detail here, we will only scrutinize the front covers of Het paneel van Vlaanderen, De club Dumas, and Het trommelvel, the three novels that in the course of the years were launched by three different publishing houses: de Prom, Anthos, and Karakter, respectively. Initially, de Prom's strategy was a very simple one: the front covers of Het paneel van Vlaanderen and De club Dumas are plain emulations of Alfaguara's original front covers, dominated by conspicuous, intriguing, classy illustrations in full colour (Het paneel van Vlaanderen: a woman standing beside a sitting man who is playing chess against the background of church pillars; De club Dumas: a bunch of old books overlapped by a blackand-white photograph of the three musketeers and company), crossed by a black part which mentions the title of the book, the name of the author, and the name of the publishing house, all in white letters. With Het trommelvel, de Prom changed strategy. The sobriety remained - only a genre indication was added ('literaire thriller') - but the classiness and modernity of the first two covers (and of the Spanish edition of La piel del tambor, which continued the design frame of the two previous novels) were lacking: below, we see a hazy picture of an old Mediterranean street (probably in Seville, where the novel is set) in sepia tone, and above there is a blue sky with a few white clouds. The text elements (author, title, publishing house, genre) are placed in the image (and not in a separate part) and printed in typewriter style.

Anthos's new editions of these three novels lack unity as well: De club Dumas (1999) and Het trommelvel (2000) show a dark interior with some light coming in from the window(s) in the background, while the front cover of Het paneel van Vlaanderen (2001) is dominated by a black-and-white photograph of a man sitting on a horse in what seems to be a plaza de toros scene. The only other paratexts are: author, title, and publishing house, with the exception of the anonymous quote on the front cover of De club Dumas.

This variety of designs hints at a trial-and-error strategy. Publishing house Karakter ${ }^{8}$ broke with this trend, opting for consistent and coherent frames for Het paneel van Vlaanderen, De club Dumas, and Het trommelvel that echo the successful De schaduw of the wind brand. Karakter makes no secret of this borrowing strategy: the front cover of De club Dumas, the first

8 Between 2008 and 2012 Karakter published nine novels by Arturo Pérez-Reverte. Two groups can be distinguished: the historical novels and the contemporary novels. The central threads on the front covers of the historical novels - labelled as historical thrillers - are stereotypical images of the commercial historical adventure genre (musketeer-esque men with big hats, swords, and daggers; crosses; old maps). The novels that are set in our times (which, for that matter, are also rich in historical elements) exude an atmosphere that is clearly Zafonesque, which is somewhat ironic considering the fact that Pérez-Reverte is one of Ruiz Zafón's maestros. 
contemporary Pérez-Reverte novel they published, boasts the following quote, attributed to 'Subterranean Press': 'A direct competitor of Zafón's The Shadow of the Wind.' In a screaming flyer headline, the publishing house frames Pérez-Reverte as follows: 'Rises head and shoulders above Zafón." ${ }^{10}$

De club Dumas's front cover image - in sepia tone, needless to say - shows a table with old books in different positions (standing, lying, closed, open) against the background of what appears to be an old wall. Het paneel van Vlaanderen has a similar classy and mysterious atmosphere: in front we have a chess piece (king); in the background, horizontally and vertically, we perceive hazy chessboard patterns in different shades of sepia filled with vague designs. The image on Het trommelvel is the most Zafonian one: on the foreground we see an old-time street lamp, in the background the extremely hazy silhouettes of a huge building, and in between a few people in a park with bare trees. We cannot distinguish their faces, and some of them are sitting on benches; two people, seen from the back, are walking and appear to be talking.

After three novels that were published in a short period of time (2009-2010), Karakter did not continue with the contemporary novel line of Pérez-Reverte's work (and three years later they also gave up the historical novel line). The Zafonian touch clearly had not done the trick. Sales were poor and so was the reception in the Dutch press; there were hardly any reviews, not even of the new novels that were published by Karakter (the Alatriste series, and De gesel van Cádiz). It comes as no surprise, then, that Wereldbibliotheek, Pérez-Reverte's next Dutch publisher, did not continue the Zafón line. It is telling, however, that so far they have only published one title. ${ }^{11}$

\section{Elia Barceló}

In 2005 the Spanish writer Elia Barceló debuted in the Netherlands with the short novel De eeuwige terugkeer van de liefde (The Eternal Return of Love).

9 'Een directe concurrent van Zafóns De schaduw van de wind.' Karakter does make a secret, however, of the quote's misleading, if not fraudulent nature: Subterranean Press is not a medium, as is suggested, but 'a small press publisher in Burton, Michigan [...] best known for publishing genre fiction' (Wikipedia). Their core business are trade editions but they also produce 'collector's and limited editions [...] issued with author signatures, in both numbered and lettered states'. The quote on the cover of De club Dumas refers to Subterranean Press' special edition of Pérez-Reverte's novel, a production that 'will rival ours of Carlos Ruiz Zafon's [sic] The Shadow of the Wind' (website).

10 'Steekt met kop en schouders uit boven Zafón.'

11 Schaduwtango (2012). Original title: El tango de la Guardia Vieja. 
The title is a far cry from the original one: El secreto del orfebre (The Secret of the Goldsmith). The image on the front cover is a soft-focus photo in sepia tone that shows, in profile, the face of a woman and vaguely on the foreground a few flowers. On the back cover the book's content is summarized as follows: 'Is love stronger than time? Can beauty remain?'12 These paratexts leave no doubt as to the way publishing house Signatuur framed De eeuwige terugkeer van de liefde: as a sentimental love story directed at a female reading public.

De eeuwige terugkeer van de liefde did not do well. Unsurprisingly, then, Signature did not publish other works by Barceló. Two years later, publishing house Q reintroduced the Spanish writer in the Netherlands with Balmasqué (2007). This translation was published three years after the Spanish original (Disfraces terribles, 2004) and one year after the German version (Das Rätsel der Masken, 2006). The Dutch cover is completely different from the Spanish and German ones, which are in full colour and show, respectively, an Asian dressed woman 'fighting' with an umbrella annex bat, and the nude back of a woman. The Dutch cover has a sepia tone. In the front we see the contours of a bridge with three old-fashioned street lamps: two big ones and one small one, surrounded by the tiny, shadow-like contours of three people whose traits cannot be distinguished (maybe they are men, but we cannot be sure). In the background the Eiffel Tower rises prominently. Hence, the links with the De schaduw van de wind package are prominently present in the cover's image, and, moreover, they are explicitly expressed in the quote from the Frankfurter Allgemeine Zeitung printed on the front cover's upper right side: 'Carlos Ruiz Zafón's The Shadow of the Wind and Elia Barceló's Bal masqué show that Spain is the country of the great storytellers.'13

Bal masqué was an instant success. In three years' time (2007-2009) fourteen editions were published. After that, it became a slow seller (reprints in 2013 and 2017). Strikingly, in all these years only a minor change was made to the front cover: in 2008 the Frankfurter Allgemeine Zeitung quote was replaced by one from the Dutch edition of Elle. The message, though, was virtually identical: 'For the fans of Carlos Ruiz Zafón's The Shadow of the Wind: Elia Barceló's Bal masqué.'14

Obviously, Q treasured Elia Barceló in its catalogue, publishing a considerable number of her novels. Did Barcelós Dutch publisher continue with

\footnotetext{
12 'Is liefde sterker dan tijd? Kan schoonheid blijven bestaan?'

13 'Spanje is het land van de grote vertellers, zoals De schaduw van de wind van Carlos Ruiz Zafón en Bal masqué van Elia Barceló onomstotelijk bewijzen.'

14 'Voor de liefhebbers van De schaduw van de wind van Carlos Ruiz Zafón: Bal masqué van Elia Barceló.'
} 
the Zafón frame, converting Barceló in a spin-off brand? The question is not easy to answer if we consider the front covers of Tangohart (2008; original title: Corazón de tango) and Stemmen uit het verleden (2009; El vuelo del hipogrifo). The sepia tone dominates both of them, but the images are quite a different matter. On Tangohart we see the sharp and prominent representations of a man and a woman passionately dancing the tango and of a street lamp right behind the two dancers. On the cover of Stemmen uit het verleden there is a panoramic view of Florence which shows a river, a bridge, and historical buildings, but no people. Explicit references to The Shadow of the Wind and Carlos Ruiz Zafón are lacking, however. Instead, both covers mention Barceló's successful Dutch debut: 'From the author of Bal masqué. Paradoxically, then, the Zafón-framed Balmasqué became Barceló's brand, a conclusion that is confirmed by the sepia-toned front cover of the omnibus containing Balmasqué, Tangohart, and Stemmen uit het verleden, published in 2010. It is telling for Q's branding strategy that in this edition, in contrast with the separate editions of these three novels, for the first time Barceló's name is printed in a strikingly larger font than the novels' titles.

This also goes for Barceló's next novels, Donker geheim (2010), Laura (2010), and De kleurvan de stilte (2017). ${ }^{15}$ Another feature that the front covers of these novels have in common, is the prominent reference to Bal masqué. Importantly, there is a third feature they share: the absence of references to the Zafón brand. In fact, the images of these covers are quite a different matter: a staircase of stones that 'flows' into the sea (first two editions of Donker geheim); a woman's head seen from the back (third edition of Donker geheim, a cover of the German cover); the cheek, ear, and hair of (what seems to be) a young woman (Laura); a still of flowers and oranges (De kleurvan de stilte). It is worth mentioning as well that the fifth edition of Stemmen uit het verleden (2011) is not the Zafonian one of the first four editions: we see a woman whose face we cannot distinguish standing between enormous pillars.

On the basis of these data, it might be tempting to conclude that for Donkergeheim, the author's name and the reference to her most successful novel Bal masqué were sufficient elements to constitute a strong front cover brand. However, the striking difference between the sales of Bal masqué and those of all of Barceló's next novels points in another direction: $\mathrm{Bal}$ masqué: sixteen editions; Tangohart: two editions; Stemmen uit het verleden:

15 We have not included Barceló's young adult novel Cordeluna (2012) and her science fiction novel Anima mundi because they do not function in the middlebrow literary segment. 
five editions; ${ }^{16}$ Donker geheim: three editions; Laura: one edition; De kleur van de stilte: one edition. Furthermore, it is revealing that today only two novels of Elia Barceló are shown on Q's website - Bal masqué and De kleur van de stilte - and that the front cover of the first one is printed much larger than that of the second one. A more plausible narrative, then, would be that initially, triggered by the success of Bal masqué, Q tried to brand Barceló as a Zafonian author. After the publication of Tangohart and Stemmen uit het verleden, however, this strategy did not produce the expected results, and other types of front cover illustrations were tested. None of them, however, succeeded in becoming Barceló's new brand, a necessity after it had become clear that the De schaduw van de wind frame had only worked well for Bal masqué.

\section{María Dueñas}

Some book titles seem to be untranslatable. A striking example is El tiempo entre costuras, María Dueñas's 2009 debut that, much to the writer's surprise, sold over a million copies in Spain and, subsequently, was translated in many languages. The richly layered title permits various interpretations. Considering the plot (set in the thirties: a young Spanish woman is cheated on by her husband and left broken in Morocco; she sets up a sewing atelier and subsequently becomes involved in the Spanish Civil War and the Second World War), the most evident translation would be something like 'The time between the sewing', but this version lacks another meaning that resonates in the original title: 'The time between the seams'. The titles of the translations are very different: Italian: La note ha cambiato rumore (2010); German: Das Echo der Träume (2013); French: Le Fil du Destin (2011) and L'Espionne de Tanger (2013); English: The Time in Between (US, 2012) and The Seamstress (Great Britain, 2012).

The title of the Dutch edition, published in 2012 by Wereldbibliotheek, is Het geluid van de nacht (The sound of the night). It has nothing to do with the book's content, but it sounds rhythmic and has a mysterious aura significantly similar to De schaduw van de wind. This is no coincidence, but a deliberate decision made by the editor if we consider the sepia-toned image on the front cover with bare trees, a street lamp and two people with their back turned to us: a man in the background, a woman in the foreground. The link with De schaduw van de wind - absent in the French, German, 
Italian and English editions - is hard to miss and may have contributed substantially to the triumph of Het geluid van de nacht in the Netherlands.

The commercial success of Het geluid van de nacht was capitalized on by Wereldbibliotheek when in 2013 they promoted Dueñas's next novel, $D e$ wereld vergeten (To forget the world; original title: Misión Olvido); on the belly band we see a small reproduction of the cover of Het geluid van de nacht and the following text: 'From the author of Het geluid van de nacht. 50,000 copies already sold'. ${ }^{17}$ The front cover itself, however, hardly shows any De schaduw van de wind traces. A part of it is in sepia tone but the other colours (the blue sky, the woman dressed in black and red) have been given much more prominence. The main echo of Het geluid van de nacht's front image is the woman in the foreground with her back turned to the reader, an element that the De schaduw van de wind cover lacks and that would turn out to be the most distinctive element of Dueñas's front cover brand in the Netherlands. ${ }^{18}$ The full-colour front cover of the Dutch edition of Dueñas's third novel, Het geluk van een wijngaard (2016; original title: La Templanza), leaves no doubt: on the foreground we see a woman dressed in white, looking at a rustic landscape. In the distance, we distinguish the tiny figure of a man, very much like the one on the cover of Het geluid van de nacht. Of course, the tiny figure and the rather kitschy title - which has nothing to do with the original one (it means 'The happiness of a vineyard') but has the same structure as De schaduw van de wind and, for that matter, Het geluid van de nacht - could be labelled as Zafonian echoes. But in this context they function as vintage Dueñas elements due to the lack of other essential $D e$ schaduw van de wind elements on the covers of De wereld vergeten and Het gelukvan een wijngaard (the sepia tone, the trees, the street lamp) and, most importantly, due to the dominating image of a woman looking back that usurps the two Zafonian echoes mentioned above.

With De wereld vergeten and Het gelukvan een wijngaard, then, designer Karin van der Meer developed a different frame for the Dutch editions of Dueñas's novels, which is quite remarkable if we take into account that, so far as sales are concerned, De wereld vergeten did quite poorly. In the marketing process of Het gelukvan een wijngaard, it might have been tempting to turn back to the Zafonian image of Het geluid van de nacht. Instead, Wereldbibliotheek only (re)used the De schaduw van de wind touch in the title and on the back cover, which includes a brief reference to Het geluid van

17 'Van de auteur van Het geluid van de nacht. Reeds 50.ooo exemplaren verkocht.'

18 Curiously, the front cover of the pocket edition of De wereld vergeten (published by Rainbow in 2017) is unmistakably De schaduw van de wind-like. 
de nacht and which, significantly, does not mention De wereld vergeten. This was a clear strategy, as Wereldbibliotheek editor Koen van Gulik explained:

All three novels look back on a life. And just like the text, the cover of Het geluid van de nacht alludes to the thirties in Spain. ${ }^{19}$ The cover of $D e$ wereld vergeten features San Francisco, again just like the book, and the text and image of Het gelukvan een wijngaard allow a dating of around 190o. Every time a woman looking back, every time the same lettering. This way, Dueñas's novels have been given identical features, so as to enable the reader to recognize them more easily. ${ }^{20}$

\section{Conclusions}

Branding authors from abroad is quite a different matter than branding domestic authors, who are much more available for media appearances than foreign authors. More importantly, they usually are not familiar with the specific codes of the literary fields in which the translations of their work function. Consequently, they are hardly able to channel or adapt their self-representation or posture. It could be argued, then, that the position of authors from abroad is most of all a question of image or hetero-representation, a process protagonized by the publisher and the book cover designer.

Having established this link, we might argue that in the case of authors from abroad, book covers can be an important if not decisive factor in the branding process. The successful branding of Carlos Ruiz Zafón's novels in the Netherlands is a paradigmatic case in point. The front cover of his Dutch debut De schaduw van de wind became a classic: it is a crucial element of the Dutch Zafón brand, while essential features of it have been used to frame a considerable amount of other Spanish authors' novels that were launched onto the Dutch market. In this chapter, we have examined three cases: the Zafonian relaunch of an author whose work had already been translated into Dutch but had not managed to gather much economic and/or

19 In fact, this is not as evident as Van Gulik asserts.

20 'In alle drie de romans wordt namelijk teruggekeken op een leven. En net als de tekst refereert het omslag van Het geluid van de nacht aan de jaren dertig in Spanje. Op De wereld vergeten figureert San Francisco, opnieuw overeenkomstig het boek. En bij tekst en afbeelding van Het geluk van een wijngaard kun je een datering rond 1900 voorstellen. Telkens een terugkijkende vrouw, telkens dezelfde belettering, zo hebben Dueñas' titels gemeenschappelijke kenmerken gekregen, opdat de lezer ze makkelijker herkent.' (Van den Berg 2016) 
literary capital (Arturo Pérez-Reverte), the Zafonian makeover of an author with only one book published in the Netherlands that did not do well (Elia Barceló), and María Dueñas, whose successful Dutch debut was packaged in an unmistakably Zafonian way.

As we have seen, publishing house Karakter's generous relaunch of Arturo Pérez-Reverte's fiction did not succeed in changing the Spanish author's position in the Dutch literary field. It is interesting to add that the same pattern can be seen in the cases of Eduardo Mendoza and Antonio Muñoz Molina, which for reasons of space could not be elaborated on in this chapter. Like Pérez-Reverte, Mendoza and Muñoz Molina are two leading Spanish authors with a considerable catalogue of Dutch translations that were fairly well received in the Dutch press but that did not sell well (the exception being Mendoza's steady seller De stad der wonderen): the Zafonian (re) framing of the covers of some of their novels did not alter their position in the Dutch literary field. ${ }^{21}$

Tellingly, the Zafonian touch did work well in the cases of two authors who were (almost) completely unknown in The Netherlands: Elia Barceló and María Dueñas. Thus, tentatively, we might conclude that as far as book covers are concerned, the framing of authors by emulating successful cover brands seems to have the best chance to succeed in the case of 'new' authors. This assumption, however, needs to be qualified. Elia Barcelós and María Duenas's cases suggest that if framing in the footsteps of a successful brand works well, it only does so in the short term. For a strong position in the long run, a non-emulative brand appears to be required. Elia Barceló's Dutch publisher Q made various strikingly different attempts, but they all failed to create a strong brand of her own. Wereldbibliotheek, on the other hand, developed a consistent strategy in its endeavour to create a sovereign brand for María Dueñas, though it remains to be seen if their efforts will pay off: her second and third novel fared less well as far as sales figures are concerned than Het geluid van de nacht.

In more general terms, we could say that emulating strong cover brands appears to be most effective in the short term. This even goes for Carlos Ruiz Zafón himself: the covers of Het spel van de engel, De gevangene van de hemel, and Het labyrint der geesten - the other three novels of the tetralogy The Cemetery of Forgotten Books - were designed in the footsteps of the cover of De schaduw van de wind, but these novels were not as successful, not in economic terms and not in symbolic terms. This, of course, cannot

21 Another case in point is Ignacio Martínez de Pisón, a minor literary god whose third Dutch translation (De dag van morgen, 2013) was framed in a clearly De schaduw van de wind way. 
only be attributed to the cover designs, but it is indisputably a relevant factor, the more so if we take into account that we are dealing with an author from abroad.

\section{References}

Erik van den Berg. 2016. 'De rug is haast een beeldmerk geworden'. de Volkskrant 14 May. https://www.volkskrant.nl/nieuws-achtergrond/de-rug-is-haast-eenbeeldmerk-geworden $\sim$ bof7e $7 \mathrm{~b} 6 /$ [accessed 24 April 2019].

Clayton Childress. 2017. Under the Cover. The Creation, Production, and Reception of a Novel. Princeton, New Jersey: Princeton University Press.

Hanneke Chin-A-Fo and Toef Jaeger. 2017. 'De romans moeten inschikken'. nrc.nl 23 March. https://www.nrc.nl/nieuws/2017/03/23/de-roman-heeft-het-moeilijk7528441-a1551554 [accessed 24 April 2019].

Lindy de Jong. 2019. 'De zomerhit van 2005: De schaduw van de wind'. Hebban. nl. https://www..nl/artikelen/de-zomerhit-van-2005-de-schaduw-van-de-wind [accessed 24 March 2019].

Philip Kotler. 1997. Marketing Management. 7 th ed. Englewood Cliffs, NJ: Prentice Hall.

Lars Lambriks. 2009. 'Ontwerp van bovenste plank'. De Limburger 12 December, p. 2. Angus Phillips. 2007. 'How Books Are Positioned in the Market: Reading the Cover'. In Nicole Matthews and Nickianne Moody (eds.),Judging a Book by its Cover. Fans, Publishers, Designers, and the Marketing of Fiction, pp. 19-30. Hampshire: Ashgate.

Jo Royle, Louise Cooper and Rosemary Stockdale. 1999. 'The Use of Branding by Trade Publishers: An Investigation into Marketing the Book as a Brand Name Product'. Publishing Research Quarterly 15.4: 3-13.

Carlos Ruiz Zafón. 2008. 'Foreword'. In La Barcelona de Català-Roca, pp. 23-25. Barcelona: La Magrana/Adjuntament de Barcelona.

Jonathan E. Schroeder. 2005. 'The Artist and the Brand'. European Journal of Marketing, 39.11-12: 1291-1305.

Claire Squires. 2007. Marketing Literature. The Making of Contemporary Writing in Britain. Hampshire/New York: Palgrave MacMillan.

Maarten Steenmeijer and Alexis Grohmann (eds.). 2006. Más allá de Cervantes y Lorca. El éxito de la literatura española actual en el extranjero. Dossier bestseller español, in Quimera 273 (July-August): 24-66.

Maarten Steenmeijer. 2017. 'The Postnational Reception of Carlos Ruiz Zafón's $L a$ sombra del viento'. In Heike Scharm and Natalia Matta-Jara (eds.), Postnational Perspectives on Contemporary Hispanic Literature, pp. 187-200. Gainesville: University Press of Florida. 
John B. Thompson. 2010. Merchants of Culture. The Publishing Business in the Twenty-First Century. Cambridge, UK/Malden, MA: Polity Press.

Bob Witman. 2010. 'De lezer die zo'n cover ziet, denkt ha! Twaalf nominaties voor de mooiste cover van 20o9'. de Volkskrant, 12 February.

Cat Yampbell. 2005. 'Judging a Book by its Cover: Publishing Trends in Young Adult Literature'. The Lion and the Unicorn 29.3: 348-372.

\section{About the Author}

Maarten Steenmeijer is Professor Emeritus of Modern Spanish and Spanish American Literature and Culture at Radboud University Nijmegen and specializes in reception and translation studies. His latest book publications include Moderne Spaanse en Spaans-Amerikaanse literatuur. Een geschiedenis (2009); Allí donde uno diría que ya no puede haber nada. Tu rostro mañana de Javier Marías (2009, volume edited with Alexis Grohmann); Schrijven als een ander. Over het vertalen van literatuur (2015); and Golden Earring in 50 Songs. Biografie van een band (2017). In 2020 he published Javier Marías, el best sellery otros capitales de la literatura española actual en Europa: estudios de recepción. 


\title{
'The Most Successful Writer of the Netherlands'
}

\author{
On the Success Myth of Dutch Bestselling Author Herman \\ Koch
}

Sander Bax

\begin{abstract}
Since the success of his bestseller novel The Dinner in 2009, Dutch literary writer Herman Koch has been branded as 'the most successful writer of the Netherlands'. In his media coverage, we encounter a narrative about his career that has all the characteristics of the 'success myth' of the contemporary celebrity. What can the construction of Koch's success myth tell us about the norms that actors and institutions of the public media use when they talk about literature? How do Koch and his critics deal with the tension between different ways of contributing value in the literary field? And does Pierre Bourdieu's conceptualization of the 'economic world reversed' still suffice to describe the distribution of capital in today's literary fields?
\end{abstract}

Keywords: literature, bestseller authorship, celebrity culture, literary field, capital

\section{Introduction}

Since the success of his bestseller novel The Dinner in 2009, Dutch literary writer Herman Koch has been often branded as 'the most successful writer of the Netherlands'. In media coverage of his work and his authorship, we encounter a narrative about his career that has all the characteristics of what the editors of this volume label an 'identity myth'. The narrative is titled: how

Helleke van den Braber, Jeroen Dera, Jos Joosten, and Maarten Steenmeijer (eds), Branding Books Across the Ages: Strategies and Key Concepts in Literary Branding. Amsterdam, Amsterdam University Press 2021 DOI: 10.5117/9789463723916_CHo9 
a serious literary writer becomes an internationally acclaimed bestseller author. From 1985 onwards, Koch used to publish his serious literary novels with publishing houses Meulenhoff and Augustus. These novels were praised by literary critics, but they did not sell well. When Koch decided to transfer to a more commercially oriented publishing house (Ambo|Anthos), he became a bestseller author and one of the most successful writers in the Netherlands. When The Dinner later turned out to be an internationally successful novel (it was translated and published in the United States and there were rumours about a film directed by actress Cate Blanchett), Herman Koch became the most successful writer in the Netherlands.

This 'identity myth', which is a 'success myth' as well, is narrated time and again in interviews with or reports about Herman Koch in the Dutch public media (Jinek 2012, Van Rhee 2014; Anon. 2014; Hustinx 2014; Bakker and Iedema 2014; Koelewijn 2014; De Veen 2014; Rozenbroek 2014; Van Velzen 2014). The success of his novel appears to turn Koch into one of the most appreciated and canonized authors of twenty-first century Dutch literature. In my contribution to this volume, I would like to explore what the construction of Koch's success myth can teach us about the norms that actors and institutions of the public media use when they talk about literature. In this contribution, I will not unravel the complex interplay of writers, agents, publishers, and others that branded Herman Koch as the Netherlands' most successful writer. Instead, I will focus on the question why literary journalists and interviewers of literary writers are so fascinated by writing about the marketing and branding of authors. Does the (journalistic) unravelling of the economic process that was involved in the construction of Koch as a bestseller author contribute to his success myth? What is the implication of the fact that public media define literary success mostly in quantitative terms (Bax 2019)? And how does that influence dominant conceptions of literature? ${ }^{1}$

Theoretically, this contribution will focus on the interplay between economic and symbolic interests. How does Koch - and how do the critics

1 My answer to these questions is based on a discursive close reading of interviews with Herman Koch, portraits of Herman Koch, and reviews written about his work (The Dinner, Summer House with Swimming Pool and Dear Sir M.) between 2007 and 2014 as retrieved from the database Literom. This close reading was performed in the context of a bigger project about the literary writer in twenty-first century media culture. The results of this project have been published in Bax 2019. I will pay special attention to two journalistic texts in two different newspapers (a Dutch right-wing, populist newspaper and a Dutch liberal weekly), both of which made a reconstruction of the success of The Dinner: one by Annet de Jong in De Telegraaf and one by Jeroen Vullings in Vrij Nederland (De Jong 2013 and Vullings 2013). 
who position Koch - deal with the tension between different ways of value contribution in the literary field? I will focus on the tension between the order of 'the economical world reversed' we know from the work of Pierre Bourdieu on the one hand and a more 'regular' business orientated economical order on the other that appears to gain more dominance in the field of publishing at the beginning of the twenty-first century. ${ }^{2}$ Does the model of the 'economic world reversed' still suffice to describe the distribution of reputation and capital in a literary field in which literary success is increasingly framed as quantitative, financial success?

\section{Publishing industry and attention economy}

The increase in attention for the success of literary writers points at an important change in literary history: in the contemporary literary field, it appears that displaying financial success is no longer an issue for gaining literary recognition. In earlier literary periods, writers were used to downplaying their commercial success in order to gain more literary (symbolic) success ('it sells well, I know, but it is a good book as well'). At the beginning of the twenty-first century, high sales figures were more often seen as a sign of literary quality. The relation between literature and market appears to be changing fundamentally.

If we search for possible causes of these changing norm systems, we should take into account the massive transformations in the publishing industry of the last thirty years or so. In Merchants of Culture, media sociologist John B. Thompson shows the huge changes in market shares in the American publishing industry: independent bookstores lost a lot of space in favour of just a few big retailers.

It is a shift in which a handful of major retailers - Barnes \& Noble, Borders, Amazon and, for certain kind of bestsellers, Costco, Wal-Mart, Target and Sam's - emerged as the key customers for publishers and as key players in the struggle to gain visibility for books and bring them to the attention of consumers in an increasingly crowded marketplace. This small set of key retailers has come to wield enormous power in the field of trade publishing, since publishers do not sell directly to consumers but depend increasingly on these retail giants to make their books available to consumers and encourage them to buy. (Thompson 2011: 50) 
This new constellation has a number of consequences: publishing houses become part of bigger media companies that are forced to increase their sales volume further every year (due to the shareholders). These media companies are always on the lookout for what they call 'big books': books with bestseller potential (Thompson 2011: 187-221). In his chapter 'The Wild West', Thompson illustrates how important bestseller lists have become for publishing houses. In Great Britain, publishers cut unprofitable deals with supermarket giants because they know how important supermarkets are in making bestsellers. In the United States, there are different problems: Thompson mentions the high advances that are the result of the increasing influence of literary agents. In both cases the profit margins of publishing houses are under pressure and that makes publishing bestsellers even more urgent.

The phenomenon of 'buzz' has become important, because nobody knows beforehand whether a potential big book will turn out to be an actual bestseller. A buzz creates a 'web of collective belief' about the success of a book. This is how publishers and their marketeers try to 'make' bestsellers. Important factors in such a buzz are information about the sales of earlier books by the same author, information about comparable books, the platforms and networks the author has, and the image of the author in the media, among literary critics, and among the public. Thompson makes explicit that for publishers it is easier to sell the books by 'brand-name authors'. Their sales figures are predictable (they have fans!) and they tend to repeat themselves: both factors make success easier to predict.

In a market in which more and more books are being published, it becomes increasingly hard to create attention for a book. Publishers look for alternative forms of marketing. Ads and signing sessions become less important, as publishers and authors are searching for a more direct connection with the targeted readers for the book. They use old and new media to achieve this (Thompson: 2011 242-224). When it comes to branding, we notice that authors as media figures play a crucial role in ensuring people start talking about a book. 'Publishers will often target what they call, rather ungraciously, "big mouths" - anyone they can think of who has some position of influence, whether they are review editors or feature writers or agents or opinion leaders of some kind, “just people who talk a lot”, as one publisher put it' (247).

In creating such a 'buzz', several actors and institutions are involved. Booksellers that talk positively about a book, readers that write about it on their blogs and on social media, public figures that talk about the book in mass media, appearances of the author on radio and television shows, interviews in dailies and weeklies, the actions of authors in their own networks. Publishers try to create buzzes by sending pressure tests to influential 
people. Then, when the book is finally out, the sales figures are monitored very precisely. Thompson claims that the six-weeks rule is crucial here: the first six weeks determine whether a book will sell or not. If not, there is no need to put any effort in that book anymore (Thompson 2011: 312-368).

The contemporary publishing industry functions under the umbrella of what cultural theorist Mark Fisher has coined as 'capitalist realism', which is the dominant economic logic that determines our society. Fisher uses the word 'realism' to point at the fact that capitalism presents itself as the natural order. When capitalism is considered to be the natural and best way to run a society, it logically follows that you should organize all components of society according to this order. 'Over the past thirty years, capitalist realism has successfully installed a "business ontology" in which it is simply obvious that everything in society, including healthcare and education, should be run as a business' (Fisher 2009; Laermans 2011a and 2011b).

As a result, the media (the public domain in general) and the cultural and literary fields were increasingly being organized as businesses. In the course of the 1980 s and 1990s, journalists' success was increasingly being measured by viewer ratings, educational success by student numbers, and diploma outcome; and artists and writers were being stimulated to become successful cultural entrepreneurs. As entrepreneurs, they search for attention and recognition in what sociologist Rudi Laermans has called the 'attention economy'. In our current information society, we have to deal with great amounts of information that want our attention. In this battle for attention, media play a crucial role as intermediaries that 'aggregate' attention (Laermans 2011a). Attention (one can think of the number of social media followers or viewer ratings) is sold to advertisers and has thus become one of the main economic principles of the twenty-first century (Laermans 2011a. ${ }^{3}$ Contemporary capitalism, therefore, characterizes itself by the 'captivation, aggregation and modulation of attention' (Laermans 2011a: 112).

\section{The Reversal of the 'Economic World Reversed'}

There is a growing tendency in contemporary literary fields towards an economic logic that perceives literary texts as products that have to be sold

3 'In order to attract and grip attention, mass media create a permanent agitation by spreading bad news, gossip or 'must see'-cues. They produce 'synchronizing hysterias and homogenizing panics' in view of a minimum of tension that can raise and sustain attention; the net outcome are 'self-stressing ensembles' or 'excitement communities' (Laermans 2011a: 115-132, 127.) 
on the market similar to other regular products, using authors' images as brands. This tendency is directly opposed to historically developed conceptions of literature that consider the literary novel as something different (higher, better, more universal) than 'just a book'. Literary writing (and publishing as a consequence) has been regarded for long as an activity that ought to free itself from direct and explicit economic constraints. "The literary and artistic world is so ordered that those who enter it have an interest in disinterestedness' (Bourdieu 1993: 40). From these conceptions of literature, the idea has grown that the literary field is functioning 'relatively autonomous' from the societal, the political, and the economical fields.

As a cultural sociologist, Bourdieu tried to describe and analyse the functioning of several fields and their autonomy in order to lay bare the economic principles that were hidden behind what to his mind was a denial of economic laws. Later in his career Bourdieu took a more political stance. His essay On Television has become famous for its intense critique of the commodification of cultural products and the use of audience ratings and marketing models in journalism (Bourdieu 1996a: 27-28; Bourdieu 2003; Bourdieu 2008). According to Bourdieu, all great achievements of the human mind (mathematics, poetry, literature, philosophy) were produced against the market (Bourdieu 1996a: 27-28). Bourdieu predicted in this essay that the logic of audience ratings and sales numbers would have a decisive influence on the domains of culture and media - I believe Thompson's book proves him right.

We might say that Bourdieu witnessed (and commented on) the slow disappearance of the 'reversed economic world' that was central in his own work and that had determined the discourse on art and literature for a significant part of the nineteenth and twentieth century. In his famous works La Distinction and Les Règles de l'art, Bourdieu claimed that in the fields of literature and culture a different economic game is being played (Bourdieu 1984; Bourdieu 1993; Bourdieu 1994; Bourdieu 1996b; Dorleijn and Van Rees 1993; Dorleijn and Van Rees 2006; Verdaasdonk 2008; Praat 2014). This economic game is made possible by a 'collective belief' - a belief shared by all actors in the literary and cultural field - that produces an 'illusio': everyone beliefs that the artist - and therefore the artwork - is exceptional. Bourdieu lays bare the fact that the quality of the literary work (or of the painting for that matter) is not something that is determined by the intrinsic characteristics of the work, but by the collective belief that becomes manifest in the behaviour of the actors in the literary field that deal with the work. Actors create a 'charismatic ideology' in this game: the myth that claims that the author is a genius and a creator. 
In Les Règles de l'art, Bourdieu described how this 'island' (the 'relatively autonomous' literary field) came into being in the nineteenth century. Since then, artistic and cultural fields have always been divided into two subfields that are each other's antagonist. On the one hand, there is a 'field of restricted production' that is driven by an 'anti-economic economy of pure art'. In this field, the most 'autonomous' actors are active. Opposing this field, there is a 'field of large-scale production', in which the 'economic logic of literary and artistic industries' is dominant. In this field, we encounter more 'heteronomous' authors (Praat 2014: 37). This economic world is reversed, because in the literary field 'economic capital' is not the only, and even not the main, kind of capital that can be earned. In artistic and cultural fields, there is also something like 'symbolic capital'. That is capital in the form of legitimization. Actors in the literary field possess a certain amount of cultural capital (that is determined by their cultural competences and by their artistic reputation) and this cultural capital can take the form of symbolic capital: when the reputation of the artist grows (with positive reviews, literary prizes), this has a positive effect on an artist's reputation. In the literary field, recognition, appreciation, and reputation are the most important keys to capital.

In the 'field of restricted production', symbolic capital is worth more than economic capital: the literary field denies the rules of regular economy and it functions as a 'reversed world' in which commercially successful authors are blamed for their success: an increase in economic capital has a negative effect on the awarded symbolic capital. Commercial success was therefore not the most important key to a big reputation as a literary writer in certain periods in literary history (at least the era from c. 1850-1980). The idea was that writers suffered for their art during their lifetimes in the firm belief that consecration and economic success would be awarded posthumously.

In his important $\mathrm{PhD}$ thesis about the authorship of Dutch writer and public figure Gerard Reve, literary scholar Edwin Praat points out the fact that in the second half of the twentieth century, several artistic revolutions took place that questioned Bourdieu's 'fundamental rules of the game'. Since then, this binary organization of cultural fields might no longer be applicable. Influences from outside the literary field were not the only ones that made these changes possible: Praat $(2014: 46)$ demonstrates that several important writers and artists have tried to change the rules of the game themselves. In the second half of the twentieth century, many literary writers became famous media figures, both in the Netherlands and internationally (Dyer 1998; Moran 2005; Franssen 2010; Heynders 2016; Franssen and Honings 2017). These writers became famous celebrities within 
popular culture, which influenced the way they looked at their profession (Collins 2010). They refused to deny their fame and their economic success, and they broke several of the unwritten rules that used to be central to the economic world reversed. They made their economic success a part of their artistic self-image. By openly breaking with the binary organization of the literary field, international 'star authors', such as Hemingway, Mailer, and Roth; and Dutch 'star authors', such as Reve, Mulisch, and Wolkers, have actively contributed to the reversal of the economic world reversed (Dyer 1998; Moran 2005; Franssen 2010, Heynders 2016; Franssen and Honings 2017).

\section{The Most Successful Writer of the Netherlands}

In May 2014, Koch's novel Dear Mr. M (Geachte heer M) was published. The release of the book was accompanied by a series of interview sessions at the publishing house on the Herengracht in Amsterdam (Desloover 2014).

Ever since The Dinner (2009), a new Herman Koch is 'an Event'. [...] Time management is necessary, since the world has become Koch's playfield: presenting a new book here, doing a promotion tour in the US, where Summer House with Swimming Pool is presented and where Cate Blanchett is screening The Dinner. That novel still works: with more than one million copies, it is the most translated Dutch novel there is. (Desloover 2014) ${ }^{4}$

In the critical and journalistic reception of Dear Mr. $M$, a novel that would turn out to be much less successful than The Dinner, we encounter several aspects of Herman Koch's success myth. First of all, we notice that success is defined in quantitative terms and in terms of celebrity culture (The Dinner sold 1.5 million copies, the novel was translated in 33 languages, it 'won' the NS Publieksprijs, it was on The New York Times' bestseller list, and there was a rumour that acclaimed actress Cate Blanchett wanted to adapt the novel as a film). In those same weeks in 2014, Koch's novel Summerhouse with

4 'Sinds Het diner (2009) is een nieuwe Herman Koch "Een Gebeurtenis". [...] Timemanagement is noodzakelijk, Kochs speelterrein is nu de wereld: hier een nieuw boek lanceren, straks een promotour door de VS, waar Zomerhuis met zwembad verschijnt en waar Cate Blanchett Het diner zal verfilmen. Dat boek is nog altijd niet uitgezongen: ruim één miljoen verkochte exemplaren, en de meest vertaalde Nederlandse roman ooit.' (Desloover 2014) 
Swimming Pool was published in the United States, which is the translation of the novel Koch wrote as a successor to The Dinner.

Koch's American 'discoverer', Alexis Washam from Hogarth and Crown Publishers, tells us she has had 70,000 copies of Koch's latest novel printed right away. That differs from the situation with The Dinner, of which she had just 12,000 copies printed initially. 'We came back to that quite soon of course. In the US, The Dinner now has a print run of 300,000 copies. I never would have thought that it would be such a success.' 'It was world news in the Netherlands. They celebrated it as if I had won a gold medal at the Olympics,' Koch laughingly tells his American public. (Hustinx 2014) ${ }^{5}$

In this quotation the journalist emphasizes many quantitative numbers. Sales numbers equal success and success equals recognition: the business ontology in optima forma. Furthermore, Koch presents himself in most Dutch media performances as a successful star author. The mentioning of Koch's international success becoming 'world news' in the Netherlands and the use of the word 'gold medal' show how Koch frames the success of his translation as a form of recognition from a global celebrity culture ('world news', 'Olympics'). A frame that has a big influence on the image the Dutch public has of Koch.

Bestselling author Herman Koch has earned a lot of air miles due to the international success of The Dinner. He 'chatted a bit' about his book in Stockholm, recently underwent the 'shit weather' of Reykjavik, visited bookstores in Moscow and Beijing, and he took his wife to the South American pressure cooker Buenos Aires. [...]

'I really like that kind of life. Beautiful hotels, good food, transport from A to B, you don't have to worry about any thing yourself. In other words: feeling like a film star. That's actually really nice. Except when I travelled to Amsterdam, Istanbul, Helsinki, Dublin, and London in a short time span. Then you become like a pop group that travels too much and you

5 'De Amerikaanse “ontdekster" van Koch, Alexis Washam van uitgeverij Hogarth and Crown, vertelt dat ze meteen maar 70.000 exemplaren heeft laten drukken van Kochs nieuwste roman. Anders dan bij The Dinner, waarvan ze in eerste instantie een voorzichtige 12.00o liet vervaardigen. "Daar kwamen we natuurlijk snel op terug. De oplage van The Dinner telt hier in de VS inmiddels 300.0oo exemplaren. Dat het zo'n succes zou zijn, had ik nooit kunnen vermoeden." “In Nederland was het wereldnieuws, het werd gevierd alsof ik een gouden medaille had gewonnen bij de Olympische Spelen," vertelt Koch zijn Amerikaanse toehoorders lachend.' (Hustinx 2014) 
want to lie down in your own bed. Since then, I only do trips that last no longer than five days.'

The Dinner - published in 39 countries, with 575,000 copies sold in the Netherlands - not only turned him into a chronic globetrotter, but it also made him financially independent. (Van Rhee 2014) ${ }^{6}$

The literary celebrity travels to a lot of different countries and earns a lot of money. Koch compares his life as a twenty-first century star author with the life of a film star or a pop group. His economic success gives him what is necessary for writing: freedom and independence.

In these quotes, we see a blending of what Jérôme Meizoz would call auto-representation and hetero-representation: Koch is presented here as a successful twenty-first century literary celebrity, and that coincides with the way he wants to present himself (Meizoz 2010). Image and posture go hand in hand. In Koch's media performances, the economic world reversed starts to play a complex role. In interviews, the writer himself constantly refers to this economic order. He mentions how people in the literary field tend to react critically (in his view mostly stemming from jealousy and vindictiveness) to his 'bestseller logic'.

Every writer who says: 'I don't have to write a bestseller' is not being honest. A bestseller is the best thing that can happen to you, if only because it has given me the freedom to do whatever I wanted for years. The downside of this success is that some people suspect that you have pandered to a certain level of readers. They tend to forget that very good books become bestsellers, too. Everywhere in the world it is the same: they like you as long as you sell no more than 5,000 to 10,000 copies. Then they say: 'How nice, a lot of quality, it is a pity that so few people know

6 'Bestsellerauteur Herman Koch grossiert door het internationale succes van Het diner in airmiles. Hij "babbelde wat" in Stockholm over zijn boek, zat onlangs in "het tyfusweer" van Reykjavik, bezocht boekwinkels in Moskou en Peking en nam zijn vrouw mee naar de Zuid-Amerikaanse snelkookpan Buenos Aires. [...]

"Ik vind dat leven echt leuk. Mooie hotels, goed eten, vervoer van a naar b, je hoeft zelf nergens over na te denken. Kortom: het filmsterrengevoel. Eigenlijk wel heel lekker. Behalve toen ik achter elkaar Amsterdam, Istanbul, Helsinki, Dublin en Londen deed. Dan ben je ineens zo'n sufgereisde popgroep en wil je in je eigen bed liggen. Sindsdien ga ik voor zulke trips niet langer dan vijf dagen van huis."

Het diner - in 39 landen verschenen, 575.00o verkochte exemplaren in Nederland - zorgde er niet alleen voor dat hij een chronische globetrotter werd, hij mag zich ook financieel onafhankelijk noemen.' (Van Rhee 2014) 
how good you are.' But when suddenly 200,00o people think you're good, you don't hear from them anymore. (Jinek 2012) ${ }^{7}$

Two things happen simultaneously in this quote. Koch refers to a literarycritical mechanism that results from what Bourdieu has called the 'reversed economy'. On the one hand, the quote illustrates that this mechanism still exists in the way writers and critics react to Koch's status as a bestseller author. On the other hand, Koch tries to turn this logic around and presents it as a negative frame that is only used by unsuccessful and vindictive colleague writers. The natural situation, according to Koch, is that 'very good books become bestsellers, too'. His logic therefore is: 'A bestseller is the best thing that can happen to you'. This is a mechanism we not only encounter in the Herman Koch interviews but also in many interviews with (more or less successful) literary writers at the beginning of the twenty-first century. They tend to refer to the 'reversed economy' - they are aware of the existence of the norm and by mentioning it they underline that it still exists in some kind of way - but they refer to the norm in order to deconstruct it.

To a celebrity author such as Herman Koch, Bourdieu's 'reversed economy' is no longer directional. It becomes evident from my analysis of the Dutch reception of Koch's novels The Dinner, Summer House with Swimming Pool, and Dear Mr. M that economic capital can be turned into symbolic capital as well at the beginning of the twenty-first century. Both interviewers and reviewers refer to Koch's sales figures when they try to make a case for the importance of his authorship.

\section{Success Stories}

One of the reasons for this change is the fact that the public media are fascinated with success stories and success myths. We can derive that from the example of two long reads in which literary journalists search for 'the secret of the success' of The Dinner. In October 2010, Jeroen Vullings

7 'Elke schrijver die zegt: "Ik hoef geen bestseller te schrijven", spreekt niet de waarheid. Een bestseller is het beste wat je kunt hebben, al is het maar vanwege de vrijheid waardoor ik bijvoorbeeld jarenlang heb kunnen doen wat ik wilde. De keerzijde van het succes is dat sommige mensen vermoeden dat je een knieval voor een bepaald niveau lezers hebt gemaakt. Ze vergeten voor het gemak dat ook hele goeie boeken bestsellers worden. Overal ter wereld is het hetzelfde: iedereen vindt je aardig zolang je 5000 tot 10.000 boeken verkoopt. Dan zeggen ze: "Wat leuk, wat een kwaliteit, wat jammer dat zo weinig mensen weten hoe goed jij bent". Maar als ineens 200.000 mensen je goed vinden, hoor je ze niet meer.' (Jinek 2012) 
published his article in the liberal weekly Vrij Nederland under the title: 'The Dinner: not a surprise success!'. In November 2011, Annet de Jong published a comparable article in De Telegraaf. Vullings is known in the Netherlands as a literary critic with a long career and a lot of cultural prestige. De Jong is a literary journalist and an author. She writes for a more popular right-wing Dutch newspaper (De Telegraaf) with less cultural capital.

In each article, we notice that both economic capital and cultural capital are at stake. We also see that the two forms of capital are intermingled more than we might expect. The central question that arises from both is whether The Dinner's success can be explained from the qualities of the text itself or from the marketing that surrounded the book. This question is fueled by what I mentioned earlier: The Dinner was the first novel that Koch published with publishing house Ambo|Anthos. Koch chose this publishing house deliberately, for they always had been able to reach a large audience for the literary thrillers in their catalogue. In doing so, he made an attempt to reposition his authorship. Did he succeed in that?

In her article, De Jong sums up various external success factors. She mentions the huge marketing budget that the new publisher used for his novel $(€ 100,000)$. They also managed to create a buzz on social media even before the book was in the stores. They successfully managed to sell the rights for the translation at the Frankfurter Buchmesse. De Jong also points out the famous cover with the orange lobster against a blue background, which gave the book a visual brand. The image in itself does not relate to the content of the novel (the association is probably that one eats lobsters in posh restaurants). De Jong indicates that the cover provided the book with a visual and recognizable sign, since there were not many books with such a cover at the time. The publisher has been using this style in the covers of Koch's other books and in reprints of his earlier work. In that sense, the cover image becomes part of the author image of Koch. A final and probably crucial factor was the fact that Herman Koch had been a television personality in the 1990s. All these factors together turned the book - according to De Jong - into a success before it was even in the bookstores. These factors make a case for the argument that the success of the novel was caused by smart marketing and branding.

De Jong does mention several internal qualities of the novel as well. Firstly, she mentions aspects that we might relate to the 'bestseller format' of contemporary successful literature, such as the readability of the book: it is an approachable ('toegankelijk') book, plot-driven, and it is a 'good read'. Secondly, she mentions aspects that we might sooner link to more classic twentieth-century literature, such as the confrontational ethical theme (evil, 
politics, genetics) of the novel, the idea that it has 'universal power', and that it challenges readers to think about how they would have reacted themselves. De Jong emphasizes that the novel speaks to two different audiences at once: it is suitable for an 'elite public' ('de grachtengordellezer') and it is suitable for 'average readers'. In this combination of the elite reader (whom we may expect to recognize the author's cultural capital and who might provide the author with symbolic capital) and the average reader (who is in fact the consumer who buys the book and, in doing so, delivers economic capital), we again encounter an echo of Bourdieu's dichotomous model.

Jeroen Vullings conducts an interview with Koch's publisher Chris Herschdorfer (publisher-director of Ambo|Anthos), who speaks of 'an unprecedented record for the modern Dutch novel', ${ }^{8}$ and with literary agent Willem Bisseling, who mentions the fact that Cate Blanchett might be involved with the film: 'Such celebrities are only interested in projects that will generate more success. Its impact on Koch's novel will be huge' (Vullings 2013). ${ }^{9}$ Bisseling points out the 'bestseller logic' here: celebrities only attach themselves to things that are already successful and by doing so continue the accumulation of success.

In the interview Herschdorfer reveals that Koch approached a new publisher because he was searching for a 'different approach' in order to 'reach more readers': 'He didn't think of Ambo|Anthos at first because we don't have a large Dutch catalogue. However, he noticed many of our translated novels on his bookshelves, he liked the covers, and he could see the marketing drive behind them' (Vullings 2013). ${ }^{10}$ Koch himself underlines this quote and says he made the change mainly in order to sell his work to a higher number of readers. Of course, the author wants us to take note that his earlier work sold quite well already, but that he has become even more successful in later years:

'I had three wishes. Most of my books sold between 8,000 and 15,000 copies, sometimes maybe 20,000 . It would be nice, I said, if we could sell 25,000 copies of The Dinner. I also wanted my books to be reprinted, preferably in a recognizable series. Lastly, I really wanted a book of mine to be translated for once, it didn't matter which one. Chris said: "We will

8 'een ongekend record voor een modérne Nederlandse roman'.

9 'Zulke beroemdheden komen alleen op iets af dat nóg meer succes genereert. De impact daarvan op Kochs roman wordt énorm.'

10 'Hij dacht daarbij niet meteen aan Ambo|Anthos, omdat we niet van oudsher een groot Nederlands fonds hebben. Maar hij zag veel vertaalde boeken van ons in zijn kast, de omslagen spraken hem aan en hij kon zien dat er een marketing drive achter zat.' 
take care of that." Later he confessed to me: "I bluffed about being able to sell 25,000 copies." He hadn't even read a manuscript of mine yet at that point.' Herschdorfer confirms this, but states: 'In terms of marketing, his work clearly had a lot of potential. ${ }^{11}$ (Vullings 2013)

In the interview, both publisher and author emphasize the external factors: the main difference between the Augustus-Koch and the Ambo|Anthos-Koch is the marketing. This demonstrates that not only publishers increasingly acknowledge the importance of marketing but authors themselves work actively on their branding as well. The interview shows that the branding of a book such as The Dinner is the result of branding activities performed by both author and publisher and neither of them tries to keep that fact hidden from public discourse. On the contrary, they emphasize the effort they took in making the book become such a success.

\section{Critical Reception of The Dinner}

The Dinner's story turned out to be a success story. The novel sold well and the reviews were mainly positive (Serdijn 2009; Vullings 2009; Steinz 2009). 'Exciting, humorous, and well-written', ${ }^{12}$ Max Pam (2009) stated. Jeroen Vullings wrote about the novel: 'After The Dinner, no one can deny that Herman Koch is an accomplished writer.'13 Literary critics were mainly positive about the way Koch had composed the plot, the humour, and the credibility of the story (Belleman 20o9).

In Dutch newspaper NRC Handelsblad, critic Pieter Steinz had written a fairly positive review in January. Two months later, the newspaper published a second and more negative review by famous critic Arnold Heumakers (2009). He wondered why this book had become such a success. It is a 'well-written' book, 'approachable, exciting, funny', but wasn't it 'a

\footnotetext{
11 '"Ik had drie wensen. De meeste van mijn boeken deden tussen de 8000 en de 15.000 exemplaren, met een uitschieter naar de twintig. Het zou mooi zijn, zei ik, als van Het diner 25.000 exemplaren zouden worden verkocht. Ook wilde ik graag dat al mijn boeken herdrukt zouden worden, liefst in een herkenbare reeks. En ten laatste zou ik zo graag eens vertaald willen worden, met welke titel dan ook. Chris zei: daar gaan we voor zorgen. Later biechtte hij me op: ik heb tegen je gebluft dat ik er 25.00o van kon wegzetten. Hij had toen ook nog geen manuscript van mij." Herschdorfer beaamt dat, maar stelt: “Marketingtechnisch viel er duidelijk meer met zijn werk te doen."' (Vullings 2013)

12 'Spannend, humoristisch en strak geschreven'.

13 'Na Het diner kan niemand meer ontkennen dat Herman Koch een volleerd schrijver is.'
} 
shadow of what it could have been'? Heumakers criticizes the way Koch ended his novel and was disappointed with the technique of this usually good writer. 'What initially looks like a drama of fate changes into a case study more fit for the psychiatrist than for literature. ${ }^{14}$ Marja Pruis takes a comparable stance in De Groene Amsterdammer: 'Koch damages his drama by suddenly turning his main character into a real madman with a pathological disease pattern instead of someone like you, me, and everyone else' (Pruis 2009). ${ }^{15}$

Paradoxically, Heumakers's review helped Koch to enlarge his book's success story. Part of a good success myth - we know - is a moment of contestation: the successful writer should have to overcome something (Dayan and Katz 1992; Bax 2015: 361-380). In addition to that, Heumakers's intervention provided Koch with an opportunity to point out the fact that he is a writer for the 'average readers', who do appreciate his novel (by buying it), while the literary elite is blind to what the public wants to read. Koch enacts the discourse about a dichotomy between small-scale and large-scale production and again he describes the small-scale pole as something very negative.

Koch provides this narrative in an episode of Dutch television show De wereld draait door, for which both critic and writer were invited. On air, it became clear that Koch could easily play the populist card of the successful writer, whereas Heumakers had serious difficulties in bringing his critique to the public. Of course, this largely had to do with the difference in television experience: Koch had been a television star since the 1980s, while Heumakers writes for a newspaper and appears on television now and then. But Heumakers was also disadvantaged by the dominant frames of television culture in which elitism, seriousness, and critique are much less accepted than populism, humour, and sympathy (Langer 2006). ${ }^{16}$

In an interview, Koch makes explicit that Heumakers's review was written as a result of the success of the novel. He positions Heumakers as an elitist representative of the 'economic world reversed'. 'I don't think this would have happened if The Dinner had sold 4,0oo copies. When a book sells well,

14 'Wat eerst een noodlotsdrama leek te worden, verandert in een casestudy, meer iets voor de psychiater dan voor de literatuur.'

15 'Dat Koch van zijn hoofdpersoon in Het diner opeens een échte gek maakt, met een pathologisch ziektepatroon, in plaats van iemand zoals jij en ik en iedereen, waardoor hij de angel uit het drama haalt.' (Pruis 2009)

16 Koch reflected on the interview in Schlikker 2011. 
however, critics believe they have to correct something' (Fortuin 2009). ${ }^{17}$ Koch framed the 'economic world reversed' as a system in which a small literary elite (the connoisseurs) decide what is worthwhile and what is not. He dismisses this system: for him, the judgment of the 'average readers', the public, is far more important (Fortuin 2009). In the frame of Koch, an elitist mechanism ('the economic world reversed') is confronted with a populist mechanism ('the real economy').

In a reflective article titled 'Hundreds of thousands of readers can't be wrong, ${ }^{\prime 8}$ literary critic Arjen Fortuin coined the literary year 2009 as the year of rebellion against the literary elite. Dutch bestseller authors like Kluun, Saskia Noort, and Herman Koch 'are fed up' with being framed as second-rate writers. 'It is a battle over the question what is literature, why that is the case, and who gets to decide - indeed: topical questions don't have to be new ones' (Fortuin 2009). ${ }^{19}$ Fortuin - a literary critic himself - witnesses an important shift in the way publishing houses market their books. They no longer put quotes of literary critics on the back of the books but prefer quotes by famous celebrities.

They still contain compliments from critics, just like sales figures, but they also increasingly contain praise from famous Dutch celebrities, often uttered during an interview with the author: [Dutch celebrities] have become a productive literary promotion machine. (Fortuin 2009) ${ }^{20}$

In this quote, we see how the changes in the literary-critical system and the changes in the relation between literature and economy influence the choices publishers and authors make in their (self-)branding. On the cover of the books, quotes by serious literary critics (symbolic capital) are easily mingled with quotes from celebrity figures (celebrity image) and with remarks about sales (economic capital). Together, they serve the goal of underlining the success (and the success myth) of the celebrity author and his bestseller.

17 'Ik denk ook niet dat het was gebeurd als er 4.00o exemplaren van Het diner waren verkocht. Maar als een boek heel goed loopt, ontstaat kennelijk de behoefte om iets te corrigeren.' (Fortuin 2009)

18 'Honderdduizend lezers vergissen zich niet'.

19 'De strijd draait om de vraag wat literatuur is, waarom dat zo is en wie dat mag bepalen inderdaad: actuele vragen hoeven geen nieuwe vragen te zijn.' (Fortuin 2009)

20 'Complimenten van critici staan daar nog altijd in, net als verkoopcijfers, maar ook steeds vaker de lovende woorden van bekende Nederlanders, vaak uitgesproken tijdens een interview met de auteur: Matthijs van Nieuwkerk, Paul de Leeuw, Hanneke Groenteman, Mieke van der Weij, Kluun en inmiddels ook Herman Koch zelf zijn gestaag werkende literaire aanprijzingsmachines geworden.' (Fortuin 2009) 


\section{International Success}

Positive reviews, high sales numbers, and a primetime television discussion with a literary critic - the Herman Koch marketing machine did a good job in 2009 and 2010. But the success story of The Dinner did not end with its Dutch success: the book would become an international bestseller as well. Jeroen Vullings discusses this issue with Michael V. Carlisle, the agent who sold the translation rights in the United States (for a six-figure sum, according to Ambo|Anthos). Carlisle explains that the book was attractive because of the success it had already had and because of the fact that it was a 'sophisticated book': 'The American public is craving sophistication right now. The Dinner is a dark story with a drama - perhaps even a classical Greek drama - unfolding in the background that is of all times. [...] For me, that specifically is the international aspect of Herman's book' (Vullings 2013) ${ }^{21}$

In his analysis, Carlisle does not only focus on the accumulation of success but also points at several intrinsic qualities of the novel as well. Another factor was that the American publisher (Hogarth Press) turned out to be a publisher that wanted to put effort in this book. The publisher initiated an 'internet buzz' that created a lot of pre-publicity through bloggers and social media, resulting in a lot of media attention for the book. On 18 February, a week after the launch of the book, Koch appeared on National Public Radio for half an hour: 'It has 13 million listeners. Nationwide. People who would read Vrij Nederland and NRC here in the Netherlands, that kind of audience, they listen to that station all day for cultural news and current affairs in politics' (Vullings 2013). ${ }^{22}$

This all helped to make The Dinner successful in the United States, so the story goes. The novel entered the 'hardcover fiction' list of The New York Times on the ninth spot - according to Jeroen Vullings, this is 'the most famous bestseller list in the world'. While this happened, Koch was doing a tour of interviews in bookstores. 'I kept receiving enthusiastic text messages from my New York publisher. They were looking forward to that list for days and were hoping for a spot in the top 35. This differs from success in Europe. America is the top when it comes to books. It is starting to feel very real

21 'Het Amerikaanse publiek heeft nu enorme behoefte aan sophistication. The Dinner is een donker verhaal, met een drama op de achtergrond, misschien wel een oud-Grieks drama, dat van alle tijden is. [...] Voor mij is dat het specifiek internationale aan Hermans boek.' (Vullings 2013)

22 'Dat heeft dertien miljoen luisteraars. Nationwide. Mensen die hier Vrij Nederland en NRC zouden lezen, zulk publiek dus, hebben die zender de hele dag opstaan voor cultuurnieuws en politieke actualiteiten.' (Vullings 2013) 
now' (Fortuin 2013). ${ }^{23}$ Koch mentions his American success in several Dutch interviews, claiming that he has reached 'the top' now. His international success story consists of a series of good choices: good agent, good publisher, right buzz, good launch, and good media attention, resulting naturally in a spot on the top of 'the most famous bestseller list of the world'.

In the American context, Koch profited again from some commotion. In the United States, Koch was soon called the 'Dutch master of the feel-bad novel'. Several readers had ethical difficulties with the main character of the novel (Vullings 2013). This led to a devastating review in The New York Times by Janet Maslin (Maslin 2013). According to Maslin, the morality of the novel is 'really sickening' and she considers the main characters 'indigestible'. This negative review was covered extensively in the Dutch media. In NRC Handelsblad, for instance, Sebastiaan Kort reported that Koch's marketing machine had finally jammed (Kort 2013). However, the Dutch journalist at the same time defended Koch: to him, the morality of the review itself is sickening. He quotes Koch's unaffected reaction to the news.

A week later The Dinner peaks at the seventh place, its highest position ever (Fortuin 2013). In an interview Koch uses this fact to strengthen his position in the Dutch literary field again and to distinguish himself from some other writers with whom he sometimes is compared:

I was a little shocked when I read that review, but it isn't bad for a writer. Especially when it concerns a novel about which a few Dutch reviewers had said that it comes close to empty-headed entertainment. I suddenly belong with the bestseller authors now because of the success and that automatically makes you seem suspicious. Best-case scenario, they compare you to Tim Krabbé, Robert Vuijsje, or Kluun. Some critics categorize me with them, which makes me laugh. However, this does mean that these critics must not be paying attention very well: the literary differences between authors like them and me are much more significant than the single similarity of our bestseller status. (Vullings 2013) ${ }^{24}$

23 'Ik krijg steeds wild enthousiaste sms'jes van mijn uitgever in New York. Ze keken al dagen naar die lijst uit en hoopten op een plek bij de eerste 35. Dit is toch anders dan succes in Europa. Als boekenland is Amerika de top. Nu wordt het allemaal wel heel echt.' (Fortuin 2013)

24 'Ik schrok me een hoedje toen ik die recensie las, maar voor een schrijver is dat niet slecht. Zeker bij een boek waarover door sommige recensenten in Nederland gezegd wordt: het schurkt tegen leeghoofdig entertainment aan. Opeens hoor ik nu door het succes bij de bestsellerschrijvers en dan ben je automatisch verdacht. In het vriendelijkste geval word je ingedeeld bij Tim Krabbé, Robert Vuijsje of Kluun. Sommige recensenten afficheren mij graag als zodanig, ik moet daar 
Koch shares the 'bestseller status' with colleagues like Kluun and Krabbé, but unlike them, he does not write 'empty-headed entertainment' but 'real literature'. The fact that serious literary critics (Heumakers, Maslin) discuss the morality of his novel contributes to his status as a serious literary author. This goes to show how Koch plays his game with the concepts of economic and symbolic capital. In the earlier interviews, he simply attacked the notion of symbolic capital and the mechanism behind it. Here, however, he points out the 'literary differences' between him and true bestseller authors: in the end, symbolic capital does seem to be important to him.

This illustrates how complex the battle over reputation and recognition is in the contemporary literary field. While we had come to know Koch as a writer who claimed that economic capital ought to lead to symbolic capital, he now appears to have made a shift in that claim. This rule should only apply to a certain kind of book that has literary quality and is written by a serious author. Economic capital should only lead to symbolic capital if it is in some way connected to a certain amount of cultural capital. The field of tension in which contemporary authors have to position themselves has become very complex. In the process of (self-)branding, the construction of the (quantitative) success myth is crucial to become recognized, but you have to ensure that the amount of economic capital you acquire is countered with enough symbolic capital. Authors need to ascertain they do not depend on symbolic capital too much, though. They have to present themselves as being completely indifferent to the judgement of what they ought to frame as a literary elite'.

This demonstrates how cleverly Koch positions his authorship and his success myth in interviews and performances in the Dutch public media. Both in the case of Heumakers and in the case of Maslin, Koch leaves the pitch as a winner. The very negative review probably bothered The New York Times as well. One month later, a new review was published and the book was promoted to 'editor's choice' (Vullings 2013). Claire Messud, the second reviewer, also analyses the morality of the story, but she considers it to be a quality of the novel: it is a novel that provides the reader with difficult ethical questions (Messud 2013). Again, Herman Koch does not hesitate to use this American intervention to promote his authorship in Dutch media coverage.

Insiders assure me that I should consider the second article a correction of the first one. Later on, they even chose The Dinner as 'Editor's Choice 
of The Week'. It is obvious that behind the scenes of that newspaper they must have said: 'rejecting such a book for moral reasons, that goes too far. We want to rectify that.' Not insignificantly, Messud also happens to be the wife of the influential literary critic James Wood. It saved my book from the moralists. (Vullings 2013) ${ }^{25}$

As we have seen, the success story of The Dinner is narrated as a logical and natural story in which one crucial step or choice led to a new phase and a new choice. Arguments that point at the marketing of the book alternate with arguments that point at the specific qualities of the book. In the media coverage of the success myth, these two positions are deliberately played out against each other. In doing so, the literary journalists - Vullings, De Jong, and a lot of the other interviewers - provide Koch with what he was looking for: they enlarge his economic capital (by being a part of the marketing chain) and cultural capital (by their appreciation and recognition) by presenting both the marketing machine and the intrinsic qualities of the novel as crucial factors in the success myth. Along the way, the image of Herman Koch as 'the most successful Dutch writer' is constructed and repeated again and again.

\section{Conclusion}

This analysis of the media coverage of The Dinner makes clear that the 'economic world reversed' still plays a crucial but paradoxical role in how the contemporary literary field functions (Bourdieu 1984; Bourdieu 1989; Bourdieu 1996b; Dorleijn and Van Rees 2006; Dorleijn 2010; Moran 2005; Collins 2010; Praat 2014). In several interviews Koch brings up this logic, but he does so in order to confront it with another logic: his 'bestseller logic'. Koch plays a quite complex game with these two logics. On the one hand, he criticizes the 'economic world reversed' as an elitist model and claims that, for him, the verdict of his 'average readers' is far more important. In doing so, he appears to attribute more importance to economic capital and success than to symbolic capital and literary recognition. On the other

25 'Insiders vertelden me dat ik dit tweede stuk als een correctie moest zien op het eerste. Daarna werd The Dinner ook nog uitverkoren als "Editor's Choice of The Week". Binnen die krant was merkbaar gezegd: zo'n boek afwijzen om morele redenen, gaat te ver. Dat gaan we rechtzetten. Dan speelt ook nog mee dat Messud de vrouw is van de invloedrijke literair criticus James Wood. Mijn boek was gered van de moraalridders.' (Vullings 2013) 
hand, however, he stresses that symbolic capital is important in order to be able to differentiate between literary bestseller authors and 'average' bestseller authors (Van Boven 2015). Koch thereby uses a rhetoric strategy that we encounter in the self-fashioning of many other authors at the beginning of the twenty-first century (such as Leon de Winter and Kluun). The paradox lies in the fact that these authors attack the mechanism that we call 'economic world reversed', but in doing so, they underline that this logic still functions as an implicit norm in twenty-first century literary culture. Additionally, they use this mechanism when it might help them in their process of self-branding.

Bourdieu's 'economic world reversed' is one of the conventions that determined twentieth-century literary life. This case study illustrates how these conventions function in the literary media culture of the beginning of the twenty-first century (Bax 2019). The notion of the 'success myth' that is so central to functioning as a celebrity in media culture depends highly on the quantification of success. This success can take on the form of literary prizes, but we see a tendency to point at factors such as sales numbers, amounts of reprints, amounts of translations, etc. This emphasis on quantitative success in media culture is the result of the business ontology that plays such a crucial role in our contemporary notion of capitalism. Both media culture and the publishing industry work with an economic logic that opposes the idea of a 'reversed economic world'. Both novels and their authors are seen as products that can be marketed on a 'normal' economic market.

Literary writers such as Herman Koch are confronted with the need to present themselves as writers who have earned both economic and cultural capital and who therefore are on top of the literary chain. The manner in which the success story of Herman Koch's The Dinner is told and retold in the Dutch public media illustrates how twenty-first-century authorship functions in a media culture in which a business ontology dominates, and in a celebrity culture in which the image of the author might be the most important brand on the other. We have seen how Koch used public interviews to 'rebrand' his authorship and to make the narrative of the enfolding success into a natural part of his writer's image. We have also seen how the public interviews unconsciously contribute to this image and the brand that is its result. The interviews, the positive reviews, and in this case even the negative reviews all help Koch and his publishing house to achieve what they want to achieve. Journalistic articles such as the ones by Vullings and De Jong may appear to be objective reportages of the process of branding but are in fact important boosters of Koch's ongoing success myth. 


\section{References}

[Anon.] 2014. 'De burgerman als mikpunt', Reformatorisch dagblad, 7 June.

Enzio Bakker en Marith Iedema. 2014. 'Wie denkt Herman Koch wel dat hij is?'. Nieuwe Revu, 14 May.

Sander Bax. 2015. De Mulisch Mythe. Harry Mulisch: schrijver, intellectueel, icoon. Amsterdam: Uitgeverij Meulenhoff.

Sander Bax. 2019. De literatuur draait door. De schrijver in het mediatijdperk. Amsterdam: Uitgeverij Prometheus.

Bas Belleman. 2009. 'Dat moet wel leiden tot een explosie'. Trouw, 10 October.

Erica van Boven. 2015. Bestsellers in Nederland 1900-2015. Antwerp/Apeldoorn: Garant Publishers.

Pierre Bourdieu. 1984. Distinction. A Social Critique on the Judgement of Taste. Cambridge, MA: Harvard University Press.

Pierre Bourdieu. 1993. The Field ofCultural Production. Essays on Art and Literature. Columbia: Columbia University Press.

Pierre Bourdieu. 1996a. On Television. New York: The New Press

Pierre Bourdieu. 1996b. The Rules of The Art. Genesis and Structure of The Literary Field. Stanford: Stanford University Press.

Pierre Bourdieu. 2003. Firing Back. Against the Tyranny of the Market 2. New York: The New Press.

Pierre Bourdieu. 2008. Political Interventions. Social Science and Political Action. London: Verso Books.

Jim Collins. 2010. Bring On The Books For Everybody. How Literary Culture Became Popular Culture. Durham, NC/London: Duke University Press.

Daniel Dayan and Elihu Katz. 1992. Media Events. The Live Broadcasting of History. Cambridge/Massachusetts: Harvard University Press.

Jan Desloover. 2014. 'Een klein hoekje opruimen, kan ik zó blij van worden'. De Standaard, 9 May 2014.

Gillis Dorleijn. 2010. 'Poetry Doesn't Pay. On The Income Position of Prominent Dutch Poets, 1900-1942'. In Gillis Dorleijn, Ralf Grüttemeier, and Liesbeth Korthals Altes (eds.), Authorship Revisited. Conceptions of Authorship Around 1900 and 200o, pp. 53-80. Leuven: Peeters Publishers.

Gillis Dorleijn and Kees van Rees. 1993. De impact van literatuuropvattingen in het literaire veld. Aandachtsgebied literaire opvattingen van de Stichting Literatuurwetenschap. 1993. The Hague: Stichting Literatuurwetenschap.

Gillis Dorleijn and Kees van Rees (eds.). 2006. De productie van literatuur. Het literaire veld in Nederland 1800-2000. Nijmegen: Uitgeverij Vantilt.

Richard Dyer. 1998. Stars. London: BFI Publishers.

Mark Fisher. 2009. Capitalist Realism. Is There No Alternative? London: Zero Books. 
Arjen Fortuin. 2009. 'Ik heb een driftige natuur, maar ik houd me in'. NRC Handelsblad, 10 July.

Arjen Fortuin. 2009. 'Honderd duizend lezers vergissen zich niet'. NRC Handelsblad, 24 December.

Arjen Fortuin. 2013. 'Ik weet ook niet precies waarom ze me daar willen hebben'. NRC Handelsblad, 21 December.

Gaston Franssen. 2010. 'Literary Celebrity and The Discourse on Authorship in Dutch Literature'. Journal of Dutch literature 1: 91-113.

Gaston Franssen and Rick Honings. 2017. Idolizing Authorship. Literary Celebrity and The Construction of Identity, 1800 to The Present. Amsterdam: Amsterdam University Press.

Odile Heynders. 2016. Writers as Public Intellectuals. Literature, Celebrity, Democracy. Basingstoke: Palgrave.

Arnold Heumakers. 2009. 'Licht verteerbaar, ontziet de maag'. NRC Handelsblad, 20 March.

Stijn Hustinx. 2014. “Amazing” Herman Koch ontmoet fans tijdens tournee'. $A D /$ Utrechts Nieuwsblad, 5 June.

Eva Jinek. 2012. 'Ik ben aartslui'. De Telegraaf, 28 July.

Annet de Jong. 2013. 'Het geheim van Herman Kochs megabestseller'. De Telegraaf, 5 November.

Rinskje Koelewijn. 2014. 'Ik geef de raarste geheimen prijs'. NRC Handelsblad, 10 May 2014.

Sebastiaan Kort. 2013. 'NY Times maakt gehakt van Het Diner van Herman Koch'. NRC Handelsblad, 7 February.

Rudi Laermans. 2011a. 'Lees mij! Bekijk mij! Hoor mij!' Het aandachtsregime'. Cultuur en media 6og: 12-14.

Rudi Laermans. 2011b. 'The Attention Regime. On Mass Media and The Information Society'. In Willem Schinkel and Liesbeth Noordegraaf-Elens (eds.), In Medias Res. Peter Sloterdijk's Spherological Poetics of Being, pp. 115-132. Amsterdam: Amsterdam University Press.

John Langer. 20o6. 'Television's “Personality System”'. In P. David Marshall (ed.), The Celebrity Culture Reader, pp. 181-195. New York/London: Routledge.

Jane Maslin. 2013. 'Now Serving Spite and Dutch Malaise. The Dinner by Herman Koch'. The New York Times, 6 February.

Jérôme Meizoz. 2010. 'Modern Posterities of Posture. Jean-Jacques Roussau'. In Gillis Dorleijn, Ralf Grüttemeier and Liesbeth Korthals Altes (eds.), Authorship Revisited. Conceptions of Authorship Around 1900 and 200o, pp. 81-94. Leuven: Peeters Publishers.

Claire Messud. 2013. 'Nasty Bits'. The New York Times, 8 March.

Joe Moran. 2005. Star Authors. Literary Celebrity in America. London: Pluto Press. 
Max Pam. 2009. 'Vaders en zonen'. Haagse Post, 9 January.

Edwin Praat. 2014. Verrek, het is geen kunstenaar. Gerard Reve en het schrijverschap.

Amsterdam: Amsterdam University Press.

Marja Pruis. 2009. 'Het Zwitserlezengevoel'. De Groene Amsterdammer, 13 March. José Rozenbroek. 2014. 'Bestsellerschrijver Herman Koch'. Libelle, 9 May.

Annemarie van Rhee, 'Ik vind dit leven echt leuk'. AD/Utrechts Nieuwsblad, 3 May. Roos Schlikker. 2011. 'Ik ben een enorme voyeur'. HP/De Tijd, 28 January.

Daniëlle Serdijn. 20o9. 'Het recht een klootzak te zijn'. de Volkskrant, 9 January.

Pieter Steinz. 2009. 'Dr Jekyll in de Watergraafsmeer'. NRC Handelsblad, 16 January. John B. Thompson. 2012. Merchants of Culture. The Publishing Business in The

Twenty-First Century. Cambridge: Polity Press.

Thomas de Veen. 2014. 'Pas op, laat u zich er niet inluizen'. NRC Handelsblad, 9 May. Joost van Velzen. 2014. 'Ik voel geen druk, ik voel me juist bevrijd'. Trouw, 6 May. Hugo Verdaasdonk. 2008. Snijvlakken van de literatuurwetenschap. Nijmegen:

Uitgeverij Vantilt.

Jeroen Vullings. 2009. 'Instinct wint'. Vrij Nederland, 24 January.

Jeroen Vullings. 2013. “'Het diner”: niet zomaar een succes'. Vrij Nederland, 19 October.

\section{About the Author}

SANDER BAX (1977) is associate professor in Literary Studies, Cultural History and Education in Dutch Language and Literature and vice-dean of education at Tilburg School of Humanities and Digital Sciences. He has published De taak van de schrijver (The task of the writer, 2007), De Mulisch Mythe (The Mulisch Myth, 2015) and De Literatuur Draait Door (As Literature Turns, 2019), and co-edited the volume Interrupting the City (2015). He is currently working on a monograph on twentieth-century authorship and on a biography of Dutch writer Bernlef. 


\title{
Young Adults as Branded Readers
}

\author{
Linda Ackermans
}

\begin{abstract}
Since 2009, Dutch publishers are increasingly marketing and branding books as young adult literature (YAL), thereby wishing to appeal to a specific target group of young people. In exploring YAL as a brand, we observe an interesting and broad branding process, within which attention is devoted to strategies that focus on branded relationships and the creation of a lifestyle, and within which the use of social media and the utilization of readers as influencers are key. This interactive branding process is explored against the theoretical backdrop of Bourdieu's theory of the reversed economy and Martens's (2016) new model of publishing. The Dutch publishing house Blossom Books provides a case study for examining the (re)distribution of the roles of publishers and readers and shows how exceptional the branding of YAL is.
\end{abstract}

Keywords: teen branding, participatory culture, community building, young adult literature, Blossom Books

'We are a generation plugged in, and if you want to reach us - and keep us - you have to plug in, too."

Young adult literature (YAL) is a term that emerged for the first time in the Netherlands in 2009, and it is now impossible to imagine the Dutch literary landscape without it. The term, which originated in the United States, refers to a category of books (translated, as well as those originally

1 Young adult reader's quote, retrieved from http://cooksplusbooks.com/how-john-greenwon-millions-of-fans-and-4-way-you-can-build-a-fanbase-too/ [accessed 11 June 2018].

Helleke van den Braber, Jeroen Dera, Jos Joosten, and Maarten Steenmeijer (eds), Branding Books Across the Ages: Strategies and Key Concepts in Literary Branding. Amsterdam, Amsterdam University Press 2021 DOI: $10.5117 / 9789463723916 \_C H 10$ 
written in Dutch) for readers from around the age of fifteen, which focuses on topics that are particularly relevant to adolescents, such as growing up, the formation of relationships, conflict, and finding one's own identity and meaning in life. YAL as a category covers a wide range of literary genres: from dystopias and fantasy novels to autobiographies and historical novels. The introduction of YAL has provided an impetus for (attention to) literature for young people and fundamental institutional shifts have taken place: a variety of developments have resulted in changing relationships in distribution and production in the Dutch literary field. ${ }^{2}$

Firstly, youth culture has become more visible in bookshops and libraries. In the past, you had to root around in the children's section or the section for adults in order to find novels with something to offer for young people, but distributing agents are now increasingly setting aside a separate bookcase or section specifically for literature for young people. Furthermore, publishers that specialize in YAL have emerged over the past decade. Examples include imprints such as Best of YA - part of the Unieboek|Het Spectrum publishing house - and Young \& Awesome from the publishing house Leopold, and independent publishers such as Blossom Books and Storm Publishers in particular. Finally, a prize for literature for young people from the age of fifteen was awarded for the first time in 2010 (prior to this, the Netherlands only had literary prizes for young people up to the age of fifteen and then for an adult audience) and the Book Week for Young People, which ran for the first time in 2015, devotes attention to young people as a literary target group.

The term adolescent literature has been in use in the Netherlands for some time now. This term harks back to the Bildungsromans and disillusionment novels of the eighteenth and nineteenth centuries, as Peter van den Hoven and Helma van Lierop-Debrauwer clearly explain in their contribution to the history of youth literature, Een land van waan en wijs (2014). The terms YAL and adolescent literature are sometimes used interchangeably, which leads to confusion. This is because adolescent literature is seen as a genre in which the phase of adolescence is thematized (Van den Hoven and Van Lierop-Debrauwer 2014: 375; Van Lierop-Debrauwer 2017: 224). In historical terms, that genre developed along two separate routes: specifically aimed at adults or exclusively intended for young people. As a result of this 'bifurcation of the adolescent novel' (Van Lierop-Debrauwer 2017: 222), adolescent literature did not appeal to an audience of young people per se, even though the name may suggest otherwise. YAL does that emphatically: the term and the institutional developments that came about at the same time as 
the introduction of that term are intended to create a new market segment (including by means of branding), as an addition to children's literature on the one hand and adult literature on the other hand (Ackermans 2021).

In this chapter, I therefore do not consider YAL as a genre, but as a subfield within the literary field as a whole. By using the term YAL, I focus on books that publishers consciously market and brand as YAL, thereby wishing to appeal to a specific target group of young people. ${ }^{3}$ As YAL is a recent literary manifestation in the Netherlands, its place in the dynamic literary field is still in full development. Research in the coming years will undoubtedly shed more light on the material and ideological conditions in which this form of literature is received. In any case, YAL already presents us with an interesting dynamic in terms of the roles that agents fulfil in the literary business. In her book, Publishers, Readers, and Digital Engagement (2016), Marianne Martens discusses at length the marketing strategies available to publishers in order to reach young people in the digital era. She outlines a new publishing model 'in which books become brands and readers too are branded and commodified' (Martens 2016: 6). According to Martens, this revolves around branded relationships: the reader feels connected with a brand and wants to be part of the group that is involved with both the production (authors and publishers) as well as the consumption (other readers) of a literary product.

Of course, this new model of publishing has consequences for traditional definitions of 'author', 'publisher', and 'reader', as we clearly see when we explore YAL as a brand. Conscious of a new market segment, publishers and - to a lesser extent - authors address the young people directly and encourage them to be active members of the group that associates with the YAL brand. The young adult novels can be regarded as branded books and the readers as branded readers, who not only consume the products, but are also involved in an interactive branding process, just like authors and publishers. In this chapter I will explore the branding of young adult literature against the background of Bourdieu's theory of the reversed economy, outlined in the Introduction, and Martens's notion of branded relationships. Special attention will be given to the (re)distribution of the roles of publishers and readers, which will be examined in a case study of the Dutch young adult publisher Blossom Books.

3 In my opinion, marketing and branding are not the same. A helpful indicator of the difference is the assumption that 'a brand is a promise on the value you'll receive' (see the Introduction). Branding is about (the creation and value of an) identity. As we will see in this chapter, the brand YAL tells readers what YAL stands for and that YAL is unique. If this appeals to readers, they are then able to connect with the brand. Marketing is formed by the manifestations that give visibility to a brand. Later in this chapter I will focus more on branding and the creation of lifestyles with which the consumer is able to identify. 
The case study demonstrates how exceptional the branding of YAL is, especially in comparison with branding processes within literature for adults. Whereas the latter mainly focus on the branding of an individual author or a certain book, we see a much broader branding process with YAL, within which attention is devoted to strategies that focus on relationships and the creation of a lifestyle (as is also the case with big brands like Nike) and within which the use of social media and the utilization of readers as influencers are key. Blossom Books is one of the few independent Dutch publishers that focuses specifically on YAL and can be considered a forerunner when it comes to using social media to interact with the target group. Furthermore, the marketing strategies and image of this publisher reveal an interesting area of tension between economic and symbolic motives. The case study is therefore well positioned to offer the opportunity to investigate what the branding process surrounding YAL looks like in more detail, how publishers establish branded relationships with readers, and how their role toward readers is changing.

\section{YAL as a Brand}

At first sight, the idea of regarding YAL as a whole as a brand probably does not spring to mind when you hear the concepts of branding and YAL. After all, we are not talking about a product in the same way we might consider a novel or an author to be a product, but much more abstractly as a literary manifestation. Other types of branding, such as product placement in young adult novels (for example the Gossip Girl books, in which brands and products are seamlessly interwoven into the story) are perhaps more likely to come to mind and have been a limited subject of research. ${ }^{4}$ The way in which authors such as John Green or series such as Twilight and especially The Hunger Games have grown into powerful brands (wherein the books - alongside films, games, concert tours of the film music, and all sorts of merchandise, ranging from jewellery and T-shirts to mugs and phone covers - constitute just a small part) is a great example of branding and, in the words of Marianne Martens (2016: 54), 'a clear example of the political economy of the publishing industry'. ${ }^{5}$

4 The majority of research regarding product placement has been done in the context of film, TV productions, music videos, and video games. Mucundorfeanu and Szambolics (2017) explore the practice of product placement in written texts. See also Bullen 2009.

5 Martens here refers to the attempts of publishers to try and replicate the success of such brands with similar products. 
The reason why I interpret YAL as a whole as a brand is based on the identity myth (see the Introduction) that was created when YAL emerged: YAL embodies the idea that young people form a target group that should be taken seriously. The YAL stamp tells young people: 'This book might be of interest to me.' In the past, they were forced to search for appealing books either among children's literature or among literature for adults. The term YAL was intentionally introduced in order to reach young people and to get and/or keep them reading. You could even claim that a new label was stuck on books that were already there, but that were not yet being publicized in a separate market segment. ${ }^{6}$ If we see the brand YAL as an in the Introduction presented 'set of regimented associations', which together form a story, then the brand YAL stands for the story of young people as a potentially valuable literary audience that deserves its own books.

Publishers were the first in the Dutch literary field to tell that story. In an attempt to create greater visibility for literature for young people, a number of publishers raffled off a so-called young adult bookcase among booksellers at the Dutch book fair Manuscripta in 2009: a bookcase full of titles they deemed suitable for young people. By doing so, publishers hoped to encourage booksellers to install a separate section for young people in their bookshops and to make YAL a more distinct market segment, which actually happened in the years that followed. ${ }^{7}$ In Marketing Literature, Claire Squires (2009: 85) introduces branding as 'a way of grouping and hence distinguishing products in the marketplace in order to capitalise on customer experience and perception of products and to maximise their visibility'. This is exactly what happened with YAL; books for young people were brought together to form a recognizable category in the literary market, which meant that literature for young people - labelled YAL - became much more visible. Furthermore, it seems that publishers - at least in the early days of YAL - opted for what Squires calls a 'market-led approach' (85); initially, it wasn't so much about promoting the individual young adult titles, but more about putting YAL as a category in the spotlight. The collaboration between various publishers at Manuscripta highlights this. ${ }^{8}$

6 See Ackermans (2021).

7 Although this chapter doesn't offer the scope to do so, the concept of 'double branding' articulated in the Introduction is at least worth mentioning here. After all, the belief of booksellers in the story around YAL is crucial for the installation of a separate section for young people.

8 For more information on the introduction and spread of YAL in the Netherlands, see Ackermans (2021). 
If we think of young people as a valuable literary audience, the term 'valuable' contains an ambiguity that refers to Bourdieu's diametrically opposed concepts of economic versus symbolic capital. In the branding of YAL, the promotion of reading plays an important role; when producing and distributing agents set aside books especially for young people, they hope to get young people to read. This hope may conceal altruistic or economic motives, or - most likely - a combination of the two. It is with good reason that Squires (2009: 49) states that '[p]lacing the demands of culture and commerce in direct opposition [...] is perhaps not the most fruitful way of analysing the contemporary literary marketplace'. She cites English and Frow, who claim that each literary or cultural subfield is a complex system 'in which different kinds of agents or players [...] conduct transactions involving distinct forms of capital [...], all of which are partially but none of which is perfectly fungible with the others' (English and Frow 2006: 45, cited in Squires 2009: 49). The case study of Blossom Books will show that young people generate economic capital as a separate target group - 'publishing for young people [is] a profitable business' (Martens 2016: 6) - but also that economic and symbolic interests are constantly interacting.

If we view YAL as a brand, we must take account of the dynamics between contemporary YAL and other cultural and media manifestations. The interfaces between literature, films, series, games, and online activities are evident in the field of young adult literature. Just think of The Hunger Games series by Suzanne Collins, mentioned earlier, or titles such as 13 Reasons Why by Jay Asher and The Fault in Our Stars by John Green. In Writing Youth. Young Adult Fiction as Literacy Sponsorship (2017), Jonathan Alexander speaks of a 'media ecology':

Perhaps the most salient dimension of YA fiction is that it exists not just as a set of discreet textual products but as a media ecology in which numerous content producers working across several communication platforms vie for young people's attention. (Alexander 2017: 8)

Alexander goes on to describe, in line with Henry Jenkins (2006), among others, how our modern culture is increasingly not only transmediated but also participatory:

Contemporary fan and consumer engagement [...] is anything but passive - and book marketers know that. [...] Today's media ecologies [...] promote a 'participatory culture' in which fan communities are encouraged to 
be not just consumers but also prosumers engaged in passing along and sharing content. (Alexander 2017: 8-9)

Publishers have to acknowledge this participatory culture, especially publishers that have young people as their target audience. Young people are used to actively contribute to the marketing of products aimed at themselves. We see this phenomenon, which is part of what is called teen branding, in a range of fields from games to fashion. The case study takes a closer look at how this phenomenon takes shape within the field of young adult literature in the Netherlands and how it can be seen as unique for that field within the Dutch literary business as a whole.

In her book, Branded: The Buying and Selling of Teenagers (2003), Alissa Quart explores various forms of teen branding in detail. Quart claims that today's youth have grown up in a world in which branding is the norm:

They have grown up in the age of the brand, bombarded and defined by name products and intrusive and clever advertising strategies. Raised by a commodity culture from the cradle, teens' dependably fragile self-images and their need to belong to groups are perfect qualities for advertisers to exploit. [...] And they [teens] have taken to branding themselves, believing that the only way to participate in the world is to turn oneself into a corporate product or a corporate spy to help promote the products to other kids. (Quart 2003: xvi-xvii)

Martens's concept of branded relationships can also be seen in this context, in which young people's aspirations to contribute and be part of a group are fulfilled. Unlike in the past, when publishers depended on the traditional gatekeepers (librarians, teachers, parents) to reach young people, digital technology now enables publishers to communicate directly with the target group, as Martens (2016: 50) explains: 'technology has changed the way that books are marketed to young readers: from an established and largely print-based model, to one that relies increasingly on technology, including websites and social media.' Lots of young adult publishers are active on the social media that young people use, such as Instagram, Facebook, and YouTube. They use these media not only to promote their new books, but also to contact the target group, for example by asking readers for their input on new editions and literary events.

By doing so, publishers focus on branded relationships: relationships between those who consume literary products and those who produce them (Martens 2016: 56). As a result, a new publishing model emerges, in 
which books and authors are branded and in which "traditional definitions of "marketer", "author", and "consumer" are shifting towards collaborative communities of online immaterial and affective labor by publishers, authors, and teen consumers' (6). Publishers, authors, and young people connect with the brand YAL and therefore belong to a group that is engaged in an interactive branding process. The case study explores this specific branding process in greater depth.

\section{The Blossom Books Case Study}

The Dutch young adult publisher Blossom Books was established in February 2010 as an imprint of the children's book publisher Kluitman. Established in 1864, Kluitman is one of the oldest independent publishers in the Netherlands and it was one of the first Dutch publishers to see the potential of YAL. Contrary to other early imprints such as Prometheus Young Adult, Blossom Books has firmly anchored itself in the Dutch literary business. In 2017, it continued its activities as an independent publisher. Blossom Books is fully devoted towards publishing YAL within various genres, in particular fantasy, realistic contemporary novels, chick lit, and non-fiction. Its list primarily consists of translated work. Alongside the production and distribution of translated books, Blossom Books also distributes English-language original editions in order to attract readers who are increasingly reading in English and sometimes cannot wait for a translation of the next book in a series (Elzinga 2015).

The publisher takes a personal approach. ${ }^{9}$ On its website, the publisher describes itself as an 'accessible, open publisher with a personal character.' ${ }^{\circ}$ This personal character is reflected, for example, in publisher Myrte Spiteri's foreword to the reader in the books that she publishes. Since its establishment, the editors, who formulate their mission as convincing young people 'that reading is not boring and dull, but the greatest thing out there ${ }^{\prime 11}$, have

9 For an interesting comparison, see Smeets's chapter about the Das Mag brand. Blossom Books and Das Mag Publishers show similarities, including a personal, anti-elitist approach and publishing for a 'new' audience. It is particularly interesting how publishers focus on relationships; whereas the relationship between publisher and reader is the main focus in this case study, Smeets focuses on the relationship between publisher and author.

10 Retrieved from https://www.blossombooks.nl/over-ons/ [accessed 7 June 2018]. Translated into English by the author. Original text: 'toegankelijke, open uitgeverij met een persoonlijk karakter.'

11 Ibidem. Original text: 'dat lezen niet saai en suf is, maar het geweldigste wat er is.' 
focused on (online) interaction with the reader. This interaction is achieved via the publisher's website as well as social media such as Twitter, Facebook, Instagram, and YouTube. Blossom Books uses these media to contact the target group actively and directly and to receive feedback about products. By doing so, readers keep abreast of titles that are about to be released and are also given a voice; the editors can use social media to find out whether readers are interested in a novel before publication, for example, and which publication date they prefer. As a result, young people are given a say about products - novels in this case - that are intended for them and as such become part of the community involved with both consuming and producing YAL.

Other ways in which Blossom Books is dedicated to community building are so-called read-a-thons and book challenges. Read-a-thons involve readers reading as many books as possible within a certain time frame (often a weekend). These do not have to be books exclusively from the Blossom Books list; the readers choose for themselves which young adult books they read. Examples of book challenges include taking photos with a favourite book in a special place or carrying out projects inspired by a recently published novel or series. ${ }^{12}$ Blossom Books announces these read-a-thons and book challenges on social media. The aim is to involve young people in the collaborative community, which not only includes fans of books published by Blossom Books, but which connects more broadly with the brand YAL, consciously or not, and contributes to the promotion of this literature.

In short, branded relationships are formed between those who produce literary products and those who consume them. The idea of a participatory culture in which fans are encouraged not only to consume, but also to act as prosumers is clearly recognizable in this. After all, young people who take part in a read-a-thon or book challenge often post their experiences on their own social media. In this way, they help promote YAL in the form of peer-to-peer marketing. I take a broader view of the concept of prosumer than how Alvin Toffler, who coined the concept in 1980, described it. The young person who behaves like a prosumer does not replace the publisher and does not take over their producing role in full, but they certainly have a significant influence. In this connection, it is more about passing along and sharing content, as Alexander describes it, than the creation of semiprofessional content.

12 See, for example, \#Lunarhunt, a series of assignments on the occasion of the publication of a new novel in The Lunar Chronicles series. Retrieved from https:/www.blossombooks.nl/ wp-content/uploads/2017/o8/LunarHunt-Winter-Alle-sterren2.pdf [accessed 11 June 2018]. 
We see this idea of prosumers most specifically in the use of so-called representatives (reps), who can be seen as influencers. Since 2013, Blossom Books has been seeking readers to spend a year reading and promoting books from their list via their own social media, blogs, and sales sites such as bol. com and bruna.nl in exchange for a number of perks, such as priority tickets for author visits or free reading copies and other products. Furthermore, representatives provide input about various publishing decisions, for example book covers, and actively help with the publisher's promotional activities. As such, on the one hand, they have the feeling that they are having an impact, which ties in with Quarts's views on teen branding, and on the other hand, the importance that young people attach to the opinion of their peers is exploited.

In their role as representatives, young people perform what Martens (2016: 1) refers to as 'immaterial and affective labor' for the publisher, giving them 'an authorial role as content creators or contributors'. They influence other young people as influencers. The publisher, in turn, has the opportunity 'to exploit such labor as [it] get[s] invaluable market research, peer-to-peer recommendations, and even content which can be used in other projects - all virtually free-of-charge' (1). The publisher aims to create affective branded relationships with the target group: 'By establishing an affective relationship between producer and consumer, producers win consumer affect, which in turn attracts immaterial labor of the consumer', Martens (2016: 63) explains. Quart (2003) highlights the importance of these relationships and indicates how prevalent this tactic is for teen marketing in general. Young people want to be part of a group and (paradoxically enough) feel appreciated as autonomous figures. Marketers draw upon that wish by enabling young people to be part of a team in which their opinion counts and is respected.

The advantage of these shifting traditional roles of publisher and reader for the publisher is twofold: free peer-to-peer marketing on the one hand, and a valuable source of reader feedback, which can be used to gain an insight into the target group, on the other hand: 'Teens' participation provides rich evidence of reader preferences, engagement, and a record of activity. Through their contributions, young people construct themselves as a visible, participatory audience' (Martens 2016: 2-3). This implies that Wolfgang Iser's idea of the implied reader is partly replaced by a visible reader, who notably takes part in the marketing aimed at them. As such, the branded readership can be utilized by publishers 'to market commodified cultural products back at this population' (2). Therefore, the motives that 
appear to play a role in terms of pursuing branded relationships are mainly economical:

[B]randing allows the publishers to create products that closely fit what teens want to read (consume) and then use the labor of those same teens to sell even more products. The publishers do so by creating a community of readers dedicated to books, one in which young readers work for the publisher (free-of-charge) and then encourage their friends to join as well. (Martens 2016: 75)

However, things appear to be more nuanced in this case study and Blossom Books also strives for more idealistic motives. Before discussing this in more concrete terms, it would be useful to briefly pay attention to the idea of branding as a 'sign of a definite type of social identity, which summons consumers into relationship with it' (Hearn 2008: 165). This is how Alison Hearn describes a brand in her article 'Meat, Mask, Burden: Probing the contours of the branded "self"' (2008). She believes that the practice of branding has shifted in recent years

to working more indirectly to install definite and highly circumscribed 'sets of relations between products and services' and the consumers who use them. Branding does this by constructing a particular ambience, comprised of sensibilities and values, which may then condition consumer behaviour. A brand no longer refers to a simple commodity but to an entire 'virtual context' for consumption. (Hearn 2008: 165)

In line with Arvidson (2005), Hearn further claims that these days, a brand represents a specific approach to a product - 'a propertied form of life to be realized in consumption' (Arvidson 2005: 244) - and that brands become a cultural tool with which individuals are able to define themselves: 'Brands $[\ldots .$.$] become the ground and comprise the tools for the creation of self and$ community' (Hearn 2008: 166). Alexander (2017:34) also claims that branding today revolves around the creation of lifestyles with which the consumer is able to identify: 'Brands are invitations to adopt a lifestyle, cultivate an identity and make products or services an essential part of your life and conceptualization of who you are.' This ties in with the aforementioned identity myth, which can be clearly seen with brands such as Apple and Nike. Apple represents modernity and imagination; people who wear Nike challenge themselves to 'just do it'. 
A lifestyle or social identity is also associated with YAL as a brand. As mentioned before, YAL legitimizes the idea that young people are a profitable target group that deserves to be taken seriously. Blossom Books explicitly promotes reading as a lifestyle among young people with its motto 'Spread the booklove'. The publisher has been using this motto since 2013 to promote book-related products, such as notebooks, bookmarks, mugs, cups, and T-shirts - often featuring mottos such as 'Proud Bookjunkie' or 'Reading is for awesome people'. With these products, the consumer is able to communicate that reading is a lifestyle for them and that they feel connected with the group that shares the same social identity. The motto and the products highlight the image that the publisher wants to convey - reading is cool and fun - and its mission - to convey that image as widely as possible and to get as many young people reading as possible. The fact that Blossom Books joins forces with other publishers to provide activities that promote reading in order to accomplish this mission indicates that the publisher is not just about selling its own books; it is also about spreading the identity myth that YAL embodies.

Blossom Books therefore also has an idealistic motive: to encourage reading by promoting it as a lifestyle. Based on Bourdieu's diametrical opposition, it is striking that the publisher uses resources for this that are aimed at acquiring economic profit in the short term. An intriguing interaction between symbolic and economic capital is at play here. Blossom Books can afford to sell this type of commercial product - notably not only via traditional channels such as bookshops, but also directly via its own website - because, as a publisher, it is not only primarily occupied with what Bourdieu calls an inherent cultural product, but it also strives for a higher purpose with it. The open procurement of economic capital in the form of non-book products aims to achieve symbolic capital, meaning that the acquisition of economic capital is not only a purpose, but also a means.

At the same time, negation of the importance of economic capital takes place. This can clearly be seen in one of the activities that Blossom Books exploits in collaboration with a number of imprints from other publishers: the YALFest, a festival for the young adult community that has been held annually since 2016. Although the promotion of books and authors from the Blossom Books list is obviously a focus, the festival is not primarily aimed at driving sales, but also at bringing together the community and encouraging people to read YAL. Of course, it can be assumed that the YALFest also increases recognition for Blossom Books, which in turn boosts sales of its novels and other products. The use of representatives can also be seen as a form of negation. This is because the less visible the 
investment in economic capital is, the more productively symbolic capital can be amassed, as Bourdieu claims. This implies that publicity strategies do not need to be made explicit. The use of reps is a clever way to conceal the open acquisition of economic capital; the target group does it for you. As a result, Blossom Books appears to be less concerned with directly investing in commercial interests and more concerned with conveying its (idealistic) image.

\section{Further Findings and Research Perspectives}

Although this chapter focused on the shifting roles of publishers and readers, it goes without saying that authors are also involved in the branding process and they also assume a different role. According to Martens, it is becoming increasingly important for them to carry out part of their marketing themselves via social media. She deems the use of this media essential for YAL in particular, because young people can be reached 'via whichever social media tool is popular at a given moment' (Martens 2016: 61). Martens refers to John Green as one of the young adult authors who uses social media particularly effectively in order to build their own book-related brands. An author like Green can not only be regarded as a brand name author who is branded by his publisher; he also enters into branded relationships with his readers himself. Marketing carried out by the publisher and Do It Yourself marketing carried out by the author complement each other in this way 'by raising consumer awareness across a range of media' (63). It would be interesting to investigate how publishers and authors (are able to) mutually reinforce each other in this and to examine how an author like John Green succeeds in building a strong fan base via DIY marketing.

The marketing of literature may be becoming a collaborative community effort on the part of publishers, authors, and readers, but the boundaries between the roles and tasks of these agents are also blurring. Readers act as peer-to-peer marketers whenever they carry out promotional work for the publisher or share information with friends on their own social media sites. Readers also assume the role of authors whenever they write fan fiction or comment on storylines online, for example. Authors are their own marketers, but that is not all: they are also content creators in the marketing efforts of fellow authors: 'While each author has his or her own online audience, by cross-promoting authors via their own social media sites, authors get an exponential increase in exposure from being promoted 
across a network, and also benefit from peer-to-peer recommendations from the same', Martens (2016: 69) explains. On 18 November 2016, John Green wrote on his Twitter page that he had read Angie Thomas's debut novel The Hate U Give, 'which comes out in February. It's truly brilliant, and I think it will become a classic'. ${ }^{13}$ A debut author is bound to benefit from this kind of recommendation from such a popular author like Green, who is highly regarded by literary critics.

Finally, in the publishing model presented by Martens, publishers are not only assigned the role of marketer, but also that of producer or reader. Although the active participation of young people in the marketing process provides the publishers with a wealth of information about the target group, publishers do not have complete control over these young people. They are able to submit content to the digital world that publishers do not support or that ought to be kept secret (for example, spoilers or release dates). This requires publishers to invest more time and energy so that they can investigate the online traces of their representatives.

The developments outlined in this chapter illustrate Martens's conclusion that publishing practices 'increasingly mirror production and consumption practices of other media industries, resulting in a new political economy of the field which emphasizes earnings-power, or what McChesney (2013) calls hypercommercialism' (Martens 2016: 2). Modern technologies and social media in particular have transformed a volatile, invisible target group that was difficult to reach into a visible group of readers that participates (or at least has the opportunity to participate) in its own marketing process. Based on the online activities of the consumer, web analysts can easily see who the target group really is and what their preferences are, which helps publishers choose new publications and create new products, as well as market them.

Needless to say, the question that arises is whether a development towards hypercommercialism is desirable for the book industry. Existing ideologies still help the book industry, in view of the fact that of all products for young people, books are still highly regarded in terms of cultural capital. However, the book industry has not remained immune to branding, as Quart (2003) pointed out. For the field of young adult literature in particular, in which what Alexander refers to as a media ecology is increasingly at play, you can also question the extent to which the idea that books are inherent cultural products still holds true. It is

13 Retrieved from https://twitter.com/johngreen/status/799690432011767808 [accessed 16 June 2018]. 
abundantly clear that this industry is one in which culture and commerce come together. Developments such as the attention for branding in (young adult) literature arouse curiosity about which way the balance will tip in the coming years.

In light of the branding of YAL and the case study presented in this chapter, a point made by Royle, Cooper, and Stockdale (1999/200o) in 'The Use of Branding by Trade Publishers: An Investigation into Marketing the Book as a Brand Name Product' is also interesting. They question whether the idea of books as highly individualized products that therefore impair the opportunity for brand recognition in the modern literary business still stands. In general, it is assumed that imprints do not succeed, or are, in any case, less successful than authors, at being brands. Blossom Books started off as an imprint and grew into an independent, specialized publisher that manages to attract consumers through participation, intensive contact via social media, and the sale of products that promote reading as a lifestyle. Quotes from the publisher's followers and/or fans on Facebook - 'Blossom Books are fantastic. One of my favourite publishers' and 'I want everything from Blossom Books, book \& non-book!' ${ }^{14}$ - may offer us reason to believe that the general idea that imprints are not seen as brands is starting to shift. In further research, it would therefore be interesting to investigate the recognisability of Blossom Books as a brand. Furthermore, this type of research also gives us greater insight into the interaction between bigger branding processes - YAL as a brand as a whole - and smaller ones - a publisher as a brand within it.

Finally, the motto of this chapter was 'We are a generation plugged in, and if you want to reach us - and keep us - you have to plug in, too.' In the marketing of literature for young people, presence on social media is essential. The internet forms a natural extension of young people's social activities. The importance of online culture and entering into relationships with young people - or better still: letting young people take part - has been illustrated in this chapter. Young people want to belong and have a voice. Sharing is a key concept in their lives: a way to feel that they are contributing something to the world. Or in the words of one of John Green's characters: 'I just want to do something that matters. Or be something that matters. I just want to matter' (Green 2012: 92).

14 Quotes retrieved from https://www.facebook.com/pg/blossombooks/reviews/?referrer=page recommendations_see_all\&ref=page_internal [accessed 16 June 2018]. Translated into English by the author. Original text: 'Blossom Books zijn fantastisch. Een van mijn lievelingsuitgevers.' 'Ik wil álles van Blossom Books hebben, book \& non-book!' 


\section{References}

Linda Ackermans. 2021. 'Een decennium young adult literatuur in Nederland (2009-2019): een stand van zaken'. Tijdschrift voor Nederlandse Taal- en Letterkunde 137.1: [in press].

Jonathan Alexander. 2017. Writing Youth. Young Adult Fiction as Literacy Sponsorship. Lanham: Lexington Books.

Adam Arvidsson. 2005. 'Brands: A Critical Perspective'. Journal of Consumer Culture 5.2: $325-358$.

Pierre Bourdieu. 1993. The Field of Cultural Production. Essays on Art and Literature. Cambridge: Polity Press.

Elizabeth Bullen. 2009. 'Inside Story: Product Placement and Adolescent Consumer Identity in Young Adult Fiction'. Media, Culture \& Society 31.3: 497-507.

Michael Cart. 2010. Young Adult Literature. From Romance to Realism. Chicago: American Library Association.

Vincent Elzinga. 2015. 'Distributiedeal Blossom Books en MacMillan slaat aan.' On Boekblad, 23 March. https://boekblad.nl/Nieuws/Item/distributiedeal-blossombooks-en-macmillan-slaat-aan [accessed 9 August 2019].

John Green. 2012. An Abundance of Katherines. London: Penguin.

Alison Hearn. 2008. 'Meat, Mask, Burden. Probing The Contours of The Branded Self', Journal of Consumer Culture 8.2, 197-217.

Peter van den Hoven and Helma van Lierop-Debrauwer. 2014. 'Zoektochten zonder wegwijzers.' In Rita Ghesquière, Vanessa Joosen, and Helma van LieropDebrauwer (eds.), Een land van waan en wijs, pp. 374-404. Amsterdam/Antwerp: Atlas Contact.

Henry Jenkins. 2006. Convergence Culture. Where Old and New Media Collide. New York: New York University Press.

Helma van Lierop-Debrauwer. 2017. 'Finally Coming Together? The Bridging Role of the Adolescent Novel'. In Bettina Kümmerling-Meibauer and Anja Müller (eds.), Canon Constitution and Canon Change in Children's Literature, 222-237. New York: Routledge.

Marianne Martens. 2016. Publishers, Readers, and Digital Engagement. London: Palgrave Macmillan.

Meda Mucundorfeanu and Julia Szambolics. 2017. 'The Use of Product Placement in Books and E-Books'. Journal of Media Research 10.1: 58-69.

Alissa Quart. 2003. Branded. The Buying and Selling of Teenagers. New York: Basic Books.

Jo Royle, Louise Cooper, and Rosemary Stockdale. 1999-200o. 'The Use of Branding by Trade Publishers: An Investigation into Marketing the Book as a Brand Name Product'. Publishing Research Quarterly 15.4: 3-13. 
Claire Squires. 2009. Marketing Literature. The Making of Contemporary Writing in Britain. London: Palgrave Macmillan.

Alvin Toffler. 1980. The Third Wave. New York: Bantam Books.

\section{About the Author}

Linda Ackermans (1988) works as a PhD candidate in Dutch Modern Literature at the Radboud University Nijmegen. Her research focuses on the status and role of young adult literature within the Dutch literary field. For her research, she received a Promotion Grand for Teachers from The Netherlands Organisation for Scientific Research. She also works as a secondary school teacher and critic of youth literature. 



\title{
Of Dust and Dollars
}

\author{
Branding Poetry in the Twenty-first Century -The Case of \\ Ellen Deckwitz
}

Jeroen Dera

\begin{abstract}
This chapter explores the self-branding of the contemporary Dutch poet Ellen Deckwitz. Explicitly referring to herself as 'the product Ellen Deckwitz', this author uniquely defines her career as a poet in terms of branding. The chapter provides a vivisection of this self-proclaimed 'product' through an in-depth postural analysis. It shows how Deckwitz creates the posture of an authoritative yet relatable poetry-entrepreneur who considers herself to be the flag-bearer of the younger generation, a rhetorical strategy that enables her to blend economic and symbolic capital. This, in turn, makes it possible for Deckwitz to cater to both a highbrow and a mass audience, by effectively resisting the widespread clichés evoked by the term 'poetry'.
\end{abstract}

Keywords: poetry branding, contemporary poetry, posture analysis, Ellen Deckwitz, brand credibility

\section{Scylla and Charybdis}

According to Robert Crawford, one of T.S. Eliot's many biographers, the legendary author of The Waste Land (1922) was 'a poet with a business brain' (Crawford 2015: 442). This characterization is - especially in the case of a modernist writer like Eliot - at odds with twentieth-century stereotypes of poetry, a genre associated with dust rather than dollars. As Crawford's account of Eliot's marketing savvy shows, however, the so-called 'Great Divide' (cf. Huyssen 1986) between art and mart was already starting to

Helleke van den Braber, Jeroen Dera, Jos Joosten, and Maarten Steenmeijer (eds), Branding Books Across the Ages: Strategies and Key Concepts in Literary Branding. Amsterdam, Amsterdam University Press 2021 DOI: 10.5117/9789463723916_CH11 
diminish in the first decades of the century. This chapter argues that this is even more the case for contemporary poetry.

For many, the niche genre of poetry is not easily linked to the commercial world of marketing and money. Brown and Wijland (2015:559) borrow a metaphor from classical mythology in order to describe the oppositional nature of the two: they speak of 'the Scylla of poetry's elitist stigma and the Charybdis of managers' utilitarian taint'. Indeed, even prominent literature sociologists like Gisèle Sapiro have tended to isolate poetry from the principles of the market. Even at the beginning of the twenty-first century (decades after Eliot sophistically used his 'business brain'), Sapiro (2003: 448) framed poetry as a hermetic genre practiced in the most autonomous and closed segment of the literary field in opposition to the values of the market'.

The fact that poetry serves a relatively small audience in terms of sales figures, however, does not justify the hyper-autonomous image of the genre. Especially in the last decades, poets have become shrewder and more knowledgeable when it comes to personal branding (Brown and Wijland 2015: 552). In the case of contemporary poetry in the Netherlands, this trend is underlined by the ever-growing number of poets who combine their written work with all kinds of performances and ceremonial functions - from poet laureate of a soccer club to 'house poet' of television shows (cf. Dera, Posman, and Van der Starre 2016; Dera and De Strycker 2018). Without hesitation, one of the most eye-catching examples of 'poetry branding' in the Dutch literary field of the early twenty-first century concerns the poet Ellen Deckwitz (born 1982). In what follows, I will thoroughly analyse her posture as an authoritative yet relatable poetry-entrepreneur who considers herself to be the flag-bearer of the young generation. As I will demonstrate, this posture enables her to blend economic and symbolic capital, hence enabling her to serve both a highbrow and a mass audience, by effect resisting the widespread clichés evoked by the term 'poetry'.

\section{Ellen Deckwitz: An Omnipresent Product}

Ellen Deckwitz officially debuted in 2011, publishing her poetry collection De steen vreest mij ('The Stone Fears Me') with the reputable Dutch editor Nijgh \& Van Ditmar. It is appropriate to use the adverb 'officially' here, since Deckwitz managed to attain a promising position in the poetry field long before her debut in 2011. In 2009, she was crowned winner of the NK Poetry Slam, the Dutch national championships in performing poetry. In that same year, Deckwitz was the first recipient of the Meander Dichtersprijs, the 
poetry prize of the widely read digital magazine Meander. Hence, before traditionally entering the literary field with a collection of poems in print, Deckwitz had already acquired a name in both the performing and the online circuit - a mechanism that I will address more thoroughly later in this chapter.

Deckwitz's first collection of poems generated positive reviews and, more importantly, received the most distinguishing prize for a poetry debut in the Low Countries, the C. Buddingh'-prijs. Her next collections, Hoi feest ('Hi, Party!', 2012, crowned with the C.C.S. Crone Stipend) and De blanke gave ('The White Gift', 2015), also attained favourable criticism - the third collection having been published by Atlas Contact instead of Nijgh \& Van Ditmar. Some quotes from prominent poetry critics in the Dutch language area might illustrate Deckwitz's strong reputation in the field of symbolic production: her poetry is praised for its 'evocative sentences' (Monna 2012), 'alive-and-kicking language' (Menkveld 2012) and 'subtle play with sounds' (Gerbrandy 2015), which leaves critic Mario Molegraaf (2012) wondering: 'Who could resist the poet Ellen Deckwitz?'1

Next to her successes in print, Deckwitz further strengthened her reputation through other activities in the poetry field. She delivered numerous performances at all kinds of festivals (ranging from the literary stage of the Dutch pop phenomenon 'Lowlands' to a yurt festival in Mongolia), taught several poetry workshops per week at secondary schools, and participated in different television quizzes, including repeated appearances on the prime time show De Slimste Mens ('The Smartest Human') of the public broadcaster KRO-NCRV. The latter generated so much enthusiasm among people outside the Dutch literary field that the newspaper nrc.next offered Deckwitz a column to promote her ideas on poetry to a larger audience (cf. Kleijwegt 2015). This eventually resulted in the repeatedly reprinted essay book Olijven moet je leren lezen: een cursus genieten van poëzie ('One Needs to Learn How to Read Olives: A Course in Enjoying Poetry', 2016), also published by Atlas Contact. In 2015, this publisher was already responsible for both De blanke gave and Zo word je een geweldige dichter ('This Is How You Become a Terrific Poet'), in which Deckwitz gives aspiring poets tips and tricks on reading, writing, and publishing poetry. The poet's most recent collection of poems, Hogere natuurkunde ('Further Physics'), appeared with yet another publisher - Pluim - in 2019. This publisher also distributed her

1 In Dutch: 'beeldende zinnen'; 'springlevend van taal'; 'subtiel klankspel', 'Wie kan er weerstand bieden aan de dichteres Ellen Deckwitz?'. All translations of Dutch quotes are the responsibility of the author. 
second collection of short essays on poetry, Dit gaat niet over grasmaaien ('This is not about mowing', 2020).

Deckwitz's diverse combination of activities - that also includes musical performances, literary reports on the Eurovision Song Contest, and numerous contributions to literary magazines - is striking, even in the ever-buzzling field of contemporary Dutch poetry. It is no wonder, then, that Elke Depreter (2016: 239) argues that Deckwitz is 'omnipresent'. This pervasive position alone might justify the selection of Deckwitz as a case study in this chapter. Even more persuasive, though, is the fact that the poet herself seems to be aware of the branding mechanisms analysed in this volume. In a 2011 interview with fellow poet Maarten van der Graaff, who eventually became Deckwitz's successor as laureate of the C. Buddingh'-prijs, she described the need of actively claiming a position in the literary field, referring to herself as 'the product Ellen Deckwitz' (Van der Graaff 2011: 108). In this quote, Deckwitz explicitly and uniquely defines her poetry career in terms of branding. The next sections will provide a vivisection of this self-proclaimed 'product' in terms of the central conceptual pairs in this volume: self-presentation versus image, economic versus symbolic capital, and resistance versus acceptance.

\section{Authority and Brand Credibility}

As noted in the first section, Deckwitz conveys the posture of an authoritative yet relatable poet-entrepreneur who considers herself to be the flagbearer of the younger generation. This multilayered posture contains four aspects that should be discussed in depth in order to fully grasp Deckwitz's selfpresentation: (1) authority, (2) relatability, (3) entrepreneurship, and (4) flagbearing.

The issue of authority is important in Deckwitz's posture, because she seeks to initiate the general audience in the domain of poetry - especially through her newspaper columns and her books Zo word je een geweldige dichter and Olijven moet je leren lezen. In the context of author branding, literary authority can be fruitfully analysed through the concept of 'brand credibility'. Erdem and Swait (2004) define brand credibility as trustworthiness and expertise and show statistically that credibility increases the probability of a specific brand being included in the consideration set of consumers. In Deckwitz's case, the mechanism is at work in the paratextual rhetoric of her blurbs that frequently underline her academic degree in the humanities. The blurb of the debut collection De steen vreest mij introduces 
the poet's education even before her achievements in the poetry field: 'Ellen Deckwitz (1982) studied Literary and Cultural Studies and has published in, amongst others, Bunker Hill, Dietsche Warande \& Belfort, and the anthology Ik ben een bijl.'2 The blurb of Hoi feest mentions this academic identity as well, even presenting Deckwitz as a 'literary scholar'. Interestingly, the notion does not appear on the blurb of De blanke gave, the poet's first book published by Atlas Contact, whereas this same publisher underlined Deckwitz's academic grade in the paratextual presentation of Zo word je een geweldige dichter, which appeared only six months after De blanke gave. This difference might be explained through the specific educational nature of Zo word je een geweldige dichter, a didactically oriented book that needs to be marketed as the work of an expert in the field of literature, not just of any poet. To put it differently: the educational approach of this publication is legitimized through Deckwitz's MA title. Additionally, the paratext of Zo word je een geweldige dichter highlights the poet's achievement in literary prizes, mentioning both the C. Buddingh'-prize and the NK Poetry Slam, but also the Meander Dichtersprijs - the annual award of the digital literary magazine Meander. Together, these prizes cover Deckwitz's widespread success, acquiring symbolic capital both in print, on stage, and online. Yet again, this contributes to the poet's brand credibility: Zo word je een geweldige dichter is presented as a reliable product; its academically embedded author has mastered the trajectory of the modern poet herself by establishing a name in all important subfields of contemporary poetry. A similar device applies to Olijven moet je leren lezen, although Deckwitz's academic achievements are replaced by her public appearances in this case: 'Thanks to performances in television shows like De Wereld Draait Door and a column in nrc.next, Deckwitz has developed into one of our most transmissible ambassadors of poetry'.3 This time, the noun 'ambassador' does the trick, telling potential buyers that they are about to be guided by somebody who is famous for her enthusiastic ambassadorship.

The emphasis on Deckwitz's authority, then, functions as a mechanism that increases her credibility as a brand; it implies a promise of the value that readers will receive. While this promise is virtually attached to the author, it is de facto made by the publisher, who holds the final responsibility for the paratextual representation of its authors in catalogues and blurbs.

2 'Ellen Deckwitz (1982) studeerde Literatuur- en Cultuurwetenschap en publiceerde in onder meer Bunker Hill, Dietsche Warande \& Belfort en de bloemlezing Ik ben een bijl.'

3 'Dankzij optredens in televisieprogramma's als De Wereld Draait Door en een column in $n r c$. next heeft Deckwitz zich ontwikkeld tot een van onze meest aanstekelijke poëzieambassadeurs.' 
Interestingly, Deckwitz herself articulates a somewhat ambiguous position towards the authoritative aspect of her posture. On the one hand, she affirms her knowledge of literary theory and scholarly debates in literary studies; on the other, she downplays the importance of such repertoires. A striking example is provided by her comments on the oeuvre of Tonnus Oosterhoff, a postmodernist poet whose works received all major Dutch poetry prizes. Contending that a joke becomes less funny when explained, Deckwitz states: 'The same often goes for the poems of Tonnus Oosterhoff, in spite of decennia of well-meant literary studies' (Deckwitz 2016: 40). ${ }^{4}$ In this quote, Deckwitz implies that she is aware of the reception history of Oosterhoff's poetry, hence demonstrating her posture as a literary scholar. At the same time, by framing literary studies as 'well-meant', she implicitly conveys the message that one does not need literary scholars (like herself) to enjoy or understand poetry.

\section{A Relatable Mediator}

The latter is also important with regard to the second aspect of Deckwitz's posture: relatability. Being relatable is crucial in the personal branding of cultural mediators: in order to persuade consumers to pursue an active interest in a specific cultural phenomenon (such as poetry), cultural mediators should present themselves and their 'product' in an approachable manner. Although they are authorities who have acquired the legitimacy to shed their light on cultural matters, participating in public discourse often requires a relatable image. In Deckwitz's case, this mechanism is at work on both the institutional and the discursive level. Institutionally, she presented herself in popular media (such as the daily talk show De Wereld Draait Door and the television quiz De Slimste Mens), talking about poetry in contexts that people usually do not associate with the genre. Such television performances definitely help to strengthen the Deckwitz brand because of their outreach in terms of audience ratings, but they also underline that author branding is a collective process. Presenting herself in popular media indeed helps Deckwitz to relate to a large(r) audience of (possible) readers, but she relies on television producers and directors to do so effectively.

The author has relatively more control on the discursive level, for instance by adopting an accessible writing style that does not chase non-poetry readers away. This strategy breaks with a tradition that might be described

4 'En decennia van goedbedoelde literatuurwetenschap ten spijt: hetzelfde geldt vaak voor de gedichten van Tonnus Oosterhoff.' 
in terms of 'branding the inaccessible': for many, poets are associated with mystery and inscrutability rather than relatability. Deckwitz also deconstructs such a distance between poet and (general) audience by addressing popular phenomena in pop culture (e.g. the tv series Game of Thrones and the Eurovision Song Contest), as well as by incorporating the ordinary in the discourse on poetry. For instance, she reveals that one of her poems resulted from a phone call with her mother (Deckwitz 2015: 37), while at the same time asserting that one does not need an elitist Moleskine notebook to write poems: 'A Hema-notebook sometimes works better, for this makes writing poetry somewhat less official' (Deckwitz 2015: 39). ${ }^{5}$

To some extent, Deckwitz's emphasis on popular and ordinary events mirrors classic teleological ideas about taste development. 'You will think Stravinsky sounds terrible if you haven't heard the Lord of the Rings soundtrack first', she claims in Olijven moet je leren lezen (Dohmen 2013). ${ }^{6}$ The poet seems to defend a logic in which cultural taste is acquired in a stepwise process - a vision common to Dutch cultural mediators from the interwar period onwards (Dera 2017a). With this attitude goes a strong ambition. Claiming that we live 'in a time in which media and politicians excel in blazing abroad claptrap' (Deckwitz 2016: 10), she asserts that precise reading is crucial to maintain a healthy democracy. ${ }^{7}$ Poetry, with its often dense and hermetic character, is especially suitable for training such a critical reading ability. Deckwitz's teleology of 'reading up', then, ideally fosters the general audience to use popular culture like Game of Thrones as a steppingstone to more complex genres like poetry - and, concomitantly, to become more critical citizens. In this respect, the posture of the relatable poet is closely intertwined with Deckwitz's ambitions as a cultural mediator. Hence, the postural aspect of relatability is more than a piece in the broader puzzle of brand credibility.

\section{An Entrepreneur in a Gift Economy}

However, a contemporary poet cannot live off this kind of idealism alone. This fact is underlined by the third aspect of Deckwitz's posture,

5 'Een Hemaschriftje werkt soms beter omdat dat het dichten allemaal iets minder officieel maakt.' The 'Hema' is a Dutch commercial store chain which sells everything from affordable clothing to bakery products.

6 'Stravinsky vind je ook teringherrie als je niet eerst de soundtrack van Lord of the Rings hebt gehoord.'

7 'In een tijd waarin media en politiek uitblinken in het rondbazuinen van holle frasen.' 
entrepreneurship. While the Deckwitz personal brand is certainly not singular for her authority and relatability, it is - at least in the field of Dutch poetry - quite unique that a poet is able to make a living out of her poetry. Even more unique is that Deckwitz frequently emphasizes this economic situation, hence turning her financial independency into a trademark that further strengthens her brand credibility. Even before she officially debuted, Deckwitz could already pay her bills thanks to four to five poetry readings per week, plus an average of two weekly workshops at secondary schools and universities (Dohmen 2013). While this might also be the case for other contemporary poets in the Netherlands, at least hypothetically, Deckwitz's success in moneymaking was even mentioned on the blurb of De steen vreest mij: 'Deckwitz lives off her writing. ${ }^{8}$

This process of postural position-taking through economic success is remarkable, especially in the case of poetry. As Ailsa Craig (2007) put it, poetry practice is often a 'career without a job'. Following Bourdieu, Craig holds that poets function at the pure pole of the literary field, where economic success is secondary (and sometimes even inferior) to symbolic value. The formative tension of the literary field is, in this view, that between commercial and non-commercial pursuits. Deckwitz's case at least raises questions about the tangibility of such a tension in the twenty-first-century poetry field, where poets apparently can reside as cultural entrepreneurs who proudly present their career as a job (and, by implication, refer to themselves as 'the product Ellen Deckwitz' without the slightest hint of irony).

Such a focus on entrepreneurship, with branded authors explicitly emphasizing their own brands, moves beyond the habitus of the literary field that dominated auctorial position-takings throughout the twentieth century. Whereas poets of older generations generally claimed an autonomous orientation, centring their identity myths around the idea that poets were not interested in money and market, poets like Deckwitz actively maintain personal brands that enable them to take part in the larger media system. Their poetry (career) is most certainly not governed by the ideology of art for art's sake but is rather enmeshed in the larger macrolevel of a businessoriented society. In this sense, the postural aspect of the entrepreneur shifts away from the logic as described by Wilson (1990: 171) a couple of decades ago: 'A poet who consciously plots his career in terms of worldly goals, e.g. a certain income, a certain reputation, is generally scorned.'

A possible reason why Wilson's remark does not apply to contemporary poets like Deckwitz, is because they have no problem with sharing their 
recipe for success with their peers. Especially in small countries like the Netherlands and Flanders, poets tend to know each other. Nowadays, many poetry careers in the Low Countries, like Deckwitz's, start in the subfield of poetry reading. Craig and Dubois (2010:442) argue that these readings, 'as a social space of activity and relations', 'are key to both poetry economies and careers'. Their central argument is that such meetings are structured by the logic of offering; that is, the giving and receiving of poems, opportunities, and friendships. For instance, poets regularly attend each other's performances and contribute to the gift economy by mentoring or being available to be mentored. Actively maintaining a broad network in the contemporary poetry scene, both in real life and online, Deckwitz holds a central position in the Dutch literary gift economy. Zo word je een geweldige dichter even might be interpreted as a 'gift' to aspiring poets, while some of the poems included in Olijven moet je leren lezen were written by young, unestablished poets (e.g. Maarten Buser, Vicky Francken, Johanna Geels) who had just debuted or had not even published a collection of poetry yet. By turning her readers' attention to their work, Deckwitz offers them a place in the literary spotlights.

\section{An Ambivalent Flagbearer}

Yet the act of giving implies benefits for the giver as well. In the context of branding, one could argue that Deckwitz's generosity contributes to her own brand value, because audiences will perceive her as social rather than egocentric. Such ambivalent altruism also manifests itself in the context of the final aspect of Deckwitz's posture, flagbearing. In an interview, the poet uses the term to mark her leading position in the contemporary poetry scene, referring to herself as 'flagbearer of the young generation' (Dohmen 2013). ${ }^{9}$ On the one hand, this rhetoric undeniably has its social side, since it affirms collectivism rather than the poetics of the individual genius. On the other hand, the metaphor of the flagbearer places Deckwitz on top of the pyramid: she might be part of a collective, but she is the spokesperson or even the icon of this group that, speaking of which, remains unspecified throughout the interview. It goes without saying that this rhetorical strategy works well when maintaining a brand. By underlining that she is in front of the pack without explicitly claiming that she is the leading poet of her generation (hence risking an arrogant image), Deckwitz conveys the message that her brand value should be taken for granted. 
The metaphor of the flagbearer is also interesting from another point of view, since it resembles the avant-garde discourse with its many military topoi. Indeed, in an early interview in her career, which appeared in the academic journal Vooys, Deckwitz applies a typical avant-garde strategy when discussing her position in the literary field, presenting herself as the 'new' and earlier generations as the 'old'. She especially resists the so-called baby boom generation in the Netherlands, who 'currently still have a hegemonic position in the academic and literary world' (Van der Graaff 2011: 107). ${ }^{10}$ Mentioning the leading critics Piet Gerbrandy and Elsbeth Etty as striking representants, the new product named Ellen Deckwitz reveals herself as the logical successor of this generation. This position-taking goes hand in hand with distinction and some controversy, with Deckwitz stating that Dante's La Divina Commedia is 'boring as hell' (Van der Graaff 2011: 108).

This statement on Dante brings us back to the issue of authority again. Deckwitz legitimizes her view through her own academic distinction: 'I received my MA in literary studies with honours, plus I took specialist courses in medieval studies, so I know what I'm talking about when I say that La Divina Commedia bores me' (Van der Graaff 2011: 108). ${ }^{11}$ Interestingly, this remark is at odds with the school of literary studies adopted by the faculty who educated Deckwitz at her alma mater, the University of Groningen. Chaired by Professor Gillis Dorleijn, Dutch Studies in Groningen laid emphasis on institutional analysis, following Bourdieu's basic insight that the value of literary texts is not intrinsic but attributed by several actors in the literary field. From an institutional point of view, it would be a fallacy for literary scholars to claim that they 'know what they are talking about' when calling a canonical text 'boring as hell', for this would imply that such an evaluation could result from an objective academic analysis. In that sense, Deckwitz risks to damage her brand credibility, at least for academics who read the interview. There is an alternative interpretation of the 'boring as hell' quote, though. To some extent, it might also be a self-reflective statement. Its irony is apparent in the use of the word 'hell' in an evaluation of Dante's inferno, but the poet's remark that she knows what she is talking about, could also be ironical. In that case, the phrase would reveal that Deckwitz is aware of using Dante as a means of strategic

10 '[M] aken op het moment van schrijven nog steeds de dienst uit in de academische en literaire wereld.'

11 'Ik heb een cum laude master in literatuurwetenschap plus een specialisatie in mediëvistiek, dus ik weet wel wat ik zeg als ik zeg dat ik De Goddelijke Komedie saai vind.' 
position-taking, ironically admitting that she is adopting an avant-garde logic throughout the interview.

It is important to mention this ambiguity, because it demonstrates how complicated it is to assess the effects of a posture on the audience (compare Dera 2015). Where some readers of the interview will doubt Deckwitz's brand credibility based on the Dante quote, others will take her authority seriously. The 'product Ellen Deckwitz', then, cannot function outside the mindset of her audience - which should not be conceptualized as a homogeneous mass, but as a heterogeneous network of individual consumers who eventually share beliefs and values that make reading Deckwitz a plausible option.

\section{Charging Economic Capital with Symbolic Value}

As we have seen, the author Deckwitz inhabits a posture that in many respects functions as a brand, in the sense that it promises the reading public that they will receive good value when purchasing a Deckwitz book: the poet is an authority, she is relatable, she is a successful entrepreneur, and she is the frontrunner of a new, young generation. This identity myth is not only constructed by the poet herself, though. Although Deckwitz certainly evokes a strong self-presentation, her image is also shaped by other actors in the branding process, especially her publishers and the media. The effectiveness of Deckwitz's posture is also underlined by statements of her fellow poets. Ingmar Heytze, for example, compares the initiation phase of Deckwitz's and his own career as follows: 'She really is a cultural entrepreneur. When I started as a poet, in the late 1980s, I took a job at the post office, since it was impossible to make a living out of poetry. I didn't come up with the idea to participate in poetry slams' (Bekkering 2012). The latter is not really a surprise, because the infrastructure of the poetry field in the eighties differed significantly from that in the first decades of the twenty-first century. The point is, though, that self-presentation and image are enmeshed in this case-Deckwitz's posture seems to be that strong that even her fellow poets enforce her brand value.

The identity myth which results from this interplay between various actors embodies a fundamental tension between symbolic and economic capital. The focus on authority and flagbearing presumes an orientation towards symbolic capital, whereas relatability and entrepreneurship are rather more linked to economic capital. As aforenoted, then, the strict opposition between the Bourdieuan subfields of restricted and large-scale production is not tangible in the case of this contemporary poet. Deckwitz 
effectively mixes activities aimed at gathering symbolic capital with strategies aimed at economic capital, hence communicating her brand to both the poetry niche and a broader audience.

An important benchmark in this respect are Deckwitz's publishers, who contribute significantly to the author's symbolic brand value. As Dubois and François (2013: 515) explain, publishing houses act as aesthetic signals understood by all actors in the poetry field. Recognized authorities like critics, booksellers, and librarians use publishers as major markers to determine a poet's position in the constantly shifting production space. This is also true for the field of contemporary Dutch poetry, despite the emergence of digital literature and bottom-up oriented publishing initiatives (Dera 2017b). Deckwitz's first publisher, Nijgh \& Van Ditmar, is a reputable actor in Dutch literature, thus laying the foundation for the poet's symbolic capital. Her second publisher, Atlas Contact, has an even higher position in the literary hierarchy. Taking the symbolic capital of her publishers as a reference point, then, Deckwitz's career seems to follow a linear path.

Yet, being a relatable poetry entrepreneur who does not confine to a classic publishing model, Deckwitz does not simply resemble the so-called ratchet effect, conceptualized by Giuffre (1999) as the logic that actors who have moved up to a certain status are not likely to go back down to an inferior class. To some extent, her attitude towards her position as a performance poet hints at the ratchet effect, for Deckwitz frames her highly successful slam career as a steppingstone in her career. She literally calls the national championships in poetry slam 'a push on occasion' (Bekkering 2012) for aspiring poets who have plenty of work ready for publication, implying that poetry readings have a peripheral position and in-print publications a central function in the poetry field. ${ }^{12}$ At the same time, in 2013, having acquired a name as a publishing poet as well, Deckwitz refers to herself as 'stage poet pur sang', hence deconstructing the hierarchy by suggesting that poetry readings are more defining for a career than poetry collections in print. This rhetoric strongly corresponds with the poet's behaviour in the field, with Deckwitz being a highly active contributor at literary festivals and a frequent host of poetry slam activities. Still, the authoritative brand Deckwitz is fully aware of the need of traditional publications in order to maintain her position, having experienced the impact of symbolic capital herself. In Zo wordje een geweldige dichter, she admits that a certain literary magazine had rejected her poetry before she debuted but suddenly accepted her work after she won the C. Buddingh'-prize for De steen vreest mij (Deckwitz 2015: 126). 
While Deckwitz's career is strongly governed by symbolic capital, then, the poet actively strives for economic capital as well. As shown in the previous paragraphs, she fruitfully engages with popular media and brands herself as a successful cultural entrepreneur, even framing herself as 'the product Ellen Deckwitz'. Such a combination of position takings aimed at both symbolic and economic capital is, quite frankly, not something to be surprised about in the context of the literary field, in which the interplay between different kinds of capital works as a structuring principle. It is typical of twenty-first-century authors like Deckwitz, however, that they tend to deny the binary opposition between pecunia and prestige. 'The product Ellen Deckwitz' constantly demonstrates how the symbolic is interwoven with the economic, at the same time charging economic capital with symbolic power.

Some examples taken from Deckwitz's essays might illustrate this point. In Olijven moet je leren lezen, she states: 'To me, giving poetry workshops is almost as much fun as making money' (Deckwitz 2016: 45). ${ }^{13}$ This quote is somewhat misleading (or ironic at the least), suggesting that Deckwitz gives workshops for free, whereas the seventy to a hundred classes she teaches annually are of great importance to her financial situation. Moreover, the poet positions moneymaking slightly higher in the hierarchy than the didactic activities she employs, hence blurring the traditional lines between economic capital and the symbolic value attached to cultural mediation. Such a reversal of values is also apparent in a second example, in which Deckwitz demystifies the aura of publishing in print while celebrating the benefits of on-stage performances: 'As poetry collections almost always end up in a clearance sale, their spiritual parents are raking the money in with their performances' (Deckwitz 2016: 143). ${ }^{14}$ A similar reassessment of the poet as a viable moneymaker is made manifest in a third example, with Deckwitz joking that Tonnus Oosterhoff could afford a lifelong holiday on the Dutch island Vlieland based on his literary prizes alone (Deckwitz 2016: 39). In this case, a classic indicator of symbolic capital (the institution of literary prizes) is explicitly loaded with economical capital, thus blurring the line between these two.

Deckwitz's deconstruction of the opposition between economic and symbolic capital might be interpreted against the background of the third conceptual pair in this volume: resistance versus acceptation. In many

13 'Ik vind het geven van een workshop bijna even leuk als geld verdienen.'

14 'Waar poëziebundels bijna altijd in de ramsj belanden, verdienen hun geestelijk ouders goudgeld met optreden.' 
ways, Deckwitz's focus on poets' business brains resists the cliché image of poetry as a niche for vagabonds who would turn down every penny for the sake of art. The rewriting of the poet as an entrepreneur is a necessary step in the popularization of the genre - it might even be considered a key mechanism in poetry branding in general. According to Deckwitz, then, a poet is not a chosen one whose accomplishments are achieved through spontaneous overflows of powerful feelings: they can be anyone who got awarded grading points for writing 'a bullshit story on an exam sheet' (Deckwitz 2015: 81).

The branding of poetry as an economical commodity is also visible in Deckwitz's account of why poetry is useful. In her defence of poetry, two of the classic answers to this question - reading poetry facilitates intellectual flexibility and fosters a multifaceted conception of reality - are not first in line. Instead, Deckwitz opens her plea noticing that poetry objects have a decorative function in interior designs and that poetry performances on television - for instance Nico Dijkshoorn's contributions to the daily talk show De Wereld Draait Door - are a form of amusement (Deckwitz 2016:112). Although she spends far more words on the intellectual benefits of reading poetry, it is meaningful that Deckwitz addresses the more approachable uses of poetry first.

\section{Concluding Remarks}

The first paragraph of this chapter used the metaphor of Brown and Wijland (2015: 559) in order to describe the common conception of the relationship between branding and poetry. The opposition between 'the Scylla of poetry's elitist stigma and the Charybdis of managers' utilitarian taint' seems inapplicable to the case of Ellen Deckwitz. Deckwitz unifies Scylla and Charybdis: her brand addresses both the elitist niche of the Dutch poetry scene and the large-scale interests of a more general audience. Embodying entrepreneurship rather than autonomy, Deckwitz seems to reinvent the image of the modern poet. It would be interesting to carry out more research on the posture Deckwitz conveys in order to (co-)communicate her brand image to the heterogeneous audiences she addresses. Other contemporary poets in the Netherlands and Flanders, such as Charlotte Van den Broeck, Ramsey Nasr, and Maud Vanhauwaert, show similar patterns, raising the hypothesis that the model of the entrepreneur is widely present in the field of contemporary Dutch poetry. Like T.S. Eliot, they all seem to be poets with a business brain. 


\section{References}

Persis Bekkering. 2012. 'Dichters uit hun schulp'. de Volkskrant, 17 December.

Stephen Brown and Roel Wijland. 2015. 'Profit From Poetry: Bards, Brands, and Burnished Bottom Lines'. Business Horizons 58: 551-561.

Ailsa Craig. 2007. 'Practicing Poetry: A Career Without a Job'. In C. Calhoun and R. Sennett (eds.), Practicing Culture, pp. 35-56. London: Routledge.

Ailsa Craig and Sébastien Dubois. 2010. 'Between Art and Money: The Social Space of Public Readings in Contemporary Poetry Economies and Careers'. Poetics 38.5: 441-46o.

Robert Crawford. 2015. Young Eliot: From St. Louis to The Waste Land. London: Jonathan Cape.

Ellen Deckwitz. 2015. Zo word je een geweldige dichter. Amsterdam: Atlas Contact. Ellen Deckwitz. 2016. Olijven moet je leren lezen: een cursus genieten van poëzie. Amsterdam: Atlas Contact.

Elke Depreter. 2016. 'Lichtvoetige duisternis: de poëzie van het "product" Ellen Deckwitz'. In J. Dera, S. Posman, and K. van der Starre (eds.), Dichters van het nieuwe millennium: Nederlandse en Vlaamse poëzie in de $2 \tau^{e}$ eeuw, pp. 239-249. Nijmegen: Vantilt.

Jeroen Dera. 2015. “En dat vindt u vrouwelijk?' Posture versus imago in een televisieinterview met Jacques Hamelink'. Nederlandse letterkunde 20.3: 253-270.

Jeroen Dera, Sarah Posman, and Kila van der Starre (eds.). 2016. Dichters van het nieuwe millennium: Nederlandse en Vlaamse poëzie in de $_{2 \tau^{e}}^{e}$ eeuw. Nijmegen: Vantilt.

Jeroen Dera. 2017a. Sprekend kritiek: literatuurprogramma's in de vroege jaren van de Nederlandse radio en televisie. Hilversum: Verloren.

Jeroen Dera. 2017b. 'Van gift naar goud. Overwegingen over de plaats van chapbooks in het poëzieveld'. Kunsttijdschrift Vlaanderen 363:28-31.

Jeroen Dera and Carl De Strycker (eds.). 2018. Bundels van het nieuwe millennium: Nederlandse en Vlaamse poëzie in de $27^{e}$ eeuw. Nijmegen: Vantilt.

Anne Dohmen. 2013. 'Ik zie mezelf als vaandeldrager'. NRC Handelsblad, 3 April.

Sébastien Dubois and Pierre François. 2013. 'Career Paths and Hierarchies in the Pure Pole of the Literary Field: The Case of Contemporary Poetry'. Poetics 41.5: 501-523.

Tulin Erdem and Joffre Swait. 2004. 'Brand Credibility, Brand Consideration, and Choice'. Journal of Consumer Research 31.1:191-198.

Piet Gerbrandy. 2015. 'Waarom blijf je toch dochter'. De Groene Amsterdammer, 26 March.

Katherine Giuffre. 1999. 'Sandpiles of Opportunity: Success in the Art World'. Social Forces 77: 815-832. 
Maarten van der Graaff. 2011. “De Goddelijke Komedie is boring as hell”: interview met Ellen Deckwitz'. Vooys: tijdschrift voor letteren 29.1-2: 104-108.

Andreas Huyssen. 1986. After the Great Divide:Modernism, Mass Culture, Postmodernism. Bloomington/Indianapolis: Indiana University Press.

David Kleijwegt. 2015. 'De poëzie heeft me gered, naast pillen en therapie natuurlijk'. Vrij Nederland, 19 December.

Erik Menkveld. 2012. 'Ellen Deckwitz wint prijs beste debutant'. de Volkskrant, 15 June.

Mario Molegraaf. 2012. 'Kijken zoals je nog nooit gekeken hebt'. De Gelderlander, 24 November.

Janita Monna. 2012. 'Akkers, bomen, water'. Trouw, 23 June.

Gisèle Sapiro. 2003. 'The Literary Field Between the State and the Market'. Poetics 31.5-6: 441-464.

Robert N. Wilson. 1990. The American Poet: A Role Investigation. New York: Garland.

\section{About the Author}

Jeroen Dera (1986) holds a PhD in literary studies from Radboud University Nijmegen. He currently works as an assistant professor at the same university. His research concerns contemporary poetry, literary education, and the relation between literature and the media industries. Dera is the programme director of the dual MA 'Education in Language and Cultural Studies' at Radboud. He also works as a poetry critic for the Flemish newspaper De Standaard. 


\title{
'This Is What We Share'
}

\author{
Co-branding Dutch Literature at the 2016 Frankfurt Book \\ Fair
}

Jack McMartin

\begin{abstract}
This chapter focuses on the joint guests of honour at the 2016 Frankfurt Book Fair, Flanders and the Netherlands - a rare case of two government organisations representing separate national groupings (Flanders and the Netherlands) coming together to present the literature of a single language (Dutch) on the international stage. It recounts how the two delegations' shared status as guests of honour for 2016 came about through a collaboration between the Dutch Foundation for Literature and the Flemish Literature Fund (now known as Flanders Literature) and analyses the branding decisions made by the 2016 organizers. Conceptually, the chapter engages with perspectives from field theory and the sociology of translation to elaborate branding as a form of position-taking and guest of honour presentations as important mechanisms of transnational capital conversion.
\end{abstract}

Keywords: Dutch literature in translation, Frankfurt Book Fair, guest of honour, Flemish Literature Fund, Flanders Literature, Dutch Foundation for Literature, sociology of translation.

\section{Introduction}

The Frankfurt Book Fair is the publishing world's largest, most important trade fair. It attracts thousands of book professionals from around the world and hundreds of members of the German and international press. A role of special prominence in this rarefied transnational space goes to

Helleke van den Braber, Jeroen Dera, Jos Joosten, and Maarten Steenmeijer (eds), Branding Books Across the Ages: Strategies and Key Concepts in Literary Branding. Amsterdam, Amsterdam University Press 2021 DOI: 10.5117/9789463723916_CH12 
the guest of honour, which 'sets the tone' for the year's fair and occupies a 2300-square-metre pavilion designed to be its 'beating heart' (Weidhaas 2007: 217). With a few notable exceptions (the present case included), invitees have been individual nation states and exhibitions have been produced by these states' cultural policy deputies, often in collaboration with national book trade associations. In the four decades since the first focus of interest in 1976 - Latin America, in the midst of the Boom - being the guest of honour has become a coveted platform for governments seeking to promote their literatures and cultures on the world stage. ${ }^{1}$ It now holds a place alongside other fora at international (cultural and sporting) mega-events as an occasion for what Kerr and Wiseman (2013: 354) call 'nation branding', or 'the application of corporate marketing concepts and techniques to countries, in the interests of enhancing their reputation in international relations'. But how to brand a guest of honour at Frankfurt when the invitee is not a single, culturally homogenous nation state?

In this chapter, I focus on the Frankfurt Book Fair's most recent exception to the single nation state norm: the jointly organized guest of honour presentation by Flanders and the Netherlands in 2016. ${ }^{2}$ It marks only the second time in the history of the fair (after Flanders and the Netherlands' first joint appearance in 1993) that two organizations representing two separate governments have partnered to present at Frankfurt. While there have been instances of countries within a given language area presenting under a single banner ('the Arab World' in 2004, for example), such constellations are rare. Add to this the fact that Flanders is not a nation state proper, ${ }^{3}$ but rather, like the 2007 invitee Catalonia, ${ }^{4}$ a stateless nation that postures

1 The focus of interest/guest of honour platform was initially conceived as a forum for sharing books about pressing social and political questions of the day, its programming curated and funded by the fair's organizers, the German Publishers and Booksellers Association (Börsenverein des Deutschen Buchhandels). The focus alternated yearly between a special topic and a guest country or region, chosen, in the words of long-time fair director Peter Weidhaas, 'to bring together and stimulate discussion of global problems in one building' (Knapp). In 1988, fair organizers switched to a new, bid-based guest of honour concept similar to those used for major international cultural and sporting events: prospective guests submit bid books with detailed budgets, strategies for reaching out to German publishers (including generous translation subsidies), the press and the general public, and plans for the guest of honour pavilion.

22016 marked only the second time that a guest has presented twice. India was the first, in 1986 and 2006. France, the 2017 guest of honour, became the third country to present twice, its first appearance being in 1989 .

3 By 'Flanders' I mean the Flemish Community, a sub-sovereign entity within the federal Belgian state with full autonomy in the areas of culture, language, education, and regional economic affairs.

4 For more on the nation branding strategies used by Catalonia, see Woolard. 
itself among nation states, and one begins to get a sense of the challenging branding task faced by the 2016 organizers.

The chapter is divided into two parts: in the first part, I discuss how the 2016 guest of honour invitation came about through a collaboration between the Dutch Foundation for Literature (DFL) and the Flemish Literature Fund (FLF). 5 These two governmental organizations are charged with supporting Dutch literature in the Netherlands and Flanders respectively, and have mandates that include both talent nurturing at home and promotional activities abroad. In the second part, I analyse the branding decisions made by the 2016 organizers: to what extent can their branding of Dutch literature be understood as a reflection of their position in the transnational literary field? The organizers clearly opted for pluriformity in their branding decisions, avoiding markers of national distinction and hierarchization between the two partners while taking great pains to underscore commonalities. This branding strategy is epitomized by the promotional campaign's baseline: 'This is what we share.' I argue that this collaborative type of nation branding, which I call 'co-branding', is borne out of a shared strategy of combining limited resources in order to overcome an otherwise hyper-peripheral position - a transnational version of the so-called 'polder model' that has been a dominant mode of socio-economic (and cultural-political) policymaking in the Netherlands since the 1980 s. $^{6}$ While capturing a stage as high-profile as the guest of honour spot at Frankfurt would probably not have been possible without such a strategy, it is neither politically innocuous nor guaranteed to be effective when translated into a brand identity. I conclude by examining the implicit legitimizing effect that co-branding affords Flanders as a stateless nation, standing alongside its bona fide nation state neighbour to the north.

\section{Field Theory, Branding, and the World Market for Translations}

It is useful to first situate the 2016 organizers' respective positions in the social sphere in which they operate: the world market for book translations. Sociologists of literature have recently begun to shed light on the structure of this market and the motivations of its producers and intermediaries. ${ }^{7}$

5 In Dutch, Nederlands Letterenfonds and Vlaams Fond voor de Letteren. The Flemish Literature Fund is now known as Flanders Literature, or Literatuur Vlaanderen in Dutch. Because this research was conducted before the name change, I retain the former name in this chapter.

6 See Hendriks and Toonen 2018.

7 See Thompson 2012; Sapiro 2008; Sapiro 2010; Sapiro 2012; Sapiro 2015; Sapiro 2016; Heilbron and Sapiro 2016. 
Several have drawn inspiration from Pierre Bourdieu's analysis of the French publishing world, in which he uses a field-theoretical model to explain its oppositional structure (Bourdieu 2008 [1999]). Bourdieu starts from the assumption that any social sphere organized around a common pursuit can be approached as a field. Actors (individuals and organizations) in any given field are endowed with unequal resources (capital) and struggle to advance their position through the strategic pursuit and use of these resources, pursuant to that field's 'rules of the game' (Bourdieu 1996). In the French literary field, as in all fields of cultural production, capital can be subdivided into economic capital (wealth) and symbolic capital (prestige) (Bourdieu 1993). Bourdieu found a homologous relationship between agents' market position in terms of scales of production and distribution on the one hand (small-scale versus large-scale), and their logics of valuation (aesthetic versus profit-driven) on the other. Agents situated at the large-scale pole were mainly interested in finding bestsellers that turn a quick profit (the accumulation of economic capital), whereas for agents at the small-scale pole this economic logic was 'reversed' (Bourdieu 1983): they sought to publish books that earned the recognition of respected arbiters of literary quality (the accumulation of symbolic capital) above - and even sometimes in diametric opposition to - commercial success. ${ }^{8}$

I follow Thompson in including an additional form of capital in the analysis: social capital, which is derived from and determined by 'the networks of contacts and relationships that an individual or organization has built up over time' in the industry (Thompson 2012: 6). An actor's social capital is reflected in the extent to which it can make use of networks of autonomy and indebtedness to improve its position in the field. ${ }^{9}$

In an effort to include geopolitical factors in the sociological analysis of world literature, Bourdieu's pupil Gisèle Sapiro superimposes a version of his national model onto the contemporary world market for books. Her 'transnational literary field' concept retains Bourdieu's structural oppositions and his emphasis on economic and symbolic capital accumulation, which she uses to understand Anglo-American-led globalization and conglomeration and its effects on the world market for translated books. ${ }^{10}$

8 See the introduction to this volume for a discussion of the opposition between economic and symbolic capital.

9 See Bourdieu 1985.

10 Sapiro observes that economic constraints have become more pressing for all book producers in the era of globalization. She reports decreased diversity in terms of source languages in the world market for translated books and a tendency toward repertory standardization among publishers of translations, or publishing only 'books that sell' (Sapiro, 2016). 
She augments her conceptual frame with an additional, interrelated form of capital borrowed from Pascale Casanova: literary capital, or the accumulated prestige of a given language as determined by such things as the number of Nobel laureates it boasts (Casanova 2004; 2010). Following her colleague Johan Heilbron, Sapiro furthermore sees the incoming and outgoing flows of translated books between languages as a supplementary indicator of a language's dominance: languages that export more and import less are central while languages that import more and export less are peripheral (Heilbron 1995; Heilbron 1999; Heilbron and Sapiro 2016). In today's world market for translated books, English is hyper-central, German and French are semi-central, and all other languages, including Dutch, are peripheral. At the actor level, this implies that each individual or organization in the transnational literary field possesses a certain amount of de facto literary capital depending on the language(s) out of which they work. An actor working out of German, French, or English will generally marshal more literary capital than one working out of Dutch.

While sociologists of literature working at the transnational level have focused mainly on publishers of translated books, another category of agent quickly becomes visible, too: state agents. ${ }^{11}$ That is, government-affiliated individuals and organizations involved in the cross-border mediation of (translated) books. This is no surprise. As the term itself conveys, the transnational literary field is structured by national literatures. Or rather, by 'the well-founded fiction of the existence of national literatures' (Sapiro 2015: 341), which, in step with the rise of nationalism beginning in the late eighteenth century, helped to transpose the lines of nationally delineated imagined communities onto the geopolitical map (Anderson 2002). Today, these national borders also largely determine the contours of book markets, copyright law, and policies supporting book producers. State agents have historically played a central role in mediating which books travel across political borders, be it through ideology (projecting ideas and ideals globally), censorship (dictating what books are deemed acceptable for import and export), or cultural diplomacy (presenting a particular image of a country or nation through its cultural products). Many governments also fund the translation and international promotion of works by 'their' authors, thereby activating literature as a marker of geopolitical status (Von Flotow 2007). ${ }^{12}$

11 See Heilbron and Sapiro 2018.

12 The German Publishers and Booksellers Association lists 39 such organizations on their website. Translation support schemes can also be found at the supranational level (e.g. translation projects supported under the European Commission's 'Creative Europe' programme) and at 
The question remains, however, of how to situate the concept of cultural branding within a field-theoretical perspective. Put differently, what does branding add to the sociology of literature? I would like to briefly explore two possible (and interrelated) answers in relation to the case at hand: branding as position-taking and branding as a strategy of capital conversion.

Field theory as it has been applied to the world market for translations conceives of translated books and their makers as conjoined in a relational space structured by national and linguistic boundaries. Following Bourdieu, we can draw a distinction between an actor's underlying position in this space on the one hand, which is objectively determined by its combined social characteristics and the structural (political, economic, linguistic) constraints of the field, and its position-takings on the other, which are the prerogative of that individual actor as expressed through its habitus-informed practice (Bourdieu 1993). This implies an intermixture of objective and subjective factors, or of structure and individual agency, and enables an understanding of the transnational literary field as both a 'field of forces' and a 'field of struggles' where people and organizations go about a whole set of 'doings' within a shared space of structures and powers (Bourdieu 1986). Within this framework, an actor's branding decisions can be conceptualized as position-takings based in a relational struggle for distinction. These positiontakings are partly realized, because they have been made materially and semantically manifest through actual marketing materials and messaging, and partly idealized, because they speak to and of an implied position that does not exist outside the material and message itself. The categories used for grouping distinction tend to be binary and inherently oppositional for Bourdieu (high culture versus low culture; autonomous versus dependent; small-scale versus large-scale; aesthetic versus commercial, etc.). For the present analysis, I frame distinction using binaries most relevant to the transnational literary field (without assuming an inherent oppositional relationship): state versus market; cooperation versus competition; nation state versus stateless nation.

Whereas individual branding decisions can be seen as (partially realized and partially idealized) position-takings, an actor's overall 'brand

the transnational level in various forms (e.g. PEN International and its national chapters). In a recent development, representatives of 22 publicly funded organizations from 19 countries and regions in Europe met on the margins of the 2016 Frankfurt Book Fair to formally establish the European Network for Literary Translation (ENLIT), indicating a new level of cooperation among national literature organizations in Europe. The network came about at the initiative of Koen van Bockstal, director of the FLF, and Tiziano Perez, managing director of the DFL, and has its headquarters at the FLF offices in Antwerp. 
identity' - the sum total of its branding decisions - can be conceptualized as a manifestation of its 'ideal position' in the field. What Bourdieu's framework obliges us to see, however, is that an actor's ideal position and its actual position are two very different things indeed, since actors' positions are not independently (self-)assigned but rather relational and objectively determined.

The conceptual space between an actor's actual position and its ideal position in the field is where the heuristic of strategy belongs, which brings me to the second point: branding as a strategy of capital conversion. Here, it is pertinent to distinguish between the mechanisms of capital conversion themselves and branding as a means to capture and, once captured, exploit these mechanisms. Let me begin with the mechanisms themselves. How do (state) agents in the transnational literary field convert one form of capital into another? What mechanisms accomplish this? In his influential book The Economy of Prestige, James F. English identifies perhaps the most effective and impactful of these mechanisms: international literary prizes. He calls prizes 'the single best instrument for negotiating transactions between cultural and economic, cultural and social, or cultural and political capital' (English 2005: 10). ${ }^{13}$ Following English, when a work is consecrated through the awarding of a prestigious prize like the Nobel or the Man Booker International, it triggers at least three types of capital conversion: a boost in sales (symbolic-to-economic), a boost in credibility to the title's producers (symbolic-to-social), and a boost in the status of the language and literature in which the work was originally written (symbolicto-literary, which, as we have seen, is political in aspect). Sapiro highlights two additional mechanisms of capital conversion, focusing on publishers of translated books: the acquisition of prestigious titles from other literary fields through the purchase of translation rights (economic-to-symbolic) and the exploitation of a steadily earning backlist of prestigious translated titles (symbolic-to-economic) (Sapiro 2012a; Sapiro 2012b; Sapiro 2015). I would posit that guest of honour platforms such as Frankfurt's perform a capital conversion function as well: they enable state agents to exchange their accumulated stores of social and economic capital for the privileged opportunity to present their (officially sanctioned) literatures to industry peers in the hopes of drumming up interest, exposure, and new book translations (which they often also subsidize). This hopefully leads to a

13 English uses the term 'cultural capital' in roughly the same way I use 'symbolic capital' in that both denote prestige. Additionally, his notion of political capital aligns roughly with my understanding of literary capital. The two sets of terms can be considered synonyms here. 
payoff in symbolic and literary capital later down the road once processes of international dissemination, reception, and canonization have run their course. Investing public funds in this way not only serves a cosmopolitan mission of sharing books that would otherwise be lost to the rest of the world; it also fulfils the dual purposes of elevating the international status of a literature and language and of enhancing the international reputation of the nations that claim them.

Let me now turn to how branding was strategically deployed by the joint FLF and DFL team tasked with securing and executing the joint guest of honour invitation for Flanders and the Netherlands at the 2016 Frankfurt Book Fair. What do the branding decisions made by this team tell us about the ideal and actual positions of these two actors in the transnational literary field? What can we learn about how Dutch literature is branded internationally?

\section{The Road (Back) to Frankfurt}

Mounting a successful bid for the guest of honour platform nowadays is a competitive, long, and expensive affair that starts years or even decades before opening day. For Flanders and the Netherlands, the journey to becoming the 2016 guests of honour began as soon as their first joint showing at Frankfurt in 1993 ended. Helped along by some 130 book translations into German published in the lead-up to and aftermath of the fair, the 1993 Schwerpunkt unleashed a niederländische Welle across the Germanspeaking world, which would flow over into other language markets as well. Since 1993, the number of translated Dutch and Flemish authors has substantially increased, as has the number of languages into which their work is translated. ${ }^{14}$ The event is widely seen as a breakthrough moment for Dutch literature in the world - a literature that, up to that point, had remained largely undiscovered beyond its borders despite a rich tradition at home (Heilbron and Van Es 2015: 48). It also played a key role in the elevation of several Dutch and Flemish writers to international stature, of which Cees Nooteboom is probably the most renowned (despite his initially tepid reception at home) (Zajas 2014:3).

On an institutional level, the experience of jointly organizing the 1993 fair helped to solidify the strategic partnership between Flanders and the

14 See Heilbron 1999: 437. The translation database maintained jointly by the DFL and FLF lists 13,837 book translations out of Dutch into 81 languages since 1993 . 
Netherlands in the area of the international promotion of Dutch literature. The groundwork for this partnership was laid in 1980 with the founding - in the midst of the Belgian federalization process - of the Dutch Language Union (Nederlandse Taalunie), a treaty-based, intergovernmental organization representing the Netherlands and the Flemish Community with a mandate to jointly promote the Dutch language and its literature in Dutch-speaking areas and abroad. For Flanders, the Union was also a way to strengthen the position of Dutch within a multilingual Belgium and to lend a measure of legitimacy to its fledgling government. Cooperation between the FLF and the DFL is further facilitated by the fact that both organizations have a similar structure and mission. Indeed, the FLF owes much of its current policy toolkit to the DFL and its two legacy organizations, the Foundation for Literature (Stichting Fonds voor de Letteren, established in 1965) and the Dutch Literary Production and Translation Fund (Nederlands Literair Productie- en Vertalingenfonds, NLPVF, established in 1991). This policy toolkit combines domestic literary production supports (including support for incoming translation) with support for outgoing translation and international promotion.

Since 1993, Flanders' and the Netherlands' international promotion efforts in the area of literature have gradually become professionalized (Missinne 2018). This has gone hand and hand with the development of highly polished brand identities along two trajectories: careful differentiation between the distinctive positions of the DFL and the FLF, respectively, when the organizations brand themselves as promoters of 'Flemish literature' (referring to literature by authors from Flanders) and 'Dutch literature' (referring to literature by authors from the Netherlands) separately, and careful collaboration when the two organizations position themselves as co-promoters of Dutch literature (referring to literature in the Dutch language). The branding of Dutch literature for an international audience consequently reflects both trajectories at once. The FLF underwent a major rebranding in March 2017 with the launch of its English-language website flandersliterature.be, which is geared explicitly toward pitching books by Flemish authors to foreign publishers. ${ }^{15}$

At the same time, the DFL and FLF have jointly organized many guest of honour presentations at international book fairs since 1993: LIBER in Barcelona in 1995, Goteborg in 1997, Tokyo in 2000, Fiera del Libro in Torino

15 Likewise, the DFL has cultivated a clear brand of its own: for a discussion of 'Holland' as a literary brand, see Laurence Ham's chapter in this volume on the DFL-organized guest-ofhonourship at the 2011 Beijing Book Fair. 
in 2001, Salon du Livre in Paris in 2003, and, more recently, Festival International de la Bande Dessinée in Angoulême in 2009, the Feria del Libro Internacional de Buenos Aires in 2013 - and the Frankfurt Book Fair in 2016.

\section{Frankfurt 2016}

In their 48-page bid to be the 2016 guests of honour, which was submitted to fair director Juergen Boos in October 2013, the DFL and FLF framed the prospect of a second joint appearance at Frankfurt as a means to 'rekindle' interest in Dutch literature in Germany and, via Germany, the world (Aerts, Van Bockstal, Pauw, Perez, Rutten, and Steinz: 11). In the same breath, they pointed to the past success of the 1993 fair and the contacts it produced, which have since been cultivated and broadly expanded. By 'combining the networks of both funds', they argued, they could more effectively reach out to the German publishing world and reading public (19). They also emphasized the prudence of sharing costs for such an ambitious and expensive endeavour (41). Their pitch was successful: Bos accepted the bid in late 2014. This marked the culmination of a quarter-century-long process of accumulating capital on the part of the DFL and FLF. By jointly activating their combined stores of social and economic capital (professional relationships and networks, and public funds), they successfully put themselves in position to exploit Frankfurt's most coveted mechanism of capital conversion.

However, while the decision to work together may have made the 2016 appearance possible, it also necessarily meant that the DFL and FLF had to collaborate closely on its planning, execution, and branding. How did they go about this? The answer reflects a long tradition in the Netherlands and Flanders (respectively) of consensus decision-making based on a pragmatic recognition of pluriformity and cooperation despite differences. In the Netherlands, a form of this approach found currency under the 'polder model' of tripartite cooperation between employers' organizations, labour unions, and the government in the formulation of socio-economic policy (Hendriks and Toonen 2018). The term alludes to different communities living on land reclaimed from the sea (polders) that coordinate joint maintenance of dykes and pumping stations to avoid flooding. It evokes the dictum 'a rising tide lifts all boats', but inverted: a collectively stymied sea allows all polder communities to thrive. One can see the cooperation between the DFL and the FLF in similar terms, transposed here to a transnational, cultural-political context rather than a national, socio-economic one. (As 
we will see, the water metaphor is also stylized in the two organizations' branding choices for Frankfurt.)

The cooperative model implemented by the DFL and FLF for Frankfurt was formalized in a memorandum of understanding signed by the two partner institutions in August 2014 (Van Bockstal 2014a). This document detailed burden-sharing provisions on the principle of 50/50 parity; staff arrangements (the regular staff of the DFL and FLF would be augmented for two years by seven additional temps, three based in Antwerp, four in Amsterdam); a decision-making structure with administrative leadership shared between the heads of the DFL and FLF; and a budget of $€ 6$ million financed by the Flemish and Dutch governments. ${ }^{16}$ Bas Pauw, a senior in-house staffer at the DFL, was tapped to manage the project's financials.

The memorandum of understanding also laid out the role and responsibilities of the artistic director, who was to be given 'the freedom and the mandate' to determine the content and creative design of programming for the guest of honourship, alongside being the 'face' of the overall project (Van Bockstal 2014a). Interestingly, the memorandum also stipulated that the artistic director be Flemish. To narrow the search, the directors of each fund created a shortlist of candidates they (separately) deemed acceptable for the job. The two lists were then compared and deliberated over until a single candidate was selected. They settled on Bart Moeyaert, a Flemish novelist and writer of young adult fiction who, as a widely translated writer and fluent speaker of German, had extensive previous experience with the German market and the Frankfurt Book Fair specifically. The choice is unique in that guests of honour rarely select authors as artistic directors. According to Moeyaert himself, the decision to name an author to the position was made to avoid infighting between Flemish and Dutch state functionaries, a lesson learned from their previous guest of honour experience in 1993 (Reichenbach 2016: 5).

From the start, and working within the creative lines set out in the bid book, Moeyaert emphasized a need to organize the branding of the project around three themes shared between Flanders and the Netherlands (and Germany): a common history, shared dynamism, and the North Sea. These 'pillars' were

16 Initially, the DFL and FLF had each pledged $€_{2.4}$ million each, with the remaining $€_{1.2}$ million to be financed by private sponsors. When (virtually) none materialized, additional public funds were sought out and received. In the final balance, the project had a total budget of $€_{5}, 880,440$ and was financed thus: DFL: $€ 2,595,077$; FLF: $€ 2,384,483$; Dutch Ministry of Foreign Affairs: $€_{721,600}$; Dutch Ministry of Education, Culture and Science: $€_{171,780}$; commercial partners $€_{7,500}$ (Reintjens et al.). Divided across Dutch and Flemish funding sources, this gives a Dutch-to-Flemish funding ratio of $59 / 41$. 
to be the guiding inspiration for the presentation's overall visual identity. Briefs were circulated to advertising agencies (for branding) and architecture firms (for the design of the pavilion) and bids were solicited. The choice to outsource branding and design to creative firms is in line with a trend of professionalization among recent guests of honour keen to present a polished product to industry peers. It also underscores the important (and understudied) role branding plays at Frankfurt. Relations with the German press were handled by an external publicity firm - a requirement imposed by the Frankfurt Book Fair as a condition of candidature. ${ }^{17}$ Ultimately, the 2016 organizers chose the Amsterdam-based firm Dog and Pony to create its branding materials and the Rotterdam-based design cooperative The Cloud Collective to design and build the pavilion installation. Let us turn now to these materials.

\section{Co-branding}

In the remaining pages, I examine the branding of the 2016 guest of honour platform and consider the implicit legitimizing effect it affords Flanders as a stateless nation presenting Dutch literature alongside its larger nation state neighbour. What do the branding decisions made by this team tell us about the ideal and actual positions of these two actors in the transnational literary field? The chosen baseline immediately sets a collaborative tone: 'This is what we share.'

As it turns out, creative nods to the partnership between Flanders and the Netherlands are omnipresent in the project's branding. Take the colour scheme: the blues in the logo, which, Moeyaert (2015) explains, represent the blues of the Westerschelde, the mouth of the River Scheldt, where the two territories of the Netherlands and Flanders flow together. Complementing the blues is a yellow/grey, the colour of North Sea beach sand. The notion of fluidity between the two partners is further activated in a font style designed by Jo De Baerdemaeker especially for the fair, whose letter structure is inspired by the famous typographical collections of Plantin-Moretus of Antwerp, Johannes Enschedé \& Zonen of Haarlem, and Lettergieterij Amsterdam. Ligatures have been added so that each letter runs into the next, illustrating again the 'dynamic flow' between the Netherlands and Flanders. We find a similar visual logic on the website: page templates are replete with a moiré effect where one pattern of lines is superimposed onto another to create the impression of waves. Waves are quoted again 
Figure 12.1
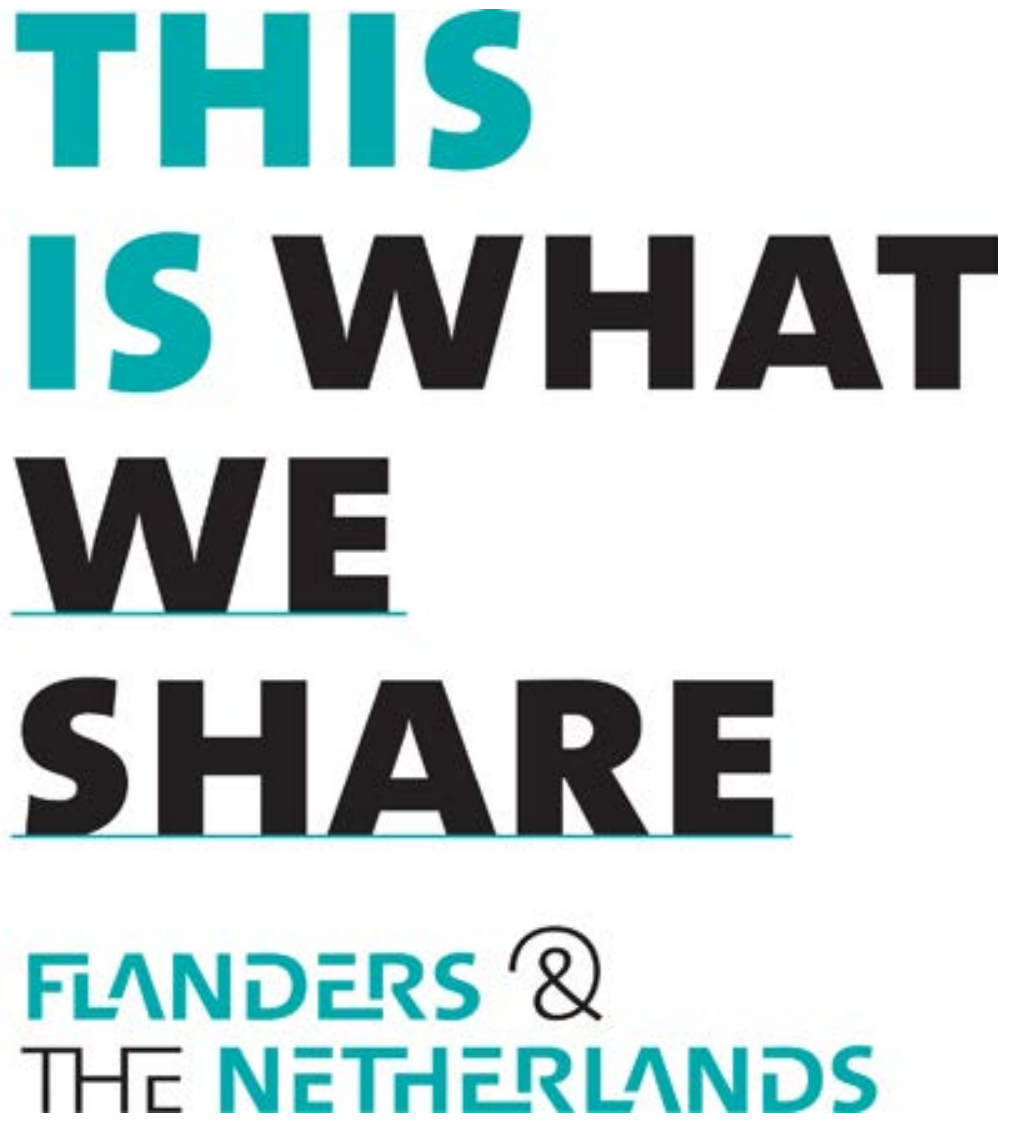

in the formatting of the (very popular) collector postcard sets produced for Frankfurt and distributed as teasers at various other book fairs on the 2016 circuit. They are printed as leporellos (an accordion-like format), the visual logic being that Flanders and the Netherlands are equal partners, with neither outsizing the other. (Making waves together is fine as long as one does not wash out the other!) And then there is the official poster featuring the work of Flemish photographer Stephan Vanfleteren: portraits of different faces of the 70-member author delegation, each superimposed over the other to create one single, not-quite-distinguishable visage (see below).

This communal, egalitarian ethos is on display in the guest of honour pavilion as well. There is a clear emphasis on the process of writing and creating rather than on the specific writers and creators themselves (much less their nationalities): shadow boxes spotted throughout the pavilion contain pictures of the writing rooms of prominent Dutch and Flemish 
Figure 12.2 $\odot$ Stefan Vanfleteren

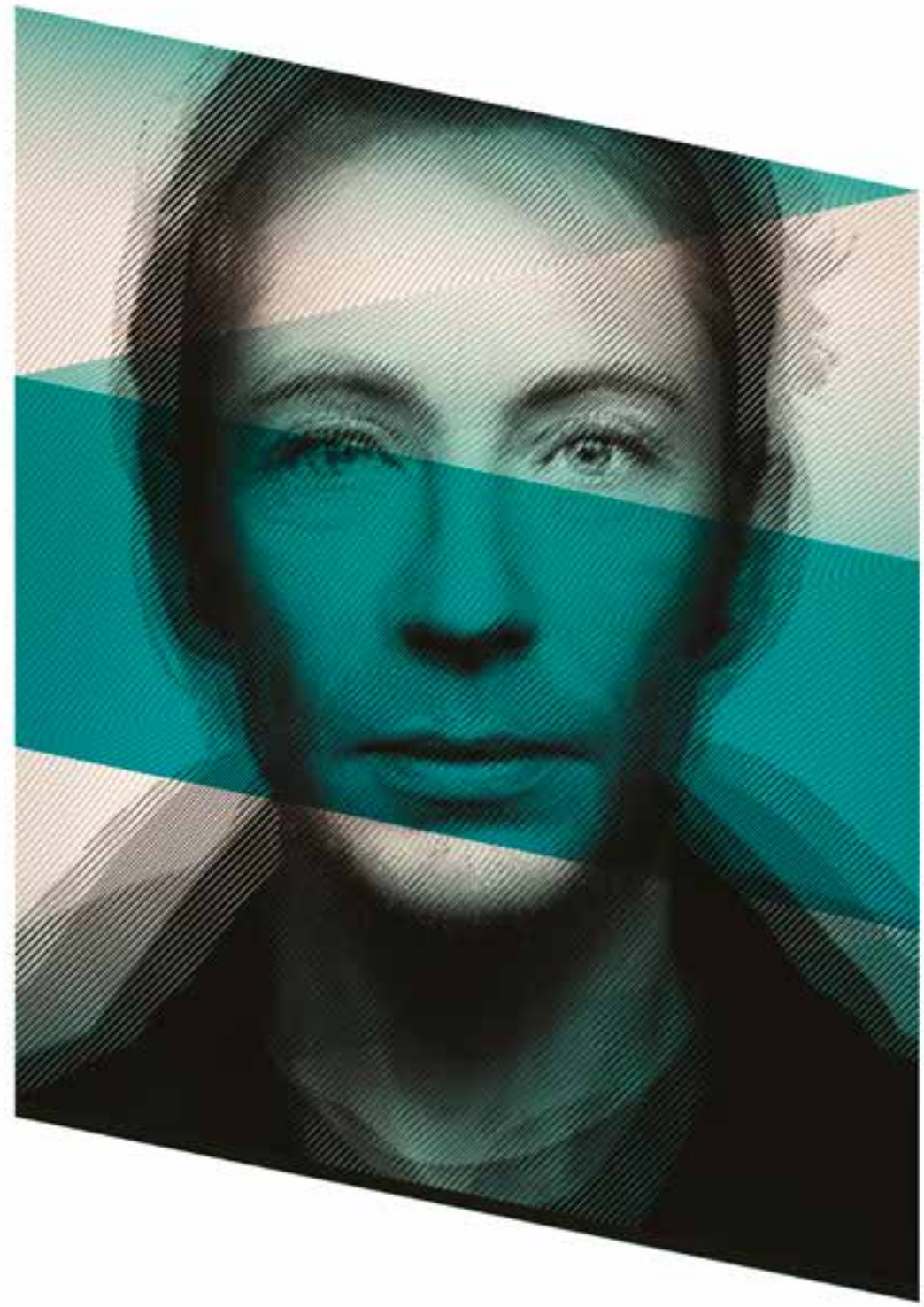

authors, but the authors themselves are absent; graphic artists are busy creating and printing a one-off comic in an actual, working atelier to be distributed at the end of each fair day, but it is the product fairgoers line up for, not the producer; on the pavilion stage, programming for the five-day 
fair follows the same set schedule of mini-shows, each day circulating different Dutch and Flemish authors through them. The related theme of fluidity discussed above is carried over in the built space of the pavilion, too. Dividing each of the various open-concept spaces (the stage, several exhibition rooms, the atelier, a bookshop, a café, and a large space spotted with lounge chairs) are walls made of spaced, translucent plastic sheets stacked on top of each other to create a semi-transparent barrier through which to gaze. The entire salon is fringed by a semi-transparent white canvas against which a slow-dynamic seascape is projected. The faint outline of bookshelves (filled with recent translations of Dutch literature) can be made out on the other side of the canvas. It is reminiscent of the landscape paintings of the sixteenth and seventeenth-century Low Countries masters, but instead of the canvas being spotted with people going about their day, there are the spines of books.

The branding materials and pavilion are just as striking for what they do not contain: no callouts to specific marque authors, no claims of excellence, prestige, or singularity, and most striking of all, no national markers. There is no orange for the Netherlands, no yellow and black for Flanders. No windmills or recreated red-light districts. No poppies or pastorals. Be it on the guest of honour website, the programming on the pavilion stage, or the membership of the official delegation, authors' Dutch or Flemish status is never outwardly advertised. The trappings of state were limited to the opening ceremony, where representatives of the Dutch and Belgian (!) royal families made a grand entrance and were given a royals-only tour of the pavilion before disappearing for the rest of the fair. Quintessential symbols of Dutch and Flemish culture were really only openly evident during the happy hour receptions each evening: beer and chips from Flanders; bitterballen and cheese from the Netherlands. Contrary to the 'celebration of nationally and ethnically branded "differences" that have been niche-marketed as commercialized "identities"' one could have expected (Apter 2013: 10), the brand identity of the 2016 Guests of Honour was distinctive precisely because it was not.

However, it would be short-sighted to interpret this lack of flag-waving as politically innocuous. For all the trouble the organizers went through to obscure national differences and emphasize sameness in their branding choices, one has only to look a little deeper to see the spectre of the nation. We have seen that the costs for the guest of honourship were split more or less half-and-half by the Dutch and Flemish governments. It turns out that there is a direct link between each partner's share of the burden and their share of representation at Frankfurt. Of the $70(!)$ authors in the official delegation, 36 are Dutch and 34 are Flemish. Of the 1,344 minutes 
of programming prepared for the guest of honour stage, $5^{2}$ per cent was allotted to Dutch authors and 48 per cent to Flemish authors. Flanders and the Netherlands were represented at the opening ceremony by Dutch author Arnon Grunberg and Flemish poet Charlotte Van den Broeck, who together presented a collaborative original work. And so on. This 50/50 partnership is far larger than Flanders' 22/78 share of the domestic book market or the 27/73 distribution of Dutch native speakers (Van Bockstal 2014b, p. 49). Could Flanders' willingness to invest so lavishly in the international promotion of Dutch literature be an indication of other (political) ambitions? Clearly it could. I finish with one final national marker that did manage to make it into the branding for Frankfurt: the official formulation of the name of the 2016 guest of honour, 'Flanders and the Netherlands': it is explicitly dual (Flanders and the Netherlands) and implicitly statist (Flanders and the Netherlands) rather than region- (the Low Lands) or language-centric (Dutch literature). ${ }^{18}$ For Flanders, this confers a de facto nation state-like status, a legitimacy by association strengthened all the more by its being named before rather than after the Netherlands. In this light, the broader strategy of co-branding Dutch literature in a way that obfuscates national distinctions can actually be seen as a covert and clever strategy by Flanders both to 'top the bill' at Frankfurt and to ensure an outsized share of the stage. Whether this will result in a proportionate share of any future payoff (book translations, international recognition, or even eventual statehood) remains to be seen.

\section{Conclusion}

In securing the 2016 guest of honour invitation and carrying out its obligations, the FLF and DFL opted for a strategy of cooperation, and this was clearly echoed in their co-branding of Dutch literature. Conventional field theory would have us see these two organizations as competitors fighting a zero-sum battle for limited resources and influence. However, as this analysis bears out, the present case suggests that cooperation is best conceptualized as a competitive strategy that agents may or may not choose to (or be able to) activate. Indeed, similar efforts by Wallonia and Quebec

18 Interestingly, the original bid book took a region-centric tack: 'Low Countries. Deep Imagination'. The official logo of the 1993 guests of honour retained the names of the two national groupings but opted to alternate the order by language. Flanders was placed first in the English and German name. The Netherlands was placed first in the Dutch name. 
to partner with the 2017 guest of honour, France, were rejected by le pays de Voltaire, which chose to claim the stage for itself (Sapiro 2018). Clearly, linguistic and regional kinship only go so far in fostering cooperation among agents in the transnational literary field, especially when the frontiers of language, nation, and state do not neatly correspond. What I have tried to do here is demonstrate how two state agents located on the periphery of the transnational literary field cooperate to their mutual competitive advantage, boosting their respective, self-serving profiles while also serving their common goal of elevating a shared language internationally - a transnational, cultural-political application of consensus decision-making that both deployed and stylized a version of the 'polder model'. The instrument by which this is made possible is the guest of honour platform itself: a coveted mechanism of capital conversion, alongside others like prizes and festivals, that neither the DFL nor the FLF could likely have secured on their own. The tensions that necessarily follow from such a cooperation were clearly and abundantly reflected in the organizers' branding decisions, which rather ingeniously emphasized commonalities over differences, production over producers, and communal identity over national identity. Conceptualizing these branding decisions as position-takings and their sum total as a brand identity opens conceptual space where cultural branding and field-theoretical perspectives of cultural production converge. In this space, the branding of Dutch literature by the DFL and FLF at Frankfurt can be understood as a manifestation of their ideal position(s) in the transnational literary field. When 'this is what we share' was dissected into 'this is how we shared', a picture emerged revealing the literary ambitions of both partners on behalf of their shared language on the one hand, and the political ambitions of a stateless nation standing alongside its larger nation state neighbour on the other.

\section{References}

Els Aerts, Koen van Bockstal, Bas Pauw, Tiziano Perez, Paul Rutten, Pieter Steinz. 2013. Low Countries. Deep Imagination. Amsterdam/Berchem: Dutch Foundation for Literature/Flemish Literature Fund. Available at: http://www.letterenfonds. nl/images//issue_download/Frankfurt-2016-bidboek.pdf [accessed 30 June 2018]. Benedict Anderson. 2006. Imagined Communities. Reflections of the Origin and Spread of Nationalism. 2nd edn. London/New York: Verso.

Emily Apter. 2013. Against World Literature. On the Politics of Untranslatability. London/New York: Verso. 
Carlo van Baelen. 2013. 1+1=zelden 2. Over grensverkeer in de Vlaams-Nederlandse literaire boekenmarkt. Amsterdam: Nederlandse Taalunie.

Koen van Bockstal. 2014a. 'Bestuursconvenant tussen het Vlaams Fonds voor de Letteren en het Nederlands Letterenfonds met betrekking tot de voorbereiding, uitvoering en financering van het gezamenlijke gastlandschap tijdens de Franfurter Buchmesse 2016', contract, Berchem, 7 August.

Koen van Bockstal. 2014b. Landschapstekening Letteren. Commissioned report. Bergem, Flemish Literature Fund. Available at: https://www.kunstenloket. be/sites/default/files/upload/document/file/landschapstekening_etteren.pdf [accessed 31 January 2018].

Pierre Bourdieu. 1983. 'The Field of Cultural Production, or: The Economic World Reversed', Poetics 12.4-5: 311-356.

Pierre Bourdieu. 1986. 'The Forms of Capital'. In John Richardson (ed.), Handbook of Theory and Research for the Sociology of Education, pp. 15-29. New York, Greenwood.

Pierre Bourdieu. 1993. The Field of Cultural Production: Essays on Art and Literature. Ed. by R. Johnson. Cambridge: Polity Press.

Pierre Bourdieu. 1996. The Rules of Art: Genesis and Structure of the Literary Field. Trans. by S. Emanuel. Cambridge: Polity Press.

Pierre Bourdieu. 1997. Outline of a Theory of Practice. Cambridge: Cambridge University Press.

Pierre Bourdieu. 2008. 'A Conservative Revolution in Publishing', Translation Studies 1.2:123-154.

Pascale Casanova. 2004. The World Republic of Letters. Trans. by M.B. DeBevoise. Cambridge, MA/London: Harvard University Press.

Pascale Casanova. 2010. 'Consecration and Accumulation of Literary Capital: Translation as Unequal Exchange'. In M. Baker (ed.), Critical Readings in Translation Studies, pp. 285-303. London/New York: Routledge.

James F. English. 2005. The Economy of Prestige: Prizes, Awards, and the Circulation of Cultural Value. Cambridge, MA/London: Harvard University Press.

Luise von Flotow. 2007. 'Telling Canada's "Story” in German: Using Cultural Diplomacy to Achieve Soft Power'. In L. von Flotow and R.M. Nischik (eds.), Translating Canada. Charting the Institutions and Influences of Cultural Transfer: Canadian Writing in Germany, pp. 9-26. Ottawa: University of Ottawa Press.

Johan Heilbron. 1995. 'Nederlandse vertalingen wereldwijd. Kleine landen en culturele mondialisering [Dutch translations worldwide. Small countries and cultural globalization]'. In J. Heilbron, W. de Nooy, and W Tichelaar (eds.), Waarin een klein land. Nederlandse cultuur in internationaal verband [In a Small Country. Dutch Culture in an International Context], pp. 206-253. Amsterdam: Prometheus. 
Johan Heilbron. 1999. 'Towards a Sociology of Translation. Book Translations as a Cultural World-System'. European Journal of Social Theory 4.2: 429-444.

Johan Heilbron and Nicky van Es. 2015. 'Fiction from the Periphery: How Dutch Writers Enter the Field of English-Language Literature'. Cultural Sociology 9.3: 296-319.

Johan Heilbron and Gisèle Sapiro. 2016. 'Translation: Economic and Sociological Perspectives'. In V. Ginsburgh and S. Weber, eds. The Palgrave Handbook of Economics and Language, pp. 373-402. Basingstoke: Palgrave MacMillan.

Johan Heilbron and Gisèle Sapiro. 2018. 'The Politics of Translation: How States Shape Cultural Transfers'. In D. Roig-Sanz and R. Meylaerts (eds.), Literary Translation and Cultural Mediators in 'Peripheral' Cultures: Customs Officers or Smugglers?, pp. 183-208. London: Palgrave Macmillan.

Frank Hendriks and Theo A.J. Toonen. 2018. Polder Politics. The Re-invention of Consensus Democracy in the Netherlands. London/New York: Routledge.

Anneke van Huisseling, Hanneke Marttin, and Ilonka Reintjens (eds.). 2017. Dit is wat we delen. Nederland en Vlaanderen eregast van de Frankfurter Buchmesse. Verslag 2013-2016. Amsterdam/Antwerp: Nederlands Letterenfonds/Vlaams Fonds voor de Letteren.

Pauline Kerr and Geoffrey Wiseman. 2013. Diplomacy in a Globalizing World: Theories and Practice. New York: Oxford University Press.

Margrit Knapp. 2007. 'A Controversial Homage to Catalonia. Commerce Replaces Politics at the Frankfurt Book Fair', Spiegel Online, 9 October. http://www. spiegel.de/international/germany/a-controversial-homage-to-cataloniacommerce-replaces-politics-at-the-frankfurt-book-fair-a-510291-2.html [accessed 30 June 2018].

Lut Missinne. 2018. 'Van 1993 tot 2016: Nederlandstalige literatuur in Duitse vertaling tussen de twee Buchmessen'. In L. Missine and Jaap Grave (eds.), Tussen twee stoelen, tussen twee vuren. Nederlandse literatuur op weg naar de buitenlandse lezer. Ghent: Academia Press.

Bart Moeyaert. 2015. 'Press Conference: Flanders \& The Netherlands Guest of Honour at the 2015 Frankfurt Book Fair'. Press kit, Frankfurt, presented 15 October.

Peter Reichenbach. 2016. 'Interview with Bart Moeyaert, Artistic Director of "Flanders \& the Netherlands Guest of Honour Frankfurt Book Fair 2016". In 'This Is What We Share. Information For the Press'. Press kit, presented 1 July.

Gisèle Sapiro. 2008. 'Translation and the Field of Publishing: A Commentary on Pierre Bourdieu's “A Conservative Revolution in Publishing”'. Translation Studies 1.2: 154-166.

Gisèle Sapiro. 2010. 'Globalization and Cultural Diversity in the Book Market: The Case of Literary Translations in the US and in France'. Poetics 38: 419-439. 
Gisèle Sapiro. 2012. 'Strategies of Importation of Foreign Literature in France in the Twentieth Century. The Case of Gallimard, or the Making of and International Publisher'. In S. Helgesson and P. Vermeulen (eds.), Institutions of World Literature. Writing, Translations, Markets, pp. 143-159. London/New York: Routledge.

Gisèle Sapiro. 2015. 'Translation and Symbolic Capital in the Era of Globalization: French Literature in the United States'. Cultural Sociology 9.3: 320-346.

Gisèle Sapiro. 2016. 'How Do Literary Works Cross Borders (or Not)? A Sociological Approach to World Literature'. Journal of World Literature 1: 81-96.

Gisèle Sapiro. 2018. 'Translation and symbolic capital: French literature in the United States in the globalisation era', Francqui Chair lecture, Leuven, 2 May. John B. Thompson. 2012. 'Merchants of Culture: The Publishing Industry in the Twenty-First Century. Cambridge: Polity Press.

P. Weidhaas. 2007. A History of the Frankfurt Book Fair. Trans. by C.M. Gossage and W.A. Wright. Toronto: Dundurn Press.

Kathryn A. Woolard. 2016. 'Branding Like a State: Establishing Catalan Singularity at the Frankfurt Book Fair'. Signs and Society 4.1: 20-50.

Paweł Zajas. 2014. 'Before the "Nooteboom Effect" - Dutch Literature at the Suhrkamp Publishing House'.Journal of Dutch Literature 5.2: 1-19.

\section{About the Author}

JACK MCMARTIN is assistant professor of Translation Studies and English at KU Leuven. His current research investigates the production and reception of Dutch literature in translation, focusing on the people, institutions, and spaces that shape the global book market. He is co-editor (with Jan Van Coillie) of Children's Literature in Translation: Texts and Contexts (Leuven University Press, 2020) and has also published on the life and work of the American-Dutch translator, translation theorist and poet James Holmes. 


\title{
The One Unforgivable Transgression?
}

\author{
Branding 'Kluun' as a Literary Strategy \\ Jos Joosten
}

\begin{abstract}
In terms of economic capital, Kluun is one of the most successful Dutch authors of the last two decades. To date, at least a million copies of his debut novel Komt een vrouw bij de dokter have been sold; the book has been translated into 26 languages. ${ }^{1}$ His later novels were less successful, but were still sold in considerable numbers. The reason why the 'Kluuncase' is remarkable is twofold. Firstly, Kluun is the former owner of an Amsterdam advertising firm, and considered his first novel not only an artistic product but an advertising venture as well; secondly, Kluun consciously played with the gap between his economic success and the the amount of symbolic capital he accrued, and used the branding of his name and work as a literary strategy.
\end{abstract}

Keywords: Raymond van de Klundert, Kluun, Komt een vrouw bij de dokter, DJ

\section{The Search for Economic and Symbolic Capital}

Komt een vrouw bij de dokter, Kluun's 2003 debut novel, is the autobiographical story about a young couple, Stijn and Carmen, and their little daughter, living a happy and successful Yuppie life in Amsterdam. Things drastically change when Carmen is diagnosed with breast cancer. While Carmen undergoes chemotherapy, Stijn, who cannot cope with the situation, starts having affairs with other women. In the end, Stijn comes to his senses and

1 See http://www.uitgeverijpodium.nl/Auteurs/book/188/Komt-een-vrouw-bij-de-dokter [accessed 18 February 2019].

Helleke van den Braber, Jeroen Dera, Jos Joosten, and Maarten Steenmeijer (eds), Branding Books Across the Ages: Strategies and Key Concepts in Literary Branding. Amsterdam, Amsterdam University Press 2021 DOI: 10.5117/9789463723916_CH13 
returns to Carmen to help her end her life in a dignified way. The title Komt een vrouw bij de dokter refers to the rather lame Dutch cliché that opens many a joke: 'A women goes to see her doctor, and...'

Kluun's novel was issued by the renowned Amsterdam publisher Podium and was not instantly the commercial mega-success that it would ultimately become. ${ }^{3}$ In fact, it took a relatively long time before it became a success. The book appeared in October 2003, and at the end of February 2004 the number of copies sold was 27,861, which by Dutch standards is still considerable. However, this was not the real public mega-breakthrough. That only came one year later, when the novel at last ended up in the Book Top 6o, after winning the NS-Publieksprijs, a literary prize awarded by popular vote. ${ }^{4}$

From the beginning, Kluun has taken a remarkable position as an author. He made no secret of the fact that he wanted to obtain economic capital - for example, by making a living as a writer - but on the other hand, he has also constantly hinted at symbolic recognition. This crossroads makes the Kluun-case remarkable from the perspective of branding. In the Introduction to this book, the following is stated about the phenomenon:

We aim to research all stages in this process, both in the present and in the past, paying special attention to the dynamic between the three most important participants: author, publisher, and readership. We ask to what extent this entire process is intentional. Often, the publisher is the initiator of the branding process, whereas the author is the one who is being made into a brand, and the readership is the target group considered to be sensitive towards that branding, yet these roles are unstable. ${ }^{5}$

Perhaps the most striking aspect about the case under discussion is that the process of product branding - starting with the catchy brand name, 'Kluun' - is from the beginning already largely intentional, and although it was of course carried out in cooperation with his publisher, it was initiated

2 In 2007 an English translation of the novel (by Shaun Whiteside) was published, entitled Love Life (St. Martin's Griffin, New York). In this article I will refer to the book by its title in Dutch.

3 The first part of this article is a revised and updated version of 'Waarin gelooft Kluun? Het geloof van Bourdieu en Kluuns Komt een vrouw bij de dokter'. In Joosten 2017, in particular 62-69. 4 See for more information: https://www.nspublieksprijs.nl/over_ons [accessed 22 February 2019]. The price is awarded by a combination of votes from the general public (in 2006 24,976) and 600 members of a so called 'kernjury' ('core jury') - in a ratio of $2 / 3$ to $1 / 3$ ('Kluun krijgt NS Publieksprijs voor debuut: Komt een vrouw bij de dokter is “Boek van het Jaar"', in Dagblad van het Noorden, 16 October 2006).

5 Introduction p. 17 . 
and designed as such by the author Raymond van de Klundert, who himself was the former owner of an advertising company.

Kluun broke, for instance, a basic rule Pierre Bourdieu formulated regarding press publicity in the literary field: 'The strategies which [an author] applies in his relations with the press are perfectly adapted (without necessarily having been so conceived) to the objective demands of the most advanced fraction of the field, i.e. to the "intellectual" ideal of negation, which demands refusal of temporal compromises and tends to establish a negative correlation between success and true artistic value' (Bourdieu 1993: 100). Kluun, on the contrary, consciously and explicitly did not ignore the possibilities of publicity.

In his recent and interesting book De literatuur draait door: de schrijver in het mediatijdperk, Tilburg scholar Sander Bax dedicates a couple of pages to Kluun's work and media strategy. ${ }^{6}$ Clearly Bax is not a great admirer of the author's approach to the literary field. He interprets Kluun's acts as being solely focused on economic capital and sees commercial profit as his only purpose: 'The fact that Kluun in interviews constantly elaborates on his initiatives in favour of "the literature" or "young, unknown writers" is just a clever strategy of positioning himself: it makes unashamed commercialism look like altruism' (Bax 2019: 89). ${ }^{7}$ Bax calls Kluun an author who 'practices literary-institutional populism' (90). In his book he approaches Kluun's activities and work only from the angle of the classic-modernist doxa with its clear distinction between highbrow and lowbrow literature. Exactly the opposite appears to be the starting point for the reflections on the subject of branding by the Polish scholar Dominik Antonik. In his article 'The author as a brand', he analyses the case of author Michał Witkowski, which to a certain extent looks similar to Kluun's, although the marketing strategy of this Polish author is far more radical: 'The author functions as a brand, integrating a broad space of signs and bestowing external value on products. [...] His work affects us not through books, but through the brand' (Antonik 2016:185). One of Antonik's conclusions is that ' $[\mathrm{i}] \mathrm{t}$ is becoming increasingly difficult to examine culture strictly in terms of a superstructure or sphere of values that is separate from us and operates somewhere above our heads; art, meanwhile, no longer fits into the traditional model. The division between culture and economy or the domain of art and material reality is becoming

6 See Bax 2019, in particular the pages 85-91 and 105-109.

7 'Dat Kluun het in interviews voortdurend heeft over zijn initiatieven voor "de literatuur" of voor "jonge, onbekende schrijvers" is een slimme positioneringsstrategie: daardoor doet onverbleomd commercialisme zich voor als altruïsme.' 
inoperable' (182). According to Antonik, the Witkowski-case indicates a major turn in the literary field:

This is a literature that relies on novelty and nowness, in the broad senses. Traditional literature is geared towards transmission and is linked to the dynamic of collective memory. The work of Witkowski and his ilk is based on communication, the flow of information at a given moment. It operates in a narrow time frame, focusing on topicality and synchronicity, rather than diachronicity, and does not seek to leave a permanent mark. It operates on quickly processable information, not values and knowledge that appeal to our long-term memory. (189)

Kluun evidently manoeuvres between the classical high-culture doxa (whose gatekeepers still have not fully accepted him), and the extreme opposite: the branded position of Witkowski.

What can be said about Kluun's literary strategy in the field and in what direction is his authorship moving? It appears that Kluun attempts to gather both economic and symbolic capital, what, following Bourdieu, is strictly spoken impossible since the one excludes the other. Kluun has always been explicit about his commercial intentions and even makes it part of his branding. His commercial strategy even became subject of the daily cartoon 'Fokke en Sukke' in quality newspaper NRC Handelsblad. The cartoon is entitled 'Fokke and Sukke call Kluun for advice'. Fokke: 'We're working on a really lousy cartoon...', Sukke: '...but yet we want to sell a million of them,. ${ }^{8}$ In fact this way Kluun came quite close to what Bourdieu (1993: 80-81) called 'the one unforgivable transgression': calling into question 'the game itself and the belief which supports it.' We will discuss that further on.

From the moment Kluun started to gain his huge success in terms of economic capital, his somewhat problematic relationship with what one could call the 'literary establishment' was unveiled. The writer himself has, especially in this early stage of his career, never made a secret of his intentions (here he is writing about himself in the third person):

Former advertising and marketing man Kluun did have a commercial objective, and that was in fact very practical: in order to become a full-time writer, able to earn a living with writing, a couple of tens of thousands of

8 See http://fokkesukkearchief.nl/cartoon/bellen-kluun-voor-tips(1302) [accessed 7 November 2019]. 
copies would have to be sold. Because this only happens to a few debutants in a decade(!), he had this personal, more er ... ego-bound aim: to become one of the three best-selling debut novels of that year. (Van de Klundert 2005) ${ }^{9}$

Kluun thus had uninhibited commercial intentions, and his view on and relationship with the traditional literary field appeared, at first glance, to be purely negative. The traditional book reviewers paid very little attention to the debutant. The reception in that category remained limited to two very negative reviews in the student weekly Propria Cures and the Amsterdam daily newspaper Het Parool. ${ }^{10}$ The rest of the traditionally canonizing institutions completely ignored the book: none of the serious newspapers reviewed it. In terms of Bourdieu, the gained symbolic capital of the book was zero. On the other hand, Komt een vrouw bij de dokter accumulated a huge amount of economic capital.

\section{Kluun's Moves Towards the Field of Literature}

At first glance, Kluun's own attitude towards the literary establishment is ambivalent. He is probably not the first Dutch author to use varied marketing techniques to make a success of his book, but he is definitely the first one to be this frank on the subject. As an example, a few passages from an interview with the author follow, which are typical of many of the interviews he has given since his novel became successful (the journalist's remarks are in italics).

'I created a dream team of people I used to work with. The book cover was created by a designer who worked for Nike, Audi and Volkswagen.'

'The special book presentation at Hotel Arena, where visitors could walk, as it were, through the book, was designed by a friend who was founder of the Sensation House Parties, and the website kluun.nl was created by yet another person. I wanted to create a hype.'

9 'Ex-reclame- en marketingman Kluun had wél een commerciële doelstelling en die was zeer praktisch van aard. Om full-time schrijver te kunnen worden en er van te kunnen leven, zouden er enkele tienduizenden exemplaren moeten worden verkocht. Omdat dit hooguit enkele debuten in een decennium (!) overkomt, had hij voor zichzelf een persoonlijke, meer eh... ego-gebonden doelstelling: bij de drie bestverkochte debuten van dat jaar te komen.'

10 Arie Storm, 'Kluuniaanse aanstellerij', Het Parool, 17 October 2003, and JvdH, 'Kankerlijer. Vreemdgaan was nooit zo gemakkelijk', Propria Cures, 13 November 2003. 
The literary establishment did not appreciate it, and accused him of posing. 'When it comes to beer, sanitary napkins, films or music it's all about marketing, but somehow that is not allowed for books in the Netherlands. Book covers are changed regularly, but my cover is still the same after the fifteenth edition and it will remain this way. Everyone knows the black cover of Pink Floyd's Dark Side of the Moon with the silver triangle and the rainbow on it, or the Arrival album by Abba, with the helicopter. That's the power of an image.'

'And besides that, the literary world is convinced that a debutant should be presented quietly to the public, and only if you already have a big name like Harry Mulisch or my next-door neighbour A.F.Th.van der Heijden, you will be launched like a rocket. In that respect, the Netherlands is very conservative. I wanted to give a wake-up call to the world of literature.'

In spite of the criticism from the official literary world, Komt een vrouw bij de dokter became the best-selling Dutch debut novel of the pastyears. ${ }^{11}$ (Anon. 2005)

This interview presents a double view on the way literature works - or is supposed to work. On the one hand, Kluun elaborates on the new, innovative way he approached the launch of his book; on the other hand, it is clear that what might be called the traditional literary field still is (at least also) the author's point of reference - which he might as well have totally ignored.

11 'Ik had een dreamteam gecreeerd van mensen met wie ik vroeger werkte. De omslag is bedacht door een ontwerper die voor Nike, Audi en Volkswagen heeft gewerkt.'

'De opmerkelijke presentatie in hotel Arena waar bezoekers als het ware door het boek wandelden, was bedacht door een vriend die aan de wieg van de Sensation-housefeesten stond. De website kluun.nl werd weer door een ander verzonnen. Ik wilde een hype rond het boek en de site creeren.'

Het literaire establishment pikte het niet en beschuldigde hem van aanstellerij. 'Bier, maandverband, films en muziek worden met marketing-sausjes overgoten, maar voor boeken mag dat niet in Nederland. Hier worden covers regelmatig veranderd, maar mijn omslag is na de vijftiende druk nog steeds hetzelfde en blijft dat ook. Uiterlijke herkenning is zo belangrijk. Iedereen kent de zwarte platenhoes van Pink Floyds Dark Side Of The Moon met die zilveren driehoek en een regenboog erop of de Arrival-elpee van Abba met een helikopter. Dat is de kracht van het beeld.' 'En daarnaast vindt de literaire wereld dat een debutant rustig moet worden gebracht. Alleen als je een grote naam als Harry Mulisch of mijn buurman A.F.Th. van der Heijden bent, word je spetterend gelanceerd. Wat dat betreft is Nederland heel conservatief. En ik wilde dat eens lekker wakker schudden en dit heilige huisje omver werpen.'

Ondanks kritiek uit de literaire hoek werd Komt een vrouw bij de dokter het best verkochte Nederlandse romandebuut van de afgelopen jaren. 
The alleged new approach is clear from the opening of the article, entitled 'The writer as a brand: the unorthodox approach of best-selling writer Kluun'. But of course an unorthodox position is still related to a doxa, in this case that of the traditional literary field that Kluun puts in opposition to the world of 'beer, sanitary napkins, film, and music'. Thus, it becomes part of Kluun's strategy to combine economic success with symbolic recognition. It is only useful to suggest that you are neglected and even rejected by the official literary elite if you want to be recognized by them. As we already saw, the 'criticism from the official literary world' was not so bad, but Kluun's novel was in fact almost completely ignored by the 'official' reviewers. In the light of the strategy to find recognition within the literary field, any - even negative - review is nevertheless more than welcome as an essential part of the consecration - paradoxically, even if this criticism is utterly negative: being reviewed means being eligible for discussion in the book section, and thus that you are a possible candidate to take in a position in the literary field. That would be doubtful if your novel was completely ignored by the reviewers. By expanding the only two negative reviews (which were not even written by traditional dominant actors in the literary field such as NRC Handelsblad or Vrij Nederland) to 'criticism from the literary field', Kluun paradoxically stresses his position in the literary field.

There are more indications that Kluun, besides being commercially successful, wants to be eligible for a position in the literary field. In spite of his outspoken opinion on the so-called conservative literary world, Kluun has included two quotes from, respectively, NRC Handelsblad and de Volkskrant (both quality newspapers) in the reprints of Komt een vrouw bij de dokter right on top of the very first page that is filled with praise for the book from all angles. Interestingly enough, however, the quotes in question do not originate from literary reviews on the book but come from general articles from the entertainment pages of both papers, which were about the public presentation of Kluun's novel. ${ }^{12}$ The suggestion that they are literary reviews is nevertheless further strengthened by explicitly mentioning the name of one of the 'reviewers': the late Adriaan Jaeggi from de Volkskrant, who was not only a journalist but also a literary writer.

There is another clue that Kluun at this time is strategically searching for recognition from actors in the literary field. After the negative review of critic Arie Storm was published in Het Parool, both Kluun and his publisher Joost Nijsen responded directly to the article with a letter to the editor. Both comments refer explicitly to the literary quality of the publishing house.

12 Kluun uses the same quote from NRC Handelsblad on the back cover of the English translation of Komt een vrouw bij de dokter, next to, amongst others, lines from The Daily Mail and Der Spiegel. 
Nijsen points out: 'The point is that Podium, besides the proud publisher of Ronald Giphart, is the publisher of a large variety of writers of fiction and non-fiction, from Dutch authors such as Manon Uphoff, Herman Franke, Joris Luyendijk, and Henk van Woerden to poets such as Ingrid Jonker, Tjitske Jansen, and Antjie Krog, as well as internationally renowned writers such as Michel Faber and Booker Prize winner DBC Pierre' (Nijsen 2003). ${ }^{13} \mathrm{~A}$ week earlier, Kluun himself had also already mentioned in a letter to Het Parool 'all authors connected to Podium publishers (among others DBC Pierre, winner of Booker Prize 2003, Henk van Woerden, Manon Uphoff, Herman Franke, Michael Faber, etc.)' (Kluun 2003). It is, of course, quite unusual to respond to a bad review, especially when you are the criticized author in question. Kluun and his publisher broke this rule in a clear attempt to get as much attention as possible from this single review.

A last indication for Kluun's link to high literature, lies in the fact that the novel appears to have become a subject of debate in intellectual circles, where the question whether or not it had literary value became a topic of conversation. Typical is a column by Frits Abrahams, one of the prominent columnists in The Netherlands, in quality newspaper NRC Handelsblad, in autumn 2006, which begins thus: 'More and more I got involved in confusing discussions about Kluun, writer of the bestsellers Komt een vrouw bij de dokter and De weduwnaar [The Widower, Kluun's second novel]. On the one hand there are the defenders, often women of about thirty years old, and on the other hand the sceptics, often men over fifty years old. For the first group, Komt een vrouw bij de dokter is a "beautiful, moving book", the other group considers it a load of crap' (Abrahams 2006). ${ }^{14}$

\section{Branding Kluun}

It is evident that Kluun also seeks access to the literary field with his book. A curious document provides, from a quite unexpected angle, additional

13 'Feit is, dat Podium behalve de trotse uitgever van Ronald Giphart de uitgever is van de meest uiteenlopende schrijvers van fictie en nonfictie, van Nederlandse auteurs als Uphoff, Franke, Luyendijk en Van Woerden tot dichters als Ingrid Jonker, Tjitske Jansen en Antjie Krog en internationaal befaamde schrijvers als Michel Faber en Bookerprize-winnaar DBC Pierre.' 14 'Steeds vaker kwam ik in warrige discussies terecht over Kluun, schrijver van de bestsellers Komt een vrouw bij de dokter en De weduwnaar. Aan de ene kant had je de pleitbezorgers, vaak vrouwen van omstreeks de dertig, en aan de andere kant de sceptici, vaak mannen van boven de vijftig. Voor de eerste groep was Komt een vrouw bij de dokter een "mooi, ontroerend boek", voor de andere groep "complete bagger".' 
material to illustrate the strategy that Kluun used to brand his book both as a potential public success as well as a literary novel. In 2005, Raymond van de Klundert filled out a twelve-page application form in order to compete for an Effie, the most important Dutch advertising prize, using the motto 'Advertising works, also in literature'. ${ }^{15}$ Kluun - or rather Van de Klundert - describes in the document, apparently following a given questionnaire, the strategy he designed to make his debut a public success.

The document in question is interesting because Van de Klundert's answers and remarks show a number of, not necessarily proven, assumptions about the situation of the current literary field, matters like literary value (an issue such as 'taste', for example) and the influence of 'traditional' literary criticism. Here, too, he turns against the high-culture oriented literary establishment: the form contains numerous references to the official literary world (often with a slightly ironic tone), where the actors seem to know all about the intrinsic qualities of books. Never before has a book been described and analysed this explicitly as a project of advertising by its own author. Once again, we witness the complex manoeuvres between economic and symbolic success, where for the sake of the matter it is time the commercial aspects prevail.

The interest in the literary field as a focal point becomes clear from the so-called SWOT-analysis Kluun presents of his own book. This is an American-based analysis that advertising professionals often use. These analyses examine both the main Strengths and Weaknesses of a company or a product, as well as the Opportunities and Threats of the product in question. Kluun's/Van de Klundert's analysis is quoted extensively (Van de Klundert 2006).

The Manuscript of Komt een vrouw bij de dokter was proofread by a few dozen people and provoked emotional reactions. People had to cry, laugh, they were angry, happy, sad. The story remained in people's head for a long time. That is - to get into Effie jargon - a Strength for a literary novel.

The biggest Weakness? Publisher Joost Nijsen estimated that there was only a very slight chance that book reviewers would go totally flat out for Komt een vrouw bij de dokter. The story is largely autobiographical, something most literary book reviewers consider a weakness for a debutant. In their opinion, it confirms the cliché image of the hundreds of thousands of would-be writers, wanting the world to take notice of their life story, 
while not being bothered by any talent for storytelling or rich literary imagination at all. In addition, Kluun's populist writing style was not exactly salonfähig:

Metaphors, for example football comparisons. Frequent use of brand names. Windows-like popups with descriptions of all the pubs, restaurants, and clubs that appeared in the novel. And the so-called 'wramples' - or written samples: pieces of text - of course with the source mentioned, but still - taken from literature, film, pop music, comic strips, cabaret, and - how vulgar! - even from advertising campaigns.

However, that was also the Opportunity right away. The advantage of a writer - just like a rock band, sportsman, or DJ - who deviates from the usual is that he can acquire real fans, who want to share their enthusiasm with as many people as possible. Fans provide word-of-mouth advertising of the kind product managers of 'ordinary' products can only dream of.

The second biggest Threat to a debut are bad reviews. There is only one bigger threat: no reviews. To be ignored by the literary press. For an established author with a large fan base that is not an insurmountable problem (writers like Coelho and Grisham are rarely reviewed), but, for a debut novel, to be neglected is equal to a postnatal abortion. ${ }^{16}$

16 'Het manuscript van Komt Een Vrouw Bij De Dokter was door enkele tientallen mensen gelezen en riep emotionele reacties op. Mensen moesten huilen, lachen, waren boos, gelukkig, verdrietig. Het boek bleef lang hangen bij iedereen. En dat is - om in Effie-jargon te komen - een Strength voor een literaire roman.

De grootste Weakness? Uitgever Joost Nijsen schatte de kans klein in dat literaire recensenten en masse plat zouden gaan voor Komt Een Vrouw Bij De Dokter. Het verhaal is grotendeels autobiografisch, iets wat door de meeste literaire recensenten wordt gezien als een zwaktebod voor een debuut. Het bevestigt in hun ogen het cliché-beeld van de honderdduizenden would-be schrijvers die vinden dat de wereld kennis moet nemen van hun levensverhaal, daarbij niet gehinderd door enig talent voor vertelkunst of rijke literaire verbeeldingskracht. Daarbij komt dat Kluuns populistische schrijfstijl bepaald niet salonfähig was. Metaforen o.b.v. voetbalvergelijkingen. Veelvuldig gebruik van merknamen. Windows-achtige pop ups met beschrijvingen van alle kroegen, restaurants en clubs die in de roman voorkwamen. En de zogenaamde 'wramples', ofwel written samples: gejatte stukken tekst - weliswaar met bronvermelding, maar toch - uit literatuur, film, popmuziek, strips, cabaret, en - hoe ordinair - zelfs reclamecampagnes).

Maar dat was ook meteen de Opportunity. Het voordeel van een schrijver - net als een rockband, sportman of dj - die afwijkt van het gangbare is dat hij echte fans kan verwerven, die hun enthousiasme met zoveel mogelijk mensen willen delen. Fans zorgen voor mond-tot-mond reclame van het soort waar productmanagers van 'gewone' producten van dromen.

De op één na grootste Threat van een romandebuut zijn slechte recensies. Er is maar één grotere 
There are many similar clauses in the document, all of them indicating that the established literary order is Kluun's most important target group. The author mentions as the strength that his book is a literary novel. Joost Nijsen evidently manifests himself as a literary publisher, and both publisher and author consider the 'literary reviewers' the main target group.

Kluun did not win the Effie award. There is much irony in the reason why: the jury thought 'the product itself has had an influence on success, not communication'. In other words: the book itself had apparently intrinsic qualities - with which the jury from the very state-of-the-art industry that the advertising world is, paradoxically shows a very traditional view on what literary value is.

\section{Branding as a Strategy of Complicity and Distinction}

Of course it is questionable whether Kluun's outline of the way the literary world works is correct. It looks like this largely is an (in itself very interesting) matter of individual perception rather than empiricism. However, the matter whether his vision is correct or not is not relevant now. It is about a more basic topic: Kluun evidently focuses on recognition in the literary field. It is not a coincidence that he mentions 'being ignored' as a major threat.

In one of the articles in which Bourdieu most explicitly dwells on the properties of fields, he makes the following observation: 'Autre proprièté, déjà moins visible, d'un champ: tous les gens qui sont engagés dans un champ ont en commun un certain nombre d'intérêts fondamentaux, à savoir tous ce qui est lié à l'existence même du champ: de là une complicité objective qui est sous-jacente à tous les antagonismes' (Bourdieu 1984: 115). The battle on the literary field can only be fought with the (unspoken) assumption of both parties that it is all worth the game: Bourdieu's 'complicité objective', or 'objective complicity', involves an (implicit) mutual agreement on the preconditions, a shared belief.

What can be said about Kluun's objective complicity? On the one hand, there are the obvious indications mentioned above that he aims at a position within the traditional literary field (the acquisition, therefore, of symbolic capital); on the other hand, it became clear that his strategy in terms of form and content almost entirely seeks to collect economic capital.

threat. Geen recensies. Genegeerd worden door de literaire pers. Voor een gevestigd auteur met een grote schare fans geen onoverkomelijk probleem (schrijvers als Coelho en Grisham worden zelden gerecenseerd), maar voor een debuutroman staat totale windstilte gelijk aan een postnatale abortus.' 
In his text, we find many such assumptions about the characteristics of the literary field (and they sometimes seem almost borrowed straight from Bourdieu, for instance when Kluun (ironically) states: 'the noble world of literature has its own codes'). The alternative to recognition by the settled actors is always the commercial success that Kluun aims at with his branding strategy.

So here we come to a striking point of intersection: after all, economic success does not in itself make it necessary or even desirable to enter the symbolic capital market. In addition, here the Kluun-case seems more complex. Unlike what Bourdieu argues in 'The production of faith', Kluun tries to enter both the symbolic and the economic market. Following Bourdieu, success in one market generally excludes success in the other.

There are also two opposing images of the criteria of success. For 'bourgeois' writers and their readers, success is intrinsically a guarantee of value. That is why, in this market, the successful get more successful. Publishers help to make best-sellers by printing further impressions; ${ }^{17}$ the best thing a critic can do for a book or play is to predict "success" for it. [...] As for the opposing camp's vision, in which success is suspect and asceticism in this world is the precondition for salvation in the next, its basis lies in the economy of cultural production itself, according to which investments are recompensed only if they are in a sense thrown away. (Bourdieu 1993: 101)

As far as the recognition of his work is concerned, Kluun is not totally depending on those who determine success on a symbolic level. Success, following Bourdieu, does not indicate autonomous, objective quality but stems from the conscious and unconscious obeying of the written and unwritten rules of the game by judges that are judged to be competent, with knowledge of (faith in) literary value: 'Le producteur de la valeur de l'oeuvre de l'art n'est pas l'artiste mais le champ de production en tant qu'univers de croyance qui produit la valeur de l'oeuvre d'art comme fétiche en produisant la croyance dans le pouvoir créateur de l'artiste' (Bourdieu 1998: 375).

Kluun is evidently a 'complicit' player in the literary field. His 'antagonistic' attitude is clear, but it does not stand complicity in the way. On the contrary: antagonism is a traditional part of the game. In his classic study The Theory of the Avant-Garde, Renato Poggioli distinguishes between two

17 Actually, it says here in French: 'on contribue à faire les best sellers en publiant leurs tirages', which literally means: 'Publishers help to create bestsellers by publishing the circulation figures'. 
types of antagonism as a trademark of the classic avant-gardist (Poggioli 1968: 30). Firstly, there is the antagonism against the general public. Of course, this does not apply to Kluun: reaching a big audience is one of Kluun's main goals. Secondly, there is literary antagonism. In fact, that does not apply to Kluun's novel either. His prose is not innovative, nor is his book experimental or hermetic. His battle is not one of the usual ones on formal matters orientated 'literary' nature. Kluun's campaigns to take up a position in the literary field are of a different nature and need to be sought in his strategy of being open about the branding of his novel. From that point of view, Kluun might even be considered more radical than any avant-gardist in the last few decades. Bourdieu calls it 'significant' that

all attempts to call into question the field of artistic production, the logic of its functioning and the functions it performs, through the highly sublimated and ambiguous means of discourse or artistic 'acts' [...] are no less necessarily bound to be condemned even by the most heterodox guardians of artistic orthodoxy, because in refusing to play the game, to challenge in accordance with the rules, i.e. artistically, their authors call into question not a way of playing the game, but the game itself and the belief which supports it. This is the one unforgivable transgression. (Bourdieu 1993: 80-81)

Indeed, Kluun does not attack with literary strategies (like more or less radical renewals of formal aspects, a revolutionary world view, or otherwise shocking linguistic experiments) but by radically denouncing a basic condition of the literary game, namely: high art with symbolic value keeps itself far away from economic laws. Nevertheless, at the same time, Kluun never loses sight of that established field and the recognition that it could provide. Kluun ultimately does not criticize the game itself.

\section{After the Gold Rush}

Kluun's career after Komt een vrouw bij de dokter shows an interesting development. His second novel, the afore mentioned De weduwnaar appeared in $2006 .{ }^{18}$ It was immediately reviewed in the book sections of most of the

18 De weduwnaar was translated into English by Shaun Whiteside, the translator of Kluun's debut novel. It was entitled The Widower and published by Pan Books, an imprint of Pan Macmillan Ltd, London in 2008. 
nationwide quality newspapers such as NRC Handelsblad, Vrij Nederland, de Volkskrant and in various local papers after it was issued. All of these reviews were negative, but the amount of attention from the literary field was considerable - particularly compared to the two reviews of the debut. Kluun's next two novels, Haantjes (2011) and DJ (2017) were in terms of critical attention seen as 'regular' literary works. The judgement in the quality papers of those novels was in general rather positive. Kluun himself noticed the change too. He reflected on the apparently changing attitude of literary reviewers in an interview:

Is there some truth in in it? There seems to be growing recognition for your work from the side of, let us say, the literary elite.

'Yes, I think I detect that tendency too. It is still reluctant and a bit hesitant, but something seems to be changing. I now hear more often: "It's well done." Apparently, I have to make more efforts to earn recognition. [...] I know what I am capable of, and I am very self-critical, but this is simply a good book. If that results in a very positive review from Jeroen Vullings in Vrij Nederland, then that is nice, of course. A friend of mine sent me a WhatsApp-message: “They're getting convinced." (Van Velzen $2017)^{19}$

Without doubt, the novel $D J$ that was published early 2017 is technically more complex than Kluun's earlier books. Viewed from the angle of the antagonism between symbolic and economic capital, the novel is very interesting. The outline of the story itself appears (again) to be to a certain extent autobiographical: it is about a writer, named 'Kluun' (also appearing in the novel under his real surname, Van de Klundert) who got divorced and has to deal with his ex-wife, with financial problems, and with writer's block. However, it is evident that the rest of the story is purely fictional.

Of particular interest is a motive that plays on the background. 'Kluun' is, without much success, working on his next book: a family saga, intended to be a serious, literary novel. His publisher, someone with high cultural standards ('he was convinced that no one could ever grow up to become a

19 'Zit daar iets in? Er lijkt nu ook uit de hoek van, laten we zeggen, de literaire elite, erkenning te komen voor uw werk.

"Ja, die teneur herken ik wel. Het is een schoorvoetend erkennen, het is hier en daar nog wat stekelig, maar er lijkt iets te veranderen. Ik hoor nu vaker: 'Het zit toch wel goed in elkaar'. Blijkbaar moet ik er meer voor doen om erkenning te verdienen. [...] Ik weet wat ik kan en ik ben heel zelfkritisch, maar dit is gewoon een goed boek. Als dan die goede recensie van Jeroen Vullings in Vrij Nederland komt, dan is dat natuurlijk wel lekker. Een vriend van me appte: 'Ze zijn om..' 
full-fledged educated human being if he did not read Reve, Hermans and Mulisch') keeps enquiring, more and more urgently, when he will receive the manuscript of the new novel.

In the meantime, 'Kluun' has accepted a lucrative job: a production company called EndofWorks (an allusion to the big Dutch production company Endemol) asked him to make a television documentary about the world famous DJ Thor, who used to be his roommate when they both were students. Due to all sorts of circumstances a rivalling - very commercially orientated - publisher becomes interested and asks 'Kluun' to write Thor's biography, in which he sees large commercial potential.

In this way, Kluun has turned his own antagonism as a writer in the one and a half decades before into a thematic thread in the novel itself: the conflict between the economic and symbolic success. Kluun often uses self-irony as a technique, for instance when he describes a literary panel in which he takes part.

At my other side, a book reviewer was seated whom I only knew by name. He had called my last novel an Offence to Literature. That same night I discovered that he wrote books himself as well, and according to our interviewer, those were novels 'that mattered'.

In an attempt to create a happy atmosphere, I sincerely apologized for the fact that all my novels were bestsellers, and I said that of course I'd rather have had it the other way. And I added that I was hoping that tonight I would be able to learn from my colleagues how to write a really good novel.

Throughout the novel this sort of self-mockery turns up. For instance: when the producer of EndofWorks tries to persuade 'Kluun' to go on with the documentary, even though a friend of Thor, a young girl, has just died from drug abuse. This telephone conversation follows:

I answered that EndofWorks should be bloody ashamed of themselves for wanting to exploit the death of a loved one this way. 'What about Komt een vrouw bij de dokter?' Molenaar asked. 'Sorry! Gotta go.'

One conversation, somewhere in the beginning of $D J$, between 'Kluun' and his own publisher is of particular interest.

'What would you say if I put the Family Novel on hold and write a book about a DJ?'

'About this friend of yours?' 
'Yes. There is a big chance he will be elected most popular DJ of the world next month.'

'People that like dance don't buy books, Kluun.' My publisher crumbled the napkin beside his plate. 'I urgently demand you to speed up the writing of the family novel. I cannot tolerate you pushing the deadline back any further. I have got a company to run.'

The old-school publisher of 'Kluun' thinks that there is no commercial profit to be gained from a novel about a DJ, and insists on the initially promised 'literary' product. His last line is of particular interest: he makes explicit that he, too, has to take economic capital into consideration. In this way Kluun has turned his own initial real-life marketing strategy into a literary theme in his most recent novel. It all indicates a final move towards the literary field.

\section{Changing Positions}

Parallel to Kluun's march in the direction of the literary field there is a remarkable development to be detected in his economic success. Komt een vrouw bij de dokter sold 1.2 million copies; De weduwnaar 700,000 copies; ${ }^{20}$ Haantjes 150,000 copies. ${ }^{21}$ All three novels reached the Number 1 position in the weekly Dutch Book Top 6o. Komt een vrouw bij de dokter remained in the list for 216 weeks, De weduwnaar 114 weeks, and Haantjes 33 weeks. DJ never made it to the highest position.

Before $D J$ was issued, publisher Joost Nijsen already anticipated in Boekblad (the professional magazine for the Dutch book industry) that there would be less economic success for the new book compared to Kluun's earlier novels:

A success like Komt een vrouw bij de dokter will never happen again. It was published in a time the book market reached heights that it will never reach again. I remember estimating that 140,000 copies of Haantjes would be modest at the time, but with $D J$ we aim at 100,000 copies to begin with. The market has totally changed. Moreover: we all know the

20 Information from Website Podium Publisher: http://www.uitgeverijpodium.nl/Auteurs/ author/63/Kluun [accessed 14 February 2019].

21 Information in Rinskje Koelewijn, “"Vrouwen willen beledigd worden”', NRC Handelsblad, 19 March 2011. 
female readers are decisive. They might be touched more by the emotional character of Komt een vrouw bij de dokter than the laugh and punch that $D J$ is. (Dessing 2017) ${ }^{22}$

In the end, $D J$ ended up in the Top 100 of 2017 as number 59, indicating that between 30,000 and 40,000 copies were sold, which means less than half of the amount Nijsen estimated (CPNB 2017).

Of course Nijsen, as an experienced publishing expert, will be right with his explanation of the developments in the changing book market as one of the reasons for the smaller success of Kluun's latest novel. But it is also an undeniable fact that $D J$ is the most 'literary' novel Kluun has written so far. In the meantime, Kluun himself had started to downplay the role of the (attempts to launch the) brand 'Kluun' in the years following the publication of his first two novels. Only three years after he had applied for the Effie, he said in an interview, when asked if he had any idea about the reason for the 'tremendous success' of Komt een vrouw bij de dokter: 'It definitely wasn't the marketing, like some people suggest. Good marketing can give a book two reprints the most. After that the book itself should do the job' (Verbraak 2008). ${ }^{23}$

Spring 2018 brought some remarkable book news concerning Kluun. On 22 February Lebowski Publishers in Amsterdam published a press statement:

Raymond van de Klundert, in an earlier life as a writer known as 'Kluun', switches to Lebowski Publishers. After fifteen successful years and over 2,5 million copies sold with Podium it is, in the words of the writer 'time for new élan. After fifteen years with Podium I felt I needed to make a new step. And use a new name: my own.'

The switch to Lebowski indicates a new direction in Van de Klunderts authorship. To begin with he literally goes back to his roots: the Brabant

\footnotetext{
22 'Zo'n succes als Komt een vrouw bij de dokter zal nooit meer voorkomen. Dat verscheen in een boekenmarkt die nooit meer zal pieken als toen. Ik weet nog dat we 140.000 exemplaren van Haantjes destijds bescheiden vonden, maar nu mikken we eerst maar eens op 100.000 exemplaren. De markt is gewoon totaal veranderd. En we weten allemaal dat vrouwen de markt bepalen: die vallen misschien eerder voor ontroering, zoals in Komt een vrouw bij de dokter, dan voor de lach en de stomp van $D J$.'

23 'Het kwam in elk geval niet door de marketing, wat sommige mensen beweren. Met goede marketing overleeft een boek hooguit de eerste twee drukken. Daarna moet het boek het toch echt zelf doen.'
} 
of his early youth. Thus, it is the right moment to publish in future under the name that his parents gave him: Raymond van de Klundert. (Anon $2018)^{24}$

This appears to be the final step away from the commercial project that 'Kluun' was (too).

The strategy applied by Kluun - that is, explicitly collecting economic capital in order to gain a position in the literary field - was noticed by Bourdieu in his later work (as quoted in the Introduction) as a more general recent strategy in the publishing world: 'Certain publishers new to the game may try to reconcile strategies that would be irreconcilable if the literary field were more autonomous: those geared toward a long-term investment in writers promising long and productive careers, and those geared toward more immediately profitable literary production over the short term. They are supported in this ambition by a type of modernized marketing based on the methodical use of the allodoxia' (Bourdieu 2008: 140). Kluun appears to be a Dutch example of this strategy that Bourdieu criticizes strongly in the texts he published in the last couple of years before his death.

As we saw earlier, the scholars Bax and Antonik represented two diametrically opposing positions regarding the current trends in the field of literature. The Kluun-case cannot be interpreted as the radical change Antonik describes regarding Witkowski ('a radical shift in how literature operates' (Antonik 2016:190)). Kluun's intentions are evidently still orientated on recognition of the traditional literary field, and probably closer to the doxa than Bax appears to think.

At this point it is important to note that that literary field in question is not, as Bax (at least implicitly) seems to suggest, an eternally fixed phenomenon. On the contrary, one of its basic (though often underexposed) characteristics is its dynamicism. Therefore, one cannot simply say, 'Kluun has entered the Dutch literary field,' but rather it has to be considered as a mutual development, with changing positions on both sides. Actors in

24 'Raymond van de Klundert, in een vorig schrijvend leven bekend als Kluun, stapt over naar Lebowski Publishers. Na vijftien succesvolle jaren en tweeënhalf miljoen verkochte exemplaren bij uitgeverij Podium is het nu, zoals de auteur zegt, "tijd voor nieuw elan. Na vijftien jaar samenwerken met Podium voelde ik dat ik toe was aan een nieuwe stap. En een nieuwe naam. Die van mezelf."

De overstap markeert een nieuwe richting in Van de Klunderts schrijverschap: om te beginnen een letterlijke terugkeer naar zijn roots, het Brabant van zijn jeugd, en een uitgelezen moment om in de toekomst te publiceren onder de naam die zijn ouders hem gaven: Raymond van de Klundert.' 
the Dutch literary field, such as publishers, academics and book reviewers consider Kluun more and more apt to be part of their field, which inspires the field to partly reshape itself at the same time.

Of course, no one can tell what the future has in store. Until his next novel is published, it will remain unclear what effect the drastic change - new publisher, new name - will have for the literary career of the writer formerly known as Kluun. One thing appears to be certain: dropping the name 'Kluun' means the end of the brand.

\section{References}

[Anon.] 2005. 'De schrijver als merk. Bestsellerauteur Kluun pakt zaken onorthodox aan'. De Telegraaf, 16 October, 22.

[Anon.] 2006. 'Kluun krijgt NS Publieksprijs voor debuut: Komt een vrouw bij de dokter is "Boek van het Jaar"'. Dagblad van het Noorden, 16 October.

[Anon.] 2018 'Persbericht: Kluun publiceert als Raymond van de Klundert een autobiografische familieroman bij Lebowski Publishers'. https://www.lebowskipublishers.nl/post/PERSBERICHT--KLUUN-PUBLICEERT-ALS-RAYMOND-VANDE-KLUNDERT-EEN-AUTOBIOGRAFISCHE-FAMILIEROMAN-BI-LEBOWSKIPUBLISHERS-N2865.html [accessed 24 February 2020].

Frits Abrahams. 2006. 'Kluun'. NRC Handelsblad, 26 October.

Dominik Antonik. 2016. 'The Author as a Brand'. Teksty Drugie [English Edition], 2: 174-190.

Sander Bax. 2019. De literatuur draait door. Amsterdam: Prometheus.

Pierre Bourdieu. 1984. Questions de sociologie. Paris: Éditions de Minuit.

Pierre Bourdieu. 1993. 'The Production of Belief: Contribution to an Economy of Symbolic Goods'. In Pierre Bourdieu, The Field of Cultural Production. Essays on Art and Literature, pp. 74-111. Cambridge: Polity Press.

Pierre Bourdieu. 1998. Les règles de l'art: Genèse et structure du champ littéraire. Paris: Seuil.

Pierre Bourdieu. 2008. 'A Conservative Revolution in Publishing'. Translation Studies, 1.2: 123-153.

CPNB. 2017. 'CPNB top 100 2017'. https://www.cpnb.nl/sites/default/files/cpnb_files/ CPNB\%20Top\%20100\%202017\%2oBestverkochte\%2oboeken\%20-\%2oDEF.pdf [accessed 24 February 2020].

Maarten Dessing. 2017. 'Gesprek op Zondag: Joost Nijsen (Uitgeverij Podium)'. Boekblad, 12 February. https://boekblad.nl/Nieuws/Item/gesprek-op-zondagjoost-nijsen-uitgeverij-podium. Last visited on 7 November 2019.

Jos Joosten. 2007. Misbaar. Hoe literatuur literatuur wordt. Nijmegen: Vantilt. 
JvdH. 13 November 2003. 'Kankerlijer. Vreemdgaan was nooit zo gemakkelijk'. Propria Cures.

Raymond van de Klundert. 2005. Deelnameformulier Reclame Kluun. Amsterdam. https://medium.com/@samgerrits/deelnameformulier-reclame-kluunb419c6d6b49e. Last visited on 15 February 2019.

Kluun. 2003. 'Letter to the Editor'. Het Parool, 25 October.

Kluun. 2017. DJ. Amsterdam: Podium.

Rinskje Koelewijn. 2011 “"Vrouwen willen beledigd worden”. NRC Handelsblad, 19 March.

Joost Nijsen. 2003. 'Letter to the Editor'. Het Parool, 1 November.

Renato Poggioli. 1968. The Theory of the Avant-garde. Cambridge/London: Harvard University Press.

Arie Storm. 17 October 2003. 'Kluuniaanse aanstellerij'. Het Parool. Joost van Velzen. 2017. 'Kluun: “Dit is gewoon een goed boek”'. Trouw, 22 February, pp. 14-15.

Coen Verbraak. 2008. 'Raymond van de Klundert; interview'. de Volkskrant 1 November.

\section{About the Author}

Jos Joosten (1964) is Professor of Dutch Literature at Radboud University Nijmegen. He is a member of the research group SCARAB (Studying Cultural Infrastructure and Reception Across Borders) and has published several articles and books on the theory and practice of literary criticism and book reviewing. His most recent book is a biography of the Belgian avant-gardist and writer Jan Walravens: De verdeelde mens:Jan Walravens (1920), schrijver, ijkpunt, avantgardist (2018). 


\title{
Branding the Open-minded Nation
}

\author{
Dutch Authors at the 2011 Beijing Book Fair
}

Laurens Ham

\begin{abstract}
In 2011, the Netherlands was invited to be the guest of honour at the Beijing Book Fair. This fair attracted controversy that revealed the tensions that exist between nation branding, public diplomacy, and literary autonomy: while its sponsor, the Ministry of Culture, regarded the fair as a perfect marketing opportunity, Amnesty International used the occasion to protest repression in China. Dutch authors invited to participate in the fair forged an alternative position by emphasizing their status as autonomous artists. However, an analysis of the debate in the Dutch media shows that both the Ministry, Amnesty International, the Dutch Foundation for Literature, and many authors interpreted the contact between Chinese and Dutch authors as a clash between an open(-minded) culture and a closed one.
\end{abstract}

Keywords: literary policy, cultural diplomacy, nation branding, book fairs, literary autonomy, activism

\section{Introduction}

On 9 September 2010, Dutch blogger Chrétien Breukers asked national poet laureate Ramsey Nasr to 'take a strong stand against the intended participation of the Dutch Foundation for Literature [DFL] in the 2011 Beijing Book Fair'. The DFL - the main subsidizing body in the Dutch literary field - had an important role in the book fair programme as guest of honour for 2011. Breukers found this highly problematic:

Helleke van den Braber, Jeroen Dera, Jos Joosten, and Maarten Steenmeijer (eds), Branding Books Across the Ages: Strategies and Key Concepts in Literary Branding. Amsterdam, Amsterdam University Press 2021 DOI: 10.5117/9789463723916_CH14 
For many years now, China has been the country issuing and implementing the most death sentences. China has also been pursuing a settlement policy for years (just like Israel), in particular in Tibet. China is not a democracy. Human rights are not guaranteed in China - quite the opposite. $[\ldots]$

As poet laureate, you should launch a new Poet Laureate Poem, which will have the added advantage that for once it need not discuss that triplet of Palestine, silly Christians, and Arrogance. ${ }^{1}$ (Breukers 2010)

A year later, on 5 September 2011, Nasr did indeed discuss the Dutch participation in the Beijing Book Fair during an appearance on the daily television show De wereld draait door. However, he chose to defend the opposite position from the one advocated by Breukers the year before: Nasr did not argue against Dutch participation but defended his decision to be part of the delegation sent by the DFL. According to Nasr, this was the best way of protesting the human rights situation in the People's Republic of China (PRC) and the restrictive climate Chinese authors are forced to work in (Anon. 5 September 2011).

In August and September 2011, a controversy over the Beijing Book Fair caused an uproar in the Dutch literary world. The resulting discussion revealed the tensions that exist between nation branding, public diplomacy, and literary autonomy. For while the sponsoring Ministry of Culture appeared to regard the fair as a perfect opportunity for marketing Dutch books to a huge upcoming market, Amnesty International used the occasion to protest censorship and repression in China. Dutch authors invited to participate in the fair were caught between these two intense fires: they could be part of either a promotional campaign for the branding of Dutch literature or of a solidarity campaign for their persecuted Chinese colleagues. Finding these instrumental, politicized roles highly uncomfortable, many authors began forging an alternative, third position by emphasizing their status as autonomous artists who would not let others pigeonhole them as either advertisers or activists.

The present paper will reconstruct the divergent positions in this debate, paying particular attention to the discursive field in which the discussion

1 'China is al jaren het land dat de meeste doodvonnissen oplegt, én uitvoert. China voert al jaren een nederzettingenpolitiek (net als Israël), vooral in Tibet. China is geen democratie. De mensenrechten zijn in China niet gewaarborgd. Integendeel. / [...] / U, als Dichter des Vaderlands, zoudt [...] weer eens een keer een DiDeVa-gedicht de wereld inzenden; met als extra voordeel dat het deze keer niet zou gaan over de trits Palestina, domme Christenen en Eigenwaan.' 
took place: a discourse on openness and 'closedness' - which in itself also vacillated between tolerance and receptiveness on the one hand and (wilful) ignorance on the other - which was used to characterize the Dutch-Chinese relationship. Both the DFL and Amnesty deployed this discourse in their branding campaigns, and most of the writers involved conformed to these demarcations. The fact that the discourse of openness was so easily applied by several different players in the field illustrates that there can sometimes be but a fine line between literature, state, and market, particularly in international branding processes.

\section{How to Deal with Intermingling Fields?}

As the Introduction to the present volume shows, the concept of cultural (or literary) branding poses somewhat of a problem to field theorists. Field theory commonly studies the literary field as a relatively autonomous conceptual domain, functioning according to its own rules of the so-called reversed economy: actors strive for symbolic capital, not for economic success. To be sure, Pierre Bourdieu's seminal works on field theory make clear that a perfect autonomy can never be obtained. The literary field, after all, is embedded in the larger field of power and will always be susceptible to power influences (Bourdieu 1983: 319). However, Bourdieu credits literature as a form of expression that is able to 'struggle against the field of forces' to which it belongs - suggesting that the literary field is bound to offer resistance to heterogeneous influences that threaten its autonomy (Brouillette and Doody 2015: 100).

The Introduction also points out that by the 199os, Bourdieu had become markedly uncomfortable about the growing influence of the news media and the large book publishing companies which, as he saw it, would put severe pressure on literary autonomy (Bourdieu 2008). He would arguably be even more alarmed by the situation a few decades later, now that it had become quite uncontroversial to openly brand literary works and authors using all possible (social) media, advertising campaigns, and festivals. ${ }^{2}$ The growing impact of media in the literary field has led several researchers to propose new field and capital concepts. Couldry (2003) and Driessens (2013), for example, argue for the introduction of the concepts of 'media meta-capital' and 'celebrity capital', respectively, to account for the crucial role that media play in forming an author's reputation. Driessens (2013: 543) 
states that 'celebrity has become a valued power resource' in multiple social fields, 'such as the political, cultural, or economic field', which suggests that the boundaries between the formerly separate fields of culture, state, and market have begun to fade.

In her seminal paper text, Gisèle Sapiro (2003:442) positions the literary field 'between the state and the market' (emphasis added) - so she appears to assume we can still separate these domains from one another. According to Sapiro (457), the autonomy of the literary field is both hindered and facilitated by states and markets: ' $[\mathrm{W}]$ hile the market helped literary activity to free itself from the supervision of the State, the State can also become an instrument for saving the rights and freedom of creation from the merciless sanction of the market and the risks of the cultural producers of being exploited.' From this perspective, cultural policy is aimed at making authors less dependent on a constant production of easily marketable texts.

However, this reciprocal permeation of fields and forces makes it ever harder to consider interpreting states as protectors of literary autonomy. While presenting any literary field without taking the role of the modern media landscape into account would be a highly artificial enterprise, it appears to be equally unproductive to see the contemporary nation state as a purely public affair, protecting the literary and other cultural fields from commercial influences. Several recent critical cultural policy studies have attempted to show that cultural policies have been internationally instrumentalizing in new ways over the past few decades. Whereas many governments still fund arts and culture partly because of their supposed intrinsic value (supporting its autonomous status), instrumentalist policies that emphasize the economic importance or societal value of culture have been on the rise (Gray 2007; Belfiore 2012; Hesmondhalgh 2015). Perhaps the current literary and cultural policy domains should not be operationalized as (semi-)autonomous fields, but rather be situated - to quote Geir Vestheim (2012) - in an 'overlapping zone between culture, politics and money'.

This situation of overlapping spheres can perhaps be best observed when literary products and authors become part of a nation-branding campaign. Following Nadia Kaneva's working definition, nation branding is 'a compendium of discourses and practices aimed at reconstituting nationhood through marketing and branding paradigms' (Kaneva 2011: 118). Melissa Aronczyk's (2013: 16-17) definition is helpful as well, because it stresses the importance of the overlap or 'interpenetration': 'Nation branding can be provisionally defined as the result of the interpenetration of commercial and public sector interests to communicate national priorities among domestic and international populations'. According to Aronczyk, 
this branding process can be used to pursue a range of different purposes. Firstly, it can be 'a conscious strategy of capital (re)generation, combining public and private sector resources to generate fiscal advantage'. Secondly, it can be a diplomatic tool, by conveying 'an image of legitimacy and authority in diplomatic arenas'. Thirdly, national leaders might want to generate 'positive foreign public opinion that will "boomerang" back home', leading to domestic feelings of patriotism. All in all, nation branding could be seen as a positively connotated form of 'soft power', both for the home country and for the outside world. This is why there is a lively scholarly debate going on about the differences between nation branding and public diplomacy: one could argue that nation-branding activities nowadays have at least some diplomatic functions. ${ }^{3}$

Emphasizing the cultural uniqueness of a nation is one of the prime instruments in a nation-branding process. This can serve important political purposes, as was quite clear when Catalonia, an autonomous region within Spain that has been struggling for years to gain a greater degree of selfgovernment, was invited as a guest of honour at the Frankfurt Book Fair 2007. The Catalan organization used the fair to position Catalonia as a unique brand within the global marketplace. ${ }^{4}$ The Netherlands, in contrast, did not have a similarly contested political status when the country was invited as the guest of honour at the Beijing Book Fair 2011. This raises the question as to what aims the DFL and the Dutch Ministry of Culture had in mind when they decided to participate in the fair in such a prominent capacity.

\section{Open Landscape - Open Book: 'Holland' as a Brand}

To answer this question, it is helpful to first focus on the Dutch cultural policy over the period 2010-2011, when Halbe Zijlstra was Undersecretary for Education, Culture and Science in Prime Minister Mark Rutte's first cabinet (2010-2012), a coalition between the conservative-liberal VVD and the Christian-democratic CDA, with support of the right-wing populist PVV. Even before the cabinet had been formally installed on 14 October 2010, it had become clear that the new government planned to implement major cuts in the total budget for national subsidies for the cultural sector, reducing the funds by approximately 25 per cent, from $€ 900$ million to $€ 700$

3 Szondi. Some critical scholars regard nation branding as a type of 'commercial nationalism': see Volcic and Andrejevic.

4 Woolard. 
million a year. Soon after Zijlstra had been installed as Undersecretary, he became the embodiment of the 'cultural erosion'5 thousands of protesters feared would come to dominate the arts in the Netherlands. Large-scale demonstrations were held in November 2010 and June 2011, but generally to no avail: over the next few years, Zijlstra implemented most of the planned financial measures.

But Zijlstra also went beyond the purely fiscal, edging into the rhetorical and ideological to legitimize the government's actions. In his memorandum More Than Quality: A New Perspective on Cultural Policy (Meer dan kwaliteit:Een nieuwe visie op cultuurbeleid), presented in early June 2011, the Undersecretary outlined a cultural policy that was to be much more instrumentalist than before. This document explicitly not only stated that the budget cuts were necessary to meet the broader policy objective of cutting public expenditure, but that they had a symbolic function too:

The government acts too much as a financier, and in the current allocation of grants, not enough attention is paid to audiences and to entrepreneurship. The cabinet wants cultural institutions and artists to become more entrepreneurial and to realize a larger part of their income themselves. Cultural institutions need to become less dependent on the government in order to be more flexible and robust. That is why the cabinet is cutting spending on culture. ${ }^{6}$ (Zijlstra 2011a: 2 )

Although the DFL was confronted with fewer direct budget cuts than other Dutch art funds, the new policies did directly affect the literary landscape as well. Zijlstra (2011a: 28) asked the DFL to focus less on personal project grants for authors and more on digital innovation and on advancing translations. This fitted better with the policy's general aim of stimulating the international circulation of Dutch cultural goods, with 'economic interests' being the main driver (5). Among the new priorities of this international cultural policy were enhancing cultural exchange with emerging markets (such as the BRIC countries - Brazil, Russia, India, and China), and employing

5 See, for instance, Van Klink 2010; Van der Ploeg and Dommering 2011.

6 'De overheid treedt te veel op als financier en bij de verlening van subsidies is nu te weinig aandacht voor publiek en ondernemerschap. Het kabinet wil dat culturele instellingen en kunstenaars ondernemender worden en een groter deel van hun inkomsten zelf verwerven. Culturele instellingen moeten minder afhankelijk worden van de overheid en daardoor flexibeler en krachtiger worden. Daarom bezuinigt het kabinet op cultuur.' 
cultural diplomacy "[to open] doors in international politics [and contribute] to a positive image of the Netherlands' (6). ${ }^{7}$

The Beijing Book Fair 2011 was one of the first opportunities for these ambitions to bear any fruit. The guest of honour theme the DFL had landed on was 'Open Landscape - Open Book', a theme that was not a completely novel invention: in 1993, when the Netherlands and Flanders had been guests of honour at the Frankfurt Book Fair, their joint title had been 'Flandern und die Niederlande: weltoffen' (Flanders and the Netherlands: open to the world) (Van Voorst 2016: 22). 'Open Landscape - Open Book' has a broad array of connotations: it literally points to the openness and flatness of the Dutch landscape - one of the country's touristic unique selling points - while at the same time connecting this to the act of reading a book. ${ }^{8}$ Openness could here also be interpreted more broadly, as a general quality of the Netherlands and the people who live there. If the most prevalent stereotypes are to be believed, the Dutch are exceptionally direct and straightforward; ${ }^{9}$ Dutch society is supposedly tolerant and open to all kinds of people, $;^{10}$ and the Dutch economy is considered open as well, being heavily dependent on exports. 'Open Landscape - Open Book' cleverly merges all these assumptions and connotations.

It is interesting to see how seamlessly this framing aligns with the 'official' Dutch national brand that was beginning to take shape in 2010-2011. ${ }^{11}$ Since then, a distinguished 'Holland' brand has been developed, characterized by a logo featuring an orange tulip and propagated by tourist agency NBTC Holland Branding, the governmental portal Holland Trade and Invest, and Creative Holland, an initiative of the Dutch creative industries supported by the Ministry of Education, Culture and Science. ${ }^{12}$ The assumed openness of the Dutch economy, culture, people, and landscape are some of the central

7 On translated literature as cultural diplomacy, see von Flotow 2007.

8 For the Dutch pavilion, Ira Koers and Roelof Mulder (Bureau Ira Koers) created a design defined by 'low-lying landscape walls that signified the low lying dykes which are such an important characteristic of the Dutch landscape' ('Dutch pavilion').

9 To name just two of the recent popular articles about this topic: Daveney 2015 and Mecking 2018.

10 Dzodan discusses and deconstructs these stereotypes.

11 On 13 September 2011, the Dutch government published its memorandum Naar de top. Het bedrijvenbeleid in actie(s) (To the Top: Business Policy in Action(s)), in which investments in 'Holland Branding' were explicitly mentioned, particularly in connection to the 'creative industries' and the 'creative sector' in general (Naar de top 36 ). For Dutch nation branding, see also Hospers 2015 .

12 One of the earliest attempts to formulate this Dutch national brand is Duijvestijn, Van Ham, Van Kralingen, Van Bekkum, Melissen, and Olins 2004. 
features of this brand. ${ }^{13}$ The 'Holland Brand Story' presents the idea of open-mindedness as the 'core of Holland's brand DNA':

Holland is characterized by an open mind that welcomes the unknown and approaches challenges in a creative way. Unafraid, Holland grabs opportunities with both hands and often veers left where others would go right. An open mind leads to free thinking: Holland thinks only you can decide what's right for you. In fact, Holland's curtains are always open, simply because she has nothing to hide. Holland accepts and welcomes whoever you are and whatever you think. This makes Holland a melting pot of cultures, opinions, and views, all in a setting that is just as extraordinary and colourful. ('Holland brand story')

Cultural institutions have not been left untouched by such branding campaigns. The NBTC website presents tourists and potential business partners with several Dutch 'storylines', many of which are directly linked to cultural institutions such as museums and heritage sites: 'Mondrian to Dutch Design', 'Vincent van Gogh', 'Castles \& Country Houses', 'The Golden Age', and so on ('Storylines'). Literary policy, however, was not directly integrated into this campaign: whereas the visual arts are among the most prominent international branding instruments for the Netherlands, Dutch literature is largely unknown on the world stage. Still, there is a striking similarity between NBTC's Holland Branding rhetoric and the speech with which Halbe Zijlstra opened the Beijing Book Fair on 31 August 2011:

[The Dutch pavilion] sets itself apart through its open, inviting character that is in keeping with the openness of Dutch society; a society which has for centuries been characterized by transparency, hospitality, tolerance for the views of others, freedom of speech, and a culture of freedom of the press.

In this way, the pavilion functions as an outpost of the Netherlands, as a true free port. ${ }^{14}$ (Zijlstra 2011b)

With this last sentence, his speech took a mercantile turn, with was made explicit later on: 'This government desires to allocate a larger role to the interview on 30 August 2011, Zijlstra again emphasized the economic importance of the fair: Anon. 30 August 2011. 
economic importance of cultural policy. That is one reason why we are so happy about our ties with China, an emerging economic power with a strong cultural tradition'. However, it was not exclusively economics that Zijlstra hinted at. By mentioning 'freedom of speech and a culture of freedom of the press', he also alluded to a more political interpretation of the slogan 'Open Landscape - Open Book'. This is a subtle but clear reference to the substantial press and literature censorship in China ( $\mathrm{Ng} \mathrm{2015}$; Sun 2015).

By alluding to this interpretation, the DFL and the Ministry responded to the wishes of parties who were concerned about Dutch writers and organizations participating in a fair in a country where the freedoms of press and literature are far from respected. The Dutch division of Amnesty International arguably most visibly took this stand, but they were not the only one: the Christian opposition party ChristenUnie (CU) questioned the Minister for Foreign Affairs on Chinese censorship measures in parliament on 2 September 2011 (Voordewind 2011).

Amnesty made 'Support the persecuted writers in China' into one of its core campaigns of 2011. The NGO collected almost 105,000 signatures under a petition for the Chinese authorities, pleading for the release of writers Liu Xiaobo, Nurmemet Yasin, and Yang Tongyang; it called on the Dutch government to openly protest the lack of freedom of speech in China; it informed the Dutch audience about the human rights situation in China, for example at the music festivals Lowlands and Pinkpop; and it tried to inspire Dutch writers to show solidarity with their Chinese colleagues (Anon. 2011: 13-14).

It was this last part of the campaign that caused such a stir in the Dutch literary world in August and September 2011. Authors suddenly found themselves in the midst of a discussion that brought an array of difficult questions to the fore: was this fair merely meant for doing business, or did it primarily have a diplomatic, political aim? What was needed: nation branding or humanitarian action? And perhaps most importantly: would Dutch writers even have the opportunity to maintain an independent position?

\section{The Debate in August and September 2011}

It took quite a while for these questions to really percolate into public consciousness. Amnesty International tried several times to start a large national debate about the ills of Chinese censorship, but they initially had little success. In May 2011, the NRC Handelsblad newspaper reported that explicit sex scenes in the Chinese translation of Love Life, a novel by Dutch 
bestselling author Kluun, ${ }^{15}$ had been censored. Sinologist Daan Bronkhorst had discovered this during a research project on Chinese censorship that had been initiated by Amnesty (Kist 2011). ${ }^{16}$ However, the findings did not cause the broad public discussion Amnesty was evidently hoping for, and the Dutch delegation of authors did not change their plans. Amnesty also reprimanded the arts organization Den Haag Onder de Hemel for not exhibiting the artwork The Empty Chair by Maarten Baas during a visit of the Chinese ambassador on 6 June. This work was made as a reference to the Nobel Prize-winning dissident Liu Xiaobo, whose chair had stood empty during the ceremony because he was imprisoned in China (Nazarski 2011). Again, Amnesty's efforts to drum up publicity and awareness had little effect.

After its two unsuccessful attempts to capture the public's attention, Amnesty finally succeeded in starting a censorship debate on 29 August, one day before the fair's opening. The NGO announced that 120 Dutch novelists, poets, translators, and editors had signed a declaration of solidarity with repressed Chinese authors. Among the signatories were the delegated authors Bernlef ${ }^{17}$ and Ramsey Nasr. In the same press release, Amnesty asked the members of the delegation to wear a brooch that depicted The Empty Chair (Anon. 29 August 2011). The NGO appeared to expect that Dutch authors intended to openly protest the Chinese government both at home and at the fair.

However, on that same day Bernlef declared in a public radio interview that he did not have much faith in the political effectiveness of their trip, exactly because of Amnesty's efforts to raise awareness of the human rights situation in the PRC: 'Partly due to Amnesty International's meddling in the Netherlands, there has been so much publicity that anyone in China who was not alarmed yet, now surely is' (Wielaert 2011). ${ }^{18}$ In the following days, there was a lot more criticism of Amnesty's 'meddling': not only Bernlef, but all authors taking part in the delegation declared they would not wear the brooch, which they considered 'childish' and 'nonsense' (Moleman $31 \mathrm{Au}-$ gust 2011; Garschagen 31 August 2011). At the same time, many authors and opinion makers back in the Netherlands regarded this refusal as cowardly and non-solidary behaviour (Holman 2011; Ephimenco 2011). The brooch

\footnotetext{
15 Pseudonym of Dutch author Raymond van de Klundert.

16 Most newspaper sources cited in this paper have been consulted using the digital newspaper database LexisNexis. Since this database does not systematically mention page numbers, all newspaper sources in this paper lack page numbers.

17 Pseudonym of Dutch autor Hendrik Jan Marsman.

18 'Mede door de bemoeienissen van Amnesty International in Nederland is er zoveel ruchtbaarheid aan gegeven dat als ze in China nog niet wakker waren dat nu wel zijn.'
} 
became a symbol for a larger question: should the authors of the Dutch delegation show their solidarity with repressed Chinese authors or not? ${ }^{19}$

In the weeks after 29 August, dozens of newspaper, television, radio, and weblog items were published in which the Dutch participation was discussed as a literary-political issue. In many of these items, authors took a leading role. The concept of openness, with its connotations of freedom and autonomy, proved to be the central 'discursive node' in the debate. Interestingly, all parties in the discussion, no matter their viewpoint, adhered to the general framing of the Dutch participation in the fair: the suggestion that the Netherlands are characterized by an open-mindedness not common to the PRC. It is thus interesting to note that the framing itself was hardly questioned; one could wonder whether artists should be expected to simply accept and participate in such a nation-branding story.

Because Amnesty had not presented the declaration of solidarity until 29 August, the positioning of Bernlef and Nasr looked inconsistent: both had first signed the declaration and had then defended the Dutch participation in the fair or even openly criticized Amnesty. In fact, they had merely changed their minds over the course of several months: on 31 August, Bernlef declared that he had signed the declaration two and a half months earlier (Garschagen 31 August 2011). Soon after arriving in China, not only Bernlef and Nasr but also the DFL's general manager Henk Pröpper had changed their minds about the objectives of the trip. Pröpper's self-assured declaration in May ('We will invite critical writers and we will meet dissidents, even if it is in the back of a teahouse') (De Fauwe 2011) had changed into a much more relativist positioning on 1 September: 'We rightly consider censorship and freedom of speech very important in the Netherlands, but these are at risk of becoming hollow concepts if we keep using them to contrast our own culture with the Chinese '(Tanis 1 September 2011). ${ }^{20}$ This turn to a more cautious approach was perhaps not unwise: on 2 May, journalist and China expert Petra Quaedvlieg had already suggested that it would be crucial to mention the Chinese repression only indirectly. 'Taking an aggressive stance will have an adverse effect. But by not saying anything at all, imprisoned

19 In an evaluation, Amnesty presented this as the most important lesson learned: the NGO had tried to start an open and massive authors protest against Chinese censorship, but this made the delegation feel highly uncomfortable ('Amnesty International Nederland Jaarverslag 2011' 15).

20 'We nodigen daar kritische schrijvers uit en we zullen dissidenten gaan spreken, al is het achterin een theehuis'; 'Censuur en vrijheid van meningsuiting vinden we in Nederland terecht heel belangrijk, maar het dreigen lege begrippen te worden als dat steeds het uithangbord is om je eigen cultuur tegenover de Chinese te zetten.' 
Chinese authors will feel abandoned by their Western colleagues'(Quaedvlieg 2011). ${ }^{21}$ The question was what could still be achieved now that all active participants (writers, administrators, and policymakers alike) appeared to consider an open conversation about human rights to be impossible.

During the fair, several authors sought to answer this question. Kader Abdolah, an Iranian-born writer who has lived in the Netherlands since 1988 , was the most outspoken in exploring the limits of what was possible. He declared that he first intended to give a lecture with the title 'Holland for Beginners', but he decided to switch to a more personal story about individual freedom. After his arrival in the Netherlands, he said, 'I suddenly felt free, as an astronaut. [...] When I wrote in freedom, I became myself. It is important for everyone, everywhere, to be themselves' (Tanis 3 September 2011). ${ }^{22}$ In a conversation with a Tibetan author, he also tried to raise the question of freedom (Moleman 5 September 2011). Other authors followed suit, albeit less explicitly. Adriaan van Dis, for example, spoke of an earlier visit to China in the 1980 s, which then appeared to be a country 'created by "prison guards"'. But he decided to love China anyway. He saw couples kissing in the street - in other words, he decided to praise the human, non-repressive aspects of the country (Moleman 31 August 2011). ${ }^{23}$ Margriet de Moor surprisingly described the openness of the Netherlands as a danger: because the country is so open to the sea, it would be vulnerable to natural threats, de Moor suggested (Moleman 31 August 2011). It is unclear what this geographical feature had to do with either the literary or the political message of the Dutch delegation to the PRC, or how it could be reconciled with the officially-sanctioned positive message about Dutch open(-minded)ness.

In many of the contributions by writers who attended the fair, a contrast is implied between the closed and repressive nature of the Chinese state and the frankness of the Chinese people. In a series of reactions, the DFL published after the fair, the openness of Chinese conversation partners was mentioned remarkably often. Literary non-fiction author Geert Mak reports experiencing 'during all meetings [...] a great openness', children's book authors Ingrid and Dieter Schubert praise the 'unprecedented openness' of their conversations, and several publishers mention the Chinese 'frankness'

21 'Door het mes op tafel te gooien bereik je een averechts effect. Maar door niets te zeggen, zullen Chinese schrijvers die vastzitten zich door hun westerse collega's in de steek gelaten voelen.' See also Benali 2011.

22 'Opeens voelde ik me vrij, als een astronaut. [...] Toen ik in vrijheid schreef, werd ik mezelf. Het is voor iedereen, overal, belangrijk zichzelf te zijn.'

23 'geschapen door "gevangenisbewaarders".' 
(DFL 2011). At the same time, it was often apparent that any openness on the political and institutional level was wholly illusory. Not only was the book fair literally closed off during a visit of party official Li Chuangchun - a 'security measure' that served as an unintentional, ironical commentary on the theme 'Open Landscape - Open Book' - but open conversations were also practically impossible. Several of the Chinese authors the DFL had invited were not able to attend because they were under house arrest (Moleman 2 September 2011; Garschagen 2 September 2011).

Of course, this discrepancy did not pass unnoticed by the delegation. During the fair, delegation members often emphasized that they had to operate 'in the margins', 'out of the public eye' (Moleman 2 September 2011; Enquist, Perez and Pröpper 2011). ${ }^{24}$ This led to a paradoxical discourse in authors' reflections on their conversations with Chinese authors and publishers: openness was seen as a quality which could only function in private conversations and literary allusions. Van Dis for instance said: 'In the shadows of the fair, I spoke in all openness with several writers and scholars who were very outspoken' (DFL 2011, emphasis added ). According to Pröpper (2011), Chinese writers saw the Dutch pavilion as a 'port of refuge' in which they nevertheless spoke about their country very carefully, 'in literary terms'. ${ }^{25}$ Ramsey Nasr (8 September 2011) represented China as a 'closed country', in which the Dutch delegation entered 'as a virus of curiosity'. ${ }^{26}$ All delegates appeared to feel a tension between openness and the lack thereof, which is closely related to their choice not the wear the Amnesty brooch. On the one hand, openness seemed to be unfeasible; on the other hand, conversation partners were praised constantly for their frankness. This suggests that the chosen frame for this fair, openness as the distinctive feature of Dutch society and culture, was reproduced by the Dutch authors when confronted with the fairly different Chinese cultural and institutional context. Chinese authors were integrated into this frame: they were praised because they proved to be open and frank as well.

It is striking that the delegation reproduced this official branding so easily, and that they implicitly considered it superior to other models of considering intercultural conversations, as is attested to by their constant framing of all encounters in the terms that were established by the DFL and the Ministry. Within the debate held in the Dutch press, the authors had generally criticized the 'typically Dutch' tendency to entertain feelings 
of moral superiority. According to members of the delegation, Dutch commentators were quick to 'wag a finger' (Tanis 1 September 2011; Garschagen 31 August 2011; Koch 2011) at other nations: Dutch people, it was said, all too often assumed the right 'to teach other people lessons' (Anon. 5 September 2011). ${ }^{27}$ Commentators also recalled the 1970 s and the 1980 s, when Dutch intellectuals protested against the repressive regimes of Argentina and against South African apartheid (De Fauwe 2011; Koch 2011; Truijens 2011). ${ }^{28}$ This led to cultural and economic boycotts, which were particularly drastic in the case of South Africa. According to author Herman Koch and to Henk Pröpper, these policies had had many negative consequences, both for the Dutch and the South African cultural climate. Not only should every human being feel free to act, but particularly for autonomous authors joint actions would be inappropriate: 'We are here as a group of writers, but also as free individuals who should be able to talk freely to everyone, without our conversation partners being frightened or embarrassed by an action group's brooch', Koch said (FDL 2011). He did not appear to notice that precisely this freedom to speak was not self-evident for the Chinese writers, which was what the entire debate and controversy were actually about in the first place.

Perhaps unsurprisingly, every single author that had joined the delegation remained silent about the economic motives behind the fair. Rather, the fair was presented as an opportunity to look, smell, feel, and experience' (Garschagen 31 August 2011) or to 'start a conversation' (Tanis 1 September 2011). ${ }^{29}$ Bernlef was the only writer to mention an economic driver, in an interview preceding the fair: 'If repression intensifies, there might be a moment when one says: are we only going there to the greater honour and glory of the Dutch economy, with culture as a lubricant? But as of yet there has been no reason to say: we're not going to go' (Anon. 17 May 2011). $3^{\circ}$ Some authors and journalists who were not part of the delegation ridiculed this disinclination to broach the matter of economic capital..$^{31}$ This discrepancy can be interpreted using Bourdieu's terminology: whereas the delegation

27 'Opgeheven vingertje', '[E]en lesje leren.'

28 Historical analyses of earlier cultural boycots include: Anon. 2 September 2011; van Velzen 2011.

29 'kijken, ruiken, voelen en indrukken opdoen' (Garschagen, 'Protesteren is dom'); ‘[...] het gesprek aan te gaan.'

$3^{0}$ 'Als de repressie zich verhevigt, kan er een punt komen waarop je zegt: gaan we er alleen maar heen ter meerdere eer en glorie van de Nederlandse economie, met cultuur als glijmiddel? Maar voorlopig is er geen reden om te zeggen: we gaan niet.'

31 See for instance Möring 2011. 
maintained the illusio that theirs was no more than a 'literary field trip', outsiders time and again shattered this illusio by emphasizing that this was a 'culturally-furnished trade mission' (Anon. 31 August 2011). ${ }^{32}$

Two general tendencies can be discerned in the positioning of criticasters who did not go to the fair. The first accepts the economic rationale of the 'trade mission', but reprimands the delegation for not being honest about it - and therefore, implicitly, for not being 'open' about it. Chrétien Breukers, for one, often presented this point of view in a series of blog articles published during the fair. The fact that the Netherlands used the human rights discussion as a 'stalking horse' for trade was reprehensible, but he considered this only natural for a Dutch delegation. He cynically cites a slogan used by the Dutch East India Company - the first Dutch multinational, which became a huge global player in the colonial trade of the seventeenth century - and which according to Breukers was still typical for 'the' Dutch: 'Nothing ventured, nothing gained'. From this perspective, the human rights advocacy was only meant to function as an 'investment' to attain what the Dutch were really after: huge profits. Breukers wrote: 'Every attempt to frame this as "cultural exchange" or an "attempt to transport our principles to China" is not only insincere but even quite hypocritical. Let us value our authors for what they are: pioneers in a new market' (Breukers 30 August 2011).33

Other commentators, such as Theodor Holman (2011), Sylvain Ephimenco (2011), and Joris van Casteren (2011), also blamed the delegation first and foremost for a lack of sincerity and courage. They use the same cynical tone as Breukers. Arnon Grunberg (2011), pointing at the entrepreneurial direction in Dutch cultural policy since Halbe Zijlstra, wrote ironically: 'The shopkeeper mentality is nowadays the pinnacle that writers and artists can achieve, after all, and I readily adjust myself to this mentality'. ${ }^{34}$ Grunberg mocked this 'shopkeeper mentality' but did not reject it. Several other commentators even suggested that a lack of sincerity made the Dutch delegation look like a Chinese one. Stephan Sanders (2011) for instance referred to the univocal moral positioning of the delegation: 'The Dutch group has [...] undergone a simultaneous reality check. Suddenly, these twenty individual writers have been transformed into a single Dutch delegation, which collectively

32 'cultureel aangeklede handelsmissie.'

33 'Iedere poging om dit als "culturele uitwisseling" of een "poging om onze waarden naar China te transporteren" in te kleden, is niet alleen onwaarachtig, maar zelfs lichtelijk hypocriet. Laten wij de schrijvers die in Peking zijn daarom eren als wat zij zijn: pioniers op een nieuwe markt.'

34 'De middenstandsmentaliteit geldt tegenwoordig immers als het hoogst haalbare voor schrijvers en kunstenaars en ik pas mij gaarne aan.' 
opposes the swelling critique from the home front. From a distance, one should observe that this group sports a suspiciously larger number of Chinese features'. ${ }^{35}$ 'Typically Dutch' qualities such as candour and individuality are here contrasted with 'Chinese' groupthink and artifice.

The second tendency was more fundamental: some commentators argued that human rights should always take precedence over trading motives. Multiple articles mention the opposing positions of 'the clergyman' and 'the merchant', two symbolic figures allegedly typical for Dutch international relations. While the Netherlands acted as a 'clergyman' against repressive regimes in the 1970s and 1980s, the country now, according to these critics, all too pragmatically positioned itself as a 'merchant'. This is the frame adapted by, for instance, the author Marcel Möring (2011). ${ }^{36}$ The tone of the argument was (again) heavy with irony and sarcasm: the clergyman and the merchant are figures with negative connotations in the Dutch capitalist-Calvinist past, and both are associated with puritanical and at the same time unscrupulous condescension. Only a few letters to the editor by the general public referred more principally to the importance of human rights, making an unambiguous plea for a form of cultural diplomacy that emphasizes human rights and the freedom of speech. Even these letters were not wholly free of irony: 'Economic interests are more important than the freedom of those who fight for democracy [...]. Pennies precede freedom. A terrific statement on the second page of your newspaper. Congratulations' (Rudolph 2011).37 But unlike most contributions by literary insiders, these letters did not start from the sarcastic assumption that 'Dutch economic pragmatism' would be all-determining.

\section{Conclusion}

In many regards, this sarcasm made the debate over the 2011 Beijing Book Fair little more than a rhetorical exchange, instead of the fundamental discussion about the new course of Dutch (international) cultural policy it could have been. In the late summer of 2011, there were reasons to have this discussion:

35 'De Nederlandse groep krijgt gelijktijdig een injectie van wereldwijsheid toegediend. Plotseling zijn die twintig individuele schrijvers veranderd in één Nederlandse delegatie, die zich gezamenlijk verzet tegen de aanzwellende kritiek van het thuisfront. Van een afstand zou je kunnen vaststellen dat die groep verdacht veel Chinese trekken heeft gekregen.'

36 See also Garschagen 31 August 2011; Anon. 2 September 2011; Breukers 1 September 2011.

37 'De economische belangen zijn belangrijker dan de vrijheid van vechters voor de democratie [...]. Centjes zijn belangrijker dan vrijheid. Een geweldig statement op uw pagina 2. Gefeliciteerd.' 
two large demonstrations had tried to counter the economic rationale of Undersecretary Zijlstra's new cultural policy in 2010 and 2011. The fact that the book fair was framed as a nation-branding campaign ('Holland: the OpenMinded Country') would all the more give cause for fundamental critique.

Criticasters who did not participate in the fair certainly expressed this critique, but they did so only in vitriolic, cynical ways that were not constructive or truly critical. They either assumed that the economic nature of the mission was not the problem, but that the delegation had simply not been 'open enough' about these aims; or they used metaphors (the clergyman and the merchant) that suggested that every Dutch diplomatic mission could only result in a negative extreme: pedantic moralism or blind greed.

The literary delegation appeared to feel unable to question the aims of the Dutch participation in this fair. The lack of openness about the commercial rationale of the fair, particularly by the authors, is easy to explain: many people in the literary field are still averse to discussing economic capital. What is surprising, though, is that the authors so easily adapted to the frame of openness introduced by the DFL and then confirmed by Zijlstra. Explicitly and implicitly, openness was interpreted as a praiseworthy feature not to be questioned or operationalized - a feature that Chinese authors had to conform to as well. There was no open, critical debate about cultural norms and the limits of nation branding, despite authors' assurances that they wanted to act as autonomous intellectuals.

Even Amnesty International, the most fundamental protector of human rights in this debate, adopted the metaphor of the Netherlands as the quintessential 'open(-minded) country'. In a video campaign the NGO launched before the fair, six Dutch authors read a Chinese poem, emphasizing that they had written their oeuvres in freedom and that they were worried about the fate of their repressed colleagues in China. What is most telling about the campaign is the environment most of the videos are set in: the authors read the works in 'typically Dutch' open polder landscapes..$^{3}$ Again, this connection between an 'open landscape' and an 'open publication culture' was invoked; again an essentialist view on the alleged Dutch openness was being brought forward.

This case study clearly shows the political complexities of branding, both on a diplomatic and on a literary level. It shows how national stereotypes can penetrate the discourses in both these fields, demonstrating how porous the borders between (the aims and discourses of) literature, state, and market can be. At the same time, the paradoxical status of literary branding becomes fully visible. Most authors nowadays seem to accept, albeit hesitantly or 
with a heavy dose of sarcasm, that on the international stage, literature requires active branding. However, the taboo on explicit reflections on how this branding should take place and how it should be combined with humanitarian considerations makes the debate rather cynical. In a time when the state and the market are deeply linked when it comes to cultural policies, critical debates about what should take precedence - cultural values, humanitarian values, or money - become more urgent than ever.

\section{References}

[Anon.] 17 May 2011. 'Schrijvers 'niet als diplomaten' naar China'. NRC Handelsblad. [Anon.] 29 August 2011. 'Schrijvers in actie tegen de Nederlandse censuur'. NRC Handelsblad.

[Anon.]. 30 August 2011. 'Staatssecretaris Halbe Zijlstra opent boekenbeurs in China'. Goedemorgen Nederland, KRO.

[Anon.] 31 August 2011. 'Op de boekenbeurs in Peking'. NRC Handelsblad.

[Anon] 2 September 2011. 'De protestspeld bleef in de koffer'. Nederlands Dagblad. [Anon.] 5 September 2011. 'Schrijvers terug uit China'. De wereld draait door, VARA. [Anon.] 14 September 2011. Tommy Wiering a zet zich in voor Chinese dichters. Amnesty International Nederland. https://www.youtube.com/watch?v=lPfS4vQaHbA [accessed on 6 July 2018].

[Anon.] 'Storylines'. NBTC Holland Marketing. https://www.nbtc.nl/en/homepage/ collaboration/storylines.htm [accessed on 20 December 2018].

[Anon.] 'Amnesty International Nederland Jaarverslag 2011'. Amnesty International. https://www.amnesty.nl/content/uploads/2017/04/Amnesty-InternationalNederland-Jaarverslag-2011.pdf?x23787 [accessed on 6 July 2018].

[Anon.] 'Dutch Pavilion at the Beijing International Book Fair'. Hypsos. http://www. hypsos.com/en-us/cases/exhibition/dutch-pavilion-at-the-beijing-internationalbook-fair.aspx [accessed on 6 July 2018].

[Anon.] 'Holland Brand Story'. NBTC Holland Marketing. https://www.holland.com/ global/brandtoolkit/holland-brand.htm [accessed on 6 July 2018].

Melissa Aronczyk. 2013. Branding the Nation: The Global Business of National Identity. Oxford: Oxford University Press.

Sander Bax. 2016. 'De publieke intellectueel als literair populist: Het publieke schrijverschap van Leon de Winter'. Nederlandse letterkunde 21.2: 97-129.

Eleonora Belfiore. 2012. "Defensive Instrumentalism" and the Legacy of New Labour's Cultural Policies'. Cultural Trends 21.2: 103-111.

Abdelkader Benali. 2011. 'Verstandig om dat Amnestyspeldje te weigeren'. NRC Handelsblad, 5 September. 
Pierre Bourdieu. 1983. 'The Field of Cultural Production, or: The Economic World Reversed'. Poetics 12.4-5: 311-356.

Pierre Bourdieu. 2008. 'A Conservative Revolution in Publishing'. Translation Studies 1.2: 123-153.

Chrétien Breukers. 30 August 2011. 'China, tempel van wijsheid en cultuur (1)'. Literair Weblog De Contrabas. http://decontrabas.typepad.com/de_contrabas/2011/o8/ china-tempel-van-wijsheid-en-cultuur.html [accessed 6 July 2018].

Chrétien Breukers. 1 September 2011. 'China, tempel van wijsheid en cultuur (2)'. Literair Weblog De Contrabas. http://decontrabas.typepad.com/de_contrabas/2011/og/china-tempel-van-wijsheid-en-cultuur2.html [accessed 6 July 2018]. Chrétien Breukers. 9 September 2010 .'Het getal van het beest, met extra sambal + update'. Literair Weblog De Contrabas. http://decontrabas.typepad.com/ de_contrabas/2010/og/ramsey-nasr-doe-er-wat-aan.html [accessed 6 July 2018].

Sarah Brouillette and Christopher Doody. 2015. 'The Literary as a Cultural Industry'. In Kate Oakly and Justin O'Connor (eds.), The Routledge Companion to the Cultural Industries, pp. 99-108. London: Routledge.

Jim Collins. 2010. Bring on the Books for Everybody: How Literary Culture Became Popular Culture. Durham, NC: Duke University Press.

Nick Couldry. 2003. 'Media Meta-capital: Extending the Range of Bourdieu's Field Theory'. Theory and Society 32.5-6: 653-677.

Loes de Fauwe. 2011. 'Literaire wereld gaat toch naar Peking'. Het Parool, 28 May. Beulah Devaney. 2015. 'Are the Dutch Direct of Just Rude?' The Telegraph, 19 March. Olivier Driessens. 2013. 'Celebrity Capital: Redefining Celebrity Using Field Theory'. Theory and society 42.5:543-560.

H.H Duijvesteijn, P. van Ham, R. van Kralingen, T. van Bekkum, J. Melissen, and J. Olins. 2004. Branding NL: Nederland als merk. The Hague: Stichting Maatschappij en Onderneming.

Dutch Foundation for Literature. 6 September 2011. 'Auteurs, illustratoren en uitgevers over hun ervaringen op de Beijing International Book Fair 2011'. Letterenfonds.nl. http://www.letterenfonds.nl/nl/entry/67/beijing-internationalbook-fair-2011-bijzonder-succes [accessed 6 July 2018].

Anna Enquist, Tiziano Perez and Henk Pröpper. 2011. 'Chinese auteurs in stilte benaderd'. NRC Handelsblad, 8 September.

Sylvain Ephimenco. 2011. 'Oprechtheid en moed'. Trouw, 1 September.

Oscar Garschagen. 31 August 2011. 'Protesteren is dom en kortzichtig, want dan gaat de boel potdicht'. NRC Handelsblad.

Oscar Garschagen. 2 September 2011. 'China houdt schrijvers weg van Nederlandse collega's'. NRC Handelsblad.

Clive Gray. 2007. 'Commodification and Instrumentality in Cultural Policy'. International Journal of Cultural Policy 13.2: 203-215. 
Arnon Grunberg. 2011. 'Voetnoot: Middenstandsmentaliteit'. de Volkskrant, 2 September.

Odile Heijnders. 2015. 'De dichter als publieke intellectueel: Ramsey Nasr'. Nederlandse letterkunde 20.3: 291-316.

David Hesmondhalgh, Kate Oakley, David Lee. 2015. Culture, Economy and Politics: The Case of New Labour. Basingstoke: Palgrave Macmillan.

Theodor Holman. 2011. 'Helden'. Het Parool, 1 September.

Gerrit J. Hospers. 2015. 'The Dutch Quest for a Nation Brand'. In Keith Dinnie (ed.), Nation Branding: Concepts, Issues, Practice, pp. 181-184. London: Routledge.

Nadia Kaneva. 2011. 'Nation Branding: Toward an Agenda for Critical Research'. International Journal of Communication 5: 117-141.

Reinier Kist. 2011. 'China censureert roman van Kluun'. NRC Handelsblad, 16 May. Herman Koch. 2011. 'Het Nederlandse vingertje is weer opgeheven: Hollands Dagboek'. NRC Handelsblad, 10 September.

Erika Koehler (ed.). 2017. Holland Compared: Facts and Figures. Netherlands Enterprise Agency.

Olga Mecking. 2018. 'Where the Dutch Directness Comes From'. BBC Travel, 1 February. http://www.bbc.com/travel/story/20180131-where-dutch-directness-comesfrom [accessed 6 July 2018].

Minister of Economic Affairs, et al. [2011]. Naar de top: Het bedrijvenbeleid in actie(s). [The Hague].

Hans Moleman. 31 August 2011. 'Lichte plaagstootjes tegen de censuur'. de Volkskrant.

Hans Moleman. 2 September 2011. 'Chinese schrijvers onder huisarrest door boekenbeurs'. de Volkskrant.

Hans Moleman. 5 September 2011. 'Een ongemakkelijk gesprek in Peking'. de Volkskrant.

Marcel Möring. 2011. 'Die schrijvers zijn net zo hypocriet als Shell'. NRC Handelsblad, 2 September.

Ramsey Nasr. 8 September 2011. 'Rel van Het Speldje, Made in Holland'. de Volkskrant. Ramsey Nasr. 2013. Mi have een droom: Alle vaderlandse gedichten. De Bezige Bij. Eduard Nazarski. 2011. 'Waar is De Lege Stoel?'. Joop, 6 June. https://joop.bnnvara. $\mathrm{nl} /$ opinies/waar-is-de-lege-stoel. Accessed on 6 July 2018.

Lynda Ng. 2015. 'China's Elusive Truths: Censorship, Value and Literature in the Internet Age'. In Nicole Moore (ed.), Censorship and the Limits of the Literary: A Global View, pp. 233-246. London: Bloomsbury.

Henk Pröpper. 2011. 'Als we respect tonen, luisteren Chinezen wel'. de Volkskrant, 3 September.

Petra Quaedvlieg. 2011.Alle Chinese dissidenten zitten in een spagaat'. de Volkskrant, 2 May. 
Herman Rosenberg. 2011. 'Stil protest bij expo Voorhout'. AD/Haagsche Courant, 7 June.

Martin Rudolph. 2011. 'Dus de krant vindt centjes belangrijker dan vrijheid?'. NRC Handelsblad, 1 September.

Stephan Sanders. 2011. 'Je zou kunnen vaststellen dat die groep Nederlandse schrijvers verdacht veel Chinese trekken heeft'. Vrij Nederland, 10 September.

Gisèle Sapiro. 2003. 'The Literary Field Between the State and the Market'. Poetics 31.5-6: $441-464$.

Gyorgy Szondi. 2008. 'Public Diplomacy and Nation Branding: Conceptual Similarities and Differences'. In Virginie Duthoit and Ellen Huijgh (ed.), Discussion Papers in Diplomacy. Netherlands Institute of International Relations 'Clingendael'.

Sofie Sun. 2015. Drugs for the Mind: Censorship in China. Trans. by Cômeng Tang. Eva Tas Foundation.

Remko Tanis. 1 September 2011. 'Nederland gastland op internationale boekenbeurs Peking: “Debat hier links laten liggen zou slecht zijn”'. Brabants Dagblad.

Remko Tanis. 3 September 2011. 'Nederland breekt in Peking een lans voor vrijheid'. Brabants Dagblad.

Aleid Truijens. 2011. 'Culturele boycot maakt niemand gelukkiger'. de Volkskrant, 7 September.

Flavia Tzodan. 2017. 'In the 'Tolerant' Netherlands, Solidarity is for White Women'. The Washington Post, 14 May.

Rick van der Ploeg and Egbert Dommering. 2011. 'Kunstbezuinigingen leiden tot lege zalen en tot jutlandisering'. NRC Handelsblad, 21 June.

Joris van Casteren. 2011. 'Uilskuiken van de week: Bernlaf'. HP/De Tijd, 16 September. Pim van Klink. 2010. 'Kaalslag of keerpunt?'. Het Financieele Dagblad, 16 October. Joost van Velzen. 2011. 'De vrije val van het engagement'. Trouw, 3 September.

Sandra van Voorst. 2016. 'From Frankfurt Book Fair to Frankfurt Book Fair: DutchLanguage Literature in Germany, 1990-2015'. Journal of Dutch Literature 7.2: 20-34. Geir Vestheim. 2012. 'Cultural Policy-making: Negotiations in an Overlapping Zone Between Culture, Politics and Money'. International Journal of Cultural Policy 18.5: 530-544.

Zala Volcic and Mark Andrejevic (eds.). 2016. Commercial Nationalism: Selling the Nation and Nationalizing the Sell. Palgrave MacMillan.

Luise von Flotow. 2007. 'Revealing the 'Soul of Which Nation'? Translated Literature as Cultural Diplomacy'. In Paul St-Pierre and Prafulla C. Kar (eds.), In Translation: Reflections, Refractions, Transformations, pp. 187-200. Amsterdam and Philadelphia: John Benjamins Publishing Company.

Joël Voordewind. 2011. 'Chinese journalisten onder huisarrest: Kamervraag 2011Z16758'. Open kamer, 2 September. https://www.openkamer.org/ kamervraag/2011Z16758/ [accessed 6 July 2018]. 
Jeroen Wielaert. 2011. 'Bernlef sceptisch en hoopvol over boekenmissie naar China'.

Radio 1 journaal, 29 August. http://weblogs.nos.nl/radioijournaal/2011/o8/29/ bernlef-sceptisch-en-hoopvol-over-boekenmissie-naar-china/ [accessed 6 July 2018].

Kathryn A. Woolard. 2016. 'Branding Like a State: Establishing Catalan Singularity

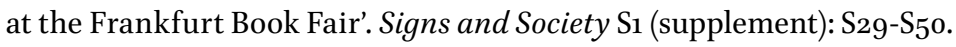

Halbe Zijlstra. 2011a. Meer dan kwaliteit: Een nieuwe visie op cultuurbeleid. Ministerie voor Onderwijs, Cultuur en Wetenschap.

Halbe Zijlstra. 31 August 2011b. 'Opening of the Beijing International Book Fair 2011'. Rijksoverheid. https://rijksoverheid.archiefweb.eu/\#archive [accessed on 6 July 2018].

Halbe Zijlstra. 30 August 2011c. 'Open Landscape - Open Book: Speech Opening Night Beijing International Book Fair’. Rijksoverheid. https://rijksoverheid. archiefweb.eu/\#archive [accessed on 6 July 2018].

\section{About the Author}

Laurens Ham is Assistant Professor in Modern Dutch Literature at Utrecht University, the Netherlands. In 2015, he published Door Prometheus geboeid, which focused on how Dutch writers between 1820-1970 combined an 'autonomous' self-presentation with political critique. Currently, he is working on a cultural history of Dutch literary policy since the 1960 , focusing on the ways in which authors have shaped and influenced the policy climate. 


\title{
Against the Grain
}

\author{
The Das Mag brand and Lize Spit's The Melting (2016) \\ Roel Smeets
}

\begin{abstract}
By contesting what they see as the norms and values of the literary field, 'mavericks' such as Das Mag run the risk of being neglected or excluded. This contribution explores how this self-branding process takes place in the context of Lize Spit's bestselling debut The Melting (2016). Key to the Das Mag brand are anti-conventional, ironic, and democratic rhetorical devices. This chapter examines how Spit conforms to or deviates from this brand, as well as how other actors in the literary field respond to this. This contribution demonstrates how Das Mag's self-proclaimed maverick position does not lead to an expulsion from the literary field but on the contrary sees the Das Mag brand flourishing.
\end{abstract}

Keywords: self-branding, posture analysis, Das Mag, Lize Spit, The Melting

\section{Introduction}

Since its foundation in 2011, Das Mag has rapidly established itself as a brand in the Dutch literary field. Starting out under the header of the crowdfunded literary magazine Das Magazin (2011-2018), ${ }^{1}$ they gradually developed into a diverse business conglomerate, organizing literary festivals, book clubs, and creative writings camps. In 2015, publishing house Das Mag Publishers

1 Crowdfunding is an alternative, quickly growing way of acquiring a starting capital for financing a project. There is no mediation by a third party such as a bank; the public invests directly in the project. In exchange for their financial contribution, investors commonly receive a compensation in proportion to the size of their investment (e.g. the first edition of the journal or a meet and greet with the editors).

Helleke van den Braber, Jeroen Dera, Jos Joosten, and Maarten Steenmeijer (eds), Branding Books Across the Ages: Strategies and Key Concepts in Literary Branding. Amsterdam, Amsterdam University Press 2021 DOI: 10.5117/9789463723916_CH15 
was kickstarted through a second successful crowdfunding campaign. ${ }^{2}$ Although their second published author was relatively unknown to the public, ${ }^{3}$ Lize Spit's debut novel instantly became an international success. Over 250,000 copies of The Melting (2016) were sold in less than three years, it was translated into ten languages, the movie rights were sold, it was shortlisted for the Libris Prize 2017, and Spit received the Bronzen Uil Prize 2017 for best Dutch debut. These achievements, however, are not solely due to the quality of Spit's writing. The prosperity of the Das Mag brand appears to have influenced her success up to a considerable extent.

From the beginning onwards, Das Mag has been presenting itself as an anti-conventional platform for literature, a fresh alternative to the dusty old gatekeepers of the literary field. In 2011, the fundamental idea for literary magazine Das Magazin was presented on crowdfunding platform Voordekunst:

Completely against the economic climate, as Keynes would have wanted it, the launch of a new literary magazine: Das Magazin. We don't care about the government and the crisis, we will sell our magazine ourselves. $[\ldots]$ You shall make this happen. ${ }^{4}$

Three things stand out in this statement: (1) an anti-conventional stance voiced through a do-it-yourself attitude ('we will sell our magazine ourselves'), (2) an ironic undertone ('as Keynes would have wanted it'), and (3) an explicit democratic appeal to the public ('You shall make this happen'). Over the years following their crowdfunding campaign, these anti-conventional, ironic, and democratic rhetorical devices would continue to play a key role in Das Mag's self-representation.

2 Das Mag calls it 'one of the most successful literary crowdfunding campaigns worldwide', as 3000 so called 'co-founders' together raised almost $€ 200,000$. (Donk 2016: last accessed 11 April 2018). On top of the money raised by these co-founders, an unknown amount was invested by famous Dutch shareholders such as author Arnon Grunberg and TV personalities Arie Boomsma and Arjen Lubach (Jansen).

3 The first three books published by Das Mag are (in chronological order) Maartje Wortel's Er moet iets gebeuren (2015), Lize Spit's Het smelt (2016), and Walter van den Berg's Schuld (2016). 4 'Volledig tegen de conjunctuur in, zoals Keynes het zou willen, de oprichting van een nieuw literair tijdschrift: Das Magazin. Het kabinet en de crisis kunnen ons wat, wij verkopen ons tijdschrift zelf wel. Het nulnummer, met als thema 'De Mislukking', verschijnt in een gelimiteerde oplage van $25^{\circ}$ exemplaren en is exclusief verkrijgbaar via voordekunst. Jan Jaap van der Wal, Pepijn 'Faberyayo' Lanen, Daan Heerma van Voss ea. verzorgen de inhoud. Studio Vruchtvlees zorgt dat het er goed uitziet. Jij zorgt dat het wordt gedrukt' https://www.voordekunst.nl/ projecten/69-das-magazin [accessed 22 March 2018]. All Dutch has been translated into English by the author of this article. 
Three years after the launch of the magazine, the first academic study on Das Mag was published in a special issue of Spiegel der Letteren on Dutch literary fan culture (2014). In their contribution, Thomas Vaessens and Lara Delissen argue that Das Mag creates an online literary community by actively responding to the fan culture of present-day readers. Next to Das Mag's direct appeal to the crowd, the authors highlight its anti-conventional position in the literary field. Since the nineteenth century, literary magazines used to represent specific, opposing visions on the content of literature. Das Magazin broke with this convention; their aim was to find a potential market gap and not to represent an innovative literary-artistic vision (Vaessens and Delissen 2014: 404).

Das Mag has repeatedly been framed by journalists as a platform of and for young people. Founders Toine Donk and Daniël van der Meer said that it was 'a shame that we are still viewed as young and hip after seven years' (De Veen 2018). ${ }^{5}$ One of the reasons why Das Mag continues to be framed like this is that they operate in relatively divergent ways. This pertains to Howard Becker's notion of 'mavericks': people 'who have been part of the conventional art world of their time, place and medium but found it unacceptably constraining' (Becker 1982: 233). Mavericks openly contest conventions of art worlds, while actively searching for new audiences (236). Their innovative spirit makes them vulnerable for 'hostile reception' by their peers (233). ${ }^{6}$ Das Mag explicitly questions the status quo of the literary domain, not only through their anti-convention rhetoric but also by distorting the traditional triangle between publisher, author, and audience.

Traditionally, publishers target their audiences by branding the work of their authors (Childress 2017). Das Mag targets the public also directly by organizing festivals and book clubs for their readers, as well as by using democratic rhetoric. All these activities combine to shape the Das Mag brand that surrounds the promotion of its authors. In the case of Spit's debut novel The Melting, this results in a situation where readers were already familiar

5 'Ja, dat we na zeven jaar nog steeds als jong en hip gezien worden, is een schande' (De Veen 2018).

6 Becker applies the notion of mavericks specifically to artists, but it can be applied to all actors that are active in an art world. The following quote summarizes the position of mavericks in an art world: 'Not surprisingly, mavericks get a hostile reception when they present their innovations to other art world members. Because it violates some of the art world's conventions in a blatant way, the work suggests to others that they will have trouble cooperating with its maker; its blatant disregard of established practice suggests that the person who made it either doesn't know what is right or doesn't care to do what is right (the same reasoning leads people to overreact to allegedly deviant activities in other areas of lie [cf. Becker, 1963])' (Becker 1982: 233-234). 
with Das Mag before they became acquainted with the author. "The Das Mag brand' therefore preceded 'the Lize Spit brand', which was, for example, not the case for a Das Mag author such as Maartje Wortel who already had a brand she had established through previous works.

In this contribution, the self-branding of Das Mag will be explored through a case study of the production and reception of Lize Spit's The Melting, the second book Das Mag published. In order to do so, the interrelations between the postures of Das Mag and Spit surrounding The Melting will be considered, as well as how images that others in the Dutch literary field create of both Das Mag and Spit's novel tie in to those postures. To what extent does Das Mag's self-branding as seemingly anti-conventional, ironic, and democratic lead to either acceptance or resistance on the part of their author Lize Spit, as well as book reviewers, journalists, other publishers, and readers? By answering this question, this chapter reconstructs how the Das Mag brand was able to flourish despite resistance of some of the main representatives of the literary establishment.

\section{Conceptualizing self-branding}

According to Clayton Childress (2017), books travel through three interlinked fields of creation, production, and reception. In Childress' theoretical scheme, different actors are dominant in each separate field. Naturally, the author is the dominant actor in the field of creation (where the artwork is made). Literary agents and acquisition editors oscillate between the field of creation and the field of production (where business takes place). As such, the agents and the editors are able to go back and forth between both of these fields: they are in a position to direct the author in a certain direction so that the book as an artwork fits the publisher's demands. For the publisher, in the field of production, the book as a work of art becomes a commercial product. In turn, this product will be evaluated by book reviewers on aesthetic grounds and by booksellers predominantly on commercial grounds, a process through which the symbolic and economic 'meaning' of the book is generated. In order to influence this meaning making process, the marketing staff and the fields reps of the publishing house can adopt a wide range of strategies.

A convenient way to study these strategies is by adopting a postureanalytical methodological framework. Taking Meizoz's work as a point of departure (Meizoz 2007; Meizoz 2010) on the concept of posture, this chapter will consider how Das Mag's branding strategies are met with 
either acceptance or resistance by Lize Spit, book reviewers, journalists, other publishers, and readers. In the context of The Melting, the following conceptual layers are distinguishable, all of which take place in the field of reception:

1 The posture that Das Mag creates;

2 The posture that Lize Spit creates;

3 The images that book reviewers, journalists, fellow publishers, and the audience create of Lize Spit;

4 The images that book reviewers, journalists, fellow publishers, and the audience create of Das Mag.

First, it is insightful to see how the first two layers interact. How does Lize Spit conform to or deviate from the Das Mag posture? In the field of production, The Melting has become a commercial product construed by marketing employees and booksellers. In the field of reception, however, the product's success relies on how often readers buy the book and how well it is reviewed. All of this is also dependent on the way Lize Spit presents herself to the readers and critics; an image of Spit is not only formed through the book's content but also through the conception of the book's author. In order for the Das Mag brand to thrive, the branded author should ideally conform to the values and norms it represents. Second, the relation between the first two layers and the third and fourth layer might yield insights into how Das Mag is able to survive as a successful brand. For the branding process to be fruitful, Das Mag's and Spit's postures have to be met with a certain amount of acceptance by actors in the field of reception, as they are determining factors in the process of symbolic and economic meaning making. If no one buys The Melting, the branding has failed in economic terms. If no one praises its artistic content, the branding has failed in symbolic terms.

Framed in this way, a variety of conditions have to be met in order for the branding process to be successful. Das Mag and Lize Spit ideally have to adopt the same line in their posturing and in a later stage both their postures have to be accepted to a certain extent by actors in the field of reception. This is a delicate issue: it only takes one hitch in Childress's conceptual scheme for the branding process of Das Mag to start falling apart.

A posture consists of all (non-)discursive expressions of an actor in the literary field (Meizoz 2010). For an analysis of Das Mag's and Lize Spit's posturing surrounding The Melting, a convenient point of departure is to look at the paratexts accompanying its promotion, an approach that is similar to the study of Vaessens and Delissen (2014) on Das Mag's community building. In what follows, Das Mag's mission statements, blog posts, posts 
on social media, and interviews are scrutinized to gain better insight into how Das Mag creates a brand. Traditionally, a publisher's self-branding takes place equally in the field of production (towards booksellers) and in the field of reception (towards readers). Das Mag presents their brand directly to the readers in the field of reception and not primarily via their authors, as the Das Mag brand was already visible in its own right. It will therefore also be considered how Lize Spit conforms to or deviates from the brand in interviews. Finally, Das Mag's and Spit's postures will be compared with the images that book reviewers, journalists, fellow publishers, and the audience created of the Das Mag brand and Lize Spit.

\section{Das Mag's posture: creating the Das Mag brand}

\section{Democratic}

As The Melting was among the first publications of Das Mag Publishers, its promotion was paralleled by the launch of the publishing house. Through a large-scale crowdfunding action, Das Mag searched for 3000 co-founders to contribute financially to their business. The fact that they label the crowdfunders 'co-founder' of their publishing house is significant in their self-branding process as it illustrates their use of democratic rhetoric: people are not just financial contributors but also part of the very foundation of their undertaking. This democratic undertone is apparent from Das Mag's first entrance into the literary field when they stated that they are 'not hindered by any knowledge of affairs' (Donk 2016).7 The suggestion is that everyone is able to read, evaluate, and even publish literature, not only insiders of the literary elite. In doing so, Das Mag engages people from the field of reception in matters of publishing (situated in the field of production) that, traditionally, are not disclosed to them.

In a blogpost on their website in 2018, the Das Mag editorial team clarifies why they decided to stop with the literary magazine and focus on the publishing house and their other activities. They call this 'necessary' for the following reasons:

Literature is less and less capable of seducing readers. This is not remarkable. Nowadays, the possibilities for other forms of entertainment are endless. But oddly enough, readers send out different signals. Start talking 
about smartphones and the first you will hear is: I want to spend less time online. People want to read books. ${ }^{8}$ (Donk 2018; emphasis added)

They make it seem as if their own ambitions are subservient to the needs of the reading audience. Allegedly, Das Mag looks ahead not for their own good but for the good of the readers who would rather be seduced by a book than by their smartphones. This needs to change, and this is a task Das Mag feels obliged to carry out. A remarkable way of reasoning: they pulled the plug on a widely-read literary magazine because of a bigger ambition to serve the needs of the public, whose needs were already being served by that very literary magazine. The launch of Das Mag Publishers and the publication of The Melting is presented as a step in the right direction: 'Bigger steps: with The Melting we addressed more than a quarter million (!) readers' (Donk 2018). ${ }^{9}$

More generally, what stands out in blog posts such as these are specific words with which the audience is referred to. Their message is closed off with 'Bisous, dear readers' (Donk 2018), and their subscribers are addressed as 'our subscribers $(\varnothing !)$ - the backbone of our magazine'. ${ }^{10}$ Das Mag flirts with online culture by using a heart symbol followed by an exclamation mark - a rather informal way to address subscribers. Although it holds true for every magazine and publishing house that the people who buy their products are 'the backbone' of their undertaking, most publishers would call their authors their backbone. Das Mag stresses the importance of the reader for its success, a strategy which is also visible in the field of young adult literature (see the chapter by Linda Ackermans in this book). Not only is this apparent in their use of these rhetorical devices, but also through their organization of festivals and book clubs in which the readers can partake, all of which contributes to the creation of a literary community (Vaessens and Delissen 2014). This brings to mind the ways in which artists in the music industry express their gratitude to fans by giving something back, for instance a living room concert, a meet and greet, a song written for a fan, and so forth.

8 'De literatuur is steeds slechter in staat lezers te verleiden. Dat is niet gek. De mogelijkheden voor ander vermaak zijn tegenwoordig eindeloos. Maar vreemd genoeg geven die lezers zelf andere signalen. Begin over smartphones tegen iemand en het eerste wat je hoort is: ik wil er minder op zitten. Men wil boeken lezen.' (Donk 2018)

9 'Grotere stappen: met Het smelt van Lize Spit vonden we meer dan een kwart miljoen (!) lezers' (Donk 2018).

10 'Tot slot, een bericht aan onze abonnees ( $\bigcirc$ !) - de backbone van ons blad' (Donk 2018). 


\section{Anti-convention}

These democratic rhetorical devices are closely related to the second pillar of Das Mag's self-branding: their anti-convention rhetoric. From the start of literary magazine Das Magazin up until the present, they have presented themselves as opposed to conventions in Dutch literary publishing. Exemplary is a statement in the editorial of De Tien, the tenth, special edition of Das Magazin: 'Literary magazines were reduced to frail flowers - and the heating was turned off' (Donk and Van der Meer 2014: 6). ${ }^{11}$ This might refer to both bad subsidy policies and to the unattractiveness of contemporary literary magazines. In those first years, they presented themselves as resistant to contemporary practices of literary magazines in the Dutch language world. When they were interviewed in January 2018 about their reasons for giving up their successful magazine, publishers Donk and Van der Meer looked back on the landscape of Dutch literary magazines before 2011:

When we started in 2011, I worked in a bookshop where only males of sixty years plus bought literary magazines. Those magazines were also written by the same old people, who did not seem interested in finding a new audience. We made a case against that. We wanted to demonstrate that a young audience for literary magazines actually exists. As long as it is relevant, works with new writers, and looks fabulous. ${ }^{12}$ (De Veen 2018; emphasis added)

This quote illustrates how their oppositional stance has nothing to do with a dissatisfaction with the content of literature (Vaessens and Delissen 2014); their main concern is how to find a gap in the market. Paradoxically, their self-proclaimed innovations in the publishing industry are not necessarily reflected in editorial choices to publish innovative books.

Going against the grain is a common thread in Das Mag's self-branding strategy, which becomes even more apparent in the context of the launch of Das Mag Publishers. In the same interview they state: 'More people

11 'Literaire tijdschriften waren tot kasplantjes gereduceerd - en de verwarming was uitgezet' (Donk and Van der Meer 2014).

12 'Toen we in 2011 begonnen werkte ik in een boekhandel, waar alleen mannen van zestigplus literaire tijdschriften kochten. Die werden dan ook nog volgeschreven door steeds dezelfde mensen, die niet geïnteresseerd leken in het vinden van een nieuw publiek. Daar gingen wij tegenin. Wij wilden laten zien dat er wel degelijk een jong publiek bestaat dat literaire tijdschriften wil lezen. Zolang het maar relevant is, met nieuwe schrijvers werkt en er fantastisch uitziet' (De Veen 2018). 
in the world of books should ask themselves the question: isn't it time to change direction?' (De Veen 2018). ${ }^{13}$ In this statement, their self-proclaimed resistance towards conventions is not found somewhere between the lines but is rather explicitly formulated - things have to change. Their motto 'Less books, more attention' directly attacks what they see as the status quo of Dutch publishing. Established publishers are implicitly accused of publishing too many books, a consequence of which is that their individual authors receive less attention ('More books, less attention'). In a sense, Das Mag opts for a 'fair trade' publishing process in which all those involved benefit equally from the product. In the analogy with the fair trade food industry, the author here represents the hardworking farmer who is saved from being commercially exploited by a benefactor. Others, however, do not agree with this declared opposition between Das Mag's fair-trade business model and other business models, and it indeed remains to be seen whether or not this is a fair representation of contemporary Dutch publishing (see the paragraph 'Das Mag's and Spit's image' in this chapter).

In an interview with PROFILE, Donk states that '[p]ublishing is more than throwing out a book. I believe that we have a method that is different and better than the traditional relation between publisher and author' (PROFILE 2016). ${ }^{14}$ Further along in the same interview, Donk says that they are inspired by other publishing industries, such as the music industry, 'because the book industry is lagging behind'. This point is repeated by Van der Meer in an interview with Börsenblatt on the Frankfurter book fair, where he states that ' $[\mathrm{w}] \mathrm{e}$ have no idea about how it has been done the last forty years. [...] We can question the status quo and the way other publishing houses, that have existed for many years, work' (Börsenblatt 2016). This brings back to mind their motto 'not hindered by any knowledge of affairs', with which they notoriously presented themselves as a magazine in 2011. Das Mag has repeatedly claimed that they question the status quo and that they go against conventions in the publishing world. They present themselves as a genuine alternative in the world of publishing, which is significantly highlighted by Donk's use of the expression 'normal publishing house' (PROFILE 2016) in the above-mentioned interview. Although one can be sceptical about this alleged opposition between 'normal' and 'alternative' or 'innovative', Donk and Van der Meer repeatedly underscore

13 'Meer mensen in de boekenwereld zouden zich de vraag moeten stellen: is het niet tijd om de koers te herzien?' (De Veen 2018).

14 'Uitgeven is meer dan een boek eruit gooien. Ik geloof dat wij een werkwijze hanteren die anders én beter is dan de traditionele relatie tussen uitgever en schrijver' (PROFILE 2016). 
the unconventional and non-traditional aspects of the Das Mag brand. Obviously, postulating such oppositions caters to the success of their brand: it sounds better to be alternative, innovative, and fair trade than traditional, conservative, and exploitative.

\section{Irony}

An ironical attitude towards the literary field is the third pillar of Das Mag's self-branding. Das Mag uses a wide variety of playful elements to ironize the intellectualism and seriousness commonly associated with the creation and production of highbrow literature. This is exemplified by a series of Facebook posts on 8 October 2015 containing several photos in which the editorial team drinks a shot of Gold Strike with one of their contributing authors. ${ }^{15}$ Gold Strike is also referred to in the announcement of Das Mag Festival 2017: 'All this over a shot of Gold Strike'. ${ }^{16}$ In an interview with Check Dit Ff, they asserted that this liqueur is 'really gross' but that it made things very pleasurable, which was a good reason for some authors to drop by because here it is less serious than at their publishers' (Anon 2014). ${ }^{17}$ Here, the Gold Strike liqueur symbolizes the YOLO (you-only-live-once) attitude that became popular in online youth culture as a reaction to the song 'The Motto' (2011) by American rapper Drake. ${ }^{18}$ By incorporating playful elements such as these in their self-presentation, Das Mag sends out the message that literature can be fun and does not have to be a serious, highbrow, elitist endeavour.

Furthermore, they tend to ironize responses of critics to their products. One way they do this is by sharing memes of reviewers' quotes on social media. By appropriating online cultural phenomena they again try to connect with a young audience. Mostly, these memes contain positive reactions to their books, ${ }^{19}$ but also negative reactions are posted as memes. When

15 https://www.facebook.com/pg/dasmagbooks/photos/?tab=album\&album _ $\mathrm{id}=192437920819100$ [accessed 21 March 2018]. Gold Strike is a cinnamon-flavoured liqueur containing gold snippets, with an alcohol content of $5^{\circ}$ per cent by volume.

16 https://amsterdamsfondsvoordekunst.nl/en/over-afk/kalender/das-mag-festival/ [accessed 27 March 2018].

17 'Echt ranzig spul. Maar het werd er wel gezellig van. Er kwamen zelfs nog een paar schrijvers langs om er eentje mee te drinken. Die komen hier overigens wel vaker, het is hier toch wat minder serieus dan bij hun uitgevers' (Check Dit Ff 2014).

18 Incorporating elements from online culture is also a key feature of promotional strategies in the business of young adult literature in order to connect with young audiences (see the chapter by Linda Ackermans in this book).

19 For The Melting the meme only contains positive quotes, as the reception was almost entirely positive: https://www.instagram.com/p/BAw4LfdB-b1/?taken-by=dasmag [accessed 21 March 2018]. 
their first published book, Maartje Wortel's Er moet iets gebeuren (2015), was called 'Thirteen stories for toddlers' by prominent critic Arjan Peeters (de Volkskrant), Das Mag posted a meme on Instagram on which this quote was shown alongside other responses from critics. ${ }^{20}$ Obviously, Arjan Peeters's criticism is made fun of and is not taken seriously. By ironizing his judgement, Das Mag tries to create a distance between the serious, intellectual practices of literary criticism and their own playful attitude. In a similar vein, an Instagram post on 31 January 2017 shows a picture of Lize Spit alongside the Barcelona football star Lionel Messi, informing the public that The Melting will be translated in Catalan. ${ }^{21}$ The suggestion here is that Spit is the Messi of literature, a hint that is recognized by an Instagram follower who responds with 'Check out that superstar! Oh, and Messi is also in the picture'. The idea of Lize Spit as a potential canonical author is ironized via a reference to popular culture: although her name does not yet feature in literary histories, she is already associated with a 'superstar' such as Messi. An early blogpost in which Das Mag Publishers is introduced illustrates all three pillars of Das Mag's self-branding:

In de Volkskrant, we talked about how certain things in the world of publishing could be better. As a response to that, some publishers sent us pie (thanks, Mizzi!) or became co-founder (nice, Oscar!). But some other publishers thought we were vain (hi Vic!), avaricious (hey Joost!), or compared us with resentful hipsters and claimed we sell thin air. However, it is not clear to us what these people want to do for the author and the reader. Therefore, in short: what we do and what no other publisher does, and what you gain from it as a reader. ${ }^{22}$ (Donk 2015).

The irony is displayed by addressing their fellow publishers Vic van de Reijt ('hi Vic!') and Joost Nijsen ('hey Joost!!') in a quasi-comical, sarcastic way; Das Mag does not seriously respond to the criticism on their new publishing model but chooses to ridicule their opponents. Their anti-conventional stance is visible in their opposition towards established publishers such as

20 https://www.instagram.com/p/-tTjRNh-Zr/?taken-by=dasmag [accessed 21 March 2018].

21 https://www.instagram.com/p/BP7 MHV 7 DogY/?taken-by=dasmag [ accessed 21 March 2018].

22 'In de Volkskrant schreven we hoe het boekenvak volgens ons beter kan. Als reactie stuurden sommige uitgevers ons taart (dank Mizzi!) of werden mede-oprichter (leuk Oscar!). Maar ook noemden andere uitgevers ons ijdel (hoi Vic!), gierig (hé Joost!) of werden we vergeleken met verbitterde hipsters en verkochten we 'gebakken lucht'. Maar wat die laatste uitgevers nou willen doen voor de lezer en de schrijver, dat werd ons niet duidelijk. Daarom in het kort: wat wij doen wat geen enkele andere uitgever doet en wat jij daar als lezer aan hebt' (Donk 2015). 
Van de Reijt and Nijsen. Finally, this short polemical passage ends with a democratic rhetoric in which they directly address the reader.

\section{Lize Spit's posture: endorsing the Das Mag brand}

To what extent does Lize Spit's self-representation conform to Das Mag's selfbranding? Since the publication of her debut novel, she has been a frequent guest on talk shows and at literary events, and the press has reported on her work extensively. As her novel is semi-autobiographical, a significant portion of the questions are about how her own life relates to the book.

Whenever Spit speaks about her publishing house, few discrepancies with Das Mag's posture are observable. Interviewers repeatedly ask about Das Mag's publishing model of 'Less books, more attention', which she publicly endorses and praises. In an interview with $N R C$, Spit asserts that she speaks to her editor on a daily basis: 'I had an editor who was exclusively occupied with my book, and I always got a reply within a few hours' (Fortuin and Jaeger 2016). ${ }^{23}$ In an interview in Knack, she suggests that she gets all the space she needs from her publishing house, whereas '[s] ome authors [from other publishing houses; RS] are pressured by their publisher' (Leen 2016). ${ }^{24}$ Statements such as these support the wholehearted attention Das Mag claims to have for its authors.

In that same interview, she tells why she chose Das Mag over other publishers:

When Das Mag Publishers appeared on the radar, I was already talking to other publishers for two years without anything being written in black and white. I wanted to know what publishers would be willing to give. I wanted an advance that would enable me to write for a long period of time. One of the publishers wanted to do a pre-empt on my book, which means that other publishers could not offer me a contract, and all of a sudden I thought: it's not only about a nice advance, especially the relation with the editor is of importance.

$[\ldots]$

I knew that the launch of Das Mag Publishers would attract a lot of attention, its foundation would parallel the publication of my book. If their structure

23 'Debutante Lize Spit: "We begaan allemaal kleine gruwelijkheden"' (Fortuin and Jaeger 2016).

24 'Sommige auteurs worden door hun uitgevers onder druk gezet' (Leen 2016). 
with 3000 co-founders would work, I could already be sure of 3000 readers. That is a lot for a debut. And I have faith in publisher Daniël van der Meer and editor Marscha Holman. ${ }^{25}$ (Leen 2016; emphasis added)

In Childress's scheme of creation, production, and reception (Childress 2017), deals between authors and publishers usually take place in the field of production, but the field of reception also played a part in this deal. By signing a deal with Das Mag Publishers (field of production), Spit simultaneously signed up for a relatively large pre-established reading audience (field of reception).

Furthermore, she explicitly confirms the good terms and conditions that Das Mag uses as a branding strategy: she gets paid well and receives extensive guidance by her editor. She is also aware that the reception of her debut would be influenced by the great fuss that the launch of Das Mag Publishers would attract. Published by Das Mag, she would be able to count on a great amount of media attention that she otherwise might not have had, especially when it is taken into account that this was her first novel and that she was relatively unknown to the public. Although Spit claims that her choice for Das Mag is a strategic one (in terms of money, supervision, and potential readers), she does not appear to consider how Das Mag's maverick position (Becker 1982) could - either positively or negatively - affect her book's success. As mavericks are in a position to be excluded by established figures in the literary field, conforming herself to the Das Mag brand would potentially damage the reception of The Melting.

In the context of the quote above, it is slightly odd that Spit states in an interview with $8 W E E K L Y$ that she could not stand that 'it is presented as if I came out of the blue' (Dedeurwaerder 2016). ${ }^{26}$ Although it is true that she had already made her entrance in the literary field before publishing with Das Mag (she won the creative writing contest WriteNow in 2013), it was only

25 'Toen Das Mag als uitgever op de radar verscheen, was ik al twee jaar in gesprek met andere uitgevers, zonder dat er eigenlijk een letter op papier stond. Ik wilde weten hoeveel uitgeverijen voor me over hadden. Ik wilde een voorschot dat me in staat stelde om lang te kunnen schrijven. Een van de uitgeverijen wilde een pre empt doen op mijn boek, wat betekent dat andere uitgevers geen contract meer konden bieden en plots dacht ik: het gaat niet alleen om een mooi voorschot, vooral het contact met de redacteur is van belang. [...] Ik wist dat de lancering van Das Mag als uitgeverij op veel aandacht zou kunnen rekenen, het vestigen van de uitgeverij zou onder andere met mijn boek gebeuren. Als hun structuur met 3.000 aandeelhouders van de grond kwam, wist ik me al verzekerd van 3.000 lezers. Voor een debuut is dat veel. En ik heb vertrouwen in uitgever Daniël Van der Meer en redactrice Marscha Holman' (Leen 2016).

26 'Maar waar ik niet zo goed tegen kan, is dat het soms wordt voorgesteld alsof ik uit het niets ben opgedoken' (Dedeurwaerder 2016). 
with the publication of The Melting that she became a well-known author. She appears to feel uncomfortable being hyped by the press as a young author who all of a sudden shakes up the literary world. This is, however, in great part the result of her conformity with the Das Mag brand. Being a Das Mag author, Lize Spit is quickly associated with Das Mag's anti-conventional stance in the literary field.

Despite this small crack in an otherwise smooth wall, Spit appears to support the brand by repeating Das Mag's message of the alternative publishing model in her presentation to the outside world. She, however, only conforms to the anti-conventions pillar of Das Mag's self-branding. Democratic and ironical rhetorical devices are not something she incorporates explicitly in her self-presentation. Spit's main role lies in the field of creation, whereas Das Mag's focus is on the promotional strategies in between the fields of production and reception. In order for her to be taken seriously as an author in the field of reception, her reputation would not necessarily improve by expressing ironical attitudes towards the literary field in which she is trying to inscribe herself. Although there are examples in Dutch literary history of successful authors who adopted an ironical stance towards the literary field as a core feature of their posture, such as Gerard Reve (Praat 2014), it does not necessarily follow that irony is a recipe for success in the field of reception.

\section{Das Mag's and Spit's image: acceptance of and resistance to the Das Mag brand}

The postures of Das Mag and Lize Spit mainly take shape along the borders of the fields of production and reception where the promotional strategies for The Melting are carried out. While Spit endorses the self-branding process of Das Mag, this does not automatically lead to the establishment of the Das Mag brand in the Dutch literary field. In order for that to happen, actors in the field of reception have to accept the norms and values Das Mag promotes up to a certain extent. In case critics, journalists, and readers approach Das Mag's self-branding with resistance, the acceptance of the Das Mag brand in the literary field and the branded book The Melting could be in danger. Furthermore, responses from actors in the field of creation (fellow authors) and production (fellow publishers) could also influence the prosperity of the brand.

On a general level, the Das Mag brand has been promoted by Arnon Grunberg, one of the most established authors in the Dutch literary field, 
as well as by celebrities Arjen Lubach and Arie Boomsma, ${ }^{27}$ who all invested in Das Mag Publishers. These investments obviously represent an endorsement of Das Mag's norms and values. Furthermore, established author Charlotte Mutsaers transferred from her former publisher to Das Mag, which is also a clear sign of endorsement. This is equally true for the readers who contributed financially to the founding of Das Mag Publishers, which is perhaps an indirect result of Das Mag's democratic address to the crowd. Subsequently, the crowd supported the Das Mag brand by buying The Melting in massive numbers; it has sold over 250,000 copies and can thus be labelled a bestseller. Of course, readers did not necessarily buy the book because they wanted to support the publishing house, but the great sales records definitely contributed to the brand's success. On top of that, critics have almost unanimously praised the artistic content of the book, both in daily newspapers and in literary magazines. ${ }^{28}$

However, not all actors in the literary field have been so compliant with Das Mag. This was most apparent in the reactions from fellow publishers to Das Mag's publishing model. Although some of them were positive, ${ }^{29}$ an important share was critical of Das Mag's self-proclaimed innovations. Although Eric Vissers (De Geus Publishers) said to 'admire' the progressive ideals of Das Mag, he thought that their innovations were 'marginal' and 'possibly not feasible' (De Jong 2015) $\cdot{ }^{30}$ Vissers also stated that there always have been publishers who have plenty of attention for their authors in spite of Das Mag claiming otherwise. Joost Nijsen (Podium Publishers) was extremely critical, accusing Das Mag of 'an inexpertly and generalized representation of the current state of affairs' (idem). He explicitly refers to their self-branding, claiming that authors 'won't be impressed by their transparent attempt at self-branding' (idem). ${ }^{31}$ These points of criticism place Das Mag's alleged

27 Arie Boomsma and Arjen Lubach are both TV celebrities, both particularly popular among young people. As a host of the widely viewed prime-time programme Zondag met Lubach, Arjen Lubach might even be regarded as one of the Netherlands' top influencers.

28 For an overview of the reception of The Melting, see van Gerrewey 2016.

29 In 2017, the influential Mizzi van der Pluijm even quit her job at Atlas Contact to join Das Mag Publishers (De Rek 2017).

30 'Ook heb ik een ander idee over de vernieuwingen die Das Mag aankondigt. Die vind ik marginaal en vraag me af of het haalbaar is. [...] Ik bewonder de oprichters van Das Mag, ik herken waarom ik zelf ook ooit begonnen ben met uitgeven, ik had dezelfde soort idealen. Wel ben ik benieuwd of ze hun principes waar kunnen maken' (De Jong 2015).

31 'Wat een ondeskundige en generaliserende voorstelling van zaken geven ze in hun rammelende opiniestuk. [...] Dit alles verloopt bijna overal in nauwe, vruchtbare samenwerking met hun auteurs, die van deze doorzichtige poging tot zelf-etalering van Das Mag niet onder de indruk zullen raken' (De Jong 2015). 
innovative spirit in a different light. Although 'Less books, more attention' is a powerful branding strategy, it does not necessarily follow that 'More books, less attention' is a defining feature of the majority of contemporary Dutch publishers.

Also significant is that Das Mag and its authors, including Spit, were not invited by Collectieve Propaganda van het Nederlandse Boek (CPNB) to the 'Boekenbal' in 2017..$^{22}$ The reason for this is that Das Mag refused to join the national publisher's foundation GAU because Das Mag thinks it lags behind in innovative action (Steinz 2017). CPNB Press Officer Peter Roosendaal stated that: '[Das Mag] rebels against the establishment and apparently thinks we are not fun enough. They should organize their own gala' (cited in Steinz 2017). ${ }^{33}$ Despite Spit being a highly relevant author in that year, she was not welcome at the yearly gathering of all the big shots in Dutch literature. This is more likely the result of Das Mag's self-branding as anti-conventional and has little to do with Spit as such. As the main representative of the Dutch literary establishment, CPNB thus takes an oppositional stance towards the anti-conventional aspect of Das Mag's branding strategy, which is what one would expect in light of Becker's theory on the position of mavericks in art worlds.

As an exception to all the positive reviews and media attention, one critical piece on The Melting appeared. Reflecting on the reception of the novel, Christophe van Gerrewey laments that the media attention was mainly focused on the autobiographical nature of the novel and Das Mag's online promotional strategies instead of focusing on 'content, style, influence or meaning' (Van Gerrewey 2016). ${ }^{34} \mathrm{He}$ also accuses Das Mag of bad editorial work, as the novel contained 'sloppy language'. This is in opposition to Das Mag's claim that they put extensive effort into editorial guidance, a message also corroborated by Spit. Furthermore, Van Gerrewey is resistant towards Spit's 'predictable and spectacular' plot-based style which only contributes to drawing the reader in and does not relate to the literary-historical context of the novel as such. In general, he taunts the 'one-dimensional positive reception, followed by a success similar to mass

32 The 'Boekenbal' is a yearly gala where all relevant people in the Dutch literary field are invited. Invitations are sent by the CPNB to those people who are deemed important to the literary production of that particular year.

33 'Ze strijden tegen het establishment en vinden ons blijkbaar niet leuk genoeg. Dan moeten ze zelf maar een bal organiseren' (Steinz 2017).

34 'En dan gaat het niet eens over het soort aandacht, die zelden rond inhoud, stijl, invloed of betekenis draait, maar meestal rond marketing, pronostieken en het geboortedorp van de auteur' (Van Gerrewey 2016). 
psychosis' (idem). ${ }^{35}$ As a critic, Van Gerrewey appears to be alone in his critique of the commodification of The Melting. Although its artistic content has been praised widely, Van Gerrewey argues that Das Mag's branding of the novel has resulted in a primarily commercial rather than artistic product. Van Gerrewey's criticism is especially relevant in light of Das Mag's aim to revive literature by connecting with a new audience whilst not driven by an artistic vision on what good literature entails (Vaessens and Delissen 2014). These democratic and anti-conventional aspects of the Das Mag brand might have offended Van Gerrewey, who represents the more traditional idea that literature should be situated within a specific literary-historical framework.

\section{Conclusion}

In line with the idea of a maverick (Becker), Das Mag has been rebelling against what they present as the customs and rules of the literary field. Clayton Childress remarks that every publisher has to take on a certain number of manuscripts per year in order to have a reasonable chance of commercial success (Childress 2017: 94). Das Mag turns this upside down: they claim to publish fewer books and give more money to their authors, which makes their undertaking more commercially uncertain than if they conformed to the traditional publishing model as described by Childress. In general, uncertainty is one of the governing principles in the creation, production, and reception of books (233) as a publisher can never be sure how good the quality of the book will be (in the field of creation), or how the public and the press will react to it and what the sales figures will look like (in the field of reception). In the case of The Melting, this level of uncertainty was relatively high as it was a debut by an author whose name was not yet established and also one of the first novels for the publishing house. This turned out to be a risk worth taking. Despite - or perhaps partly because of - the great amount of uncertainty inherent in Das Mag's allegedly non-traditional publishing model and the publication of Spit's debut novel, The Melting received predominantly positive reactions from readers and critics, and the sales figures skyrocketed. There was, however, an obvious

35 'De veelgeprezen plot is foutloos, maar ook voorspelbaar en spectaculair nadrukkelijk, zonder levenskansen voor de contingentie die menselijke motieven eigen is. [...] Het geldt voor andere recente boeken, maar in Het smelt komt het samen: een eenzijdig positieve receptie, gevolgd door succes dat aan massapsychose grenst, van een roman zonder stilistische precisie, met een overaanbod aan spectaculaire ellende en schaamteloosheid, en vol eendimensionale verhoudingen' (Van Gerrewey 2016). 
discrepancy between the uncertainties regarding the launch of Das Mag Publishers and the self-confident bravado of their self-branding. Das Mag cultivated this uncertainty and made it part of their brand.

In this contribution, the publication of The Melting has been studied through the lens of Das Mag's self-branding. In that process, three key features of the Das Mag brand stand out: a democratic appeal to the reader, a self-proclaimed anti-conventional attitude, and irony. As an author, Lize Spit publicly endorses the brand's anticonventional message about the Dutch publishing industry but does not explicitly incorporate the same ironical and democratic attitudes in her self-presentation. This has led to little resistance in the field of reception: The Melting became a bestseller, received mainly positive reviews from critics, and the Das Mag brand was widely endorsed by actors in the field of reception. Interestingly (and perhaps expectedly), resistance mainly came from actors who operate in the field of production. Some fellow publishers and the CPNB refused to go along with Das Mag's rhetoric, accusing them of an amateurishly false representation of the current state of affairs in the literary field. Their resistance is understandable: Das Mag proclaims to oppose the publishing model they allegedly represent.

Through this posture-analytical perspective on Das Mag's and Spit's postures, and the ways in which critics, journalists, and fellow publishers responded to them, this chapter has reconstructed how The Melting did not suffer from the anti-conventional, democratic, and ironical tone Das Mag adopted in their self-branding. Still, it would be going too far to conclude that The Melting's commercial and symbolic success is a direct result of these rhetorical devices, as the book's alluring content undoubtedly played a part in that as well. It is, however, remarkable that the resistance to the Das Mag brand appeared to have played a negligible part in its reception. Mavericks such as Das Mag take a risk by publicly contesting what they see as the norms and values of the establishment. Becker asserts that mavericks mostly remain 'curiosities' as 'very few mavericks gain the respect of the art world they are quarrelling with' (Becker 1982: 245). Das Mag appears to be one of those 'very few'. They have not been neglected or banned from the Dutch literary field but have instead received support from some of the most established actors in the field (e.g. Arnon Grunberg, Charlotte Mutsaers, Mizzi van der Pluijm), although they were met with resistance by equally established actors (e.g. CPNB, fellow publishers). As such, the Das Mag brand has created an environment in which authors such as Lize Spit can prosper. This prosperity is partly due to the strategies Das Mag used to put their brand on the map. 


\section{References}

[Anon.] 2014. 'Hoe is het nu met Das Magazin?', CheckDitFf, 8 November. https:// www.checkditff.nl/random/hoe-is-het-nu-met-das-magazin/ [accessed 7 October 2019].

Howard Becker. 1982. Art Worlds. Berkeley/London: University of California Press. Börsenblatt. 2016. 'Das Mag - Interview with Daniel van der Meer', YouTube, 25 October. https://www.youtube.com/watch?v=cYC_UogyUqo [accessed 7 October 2019].

Clayton Childress. 2017. Under the Cover. The Creation, Production, and Reception of a Novel. Princeton: Princeton University Press.

Hannes Dedeurwaerder. 2016. 'Ik vind het geruststellend om van onder mijn stolpje naar de wereld te kijken', $8 W E E K L Y, 22$ April.

Toine Donk. 2015. "IJdel, gierig, gebakken lucht" - hoe sommige uitgevers reageren als je zegt dat het beter kan', Das Mag blog, 30 October. https://updates.dasmag. nl/ijdel-gierig-gebakken-lucht-hoe-uitgevers-reageren-als-je-zegt-dat-uitgevenbeter-kan-26d57eeee7c2 [accessed 21 December 2020]

Toine Donk. 2016. 'Over Das Mag' (mission statement), Das Mag Blog, 16 February. https://updates.dasmag.nl/over-das-mag-22fa0146777/ [accessed 7 October 2019]

Toine Donk. 2018. 'Das Magazin, het tijdschrift waarmee alles begon, S-T-O-P-T. In februari verschijnt het aller, állerlaatste nummer', Das Mag Blog, 22 January. https://updates.dasmag.nl/das-magazin-het-tijdschrift-waarmee-alles-begons-t-o-p-t-e7729e25b65 [accessed 26 June 2020].

Toine Donk and Daniel Van der Meer. 2014. 'Op voorhand'. I, in De Tien, ed. by T. Donk, D. van der Meer, H. Brusselmans, and K. van Hauwermeiren, De Tien, pp. 6-7. Amsterdam: Das Magazin.

Arjen Fortuin and Toef Jaeger. 2016. 'Twee debutanten: niemand slaat zich op de borst'. In NRC Handelsblad, 4 March.

Christophe van Gerrewey. 2016. 'De miserie van 100.000 lieve lezers. Het Smelt van Lize Spit', De Gids 5 .

Tim Jansen. 2015. 'Oprichter Das Mag: “Uitgevers zijn niet nieuwsgierig genoeg”'. HP De Tijd, 17 November.

Laura de Jong. 2015. 'Rondvraag nieuwe uitgeverij Das Mag: “Ze zijn allesbehalve vernieuwend"'. de Volkskrant, 21 October.

Michiel Leen. 2016. 'Debutante Lize Spit: "We begaan allemaal kleine gruwelijkheden"'. Knack, 24January.

Jérôme Meizoz. 2007. Postures littéraires. Mises en scène modernes de l'auteur. Geneva: Slatkine.

Jérôme Meizoz. 2010. 'Modern Posterities of Posture. Jean-Jacques Rousseau'. In G.J. Dorleijn, R. Grüttemeier and L. Korthals Altes (eds.), Authorship Revisited: Conceptions of Authorship Around 1900 and 200o, pp. 81-93. Leuven: Peeters. 
Edwin Praat. 2014. Verrek, het is geen kunstenaar. Gerard Reve en het schrijverschap. Amsterdam: Amsterdam University Press.

PROFILE. 2016. 'Toine Donk (Das Mag): “Uitgeven is meer dan een goed boek eruit gooien”', 7 DTV, 14 September. https://www.youtube.com/watch?v=tBdeCMltRos [accessed 27 August 2020].

Wilma de Rek. 2017. 'Invloedrijke speler uit de boekenbranche voegt zich bij uitgeverij van jonge honden'. de Volkskrant, 5 July.

Jet Steinz. 2017. 'Das Mag-auteurs uitgesloten van Boekenbal, literair Nederland is verontwaardigd'. de Volkskrant, 22 March.

Thomas Vaessens and Lara Delissen. 2014. '\#DasMag. Het literaire tijdschrift als community', Spiegel der Letteren 56.3, pp. 393-419.

Thomas De Veen. 2018. 'Das Mag stopt met literair tijdschrift'. NRC Handelsblad, 22 January.

Marijke de Vries. 2016. 'AAls je pech hebt, schrijft je kind een boek over je”'. Trouw, 6 October.

\section{About the Author}

Roel SmeEts (1991) studied philosophy and Dutch literature at Utrecht University. He currently works as Assistant Professor of Modern Literature and Digital Culture at Radboud University Nijmegen. He specializes in data-driven, quantitative methods for the study of cultural representation. 


\title{
In Search of the Most Effective Way of Branding
}

\author{
The Label 'Literature' as a Means to an End
}

Bertram Mourits

\begin{abstract}
For fifteen years, Bertram Mourits has worked as an editor with prominent Dutch literary publishing houses. With a history in academia, he could not help but relate his work surroundings to the literary-historical developments he wrote about as an academic. This chapter looks at fifteen years of branding in practice, the relation between symbolic and economic capital, and the creation of new literature.
\end{abstract}

Keywords: publishing, editing, marketing, poetry, contemporary literary history, media

\section{Beginnings}

When I started working as an editor, at the beginning of the twenty-first century, publishing houses no longer functioned as actual brands. They had done so to a certain extent and the rudiments of their respective reputations remained: Querido was a highly literary house and possibly the best at publishing debut novels; Van Oorschot was known as the publishing house for tradition, with its cover designs that were text-only and the plethora of dead Russian authors on their list; De Bezige Bij was the strongest house for post-war Dutch literature, and so on. I am sure most Dutch readers still recognize these characterizations, but I doubt that the publisher's brand is still taken into consideration when they buy a book. Prometheus, where I worked, was a case in point: a house without a fixed identity. The reputation

Helleke van den Braber, Jeroen Dera, Jos Joosten, and Maarten Steenmeijer (eds), Branding Books Across the Ages: Strategies and Key Concepts in Literary Branding. Amsterdam, Amsterdam University Press 2021 DOI: $10.5117 / 9789463723916 \_C H 16$ 
of a publishing house is now often based upon its marketing power - and the goal is not to present the company as a brand, but the authors as individual brands. The articles in this book gave me the chance to evaluate my work as an editor in these terms and confront practice with theory - and vice versa.

I rarely worked with bestselling authors as a junior editor. My thoughts about branding - to be honest, I did not have many - bore little relevance on my work at that time. In 2003, I started working at Contact Publishers, which later became, after a merger in 2012, Atlas Contact. The influence of marketing increased; not only when publishing bestselling authors but across the board. We did not call it branding; it was all part of marketing.

\section{Traditional Views}

In publishing there is often a gap between the editorial and marketing departments. In terms of Bourdieu's argument, marketing is seen as the way to gain economic capital, whereas the editor acquires symbolic capital. The value judgment implied here is real: often, editors view themselves as the providers of content, having to protect high literature against the low forces of commerce. Of course, this is a simplification, but it is based on practice as well as theory. The dichotomy between symbolic and economic capital is found in numerous places in the pages of this book.

In this book we read about Raymond van der Klundert, better known as Kluun, an author with a background in advertising who managed to brand himself with the help of qualified people: marketing people. We also read about how Herman Koch turned from a quirky storyteller to a commercial powerhouse with the controversial novel Het diner. Also, we followed the reputations of international authors with a strong Dutch readership: Gustave Flaubert, Charles Bukowski, and Carlos Ruiz Zafón. A chapter is devoted to the way in which The Netherlands presented itself on international book fairs in Frankfurt and Beijing. And where in some cases 'branding' appears to be a process closely linked to canonization, in the more contemporary cases, explicit marketing efforts have increasingly more influence than literary value.

There is an exception to the rule that publishing houses do not brand themselves: Roel Smeets writes about 'Das Mag' - which presented itself as a new house doing things differently. Their subscription model was innovative, the books all had highly recognizable designs, and the house had a rebellious appeal that attracted young authors - and some established names as well, disgruntled with the performance of their 'traditional' publishing houses. In 
non-fiction, De Correspondent does something similar. Both Das Mag and De Correspondent have their origins in a different realm: the first initially was a literary magazine, the latter a current affairs website. It is too soon to tell if Das Mag and De Correspondent have actually introduced a new kind of publishing, or if they will grow and develop into something more traditional. Their innovations have succeeded with books that sell well, but it is obviously impossible to build a house solely on bestsellers. Traditional publishing is well-equipped to deal with economic failures; this explains the relative inertia as well as the longevity of traditional publishing houses.

\section{A Symbolic Contract with the Reader}

The role that a publishing house can play in the branding process is aptly analysed by Sander Bax in his chapter on Herman Koch. Koch's commercial success came after switching publishing houses. His new house, Ambo|Anthos, presented Koch as an accessible author whose work was close to a suspense novel, whereas his previous publishers (Meulenhoff, Augustus) had stressed the literary value of his work.

To be sure, that had not been a mistake: parallel to his literary career, Koch was a brilliant clown in the VPRO TV show 'Jiskefet' - and it made sense to present him to the book market as a serious author and not the irreverent comedian he was on TV. It worked, but almost too well: while Koch's first book had been a modest bestseller (Red ons Maria Montanelli, in 1989 - a sharp, satirical approach to Montessori education), the sales of his subsequent books never improved. The TV personality had become completely unrelated to the 'serious author'.

When Het diner was published in 2009, the emphasis of the marketing campaign was on Koch as a successful author, even before the book became a bestseller. It is somewhat ironic that the book only really took off after an appearance on a primetime TV show (De Wereld Draait Door), where Arnold Heumakers (a serious reviewer) and Hugo Borst (then mostly known as a TV personality with a love for football) fought over the literary merits of the book. In my view, Heumakers had a valid point, but Borst was not convinced. Meanwhile, Herman Koch was smiling in the background, all the way to the bank. As Bax notes: from then on, there was a strong focus on the retailers. They like sales figures, and Het diner would deliver soon enough. The success of that book provided the publishing house with a style and format for his next book. The cover design had a similar concept, and there was a sticker on the cover with 'by the author of Het diner' on it. 
Koch was branded as 'the author of a bestseller', and the cover design for that had become his trademark.

This approach, as we read in Rob van de Schoor's chapter about the nineteenth century, is rooted in the school of Busken Huet, who claimed that the recipe for success was to become known as 'the author of just one book'. And indeed, Koch has ever since been 'the author of Het diner'.

TV can be helpful or a hindrance, and the career of Adriaan van Dis is a case in point. His role in the reception of literature in The Netherlands can hardly be underestimated, and his TV shows are mentioned in this book more than once as places where authors became well-known. But it is telling that there is no mention of Van Dis's own literary work, nor his attempts to be branded as an author in his own right. When he started publishing books, he was a journalist and TV personality who branched out by writing fiction. In De Telegraaf, Van Dis was introduced as follows: 'VPRO's calling card wants to become a famous author' (Sitniakowsky 1986). Interviews invariably mentioned his TV work, and it took him thirty years before he could reverse the order and become the author who used to have a TV show.

In my own branding practice, I should mention Nico Dijkshoorn, a Dutch author with a highly unusual career: he started out as a columnist for a commercial TV station and wrote poetry in the comments section of the infamous Dutch website geenstijl.nl. He was discovered by more traditional media and published a highly unusual, if not unique poetry collection, Daar schrik je toch van (2008, subtitled 'The First 1000 Poems'), a fragmented tragicomic novel (De tranen van Kuif den Dolder, 2009), and a highly successful collection of columns, simply yet effectively titled Dijkshoorn (2010). In the meantime, he had a weekly column as the 'house poet' of De Wereld Draait Door, where he mostly commented on current events and on things that had just happened on said show.

These books were published by Nieuw Amsterdam, a relatively new publishing house with a commercial management and literary ambitions. Dijkshoorn was commercial; Nieuw Amsterdam capitalized on his popularity on TV and internet. But Dijkshoorn had serious literary ambitions, which were sometimes difficult to ascertain between the carnivalesque columns and the unpoetic poems. When he made his transition to Contact, we made a deliberate attempt to change the Dijkshoorn 'brand', so as to align the image with his literary ambition. To do that, we deliberately broke some commercial rules.

The first book Contact published by Dijkshoorn was a short story collection - which as a genre in itself guarantees less commercial appeal. The 
cover was a still-life photograph of a glass of stale beer, a coffee cup, a plastic flower, and a pair of glasses. It bore little relation to the contents of the book, nor to the author. There was no author photograph - a big contrast with the column collection Dijkshoorn, which had his face prominently on the cover. And as the icing on the cake, the stories were tied together by a long poem: the result was Kleine dingen (2001). This was a modest seller, a step back from the column collection, but this decrease in sales had been calculated. It was more important for us that reviewers wrote that Dijkshoorn showed he was 'more than someone telling jokes', and he got the chance, in interviews, to assume the posture of a sombre and serious author.

It would probably have worked even better if he would have quit his TV appearances, but at least the set-up for the following book, a serious novel, was there. The publishing house had managed to change the content of the brand 'Nico Dijkshoorn' and had done it by telling this story: 'Tough TV personality proves to be a sensitive literary author'. Nooit ziek geweest (2012), the novel, got mixed reviews, but it was the first time Dijkshoorn was widely reviewed in literary media.

With Dimitri Verhulst, the route taken was entirely different. Verhulst had the reputation of being quirky, highly literary, inaccessible, a 'writer's writer', specializing in novellas and short stories. When De helaasheid der dingen (2006) was published, Contact managed to draw attention to the autobiographical aspects of the novel, even though the book was filled to the brim with grotesque details. A big interview in Volkskrant Magazine was the starting point for a campaign that changed the brand implications of Verhulst from (the generic) 'serious literary author, language virtuoso' to 'author who managed to escape his dismal youth by means of his language.'

The third example worth mentioning is Peter Buwalda, since he committed himself to the reader in a way that suggested he was counting on brand loyalty from the start. In interviews published when he was working on his second novel, the successor to the hugely successful Bonita Avenue, he mentioned the implicit 'contract' he had with the readers of his first book, which forced him to write something that readers of Bonita Avenue (2010) might enjoy. The second novel had to be 'a real Buwalda', no change in recipe necessary, let alone wanted. Buwalda was not going to make the mistake that Coca-Cola made with their new recipe. Although Buwalda's tongue was firmly in cheek, there were a lot of reactions - not in the least from readers who were insulted to be portrayed as predictable. NRC Handelsblad's reviewer bought into Buwalda's frame, not just by repeating it in the review of Otmars zonen (2019), but also by proclaiming that Peter Buwalda kept his promise. (De Veen 2019). 
Despite NRC Handelsblad's enthousiasm about Buwalda's promise, Buwalda did lose some readers in the process; Otmars zonen is a bestseller but not at the same level of his first novel. And similarly, Herman Koch is still a bestselling author, but the numbers of Het diner have not been repeated, nor have those of De helaasheid der dingen. There are limitations to what branding can do as a means to continue success. But creating initial success is a different matter.

\section{When Marketing is King}

It is easy to think of ways in which authors have been branded or worked on their own brand and posture. Publishing houses often present authors by means of narratives that have very little to do with their books. Those are stories that try to connect the potential reader to the product. The plot of the campaign is the brand; the plot of the book comes afterwards and is mostly irrelevant for marketing efforts. The difference between the two should not become too big, because consumers will notice a lack of authenticity. But it is a truth widely acknowledged in publishing: for a book to sell, it has to have a story as a way to reach a potential audience.

In a 2007 article about book promotion for Boekblad (the trade journal for booksellers and publishers), journalist Hans van der Klis commented on the state of marketing in the form of several tips and tricks: a goodie bag works, press releases do not; an advertisement in a newspaper does not work, one on TV does; and first and foremost, one has to create a story. As said, that story is not the plot of the novel, because "no one is interested in the sixth novel of a 46-year-old male writer, unless he had a five-figure advance, was beat up by a gang, killed his wife, or is a jury member of Dancing with the Stars' (Van der Klis 2007: 8). Literature is boring by itself; marketing should provide the attractive packaging. Hans van der Klis approaches these developments from a cynical angle, but he is not wrong: 'emotional branding' needs to appeal to the consumer and painting a truthful picture of the product comes second. ${ }^{1}$

This approach to market bears witness to the chasm between the fields of creation, production, and reception, which is described in the Introduction to this volume. Remarkably, in practice that chasm is often easily bridged, at least when dealing with books that carry high commercial expectations. Marketing plans for potential bestsellers are created in constant consultation 
with the author. With less commercial books though, for which there is less time and money, authors are sometimes averse to the marketing ideas of the publisher, and a struggle based upon authorial anxiety might ensue. Especially in the case of new authors, there is often resistance against the notion of branding, since it reduces the aura of originality, a romantic notion that has value in symbolic terms but might be a hindrance in economic terms. If an author has reached the status of a bestselling author, being branded is not a problem: 'from the author of Het Diner' still refers to the same author. But 'for readers of Herman Koch' reduces one's individuality (the recommendation has been used for novels by John Kenney, Monique Koemans, Pepijn Lanen, Benjamin Burg, Henk Rijks, and Dimitri Casteleyn).

It is easy to see the parallels between the notions of 'creating a story', 'presenting convincing packaging', and 'building the brand.' This is what a publishing house tries to do in the first instance. Cultural economist Clayton Childress - quoted in the Introduction - is right when he explains that branding is not limited to the marketing and publicity departments but permeates the whole production process. This process often begins with the literary agency - in The Netherlands its role may still be relatively limited, but the influence of literary agents is increasing here as well. An agent submits to selected editors and presents the author in a specific light, tailored towards the publishing houses - the first elements of the brand are being determined before a publishing house comes into view. The next step in the branding effort is the catalogue, compiled by the publisher and meant for distribution among booksellers and the press: the gatekeepers to the market. Around the time of publication, marketing and publicity departments do their work, usually in cooperation with the author, who might appear on TV, do a book tour, or be interviewed by small presses and internet radio stations. All of this to make sure the right story gets across to the audience.

The chapter about the early modern period shows that, even though the means have changed, the approach is by no means new. The emblematic poetry of P.C. Hooft proves a wonderful example, as Lieke van Deinsen and Nina Geerdink show in their chapter on 'Cultural Branding in the Early Modern Period: The Literary Author'. Hooft himself, as 'a member of the literary elite [...] initially not eager to be printed and traded as a brand', published his first collections without his name on the cover. He did make sure that the inner crowd knew who the author was: 'Zij steeckt om hoogh het hooft' was the motto of one of his collections. You could argue this was branding at its most effective: banking on the know-how of the public. The rise of print (a new medium at the time) created numerous new possibilities 
for marketing and dissemination of literature, and the role of publishers here was as essential as it is now for Kluun, Koch, or Buwalda.

\section{Poetry}

Although the examples in this book go back to the seventeenth century, the emphasis is on the novel in the twentieth century. That is no coincidence, since the novel is the most commercially potent form of literature. But branding is not limited to the novel, as Jeroen Dera shows in his chapter devoted to the branding of a poet: Ellen Deckwitz. Dera observes that usually poetry 'is not easily linked to the commercial world of marketing and money' and it serves a small audience, but that 'does not justify the hyper-autonomous image of the genre'. He is right, but it is interesting to observe that the position of the poetry editor is much more autonomous than that of the editors dealing with potentially bestselling fiction or non-fiction - in my personal experience, that is. There are hardly any commercial expectations, so when poets are being branded, there are other reasons at play. This is where 'symbolic capital' is not something that is being undermined by economic capital but works in service of it. Publishing poetry is a way of saying: 'This publishing house values literature, even when we do not make money on it.' And having that reputation, makes a house attractive for serious literary authors. They want to sell books, but prefer surroundings that are not strictly commercial.

This is also because many authors - especially poets - resist the notion of having to be 'branded'. (The irony is, of course, that 'author who does not want to deal with the commercial aspects of literature' is a quite common trope - if not to say a 'brand characteristic'.) Dera assumes Ellen Deckwitz is not one of them and traces the way in which her 'posture enables her to blend economic and symbolic capital, hence enabling her to serve both a highbrow and a mass audience'. Deckwitz did not reach the mass audience with her poems but as a columnist for NRC Handelsblad and De Morgen. Dera focuses on her activities on social media and on her efforts to employ popular culture in making 'difficult poetry' accessible. In several books about reading as well as writing poetry, she assumes the posture of an authority, but of the friendly, relatable kind. She quotes famous and unknown poets with similar ease: there is no traditional hierarchy in her poetics.

Full disclosure: I was the editor of her Atlas Contact poetry collection, and marketing aspects definitely came into consideration when we were discussing the form of the book. Where Deckwitz's first two collections with 
Nijgh \& Van Ditmar had frivolous cover designs, we opted for a traditional illustration for De blanke gave (2015): a painting of a beetle by Albrecht Dürer with traditional lettering. This early sixteenth-century illustration was a deliberate attempt to point towards the literary-historical value Deckwitz's work has, contrasting with the cartoon-style covers that are more easily associated with her fame as a slam poet.

\section{The Word 'Literature' as a Brand}

Even though publishing houses point the attention towards authors, and much less to their own brand name, there is value to be found in being published by an established publishing house. It will be interesting to return to this observation in ten years, but at the moment of writing, it is true that being published by De Bezige Bij, De Arbeiderspers, or Cossee (the examples are random) gives an author a better chance, in the press and on the market, than when she or he chooses to self-publish. A novel published by an established literary house will immediately be read as literature, whereas a self-published book will initially be received as a failure: the author apparently did not manage to find a 'real' publishing house.

These mechanisms are changing, though. Frank Krake's book Menthol is self-published. It became a commercial success, and the author is getting serious reviews and interviews. Jos Joosten makes a case in point that Kluun and his publisher use the literary reputation of the other authors on Podium's list to give credence to his novels. And the self-publishing platform Brave New Books became part of Singel Uitgeverijen - under the same roof as Arbeiderspers, Nijgh \& Van Ditmar, Querido, De Geus, and others. And Ambo|Anthos started publishing thrillers with the adjective 'literary' printed on the cover. These are three instances where the borders between the commercial and the literary are being crossed, and the last example is especially interesting since it uses the word 'literature' to sell a genre that is inherently not literary. The publishing house appropriates the agency to provide a work with the label 'Literature', even though it is usually an implicit stamp of approval, not a commercial term.

To be sure, the thriller did not need the new adjective to obtain a space in the bookstore. It has a separate means of canonization and its own measures of success. Yet with the publication of 'literary thrillers', Ambo|Anthos created a new brand and other publishers followed suit. Even traditional literary houses such as Van Oorschot and Querido published literary thrillers'. There is something to be said for the idea that this is the most successful case of 
branding of the last twenty years. But the brand 'literature' does not do justice to the thriller. There are psychological thrillers, political thrillers, horror fiction, detective fiction - and most of the books that are presented as 'literary' neatly fit into one of the categories that are already available. Still, René Appel, for example, one of the most successful authors of psychological thrillers, is happy with the new brand. 'Literary' implies respect and might draw readers who, before then, were hesitant to buy a thriller, because it would be 'not done'. I wrote about the literary thriller in NRC Handelsblad (Mourits 2007). Appel replied: 'I am glad I no longer have to hear “I don't read that kind of books", as if it were a lower form of print. My credo: Long live the thriller, it's good for you, but still a good read!' (Appel 2007).

This could also have been a marketing slogan for so-called 'Young Adult' literature, but the difference here is that this label aims at 'a specific target group of young people,' as Linda Ackermans explains in her chapter on Young Adult literature as a brand. The literary thriller' aims at the general 'literary' reading public instead of focusing on a specific group of readers.

\section{Read What You Know}

The word 'literature' has become a marketing tool and the next step was to be expected: why stop at thrillers? In 2007, De Arbeiderspers submitted Tineke Beishuizen's novels Dood door schuld and Schaduwtuin for a literary prize. Beishuizen is by most traditional definitions not a literary author. She worked at Personal Book Publishers, which delivers bespoke novels: most plot elements remain the same, but some traits of the characters can be adapted by wish of the reader/client. Plus, her previous books had been marketed as thrillers, yet De Arbeiderspers attempted to elevate her to the status of what traditionally is considered literary.

It is easy to dismiss this development as the cynical attempt by a publishing house to expand the market for non-literary books. Unsurprisingly, Beishuizen's work has not reached a literary shortlist yet. But the underlying changes are interesting and telling. Everything that Beishuizen had done until then depended on the familiar: novels with (literally) real-life characters, adaptations of things we saw on TV: the idea that literature should be original and provide some 'estrangement' is not present in her work. But these notions are changing. The question has become: who has the agency to define literature? The question 'What is literature' had long been considered impossible to answer. Partially because those who were into literature knew without saying. It is similar to Louis Armstrong's definition 
of jazz: if you have to ask what it is, you will never know. It was this autonomy that reigned supreme from the romantic period onwards.

This autonomy always had its limits, but even the fiction of 'art for art's sake' has become outdated. In the heyday of that view - the late romantic period - everyone knew 'literature' to mean a text that functions as literature without having to justify itself to the world. Interest in formal beauty and emotional authenticity was warranted and there was an institution that protected these notions against the merciless mechanisms of consumer capitalism. Albert Verwey is a case in point with his literary magazine $D e$ beweging. As Helleke van den Braber describes it (in this volume): he 'valued maximal artistic, economic and ideological freedom and took pride in "the complete independence from profitability" [...] Albert Verwey's definition of autonomy as a form of artistic and economic independence is consistent with that of sociologist Pierre Bourdieu, who stated that in 1880s Europe, autonomy meant "the right of artists to legislate within their own sphere - free from subordination to religious or political interests"'.

In addition, the circumstances were created in which the creative spirit could thrive and was protected: copyright was invented, reviewers started focusing on aesthetics instead of ethics, and literature was more important than commerce. William Marx (2005) explains in L'adieu à la littérature why this autonomy was short-lived: it was a fiction. Symbolic capital could not be separated from economic capital, and after literature proved to be a profitable business, it had to fend off the socio-economic world. Literature was so successful that it became a marketing term, but that was the end of meaningful autonomy in literature. Autonomy was only possible when literature had no concrete influence in the physical world (the problem of poetry), or autonomy was being used by the market to sell books (the problem of prose). Literature used to mean fiction that was not part of a specific marketing strategy. It now means fiction that falls under the marketing heading literature'.

\section{Branding as a Literary Strategy}

After these observations, I return to the Introduction of this book. It poses three juxtapositions that demarcate the playing field of branding. There is a distinction between public image versus self-image, and for branding to be successful, these cannot be too far apart. An author who tries to sell him- or herself as something he or she is not will most likely fail, since authenticity is a persistent romantic notion. The public image is the way 
to the market; the self-image reflects the romantic ideal that many literary authors still have.

The conceptual pairing of resistance versus acceptance follows the relation between self-image and public image. This is something an editor comes across quite often: authors tend to resist the simplified version of themselves that the public image of them portrays. Acceptance of this image is seen as a necessary step to start gaining economic capital, but resistance is common for authors who feel their contribution to the symbolic capital of a publishing house is more important.

Both these conceptual pairs have a basis in Bourdieu's distinction between economic and symbolic capital (Bourdieu 1984). The two are often seen as contrasting forces. Simply put: more symbolic capital means less commercial appeal, and quite often there is indeed a reverse correlation. Large scale production yields economic capital; restricted production is the domain of symbolic capital. Still, no serious literary publishing house will refrain from publishing poetry - even though it is rare that poetry collections make money (and if they do, they are usually the kind of collections that do not contribute to symbolic capital: poetic thoughts by TV personalities or thematic anthologies).

The idea that symbolic and economic capital work against each other has become problematic in the twenty-first century. It is therefore useful to note that the research on which Bourdieu based the distinction that lies at the basis of these juxtapositions was done from 1963 to 1968 . This should be taken into account when applying it to a situation more than fifty years later. Moreover, Bourdieu was not impartial. He preferred the situation in which literature had its unequivocal autonomy, a situation that was in the first stage of deterioration in the late 196os, though it had not yet been recognized as such. The notion of symbolic versus economic capital is valid, but in contemporary publishing practice, economic capital does not undermine symbolic capital as much as it uses it.

It is true that in the world of literature, explicit promotion might backfire and must be 'euphemized' in order to work. The success of Herman Koch's Het diner is a good example: the publisher was very effective in putting the publicity to use without shouting their message from the rooftops. But Kluun and Ellen Deckwitz are not shy about presenting themselves with explicit references to advertising, marketing, and matters of canonization.

Adaptations to Bourdieu's model have been suggested, and this book suggests one as well; it proposes a new distinction between economic branding and symbolic branding. But this is a false distinction as well; the reality is that everything is economic branding. If symbolic branding appears to be something different, it is because it is economic branding with a detour. 
The Introduction mentions altruistic institutions and remarks: 'gaining symbolic capital is crucial in order to realize the intended goals'. This is true, but commercial capital is just as necessary, even if it is not the final goal.

Let me illustrate the consequences of this development with a final example: the position of the literary magazine. It used to be the case that no publisher could be without one. It was a necessary breeding ground, and a place where a publisher could show his or her true colours. But the importance of the medium declined; authors debuted sooner and sooner (without a testing period in magazines). Literary pamphlets got out of fashion with the increasing amount of space that newspapers would devote to opinion. If an author wanted to say something about the world, he could turn to a newspaper, which was much more effective than an essay in a literary magazine.

Did publishers cherish them as a crucial part of the literary field? Van Oorschot still publishes Tirade, but Querido let De Revisor go, Atlas stopped publishing Atlas, Contact never even had a literary magazine, Maatstaf was not saved by De Arbeiderspers, and even De Gids had to find a way to survive outside of traditional literary publishing when Meulenhoff called it quits. The symbolic capital represented by these journals was not significant enough to warrant their continuing existence.

Could this happen to poetry? For now, it appears to be extremely unlikely. Poetry is more alive than ever - but that is not because publishers cherish the symbolic value per se. It is because bestselling authors are drawn to symbolic capital. Every author wants to be part of a house that shows it values serious literature. Publishing poetry is one way of showing your literary credentials. So in this way, symbolic capital is nothing more or less than the means to the real end: economic capital. The dissolving of these opposites is one way in which the end of autonomy in literature shows itself. Symbolic capital is being employed to increase economic capital and branding has become an integral part not just of the dissemination, but of the actual creation of literature.

\section{References}

René Appel. 2007. “Literatuur” klinkt zo suf'. NRC Handelsblad, 14 September. Pierre Bourdieu. 1984. Distinction: A Social Critique on the Judgement of Taste. London: Routledge.

Hans van der Klis. 2007. '10 Wenken voor Moderne Boekpromotie'. Boekblad 174: 8-9. William Marx. 2005. L'adieu à la literature. Histoire d'une dévalorisation XVIIIe-XXe siècle. Paris: Éditions de Minuit. 
Bertram Mourits. 2007. 'Het einde van de literatuur'. NRC Handelsblad, ${ }_{1}$ August. Ivan Sitniakowsky. 1986. 'De torenhoge ambities van Adriaan van Dis'. De Telegraaf, 21 June.

Craig J. Thompson, Aric Rindfleisch, and Zeynep Arsel. 2006. 'Emotional Branding and the Strategic Value of the Doppelgänger Brand Image'. Journal of Marketing 70.1: 50-64.

Thomas de Veen. 2019. 'De nieuwe Buwalda is geweldig meeslepend en maakt hongerig naar meer'. NRC Handelsblad, 8 March.

\section{About the Author}

Bertram Mourits (1969) is head of Collections at the Literature Museum in The Hague. He studied Dutch Language and Literature in Utrecht and wrote a dissertation about Dutch poetry in the 196os: Zestig. Een nieuwe datum in de poëzie (Sixty. A New Era in Poetry). He has written about Dutch literature in journals and magazines such as Poëziekrant, De Revisor, Dutch Crossing, and De Gids. He has worked as a poetry and non-fiction editor at several publishing houses (2004-2019). He also writes about music for Heaven and NRC Handelsblad and wrote a book about classic albums with Pieter Steinz: Luisteren \&cetera. 


\section{Index of Names}

Aaker, Jennifer L. $\quad 11$

Abdolah, Kader 324

Abrahams, Frits 300

Ackermans, Linda $\quad$ 19, 23, 341, 364

Acket, Désiré 118

Alberdingk Thijm, J.A. $\quad$ 155-156

Albers, Frank 193

Alexander, Jonathan $\quad 244,247,249,252$

Amossy, Ruth 22

Andreus, Hans 182

Antonik, Dominik 295-296,310

Appel, René 364

Armstrong, Louis 364

Aronczyk, Melissa 316

Arsel, Zeynep $\quad 26$

Artaud, Antonin 182

Asher, Jay 244

Baas, Maarten 322

Baerdemaeker, Jo De 284

Bakker, Margot 121-122

Banning, H.A. $\quad 156$

Barceló, Elia $\quad$ 197, 203, 206-209, 212

Barthes, Roland 134, 136

Bastet, F.L. $\quad 166$

Bax, Sander $\quad 27,295,310,357$

Becker, Howard $\quad 23,25,337,351-35^{2}$

Beer, Taco de 109-110

Beishuizen, Tineke 364

Belinfante, Jacob $\quad 157,159$

Berensmeyer, Ingo $\quad 34,38$

Berg, Walter van den 336

Berg, Willem van den $\quad 165$

Bergh, S.J. van den 158-159

Bergsma, Stella 143-144

Bernlef $\quad 322-323,326$

Bisseling, Willem 227

Blanchett, Cate $\quad 216,222,227$

Bloem, J.C. $\quad 68,79$

Bogaerts, Henri 156

Bogard, Humphrey 138

Bontridder, Albert $\quad 185$

Boomsma, Arie $\quad 336,349$

Boon, Louis Paul $179,185,189$

Boos, Juergen 282

Bordewijk, Ferdinand $\quad 187$

Borges, Jorge Luis 198

Börsenblatt 343

Borst, Hugo 357

Bosboom, N. 157

Bosch, Bernardus de $\quad 5^{0}$

Bouilhet, Louis 123

Bourdieu, Pierre $16-18,25,34,64,66,112$, $117,152,217,220-221,225,251,264,276,278$, 295-297, 303-305, 310, 315, 365-366
Braber, Helleke van den $\quad$ 13-14, 365

Bredero, Gerbrand Adriaensz. 33, 42-43

Breukers, Chrétien $\quad 313-314,327$

Bril, Martin 142

Broeck, Charlotte Van den $\quad 270,288$

Bronkhorst, Daan 322

Brown, S. 258,270

Bruyninx, Daniël $\quad 5^{2-53}$

Buelens, Geert 34,38

Bukowski, Charles $13,26,132-146,356$

Burg, Benjamin $\quad 361$

Busken Huet, Conrad 110, 152, 164, $35^{8}$

Buwalda, Peter $\quad 359-360,362$

Buysse, Cyriel 179

Calisch, E.M. $\quad$ 157, 159

Campert, Remco 128

Campo Weyerman, Jacob 40

Carlisle, Michael V. $\quad 231$

Casanova, Pascale 277

Casas, Gabriel 199

Casteleyn, Dimitri 361

Casterman, J. 94

Català-Roca, Francesc $\quad$ 198-199, 203

Cats, Jacob 163

Céline, Louis-Ferdinand 179

Cervantes, Miguel de 197

Charlemagne 100

Charlson, David 137

Chaucher 35

Childress, Clayton $\quad 12-14,23-25,62-63,65,135$, $338,351,361$

Chonia (Jan Christiaan Kindermann) $\quad 161$

Chuangchun, Li 325

Claus, Hugo 20, 177-193

Cleef, Pieter van $\quad 157,159$

Coelho, Paulo 302-303

Collins, Suzanne 244

Cooper, Louise 253

Corneille 182

Corrington, John William 139

Cosinus 161

Couldry, Nick 316

Couperus, Louis $110,162,165^{-169}$

Craig, Ailsa $\quad 264-265$

Crawford, Robert $\quad 257$

D'Ablaing van Giessenburg, R.C. 155

d'Albani, Giunta $\quad 156$

Dalí, Salvador 182

Danneels, Godfried 191

Dante Alighieri $\quad 35,163,266-267$

Deane-Cox, Sharon 111-112

Debritto, Abel 137

Deckwitz, Ellen 22, 26-27, 257-27o, 362, 366 
Deinsen, Lieke van $\quad 49,87,361$

Delissen, Lara $\quad 337,339$

Demedts, André $\quad 187-188$

Depreter, Elke 260

Dera, Jeroen $\quad 22,26,362$

Deruddere, Dominique 142

Descartes, René 185

Dijkshoorn, Nico 358-359

Dis, Adriaan $\quad 324-325,35^{8}$

Donk, Toine $337,342-343$

Dorleijn, Gillis $\quad 170,266$

Dostoyevsky, Fyodor 113

Dotremont, Christian 181

Drake 344

Driessens, Oliver 315

Dubois, Sébastien $\quad 265,268$

Dueñas, María $\quad$ 203, 209-212

Duinkerken, Anton van $\quad$ 187-188

Dürer, Albrecht $\quad 363$

Eeden, Frederik van $\quad 165$

Eliot, T.S. $\quad 257-258,270$

Emants, Marcellus 164-166

English, James F. 279

Ephimenco, Sylvain 372

Erasmus, Desiderius 31

Erdem, Tulin 260

Etty, Elsbeth $\quad 266$

Faber, Michel 300

Faulkner, William 179

Fisher, Mark 219

Flaubert, Gustave $\quad 109-111,113-115,117,121,123$, $125,127-128$

Flines, Quirijn de $\quad 87,92-93,95$

Floyd, Pink 298

Fortuin, Arjen 230

Francis I 94

François, Pierre $\quad 268$

Franke, Herman 300

Franssen, Gaston $\quad 13-14,26$

Frederic the Great of Prussia 96

Fuhri, K. 154, 156-157, 159, 162

Geel, Nelleke 203

Geerdink, Nina $\quad 15,46,87,361$

Gemeren, Rémon van 166

Gerbrandy, Piet 266

Gerretson, F.C. 72

Gerrewey, Christophe van $\quad 350-35^{1}$

Ghekiere, Anatole 179-180, 188

Ginsberg, Alan 138

Giphart, Ronald 300

Giuffre, Katherine $\quad 268$

Graaff, Maarten van der 260

Greb, F.H. $\quad 157,159$

Green, John $\quad 242,244,251^{-2} 5^{2}$

Greenblatt, Stephen 34

Griffiths, Anthony 49

Grisham, John 302-303
Groenteman, Hanneke 230

Groot, H.S.J. de $\quad 156$

Grunberg, Arnon $\quad 288,327,336,348,352$

Gustavus II Adolphus of Sweden 96

Gutteling, Alex 67-69

Haaft, J.M. van 't $\quad 157,159$

Haan, J.I. de 72

Haar, B. ter 157

Hacke van Mijnden, J.C. $\quad 163$

Hagen, J.W. ten 156

Hagen, Th.C.B. $\quad 156$

Ham, Laurens 19

Hanauer, Mark 144

Harrison, Russell 139

Hearn, Alison 249

Heel, A. van 157

Heerma van Voss, Daan 336

Heijden, A.F.Th. $\quad 298$

Heije, J.P. $\quad 163$

Heilbron, Johan 277

Heinsius, Daniël 43

Hemingway, Ernest $\quad 136,138,144,222$

Hemmingson, Michael 137,142

Hermans, Willem Frederik 192, 307

Herreman, Raymond $\quad 180,186$

Herschdorfer, Chris $\quad$ 227-228

Heumakers, Arnold $\quad$ 228-229, 233, 357

Heytze, Ingmar $\quad 267$

Holman, Marscha 347

Holman, Theodor 327

Hooft, P.C. $37,43,361$

Hooghe, Romeyn de 100

Houbraken, Jacobus $\quad 5^{0-51,53-54}$

Houellebecq, Michel 20

Hoven, Peter van den 240

Hulsenboom, Paul 22

Immink, Wil 201

Iser, Wolfgang 248

Jaeggi, Adriaan 299

Jan III Sobieski $\quad 22,83-84,101-102$

Jansen Wellens, Boudewyn 43

Jansen, Tjitske 300

Jenkins, Henry 244

Jong, Annet de 216, 226

Jonge van Ellemeet, W.C.M. de 163

Jonker, Ingrid 300

Joosten, Jos $\quad 23,363$

Jorn, Asger 182

Joyce, James 179

Julius Caesar 100

Kaneva, Nadia $\quad 316$

Kara Mustafa Pasha 84

Kate, J.J.L. ten 157-159

Kelk, Conelis $\quad 117-121,123,127$

Kenney, John $\quad 361$

Kerr, Pauline $\quad 274$ 
Keynes, John Maynard 336

Klein, Maarten 166

Klis, Hans van der 360

Kloos, Willem 165

Kloots, A. $\quad 85-88$, 91-92, 94-96, 98-99, 101-104

Kluun/Klundert, Raymond van de 18, 23 , 230, 232-233, 235, 293-311, 322, 356, 362-363, 366

Koch, Herman $\quad$ 27, 215-217, 222-235, 326, $35^{6}-35^{8}, 360-362,366$

Koemans, Monique 361

Koers, Ira 319

Koetsveld, C.E. van $\quad 161$

Komter, Aafke 64

Kort, Sebastiaan 232

Kousbroek, Rudy 182

Krabbé, Tim 232-233

Krake, Frank 363

Krog, Antjie 300

Kruseman, A.C. $\quad$ 153-154

Kuiper, Geerdina Aaltje 121

Kuitert, Lisa 117

La Grange d'Arquien, Marie Casimire Louise de 84

Laarman, J.H. $\quad$ 157-159

Laermans, Rudi 219

Lagerwey, Hendrik $\quad 158,160,167$

Lanen, Pepijn 'Faberyayo' 336,361

Langenhuysen, A.P. $\quad 156,159$

Langenhuysen, C.L. van 155

Leesberg, J.F.A. $\quad 156,159$

Leeuw, Paul de 230

Lennep, Jacob van 161

Lescailje, Katharina 40-41

Lierop-Debrouwer, Helma van 240

Limburg Brouwer, P. van $\quad 161$

Louis XIV of France $\quad 89,94,96$

Lubach, Arjen $\quad 336,349$

Lucebert 336,349

Luther, Martin 33

Luyendijk, Joris 300

Maas, Nop $\quad$ 165-166

Madigan, Andrew J. $\quad 138$

Madonna 138

Maeterlink, Maurice 113

Mailer, Norman $\quad$ 138, 222

Mak, Geert 324

Man, Paul de 132

Mandele, Egberta van der $\quad 162$

Manson, Mark 132

Marinkelle, Joseph 50-54

Marsman, Hendrik Jan 322

Martel, Charles $\quad 89,93,95$

Martens, Marianne $\quad$ 241-242, 251

Marx, William 365

Marx-Aveling, Eleanor 115

Maslin, Janet $\quad$ 232-233

Masure, Dries 180
Maurice of Orange $\quad 92,100$

McChesney, Robert W. $\quad 252$

Meer, Daniël van der $\quad 337,347$

Meijer, Ischa 185

Meijer, Pieter $\quad 50,54$

Meizoz, Jérôme $\quad$ 20-22, 152, 224, 338

Mensing, C. $\quad 157,159$

Messi, Lionel 345

Messud, Claire 333-334

Meulenhoff, J.M. 115

Michaud, L.G. $\quad 94,96$

Mieghem, Hilde Van 185

Mihailovich, Phillipe 19-20

Miles, Barry 137

Moeyaert, Bart $\quad$ 283-284

Molegraaf, Mario $\quad 259$

Moor, Margriet de 324

Moore, Robert E. $\quad 21$

Moore, Thomas 158-159

Mortier, Erwin 191

Mourits, Bertram 27

Mulder, Roelof 319

Mulisch, Harry $\quad$ 192, 222, 298, 307

Multatuli 155

Mutsaers, Charlotte $\quad 349,35^{2}$

Nasr, Ramsey $\quad 270,313-314,322-323,325$

Nietzsche, Friedrich 113

Nieuwkerk, Matthijs van 230

Nievelt, Carel van 164

Nijsen, Joost $\quad$ 299-303, 308-309, 345-346, 349

Noort, Saskia 230

Nooteboom, Cees 280

Oosterhoff, Tonnus $\quad 262,269$

Oude, J. van den 164

Overzier, Elly $\quad$ 181-183

Palier, Hendrik $\quad$ 158-159

Pam, Max 228

Pauw, Bas 282-283

Penn, Sean 138

Pérez-Reverte, Arturo ～203-206, 212

Peters, Tom 15

Petrarca 35

Pettegree, Andrew $\quad 33,36$

Pinxteren, Hans van 123-128

Pisón, Ignacio Martínez de 212

Plasse, Cornelis van der $33,42,46$

Plater, Stanisław $87,94-98,100$

Pluijm, Mizzi van der 349,352

Poggioli, Renato 304

Praat, Edwin 221

Priem, Gerrit Hendrik $\quad$ 113-115, 118-119, 127

Pröpper, Henk $\quad 323,325-326$

Pruis, Marja 229

Quaedvlieg, Petra 223

Quart, Alissa 245, 248, 252

Queneau, Raymond 182 
Rabutin-Chantal, marquise de Sévigné, Marie de 89,96

Raczyński, Edward $\quad 84,96-99,102,104$

Ram, Johan 166

Raveel, Roger 186

Reijt, Vic van de $\quad 345-346$

Reve, Gerard $\quad 348,192,221-222,307$

Rijks, Henk 361

Rindfleisch, Aric $\quad 26$

Rodenko, Paul 187

Roelants, Maurice $\quad 187$

Roland Holst, R.N. $\quad 169$

Romondt, H.H. $\quad$ 158-159

Roosendaal, Peter 350

Rosenboom, Thomas 125,128

Roth, Phillip 187, 222

Royle, Jo 253

Ruiz Zafón, Carlos $\quad$ 22, 197-200, 202, 205-208, 211-212, $35^{6}$

Rushdie, Salman 190

Rutte, Mark 317

Salvandy, Narcisse-Achille de 94-97

Sanders, Stephan $\quad 327$

Sapiro, Gisèle $\quad 64,258,276-277,279,316$

Schinkel, A.D. $\quad 157,159$

Schoonekat, M.H. $\quad 157,159$

Schoor, Rob van de $\quad 28,35^{8}$

Schreuders, G. 74,76

Schroeder, Jonathan E. 12, 135

Schubert, Dieter 324

Schubert, Ingrid 324

Schurman, Anna Maria van 32

Sénard, Antoine 123

Sinus 161

Smeets, Roel $\quad 22-23,26,246,356$

Smith, Helen 39

Smith, Peeter 100

Sounes, Howard 137-138

Spit, Lize $\quad 335-341,343,345^{-352}$

Spiteri, Myrte 246

Squires, Claire $\quad 14,23,25,243$

Stalin, Joseph 11

Starter, Jan Jansz. $\quad 31,33,37,41-49,55$

Steenmeijer, Maarten 22

Steinz, Pieter 228

Stockdale, Rosemary 253

Stockum, W.P. van $157,159-160,163$

Storm, Arie 299

Stravinsky, Igor $\quad 263$

Streng, Toos 110

Streuvels, Stijn $\quad 183$

Thierry, J. 157

Thököly, Imre 84

Thompson, Craig J. $\quad 26-27$

Thompson, John B. 201, 217-219, 276

Tongyang, Yang 321

Toorop, Jan 168
Uphoff, Manon 300

Uyldert, Maurits $69,72,75,77$

Vaessens, Thomas $\quad 337,339$

Vandeputte, Henri 181

Vanfleteren, Stephan $\quad 285$

Vanhauwaert, Maud 270

Veen, L.J. $\quad 119,121-124,167$

Veldt, C.L.G. $\quad$ 112-113

Veran, Jacques-Marie 95

Verhoeven, P.N. $\quad 156$

Verhulst, Dimitri 359

Veritas (A.D. van Buren Schele) $\quad 161$

Vermeylen, August 66

Versluys, W. $\quad 73-77,79-80$

Verwey, Albert $\quad 13,61-81,365$

Vestdijk, Simon $\quad 187$

Vestheim, Geir $\quad 316$

Vinkeles, Reinier $\quad 52-54$

Vinkenoog, Simon $\quad 182,186$

Vissers, Eric 349

Vliet, J.L. van der 154

Voltaire $89,96,289$

Vondel, Joost van den $\quad 40,55$

Vooys, Is.P. de $\quad 66,68,71-72,74,76-77,79$

Vos, Jan 39-40

Vuijsje, Robert 232

Vullings, Jeroen $\quad 216,225-228,231,234-235$, 306

Wal, Jan Jaap van der 336

Walravens, Jan $\quad 180-182,185,187$

Washam, Alexis 223

Weidhaas, Peter 274

Weij, Mieke van der 230

Whiteside, Shaun 294, 305

Wijland, Roel $\quad 258,270$

Wilde, Oscar 136

Wilp, Sara Maria van der $\quad 33,36-37,49-55$

Wilson, Robert N. 264

Winter, Leon de 235

Wiseman, Geoffrey 274

Witkowski, Michał 295-296, 310

Witsen, Willem 165

Woerden, Henk van 300

Wolkers, Jan 222

Wood, James 234

Wortel, Maartje $\quad 336,338,345$

Xiaobo, Liu $\quad 321-322$

Yasin, Nurmemet 321

Zeggelen, W.J. van $\quad 155^{-15} 8,164,166-167$

Zielens, Lode 179

Zijlstra, Halbe $\quad 317-318,320-321,327,329$

Zola, Emile 113 